


I mice Bravuras

$D u$

Ped: $23=1895$.

THE BIRDS OF BERWICKSHIRE VOL. II. 
Edinburgh: Printed by George Waterston \& Sons

FOR

\section{DAVID DOUGLAS.}

LONDON, - . SIMPKin, MARShaLl, HAMILTON, KENT, AND CO., LIMITED,

CAMBRIDGE, MACMILLAN AND BOWES.

GLASGOW, - JAMES MACLEHOSE AND SONS. 
Nature never did betray The heart that loved her; 'tis her privilege, Through all the years of this our life, to lead From joy to joy.

WORDSWORTH.

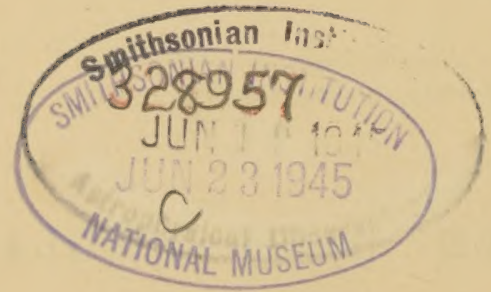




\section{CONTENTS OF VOL. II.}

ACCIPITRES.

FALCONIDE.

Falco peregrinus.

Falconry in Berwickshire, Falco subbuteo.

, cesalon.

, tinnunculus.

Pandion halicetus.

Pelecanid a.

Phalacrocorax carbo. ,, graculus.

Sula bassana.

Peregrine Falcon, . . . . 1

. . . . . . . 10

Hobby, . . . . . . 20

Merlin, . . . . . . 21

Kestrel, . $\quad$. $\quad$. $\quad$. $\quad$. $\quad$. 25

Osprey, . . . . . . 27

\section{STEGANOPODES.}

Common Cormorant, . . . 30

Shag or Green Cormorant, . . 33

Gannet or Solan Goose, . . . 35

ARdeide.

Ardea cinerea.

Nycticorax griseus.

Botaurus stellaris.

Ciconimde.

Ciconia alba.

\section{HERODIONES.}

Common Heron, $\quad$. $\quad$. $\quad$. $\quad 39$

Night Heron, . . . . . 52

Common Bittern, . . . . 53

White Stork, . . . . . 64

ANSERES.

ANatide.

Anser segetum.

, brachyrhynchus.

, albifrons.

Bermicla brenta.

" leucopsis.

, canadensis.

Cygnus musicus.

Cygnus Bewicki.

Tadorna cornuta.

Anas boscas.

Spatula clypeata.

Dafila acuta.

Querquedula crecca.

, circia.

Bean Goose, · . . . $\quad$. 66

Pink-footed Goose, . . . . $\quad$. 66

White-fronted Goose, . . 90

Brent Goose, . . . . 91

Bernacle Goose, . . . $\quad$. 93

Canada Goose, . . . . . 95

Whooper, . . . . . 96

Bewick's Swan, . . . . $\quad 99$

Common Sheld-Duck, . . . 100

Mallard or Wild Duck, . . . 101

Shoveller, . . . . . . 107

Pintail Duck, . . . . . 109

Teal, . . . . . . 110

Garganey, . . . . . 112 
Anatide-continued.

Mareca penelope.

Fuligula ferina.

, cristata.

," marila.

" clangula.

Harelda glacialis.

Somateria mollissima.

Edemia nigra.

, fusca.

Mergus merganser.

," albellus.

\section{Columbida.}

Columba palumbus.

" anas.

" livia.

Turtur communis.

Ectopistes migratorius.

PtrRoclidid,

Syrrhaptes paradoxus.

\section{TETRAONID王.}

Tetrao tetrix.

Lagopus scoticus.

\section{Phasianider.}

Phasianus colchicus.

Perdix cinerea.

Coturnix communis.

RALLIDA.

Crex pratensis.

Porzana maruetta.

Rallus aquaticus.

Gallinula chloropus.

Fulica atra.
ANSERES-continued.

Wigeon, . 113

Pochard, . . . . . . 115

Tufted Duck, . . . . . 118

Scaup Duck, . . . . . 119

Golden-Eye, . . . . . 120

Long-tailed Duck, . . . . 122

Eider Duck, . . . . . 123

Common Scoter, . . . . 126

Velvet Scoter, . . . . . 127

Goosander, . . . . . 128

Smew, . . . . . . 130

\section{COLUMBA.}

Ring Dove, . . . . $\quad$. 131

Stock Dove, . . . . . 141

Rock Dove, . . . . . 145

Turtle Dove, . . . . . 151

Passenger Pigeon, . . . . 153

\section{PTEROCLETES.}

Pallas's Sand Grouse, 155

\section{GALLINAE.}

Black Grouse, . $\quad$ • . $\quad . \quad 158$

Red Grouse, . 162

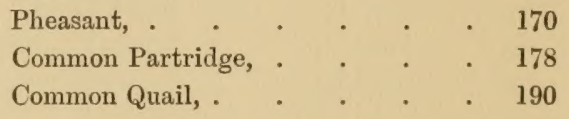

FULICARIAE.

Landrail, . . . . . . 194

Spotted Crake, . . . . . 198

Water Rail, . . . . . 200

Moor Hen, . . . . . 202

Common Coot, . . . . . 204 
OTIDIDE.

Otis tarda.

\section{CharadriId}

Charadrius morinellus. , pluvialis.

Egialitis hiaticula.

Vanellus vulgaris.

Homatopus ostralegus.

SCOLOPACID E.

Phalaropus fulicarius.

Scolopax musticula.

Gallinago major.

, coelestis.

, gallimula.

Tringa alpina.

"striata.

Machetes pugnax.

Totanus hypoleucus.

", ochropus.

" calidris.

", canescens.

Limosa agocephala.

Numenius arquata.

", phoopus.

\section{LARID}

Hydrochelidon nigra.

Stema fuviatilis.

Larus minutus.

" ridibundus.

", canuss.

", argentatus.

,fuscus.

," marinus.

", glaucus.

Rissa tridactyla.

Stercorarius pomatorhinus.

, crepidatus.

", parasiticus.
ALECTORIDES.

PAGE

Great Bustard,

\section{LIMICOLAE.}

Dotterel, . . . . . . 210

Golden Plover, . . . . . 221

Ringed Plover, . . . . . 224

Lapwing, . . . . . . 225

Oyster Catcher, . . . . 231

Grey Phalarope, . . . . 232

Woodcock, . . . . . . 233

Great Snipe, . . . . . 240

Common Snipe, . $\quad$. $\quad . \quad$. $\quad . \quad 241$

Jacksnipe, . $\quad$. $\quad$. $\quad$. $\quad$. 244

Dunlin, . . . . . . 246

Purple Sandpiper, . . . . 247

Ruff, . . . . . . . 248

Common Sandpiper, . . . . 250

Green Sandpiper, . . . . 252

Common Redshank, . . . . 254

Greenshank, . . . . . 256

Black-tailed Godwit, . . . 257

Common Curlew, $\quad$. $\quad . \quad$. $\quad .258$

IVhimbrel, . $\quad . \quad . \quad . \quad .263$

\section{GAVIA.}

Black Tern, $\quad . \quad$. $\quad$. $\quad$. $\quad$. 264

Common Tern, . . . . . 265

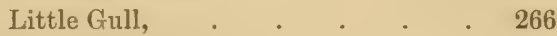

Black-headed Gull, . . . . 268

Common Gull, . . . . . 275

Herring Gull, . . . . 279

Lesser Black-backed Gull, . . 285

Great Black-backed Gull, . . . 286

Glaucous Gull, . . . . . 287

Kittiwake Gull, . . . . 288

Pomatorhine Skua, . . . . 292

Arctic or Richardson's Skua, . . 293

Long-tailed or Buffon's Skua, . . 294 
ALCID KE.

PYGOPODES.

Alca torda.

Uria troile.

"grylle.

Miergulus alle.

Fratercula arctica.

Razor-Bill, . . . . . 295

Common Guillemot, . . . . 297

Black Guillemot, . . . . 303

Little Auk, . . . . . 305

Puffin, . . . . . . 307

Colymbide.

Colymbus glacialis.

Great Northern Diver, · . . 309

", septentrionalis. Red-throated Diver, . . . . 311

PODICIPEDID E.

Podiceps cristatus.

, griseigena.

, nigricollis.

, fluviatilis.

Great Crested Grebe, . . 313

Red-necked Grebe, . . . . 315

Eared Grebe, . . . . $\quad$. 317

Little Grebe or Dabchick, 318

Procellarimd.

Procellaria pelagica. $\quad$ Storm Petrel, . . . . . 321

Migration of Brrds in Berwichshire, . . . . . 324

Table of Ornithological Odservations made in Beriwichshire from 1799 until 1S87, . . . . . • • . 329

Calendar of Migrations and Observations of Birds in BerwickSHIRE, 1799-1887, . . . . . . . . .

T.ABLE showing the earliest, latest, and average diates of the arrivals and departures of the true migratory birds which visit Berwickshire annually, with approximate notes regarding the average temperatures, and the prevailing winds, during the periods when their migrations took place, 1799-1887, .

TABLE showing mean monthly temperatures at Milue Graden, Berwickshire, 1857-87, . . . . . . . . 356

Appendix.

Hawfinch, . . . . . . . . . . 358

Great Spotted Woodpecker, . . . . . . . 359 


\section{ILLUSTRATIONS}

I N V L. I I.

BIITIE MTEE Hawksheugh, near Fast Castle. By John Buarr, from Photograph, 9

HAwK's Hood. By MrS. Mutrhead, . . . . . . 19

Kimmerghame House. By Mrs. Muirhead, from Photograph, . 20

Merlin on Falconer's Glove. By George E. Lodge, . 24

Osprey. By Mrs. Muirhead, • • . . . . . . 29

Common Cormorants. By Mrs. Murrhead, . . . . 32

Sea Shell. By Mrs. Muirhead, . . . . . . . 34

Gannet and its Youna. By Mrs. Mutrhead, from Photograph by WM. Green, Berwick-on-T'weed, . . . . . 38

Mertoun. By the Hon. R. H. Scott, . . . . facing page 48

Heron's Nest. From Nature, by Mrs. Murrmead, . . . 51

Hirsel Locir. By Mrs. Muirhead, from Photograph, . 52

Plan of Billie Mire as it was in 1759 and 1816. By George

Muirhead, from Old Plans, . . . . facing page $5 \mathrm{~S}$

Hone Castle. By John Blair, from Photograph, . . . . 63

Coldingham Village. By John Blair, . . . . . 65

The Hole Moss, with Dirringtons and 'Tiwinlaw Cairns in

Distance. By John Blatr, . . . . facing page 86

Shepherd's Hodse at Wedderlie. By John Blair, . • . $\quad 89$

Cove Harbour, near Cockburnspath. By John Blair, · . 92

Batty's Stane, near Remains of St. Abb's Kirik. By John Blair, 94 
Head of Canada Goose. By Mrs. Muirhead, . . . . 95

Wild Swans. From Nature, by Mrs. Muirhead, • . . 98

Head of Bewick's Swan. By Mrs. Muirhead, . . . . . 99

Common Wild Duck's Nest. From Nature, by Mris. Muirhead, 106

Duns Castle. By Mrs. Muirhead, from Photograph by George Fortune, Duns, . . . . . . . 108

Sathion Fishing on the Tweed. By John Blair, . . . 109

Teal's Nest. From Nature, by Mrs. Murnead, • • . 112

Star Fish. By Mrs. Mutrhead, . . . . . . . 114

Old Bridge on the Leader at Earlston. By John Blair, 117

Sea Sheld. By Mrs. Mutrhead, . . . . . . . . 119

Abbey St. Bathans. By Mrs. Muiriiead, from Photograph, . 121

Eider Ducir's Nest. From Nature, by Mrs. Moiriead, . . 125

Trap for Catching Crabs. By John Blair, . . . . . 126

The Wheat Stack Rock, near Fast Castle. By John Blatr, from Photograph, . . . . . . . . . 127

Ladyikik on the Tweed. By John Brair, . . . . 129

The Hirsel. By Mrs. Murriead, from Photograph, . . . 130

Wood Pigeon's Nest. From Nature, by Mrs. Mulriend, . . 140

Galium Aparine. By Mrs. Mutrhead, . . . . . 144

The Cleaver Rock, St. Abb's Head. By John Blair, facing page 146

Doocot at Mertocn. By John Blair, . . . . . 150

Rocks on Whitadder at Edrington. By John Blair, . . 152

Mellerstayn House. By John Blaik, from Photograph, . . 154

Spital House. By Mrs. Muinhead, from Photograph, . . 157

Byrecleugir. By John Blair, . . . . . facing page 161

Blaeberries. By Mrs. Mulrilead, . . . . . . 169

Lettholm Village. By John Blatk, . . . . . . . 159 
Nisbet House. By John Blair, . . . . . . . 193

Corncrake's Nest. From Nature, by Mrs. Mutritead, _ . 197

Doorway, Greenknowe Tower. By John Blair, · . . 199

Coot's Nest. From Nature, by Mrs. Mutrhead, · . . 206

Rentains of Buncle Castle. By Mrs. Mutrhead, from Photograph, 209

Golden Plover's Nest. From Nature, by Mrs. Motrinead, . 223

Ringed Plover. By Mrs. Mtirhead, . . . . . 224

Lapwing's Nest. From Nature, by Mrs. Mutrhead, . . . 230

Oyster Catcher. By Mrs. Mutrhead, . . . . . 231

Nentiorn House. By Mrs. Mutrhead, from a Sketch, . . . 232

Woodcock's Nest. From Nature, by Mrs. Muirhead, . . 239

Longformacus Bridge. By John Blatr, · . . . . 245

Sea Weed. By Mrs. Muirhead, . . . . . . . 247

Common Sandpiper's Nest. From Nature, by Mrs. Miuirhead, . 251

Oldcambus Dean. By John Blatr, . . . . . . 253

Common Redshank's Nest. From Nature, by Mrs. Mutrhead, . $25 \pi$

Sea Shells. By Mrs. Mutrhead, . . . . . . 257

Common Curlew's Nest. From Nature, by Mrs. Mutrhead, . 262

Sea Sirell. By Mrs. Mutriead, . . . . . . . 263

Crab. By Mrs. Mutrhead, . . . . . . . . 264

Terns and their Young. By Mrs. Mutrhead, . . . . 265

Coldingham Loch. By John Blatr, . . . . . . 267

Black-Headed Gulz's Nest。 From Nature, by Mrs. Mutriread, 274

Top of Foul Carr, from Cliff near Rlimains of St. AbB's Nonnery. By JoHN BLaIr, from Photograph, . . . 284

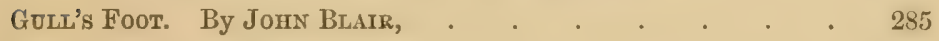

Herring Boats at Eyemouth. By Mrs. Mutrhead, from Photograph, . . . . . . . . . . 287 
Flot Carr and Skelly. By John Blatr, . . . . . 291

On the Berwickshire Coast. By the How. R. H. Scott, • . 292

Steeple Rock, Petticowick. By Jomn Blair, . • • • • 294

Eyemouth, from near the Fort. By John BuAtr, - facing page 294

Whitehedgr. By John Blair, . . . . . facing page 298

Plan of St. Ame's Head, . . . . . . facing page 300

Common Guillemots. By Mrs. Mutrhead, from Photograph by

William Green, Berwick-on-Tweed, . . . . . 302

Horse Castle Cove. By John Blair, . . . . . . 304

Little Auk. By Mrs. Moirhead, . . . . . . 306

Foul Carr and the Stack. By Jomn Blair, from Photograph, . 308

Salmon Fishers' Shitel on the Tweed. By John Blair, . . 310

Const of Berwickshire, from the Neighbodrhood of CockbuRnspath. By John Blatr, . . . . . . 312

Horndean Churchyard. By John Blatr, . . . . . 314

Wedderle House. By John Blair, . . . . . . 316

Fishing on the Dye. By John Brair, . . . . . 320

St. AbB's Head: Storm on the 14 tit of October 18s1. By

J. Campell Noble, R.S.A., • . . . . . 323

Swallows. By Mrs. Mulrhead, . . . • • . 328

Cuckoo. By Mrs. Mutrhead, . . . . . . . 350

The "Riding Tree" at Salton, East Lothlan. By Mrs. Muirhead, from Photograph, . . . . . . $35 S$

Whitsome Village. By John Blair, . • • • • . 359

Porch of Author's Hodse at Paxton. By John Blatr, • • 383

Beehives. By Join Blair, . • . . . • . . 390 


\section{THE PEREGRINE FALCON.}

BLUE HAWK, HUNTING IFAWK, GOSIIAWK, GAME HAWK, GREY HAWK, FALCON, COMMON FALCON.

Falco peregrinus.

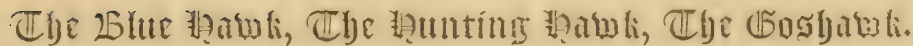

A Faucon Pergyrine secmed she of fremde londe.

Chaucer, Squire's Tale.

As a Faucon fayre,

That once hath failed of her souse full neare,

Remounts againe into the open ayre,

And unto better forlune doth herselfe prepayre.

SPENSER, Fairie Qucen.

Thus noble bird, which has obtained the name of the Hunting Hawk on account of its having been so much used in former times for the chase, breeds amually on the sea-coast of Berwickshire, in the neighbourhood of St. Abb's Head and Fast Castle, where it has had its eyrie from time immemorial. ${ }^{1}$

Writing in 1833 regarding a visit of the Berwickshire Naturalists' Club to St. Abb's Head on the 19th of June of that year, Selby, the well-known ornithologist, mentions that on reaching the clifi's immediately north of the Head, where they rise from the sea in fine, broken, and perpendicular faces to the height of severil lundred feet, the attention of the members was attracted to the cry of two Peregrine Falcons-a male and a female-which were seen soaring at

1 In an ancient Rental of Coldingham drawn up after the battle of Falkirk in 1298 , there is an entry of "two aeries of Falcons," which were cloubtless situated on the adjoining coast.

VOL. II. 
a considerable height in the air, the cause of their solicitude being two of their young, which har apparently just quitted the nest, and which were seen perched on a projecting angle of the rock. ${ }^{1}$

The Rev. Andrew Baird, in his report on the united parrishes of Cockbumspath and Oldeambus written for the New Statistical Account of Scotland in 1834, states that the "Hunting Hatwk" is frequently seen on the Redheugh Coast. ${ }^{2}$

Mr. Robert Cowe, Oldcastles, who lived at Dowlaw for many years, has informed me that, from 1839 to 1850 , it nested regularly every season near Fast Castle; and Mr. Archibald Heplum, who contributed many interesting notes to Macgillivray's IFistury of Birtish Birds, records in 1850 that "four pairs of the Peregrine Falcon breed on the coast of Berwickshire; one at Burnmouth, one at Petticowick Cove to the west of St. Abb's, one at Ernesheugh, and a fourth at Fast Castle." 3 My friend Mr. Hardy, Oldeambus, writes that the Peregrine nested at Halternsloup near Coldinghim shore in 1836 and 1853 , and has occasionally bred in a steep, massive rock, ${ }^{4}$ a short distance to the east of the Rammel Cove, since 1856. He adds that it had its eyrie at Fast Cinstle, Whitchugh, and near Burmmouth, in 1857 . and that it was from the last-mentioned locality that Mr. Baird of Newhyth sometimes got his Falcons. ${ }^{5}$ Mr. Iiobert Galder, Little swinton, who spent his youth at Fairnieside, a farm on the coast near Burnmouth, of which his father was temant, relates that the Peregrine often nested, previous. to 1857 , in "the clill of the high perpendicular rock over-

1 Hist. Ber, sitat. Clut, vol. i. p. 21.

2 New Statistical Account of Scotland, vol, ii. (Berwickshire), 1) 299.

:Hist. Ber. Nat. C'lub, vol. iii. p. 71.

* Mr. Hardy says that an old fishurman nimed James Fairbairin, who lived at the Cov', told hin that long ago the Raven used to have its nest on this rock.

5 Letter from Mr. Hardy, Olicambus, dated the 5th of November 1884. 
hanging the well-known Gull Liock, and that Mr. Belany ${ }^{1}$ frequently got the young Falcons from the nest there, and trained them, a man or hoy being lowered down to the nest by a rope. ${ }^{2}$

Two pairs of Faleons appear to have bred in the vicinity of St. Abb's Head in $1859 ;^{*}$ and in 1860 there was a nest in the precipice at Ifawksheugh immediately to the east of Fast Castle, which seems to have been occupied on the 3rd of May 1865, when I visited that part of the coast with Mr. William Cowe, Dowlaw, who showed me the cliff at Hawksheugh up which his hother, Mr. Peter Cowe, was drawn with a rope to get the young Falcons from their eyrie in $1860 .^{4}$

Nr. John Wilson, Chapelhill, Cockburnspath, has lindly funished me with the following interesting account of the talking of the young Falcons from their eyrie in the precipice at Ilawkshengh in June 1 S66-the parties engaged in the arlventure being Mr: Wilson, MIr. Frederick Smith, Hoprig, and Mr. William Cowe, Dowlaw. "The nest," says Mr. Wilson, "was just a little to the east of the castle, and from that point we could see the young ones sitting in it. We attached a blanket to a rope and dangled it over the nest, so that the Hawks might strike at it, and we thought we could draw them up to the top of the cliff while they

1 Mrr. James Cockluurn Belany was a surgeon in Ayton, and kept Hawks there at one time. On the occasion of the Highland and Agricultural Society's Show at Berwick, in 1841, he exhibited his Falcons flying at Pigeons in the Magdalen Fields. He wrote a treatise upon Falconry, which was printed in Berwick in the above yenr.

2 Letter from Mr. Robert Calder, Little Swinton, dated 29th November 1881.

3 Hist. Ber. Nat. Clut, vol. iv. p. 131.

\pm Mr. Peter Cowe, Lochton, who formerly lived at Dowlaw, informed me on the 5th of Angust 1886, that, in the begimning of June 1860, he took tour young Peregrines out of their nest in the precipice at Hawlshengh, immediately to the east of Fisst Castle. He was drawn up the face of the cliff from the bench, by four or five men stationed at the top of the rock, with a long rope, a elain being attached to the upper part of the rope to come in contact with the rocks and thus prevent the danger of it chating on their sharp points. 
were holding on by their talons. When they found they were being pulled up, they took to wing-being almost fully fledged-and alighted on the rocks down at the beach. We marked the spots where they settled, and, going down, had no difficulty in catching them, as they were too inexperienced to attempt a second flight. I think we got four -Mr. Smith taking two and Mr. Cowe two. Mr. Smith reared his and had them six or eight months, when, after a long fast, they were fed unhooled, and fought over the fool, the result being that one was killed in the fight, and the other clied some days afterwards. Mr. Smith had begrun to train them, and they would take long flights and come back at his call, and settle on his hand, but he had never flown them at game. Mr. Cowe reared one, and had it for a year or more, but it flew away and did not return, though it remained in the neighbourhood for several seasons, and used to attend him at a safe distance when he was out shooting, to pick up wounded birds." 1

Dr. Stuart of Chirnsicle records that upon one occasion a "cottoned" fleece - that is, one taken from a sheep out of health, and in which the wool is all matted together-was lowered over the precipice at Hawkshengh to the Falcon's nest for the same purpose as the blanliet was employed by Mr. Wilson and his friends."

The Peregrine is said to have bred at Blakey on the coast near Burnmouth in 1875, when a young one was found at the bottom of the rock there; ${ }^{3}$ and Mr. Hardy notes that on the 12th of June 1877 he saw a pair of Falcons fly from their eyrie below the Standing Man or Souter Rock, a short distance to the west of the mouth

1 Letter from Mr. John Wilson, Chapelhill, Cockburnspath, daterl the 2nd of July 1888.

2 Hist. Ber. Nat. Club, vol. xi. p. 242.

3 Information from Mr. John Crockett, salmon-fisher, Burnmouth. 
of Dowlaw Burn. ${ }^{1} \quad$ The Peregrine nested at Fast Castle in 1879, and at Lumsden rocks in $1880 .^{2}$ In 1881 it had its eyrie in the cliff at Hawksheugh, near Fast Castle; ${ }^{3}$ and in the following year it appears to have nested at Blakey. ${ }^{4}$ Mr. J. Campbell-Noble has informed me that the eyrie was at Earnsheugh in 1885. On the 22nd of April 1856, a pair of Peregrines were seen by Mr. W. Evans, Edinburgh, at Fast Castle, where they appeared to be nesting; and the young were observed there in the following June. $^{5} \quad$ The eyrie at Fast Castle was again occupied in the summers of 1887 and $1888 .{ }^{6}$

In former times this species had its home in precipices on the banks of the Whitadder, and in the Lammermuirs, as well as upon the sea-coast. Mr. John Wilson, late of Edington Mains, the well-known author of British Agriculture, has informed me that, about the begimning of this century, it bred every year in a high, red scaur at the "Blue Braes" on the south bank of the Whitadder, a short distance above Hutton Hall Mill, the nest being placed under an overhanging ledge of rocks immediately above a very deep pool called "Patie's Pat." The picturesque scenery on the river there, near the old tower of Hutton Hall ${ }^{7}$ - the ancient seat of the Homes and the Johnstons -would then possess an alditional interest to all lovers of

1 Mr. Ilardy's MS. Notes.

2 Ilist. Ber. Nat. Club, vol. ix. p. 387.

3 Information from Mr. W. Edington, Dowlaw.

4 Information from Mr. John Crockett, salmon-fisher, Burnmouth.

5 Information from Mr. W. Evans, Edinburgh.

6 Information from Mr. W. Edington, Dowlaw, in letter dated the 20th of July 1888.

7 One of the most picturesque seats on the banks of the Whitadder, mentioned in a ballad celebrating one of Jolnnie Armstrong's rides-

Then they're come on to IIutton-ha, They rade that proper place ahout;

But the laird he was the wiser man, For he had left na geir about. 
nature, for, to its romantic beanty in the spring and early summer months, would be added the charm of

A pair of Falcons wheeling on the wing, In clamorous agitation.

WORDSWORTH, Exxcursion.

My friend Dr. Stuart of Chirnside mentions that his brother-in-law, the late Mr. Abraham Edgar of Hutton Manse, was lowered over the cliff at the "Blue Braes" with a rope, about 1826, and took the young Falcons from the nest. ${ }^{1}$ The Peregrine seems to hare occasionally frequented this neighbourhood for some jears afterwards, for Mrs. Fairbairn, late of Allanton, relates that a specimen in the second year's plumage was shot between Hutton Hall and the "Blue Braes" in 1833." The red scaur, which is now the home of a colony of Jackdaws, can be seen from a distance in the direction of Chimside, and as it is of considerable height and precipitous, it was one of the most suitable places on the banks of the Thitadder for the eyrie of the Falcon. The rock under which the nest was placed has now fallen down, and the Peregrine has not bred there for the last sixty years. ${ }^{3}$

Lady John Scott-Spottiswoode of Spottiswoode has been so good as to inform me that, in former times, a "Blue Hunting Hawk" userl to rear its young at Corbie's Hengh -a crag over the Bruntiburn-on Raecleugh Farm; ${ }^{4}$ and Mr. Peter Scott, Lauder, whose father was for many Jears

1 IIst. Ber. Wat. Club, vol. xi. p. 212.

2 Information from MIr. Firloaim on the 17th of Octoher 1887.

s Mr. William Patterson, late of North Berwick Albey Farm, who, when he was a boy, lived near Duus, has informed me that his father told him that the Lairl of Hutton Hall estate, on which the Falcon's nest at the "Blue Braes" was situated, had a pair of trained Falcons for hawking, and getting tired of keeping them, gave them their liberty. They remained in the neighbourhood of Hutton Hall and nested in the red scaur. This oceurred about the middle of last century, and was said to have been the origin of the Falcon's nest at the "Blue Braes."

* Letter from Mr. P. Stnrmonth Darling, Kelso, her larivsilip's factor, llatecl the 5th of March 1886. 
head gamekeeper to the Earl of Laudlerdale, states that, about fifty years ago, the Peregrine nested annually on a precipice three or four miles up the Longeroft Water, in the parish of Lauder.

Although it does not now breed in any of the inland districts of the county, it occasionally makes its appearance in localities at a distance from the coast. A male frequented the tall trees by the side of the Tweed near Paxton House for a short time in the summer of 1871 , and a female was killed near Leitholnu, on the Sth of Mary 1875 , by a man who was shooting Cushats, the Falcon having swooped down at a stuffed Wood Pigeon which he had placed on the ground as a decoy. ${ }^{1}$ Dr. Stuart of Chirnside records that, on the 14th of January 1880, a I'eregrine was captured by a gamekecper at Edington, who, observing a Cushat newly killed near the place where young Pheasants were usually reared, set a trap by the side of the dead bird and secured the Falcon, which was in immature plumage. ${ }^{2}$ In July 1881 a specimen was trapper near Quixwood.

The Pcregrine Falcon is generally to be found on the sea-coast of the county at all seasons of the year, but it is probable that the young migrute southwards in autumin along with other passing birds of this species, which then leave the northern regions of Europe for the south will the vast flocks of migrants on which they prey, and retum in spring, at both of which periods the Peregrine is seen on mignation at the lighthouses on the coasts of England and Scotland. ${ }^{3}$

It chooses for its nesting place a crevice or shelf in some lofty and inacessible cliff on the sea-coast, and has eggrs in

\footnotetext{
1 IIist. Ber. Nat. Club, vol. ix. pr. 18, 19.

Ibid. vol. ix. 1). 387.

- Reports on the Migration of Birels, 1S79-86.
} 
April or about the beginning of May. It appears often to change the site of its breeding quarters from one favourite part of the sen-hoard to another, at irregular intervals, but sometimes continues to occupy the same cyrie for a number of years in succession. The eggs, which are generally deposited on the bare earth, ${ }^{1}$ are three or sometimes four in number, and are of a dull yellow, thickly mottled and blotched with dark reddish brown. The young, which are at first covered with white down, are usually ready to be taken for taming about the second week in June, and towards the end of that month they may be seen sitting about the rocks in the neighbourhood of the nest. After leaving their eyrie, and until their first moult, the general colour of the upper parts of the young is brownish ash, the edge of each feather being rufous. The under parts are dirty white, with dark longitudinal streaks. In the adult birds of both sexes the upper parts are bluish slate colour harred with a darker tint-hence the local name of "Blue Hawk" -and the under parts rufous white, with dark brown transverse bars. The irides are dark hazel brown. The female, which is much larger and more powerful than the male, was, in the palmy days of hawking, known as "The Falcon," whilst the male was called the "Tercelgentle." 2

The flight of the Peregrine is very rapid, and resembles

1 Mr. Peter Cowe has informel me that when he climbed to the Falcon's eyrie at Fast Castle in 1860, he saw very little appearance of a nest in the crevice of the cliff where the young birds were; and Mr. John Wilson, Chapelhill, says that when he was engagel with Mr. W. Cowe taking the young Falcons in their eyrie there in June 1866, he observed scarcely any nesting materials around them. In the case of a Peregrine's eyrie on an inland precipice in Inverness-shire which I personally examined in May 1866, the eggs were merely deposited in a little hollow scraped in the earthen floor of the crevice in the rock.

2 It is sail to have derived the name of "Tercel" from being about one-third smaller than "The Falcon," but some authorities state that of the three young birls usually found in the nest of the Peregrine, two are fentales, and the third a male, which, on this account, is ealled the "Tercel." See Uarting's Ornithology of Shakespeurc, p. 52. 
that of the Rock Dove. It searches over the open country or along the sea-shore for prey, which it takes by suddenly swooping down with a perpendicular or slanting descent, or by direct pursuit; but the Falcon always endeavours to keep above the quarry until a favourable opportunity of seizing it occurs.

On the sea-coast it feeds chiefly upon sea-fowl and their young, and also on Rock Dores. In inland districts, game and Wood Pigeons form its principal quarry.

The following places in the county appear to have derived their names from eyries of this Falcon:- Hawksheugh, a cliff a short distance to the north of Bleakheugh, on the coast, about a mile north of Burnmouth; Hawksheugh or Castleholes Heugh, near Fast Castle; and Hawksheugh, a precipice on the coast near Cockburnspath. It is probable that Hawkslaw, ${ }^{1}$ a farm in the parish of Coldstream, and Huxton, a small farm near the Grange TVood in Coldingham parish, have derived their names from the same source. A part of Hallydown estate was known as Hawkslaw in $1764 .^{2}$

\footnotetext{
1 Callerl Hawkisland in a charter by Oliver Cromwell of the Lordship and Barony of Swinton, \&c., dated the 26th of November 1656. See The Swintons of that Ilk and their Cadets, by Archibalil Camploll-Swinton of Kimmerghame, July 1883.

2 Mr. Hardy's MSS. N'otes.
}

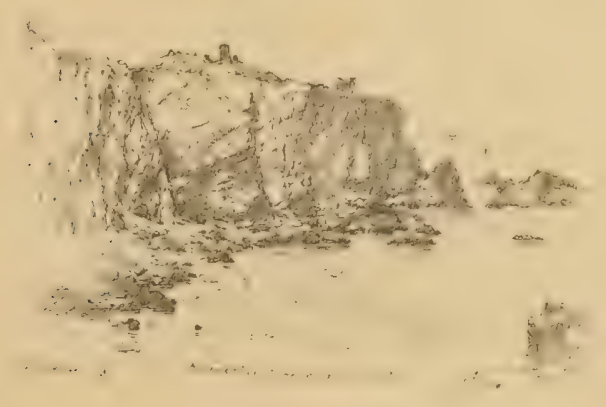




\title{
FALCONRY IN BERWICKSHIRE.
}

\author{
Next will I sing the valiant Falcon's fame. \\ Aerrial fights where no confederate brute \\ Joins in the bloody fray; but bird with bird \\ Jousts in mid air.
}

SomervilLe, Field Sports.

BEFOlie the introduction of the fowling-piece, and for centuries afterwards, until guns were so much improved that the art of shooting birds on the wing was acquired by sportsmen, hawking was one of the chief field sports in Scotland. It was a favourite amusement of many of our kings, noblemen, and others, who could afford the great expense which attended it, ${ }^{1}$ and ladies delighted to accompany the falconers to the field.

It is a very ancient sport, having been followed in the East more than 2000 years ago; in England it appears to have been practised as early as the eighth century, and in the celebrated Bayeux Tapestry Harold is represented with a Hawk upon his hand.

After the Norman Conquest it seems to have advanced rapidly, and in the succeeding centuries the rank of an individual was indicated by the kind of Hawk carried on the wrist-thus, the Gyr Falcon was carried by the king, ${ }^{2}$ the Peregrine by an earl, while to ladies belonged the Merlin.

1 The expense connected with falconry is mentioned in an Act of the Scottish Parliament the 1st of November 1600:- "For sa-meikle as by common consuetude of all countries, special prohibition is made to all sorts of persons to slay Wyldfoull, Irair, or Vemison, except sik as by their revenues may bear the charges and burdings of the Hawlies, Floundes, and Dogges, requisite in sik pastymes," \&c.

2 The gentle Faueon that witl his fote distreineth The ling's lianct.

CHaUcer, The Assemble of Foules, 1561. 
The Ladye by the altar stood,

Of sable velvet her array,

And on her head a crimson hood,

IVith pearls embroiclered and entwined,

Guaried with gold, with ermine lined;

A Merlin sat upon her wrist,

Held by a leash of silken twist. ${ }^{1}$

One of the earliest historical references to falconry in Scotland occurs in the Liber S. Marie de Mclros, where we find it recorded that, in the reign of William the Lion, when Robert of Avenel gave to the Church of St. Mary of Melrose the temitory of Eskdale, he reserved, along with the ginme, the eyries of Hawks- " accipitrum et sperveriorum nidos." - From the Exchequer Rolls of Scotlend it appears that in 1263 Alexancler III. had a falconer at Forres. ${ }^{3}$ The old Earls of Dunbar, the powerful descendants of Cospatrick, at one time had a residence at Earlston. "At the east end of the village there was once a stronghold designated the Earls' Tower, and on what is now termed the Ilawk Kaim, the hawking house of the earls is believed to have stood." 4 Iuring the War of Independence, I'atrick, the 4th Earl of March and Dumbar, strenuously supported Filward I, and he and that great English king were on the most friendly terms. On one point they were thoroughly in unison-their mutual fonchess for the noble pastime of hawking. This transpires among the Documents relative to the IIstory of Seolland, published under the direction of the

1 The Lay of the Last Minstrel, canto vi. 5. Sir Walter Scott in his notes says: "A Merlin or Sparrow-Howk was actually carried by ladies of rank, as a Falcon was, in time of peace, the constant attendant of a kuight or baron. Godscroft relates that when Mary of Lorraine was Regent, she pressed the Earl of Angus to admit a royal garrison into his castle of Tantallon. 'To this he returned no direct answer; but, as if apostrophising a Goshawk, which sat on his wrist, and which he was feeding during the queen's speech, he exclaimed, 'The devil's in this greedy glede ; she will never be full.' "- Hume's II istory of the Horse of Doreglas, 1743, vol. ii. p. 131.

Liber S. Marie de MIflros, vol. i. p. 39: Bannatyne Club.

3 Exchequer Rolls of Scolland, 1264-1359, 11). 7-15.

4 "Earlstoum," by James Tait, Falconhall, Kelso._Il ist. Bcr. Vat. Club, vol. v. p. 263. 
Lord Clerk Register, edited by the Rev. Joseph Stevenson ${ }^{1}$ and as the same Hawks which were used at Dunbar, the principal seat of the earl, would doubtless be taken to Earlston in the hawking season, the following entries have a certain local reference.

First of all, the earl visits the king in England, and on that occasion presents him with a Goshawk (Astur) on departing, and leaves behind him his falconer, whom the king afterwards allows to return home with a Falcon that the king had borrowed when staying in the castle of Dunbar, or, at least, had used when resident there:-

$1296-7$.

$$
\text { "Earr Patrick." }
$$

To the Lord Patrick, Earl of March, on return$£ \quad s . d$. ing to his own parts, of the gift of the king, as his personal expenses of his journey home, by the king's own hands at Ipswich, on the first day of January . $\mathrm{xx}-$

"A Certain Falconer of Earl Patrick."

To Elias Spot, falconer of Earl Patrick of Dunbar, who remained with the king in attendance on John de Bickenore, with a certain Goshawk which the same earl had presented to the king during the season of Goshawks, licenced by the king to return to his said lord with a certain Falcon which the said king had in the Castle of Dumbar, in the foresaid year, of the gift of the said king, by his own hands, at Plumpton, the last day of April

To the same, of the gift of the same king, to defray his expenses in returning as foresaid is, to Earl Patrick, vizt:--From Plumpton into Scotland, for xiiij days, and for feeding and liming [luring?] his said Falcon, for the same time, by his own hands, in the same place, in the same day . . .

To the same, for his expenses for vij days, coming from London to the king, at the mandate of the king himself, on the xxiij day of April for the last reckoning, receiving by the day xijd, and for the expenses of two horses and a boy of his staying for vij days at the court before his departure towards Scottish parts as foresaid is, the last day of April for

1 Vol. ii. pp. 136, 137. 
$1296-7$.

the latest reckoning, receiving by the day vij. 6 , by

his own hands, in the same place, the first day of

May, of the gift of the king ${ }^{1}$. . . . - xj iijaG

From an ancient Rental of Coldingham, drawn up after the battle of Falkirk, which took place on the $22 \mathrm{nd}$ of July 1298, we fund that there were at Coldingham at that period two eyries of Falcons which were not saleable. ${ }^{2}$ On the 25 th of Octuler of that year Edward 1. of England granted to Walter de Money all the eyries of "Falcous gentily" in his demesne lands of scotland, for his life, for" the yearly payment of "deux piers bien affaitez." 3 In 1329 , shortly before the death of King liobert the Bruce, there appear in the liolls payments for repairing and surrounding with a fence the house for his Hawks at his manor of Cardross. ${ }^{4}$ Later in the same century Falcons were brought to David II. from John of the Isles. ${ }^{5}$ James III. seems to have been devoted to falconry, for in his reign falconers were specially sent to Orkney for Hawks; ${ }^{\circ}$ and in his seventh Parliament, which was "halden at Edinburgh, the ninth daie of May, the zeire of God, ane thousand, foure hundreth, seventie foure zeires," he statutes and ordains-_."That in time cumming na manner of persons take ane uther man's hounds nor haulkes, maid or wilde, out of nestes, nor eggs out of nestes, within ane uther mannis ground, but licence of the Lord, under paine of ten poundes. And in likewise that na egges be tane out of the Pertrickes nor Wille-duik-nests,

${ }^{1}$ I an indebted to Mr. Hardy for the above interesting extracts about Earl Patrick.

2 The Correspondence, Inventories, Account Rolls, and Law Proceedings of the l'riory of Coldingham: Surtees Society, 1841.

3 Calendar of Documents relating to Scotland, vol. ii., 1272-1307, p. 261.

$\$$ Accounts of the Lord High Treasurer of Scotland, vol. i., 1473.98, Preface, pp. cexlviii., cexlix.

${ }_{5}^{5}$ Exchequer Rolls of Scotlend, vol. i., 1264-1379, p. 511.

6 Ibid. vol. viii, p. 276. 
under the paine of fourtie shillings." 1 The numerous entries in the Accounts of the Lord High Treasurer of Scotlend of expenses comnected with falcomry during the reign of James 1v. show that "the champion of the dames" was passioniately fond of that sport, and we find one to the effect that "on monnunda the iiij da Januar" 1489, the king "raide to Lauder to the halkin," 2 the extensive common there being well suited for that purpose. On the 19th of November 1496 he appears to have visited Home with his falconers, ${ }^{3}$ where he remained for ten days, and would doubtless enjoy good sport with Lord Home and other noblemen of the Merse, for they would be able to show him not only abundance of the ordinary kinds of game, such as Partridges, Black-game, and (rrouse, but likewise Herons and Bitterns in the extensive marshes and bogs which then covered the surface of the county in every direction. "In pursuing the sport the falconers rode on horseback, for the sake of following the rapid movements of the Hawks, and were accompanied by dogs ${ }^{4}$ for the purpose of 'serving' the Hawlis or mising the yuarry. This was sometimes done by persons who accompanied them on foot. Such were the "laddis that ran with the king at the halling,' and the 'childer' that chasit dukis in the dubbis and set thaim up to the halkis." "5

1 The Laus and Acts of Parliament made by the Kings and Queen of Scolland. Collected by Sir Thomas Murray of Glentook: Edinburgh, 1681, p. 64.

-Accounts of the Lord High Treasurer of Scotland, vol. i., 1173-98, 1). 127.

3 Ibicl. p. 306.

4 "It was usual on excursions of the kind to be accompanien by a water-dog, because the Hawk and its prey sometimes both fell in the water; and in their struggles the Wild-fowl, from its greater power when on the surlace of that element, frequently imperilled the safety of the Hawk by plunging and diving. 'The fowler, meanwhile watching his bird in case of danger, would seut the clog to the rescue, which was so trained that it never attempted to injure the Hawk, but seized the Mallard, or whatever fowl it might be, and brouglit it to its master."-Folkard, The Will liouler, ]. 12.

sAccounts of the Lord High Treasurer of Sichand, vol, i., 1473-98, Preface, 1. celiii. 
A trained Falcon was of great value, and was a fitting present for a prince to give or receive. On the 21 st of September 1488 James IV. gave $£ 180$ to the "Erle of Angus for a Halk;"1 and large sums were paid for the expenses of falconers going in the beginning of Maly to "the Northland for Halkis." 2

In a royal inspeximus granted by the same king at Edinburgh, on the 24th of February 1490, of a charter in favour of the Prioress of the Cistercian Abbey of Collstream, of a ploughgate of land in the town of Lancle, in the sheriffdom of Berwick, granted at "Caldstreme," on the 21 th of June 1489 , by John Liddell of "Lanele," the redcurto is fixed at a pair of hawking gloves, or twelve pennies. ${ }^{3}$ In this charter hawkings, huntings, and fishings are specially conveyed, ${ }^{4}$ as was usual in deeds of the kind at that period.

About this time it seems to have been the habit of gentlemen to carry their Hilwlis eonstantly with them, and even to take them to church. Alexander Barclay, who lived in the time of James V., thus alludes to this unseemly custom :-

Into the church then comes another sotte,

Without devotion, jetting up and downe

Or to be seene, and to showe his garded cote;

Another on his fiste a Sparhawke or Fawcone.

One time the Hawkes bells jangleth hye, Another time they flutter with their winges;

And now the houndes barking strikes the skye,

Now sounde their feete, and now the chanyes ringes,

They clap with their handes: by suche maner thinges

They make of the church for their Hawkes a mewe,

And canel for their doges, which they shall after rewe. ${ }^{5}$

Mary Queen of Scots, like her ancestors, was fond of

1 iccounts of the Lord High Treasurer of Scotland, vol. i., 1.173-98, 1. 95.

$\because$ Ibitl. pp. 177, 200, 275.

3 Chartulary of the Cisterciun Abbey of Coldstram, by the Rev. Charles Rodgers, 1879, Preface, p. xix.

$\$$ 1bid. p. 51 .

5 Sibbald, Chron. Scot. I'oct., vol. ii. 1)1. 437, 438. 
hawking, and it is in her reign that we first hear of the gum being used in scotland to kill wild-fowl, "quhairthrow, the Noblemen of the liealme, can get na pastime of halking and hunting like as has bene in times by-past." The destruction to sport, "be occasion foresaid," seems to have been considered so serious, that on the 29 th of May 1551 the Scottish l'arliament passed the following Act-"Anent them that sehuttis wilh gumis at Deare and Wilcefowle":- "The samin daye, for-sa-meikle as it was devised, statute, and ordained of before, that nane of Our Soveraine Ladies Leiges, sulde take upon hande to schutte with Halfelag, Culvering, or Pistolet, at Deare, Rae, Wilde-beasts, or Wilde-fowles, under the paine of death: Notwithstanding Our Soveraine Ladies Leiges daylie and continuallie incontrair the tenour of the Actes maid thereupon, incurrand the paines conteined in the samin, schuttis with the Halfehasg, Culvering, and Pistolette, at the saidis Wilde-beastes and Wilde-fowles, quhair-throw the Noblemen of the Realne, can get na pastime of halling an hunting, like as has bene had in times by-past, bee reason that all sik Wilde-beastes and Wilde-fowles ar exiled and banished, be occasion foresaid, etc: It is ordained that nane of Our Sov. Ladies Leiges, of quhat-sumever degree hee be of, take upon hande to schutte with Halfe-hag, Colvering, or Pistolet under the paine of death and confiscation of all their gudes. The taker sill have the escheit of the persones gudes hee apprehendis and sall be rewarded utherwaies, as accordis for his laboures." 1

On the 20th of June 1555 another Act was passed "Anent the slaying of wille-beasts, wilcle-fowles, halling and hunting," whereby it was enacted that " na man take in hand to ryde or gang in their nichbouris corne in halking or hunting, fra the Feast of Pasche unto the

I The Lans and Acts of P'arliament male by the Kings and Qucen of Scotland. Collected by Sir Thomas Murray of Glendook: Edinburgh, 1681, 1). 142. 
time that the samin be schorne, and that na man ryde or gang upon quheate na time of the zeir, and that na Partrick be taken untu the Feaste of Michacl-mes. Ten poundes for the first fault, twentic poundes the nixt, and the thrid fault escheitting of their guds moveable." 1 A third Act was passed at the same date "anentis stealing of Halkes," and it was extended to "the fowlers lyand at wait with their nettes." 2 Hawking must have been a favourite sport of King James VI, for we find him in his first Parliament, on the 15th of December 1567, passing a severe Act to the effect "that quhat-sum-ever person or personis, of quhat Estaite, degree or conditioun that ever they be of, schuttis in ony times cumming with Culvering, Cros-bow or Handbow at I)ae, liae, Hart, Hunde, Hair, Cunning, Dow, Herron, or foule of river within this realm, sall foirfault and tyne their haill moveable gudis," and for the next fault in the case of "ane vagabound not havand gudis," to "cut of his richt hand." 3 During this king's reign no fewer than ten Acts for the preservation of game, and against "schutting with gumes at wylde-fowles," were passed between 1567 and 1621, including one on the 4 th of August of the last-mentioned year which bore "That no man Hunt nor Halk at any time hereafter, who hath not a Plough of land in Heritage under the paine of ane hundredth pounds;" ${ }^{4}$ another of the same date being "Anent the harrying of Haulke Nests, and hunting in Snow." 5

In the reign of James VI., Sir George Home of Wedderburn, who was born about 1550 , and succeeded to the family estate in 1574, seems to have been very fond of hawking. Godscroft, in his MS. History of the Homes of

I The Laws and Acts of Parliament made by the Kings and Queen of Scotland. Collected by Sir Thomas Murray of Glendook: Edinburgh, 1681, 1. 157.

2 Ibid. p. 158 .

\pm Ibid. 19.479.

5 Ibid. 1). 179 .

VOL. II. 
Wedderburn, says of him: "He was very handsome and well-proportioned, and of great strength, and swift of foot. He sang after the manner of the Court, and likewise psalms to his own playing on the harp. He was a keen hunter and delighted in hawking. He was so much given to that sport that he built a hunting lodge called Handaxe Wood, in the Lammermuir Hills, in which he often spent the night. He had Hawks called Merlins and Falcons, and afterwards another kind called Tereells, ${ }^{1}$ which he delighted in even in his old age. He caught both Partridges and Muir-fowl."2

Falconry appears to have been a common sport in Berwickshire towards the end of the seventeenth century, and Mr. Campbell-Swinton of Kimmerghame relates in his Men of the Merse how a party of Merse lairds about this time went "to the setting at Kettleshiel, where the dogs set several times; but it was either an old fowl who rose before the net was ready, or young fowls that were seattered, so that there was none catched by the net but ane old lian; but a hawk of Cavers ${ }^{3}$ took severals, and some were marked where they sat down and were taken."

About the beginning of the eighteenth century guns ${ }^{4}$ lad been so much improved that sportsmen began to shoot game on the wing, and this seems to have led to the abandoument of hawking, a pastime which had delighted successive generations from the days of William the Lion.

Towards the close of the eighteenth century a consider-

1 Male Goshawks (Astur palumbarius). The female Goshawk was known as the Goshawk, and the male, which is smaller than the female, as the Iercel. The lemale Peregrine was known as the Falcon, and the male, which is considerably smaller, as the Tercel-gentle.-Harting's Ornithology of Shakespeare, p. 53.

2 I am indehted to Colonel Milne Home of Wexlderburn for the use of the MS. II istory of the Homes of IVedderburn, from which the above is extracted.

3 Carre of Cavers, who was also Laird of Nisbet.-Men of the Merse, 1p. 59, 60.

- They were formerly such miserable machines that in the middle of the fifteenth eentury it took a quarter of an hour to charge and tire one.-Hallam's Ificllle Alges, vol. i. p. 342. 
able effort was made to revive hawking in England, and about 1780 it had again lecome a common sport in S'cotland. ${ }^{1}$ Mr. Baird, a youmger brother of Sin David Baird of Newbyth, in East-Lothian, kept Falcons in the early part of the present century, and he sometimes got his Hawks from their eyries on the coast of Berwickshire. Lady John Scott-Spottiswoode of Spottiswoode informs me that amongst her very earliest recollections are the occnsional visits of Mr. Baird to Spottiswoode, with his Hawks, where he flew them at Grouse on the moors. ${ }^{2}$

The gun is now used to kill game of all kinds, and with such skill that driven Grouse and Partridges are shot with precision, even when flying at their utmost speed.

Time is like a fashionable host, That slightly shakes his parting guest by the hand; And with his arms outstretched as he would fly, Grasps in the comer: welcome ever smiles, And farewell goes out sighing.

Shañespeare, Troilus and Cressida.

1 Falconry in the British Isles, by Francis H. Salvin and W. Broderick, 1855.

2 Information in a letter from Mr. P. Stormonth Darling, Kelso, dated the 10th of April 1886.

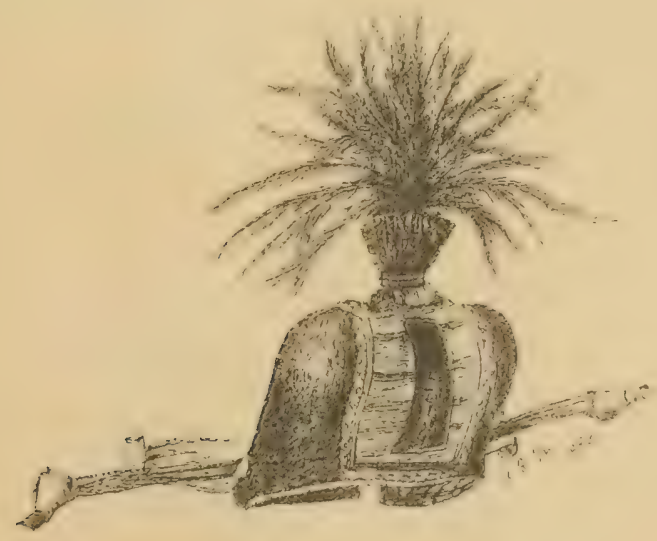




\section{THE HOBBY.}

\section{Falco subbuteo.}

Like Larks zohen they the tyrant Hobby spy, Some, wonder-struck, stand fix'd, some fly.

COWLey.

The Hobby, which may be described as a Peregrine in miniature, very seldom visits Berwickshire, and then apparently only on migration, there being no record of its nest having been found in the county.

Sir Walter Elliot of Wolfelee mentions that when the Berwickshire Naturalists' Club visited Lauder on the 24th of June 1869 , they saw in the museum of a local collector - Mr. Walter Simson, shepherd, Thirlestane Castle-a specimen of the Hobby which had been lilled in that neighbourhood; ${ }^{1}$ and Mr. John Ferguson records that two examples were shot in the vicinity of Duns in 1874, one of them being got at Kimmerghame. ${ }^{2}$

The Hobloy possesses considerable powers of tlight, and was formerly used in falconry to take Larks and other small birds.

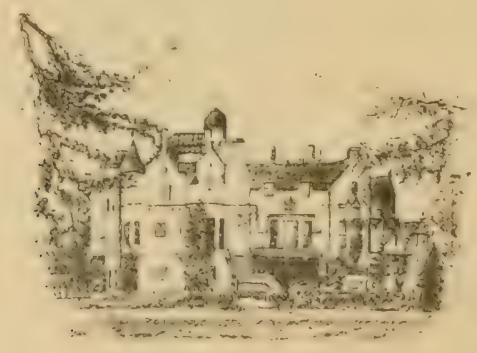




\title{
THE MERLIN.
}

STONE FALCON, ROCK HAWK, SMALL BLUE HAWK.

\section{Falco cesalon.}

\author{
Saving there came a little gray Hareke, \\ A Merlin him they call, \\ Which untill the grounde did strike the grype, \\ That dead he dorone did fall.
}

PERCY, Sir Aldingar.

This beautiful little Falcon is occasionally seen throughout the lower parts of the county in the autumn and winter months, and its nest is sometimes found during summer in the rocky deans of the Lammermuirs.

At the second anniversary meeting of the Berwickshire Naturalists' Club, which took place at Duns on the 18 th of September 1833, the Rev. Andrew Baird of Cockburnspath mentioned in his presidential address that a Merlin had been shot at Blanerne, on the Whitadder $;^{1}$ and Dr. Johnston of Berwick, writing on the 24th of April 1847, says: "To-day Mr. William Dunlop brought me a specimen of the male Merlin which he had shot on the moor above Mayfield on the 22nd inst. On the previous day he saw the bird strike down a Partridge." 2 In the spring of 1872 a young male was killed in the Crow Dean Wood at Paxton; and in February of the following year a male in full plumage was shot in the adjoining plantation of Finchy. ${ }^{3}$ According to Mr. Andrew Kelly, it is by no means rare in the Lauderdale district. A young female was trapped by the game- 
keeper of Quixwood, at a Partridge which it had killed, in October 1878; ${ }^{1}$ and $\mathrm{Mr}$. Hardy records that an example occurred at Knock Hill, four miles from Duns, in the spring of 18 $9 .^{2}$ Mr. W. Smith, samekeeper, Duns Castle, informs me that about 1880 he shot a Merlin near Greenlaw, and auother at Murraylawrigg. In 1882 a specimen was killed at the "Cockit Hat" plantation on Lamberton Moor, where this bird is said to be frequently seen." Mr. Hoggr has informed me that it is very destructive to the Partridges at Quixwood after the pairing time in spring.

The Merlin was in great repute with falconers in former' times on account of its courage and the rapidity of its flight, as well as its capability of being readily trained. Godscroft, in his MiS. History of the Homes of Wedderburn, written in 1611, mentions that Sir George Home, who lived in the time of James vi. of Scotland, had Hawks called Merlins, with which he caught both Partridges and Muir-fowl. ${ }^{4}$

It was the favourite Hawk of ladies in the palmy days of falconry, and was carried on the wrist. It is trained at the present day for the purpose of being flown at Larks, when it shows excellent sport.

A local writer on falconry says: "I once witnessed a most interesting flight between two Merlins in a wild state and a Snipe. As I was crossing Lamberton Moor, accompanied by a gentleman of Berwick, we happened to see two of these birls mounting almost perpendicularly in the air within a few paces of us. Our first impression was that they were amusing themselves by endeavouring to soar above each other, but on watching their movenents for a short time we soon discovered the object of their pursuit

1 Mr. Hogg of Quixwood showed me this specimen on the 18th of October 1882.

2 II ist. Ber. Nat. Club, vol viii. p. 532.

"Information from IIr. James Purves, gamekeeper, Norington House.

1 See article on "Falconry in Berwickshire," pp. 17, 18, sumre. 
only a short distance above them. One of the Hawks appeared from this time to gain rapidly upon the Snipe, whilst the other appeared to make but little progress. At length, and when the Snipe and foremost Hawk had almost disappeared in the sky, the latter, having apparently gained the ascendency, made a rapid stoop, but the former, by a sudden change in its course, eluded the stroke, and, having thrown its antagonist, macle now a descent like a falling star. At this moment the Hawk that had kept below, no doubt waiting for this event, darted like lightning across the sky towards it, which, however, the Snipe, by another dexterous shift, escaped also. Still, all was in vain on the part of the pursued, for before it got many yards the other Hawk shot down upon it and received it in its talons." ${ }^{1}$

The flight of the Merlin when on the outlook for prey is generally at no great height above the ground, and in autumn it may be sometimes seen sweeping along our hedge-rows, where

On the haw-clustered thorns, a motley flock

Of birds of various plume and various note, Discordant chirp."2

The prey of this Falcon usually consists of the smaller kinds of birds, such as Larks, Yellow-Hammers, Chaftinches, and Thrushes, but it likewise attacks Snijes, I'lovers, Partrirlges, and Pigeons. It also feeds upon the larger insects ami beetles, the wing-cases of which are seen in its castings. ${ }^{3}$

A tame Merlin which I kept in 1867-68, and which was taken from a nest in Glen Urquhart, Inverness-shire, in the summer of the former year, used to spread its wings and tail around small birds given to it as food, after scizing them with its claws.

1 Treatisc upon Fralconry, by James Cockburn Belany, Berwick-on-Tweed, 1841.

2 Graliame, The Pural Calender, November.

s Seebohm, II istory of British Birls, vol. i. p. 37. 
This species usually places its nest on the ground amongst heather, on the sloping side of some rocky ravine. In May 1865 Mr. William Cowe showed me a spot of this kind on the farm of Dowlaw,

\section{$? \quad$ In a glen}

Down which a little stream had furrowed deep,

and told me that he had found the eggs there in the previous summer. Mr. Kelly mentions that it breeds on the rugged, heathery braes at Broadshawrig; ${ }^{1}$ and the Pier. George Cook, Longformacus, informs me that he lately saw an egg which had been found on the moor above Byrecleugh. Very few materials are used in the construction of the nest, the eggs, which are four or five in number, and reddish brown in colour, like those of the Kestrel, generally resting on a little dried grass or a few pieces of heather.

A ravine near the Meikle Law, in the parish of Longformacus, is called the Merlin Grain.

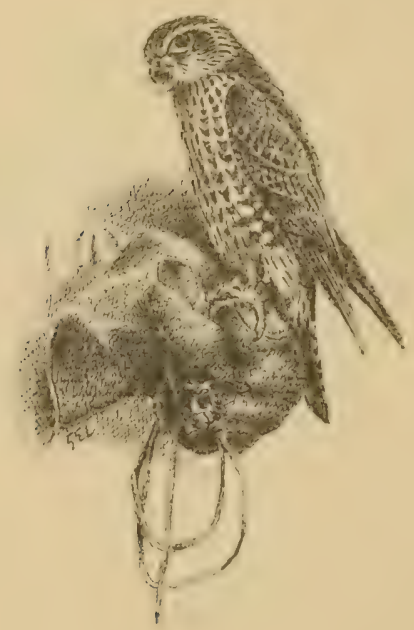




\title{
THE KESTREL.
}

WINDHOVER, STONEGALL, STEINGALL, STANNEL, IED HAWT.

\author{
Falco tinnunculus.
}

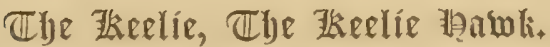

\author{
Oft hovering o'er the barn-yard is she seen \\ In early spring.
}

Grahame, Birds of Scotland.

And with what wing the Stanniel checks at it!

SHAKESPEARE, Treelfth Night.

Tine Kestrel is more frequently seen in the county during spring and summer ${ }^{1}$ than any other rapacious bird, with the exception of the Sparrow-Hawk, from which it may be easily distinguished by its habit of hovering in the air from time to time when searching for prey. Unfortumately, it is often observed nailed up on gamekecpers' vermin rails, although it is one of our most harmless birds of prey, as far as game is concerned, for its foor consists chiefly of mice. It occasionally seizes young Pheasants, however, when they are being reared, and I have seen it attack a young Hare. It also feeds upon small birds; but they do not seem to be much afraid of

1 This species has been observed on migration at the lighthouses on the coasts of England and Scotland, and it is probable that most of our Berwickshire Kestrels pass southwards at the beginning of winter, although some of them remain on the sea-coast of the county during that season. Mr. Hardy mentions in his MIS. Notes that he saw two at Penmanshiel on the 17th of January 1860. He also records (Hist. Ber. Nat. Club, vol. vii. p. 283) that he observed one near Oldcambus on the 23rd of December 1874 during the continuance of a heavy snowstorm; and (ibid. vol. ix. p. 125) that a specimen was seen at Oldcambus on the 31st of Jamuary 1879 , much snow being on the ground at the time, 
it, for, on the 12 th of January 1888, I noticed a male Kestrel sitting on an ash-tree on the farm of Girrick, in the parish of Nenthorn, while several Greenfinches and a Yellow-Hammer were hopping about on the branches within a few feet of its perch. Frogs and beetles also form a part of its food.

It frequents the precipitous rocks on the sea-coast of Berwickshire, where it breeds, some of its favourite nesting places being near Siccar Point, Fast Castle, Blakey, and the Coal Point at Lamberton. It likewise resorts to inland cliffs on the Whitadder and Blackadder, such as the Raven's Knowe near Tibbie Fowler's Glen, and the scaur at Blackcastle Rings on Greenlaw Moor, where the Fangrist joins the Blackadder. ${ }^{1} \quad$ Buildings ${ }^{2}$ are sometimes frequented by this Hawk, and in the wooded parts of the county it frequently takes possession of the deserted nest of a Magpie, Crow, or Wood Pigeon, in a spruce or Scotch fir, laying four or five eggs of a reddish-brown colour.

Its cry, "keelie, keelie, keelie," may be often heard in the breeding season near its haunts.

The Kestrel was formerly used in falconry, but was not much valued for this purpose, and was consequently assigned to persons of inferior rank. ${ }^{3}$

1 When I visiter Blackeastle Rings with Mr. Loney, Marehmont, on the 14th of July 1886, he informed me that he had occasionally olserved the Kestrel's nest there.

2 Mr. Peter Scott, Lauder, tells me that about twenty-five years ago the Kestrel used to nest regularly every season in the drainage holes of the bridge near the Saw Mill at Thirlestane Cistle.

$3 \mathrm{Mr}$. Harting, in his Ornithology of Shakespeare, p. 74, says: "The origin of the word 'Kestrel' is somewhat mncertain. By some it is derived from 'coystril,' a knave or peasant, from being the hawk formerly used by persons of inferior rank, as we learn from Dane Juliana Berners in her Bole of St. Albans. This opinion is strengthened by the rewling ' coystril ' in Twelfth Night (act i. sc. 3) and 'coistrel' in Pericles (act iv. sc. 6)." 


\title{
THE OSPREY.
}

FISH HAWK, FISHING EAGLE, BALD BUZZARD.

\section{Pandion haliocetus.}

\author{
The sailing Osprey high is secn to soar, \\ With broad unmoving wing, and circling slow, \\ Marks each loose strageler in the deep below: \\ Sweeps down like lightning, planges with a roar, \\ And hears his struggling victim to the shore.
}

AIEXANDER WILSON.

THIs interesting bird occasionally visits the sea-coast and rivers of Berwickshire during the time of its migration northwards in spring, and southwards in autumn.

Sir Walter Elliot says that it seems to appear periodically on the Tweed, and, quoting from Sir William Jardine, relates that two Ospreys were killed on Lord Home's property in $1835 . .^{1}$ According to the Bervict: Advertiser of the 30 th of May 1831, one was obtained on the Blackadder in that year. ${ }^{2}$ A specimen was shot many years ago in autumm on the Whitadder, near Ninewells Old Bridge, by Mr. John Blackadder, East Blanerne, who states that he stalked it while it was perched on a tree by the side of the river, which was in heavy flood at the time. ${ }^{3}$ Mr. Peter Hastie, Milne Graden East Mains, has informed me that one day in September 1864 he saw two birds of this species sitting on the rocks opposite Cockburn Mill, his attention having been called to them by the loud quacking of the Ducks which

1 Irist. Ber. Nat. Club, vol, vi. p. 320.

2 Dr. Johnston's MIS. Notes.

3 Information from Mr. John Blackaliler on the 5th of August 1886. 
were swimming in the stream and seemed to be greatly alarmed. He fired a shot at the Ospreys, but did not kill either of them, and they flew away along the Cockburn Braes. Shortly afterwards he heard that one of them had been so severely wounded by Mr. Andrew Bell, Cockburn, that it fell to the ground, but, recovering again, took wing in the direction of the Petreat, where it was found by a boy on the following day lying dead by the side of the Whitadder, and given to Mr. Bertram. ${ }^{1}$ The occurrence of the subject of our notice on the Leader, near the Old Craw $\mathrm{Ha}^{\prime}$ in 1867, and in the vicinity of Newmills Bridge a few years later, is recorded by Mr. Kelly. ${ }^{2}$ The gamekeeper at Mordington relates that on a Sunday afternoon in September 1871 he saw a large bird, which was apparently unable to fly, floating down the Eye, which was in flood at the time, and the current taking it into the "lead" at Netherbyres Mill, Mr. Bell helped him to lay hold of it. It was found to have a trout nine inches long in its claws, and did not, on being pursued, relax its grasp of the fish. It seemed to have been wounded in the thigh by a gunshot. He took it to Ayton Castle, where Mr. Mitchell-Innes gave directions that it should be kept at the kennels and supplied with fish; but as food of that kind could not be got in a fresh state, no boats being at sea at the time, and as it would not eat rabbits' livers, which were offered as a substitute, it died. ${ }^{3}$ From further particulars given to me by the gimekeeper at Ayton Castle, ${ }^{4}$ the bird was evidently an Osprey. The late Mr. Alexander Leitch, Fairneyside, mentioned to me some

1 I saw this specimen in Mr. Bertram's possession at the Retrent in September 1883. He informed me that it measured five feet eight inches from tip to tip of the extended wings.

2 Hist. Ber. Nat. Club, vol. vii. p. 520.

${ }^{3}$ Information from Mr. James Purves, gamekeeper, Mordington, on the 28th of December 1885.

${ }^{4}$ Mr. Hugh Fraser, now gamekeeper at Kelloe, 
years ago that a bird of this species was seen frequenting the high rocks on the sea-coast near Burnmouth about the same time as the above incident occurred.

Mr Campbell-Noble tells me that two examples were observed haunting the rocks on the coast opposite Coldingham Shore in October $1886{ }^{1}$

The Osprey feeds upon fish, which it takes by plunging into the water from a considerable height in the air and seizing them in its talons, or by swooping down and bearing them off in its claws when near the surface."

In former times its eyrie was to be found on many of the remote lakes in the Highlands, but now it is seen in very few localities.

It is a migratory bird, leaving the northerly part of its range in autumn and wintering in the sunth of Europe and north of Africa.

\footnotetext{
1 Information from Mr. Campbell-Noble, Coldingham, on the 13th of December 1886.

${ }^{2} \mathrm{~A}$ fish when seized by an Osprey is always carried lengthways in the bird's talons.-Seebohm, History of British Birds, vol. i. p. 59.
}

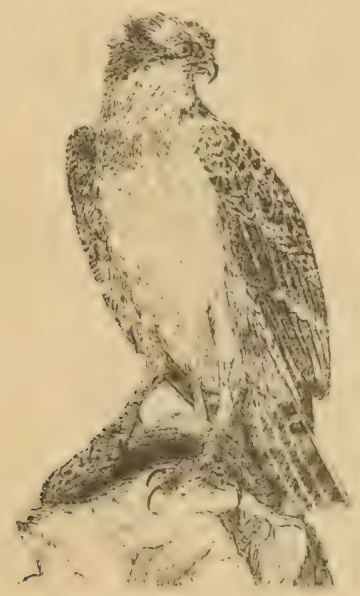




\title{
THE COMMON CORMORANT.
}

\author{
BLACK COPMORANT, GREAT CORMORANT, WHITE-HEADED \\ CORMORANT, WHITE SPOT CORMORANT, GREAT \\ SCART OR SCARVE, COAL GOOSE.
}

Phalacrocorax carbo.

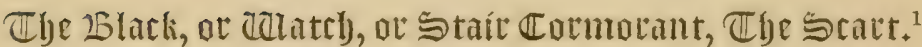

\author{
Even as the matron at her nightly task, \\ With pensive labour draws the flaxen thread, \\ The wasted taper and the crackling flame \\ Foretell the blast. But chief the plumy race, \\ The tenants of the sky, its changes speak. \\ Retiring from the downs, where all day long \\ They pick'd their scanty fare, a blackening train \\ Of clamrous Rooks thick-urge their weary fight, \\ And seck the closing shelter of the grove; \\ Assidnous, in his bower, the rvailing Owl \\ Plies his sad song. The Cormorant on high \\ Wheels from the deep, and screans along the land.
}

THOMson, Winter.

Altrougif the Common Cormorant does not breed on the Berwickshire coast, ${ }^{2}$ it is found in numbers off the shore in the autumn, winter, and spring months. It appears to have certain favourite resorts, such as the Scart Rock, ${ }^{3}$ near Siccar Point, where it may be often seen resting and preening its feathers, a habit which is thus referred to by old Gawin Douglas

\footnotetext{
1 It is also called by the Firth of Forth fishermen "Letter o' Marque," from the white patch on its thigh. - Sporting Days, by J. Colquhoun, p. 16.

$\because$ It, however, breeds at the Farne Islands, which are within a few miles of Berwickshire.-Birds of Northumberlanel and Durham, by J. Hancock, p. 131.

${ }^{3} \mathrm{Mr}$. Hardy says that there is another Scart Rock near the Green Stane, famous amongst the fishermen for the great takes of lierring near it in the olden time. The Green Stane is situate about a mile west from Dowlaw.
} 
And in the calm or loune widdir is sene, Aboue the fludis hie, ane fare plane grene, Ane standying-place quhar Skartis with thare bekkis, For gane the son gladly thaym prunyeis and bekis.

Mr. Hardy has noticed that when the assemblages of Cormorants on Craig Taw, a black rock off Siccar Point, are larger than usual, say from twenty to thirty birds, they betoken wet, stormy weather. ${ }^{1}$

The screaming of sea birds and their approach to the shore seem to have been looked upon from very ancient times as signs of a gathering storm, for we find Virgil in his Gcoryics alluding to these propensities in the following descriptive lines :-

Jam sibi tum curvis male temperat unda carinis ;

Quum medio celeres revolant ex :equore mergi,

Clamoremque ferunt ad littora.

In a recent and more prosaic age we have Bailie Jarvie saying nearly the same thing, but in other words: "Thae women at Aberfoil are like the scarts or sea-maws at the Cumries, there's aye foul wenther follows their skirling:" "2

The Cormorant is very wary and difficult to stalk. Its flight is generally low over the surface of the water, with rapid beats of the wings, and is often continued for a considerable distance in a straight line. It feeds almost wholly on fish, and swims with surprising speed, while it pursues its fimny prey uncler water with great agility and pertinacity, displaying such skill in their capture that it has from time immemorial been taned in China and Japan and trained to catch fish. Mr. J. E. Harting, in his Omithology of Shakespcarc, says that James I. kept trained Cormorants for many years, and was accustomed to travel about the conntry with them, fishing wherever he went. He mentions that on

1 "1874, Oclober 16/\%.-Twenty-three Cormorants at Siccar. I have noticed that these assemblages betoken bad weather." - Hist. Ber. Nat. Chub, vol. vii. p. 281.

2 Sir Walter Scott, Rob Roy. 
the 7th of May 1610, the King was at Thetford, in Norfolk, hunting, havking, and fishing with Cormorants; also that James had a regular establishment for his Cormorants on the river at Westminster, and created a new office, "Master of the Royal Cormorants." 1

The voracity of this bird is proverbial. A specimen obtained near Paxton in Jamuary 1877 had in its stomach a bull trout (Salmo eriox) seventeen inches in length, along with the remains of other fish. ${ }^{2}$ It occasionally comes up the Tweed from the sea in the winter and spring months, an example in immature plumage having been shot while sitting on the top of a tall tree by the side of the river at Paxton in the winter of 1871. The Rev. Thomas Mills, who wrote the report on the parish of Ladylirk in the Old Statistical Account of Scotland, 1793, mentions that "Goosanders, Wigeons, and Cormorants resort to the Tweed in severe winters, and sometimes Grebes and Speckled Divers." 3 It has apparently given its name to Scart Heugh on the Tweed, near the Old Camp at Milne Graden.

There is no difference in the colour of the plumage of the adult male and female. In their nuptial dress they have a large white patch on each thigh. The tail consists of fourteen feathers.

\footnotetext{
1 The Ornithology of Shakespecore, by J. E. Harting, 1871, pp. $261,26^{\circ} 2$.

2 Hist. Ber. Nat. Club, vol. viii. p. 184.

3 The Statistical Account of Scotland, by Sir John Sinclair, Bart., 1793, vol. viii. p. 74 .
}

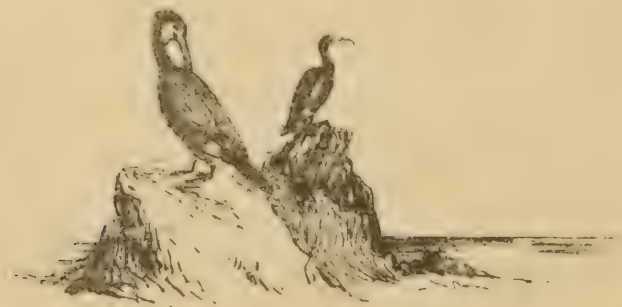




\section{THE SHAG OR GREEN CORMORANT.}

CRESTED CORMORANT, SCART, SCARF, TUFTED SKART.

Phalacrocorax graculus.

\section{The grat.}

Others there are that make their home

Where the white billows roar and foam

Around the o'erhanging rock;

Fearless they skim the angry wave,

Or, sheltered in their sea-beat cave,

The tempest's fury mock.

Hemans, Birds.

The Green Cormorant is found on the coast of Berwickshire at all seasons of the year, and breeds at the Brander Cove, a lofty shelving ridge of rocks which runs out into the sea about a mile to the east of Fast Castle. Here my friend Mr. W. Evans sav a colony of ten Green Cormorants, and put one off a nest which contained three egrgs on the 15th of May 1887. I visited the spot in a boat on the 30 th of June following, when, in addition to an old bird sitting on a nest in a crevice of the rock about thirty feet above the water, I noticed another with two young on an adjoining ledge. They were not shy, but sat quietly and allowed me to examine them with my binocular from the boat, which was close to the bottom of the rock. The Brander Cove has been long known as a favourite nesting place of this species, Mr. Hardy having noted it as such in 1855, along with Caldron Cove, Harelaw Cove, and Byreloch Heugh. He adds that about the same time Mr. Wilson of Coldingham informed him that he had seen the nest of the Shag on the shelves at the sides of Caldron Cove as well as VOL. II. 
in the dark recesses at the top. It was breeding at the Brander Cove on the 16th of July 1880.1 The nest is generally a somewhat bulky structure, principally composed of sea-weeds and grass, a favourite site for it being a ledge at the side of a cave. The eggs, which are usually three or four in number, are pale blue, encrusted with chalky white.

Selby, in his account of birds observed at St. Abb's Head on the 18th of July 1832, says: "As we returned seaward in the boat several Green Cormorants were seen perched upon the pinnacles of the smaller isolated rocks, surveying with keen and watchful eyes our progress, and always too much upon the alert to permit us to approach within gunshot." 2 Mr. Archibald Hepburn, in his Notes on birds found at St. Abb's Head on the 20th of June 1850 , mentions that " a few pairs of the Green Cormorant haunt the coast." 3

In its habits the Shag resembles the Common Cormorant, and is more or less gregarious. About the neighbourhood of St. Abb's Head it may be often seen perched on some rocky point or shelf, resting and preening its feathers, or winging its way rapidly out to sea, keeping low over the surface of the water. It is fond of frequenting caves, to which it retreats during the wild storms of winter. The food consists almost entirely of fish. The Shag is considerably less than the Cormorant, while the plumage of the male and female is alike in colour. It has twelve feathers in the tail, whereas the Common Cormorant has fourteen.

$1 \mathrm{Mr}$. Hardy's MS. Notes.

= IIist. Ber. Nat. Club, vol. i. p. 19.

${ }^{3}$ Toid. vol. iii. p. 74. 


\section{THE GANNET, OR SOLAN GOOSE.}

GAN, HERRING GANT, BASS GOOSE, CHANNEL GOOSE, SPECTACLED GOOSE.

\section{Sula bassana.}

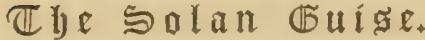

IVild around their rifled brows, with frequent cry, As of lament, the Gulls and Ganncts fly.

SiR WALTER SCOTT.

ON account of the vicinity of the Bass, the Gannet is seen in considerable numbers on the coast of Berwickshire from April to September, and is generally observed winging its way to or from that well-known breeding station, or fishing off the shore. The earliest date in spring at which its appearance on the coast has been recorded by Mr. Hardy is the 30th of March 1881. It is occasionally found in the interior of the county after tempestuous weather. About the middle of January 1877 a bird of this species was captured alive and in good condition at Duns Castle Lake, ${ }^{1}$ and Mr. Charles Watson, Duns, informed me that another was caught near Chapel in October 1882. Mr. W. Leckie states that three examples were observed in Spottiswoode bogs some years ago, having no doubt been driven there by severe weather at sea, and that one of them, which was wounded by Mr. W. Buckholm, shepherd to Lady John Scott-Spottiswoode of Spottiswoode, was put into a pond there, where it died. It was afterwards preserved by Mr. W. Renton. 
The Gannet leaves the Bass in autumn, and does not return until spring. ${ }^{1}$

Its flight is very powerful and long sustained, and it sometimes travels immense distances to feed. It is interesting to watch a party of Gannets fishing, for the birds descend headlong from various heights in the air, and plunge into the sea with such force as to leave the surface covered with foam at the spots where they disappear under the water. In a few moments they emerge, and, after sitting for some seconds on the water, mount on the wing again and renew their search. Their skill in capturing fish had been noticed by Holland, for he thus alludes to it in his Houlat :-

And als in the advent,

The Soland stewart was sent ;

For he could fra the firmament

Fang $^{2}$ the fische deid.

The salmon-fishers on the coast say that when Gannets are observed frequently plunging into the sea for fish near the shore, a good take may be expected in the nets.

Although at the present day the Solan Goose is by no means reckoned a dainty dish for the table, yet it appears to have been considered so by Berwickshire lairds long ago, for in The Men of the Merse we find Lord Crossrig inviting George Home of Kimmerghame "to a Solan Goose" in March $1699 .^{3}$ It was esteemed as an article of food in the Middle Ages. ${ }^{4}$

The grease of this bird appears to have been very much valued in the olden times, for in the General Register House,

1 It returns to the Bass early in February, and lingers there till October, although most of the birds leave the rock when the young are taken in August.Hist. Ber. Nat. Club, vol. vii. p. 17.

2 Capture.-Jamieson, Scot. Dict.

3 The Men of the Merse, by Archibald Campbell-Swinton Esq. of Kimmerghame, 1858 , p. 61 .

+ Accounts of the Lord High Treasurer of Scotland, vol. i., 1473-98, Preface, ccv. 
Edinburgh, there is a "commission by Pope Alexander" vi. to the Prior and Archdeacon of St. Andrews, to investigate a claim by the prioress of North Berwick against Robert Lauder of the Bass, and rector of the parish of the Bass, for certain barrels of grease of geese, dated 10th May, 1493." " The following interesting "Excerpts from the Books of John, Duke of Lauderdale, respecting the price of Solan Geese, from 1674 to 1678 ," were communicated to the History of the Berwickshire Naturalists' Club ${ }^{2}$ by $\mathrm{Mr}$. Robert Romanes of Harryburn, Lauder :-

"THE BASS.-John, Earl, afterwards Duke, of Lauderdale, was in 1671, March 3rd, Captain of the Bass.

"August 21st, Keeper of the Bass.

, September 7th, Gorernor of the Bass.

1674. "By pryce of Sollen-geese of the Bass, 1674. The accomptant charges himself with the pryce of 1118 Sollen-Geese, sold for $1 \mathrm{lb}$. $8 \mathrm{~s}$. 4 d. each score, p. contract accordinglie, dated 10th June, 1674, . . . £79 3s. 10d. sterling."

"To the climber of the Bass in full of his fee, waige, and allowance for the year and season 1674, and for some other small necessaries and charges that year, p. discharge upon the back of the contract accordinglie, - . . $£ 11$ 12s. 2d. sterling."

1675. "By pryce of 1060 Sollen-Geese, as the product of the Bass the season 1675 , sold for $1 \mathrm{lb}$. 9s. 2d. sterling each score, p. contract accordinglie, dated 11th May, 1675, . . $\quad £ 77$ 5s. 10d."

"To Charles Maitland in the Bass for his expense when he went to London with Sollen-Geese, p. his Grs. Order and his Receipt, dated 19th October, 1675, . . $£ 20$ 0s. 0d."

1676. "By pryce of 1150 Sollen-Geese as the product of the Bass for 1676 , sold as above, p. contract 24 May, 1676, . $\quad £ 83$ 17s. 1d."

1677. "By pryce of 985 Sollen-Geese sold at $1 \mathrm{lb} .9 \mathrm{~s} .2 \mathrm{~d}$. each score, for" the season $1677, \mathrm{p}$. contract accordinglie, . $\quad £ 71$ 16s. $5 \frac{1}{2} \mathrm{~d} . "$

1678. "For the Sollen-Geese in the Bass for year" and season 1678, Charles Maitland is settled with, and here is the agreement made with him thereanent :-

'At Edinburgh, the 10th day of May, 1678, it is agreed upon and consented to betwixt Sr. William Sharp of Stonyhill on the ane part, and Charles Maitland, son to Robert Maitland, keeper of the Bass, on the other part, That is to say the said Sr. William Sharp setts and letts to the said Charles Maitland the whole Sollen-Geese of the Bass for the season 1678, for the sum of three score fifteen pounds sterl, to be payed to the said Sr. William 
Sharp, his heires, and exrs. free of all charges whatsomever incumbant to the delivery of the said Sollen-Geese, and the said Charles Maitland binds him and his heires and excrs. to content and pay to the said Sr. William Sharp and his foresaids, the said sum of seventy-fyve pound sterling, the one half at the date of their presents and the other half upon the twenty nynth day of September next to come in this instant year 1678, with the sum of ane hundred pounds Scots of failzie, to be payed by the partie failziear to the party willing to observe the premises. In witness yrof both parties have subscribed their presents with their hands tyme and place aforesaid before these witnesses, John Robertson, writer in Edr., and David Callender, writer hereof.

'Charles Maitland is also to give to me in this season two dozen good Sollen-Geese free.'"

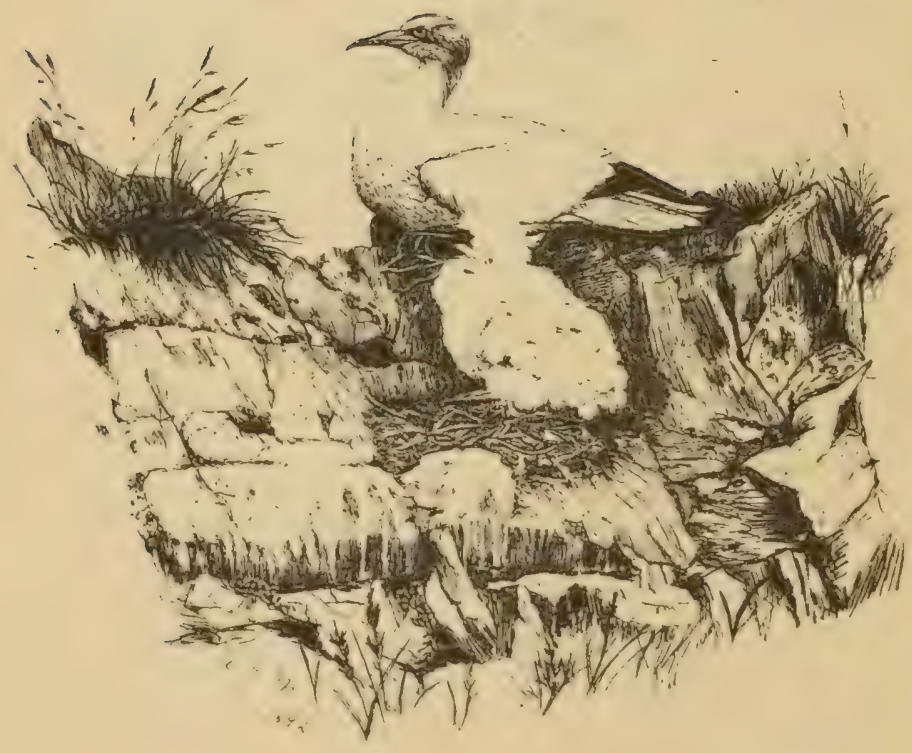




\title{
THE COMMON HERON.
}

GREY HERON, CRESTED HERON, HERONSHAW, HURON, FRANK, CRANE, CRAIGIE HERON, LANG-NECKIT HAARAN.

\section{Ardea cinerea.}

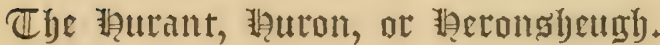

\author{
Lo! at his siege, the Hern \\ Upon the bank of some small purling brook \\ Observant stands to take his scaly prize, \\ Himself another's game; for, mark, behind \\ The wily falc'ner creeps; his grazing horse \\ Conceals the treach'rous foe, and on his fist \\ Th' unhooded Falcon sits; with eager eye \\ She meditates her prey, and in her wild \\ Conceit already plumes the dying bird.
}

IN olden times this interesting and picturesque bird, which is frequently seen in every district of the county, was so much prized for the "marvellous and delectable" sport which it yielded to the falconer, that an Act was passed by the Scottish Parliament in 1493 for preserving Herons. ${ }^{1}$ Mr. Thomas Dickson, in his Accounts of the Lord High

1 James IV. Anno 1493.- "Anent the distroying of Heron sewis."-Acts of the Parliaments of Scotland, vol. ii. p. 235. This Act was renewed in 1567 against all such as shoot with "Culveringis, Crosbow, or Handbow ony time at Dae, Rae, Hart, Hyud, Hair, Cumning, Dow, Herron, or foule of river," the penalties being that they "sall foirfault and tyne their haill moveabil gudis," and "gif the committer of the cryme be ane vagabound not havand gudis, that the judge, quhom befoir he is convict, keip and hauld him in prison for the space of fourtie dayis. And that for the first fault. And the nixt fault, to cut of his richt hand." -The Laws and Acts of Parliament of Scotland, by Sir Thomas Murray of Glendook, 1681, pp. 186, 187. 
Treasurer of Scolland, says that the Heron and the Bittern were the highest quarry at which Falcons were flown, and when struck by the Hawk, the former was " either released to furnish fresh sport, or kept to be used in perfecting the training of other Falcons. It was for this purpose- 'to mak tranis to the halkis'- that 'quyk' or live Herons were frequently brought to the king," 1 as shown by the following entries in the Accounts:-

1496. "Item, the last day of Julij, giffin to the man that brocht twa quyk herounis to the King to mak tranys to halkis, - ix s." a

1497. "Item, that samyn day (the last day of May) gevin be the Kingis command to ane man of the Lard of Dawikkis, that brocht quyk herounis to the King, . . . . . . xviij s." 3

The kings and nobility of Scotland, like their compeers in England, ${ }^{4}$ appear to have followed the sport of Heron hawking with great ardour, and as an instance of this it may be mentioned that Archibald Douglas, 7th Earl of Angus, on seeing a Heron rise from a marsh at the beginning of the battle of Ancrum Moor, ${ }^{5}$ is said to have exclaimed, "Oh! that I had my white Croshawli here, that we might all yoke at once." 6 Ladies often went out with the falconers to the Heron hawking and took an active part in the sport. ${ }^{7}$ It must indeed have

1 Accounts of the Lord High Treasurer of Scotland, 1473-1498, Preface, p. cclii.

2 Ibid. p. 287.

3 Ibid. p. 338 .

${ }^{4}$ Not only were Herons protected by Parliament in England, but penalties were incurred by taking their eggs. The fine was $8 d$. for every egg. See 3 and $4 \mathrm{Ed}$. vi. c. 7 , and 25 Henry viI. c. 2.-The Ornithology of Shakespeare: Harting, pp. 222, 223.

5 This moor, which lies $1 \frac{3}{4}$ miles north-west of the village of Ancrum, was the scene of one of the last great conflicts in the international war between Scotland and England. In 1554 an English army 5000 strong, under Sir Ralph Evers and Sir Bryan Latoun, overran and wasted the Scottish Border northward to Melrose. Returning with their booty, they were overtaken at Anerum Moor and utterly routed by a Scottish force under the Earl of Angus and Scott of Buccleuch.Ordnance Gazetteer of Scotland, vol. i. p. 49.

${ }^{6}$ Dryburgh Abbey: its Afonks and its Lords, second edition, 1860, p. 24.

7 Strutt's Sports and Pastimes. 
been a gallant sight when "the champion of the dames," accompanied by many of the nobility and ladies of his court and the falconers on horseback, went a-hawling; and we know from the Lord High Trcasurer's Accounts that he sometimes visited Berwickshire for this purpose, one occasion being "on Monnunda, the iiij da Januar (1489), quhen he raide to Lauder to the halkin." 1

The Heron was formerly esteemed as an article of food ${ }^{2}$ and held a high place at the tables of the great, where it appeared at the marriage and other principal feasts. ${ }^{3}$ An entry in the Northumberland Houschold Book in the time of Henry viII. reads that "it is thought in likewyse that hearonsewys be bought for my lorde's owne mees, so they be at xijd. a pece." Mr. James Smail, in his interesting paper on "Herons and Border Heronries," ${ }_{4}$ says that even when plump and dressed and roasted to perfection, the flavour of the Heron is so fishy as to be quite unpalatable, "but the young birds taken from the nest and properly stewed are really good."

Its beautiful plumes appear to have been used to ornament the caps of the highest in the land, and Sir Walter Scott, referring to this in his description of the meeting of Lord Marmion and Sir David Lindesay of the

1 Accounts of the Lord High Treasurer of Scotland, 1473-1498, p. 127.

2 Ibid. Preface, p. ccv.

3 The following directions for roasting the Heron appear in Le Vrai Cuisinier François, Brusselles, 1699, a copy of which is in the possession of Miss Dickenson of Norham:- "Plumez-le, et le vuidez; ensuite vous chercherez six cimeres qui sont sur son corps, et un autre faisant le septieme* qui est au-dedans; troussez les jambs le long des cuisses, faites-les blanchir sur le feu, et le piqués, envelopez le col avec du papier beurré, puis le faites rôtir, et etant cuit, servez." The Heron is mentioned in the book as being in season "depuis la S. Remy (1st October) iusques en Carême" (Lent).

Hist. Ber. Nat. Club, vol, x. p. 331.

* Rolland, in his Faune Populaire de la France, 1879, says, "Le peuple prétend que le Héron a sept vésicules de fiel," 
Mount in "Saltoun's Wood," says of the "Lord Lion King at Arms," that

His cap of maintenance was graced

With the proud heron-plume.

Folkard mentions that "among our ancient customs, was one of swearing an oath upon the dead body of a Heron, and whereby many a gallant knight has, in years long passed, plighted his troth to his 'ladye faire,' as the most solemn and honourable manner of assuring her of his sincerity." I

It is said in some parts of the county that when Herons are seen flying up the course of the Tweed in numbers it betokens stormy weather. This may be on account of the bird's habit of leaving discoloured waters and proceeding to smaller and clearer streams during floods. The association of the lofty flight of the Heron with approaching stormy weather is thus referred to by Virgil in his Georgics:-

\section{notasque paludes}

Deserit atque altam supra volat ardea nubem.

And Thomson, in his description of an approaching storm in winter, says :-

Loud shrieks the soaring Hern, and with wild wing The circling sea-fowl cleave the flaky clouds.

The Heron generally builds on lofty trees in woods, and commonly in colonies after the manner of the Rook; the nest, which is formed of sticks and lined with twigs and dry grass, being of a large size. It is an early breeder, and the eggs, which are three or four in number and of a uniform bluish-green colour, are usually laid towards the end of March. ${ }^{2}$

1 The Wild Fowler, Folkard, second edition, 1864, p. 194.

2 According to Mr. George Bolam's MIS. Notes he found eggs in the nests of the Herons at the Pistol Plantation Heronry on the 1st of April 1881. Dr. Stuart records that Mr. A. H. Evans saw young birds in the nests at the above Heronry on the 21st of A pril 1879.-Hist. Ber. Nat. Club, vol. ix. p. 135. 
The following are lists of the Heronries which are found in Berwickshire at present (1887), as well as of those which existed in the county in former times, but are now abandoned; and I take this opportunity of thanking my correspondents for the information regarding these which they have so kindly supplied:-

HERONRIES EXISTING IN BERWICKSHIRE IN 1887.

\begin{tabular}{|c|c|c|}
\hline PARish. & $\begin{array}{l}\text { SitUation of HERonRy AND } \\
\text { Aproximate NUMBER OF NESTS. }\end{array}$ & $\begin{array}{l}\text { NAME AND ADDRESS } \\
\text { OF REPORTER. }\end{array}$ \\
\hline Buncle. & $\begin{array}{l}\text { Buncle Wood. }-2 \text { or } 3 \text { nests in old } \\
\text { Scotch fir-trees. }\end{array}$ & $\begin{array}{l}\text { John Blackadder, } \\
\text { East Blanerne, } \\
\text { Chirnside. }\end{array}$ \\
\hline Duns. & $\begin{array}{l}\text { Castle Wood, on Duns Castle } \\
\text { Estate.-About } 40 \text { nests in Scotch } \\
\text { fir-trees. A Heronry has existed in } \\
\text { this wood from time immemorial, } \\
\text { but its exact locality has been } \\
\text { changed to different parts of the } \\
\text { wood at least three times, owing to } \\
\text { the destruction of the trees by high } \\
\text { winds. }\end{array}$ & $\begin{array}{l}\text { John Ferguson, } \\
\text { Duns. }\end{array}$ \\
\hline Lauder. & $\begin{array}{l}\text { Olister Dub; West Mains Brae; } \\
\text { Boiling Park; and old trees be- } \\
\text { tween Luggy and Wester Park- } \\
\text { all in and about the Thirlestane } \\
\text { Castle Policies. - From } 2 \text { to } 5 \text { nests } \\
\text { in each. }\end{array}$ & $\begin{array}{l}\text { Robert Romanes } \\
\text { of Harryburn, } \\
\text { Lauder. }\end{array}$ \\
\hline Whitsome. & $\begin{array}{l}\text { Pistol Plantation ; chiefly on tall } \\
\text { Scotch fir-trees south from forester's } \\
\text { house. - About } 50 \text { nests scattered } \\
\text { through the plantation. (Mr. Hardy } \\
\text { records the discovery of this Heronry } \\
\text { by Dr. Stuart in } 1875 \text { - History of } \\
\text { the Berwickshire Naturalists' Club, } \\
\text { vol. vii. p. 516.) }\end{array}$ & $\begin{array}{l}\text { Charles Stuart, } \\
\text { M.D., Chirn- } \\
\text { side. }\end{array}$ \\
\hline Mertoun. & $\begin{array}{l}\text { Mertoun House Policy; high } \\
\text { beech-trees.-About } 35 \text { nests. }\end{array}$ & $\begin{array}{l}\text { John Thomson, } \\
\text { Maxton, St. } \\
\text { Boswells. }\end{array}$ \\
\hline Coldstream. & Hirsel. & \\
\hline Eccles. & Lithtillum Loch. & \\
\hline
\end{tabular}


HERONRIES WHICH FORMERLY EXISTLD IN BERWICKSHIRE, BUT ARE NOW ABANDONED.

\begin{tabular}{|c|c|c|}
\hline PaRish. & $\begin{array}{l}\text { SitUation OF HeronRy AND } \\
\text { APPROXIMATE NUMBER OF NESTS. }\end{array}$ & $\begin{array}{l}\text { NAME AND ADDRESS } \\
\text { OF REPORTER. }\end{array}$ \\
\hline Longformacus. & $\begin{array}{l}\text { At the bottom of the Narch Wood, } \\
\text { between Fellcleugh and Ellemford, } \\
\text { near the junction of the Dye and } \\
\text { Whitadder. }\end{array}$ & $\begin{array}{l}\text { Rev. George Cook, } \\
\text { The Manse, } \\
\text { Longformacus, } \\
\text { Duns. }\end{array}$ \\
\hline Polwarth. & $\begin{array}{l}\text { Twenty-three years ago there were } \\
\text { from } 10 \text { to } 12 \text { nests on the highest } \\
\text { chestnut-trees at Marchmont, but } \\
\text { during the making of the Berwick- } \\
\text { shire railway the engines, which } \\
\text { were constantly running along the } \\
\text { line at night, apparently frightened } \\
\text { the Herons away, for they left their } \\
\text { nests at that time and have not } \\
\text { returned. (Mr. Hardy, in lis MIS. } \\
\text { Notes, says thero used to be a } \\
\text { Heronry at Marchmont; where the } \\
\text { birds made a great noise. They } \\
\text { were protected by Sir W. Purves } \\
\text { Campbell.) }\end{array}$ & $\begin{array}{l}\text { Peter Loney, } \\
\text { Marchmont, } \\
\text { Duns. }\end{array}$ \\
\hline Westruther. & $\begin{array}{l}\text { A small Heronry, consisting of } \\
\text { from } 8 \text { to } 12 \text { nests, formerly existed } \\
\text { in the Circle Plantation, which } \\
\text { stood about a hundred yards to the } \\
\text { east of Gateside School. About } \\
\text { twenty years ago a great gale blew } \\
\text { down the high spruce firs upon } \\
\text { which the nests were placed, and } \\
\text { this destroyed the Heronry. For a } \\
\text { few years afterwards a number of } \\
\text { Herons built on the trees at Crumles } \\
\text { Bridge, near Bruntaburn, but boys } \\
\text { interfering with their nests caused } \\
\text { them to abandon that situation. } \\
\text { The Herons always chose trees } \\
\text { having round tops, and made very } \\
\text { large circular nests. }\end{array}$ & $\begin{array}{l}\text { Walter Lockie, } \\
\text { Gateside School, } \\
\text { Spottiswoode, } \\
\text { Westruther, } \\
\text { Lauder. }\end{array}$ \\
\hline Foulden. & $\begin{array}{l}\text { A few Herons took up their abode } \\
\text { at Foulden about } 1830 \text {, on trees a } \\
\text { short distance to the south of the } \\
\text { Mansion House, but did not con- } \\
\text { tinue long there. }\end{array}$ & $\begin{array}{l}\text { John Wilson of } \\
\text { Welnage, Duns, } \\
\text { May } 4 \mathrm{th}, 1886 \text {. }\end{array}$ \\
\hline
\end{tabular}




\begin{tabular}{|c|c|c|}
\hline Parish. & $\begin{array}{l}\text { Situation of HeronRy aND } \\
\text { Aprodimate NUMBER OF NESTS. }\end{array}$ & $\begin{array}{l}\text { NAME AND ADDRESS } \\
\text { OF REPORTER. }\end{array}$ \\
\hline Edrom. & $\begin{array}{l}\text { In } 1825 \text {, when I was a boy at } \\
\text { school in Duns, there was a Heronry } \\
\text { of about } 12 \text { nests at Nesbit, all } \\
\text { clustered about one spot, and several } \\
\text { nests on one tree-great nests they } \\
\text { were, double the size of Rooks' nests. } \\
\text { We used to see the Herons' legs } \\
\text { sticking out over the edges of the } \\
\text { nests when the old birds were hatch. } \\
\text { ing. The trees on which the Herons } \\
\text { built stood to the south and west of } \\
\text { Nesbit House. }\end{array}$ & $\begin{array}{l}\text { John Wilson of } \\
\text { WVelnage, Duns, } \\
\text { July 25th, } 1884 .\end{array}$ \\
\hline Cockburnspath. & $\begin{array}{l}\text { In Dunglass Dean, besides the tall } \\
\text { trees near the Belvidere on the Fast- } \\
\text { Lothian side, where the Herons } \\
\text { built when I was a boy, it is re- } \\
\text { ported they afterwards built near } \\
\text { the Saltheugh, on the Berwickshire } \\
\text { side. They have deserted both } \\
\text { places long since. } \\
\text { Three years ago, on a flat spot } \\
\text { among dangerously steep rocks near } \\
\text { Siccar Point, a Heron's nest was } \\
\text { found. The young ones had been } \\
\text { deserted after being nearly fully } \\
\text { grown. The nest was made of large } \\
\text { sticks, and had many fish - bones } \\
\text { about it. }\end{array}$ & $\begin{array}{l}\text { James Hardy, } \\
\text { Oldcambus, } \\
\text { Cockburnspath. } \\
\text { - IIS. Notes, } \\
\text { dated August } \\
\text { 8th, 1877. } \\
\text { James Hardy, } \\
\text { Oldcambus, } \\
\text { Cockburnspath, } \\
\text { in Hist. Ber. } \\
\text { Nat. Club } \\
\text { (1875), vol. iii. } \\
\text { p. } 516 .\end{array}$ \\
\hline Hutton. & $\begin{array}{l}\text { There used to be } 2 \text { or } 3 \text { Herons' } \\
\text { nests on some old trees having their } \\
\text { tops covered with ivy near Clarabad } \\
\text { Damhead about twenty - five years } \\
\text { since. 'The trees were blown down } \\
\text { some time ago. } \\
\text { There is an old Heronry Wood at } \\
\text { Paxton, which formerly consisted } \\
\text { of lofty spruce and silver fir-trees, } \\
\text { growing in a dean near the Tweed, } \\
\text { immediately to the west of Paxton } \\
\text { House. The most of the tall silver } \\
\text { firs have been blown down, and only } \\
\text { a few giants now remain, one of } \\
\text { which is about } 110 \text { feet in height. } \\
\text { It is said that Herons at one tine } \\
\text { nested on the tall silver firs-hence } \\
\text { the name of the wood. About } 1869 \\
\text { several young Herons were confined } \\
\text { in a wire-netted enclosure below } \\
\text { the trees for about a year and a half } \\
\text { for the purpose of inducing them } \\
\text { to stay and build their nests on } \\
\text { the remaining high trees, but on } \\
\text { getting their liberty they flew away } \\
\text { and did not return. }\end{array}$ & $\begin{array}{l}\text { W. Compton- } \\
\text { Lundie of Spital, } \\
\text { Spital House, } \\
\text { Berwick-on- } \\
\text { Tweed, May 3rd, } \\
\text { 1887. } \\
\text { The Author. }\end{array}$ \\
\hline
\end{tabular}


The Heron frequents the Tweed, Whitadder, Blackadder, Leader, Eye, Dye, Eden, and other streams in the county, where it may be sometimes observed standing motionless in the water watching for its prey. As, however, it is very wary, it is more often noticed rising from the river with its slow, steady flight, and its long legs stretched out beyond its tail. It likewise visits the rocky sea-coasts of the county, including the neighbourhood of Oldcambus, at all seasons of the year, but chiefly from March to August, in search of food. "Here," writes Mr. Hardy, "the birds sleep when the tide does not suit for fishing, one by one, or by pairs, in the chinks and hollows of the great rocks at Rough-head and Swallow Craig. When they fly, their large grey wings are very conspicuous on the black winter shores. If the tide is going out, they each select their own rock, and are elegant and watchful, their shadows being reflected in the receding waters. They remain still as long as a person walks on the top of the sea banks, but fly off if a stand be made." 1 The scream of a Heron, which it often utters when rising from a river side or marsh, never fails to alarm all the wild-fowl within hearing: "the Herrons gaif an vyild skreech as the Kijl had bene in fyir, ${ }^{2}$ quhilk gart the quhaipis ${ }^{3}$ for fleyitnes ${ }^{4}$ fle far fra hame." 5

When Herons are passing singly or in small number's high overhead in the air on a prolonged journey, their cry often attracts attention, and they may then be observed in the full grandeur of their flight. Rooks sometimes mob them on these occasions, and fly after them with much persistence.

1 Mr. Hardy's MIS. Notes, dated the 13th of February 1872.

2 "To cry as if the Kill was on fire"-a common phrase to express making a great noise.-Jamieson, Scot. Dict.

3 Curlews.

4 Fear.

5 The Complaynt of Scotland, 1560. 
The food of this voracious bird ${ }^{1}$ consists of fish (of which it consumes an immense amount), small animals, such as rats and mice, young water birds, frogs, newts, molluses, crustaceans, worms, and insects. Mr. Brotherston, Kelso, mentions having examined one which had upwards of twenty newts in its stomach. ${ }^{2}$ Mr. Ferguson, Duns, informed me on the 25th of May 1887 that during the spring of that year the Herons nesting in the Heronry at Duns Castle carried off the greater number of the young Coots in the lake there to feed their young. The gamekeeper repeatedly observed them swooping down close to the water and picking up the young with their bills. The first brood of Coots escaped, as they had grown up before the young Herons were hatched.

It is well known that the Heron, when wounded, is a dangerous bird to approach, on account of its habit of striking at the eye with its long-pointed bill. An instance of this propensity is thus related in the Kelso Chronicle for August 1852: "One day last week, as two little boys from the village of Dodmill, near Spottiswoode, were strolling over Blythe Moor, one of them caught a Heron, with which he eagerly ran to his companion to show him his prize. He had no sooner, however, placed the bird on the ground than it drove its bill into one of the other boy's eyes, which it put quite out. The surgeon who examined the wound said it was a matter of surprise that the bill of the bird did not pierce the poor little fellow's brain."

Two pools in the Dye are named after this bird-the Heron's Hole, a short distance above Longformacus at a sharp turn of the river; and the Heron Scaur, on the north side of the same stream, about a mile above Byrecleugh.

1 Althongh the Heron is very ravenous, it is light for its size. An old male in full plunage which I shot on the Langton Burn, near Welderburn Castle, on the 29 th of December 1886 , weighed only $5 \frac{1}{2} \mathrm{lbs}$.

2 Hist, Ber, Nat, Club, vol, vii. p. 502 , 
Mr. John Thomson has favoured me with the following interesting account of the Heronry at Mertoun :-

"Considering its size and habits, the Heron may be termed plentiful in the south-western district of Berwickshire. At all hours of the day, and every day, it may be observed winging its heavy flight to or from its feeding places. Yet on some days the naturalist may walk mile after mile on Tweedside, even close past a Heronry, without seeing a single bird. This is especially the case when the Tweed is in high flood. On these occasions it seems to prefer the tributary streams, ditches, and pools, to the swift-ruming river and its discoloured waters. In the summer time it is nearly always on the look out for food. On several occasions, when fishing for trout at night, I have disturbed a Heron from his favourite stream, while it was so dark that, had it not been for his scream, I would have been unaware of his presence. The screaming of the bird on these occasions is rather odd, as it seldom screcches when disturbed in the day time. More than once I have seen Herons fishing by moonlight, and noticed that they sounded their alarm note. It is a remarkably sage-looking and silent bird, though when near the nest it is often heard giving warning of its approach to its mate. One of the largest Heronries on the Borders is at Mertoun. The nests are built on the high beeches on an eminence in the western part of the policies. The Heronry is situated on a peninsula, and on three sides is only about three hundred yards from the Tweed. The beeches are noble trees, large in the trunk and particularly fine in their foliage. The nests are placed in secure positions on the slender boughs, which in many cases seem to be too small to sustain them. Lord Polwarth is particularly careful that the Heronry shall not be molested in any way, and as the nests are perfectly inaccessible, the birds are always able to rear their young in peace. Yet the 


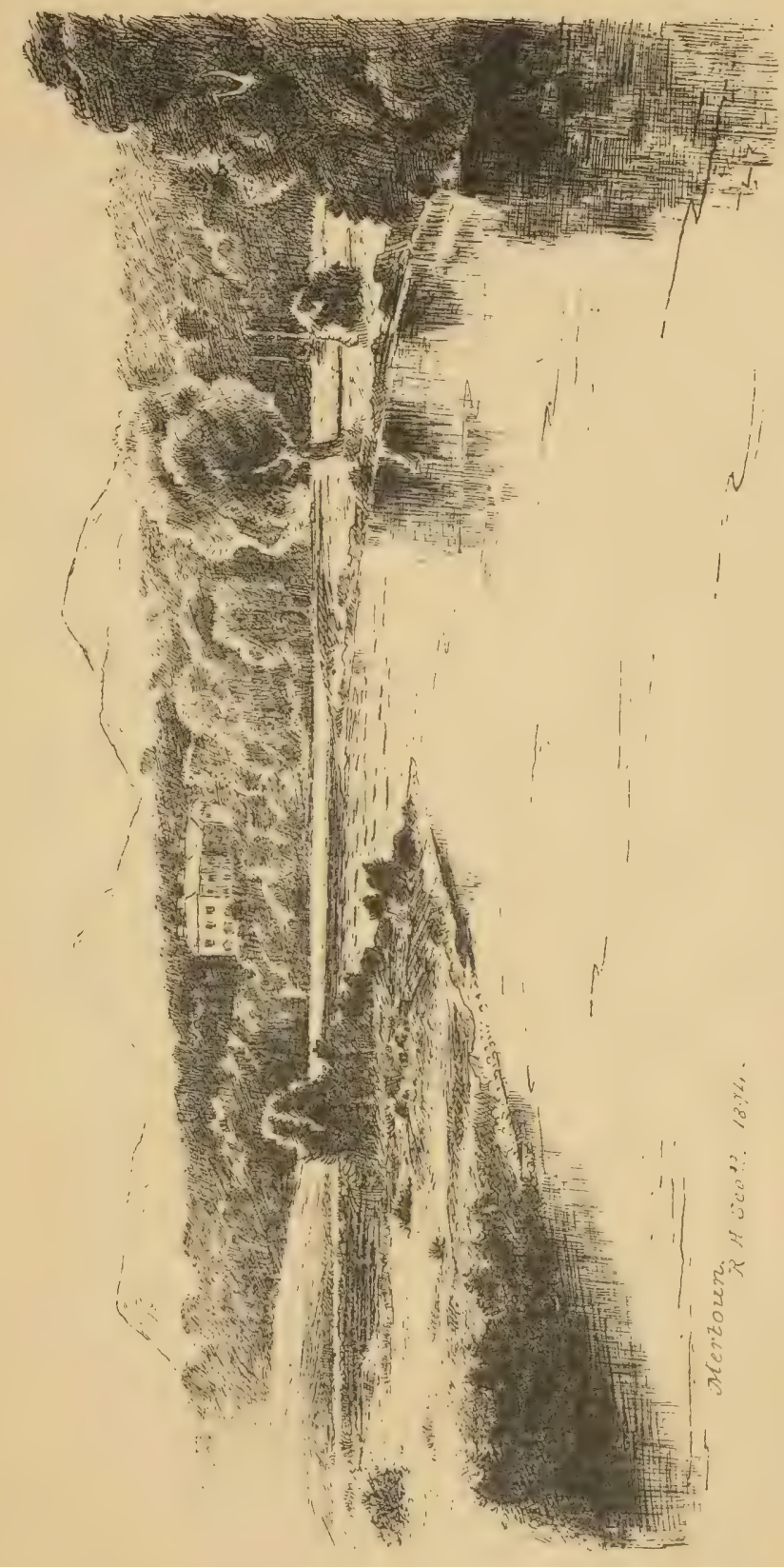



number of nests never increases in any appreciable degree, generally remaining at about thirty-five. It is not now known how long the Herons have occupied this wood conjointly with an extensive colony of Rooks. The beeches seem to be about two hundred years old, and it is probable that the Heronry has existed for at least a century. One year the Herons and Rooks had a tough battle. The Roolis apparently wished to take possession of the nests of the former, and fought hard to attain their object. In the end the Herons were able to maintain the status quo ante, and the surplus Rooks betook themselves to other trees in the parks. Only in one season during the memory of persons living have the Herons failed to nest at Mertoun. This was about 1840 . In the spring foresters were busily engaged thinning, and the birds betook themselves to the old wood at Blue Houses, near Dryburgh, where they nested and reared their young. They showed their decided partiality for Mertoun by returning next year, where they have ever since remained. In early summer from twenty to thirty of these birds may be seen sumning themselves in the grass enclosure near their nests, forming a spectacle as beautiful as it is perhaps unique in this part of the country.

From careful and continued observation I have come to the conclusion that in certain cases particular Herons take up and hold without challenge a favourite fishing stream. The right of the individual to his "private water" seems to be fully recognised by other birds of the same species, which I have never seen fishing upon it even in the regular owner's absence, though I have noticed them on the opposite margin, a hundred yards or so lower down. This privilege seems to be conceded to old male birds. In one case, at least, I have been able distinctly to identify the bird which exercised his liberty without challenge. My friend the Rev. Alexander Stewart, LL.D., F.S.A., Ballachulish, in one of his VOL. II. 
"Nether-Lochaber" papers, supports my experience (Inverness Courier, February 5th, 1886). Mr. Stewart says: "We have repeatedly seen instances of individual Herons enjoying such a monopoly as Mr. Thomson describes, and have little to say about it, except that the Heron, in such a case, is always a male, and usually a fine specimen, large and full-crested, of his long-legged race. We know a Heron in the full and free enjoyment of such a monopoly in our own parish at the present moment." Since the above was written I have obtained abundant proof of the correctness of the foregoing observations. About twenty years ago an old Heron was every day to be seen fishing in the stream on the Tweed opposite Mertoun House. This patriarch, according to the old servants of the Mertoun family, had held that stream as his peculiar possession for about forty years. There could be no mistake resarding his identity, as he was known wherever he was seen. This favourite bird, which in his day was one of the recognised "lions" of Mertoun, is thus referred to by the Hon. and Rev. Robert Liddell in his Lay of the Last Angler: ${ }^{1-}$

"I'll venture to pourtray one feature more

In sketching beauteous Mertoun's situation.

Notice that lonely fisher near the shore

(Below 'Stile-foot' he takes his usual station).

"Don't be afraid that he will interfere

With your day's sport, because he's not a caster,

Though in his own peculiar way, 'tis clear

That he's a finished and successful master.

"See! how he stalks along the pebbly strand,

With keen eye watching each sub-aqueous motion,

Wading knee-deep for hours he will stand,

Yet as to taking cold, he scorns the notion.

"He needs no rod, nor line, nor fishing-book,

Although he makes his living on the water;

He catches all his fish without a hook,

But when 'he's getten haud' he gives no quarter.

${ }^{1}$ Kelso: J, \& J. H. Rutherfurd, 1884, pp. 74-76, 
"It is an ancient Heron-I believe,

Forty years old at least-a dear relation,

Who's much at Mertoun, says he can perceive

Of its identity much indication.

"Its haunts and habits always are the same-

What lots of fish ere this he has digested.

And the old poacher's wonderfully tame,

Because he never is at all molested.

"Still, he's a wary bird, and thinks aright,

'The better part of valour is discretion;'

So if you come too near, he takes to flight,

With pompous gravity beyond expression."

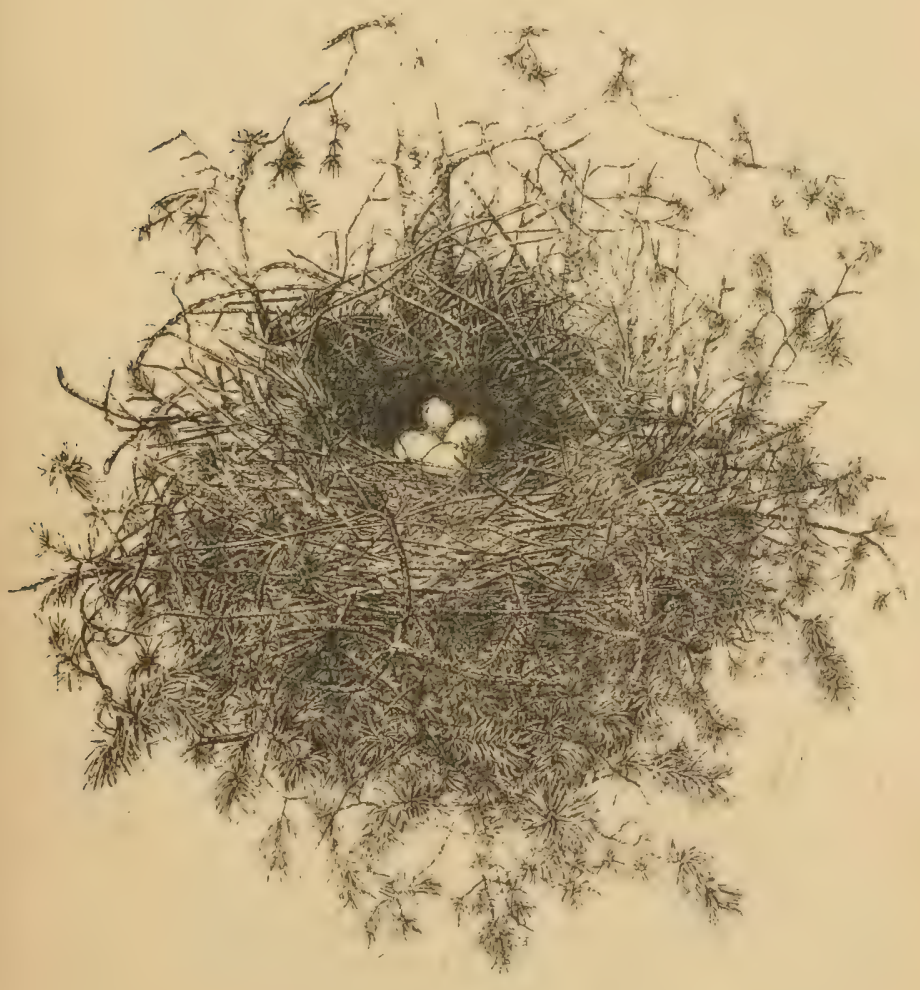




\section{THE NIGHT HERON.}

THE GREY NIGHT HERON, THE NIGHT RAVEN.

Nycticorax griseus.

The Heron came from the Witch-pule tree, The Houlet frae Deadiwood-howe:

The auld grcy Corbie hoverit aboone, While tears downe his cheehs did flowe.

The Gloamyne Buchte.

A SPECIMEN of this very rare bird was shot while sitting on the top of a tall oak-tree at the Hirsel, by the Earl of Home, on the 25 th of May 1822 . It was a male, and was presented to the Museum of the University of Edinburgh by his Lordship. A female was wounded by Lord Home on the same clay, but it fell amongst a bed of reeds and conld not be found, though a very diligent search was made for it. ${ }^{1}$ The Night Heron appears to have occurred only seven times in Scotland. ${ }^{2}$ It is not so large as the common species, and breeds in several parts of Europe.

1 Nevocastle Magazine for July 1822, and Dr. Johnston's MIS. Notes.

2 Yarrell's British Birds, fourth edition, vol. iv. (1884-85), p. 196.

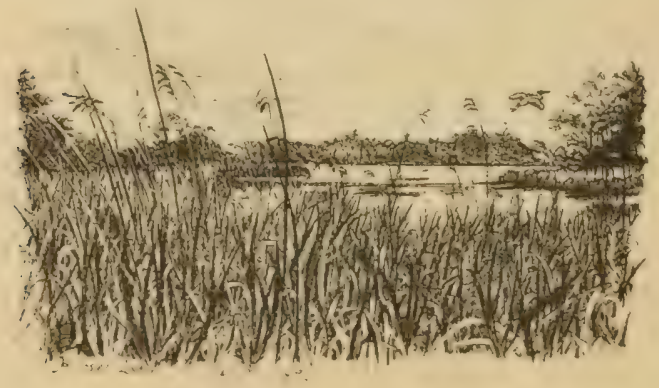




\section{THE COMMON BITTERN.}

BULL O' THE BOG, BUTTER-BUMP, BITTER-BINN, BOG-BUMPER, BOGBLUTTER, BOG-JUMPER, BOG-DRUM, MIRE-BUMPER, MIRE

DRUM, MOSS-BUMMER, BUMPY-COSS, BUMBLE.

Botaurus stellaris.

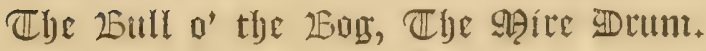

No more the screaming Bittern bellowing harsh, To its dark bottom shakes the shuddering marsh.

LEXDEN, Sccnes of Infancy.

UNTIL the early years of the present century, when Billie Mire was drained, that extensive and almost impassable morass was a favourite haunt of innumerable wild-fowl, and above their various weird cries at night the loud boom or bellow of the Bittern could be heard in spring coming from the great reed beds which surrounded the deep black pools of the bog-the bird on this account being known by the country people in the neighbourhood as the Bull o' the Bog or the Mire Drum. ${ }^{1}$

As Billie Mire was the principal resort of the Bittern in Berwickshire, as well as of several other birds which are now rarely or never secn in the cominty, amongst which may be mentioned the Hen Harrier, it may not be considered out of place to give here an account of that interesting and his-

I It is probable that the weird and unearthly cry of the Bittern at night gave rise to the superstition regarding the "Bogle of Billy Myre" and "Jock o" the Mire," which Dr. Henderson says "so long haunted its black peat-hags, grey saugh bushes, and ancient causeway." See Popular Rhymes of Bervickshire, p. 3. 
torical bog, ${ }^{1}$ which is said to have extended in ancient times from the Eye in the neighbourhood of Ayton on the east, to the Whitadder near Chirnside on the west, a distance of about five miles.

Along the northern boundary of the parish of Chirnside, and dividing it from Coldingham, lies a narrow valley, which widens towards the west, where it separates the former parish from Buncle. The bottom of this valley, for nearly its whole length of about four miles, is singularly flat, being, for the most part, about 200 feet above the level of the sea; but there is a slight declivity towards the west from a point about half a mile to the east of Causewaybank Farm House, and a gentle slope to the east from the same spot. The watershed which feeds the valley is very extensive, comprising the lands of Blackburn, Causewaybank, and Oldcastles on the south; Berrybank, Ferneycastle, Stoneshiel, Auchencrow Mains, Billie Mains, Lintlaw, Slighouses, Marygold, Mayfield, Warlawbank, Greenburn, Greenhead, and Fairlaw on the north. These lands vary in altitude from 300 feet-the height of the Piper's-knowe ${ }^{2}$ at Causewaybank-to 800 feet near the source of the Fosterland Burn, to the west of Warlawbank. Flowing into the

1 Billie Mire was the meeting place of English and Scotch Commissioners with regard to treaties between the two kingdoms on the 25th of August 1380 and the 27th of January 1384. It was passable by horses only at two places over causeways formed by plunging large stones into the bog. The course of one of these causeways is indicated by a place on the southern side of the morass callerl Causewaybank, and the remains of the other were still discernible in 1836, about eighteen feet in width, and eight or ten in lepth, on the line of road between Chirnside and Auchencrow. On the expiration of a truce the canseways were uniformly demolished as far as would obstruct the passage from the south side of the Mire-Carr's History of Coldingham Priory, pp. 31, 32.

2 Dr. Henderson of Chirnside, writing in 1846, says, in his MS. Notes on Billie Mire: "Upon its lanks are several inconsiderable elevations, consisting chiefly of sand and gravel. Among those on the south side, near the farn of Causewaybank, the Pyper Knowe is the most remarkable. A few years ago this knoll was completely covered with a luxuriant crop of broom, which might have vied in length and beauty with that of the far-famed Cowden Knowes. This place was a favourite resort of the fairies of old." 
valley from the northern watershed are several small rivulets known as the Auchencrow Burn, Fosterland Burn, Draeden Burn, and Lintlaw Burn. Auchencrow Burn has its source near Shillum Dykes, and after draining part of the lands of Coldlands, Sunnyside, Fairlaw, Stoneshiel, Ferneycastle, and Greenhead, passes Auchencrow village and Auchencrow Mains, and thence enters Billie Mire Burn or Cast, which now occupies the bottom of the valley, about half a mile to the east of Billie Mains. Fosterland Burn-which is said to have derived its name from the foresters of the ancient Priory of Coldingham having property on its banks-rises in boggy ground on the heights to the west of Warlawbank, and, after being joined by Greenburn and other lesser runnels, passes close under the ruins of Billie Castle and ardds its waters to Billie Mire Burn, about a quarter of a mile to the east of Billic Mains. Draeden Burn, a name which, says Mr. Carr, in his History of Coldingham Priory, "an etymologist can have little difficulty in tracing to the same root as the word "Druid," has its origin in a plantation situated a short distance to the enst of Slighouses, and, being angmented by the waters of several small springs, proceeds eastwards, and, crossing the public road from Lintlaw to Billie Mains not far from the spot upon which formerly stood Little. Billie, the birthplace of the late Dr. Henderson of Chirnside, passes near the Pech Stane, and falls into Billie Mire Burn about a quarter of a mile to the south-east of Billie Mains. A large circular cairn, which was removed about fifty years ago, stood near the Pech Stane above mentioned, on the farm of Little Billic. These relics of ancient times are referred to in the following fragment:-

Grisly Droedan sat alane

By the cairn and Pech Stane;

Billy, wi' a seg sae stout,

Cries "I'll turn grisly Droedan out!" 
Droeden leuch, and stall'd awa, And vanish'd in a babbanqua'?

Lintlaw Burn is said to have had its origin in Preston Cleuch, a rocky ravine to the west of Buncle Church, which is supposed to be the ancient "crahochtre" mentioned in old charters as part of the boundary of Coldinghamshire, where there is a fine perenuial spring. ${ }^{2}$ Its chicf sources now appear to be in the neighbourhood of Buncle Wood, and, being increased by many small sykes and rills, it runs eastwards a little below Slighouses, ${ }^{3}$ where it receives the Marygold Burn, and, continuing its course, enters Billie Mire Burm about half a mile to the north of East Blanerne. Not far from its mouth, on a little haugh, formerly stood Billie Mill, which was taken down in December 1845 , the site being still marked by one or two old trees. The waters from all these rivulets being united in Billie Mire Burn or Cast flow southwards and join the Whitadder a short distance below East Blanerne.

Until the beginning of this century the whole extent of the valley from Causewaybank on the east, ${ }^{4}$ to about half a mile beyond Billie Mains on the west, formed one long, continuous, and very deep quagmire, which received the

1 Billie Mire. See Popular Rhymes of Berwickshire, by Dr. Henderson of Chirnside, pp. 8, 9; also Carr's History of Coldingham Priory, pp. 11, 12.

2 The water from this spring now supplies Bonkyl Lodge, being conveyed thither by gravitation in a pipe.

3 Formerly the property of Dr. James Hutton, one of the founders of geology, who settled here in 1754, and devoted himself to agricultural pursuits.

4 Judging from the account given of Billie Mire in Carr's History of Coldingham Priory, where it is said to have been six miles in length, and from the extent of the deposit of alluvium shown on its site in Sheet No. 34 of the Geological Survey of Scotland, this bog would appear in ancient times to have reached to within about half a mile of the point where the railway crosses the valley from East Reston to Prenderguest, or ahout a mile to the east of Causewaybank. Probably the part between Cansewaybank and the eastern end of the alluvial deposit, shown on the Geological Survey Sheet, may have been drained about the middle of last century, when agricultural improvements of all kinds were begun in Berwickshire. This part would be easily drained on account of the slope of the ground enabling the water to run off freely by the Horn Burn. 
waters of the various rivulets, and the drainage of the watershed above mentioned. The superfluous waters of this great bog, which varied from one hundred to two hundred yards in width, were drained off towards the west by a stream known as Billie Burn, which joins the Whitadder near Chirnside Mill, and to the east by the Horn Burn, which flows into the Eye, in the vicinity of Ayton. During summer a great part of the surface of the Mire was thickly covered with immense beds of tall and luxuriant reeds, ${ }^{1}$ bulrushes, flags, and other aquatic plants of many kinds, which grew on the shallows, whilst here and there the deep black pools were fringed with low grey willow trees-

Where countless reeds once clothed yon narrow vale,
Their feathery heads wild streaming in the gale,
There lay the Myre, with moss-pools dark and deep,
Round whose black margin foul toads loved to creep :
The wild grey willows waving there you'd see,
Their silvery blossoms opening to the bee;
There red marsh-cinquefoil and the buck-bean grew,
And hoary cannach waving in the view ;
The yellow marigold long flourished there,
And purple orchis-Flora's offerings fair.

Scenes of Boyhood, Dr. Hewverson.2

I Mx. John Wilson of Welnage told me on the 7th of August 1884, that he remembered that, when he was a boy, Billie Mire was comparatively undrained-he was born in 1810-and that it used to be overgrown with tall reeds, which looked like a field of wheat.

2 In some MS. Notes on Billie Mire by the late Dr. Henderson of Chirnside, for the use of which I am indebted to his son, Mr. R. Henderson, chemist, Chiruside, I find the Doctor, writing about 1835, says: "A few years ago the Mire was thickly covered with the Amundo phragmitis (Common Bog-reed), Angelica sylvestris (Wild Angelica), several species of Carex (Sedge), Caltha palustris (Marsh marigold), Hydrocotyle vulgaris (Comnon White-rot), Comarum palustre (Marsh Cinquefoil), E'nanthe crocate (Hemlock Water-dropwort), Menyanthes irifoliate (Bog-Bean), Sium nodiforum (Procumbent Water Parsnip), Tiola palustris (Marsh Violet), Veronica beccabungu (Brooklime), N'asturtium officinale (Water Cress), Cardamine pratensis (Cuckoo-Hlower), several species of Eriophorum, Scirpus, and Salix, Iris psculacorus (Yellow Iris), Typha latifolia (Black-headed Reed), several species of Juncus, Potamogelon, Senecio aquaticus (Marsh Ragwort), Myosotis palustris (Forget-me-not), and many other marsh plants. Ife adds that before the Mire was drained there was also found in it in considerable abundance the medical leech (Hirudo officinalis). 
Vast numbers of Wild Ducks and water-fowl of many kinds found a plentiful supply of food in the pools and marshes of the Mire, and shelter as well as safe breeding quarters in its almost impenetrable reed beds. On the swamps the Black-headed Gulls (Larus ridibundus) bred in colonies, and enlivened the scene by hovering in noisy circling flocks over their nests, their large spotted eggs being much prized by the herd boys who loitered on the neighbouring banks in charge of the stock which grazed in the drier parts of the bog. In the mornings and evenings the Hen Harrier (Circus cyaneus) could be seen passing slowly over the rushes, and quartering the wet meadow land like a well-trained setter, in search of prey to carry to its nest of hungry young in the thickest part of some neighbouring reed bed. As evening advanced many sounds fell upon the ear-the peculiar humming of the Snipe as the bird descended on tremulous pinions from soaring at an immense height to its home amongst the tussocky grass and rushes; the continual "Crek, crek, crek," of numerous Landrails (Crex pratensis) along the grassy erlges of the marsh; and the chattering song of the Sedge Warbler (Acroccphalus schonobanus) amongst the low thick clumps of alder and grey willow bushes; whilst, later on, at nightfall, the loud "Quack, quack," of the Wild Duck, the harsh scream of the Heron, and the boom of the Bittern resounded through the air. In winter, after floods of rain, and when heavy snow melted, the whole Mire often presented the appearance of a far-extending loch, and thousands of wildfowl were then seen frequenting its waters. Such was the state of Billie Mire down to the end of last century.

The accompanying plan shows the western part of the Mire, stretching from the march between the lands of Blanerne and Billie to the road between Auchencrow and Berwick, as it was in 1759 ; and the eastern part, extending 


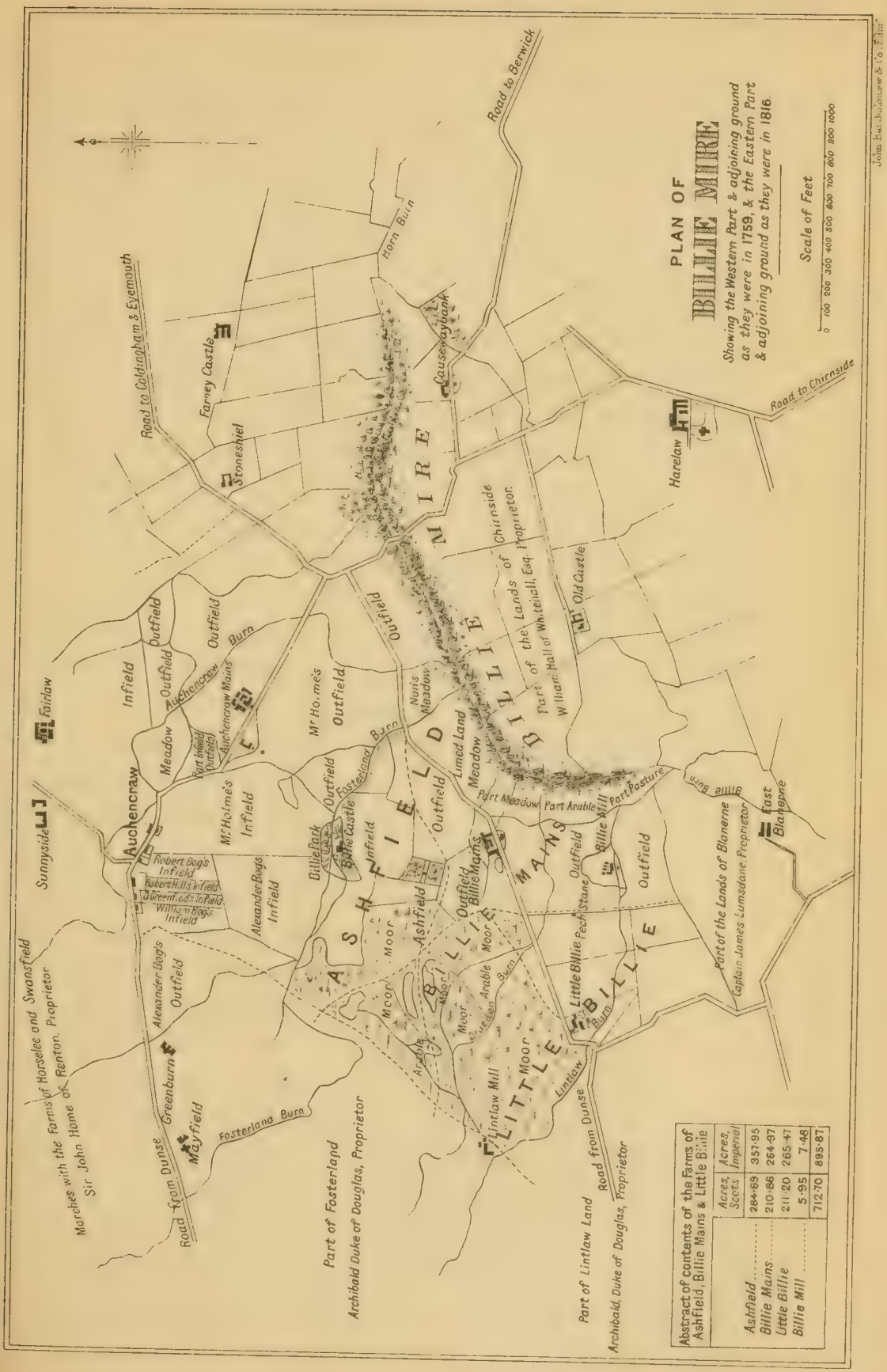



from the above road to a short distance beyond Causewaybank, as it was in 1816. For the use of the plan of the western part I am indebted to Colonel Milne-Home of Wedderburn, and for that of the eastern portion I have to thank Mr. John Blackadder, Blanerne, who has likewise kindly favoured me with some notes regarding the drainage of the Mire. This, it appears, was done by deepening the western outlet of the superfluous waters of the Mire, and cutting a deep cast or ditch along the centre of the ralley to lead the water to the western outlet. Mr. Blackadder, in his notes, says: "Sir William Hall of Whitehall, about the year 1780 or 1785 , when the Duke of Bridgewater's canals were working in Lancashire, had a survey made for a canal from Eyemouth to Duns, to pass through Billie Mire, Billie Burn, and the ravine south of Elfole, and terminate near the present Manse. The cast was cut in the year 1801 or 1802. John Wait and Thomas Wilkie, Chirnside, were the contractors. Several people in Chirnside remember the whole of the Mire on the east of the Mire Brilge being covered with water, one cart only being able to pass at a time where the present bridge is built. The edges of the swamp were covered with rushes and black-headed reeds or canes, which were cut by the people of the adjoining villages for thatching their houses. After the cast was made, Mr. George Logan, tenant of Auchencrow Mains, drained his side of the bogr, and for several summers employed his men and horses before harvest to cut the present Mire Brae road, carting the earth which came from the cuttingsome thousands of loads-and spreading it on the moss to firm it. During the drainage operations he discovered upwards of twenty querns or hand corn-mills, supposed to be some of those left by General Leslie's army when it crossed the Mire near the site of the causeway stones, which are yet to be seen at this point. It would seem that the 
cast which was made in 1801 or 1802 removed only a part of the water from the Mire, which therefore remained much in its natural state, and that the inhabitants of the neighbouring farms still occasionally heard

The Bittern sound his drum,

Booming from the sedgy shallow,

Sсотт, Lady of the Lake,

for Mr. William White, Lennel Hill Farm, has informed me that he remembers hearing the Mire Drum in the Mire when he was a boy living with his father at Causewaybank between 1815 and 1825 . He went to reside at Causewaybank in the former year, and lived there for upwards of sixty years. He says that the Mire was then much in its natural state, and that it was not effectually drained until about 1830 or $1835 .^{1}$

Mr. John Blackadder states that the late Mr. David Aitchison, Oldeastles, told him that his (Mr. Blackadder's) father, about the beginning of this century, shot the last Mire Drum that was seen in Billie Mire, and that it was killed towards the east end of the bog, near Blackburn; also that the late Mr. Archibald Hood, Sunnyside, who often went out to shoot in company with the late Mr. Blackadder, gave a corroborative account of the incident.

Mr. Wilson of Welnage informed me on the 4th of May 18S6, that an old man named Jamie Slight, who used to live at Nethermains, near Chirnside, told him that he har frequently shot the Bittern at Billie Mire before it was

1 During the drainage operations the roots of oak and other trees were discovered. The farm steward at Causewaybank informed me when I visited the site of Billie Mire with Mr. John Blackadder on the 2Sth of April 1886, that when Mr. White, the tenant of Causewaybank, had occasion to bury horses or other animals which died on the farm, graves were dug for them in the soft soil of the Mire, and at the deptl of five or six fect pieces of bog oak were found, also hazel nuts. He said that some years ago a considerable quantity of bog oak was discovered, and that a gentleman in the neighbourhood got it for the purpose of having a table made with it. 
drained; also that John Davidson, an aged farm servant at Oldcastles, who had been brought up there, had mentioned to him that in his youth he had often heard the Bull o' the Bog bellowing at night in the vicinity.

Mr. Thomas Hewit, Auchencrow, stated to me on the 23rd of June 1886, that in his younger days he had frequently heard old people speak of hearing the Bull o' the Bog in the neighbouring Mire; and Mr. John Ferguson, Duns, relates that he has got similar accounts from villagers at Chirnside. A male Bittern was shot at the Hirsel in 1817 , and another in the following year ${ }^{1}$ and a specimen was killed at Redheugh, in the parish of Cockburnspath, by Mr. Johnston, on the 6th of December 1834. ${ }^{2}$ Mr. Kelly, Lauder, writing in 1875 , says: "I have ascertained from Mr. Simson that Huntleywood Moss was once (1810) a favourite haunt of the Bittern, or 'Bull o' the Bogy;' and for thirty years later occasional bircls have been gotten, but it is now quite deserted." 3 The last example seen in the neighbourhood of Mellerstain, according to Mr. John Thomson (writing in 1886), was "shot on Minchie Moss about forty years ago." Mr. John Aitchison, plasterer, Duns, informed me on the 20th of May 1886, that a Bittern was shot by John Hogr, gamekeeper, Preston, about 1851, on the estate of C'umledge, near the Knebs Rocks, on some rough ground by the side of the Whitadder, not far from the place where the old Waulk Mill stood. It was killed in the "back end" of the year, and was "stuffed" by Mr. Henderson, cabinetmaker, Duns. It was seen in his hands by Mr. Aitchison, Mr. W. Duns, builder, Mr. W. Marshall, blacksmith, and Mr. Thomas Cockburn, baker, all

1 These specimens are in the Hawick Musenm, where I saw them on the 27th of August 1890. The labels upon them state that the birds were preserved by "John Wilson, College Preserver of Birds and Quadrupeds to the Museum in the University of Edinburgh."
2 Hist. Ber, Nat, Club, vol. i. p. 66 ,
${ }^{3}$ Ilid. vol, vii. p. 305 , 
of Duns. In October 1882 Mr. Andrew Brotherston, birdstuffer, Kelso, informed me that a Bittern was seen and heard at Lithtillum or Ferneyrig Bog, about 1874, by Mr. W. Paterson, gamekeeper to Sir John Marjoribanks of Lces, Bart.

There can be little doubt that in ancient times, long before the days of agricultural improvement and drainage, while as yet the Merse was covered with bogs and morasses which are now drained, the Bittern was found in every district of the county $;^{1}$ and it may be well supposed that King James IV., who frequently resorted to Bathgate $\mathrm{Bog}^{2}$ to fly his Falcons at the Bittern there, would not fail to take an opportunity of trying their mettle at this noble quarry in some of the Berwickshire marshes, when he visited Lauder ${ }^{3}$ and Hume Castle ${ }^{4}$ with his falconers.

The bird was in olden times esteemed as a luxury for the table, and ranked with the Heron. ${ }^{5}$ It was formerly comparatively plentiful in the fen districts of England, where it bred. It still visits many parts of that country, and occasionally Scotland, on migration during the winter months, especially in severe seasons. The latest recorded instance of its nest being found in Great Britain was at Upton, in Norfolk, on the 30 th of March $1868 .^{6}$

The Bittern is very shy and retiring in its habits, hiding in thick reed beds during the day, and generally leaving these only by night or when accidentally disturbed. Seebohm says: "Its flight is slow, steady, and silent, and,

1 See The Haigs of Bemersyde, by John Russell, Advocate, 1881.

2 See Accounts of the Lord IIigh Treasurer of Scolland, 1473-1498, Preface, p. eclii.

${ }^{3}$ The King "raide to Lauder to the halkin" on the 4th of January 1489.Ibid. p. 127.

4 The King went to Hume Castle, apparently on a hawking expedition, with Hannay and Alexander Law, falconers, on the 19th of November 1496, and remained there ten days. - Ibid. p. 306.

${ }^{5}$ Birds of Norfolk, Stevenson, vol. ii. p. 173.

6 Yarrell's British Birds, fourth edition, vol. iv. (1884-85), p. 209, 
like its allies the Herons, its legs stretch out behind in a line with the beak, the head being drawn up between the shoulders whilst flying. It is far more nocturnal in its habits than any of the Herons, and the boom or love song of the male is heard at all hours of the night during the breeding season, and never in the day. It is a weird, unearthly noise, not to be dignified by the name of note, and may be heard at a considerable distance. The bird is so shy that the noise is instantly stopped on the slightest alarm. Some writers have likened it to the bellowing of a bull; others think it resembles the neighing of a horse; whilst more imaginative ornithologists trace in it a resemblance to their ideal of demoniac laughter. It consists of two parts-one supposed to be produced as the bird inhales, and the other as it exhales its breath. Naumann attempts to express it on paper by the syllable ii-prumb, repeated slowly several times. The call-note, which is common to both sexes, is a hoarse croak like the ca-wak of the Night Heron, or ery of a Raven, and is sometimes heard when the birds are on migration; but the 'boom' is only heard from the reeds, and as it is uttered the bird is said to stand with its neck stretched out and its beak pointing upwards." 1

1 Seebohm, British Birds, vol. ii. (1884), p. 504.

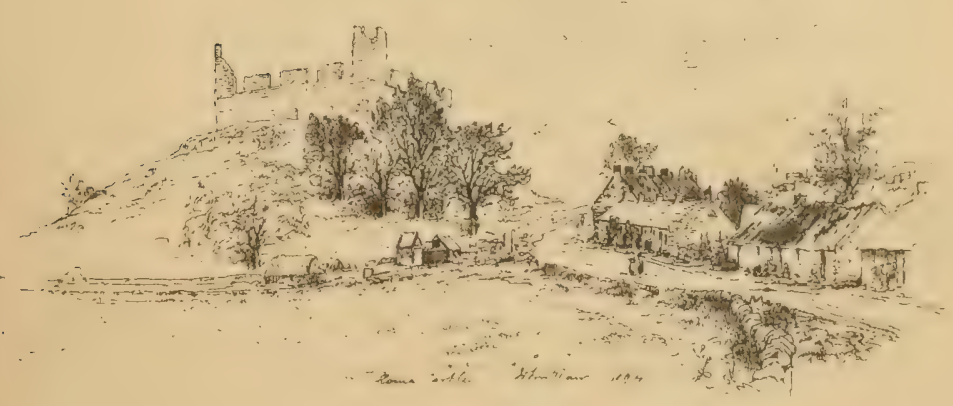




\title{
THE WHITE STORK.
}

\author{
Ciconia alba.
}

\author{
Where the Rhine loses its majestic force \\ In Belgian plains, won from the raging deep \\ By diligence amazing and the strong \\ Unconquering hand of Liberty, \\ The Stork Assembly meets, for many a day \\ Consulting deep and various ere they take \\ Their arduous voyage through the liquid sky.
}

Thomson, Autumn.

A FINE specimen of this very rare bird was shot in a field on the farm of Blackpotts, near Coldingham, in 1848, and was for many years in the collection of Mr. William Patterson, Abbey Firm, North Berwick, where I have frequently seen it.

The White Stork occasionally visits the British Islands during the spring and autumn mingrations, but has seldom occurred in Scotland. It winters in Africa, and in summer breeds in most of the countries of Europe, where its arrival in spring is looked upon with great pleasure by the inhabitants. It migrates by day, and at a great height. Seebohm says that its flight differs somewhat from that of the Heron, the neck being stretched out instead of being folded up until the head comes between the shoulders; and that, though the legs are stretehed out behind, and the neck and bill extended in front, they are not in a straight line as in that bird, but both legs and neck are slightly drooped, so as to form a distinct curve.

The Stork feeds chiefly on frogs and fish, but lizards, snakes, small animals, young lirds, and insects, are all 
devoured by it. Its supposed antipathy to snakes is thus referred to by an ancient Scottish poet :-

The Cygonie that foul so whyte

Quhill at the serpents hes despyte

Come granen to the ground.1

1 Burel's Pilg., Watson's Coll., ii. 27.-From Jamieson's Scot. Dict.

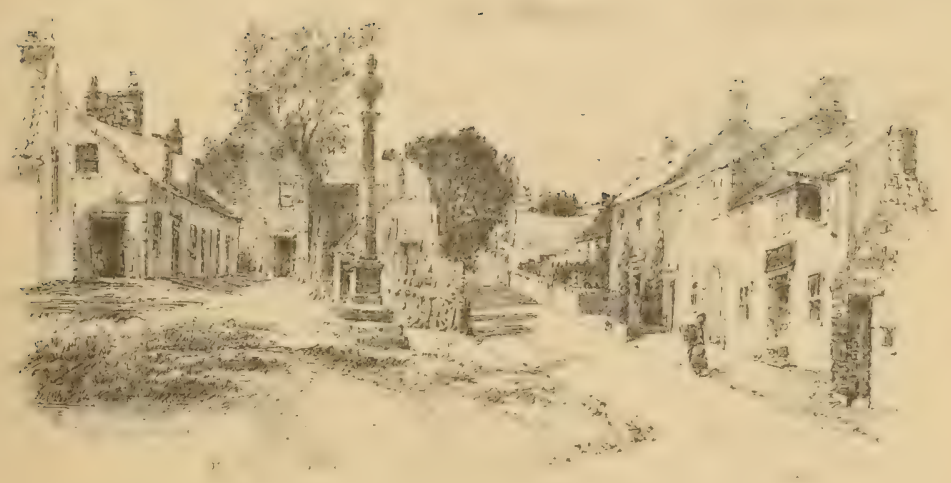

VOL. II. 


\section{THE BEAN GOOSE.}

WILD GOOSE, SMALL GREY GOOSE, NARROW-BILLED GREY GOOSE.

Anser segetum.

\section{The Talid}

\section{THE PINK-FOOTED GOOSE.}

WILD GOOSE, SHORT-BILLED GREY GOOSE.

Anser brachyrhynchus.

The datilo Booge.

And Wyld Geis eik claking by nychtis tyde, Attour the ciete fleand hard I glyde.

Gawin Douglas, A Description of Wynter.

"A straze for your wandering spirits," said Adam Woodcock, "I mind them no more than an Erne cares for a string of Wild Geese."

Sir WALTER SCOTT, The Abbot.

Imanesse flocks of Wild Geese frequent Berwickshire during the autumn and spring months, consisting of the Bean Goose, with its Pink-footed congener; ${ }^{1}$ and as the relative number of the two kinds is a matter of conjecture, owing to the similarity of their plumage-whilst their habits are

1 Seebohm says: "The Pink-footed Goose can scarcely be regarded as more than a local race, or an island form of the Bean Goose. With the exception of the fact that its notes are said to be sharper in tone and more rapidly repeated than those of the Bean Goose, it is not known to differ from that birl in any of its habits."-British Birds, vol. iii. (1885), pp. 498, 499. 
alike-it has been considered advisable to include them both in this article. ${ }^{1}$

The arrival of the Wild Geese in autumn is looked upon by the country people as a kind of land-mark in the calendar, being a subject of popular observation; and when they come before their usual period it is said to be a sign of an early winter. They are generally seen for the first time in the season passing high overhead in a werlge-shaped flock, ${ }^{2}$ the attention of the people in the neighbourhoor being usually attracted to them by the well-known "Honck, honck," of the birds; and, when they are descried, they are usually seen in stately and marshalled flight three or four hundred feet high in the air.

Amongst many records of their arrival in the county in autumn from 1800 to 1886 , kindly given to me by Mr. Hardy, Oldcambus, the earliest is dated the 1st of October 1884, when they came to the Broad Bog, near Penmanshiel, just as harvest ended, and continued there in great numbers; the average date of their first appearance in autumn is the 26 th of October, when they are generally observed flying from the north-west to the south-east.

They have certain favourite resorts, which are usually on bare, open, moory ground, such as in the locality last mentioned, or the Hule Moss in the parish of Greenlaw. They also frequent large open fields where they can have a good view of the approach of an enemy. When a flock

\footnotetext{
1 The Earl of Haddington mentioned to me in a letter in 1887 that, in his experience, the most of the Wild Geese seen in Berwickshire are Bean Geese. Mr. Gray, writing of this species in the History of the Bemoickshire Naturalists' Club, vol, vii. p. 465, says: "This bird seems to have been very scarce in the winters of 1874-75, the Pink-footed Goose having apparently taken its place. Unusual numbers of the latter bird have been seen and killed in Berwickshire and EastLothian, and even in Stirlingshire, where it lias hitherto been a complete stranger."

2 It is supposed that by flying in the shape of a wedge, or a straight line, they cut the air with greater ease individually than if they flew in a confused flock, and that the lealer drops behind when fatigued, his place being taken by another
} bird. 
has selected a spot on which to alight, the Geese may be seen circling slowly round and round, first at a considerable height, and then gradually getting lower and lower until they reach the ground, when they all stand motionless for some time, with erect head and neck, watching attentively. If nothing suspicious is noticed, they commence feeding, one of their number, however, always acting as a sentinel to warn the others of any appearance of danger. When the sentinel gives the note of alarm the Geese run up to him, and, uttering their loud grating cries, take to flight, at first without any order, though after gaining some height they assume their usual wedge shape.

There is no better sport with the gun in this country than stalking Wild Geese, the sportsman having to exercise all his powers to get within range of these wary and almost unapproachable birds. Sometimes he has to crawl on his hands and knees for long distances, behind hedges and dykes, and often along wet ditches; but these difficulties are all forgotten when his hopes are crowned with success. ${ }^{1}$

Unwearied patience, persevering toil, Alone can crown the fowler's eager hopes,

Whate'er the season or whate'er the sport.

Vincent, Fouling.

The late Earl of Wemyss was well known in Berwickshire as a keen and successful stalker of Wild Geese, and many anecdotes are related of his skill. One day, about twentyfive years ago, when fox-hunting near Reston, he was informed that some Wild Geese were frequenting the farm of Heughhead, then occupied by Mr. Joseph Allan, and although his Lordship's residence, Lennel, was about sixteen

1 John Ker, 3rd Duke of Roxburghe-the Bibliomania Duke-" "lay for hours together, though snow fell at the time, beside some lonely spring in the Cheviot Hills, where he expected the precarious chance of shooting a Wild Goose when the dawning should break."-Chamb. Scot. Biog. Dict., iii. p. 309. 
miles distant, he returned to Heughhead early on the following morning with his gun, and after a difficult stalk succeeded in shooting two Geese out of a flock on Draeden Field. ${ }^{1}$ He sometimes used a stalling pony to get up to the watchful birds, keeping it walking in front, between him and them, to conceal his approach. ${ }^{2}$ Stalking Wild Geese requires all the strength and ardour of youth on the part of the sportsman, and yet we find from the following letter, written by Mr. Alexander Brown, gameleeper, Gosford Lodge, that in 1871 Lord Wemyss, then in his seventy-sixth year, was still enjoying that exciting sport:- "Gosford Lodge, Longniddry, October 9th, 1886. I can quite well remember the occasion of my dear old master shooting the Wild Goose of which you speak. It was in the Bog Field on Little Swinton Farm, about 7 o'clock on the morning of the 15th of March 1871. There was a large flock, and his Lordship got within forty yards of them. On the following Saturday he shot other two Geese on Simprim Mains, not far from Ladykirk Lodge, about 11 o'clock in the forenoon. His Lordship was ridingr a dum pony. It was the last year we were at Lennel." 3

Great flocks of Wild Geese frequented the farm of Fentonbarns, near Drem, East-Lothian, in the autumn, winter, and spring mouths of 1867-68. They began to come there about the end of November and left in the beginning of April. The grass lands, as well as those sown with wheat after potatoes, were their principal resorts; but they had certain favourite fields upon which they alighted and fed, and seemed to prefer those which were either quite flat or had rising ground in the centre, from which they could

\footnotetext{
1 For this information I am indebted to Mr. James Bertram, the present tenant of Heughhead Farm.

2 Mr. James Hardy's MS. N'otes, 1842.

3 This letter was written to Mr. John Miller, Ladykirk West Lodge, now forester to Colonel Milne-Home of Wedlerburn, at the Grange, near Coldingham.
} 
easily observe the approach of an enemy. They very seldom ventured near any of the hedges, but generally liept about the middle of the field at a considerable distance from the fences or ditches, and were exceedingly vigilant and wary. Although I tried very often to creep up to them when they were feeding, I never succeeded in doing so, the birds always discovering me before I got near enough to use my gun with effect. The only way of getting within range of them which I found successful was by marking a flock from a distance with a telescope and then concealing myself behind a thick part of the hedge of one of the adjoining fields in the line of flight usually taken by the Geese when rising from the particular ground on which they were sitting. Before going to my place of concealment I used to instruct a boy in what direction to put them up, and, if he managed well, they sometimes came straight over my head within shot. In that way I had the satisfaction of bringing down a Goose occasionally with my gun. They sometimes sat all night in the fields when there was moonlight, but generally resorted to Gullane Sands in the evenings and returned to their feeding grounds in the mornings, shortly after sunrise. In Berwickshire Geese appear occasionally to remain on the open moors at night.

When they are seen winging their way from the northwest to the south-east it is probable that they are proceeding to Fenham Slakes in Northumberland, and when flying high to the north-west, Gullane Sands in East-Lothian may be their destination. They continuously frequent many localities in the county during the autumn months, and stay throughout the winter, when the weather is open, the latest recorded date at which they have been observed being the 22 nd of May 1886, when Mr. Clay, Kerchesters, saw a flock of twenty flying over "Gibbs' Cross" field on the farm of 
Wedderlie about 7 P.M., and heard a Cuckoo at the same time. He considered this to be unusually late for Wild Geese in that neighbourhood. During spring they are very fond of visiting ground newly sown with oats, which they greedily devour. ${ }^{1}$ They likewise do considerable damage to young grass, and render the pasturage foul with their droppings. ${ }^{2}$ They are sometimes trapped on the fields which they frequent ${ }^{3}$ by ordinary rabbit traps being set and carefully covered with fine soil on the ground where they feed, but when any are caught the flock does not usually return to the same spot for a season. ${ }^{4}$

As the haunts of Wild Geese in Berwickshire are gradually getting fewer in number, and many localities which were frequented by them in former times are now forsaken, the following list of farms and fields in each parish of the county which are still visited by them may not be without interest, and may prove useful for future reference. The information contained in the schedule has been supplied by the correspondents whose names are given below, and whom I take this opportunity of thanking for their kindness in responding to my enquiries.

1 "March 20th, 1858.-One of the outer fields on Penmanshiel, surrounded by moor, was once an extensive bog, its name being the Braid Bog. Finished sowing it to-day. It was then frequented by Wild Geese, which at night ate the corn not fully harrowed in."-J. Hardy's MSS. Notes.

2 "October 5 th, 1837.-One Goose will eat as much as a sheep, besides what it will defile. Sheep will not graze after them."-J. Hardy's MS. Notes.

${ }^{3}$ Mr. Joseph Caverhill, Abbey St. Bathans, informed me on the 18th of January 1857, that Wild Geese had been sonetimes trapped on Godscroft Woodheads hy Mr. James Hunter. He told me at the same time that, in the autumn of 1886, Mr. William Allan made a successful double shot at Wild Geese on the farm of Bowshiel, bringing down a Goose with each barrel of his gun; and that in the spring of that year Mr. David Purves, gamekeeper, Butterdean, killed two Geese in the same way on Harelawside. Mr. Caverhill likewise mentioned that Mr. John Moffat, Bankhead, killed seven Geese on Fannanside, near Godscroft, in the autumn of 1885 .

4 A female Wild Goose was canght in a trap at Penmanshiel Moor in October 1842. The Geese never went near the spot where it was trapped during the remainder of the season.-J. Hardy's MS. Notes. 


\begin{tabular}{|c|c|c|c|c|c|}
\hline Parish. & Farm. & $\begin{array}{c}\text { Fields on } \\
\text { which the } \\
\text { Wild Geese } \\
\text { alight. }\end{array}$ & $\begin{array}{l}\text { Date when they } \\
\text { come in Spring, } \\
\text { with Remarks. }\end{array}$ & $\begin{array}{c}\text { Date when they } \\
\text { come in Autumn, } \\
\text { with Remarks. }\end{array}$ & $\begin{array}{c}\text { Name and } \\
\text { Address of } \\
\text { Correspondent. }\end{array}$ \\
\hline $\begin{array}{c}\text { Abbey St. } \\
\text { Bathans. }\end{array}$ & $\begin{array}{l}\text { Abbey St. } \\
\text { Bathans. } \\
\text { Barnside. } \\
\text { Whiteburn. }\end{array}$ & $\begin{array}{l}\text { Broomhill } \\
\text { \& Yellow } \\
\text { Crairs, } \\
\text { two large } \\
\text { fields ad- } \\
\text { joining } \\
\text { each other. } \\
\\
\text { Abbey St. } \\
\text { Bathans } \\
\text { Moor. }\end{array}$ & $\begin{array}{l}\text { They do not alight } \\
\text { in spring, but } \\
\text { are seen passing } \\
\text { over from the } \\
\text { south in April. } \\
\text { From } 12 \text { to } 30 \\
\text { in a flock. } \\
\text { They do not } \\
\text { alight in spring. }\end{array}$ & $\begin{array}{l}\text { In October. They } \\
\text { have alighted } \\
\text { only once in the } \\
\text { last } 15 \text { years- } \\
\text { about } 5 \text { years } \\
\text { ago. Are seen } \\
\text { passing over } \\
\text { from north to } \\
\text { south. A bout } 30 \\
\text { to } 100 \text { in a flock. } \\
\text { The first week of } \\
\text { October. They } \\
\text { stay about a } \\
\text { week, coming } \\
\text { from north and } \\
\text { departing south- } \\
\text { wards. } 60 \text { to } \\
\text { 70 in a flock. } \\
\text { In the beginning } \\
\text { of Octoher. } \\
\text { Generally come } \\
\text { from north, } \\
\text { going south- } \\
\text { wards. } 10 \text { to } \\
\text { 20 in a flock. } \\
\text { They coine from } \\
\text { middle of Oeto- } \\
\text { ber to middle of } \\
\text { November, gen- } \\
\text { erally travelling } \\
\text { sulthwards. } \\
\text { They very seldom } \\
\text { come in autumn. } \\
\text { Flock seen alight- } \\
\text { ing on this farm } \\
6 \text { or } 8 \text { years ago. }\end{array}$ & $\begin{array}{l}\text { James Shiel, } \\
\text { gamekeeper, } \\
\text { Awbey St. } \\
\text { Bathans, Grants- } \\
\text { house, 12th Oct. } \\
\text { 1886. } \\
\text { James J. Ran- } \\
\text { kine, Barnside, } \\
\text { Grantshouse, } 7 \text { th } \\
\text { Oct. } 1886 \text {. }\end{array}$ \\
\hline Ayton. & Cocklaw. & & $\begin{array}{l}\text { Two Wild Geese } \\
\text { were seen on a } \\
\text { field on Cocklaw } \\
\text { in March } 1882 .\end{array}$ & & $\begin{array}{l}\text { James Purves, } \\
\text { gamekceper, } \\
\text { Mordington, } \\
\text { 12th April } 1884 .\end{array}$ \\
\hline Bunkle. & $\begin{array}{l}\text { Preston. } \\
\text { Blanerne } \\
\text { East. }\end{array}$ & $\begin{array}{l}\text { Damhead, } \\
\text { Herd's } \\
\text { Acres, } 32 \\
\text { acre field, } \\
\text { on lill top. }\end{array}$ & $\begin{array}{l}\text { Beginning of } \\
\text { March. Often } \\
\text { see large flocks } \\
\text { tlying north in } \\
\text { spring. Wild } \\
\text { Geese have been } \\
\text { seen on farm } \\
\text { several times } \\
\text { during last } 15 \\
\text { years. }\end{array}$ & $\begin{array}{l}\text { A flock of } 13 \text { was } \\
\text { seen on Dam- } \\
\text { head Field on } \\
\text { 13th Oet. } 1886 . \\
\text { Seen in autumn. }\end{array}$ & $\begin{array}{l}\text { John Barrie, } \\
\text { gamekeeper, } \\
\text { Preston, Duns, } \\
\text { 13th Oct. 1856. } \\
\text { John Blackadier, } \\
\text { East Blanerne, } \\
\text { Chirnside. }\end{array}$ \\
\hline
\end{tabular}




\begin{tabular}{|c|c|c|c|c|c|}
\hline Parisli. & Farm. & $\begin{array}{c}\text { Fields on } \\
\text { which the } \\
\text { wild Geese } \\
\text { alight. }\end{array}$ & $\begin{array}{l}\text { Date when they } \\
\text { come in Spring, } \\
\text { with Remarks. }\end{array}$ & $\begin{array}{l}\text { Date when they } \\
\text { come in Autumn, } \\
\text { with Remarks. }\end{array}$ & $\begin{array}{c}\text { Name and } \\
\text { Address of } \\
\text { Correspondent. }\end{array}$ \\
\hline $\begin{array}{l}\text { Bunkle- } \\
\text { continued. }\end{array}$ & $\begin{array}{l}\text { Lintlaw. } \\
\text { Mayfield. }\end{array}$ & $\begin{array}{l}\text { Bogieside. } \\
\text { About } 52 \\
\text { years ago } \\
\text { they used } \\
\text { to fre- } \\
\text { quent all } \\
\text { the fields } \\
\text { on the } \\
\text { farm, but } \\
\text { none have } \\
\text { been seen } \\
\text { on it for } \\
25 \text { years. }\end{array}$ & $\begin{array}{l}\text { They nsed to coine } \\
\text { in March and } \\
\text { April. }\end{array}$ & $\begin{array}{l}\text { Large flock } \\
\text { settled in field } \\
\text { called Bogieside } \\
\text { on } 14 \text { th Oct. } \\
1880 \text {. }\end{array}$ & $\begin{array}{l}\text { Robert Bruce, } \\
\text { gamekeeper, } \\
\text { Blanerne, Chirn. } \\
\text { side, 25th Oct. } \\
\text { 1886. } \\
\text { W. Dunlop, May- } \\
\text { field, 12th Oct. } \\
\text { 1886. }\end{array}$ \\
\hline $\begin{array}{l}\text { Channel- } \\
\text { kirk. }\end{array}$ & $\begin{array}{l}\text { Over- } \\
\text { howden. } \\
\text { Bower- } \\
\text { house. }\end{array}$ & $\begin{array}{l}\text { Road Field, } \\
\text { Croft Field, } \\
\text { and Hill } \\
\text { Field. }\end{array}$ & $\begin{array}{l}\text { In March : cease } \\
\text { coming about } \\
\text { end of April. } \\
\text { Come from } \\
\text { south, go north. } \\
\text { Flocks large. }\end{array}$ & $\begin{array}{l}\text { Sometimes alight } \\
\text { on Glengelt } \\
\text { fields, but not so } \\
\text { often now as for- } \\
\text { merly. They } \\
\text { visit the farm } \\
\text { in October and } \\
\text { Novemher. } \\
\text { In October; } \\
\text { cease coming } \\
\text { about end of } \\
\text { November. } \\
\text { Come from } \\
\text { north, go south. } \\
\text { Flocks small. } \\
\text { Flock of } 6 \\
\text { alighted on farm } \\
\text { on 6th Oct. 1886. } \\
\text { They came from } \\
\text { the east. Wild } \\
\text { Geese have al. } \\
\text { ways frequented } \\
\text { the farn. } \\
\text { Not seen in } \\
\text { autumn. }\end{array}$ & $\begin{array}{l}\text { Thomas M. Skir- } \\
\text { ring, Glengelt, } \\
\text { Channelkirk. } \\
\text { Robert Sharp, } \\
\text { Overhowden, } \\
\text { 12th Oct. 1886. } \\
\\
\text { John Fleming, } \\
\text { Jun., Bower- } \\
\text { house, Sth Oct. } \\
\text { 1886. } \\
\\
\text { Joln Bertram, } \\
\text { Hartside, 1st } \\
\text { Oct. 18s6. }\end{array}$ \\
\hline Chirnside. & $\begin{array}{l}\text { Edington } \\
\text { Mains. }\end{array}$ & . & $\begin{array}{l}\text { About } 1845 \text { a flock } \\
\text { alighted on the } \\
\text { farm on a knoll } \\
\text { in the field in } \\
\text { front of farm } \\
\text { house, three of } \\
\text { which were shot } \\
\text { by Mtr. Wilson's } \\
\text { brother. }\end{array}$ & & $\begin{array}{l}\text { John Wilson, } \\
\text { Welnage, Duns, } \\
\text { 14th May } 1886 .\end{array}$ \\
\hline $\begin{array}{l}\text { Cockburns- } \\
\text { path. }\end{array}$ & $\begin{array}{l}\text { Ecclaw. } \\
\text { Edmond- } \\
\text { dean. }\end{array}$ & Camps. & $\begin{array}{l}\text { In } \Lambda \text { pril, From } \\
\text { south to north. }\end{array}$ & $\begin{array}{l}\text { In October. } \\
\text { From north to } \\
\text { south. }\end{array}$ & $\begin{array}{l}\text { Joln Darling, } \\
\text { Ecclaw, Cock- } \\
\text { burnspath, 21st } \\
\text { Oct. 1886. }\end{array}$ \\
\hline
\end{tabular}


THE BEAN GOOSE AND PINK-FOOTED GOOSE.

\begin{tabular}{|c|c|c|c|c|c|}
\hline Parish. & Farm. & $\begin{array}{l}\text { Fields on } \\
\text { which the } \\
\text { wild Geese } \\
\text { alight. }\end{array}$ & $\begin{array}{l}\text { Date when they } \\
\text { come in Spring, } \\
\text { with Remarks. }\end{array}$ & $\begin{array}{l}\text { Date when they } \\
\text { come in Autumn, } \\
\text { with Renarks. }\end{array}$ & $\begin{array}{l}\text { Name and } \\
\text { Address of } \\
\text { Correspondent. }\end{array}$ \\
\hline $\begin{array}{c}\text { Cockburns- } \\
\text { path- } \\
\text { continued }\end{array}$ & $\begin{array}{l}\text { Bowshiel. } \\
\text { Redheugh. }\end{array}$ & $\begin{array}{l}\text { Oak Tree } \\
\text { Field, } \\
\text { Tunnel } \\
\text { Field. } \\
\text { Frequent } \\
\text { Moor, } \\
\text { Redheugh } \\
\text { Hill, and } \\
\text { Meikle } \\
\text { Blacklaw. } \\
\text { A pair } \\
\text { seen on } \\
\text { Fairside } \\
\text { Field for a } \\
\text { few days } \\
\text { in Feb. } \\
\text { 18s7, one } \\
\text { of which } \\
\text { was sliot. } \\
\text { Broad Bog } \\
\text { fields (100 } \\
\text { acresinex- } \\
\text { tent), sur- } \\
\text { rounded } \\
\text { by moor, } \\
\text { on which } \\
\text { they often } \\
\text { rest. They } \\
\text { feed on all } \\
\text { the sur- } \\
\text { rounding } \\
\text { farms. }\end{array}$ & $\begin{array}{l}\text { They usually } \\
\text { come in the } \\
\text { second week of } \\
\text { April, and leave } \\
\text { about the middle } \\
\text { of May. As } \\
\text { many as } 200 \text { have } \\
\text { been counted on } \\
\text { the Broad Bog } \\
\text { after the fields } \\
\text { were sown. They } \\
\text { have always fre- } \\
\text { quented these } \\
\text { fields, but many } \\
\text { more than usual } \\
\text { have been seen } \\
\text { during the last } \\
\text { two seasons. } \\
\text { Flocked through } \\
\text { March and April } \\
\text { l836 and } 1837 \\
\text { on Penmanshiel } \\
\text { Mloors. One was } \\
\text { caught in a trap } \\
\text { on the Moor in } \\
\text { Oct. } 1842 . \text { The } \\
\text { Geese never } \\
\text { went near the } \\
\text { spot where it } \\
\text { was trapped all } \\
\text { the remainder } \\
\text { of the season. } \\
\text { Flock seen on } \\
\text { Penmanshiel } \\
\text { 21st Feb. 1863. } \\
\text { Early year. } \\
\text { Wild Geese re- } \\
\text { appeared 9th } \\
\text { Mareh } 1865 . \\
\text { Large tlock, } 50 \\
\text { or } 60 \text {, have fre- } \\
\text { quented Broad } \\
\text { Bog and How- } \\
\text { park high } \\
\text { ground for three }\end{array}$ & $\begin{array}{l}\text { Sbout the begin. } \\
\text { ning of October, } \\
\text { and leave about } \\
\text { the end of Nov- } \\
\text { ember. 101 were } \\
\text { counted in a } \\
\text { flock in Aug. } \\
\text { 1886, but they } \\
\text { generally break } \\
\text { rp into snaller } \\
\text { flocks. }\end{array}$ & $\begin{array}{l}\text { Arthur Hardy, } \\
\text { Penmanshiel, } \\
\text { 1st Dec. 1886. } \\
\\
\\
\text { James Hardy, } \\
\text { Oldcambus.- } \\
\text { MS. Notes. }\end{array}$ \\
\hline
\end{tabular}




\begin{tabular}{|c|c|c|c|c|c|}
\hline Parish. & Farm. & $\begin{array}{c}\text { Fields on } \\
\text { which the } \\
\text { Wild Geese } \\
\text { alight. }\end{array}$ & $\begin{array}{l}\text { Date when they } \\
\text { come in Spring, } \\
\text { with Remarks. }\end{array}$ & $\begin{array}{c}\text { Date when they } \\
\text { come in Autumn, } \\
\text { with Remarks. }\end{array}$ & $\begin{array}{l}\text { Name and } \\
\text { Address of } \\
\text { Correspondent. }\end{array}$ \\
\hline $\begin{array}{l}\text { Coekburns- } \\
\text { path- } \\
\text { continued. }\end{array}$ & $\begin{array}{l}\text { Penman- } \\
\text { shiel-- } \\
\text { continued. }\end{array}$ & & 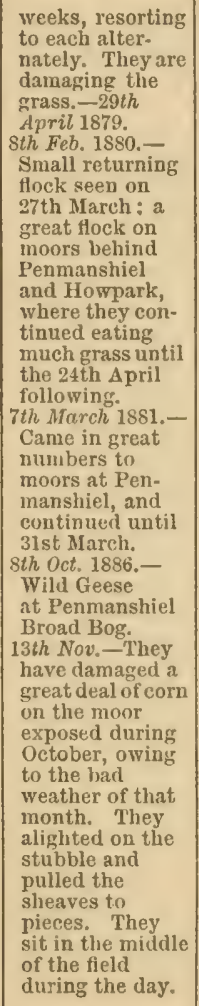 & & \\
\hline $\begin{array}{l}\text { Colding- } \\
\text { ham. }\end{array}$ & $\begin{array}{l}\text { Renton- } \\
\text { barns. } \\
\text { Mont } \\
\text { Albane. }\end{array}$ & $\begin{array}{l}\text { Fifty Acre } \\
\text { and Green- } \\
\text { wood } \\
\text { Eields. } \\
\\
\text { North Hill } \\
\text { and Moor } \\
\text { Hill. }\end{array}$ & $\begin{array}{l}\text { Come when fields } \\
\text { are sown with } \\
\text { corn, and remain } \\
\text { for a week or } \\
\text { ten days in the } \\
\text { vicinity. } \\
\text { About April, and } \\
\text { frequent newly } \\
\text { sown oat fields } \\
\text { and young grass. } \\
\text { Last seen on } \\
\text { farm in spring } \\
\text { 1882. }\end{array}$ & $\begin{array}{l}\text { Not seen on farm } \\
\text { in autumn. }\end{array}$ & $\begin{array}{l}\text { Alexander C. } \\
\text { Hastie, Renton- } \\
\text { barns, 18th Oet. } \\
1886 . \\
\text { R. J. Scott, Mont } \\
\text { Albane, Reston, } \\
\text { 7th Oct. 1886. }\end{array}$ \\
\hline
\end{tabular}


THE BFAN GOOSE AND PINK-FOOTED GOOSE.

\begin{tabular}{|c|c|c|c|c|c|}
\hline Parish. & Farm. & $\begin{array}{c}\text { Fields on } \\
\text { which the } \\
\text { Wild Geese } \\
\text { alight. }\end{array}$ & $\begin{array}{c}\text { Date when they } \\
\text { come in Spring, } \\
\text { with Remarks. }\end{array}$ & $\begin{array}{c}\text { Date when they } \\
\text { come in Autumn, } \\
\text { with Remarks. }\end{array}$ & $\begin{array}{l}\text { Name and } \\
\text { Address of } \\
\text { Correspondent. }\end{array}$ \\
\hline $\begin{array}{l}\text { Colding- } \\
\text { ham-- } \\
\text { contiurued. }\end{array}$ & $\begin{array}{l}\text { North } \\
\text { Fala- } \\
\text { knowe. } \\
\text { Cairncross. } \\
\\
\text { Auchen- } \\
\text { erow } \\
\text { Mains. } \\
\text { Crosslaw. }\end{array}$ & $\begin{array}{l}\text { Easter and } \\
\text { Wester } \\
\text { Lamb } \\
\text { Lees. } \\
\text { Ladypark. } \\
\text { Liddleshill. }\end{array}$ & $\begin{array}{l}\text { In April. Flocks } \\
\text { smaller in spring } \\
\text { than in autumn. } \\
\\
\text { Flock seen on } \\
\text { Ladypark } 26 \text { th } \\
\text { and } 27 \text { th Jan. } \\
\text { 18s7. } \\
\text { They do not visit } \\
\text { the farm in } \\
\text { spring. } \\
\text { Occasionally seen } \\
\text { on back tields. }\end{array}$ & $\begin{array}{l}\text { About end of } \\
\text { October and } \\
\text { beginning of } \\
\text { November. } \\
\text { Frnm } 7 \text { to } 25 \\
\text { in a Hlock. } \\
\end{array}$ & $\begin{array}{l}\text { John Wood, } \\
\text { North Fala. } \\
\text { knowe, Cold. } \\
\text { ingham, 8th } \\
\text { Oct. } 1886 . \\
\text { John Miller, } \\
\text { forester, Grange, } \\
\text { Coldingharn, } \\
\text { 31st Jan. 1887. } \\
\text { Thomas Calder, } \\
\text { Auchencrow } \\
\text { Mains, 4th } \\
\text { Oct. J886. } \\
\text { Thomas Cock. } \\
\text { burn, steward, } \\
\text { Whitsome New- } \\
\text { ton, 16th March } \\
\text { 1886. }\end{array}$ \\
\hline $\begin{array}{l}\text { Cold. } \\
\text { stream. }\end{array}$ & $\begin{array}{l}\text { Hawks- } \\
\text { law. } \\
\text { Skaith- } \\
\text { muir. } \\
\text { Hatchet- } \\
\text { nize. }\end{array}$ & $\begin{array}{l}\text { Wild Geese } \\
\text { used to } \\
\text { visit the } \\
\text { farm regu- } \\
\text { larly about } \\
30 \text { years } \\
\text { ago. Thoy } \\
\text { sometimes } \\
\text { alighted } \\
\text { on Lith- } \\
\text { tillum. } 3 \\
\text { were shot } \\
\text { on the } \\
\text { farm. }\end{array}$ & $\begin{array}{l}\text { Occasionally } \\
\text { alight in March } \\
\text { and A pril. Last } \\
\text { seen about 11 or } \\
\text { 12 years ago. } \\
\text { They sometimes } \\
\text { alight in March } \\
\text { on Lees Haugh, } \\
\text { and swim on } \\
\text { Iearmouth } \\
\text { Stream on the } \\
\text { Tweed. There } \\
\text { are usually from } \\
3 \text { to } 20 \text { in a flock. } \\
\text { Rarely alight. } \\
\\
\text { They fly over the } \\
\text { fields, but do not } \\
\text { alight in spring. } \\
\text { Small flocks. }\end{array}$ & $\begin{array}{l}\text { They visit the } \\
\text { farm from } \\
\text { middle to end of } \\
\text { October, seldom } \\
\text { later. From } \\
\text { south-east to } \\
\text { north-west. } \\
\text { Pretty large } \\
\text { flocks. In some } \\
\text { years they do not } \\
\text { visit the farm. }\end{array}$ & $\begin{array}{l}\text { Joln Miller, } \\
\text { Milne Graden, } \\
\text { Coldstream, } \\
\text { 12th Oct. } 1886 . \\
\text { Thomas Hood, } \\
\text { factor, Lees, } \\
\text { Coldstream, } \\
\text { 23rd Oct. 1886. }\end{array}$ \\
\hline
\end{tabular}




\begin{tabular}{|c|c|c|c|c|c|}
\hline Parish. & Farm. & $\begin{array}{c}\text { Fields on } \\
\text { which the } \\
\text { Wild Geese } \\
\text { alight. }\end{array}$ & $\begin{array}{l}\text { Date when they } \\
\text { come in Spring, } \\
\text { with Renarks. }\end{array}$ & $\begin{array}{l}\text { Date when they } \\
\text { come in Autumn, } \\
\text { with Remarks. }\end{array}$ & $\begin{array}{l}\text { Name and } \\
\text { Address of } \\
\text { Correspondent. }\end{array}$ \\
\hline $\begin{array}{l}\text { Cran- } \\
\text { shaws. }\end{array}$ & $\begin{array}{l}\text { Cran. } \\
\text { shaws. }\end{array}$ & $\begin{array}{l}\text { On all the } \\
\text { cultivated } \\
\text { fields on } \\
\text { the farm } \\
\text { when in } \\
\text { young } \\
\text { grass or } \\
\text { oat } \\
\text { stubble. } \\
\text { The two } \\
\text { fields most } \\
\text { frequented } \\
\text { are Crow- } \\
\text { hill and } \\
\text { Old Plan- } \\
\text { tation } \\
\text { Field. }\end{array}$ & $\begin{array}{l}\text { They usually ap- } \\
\text { pear in spring, } \\
\text { a bont the middle } \\
\text { of Mtarch, and } \\
\text { though they oc- } \\
\text { casionally alight } \\
\text { they do not stay } \\
\text { long. In spring } \\
\text { they come from } \\
\text { the south and go } \\
\text { north. The } \\
\text { flocks are not so } \\
\text { large in spring } \\
\text { as in auturn- } \\
\text { usually about } 30 . \\
\text { Wild Geese have } \\
\text { always visited } \\
\text { Rawburn Farm } \\
\text { occasionally, but } \\
\text { they have been } \\
\text { more numerous } \\
\text { of late years, } \\
\text { owing to more } \\
\text { land being culti- } \\
\text { vated now than } \\
\text { formeriy - the } \\
\text { attraction appar. } \\
\text { ently being the } \\
\text { young grass } \\
\text { fields. } \\
\text { They come in } \\
\text { April, Hying } \\
\text { from south tn } \\
\text { north. }\end{array}$ & $\begin{array}{l}\text { In autumn they } \\
\text { come from the } \\
\text { 20th of October } \\
\text { to the middle of } \\
\text { November, and, } \\
\text { if not molested, } \\
\text { usually stay } \\
\text { about two } \\
\text { weeks. They } \\
\text { come from the } \\
\text { north and go } \\
\text { south. Usually } \\
\text { about } 50 \text { in a } \\
\text { flock. }\end{array}$ & $\begin{array}{l}\text { H. Hewat Craw, } \\
\text { Rawburn, 5th } \\
\text { Oct. } 1886 .\end{array}$ \\
\hline Eccles. & $\begin{array}{l}\text { Printonian. } \\
\text { Lochton. }\end{array}$ & $\begin{array}{l}\text { Langbank, } \\
\text { Bowmaker } \\
\text { Hill. } \\
\text { Occasion- } \\
\text { ally seen } \\
\text { on farm. } \\
3 \text { sliot in } \\
1865 .\end{array}$ & At seed-time. & $\begin{array}{l}\text { They do not visit } \\
\text { the farm in } \\
\text { autumn. }\end{array}$ & $\begin{array}{l}\text { George Ruther- } \\
\text { ford, Printonian, } \\
5 \text { th Oct. } 1886 . \\
\text { Peter Cowe, } \\
\text { Lochton, Cold. } \\
\text { stream, 7th } \\
\text { Aug. 1856. }\end{array}$ \\
\hline Edrom. & $\begin{array}{l}\text { Greun- } \\
\text { knowe. }\end{array}$ & $\begin{array}{l}\text { Alicefield. } \\
\text { Occasion- } \\
\text { ally alight } \\
\text { on farm, } \\
\text { but not } \\
\text { often. } \\
\text { Easter } \\
\text { Ridley, } \\
\text { Sand Pit } \\
\text { Field. } \\
\text { Haugh. }\end{array}$ & & $\begin{array}{l}\text { Sinall flocks some- } \\
\text { times come. A } \\
\text { flock of } 7 \text { fre- } \\
\text { quented Alice- } \\
\text { field in } 1882 \text { for } \\
5 \text { days. }\end{array}$ & $\begin{array}{l}\text { Mark Cossar, } \\
\text { Greenknowe, } \\
\text { 16th Oct. 1886. } \\
\\
\text { John Thomson, } \\
\text { gamekeeper, } \\
\text { Kimmerghame, } \\
\text { 3rd Nov, 1886. } \\
\text { G. Nisbet, game- } \\
\text { keeper, Nesbit } \\
\text { House, Duns, } \\
\text { 12th Oct. 18s6. }\end{array}$ \\
\hline
\end{tabular}




\begin{tabular}{|c|c|c|c|c|c|}
\hline Parish. & Farm. & $\begin{array}{c}\text { Fields on } \\
\text { which the } \\
\text { wild Geese } \\
\text { alight. }\end{array}$ & $\begin{array}{l}\text { Date when they } \\
\text { come in Spring, } \\
\text { with Remarks. }\end{array}$ & $\begin{array}{l}\text { Date when they } \\
\text { come in Autumn, } \\
\text { with Remarks. }\end{array}$ & $\begin{array}{c}\text { Name and } \\
\text { Address of } \\
\text { Correspondent. }\end{array}$ \\
\hline $\begin{array}{l}\text { Edrom- } \\
\text { continued. }\end{array}$ & $\begin{array}{l}\text { Kimmer- } \\
\text { ghame } \\
\text { Ilains. }\end{array}$ & Bogs Field. & & $\begin{array}{l}3 \text { seen on Bog } \\
\text { Field in autumn } \\
\text { of } 1883 \text {. }\end{array}$ & $\begin{array}{l}\text { Jolin Gray, Bell- } \\
\text { shiel, 7th Oct. } \\
\text { j8s6. }\end{array}$ \\
\hline Duns. & $\begin{array}{l}\text { Kidshiel- } \\
\text { haugh. } \\
\text { Hardens. }\end{array}$ & $\begin{array}{l}\text { Pilgrim's } \\
\text { Acre. } \\
\text { Harelaw } \\
\text { Field in } \\
\text { Duns } \\
\text { Parish. }\end{array}$ & $\begin{array}{l}\text { During seed-time } \\
\text { in spring, and } \\
\text { continue for two } \\
\text { or three weeks. } \\
\text { Seldom alight in } \\
\text { spring. }\end{array}$ & $\begin{array}{l}\text { Have not seen } \\
\text { them on farm } \\
\text { in autumn. } \\
\text { Come about first } \\
\text { week in October, } \\
\text { and give up com- } \\
\text { ing about end of } \\
\text { same month. }\end{array}$ & $\begin{array}{l}\text { Thomas Johnston, } \\
\text { Kidshielhaugh, } \\
\text { Duns, 6th Oct. } \\
1886 . \\
\text { John H. Laurie, } \\
\text { Hardens, Duns, } \\
\text { 15th Oct. 18s6. }\end{array}$ \\
\hline Fogo: & $\begin{array}{l}\text { Fogorig. } \\
\text { Ryselaw. }\end{array}$ & $\begin{array}{l}\text { Chesters, } \\
\text { East and } \\
\text { West } \\
\text { Wormrigg, } \\
\text { both } 50 \\
\text { acre fields; } \\
\text { sometimes } \\
\text { alight on } \\
\text { adjoining } \\
\text { fields. }\end{array}$ & $\begin{array}{l}\text { Stay a short time } \\
\text { in spring. Flocks } \\
\text { smaller in spring } \\
\text { than in autumn. } \\
\text { They come from } \\
\text { south-east and } \\
\text { go north-west. } \\
\\
\text { They do not feed } \\
\text { in spring on } \\
\text { farm, but are } \\
\text { seen passing } \\
\text { over. One was } \\
\text { shot on Wester } \\
\text { Fawrig on } 2 \text { nd } \\
\text { April } 5 \text { or } 6 \text { years } \\
\text { ago. They have } \\
\text { not returned to } \\
\text { that field since } \\
\text { then. }\end{array}$ & $\begin{array}{l}\text { Visit the farm for } \\
\text { a short time in } \\
\text { autumn. They } \\
\text { come from the } \\
\text { north-west and } \\
\text { go south-east. } \\
\text { Flocks Jarger in } \\
\text { autumn than in } \\
\text { spring. } \\
\text { They come after } \\
\text { harvest, and give } \\
\text { up coming when } \\
\text { corn gets scarce. } \\
\text { They come from } \\
\text { the ponds on } \\
\text { Kyleshill Moor } \\
\text { (this is also } \\
\text { known as the } \\
\text { Hule Moss), and } \\
\text { return there. } \\
\text { Two were shot } \\
\text { on East Worm. } \\
\text { rigg Field in } \\
\text { November } 1883 \text {. } \\
\text { There have not } \\
\text { been so many } \\
\text { since that year. } \\
\text { About } 40 \text { passeil } \\
\text { over Sisterpath } \\
\text { on the } 25 \text { th Sept. } \\
\text { 1886- the first } \\
\text { flock this season. }\end{array}$ & $\begin{array}{l}\text { William Thomp- } \\
\text { son, game- } \\
\text { keeper, Charter- } \\
\text { hall, 11th Oct. } \\
1886 .\end{array}$ \\
\hline
\end{tabular}




\begin{tabular}{|c|c|c|c|c|c|}
\hline Parish. & Farm. & $\begin{array}{c}\text { Fields on } \\
\text { which the } \\
\text { Wild Geese } \\
\text { alight. }\end{array}$ & $\begin{array}{l}\text { Date when they } \\
\text { come in Spring, } \\
\text { with Remarks. }\end{array}$ & $\begin{array}{l}\text { Date when they } \\
\text { come in Autumn, } \\
\text { with Remarks. }\end{array}$ & $\begin{array}{c}\text { Name and } \\
\text { Address of } \\
\text { Correspondent. }\end{array}$ \\
\hline Foulden. & $\begin{array}{l}\text { Foulden } \\
\text { New } \\
\text { Mains. } \\
\\
\text { Foulden } \\
\text { West } \\
\text { Mains. }\end{array}$ & $\begin{array}{l}\text { Mill Pond. } \\
\text { Damhead } \\
\text { Field. }\end{array}$ & $\begin{array}{l}\text { Seen passing high } \\
\text { overhead in } \\
\text { spring, from } \\
\text { middle of March } \\
\text { to middle of } \\
\text { April, going } \\
\text { north. }\end{array}$ & $\begin{array}{l}\text { On 14th Novem- } \\
\text { ber } 1878 \text { a flock } \\
\text { alighted on the } \\
\text { Mill Pond. } \\
\text { James Purves, } \\
\text { gamekeeper at } \\
\text { Foulden, shot } \\
\text { one of them. } \\
\text { Seen only once } \\
\text { in last } 20 \text { years. } \\
\text { About } 10 \text { th } \\
\text { November, 15 } \\
\text { years ago, two } \\
\text { alighted on } \\
\text { Dainhead Field } \\
\text { when sown with } \\
\text { wheat. Large } \\
\text { flocks pass high } \\
\text { overhead in end } \\
\text { of October and } \\
\text { November, } \\
\text { going south. }\end{array}$ & $\begin{array}{l}\text { G. Millican, } \\
\text { Foulden New } \\
\text { Mains, 6th } \\
\text { Nov. 18s6. } \\
\\
\text { H. Hewat Craw, } \\
\text { Foulden West } \\
\text { Mains, 5th Oct. } \\
\text { 1s86. }\end{array}$ \\
\hline Gordon. & $\begin{array}{l}\text { Rumble- } \\
\text { ton Law. } \\
\text { Fallside. } \\
\text { Middle- } \\
\text { third. } \\
\\
\text { Rumble- } \\
\text { ton, } \\
\text { Rumble. } \\
\text { ton Law, } \\
\text { Hexpath. }\end{array}$ & $\begin{array}{l}\text { Betty Field, } \\
\text { Todrig } \\
\text { Bank and } \\
\text { Moor. }\end{array}$ & $\begin{array}{l}\text { Come in March } \\
\text { and until a bout } \\
\text { the } 20 \text { th A pril. } \\
\text { If put up, they } \\
\text { fly to Greenlaiv- } \\
\text { dean and Hally- } \\
\text { burton. } \\
\\
\text { About 20th Feb. } \\
\text { to } 10 \text { th March. } \\
\text { From 10 to 50 } \\
\text { in a flock. } \\
\text { If the winter be } \\
\text { open, the Geese } \\
\text { come about the } \\
\text { middle of } \\
\text { November, and } \\
\text { do not leave } \\
\text { until A pril. In } \\
\text { general they } \\
\text { come from a } \\
\text { northern direc- } \\
\text { tion, and leave } \\
\text { in the same way, } \\
\text { both in spring } \\
\text { and autumn. } \\
\text { As many as } 200 \\
\text { sometimes in a } \\
\text { flock. About } 20 \\
\text { years ago they } \\
\text { frequented some } \\
\text { lower down } \\
\text { tields on Mleller- } \\
\text { stain Estate. }\end{array}$ & $\begin{array}{l}\text { Come in October, } \\
\text { and remain until } \\
\text { snow-stomn } \\
\text { occurs. } \\
\\
\text { Only once seen } \\
\text { on farm during a } \\
\text { gale in autumn. } \\
\text { They have not } \\
\text { been known to } \\
\text { alight in } \\
\text { autumn. }\end{array}$ & $\begin{array}{l}\text { John Jamieson, } \\
\text { gamekeeper to } \\
\text { Lord Hadding. } \\
\text { ton, in Gordon } \\
\text { District, 9th } \\
\text { Oct. 1886. } \\
\text { Alex. White, } \\
\text { Fawside, Sth } \\
\text { Oct. 18s6. } \\
\text { Siiddlethird. } \\
\\
\text { James M'Pher- } \\
\text { son, gamekeeper, } \\
\text { Mellerstain, 13th } \\
\text { Oct. 1886. }\end{array}$ \\
\hline
\end{tabular}




\begin{tabular}{|c|c|c|c|c|c|}
\hline Parish. & Farm. & $\begin{array}{l}\text { Fielrls on } \\
\text { which the } \\
\text { Wild Geese } \\
\text { alight. }\end{array}$ & $\begin{array}{l}\text { Date when they } \\
\text { come in Spring, } \\
\text { with Remarks. }\end{array}$ & $\begin{array}{l}\text { Date when they } \\
\text { come in Autumn, } \\
\text { with Remarks. }\end{array}$ & $\begin{array}{c}\text { Name and } \\
\text { Address of } \\
\text { Correspondent. }\end{array}$ \\
\hline Greenlaw. & $\begin{array}{l}\text { Greenlaw- } \\
\text { dean, } \\
\text { Hally- } \\
\text { burton, } \\
\text { and } \\
\text { neigh- } \\
\text { bourhood. } \\
\\
\text { Greenlaw } \\
\text { Moor. }\end{array}$ & $\begin{array}{l}\text { The Hule } \\
\text { Moss, a } \\
\text { sheet of } \\
\text { water ex- } \\
\text { tending to } \\
\text { about } 17 \\
\text { aeres. }\end{array}$ & $\begin{array}{l}\text { For the last } 24 \\
\text { years have only } \\
\text { been seen on } \\
\text { farm once or } \\
\text { twice. } \\
\text { They visit the } \\
\text { farm during } \\
\text { winter and } \\
\text { spring, and are } \\
\text { sometimes seen } \\
\text { on the Mfill } \\
\text { Pond, which is } \\
\text { in the Shed } \\
\text { Park. They } \\
\text { appear to come } \\
\text { from the north, } \\
\text { and leave in the } \\
\text { same direction. } \\
\text { They come from } \\
\text { February to } \\
\text { April. }\end{array}$ & $\begin{array}{l}\text { They come in } \\
\text { October, and } \\
\text { continue coming } \\
\text { as late as Decem- } \\
\text { ber. They come } \\
\text { from north-east, } \\
\text { and go south in } \\
\text { flocks of } 20 \text { to } \\
100 \text {. As many as } \\
700 \text { have been } \\
\text { seen in a flock on } \\
\text { Greenlawdean. } \\
\text { They usually } \\
\text { arrive about the } \\
\text { lst of October. } \\
\text { Their stay de- } \\
\text { pends on the } \\
\text { weather; when } \\
\text { frost sets in } \\
\text { they leave, and } \\
\text { return again } \\
\text { when the wea- } \\
\text { ther becomes } \\
\text { mild, They come } \\
\text { from the jorth, } \\
\text { and usually go } \\
\text { southward. } \\
\text { They arrive in } \\
\text { tlocks, not ex. } \\
\text { ceedling } 50 \text { or } 60 \\
\text { birds, until they } \\
\text { accimulate to } \\
\text { nearly lo00 in } \\
\text { number. }\end{array}$ & $\begin{array}{l}\text { Edward Lithgow, } \\
\text { Bedshiel, 20th } \\
\text { Oct. 18s6. } \\
\text { William Duncan, } \\
\text { Old Greenlaw, } \\
\text { 19th Oct. 18s6. } \\
\text { James Burton, } \\
\text { Angelraw, 11th } \\
\text { Oct. 18s6. }\end{array}$ \\
\hline Hutton. & $\begin{array}{l}\text { Broad. } \\
\text { mealows. }\end{array}$ & $\begin{array}{l}\text { Gordon } \\
\text { Law. }\end{array}$ & & $\begin{array}{l}\text { A tlock was seen } 30 \\
\text { years ago sitting } \\
\text { on the Gordon } \\
\text { Law Field. }\end{array}$ & $\begin{array}{l}\text { D. Hosick, Hut- } \\
\text { ton Mains. }\end{array}$ \\
\hline
\end{tabular}


THE BEAN GOOSE AND PINK-FOOTED GOOSE.

\begin{tabular}{|c|c|c|c|c|c|}
\hline Parish. & Famn. & $\begin{array}{c}\text { Fields on } \\
\text { which the } \\
\text { Wild Geese } \\
\text { alight. }\end{array}$ & $\begin{array}{l}\text { Date when they } \\
\text { come in Spring, } \\
\text { with Remarks. }\end{array}$ & $\begin{array}{l}\text { Date when they } \\
\text { come in Autumn, } \\
\text { with Remarks. }\end{array}$ & $\begin{array}{c}\text { Name and } \\
\text { Address of } \\
\text { Correspondent. }\end{array}$ \\
\hline $\begin{array}{l}\text { Hutton- } \\
\text { continued. }\end{array}$ & $\begin{array}{l}\text { Hutton } \\
\text { Mains, } \\
\text { West } \\
\text { Fishwick. } \\
\\
\text { Spital } \\
\text { Blains, } \\
\text { Clarabad. } \\
\\
\\
\\
\text { Paxton } \\
\text { South } \\
\text { Mains. } \\
\text { Sunwick. }\end{array}$ & $\begin{array}{l}\text { Big Muir } \\
\text { Field. }\end{array}$ & & $\begin{array}{l}\text { A flock was seen } \\
\text { on Big Moor } \\
\text { Field about } 15 \\
\text { years ago; and } \\
\text { on a field of } \\
\text { West Fishwick, } \\
\text { next Wintield, } \\
\text { about } 10 \text { years } \\
\text { ago. } \\
\text { Wild Geese used } \\
\text { sometimes to } \\
\text { alight on Spital } \\
\text { Mains anil Clara- } \\
\text { bad Farms, but } \\
\text { have not done so } \\
\text { for many years. } \\
\text { Two were shot } \\
\text { some years ago } \\
\text { by Mr. Stow- } \\
\text { Compton-Lundie } \\
\text { on Spital Mains. } \\
\text { A small Hock } \\
\text { alighted on the } \\
\text { Toll Field a few } \\
\text { years ago. } \\
\text { Wild Geese used } \\
\text { to visit the fields } \\
\text { about the moor } \\
\text { long ago. }\end{array}$ & $\begin{array}{l}\text { W. Compton- } \\
\text { Lundie of Spital, } \\
\text { Spital House, } \\
\text { Oct. } 1856 . \\
\end{array}$ \\
\hline Ladykirk. & & & $\begin{array}{l}\text { "In spring Wild } \\
\text { Geese frequent } \\
\text { the country,"-- } \\
\text { Rev. Thos. Alills, } \\
\text { Mlinister of Lady } \\
\text { kirk, in Old Stat. } \\
\text { Acet. of Scot. } \\
\text { (1793), vol. viii. } \\
\text { p. 74. }\end{array}$ & & \\
\hline Langton. & $\begin{array}{l}\text { Langton } \\
\text { Lees. } \\
\text { Woodend. }\end{array}$ & $\begin{array}{l}\text { Stubble } \\
\text { fields and } \\
\text { young } \\
\text { grass. } \\
\text { On high } \\
\text { fields near } \\
\text { Damhead. } \\
\\
\text { North Hill, } \\
\text { Birks, } \\
\text { when these } \\
\text { fields are } \\
\text { in young } \\
\text { grass. }\end{array}$ & $\begin{array}{l}\text { Very seldom come } \\
\text { in spring. } \\
\text { Visit farm in Feb. } \\
\text { and March. } \\
\text { Come from } \\
\text { south-west, go } \\
\text { north-east. } \\
\text { March and begin- } \\
\text { ning of April. } \\
\text { Come from } \\
\text { south and go } \\
\text { north. }\end{array}$ & $\begin{array}{l}\text { Occasionally visit } \\
\text { farm in autumn. } \\
\text { Come to farm in } \\
\text { September and } \\
\text { October. Flocks } \\
\text { number from } 6 \\
\text { to } 50 \text {. } \\
\text { September and } \\
\text { October. Come } \\
\text { from north and } \\
\text { go south. Flocks } \\
\text { large. }\end{array}$ & $\begin{array}{l}\text { Thomas Torrance, } \\
\text { Langton Lees, } \\
\text { 23rd Oct. 1856. } \\
\text { J. 8. Brash, } \\
\text { Woodend, 15th } \\
\text { Oct. 1886. } \\
\\
\text { Alexander Penny, } \\
\text { Choicelee, 13th } \\
\text { Oct. 1886; and } \\
\text { George Miercer, } \\
\text { 8th Oct. 18s6. }\end{array}$ \\
\hline
\end{tabular}

VOL. II. 


\begin{tabular}{|c|c|c|c|c|c|}
\hline Parish. & Farm. & $\begin{array}{c}\text { Fields on } \\
\text { which the } \\
\text { Wild Geese } \\
\text { alight. }\end{array}$ & $\begin{array}{l}\text { Date when they } \\
\text { come in Spring, } \\
\text { with Remarks. }\end{array}$ & $\begin{array}{l}\text { Date when they } \\
\text { come in Autumn, } \\
\text { with Remarks. }\end{array}$ & $\begin{array}{l}\text { Name and } \\
\text { Address of } \\
\text { Correspondent. }\end{array}$ \\
\hline Lauder. & $\begin{array}{l}\text { Thirle- } \\
\text { stane. }\end{array}$ & $\begin{array}{l}\text { Higher } \\
\text { fields on } \\
\text { the farm. }\end{array}$ & $\begin{array}{l}\text { Occasionally visit } \\
\text { farm in spring. } \\
\text { They come from } \\
\text { the south, but } \\
\text { do not stay long. } \\
\text { They appear to } \\
\text { feed on the farm } \\
\text { during the day, } \\
\text { and leave for the } \\
\text { moss on Hally- } \\
\text { burton Farm in } \\
\text { the evening. I } \\
\text { do not think } \\
\text { that they come } \\
\text { so often to the } \\
\text { farm as they did } \\
\text { some time afo. } \\
\text { Come in April, } \\
\text { and occasionally } \\
\text { in May. They } \\
\text { come from } \\
\text { south-east, and } \\
\text { go south by east. }\end{array}$ & $\begin{array}{l}\text { In autumn they } \\
\text { come from north } \\
\text { and go south- } \\
\text { east. They do } \\
\text { not visit the } \\
\text { farm now as fre- } \\
\text { quently as they } \\
\text { did } 16 \text { years ago. }\end{array}$ & $\begin{array}{l}\text { Geo. M'Dougal, } \\
\text { Blythe, } 30 \text { th } \\
\text { Oct. } 1886 .\end{array}$ \\
\hline $\begin{array}{l}\text { Legrer- } \\
\text { woorl. }\end{array}$ & $\begin{array}{l}\text { Boon, and } \\
\text { Cribbs. } \\
\text { Corsbie. } \\
\text { Leger- } \\
\text { wood. }\end{array}$ & $\begin{array}{l}\text { Cribbs- } \\
\text { bank, and } \\
\text { Candle- } \\
\text { maker } \\
\text { Fields. } \\
\\
\text { Candle- } \\
\text { maker } \\
\text { Field. }\end{array}$ & $\begin{array}{l}\text { They are not ob- } \\
\text { served to visit } \\
\text { farm in spring. }\end{array}$ & $\begin{array}{l}\text { They occasionally } \\
\text { frequent farm in } \\
\text { autumn. A flock } \\
\text { here at present, } \\
\text { and been so for } \\
\text { past } 10 \text { days. } \\
\text { Wild Geese often } \\
\text { visit Corsbie } \\
\text { Farm. } \\
\text { when I went to } \\
\text { Legerwood in } \\
\text { 1841, Wild Geese } \\
\text { alighted in a } \\
\text { field called } \\
\text { Candlemaker, } \\
\text { and for some } \\
\text { years afterwards } \\
\text { (always in the } \\
\text { month of April), } \\
\text { on their way } \\
\text { north. In com- } \\
\text { ing back in } \\
\text { autumn they } \\
\text { passed overhead } \\
\text { without alight- } \\
\text { ing. After the } \\
\text { large fleld-90 } \\
\text { acres-was } \\
\text { divided and the } \\
\text { plantation grew } \\
\text { up, the Geese } \\
\text { gave up alight- } \\
\text { ing on the farm. } \\
\text { They never visit } \\
\text { the farm now. } \\
\text { It is } 35 \text { years } \\
\text { since they fre. } \\
\text { quented it. }\end{array}$ & $\begin{array}{l}\text { Robert Shirra } \\
\text { Gibb, MI. B., } \\
\text { C.M., Boon, } \\
\text { 25th Oct. } 1856 \text {. } \\
\\
\text { John Logan, } \\
\text { Legerwood, } \\
\text { 9th Oct. 1886. }\end{array}$ \\
\hline
\end{tabular}


THE BEAN GOOSE AND PINK-FOOTED GOOSE.

\begin{tabular}{|c|c|c|c|c|c|}
\hline Parish. & Farm. & $\begin{array}{c}\text { Fields on } \\
\text { which the } \\
\text { wild Geese } \\
\text { alight. }\end{array}$ & $\begin{array}{l}\text { Date when they } \\
\text { come in Spring, } \\
\text { with Remarks. }\end{array}$ & $\begin{array}{l}\text { Date when they } \\
\text { come in Autumn, } \\
\text { with Remarks. }\end{array}$ & $\begin{array}{c}\text { Name and } \\
\text { Address of } \\
\text { Correspondent. }\end{array}$ \\
\hline $\begin{array}{l}\text { Longfor- } \\
\text { macus. }\end{array}$ & \begin{tabular}{|l|} 
Fellcleugh. \\
Retreat. \\
Longfor- \\
macus.
\end{tabular} & $\begin{array}{l}\text { Moorylaw. } \\
\\
\text { Cairnfield, } \\
\text { Shepherd's } \\
\text { House } \\
\text { Field. } \\
\text { Duddieslea. }\end{array}$ & 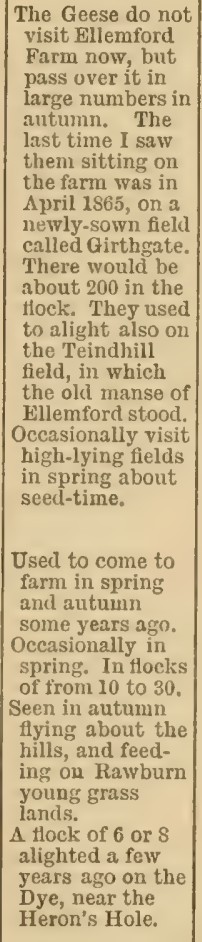 & $\begin{array}{l}\text { Autumn, after } \\
\text { the harvest. } \\
\text { Have seen them } \\
\text { frequent farm } \\
\text { for } 3 \text { weeks at a } \\
\text { time. }\end{array}$ & $\begin{array}{l}\text { J. Johnston, } \\
\text { Fellcleugh, } \\
\text { 18th Jan. 1886. } \\
\\
\text { P. Hastie, Milne } \\
\text { Graden, 10th } \\
\text { Sept. 1884. } \\
\text { James Bertram, } \\
\text { Retreat, 8th Oct. } \\
\text { 1886. } \\
\text { Colonel Brown of } \\
\text { Longformacus, } \\
\text { Oct. 1886. } \\
\\
\text { Rev. George Cook, } \\
\text { The Manse, } \\
\text { Longformacus, } \\
\text { Oct. 1886. }\end{array}$ \\
\hline $\begin{array}{l}\text { Mording- } \\
\text { ton. }\end{array}$ & $\begin{array}{l}\text { Mording. } \\
\text { ton } \\
\text { Mains. }\end{array}$ & $\begin{array}{l}\text { Brother- } \\
\text { stone and } \\
\text { Millburn- } \\
\text { two knolly } \\
\text { fields close } \\
\text { to the } \\
\text { cosst. } \\
\text { Camp Field. } \\
\\
\text { Big Moor, } \\
\text { Jock's } \\
\text { Park. }\end{array}$ & $\begin{array}{l}\text { Have not been } \\
\text { noticed on the } \\
\text { farm in spring. } \\
\\
\\
\text { On 1st Jan. 18S4 } \\
\text { a flock of } 20 \\
\text { alighted on the } \\
\text { Camp Field. } \\
\text { They seldom } \\
\text { alight. Saw } \\
\text { two in March } \\
\text { 1882 on the Big } \\
\text { Moor Field. }\end{array}$ & $\begin{array}{l}\text { They occasionally } \\
\text { visit the farm in } \\
\text { September or } \\
\text { October. }\end{array}$ & $\begin{array}{l}\text { James Mein, } \\
\text { Lambertorl, } \\
\text { 28th Oct. } 1886 . \\
\\
\\
\text { James Purves, } \\
\text { gamekeeper, } \\
\text { Mordington, } \\
\text { 12th A pril 1884. } \\
\text { James Furves, } \\
\text { gamekeeper, } \\
\text { Arordington, } \\
\text { 11th Oct. 1836. }\end{array}$ \\
\hline
\end{tabular}




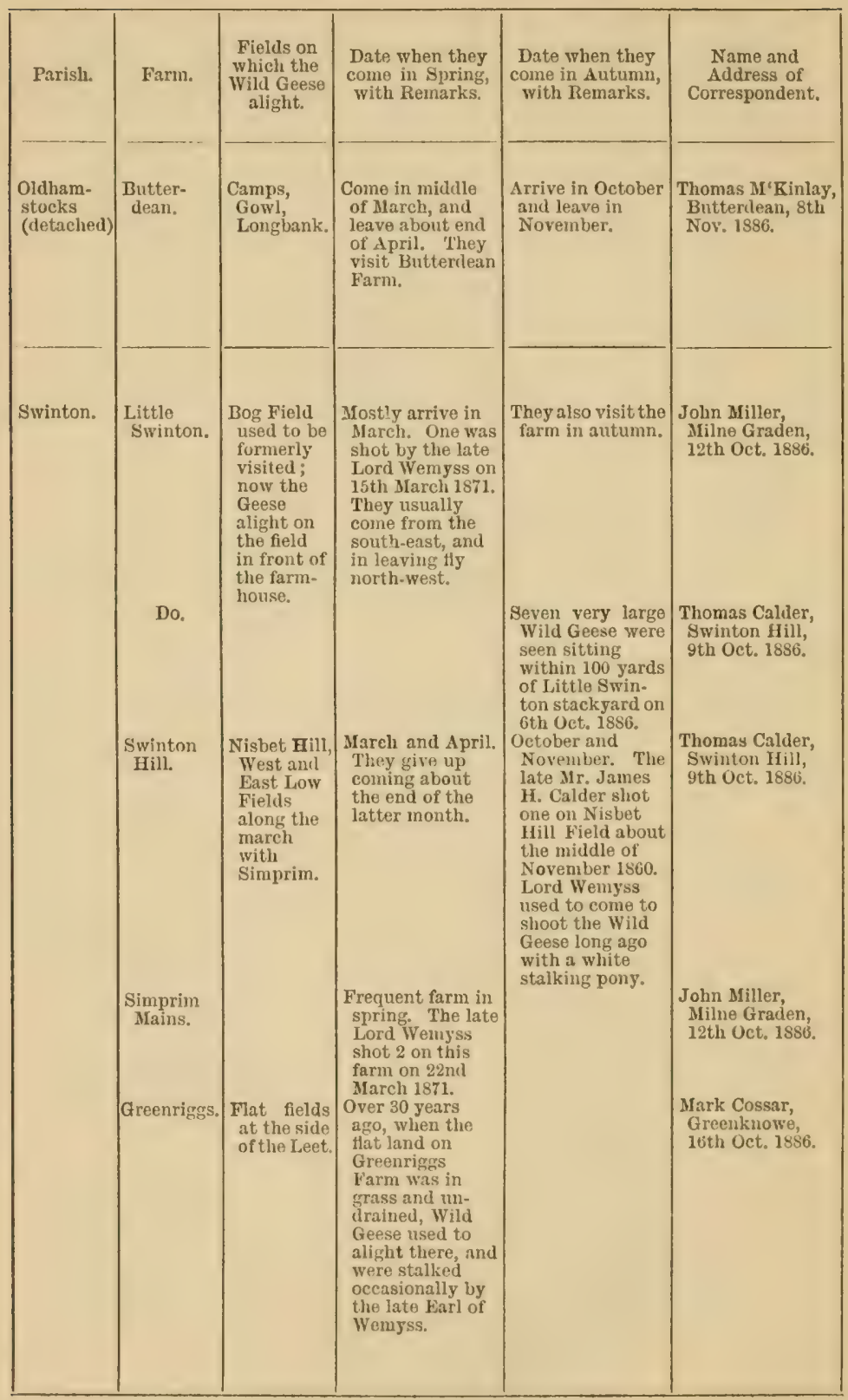




\begin{tabular}{|c|c|c|c|c|c|}
\hline Parish. & Farm, & $\begin{array}{l}\text { Fields on } \\
\text { which the } \\
\text { Wild Geese } \\
\text { alight. }\end{array}$ & $\begin{array}{l}\text { Date when they } \\
\text { come in Spriug, } \\
\text { with Remarks. }\end{array}$ & $\begin{array}{l}\text { Date when they } \\
\text { come in Autumn, } \\
\text { with Remarks. }\end{array}$ & $\begin{array}{l}\text { Name and } \\
\text { Address of } \\
\text { Correspondent. }\end{array}$ \\
\hline \multirow[t]{7}{*}{$\begin{array}{l}\text { West- } \\
\text { ruther. }\end{array}$} & $\begin{array}{l}\text { West- } \\
\text { ruther } \\
\text { Mains. }\end{array}$ & & $\begin{array}{l}\text { Occasionally, but } \\
\text { not often. Have } \\
\text { observed them } \\
\text { alight on the } \\
\text { farm only three } \\
\text { times. }\end{array}$ & & $\begin{array}{l}\text { James Gibson, } \\
\text { Westruther } \\
\text { Mains, West- } \\
\text { ruther, 20th } \\
\text { Oct. 1886. }\end{array}$ \\
\hline & $\begin{array}{l}\text { Cammer } \\
\text { Laws. }\end{array}$ & $\begin{array}{l}\text { Pond Field, } \\
\text { Wood } \\
\text { Park, } \\
\text { Backrig } \\
\text { 'ark. }\end{array}$ & $\begin{array}{l}\text { They come about } \\
\text { the end of Mareh, } \\
\text { and give up com- } \\
\text { ing about the end } \\
\text { of A pril. They are } \\
\text { very fond of grass } \\
\text { that has been } \\
\text { sown down with- } \\
\text { out a crop. The } \\
\text { flocks are usually } \\
\text { smaller in spring } \\
\text { than in autumn. }\end{array}$ & $\begin{array}{l}\text { They arrive about } \\
\text { the middle of } \\
\text { October, and } \\
\text { leave about the } \\
\text { end of Novem- } \\
\text { ber, but occa- } \\
\text { sionally stay } \\
\text { later. The aver- } \\
\text { age number in a } \\
\text { flock varies from } \\
40 \text { to } 60 \text {, but as } \\
\text { many as } 150 \text { bave } \\
\text { been seen. }\end{array}$ & $\begin{array}{l}\text { Robert Lyal, } \\
\text { Cammer Laws, } \\
\text { 9th Oct. 1886. }\end{array}$ \\
\hline & $\begin{array}{l}\text { Hindside- } \\
\text { hill. }\end{array}$ & & $\begin{array}{l}\text { About } 8 \text { years ago } \\
\text { two were shot on } \\
\text { this farm near } \\
\text { the village of } \\
\text { Houndslow by a } \\
\text { Spottiswoode } \\
\text { gamekeeper. }\end{array}$ & & $\begin{array}{l}\text { John Xoung, } \\
\text { gamekeeper, } \\
\text { Spottiswoode, } \\
\text { 11th Oct. } 1889 .\end{array}$ \\
\hline & & & $\begin{array}{l}\text { They used to come } \\
\text { in spring to } \\
\text { Easter Langrigs } \\
\text { Field, where } \\
\text { there was a pond. }\end{array}$ & & $\begin{array}{l}\text { IR. Renton, Spot- } \\
\text { tiswoode, 30th } \\
\text { Aug. } 1886 \text {. }\end{array}$ \\
\hline & Werlderlie. & $\begin{array}{l}\text { Outer } \\
\text { House, } \\
\text { Edsar } \\
\text { Hill, } \\
\text { Gibb's } \\
\text { Cross. } \\
\end{array}$ & $\begin{array}{l}\text { Come in Marcl if } \\
\text { weather be good, } \\
\text { and generally in } \\
\text { April. Flocks } \\
\text { large-up to } 60 \\
\text { birds. The Geese } \\
\text { visit the farm } \\
\text { only when the } \\
\text { fields mentioned } \\
\text { are in young } \\
\text { grass. } 82 \text { Geese } \\
\text { were seen sitting } \\
\text { on Gibb's Cross } \\
\text { Field on 3ri } \\
\text { March } 1885 \text {. }\end{array}$ & $\begin{array}{l}\text { Occasionally } \\
\text { come in autumn } \\
\text { during October. } \\
\text { Flocks small. }\end{array}$ & $\begin{array}{l}\text { W. Anderson, } \\
\text { shepherd, Wed- } \\
\text { derlie, 1st Oct. } \\
1856 \text {. }\end{array}$ \\
\hline & & $\begin{array}{l}\text { Hally- } \\
\text { burtons. }\end{array}$ & $\begin{array}{l}\text { About } 18 \text { years } \\
\text { ago they used } \\
\text { sometimes to } \\
\text { frequent the flat } \\
\text { mossy ground } \\
\text { to the west of } \\
\text { Wedderlie } \\
\text { House. }\end{array}$ & & $\begin{array}{l}\text { Matthew Craig, } \\
\text { steward, Wed- } \\
\text { derlie, Aug. } 1886 .\end{array}$ \\
\hline & Harelaw. & & $\begin{array}{l}\text { Come in spring to } \\
\text { the mossy grass } \\
\text { fields of the } \\
\text { farm. }\end{array}$ & $\begin{array}{c}\text { visit the } \\
\text { farm in autumn. }\end{array}$ & $\begin{array}{l}\text { Farn steward at } \\
\text { Harelaw, West. } \\
\text { ruther, 24th } \\
\text { April 1885. }\end{array}$ \\
\hline
\end{tabular}




\begin{tabular}{|c|c|c|c|c|c|}
\hline Parish. & Farm. & $\begin{array}{l}\text { Fields on } \\
\text { which the } \\
\text { Wild Geese } \\
\text { alight. }\end{array}$ & $\begin{array}{l}\text { Date when they } \\
\text { come in Spring, } \\
\text { with Remarks. }\end{array}$ & $\begin{array}{l}\text { Date when they } \\
\text { come in Autumn, } \\
\text { with Remarks. }\end{array}$ & $\begin{array}{l}\text { Name and } \\
\text { Address of } \\
\text { Correspondent. }\end{array}$ \\
\hline \multirow[t]{4}{*}{ Whitsome. } & Winfield. & $\begin{array}{l}\text { Gordon Law } \\
\text { and Whito } \\
\text { Field. }\end{array}$ & $\begin{array}{l}\text { They visit the } \\
\text { farm, but not } \\
\text { regularly every } \\
\text { year now as they } \\
\text { did from } 25 \text { to } \\
46 \text { years ago. } \\
\text { They come in } \\
\text { March and April, } \\
\text { their visits de- } \\
\text { pending upon } \\
\text { the weather. } \\
\text { They arrive from } \\
\text { the south-east, } \\
\text { and leave in a } \\
\text { north-westerly } \\
\text { direction. }\end{array}$ & $\begin{array}{l}\text { They do not come } \\
\text { regularly, but } \\
\text { sometimes visit } \\
\text { the farm in } \\
\text { October and } \\
\text { November. They } \\
\text { have been known } \\
\text { to stay a week } \\
\text { at a time, feed- } \\
\text { ing on the young } \\
\text { grass fields. } \\
\text { Mrrive from the } \\
\text { north-west, and } \\
\text { leave in a south- } \\
\text { easterly direc- } \\
\text { tion. The flocks } \\
\text { are larger in } \\
\text { autumn than in } \\
\text { spring. }\end{array}$ & $\begin{array}{l}\text { John Clay, Win. } \\
\text { field, 10th Oct. } \\
\text { 1886. }\end{array}$ \\
\hline & $\begin{array}{l}\text { Whitsome. } \\
\text { hill. }\end{array}$ & Rippleton. & $\begin{array}{l}\text { Very rarely visit } \\
\text { this farm. }\end{array}$ & & $\begin{array}{l}\text { James Craw, } \\
\text { Whitsomehill, } \\
\text { 14th Oct. } 1886 .\end{array}$ \\
\hline & Leetside. & $\begin{array}{l}\text { Catchhill } \\
\text { and Merry- } \\
\text { lees Fields. }\end{array}$ & $\begin{array}{l}\text { Visit the farm } \\
\text { sometimes, but } \\
\text { not so often } \\
\text { as they did for. } \\
\text { merly. }\end{array}$ & $\begin{array}{l}\text { Occasionally } \\
\text { alight in } \\
\text { autumn, but } \\
\text { not often. }\end{array}$ & $\begin{array}{l}\text { David Herriot, } \\
\text { Leetside, 11th } \\
\text { Oct. 18s6. }\end{array}$ \\
\hline & $\begin{array}{l}\text { Whitsome } \\
\text { Laws. }\end{array}$ & & $\begin{array}{l}\text { Very seldom visit } \\
\text { this farm. Have } \\
\text { seen them only } \\
\text { twice on it } \\
\text { during last } 20 \\
\text { years. }\end{array}$ & & $\begin{array}{l}\text { Thomas Torrance, } \\
\text { Whitsome Laws, } \\
\text { 23rd Oct. 18S6. }\end{array}$ \\
\hline
\end{tabular}

The Hule Moss-a picturesque sheet of water on a lonely part of Greenlaw Moor, between Marchmont and Dogden Moss, and extending to nearly seventeen acres-is a favourite resort of Wild Geese. ${ }^{1}$

A correspondent who is well acquainted with their habits informs me that they usually come to this haunt in October and November, though he has seen them there as early as the middle of September and as late as December. In spring they frequent the Moss from February to the

1 See Sheet xxi. 4, 54, Ordnance Survey Map of Parish of Greenlaw. The extent of the water is $16 \cdot 869$ acres. 


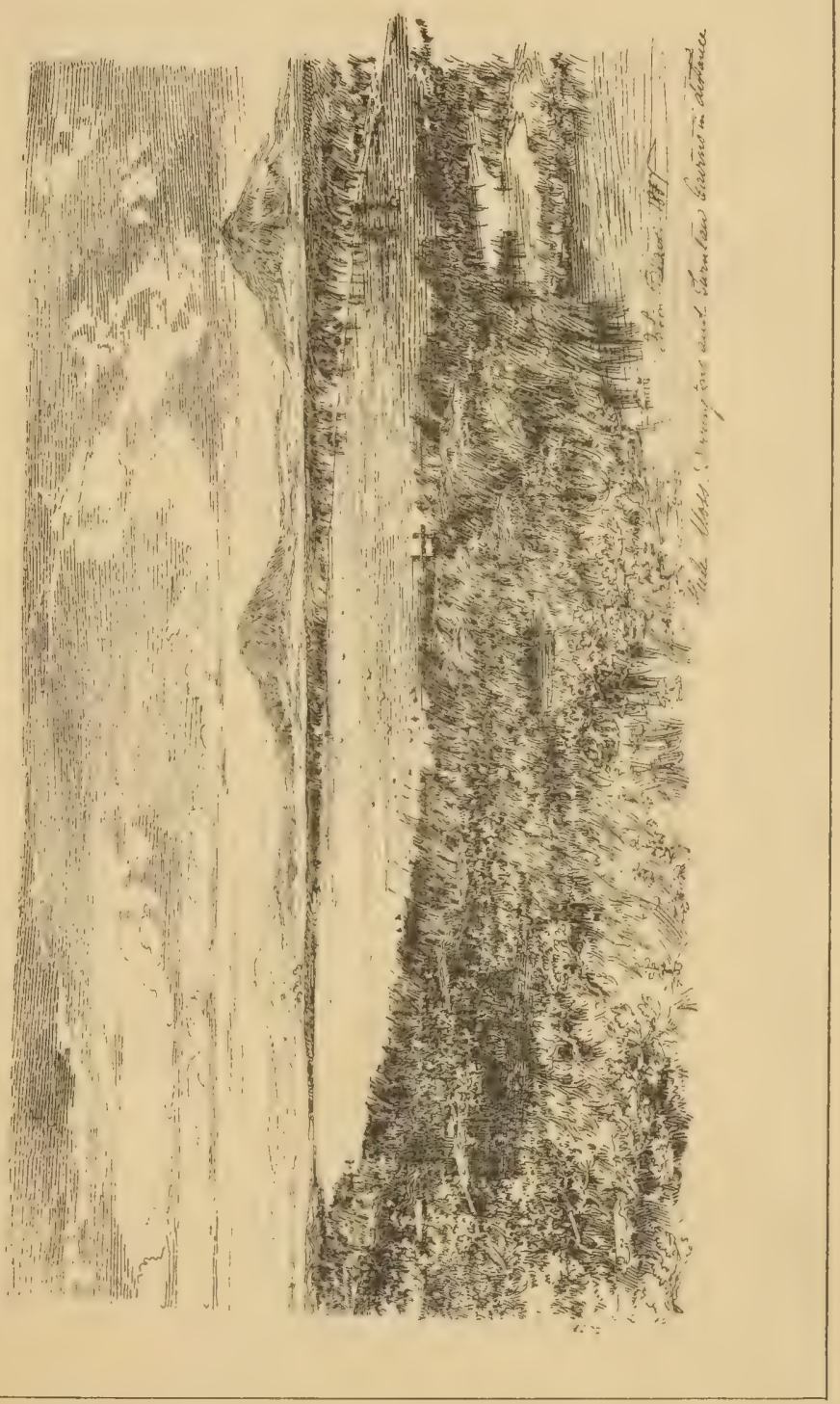



middle of April. They generally arrive in the dusk of the evening, and alight about the middle of the lake, where they remain for some time, afterwards swimming ashore to rest on the heather until the morning, when they depart to feed on the stubble fields. When alighting they sweep down with a sloping flight into the water, and on windy nights they are seen flying low over the moor.

Mr. Loney relates that about fifteen or sixteen years ago a gamekeeper at Marchmont shot seven Wild Geese at the Moss in one night, when it was so dark that he could not see where the birds fell. On going in search of them next morning he found five lying in the water and two on the heather at its edge. He says that the Geese come regularly every year to the Moss in spring and autumn.

Greenlaw Moor is extensive, and comparatively flat; and, as the sheet of water called the Hule Moss has no banks surrounding it, the Geese can float on its surface in safety, the approach of an enemy even at a distance being easily observed. I visited the Hule Moss with Mr. Loney and Mr. John Blair, artist, on the evening of the 14th of July 1886, when the accompanying sketch was made by Mr. Blair. The Moss then presented a beautiful and interesting appearance, with its clear water rippling in the breeze, and gleaming from afar in the light of the setting sun. From its southern edge, looking towards the north, were seen the two Dirringtons, Great and Little, towering towards the sky, in connection with which the following popular rhyme relating to the weather is sometimes heard:-

When Dirrington puts on its hood, And Cockburn Law its cowl, A' the herds o' Lammermuir Ken that it will be foul.

Behind the Dirringtons, and in the direction of Wedderlie, could be observed the Twinlaw Cairns, around which the 
beautiful ballad of "The Battle of Twinlaw" 1 has thrown a halo of romance like the soft purple light of the evening which then coloured the landscape. Far away in the distance to the south-west the Eildons rose above the horizon, bringing recollections of "the wondrous Michael Scott" and

The words that cleft Eildon Hills in three,

And bridled the Tweed with a curb of stone. ${ }^{2}$

Mr. Hardy says that boys in the county believe that the Wild Geese in their flight can form all the letters of the alphabet. ${ }^{3}$ They sometimes call to the Geese-

Tring a' tring o' Wild Geese

Black Jock forenent.

Another rhyme heard among children in Berwickshire is-

Wild Geese ! Wild Geese ! how far will ye flee,

To Herrington and Berrington and owre the Red Sea?

Where do ye sit? Down the water-fit.

Where do ye stand? On the dry land.

When heavy snow is falling in large flakes the Berwickshire boys say that

The folk o' the East are plucking their Geese, And sending their feathers to me, $\mathrm{O}$ ! $^{4}$

The Wild Goose appears to have been much used for the table in Scotland in olden times, for we find the Scottish Parliament in 1551 fixing the price of the "Wild Guse of the great kind" at "twa shillinges." 5

The Bean Goose has yellow legs and the middle portion

1 New Statistical Account of Scotland, vol. ii. (Berwickshire), p. 73.

2 Lay of the Last MInstrel, eanto ii. 13.

${ }^{3}$ In the neighbourhood of Saltoun, in East-Lothian, I have heard boys thirty years ago calling to the flocks of Wild Geese, as they passed high overhead in the air, "Make A, make O," and so on.

IA similar rlyme is heard in East-Lothion-

" 'The folk o' the East are plucking their Geese,

"And sending their feathers to our toon."

5 Lavs and Acts of Parliament of Scotland, by Sir Thomas Murray of Glendook : Edinburgh, 1681, p. 145. 
of the bill orange, whilst in the pink-footed variety these parts are flesh-coloured. In both birds the "nail" at the tip with the base of the bill is nearly black.

Although it is probable that the Grey-lag Goose (Anser cinereus) visits Berwickshire at the same season as the other species, yet there appears to be no record of its occurrence in the county. It differs from the subjects of our notice by having the lower back of a lavender grey, some of the feathers of the under parts blackish brown, and the bill flesh-coloured, without any black on the "nail" or at the base, where there is a narrow margin of white feathers.

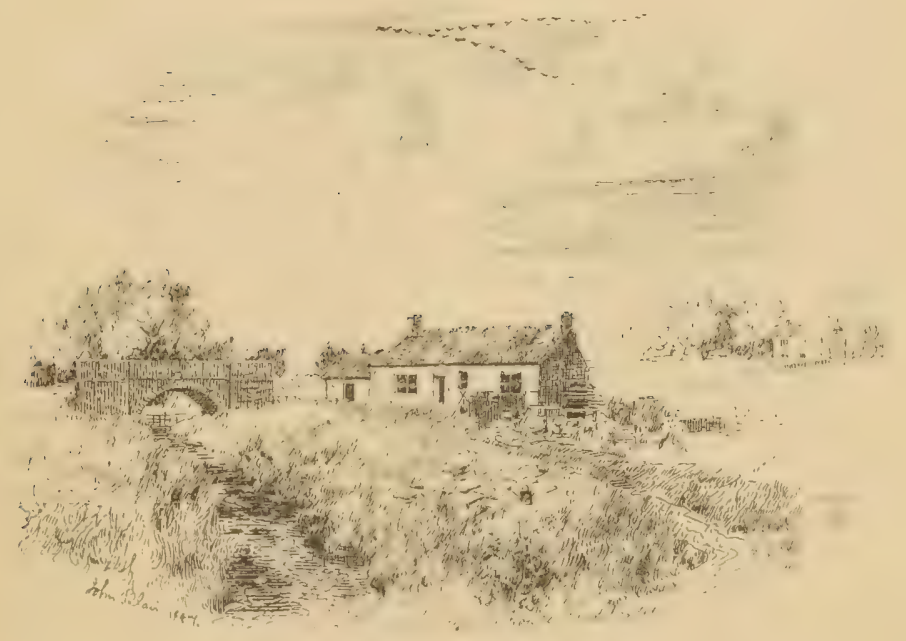




\section{THE WHITE-FRONTED GOOSE.}

LAUGHING GOOSE, BALD GOOSE, WHITE-FACED GOOSE.

$$
\text { Anser albifrons. }
$$

\section{catild}

Winter's not gone yet if the Wild Geese fly that way.

ShaKespeare, King Lear.

I have a wie lairdschip down in the Merse, The nyneteenth pairt of a Gusse's gerse, And I wo' na cum every day to wow.

SCOTTISH BALLAD.

The White-fronted Goose is very like its Bean and Pinkfooted congeners in size, general colour, and appearance, but it may be easily distinguished from them by the white feathers on the forehead and round the base of the bill, and the black bars on the lower part of its breast. It frequents bogs and marshes more than they do, and is not considered to be so difficult to stalk.

This species probably visits the county in small numbers in autumn and spring, but the only authentic record of its occurrence in Berwickshire, which I have been able to obtain, is that of an example shot in the Sandpit Field, on the farm of Greenknowe, by the gamekeeper of Kimmerghame estate, on the 1st of February 1884, who informed me that it was alone when he killed it. It was identified by Mr. George Bolam, Berwick-on-Tweed, shortly afterwards. 


\section{THE BRENT GOOSE.}

THE BLACK-FACED BERNICLE GOOSE, BRAND GOOSE, BLACKHEADED BARNACLE, RING - NECKED BARNACLE, CLATTER GOOSE, HORRA GOOSE, WARE GOOSE, BLACK GOOSE.

\section{Bernicla brenta.}

\section{dấld Googe.}

From the frozen North, where Winter's hand, With sway despotic and untan' $d$, locks up The shrinking world; o'er the wide ocean borne On vig' rous wing, pour forth the feather'd tribes Diverse and strange.

Rev. John VinCEnt, Fowling.

TuE Brent Goose is a winter visitor, and is the smallest of the various species of Wild Geese which are found on our shores. It is occasionally seen off the coast of Berwickshire during the winter months, but it seldom visits the interior of the county, the only instance of its occurrence in the Merse with which I am acquainted being that of an immature specimen in the possession of Mr. Allan of Peelwalls, which was shot on Billie Mains Mill Pond about thirty years ago. Immense flocks frequent Fenham Flats, near Holy Island, in Northumberland, from autumn until spring, where numbers are frequently killed, as they are excellent birds for the table.

This species feeds chiefly upon marine plants $^{1}$ and insects.

$1 \mathrm{Mr}$. Andrew Brotherston, bird-stuffer, Kelso, records that in the early part of February 1879 he had two Brent Geese sent to him for preservation, and their stomachs were filled with grass-wrack (Zosterc marina). He adds that they had probably been feeding on the slakes between Fenham and Holy Island, where this plant occurs in great abundance, and where so many Brents were killed at the time above mentioned that they were selling at one shilling each.-Hist. Ber. Nat. Club, vol, viii. p. 537. 
The ancient Scottish name of the Brent Goose was the Rood, Rude, or Rute Goose, and we find Queen Mary, in her fifth Parliament (1st of February 1551) fixing the price of this bird at "auchteen pennies."

The Brent Goose can at once be distinguished from the Bernacle Goose by its black head and the white patch on the side of the neck. Young birds of the year have not the white patch.

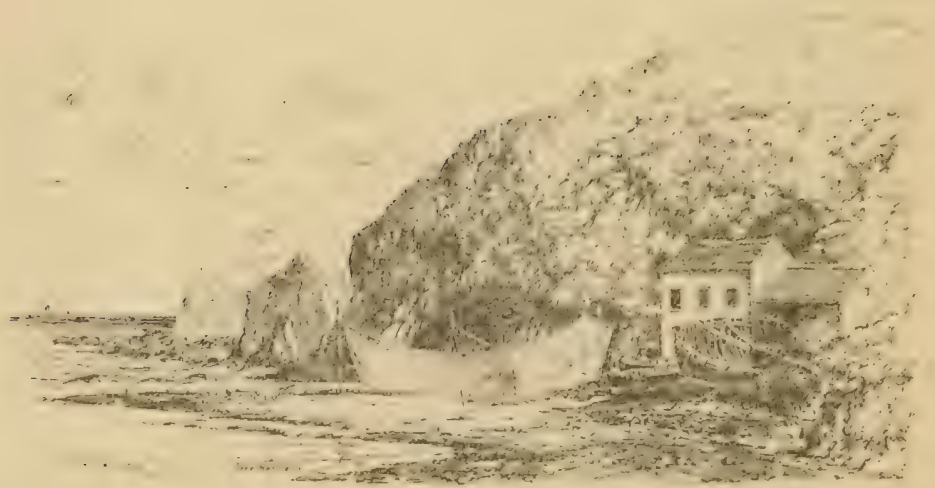




\section{THE BERNACLE GOOSE.}

THE WHITE-FACED BEIRICLE GOOSE, CLAIKIS, CLAKIS, CLAIK GOOSE, BARNACLE, WHITE-CHEEKED BARNACLE,

LAND BARNACLE.

Bernicla leucopsis.

\section{datild Cᄄooge.}

All Water-foullis war swemand thair gude speid;

Alse out of growand treis thair saw I breid.

Fowlis that hingand be thair nebbis greze.

Gawin Douglas, 1 The Palace of Honour.

THIs winter visitor, which can be easily distinguished from the Brent Goose by its white forehead and cheeks, is occasionally seen off the coast of the county. It seldom visits the inland parts of Berwickshire, but stragglers have been sometimes shot at a distance from the sea. Mr. Lockie informs me that one visited Dod Mill Pond in the autumn of 1883 , and remained there for about two months. It became somewhat tame, and used to follow the farmyard ducks, but disappeared when the pond became frozen over in winter. Mr. John Wilson, Chapelhill, Cockburnspath, writes that a flock of ten Bernacle Geese visited Chapelhill Farm in January 1876, when he shot two of them.

It is a very noisy bird, and both when feeding and on the wing keeps up a continual cackling sound. Its food consists chiefly of grass and bents.

1 Gawin Douglas, who was born in 1475, was Rector of the parish of Prestonkirk, in East-Lothian, 1496, and in 1509 Dean of the Collegiate Church of St. Giles, Edinburgh. He was made Bishop of Dunkeld 1516, and died of the plague in London 1522 . 
In olden times it was believed that this Goose was generated from the Barnacle (Lepas anatifera), and Hector Boece, our oldest historian, gives a curious account of

The Scottish Barnacle, if I might choose, That of a worme doth waxe a winged goose.

Its price was fixed by the Scottish Parliament in the time of Queen Mary (1551) at "auchteen pennies." It is an excellent bird for the table.

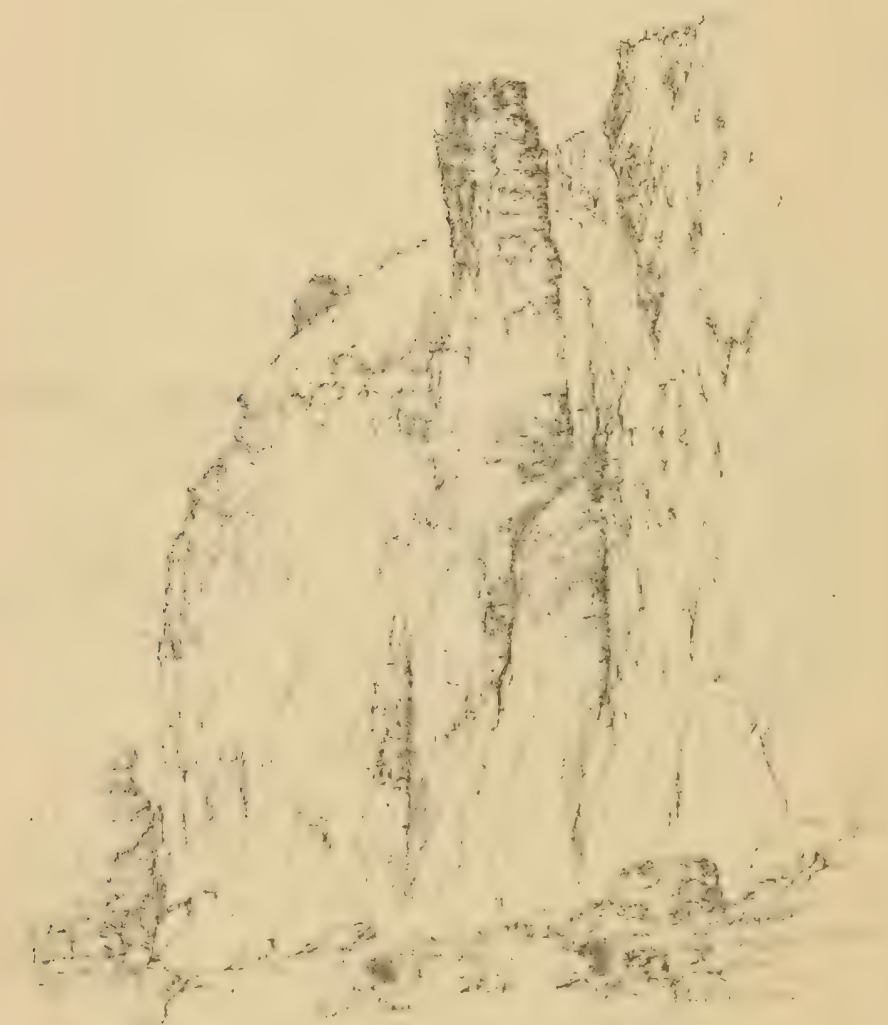




\section{THE CANADA GOOSE.}

THE CRAVAT GOOSE.

\section{Bernicla canadensis.}

They flock together in consent, like so many Wild Geese.

Shakespeare, Henry $I V$.

THis large and handsome Goose has occasionally occurred in Berwickshire. Five specimens were shot at Dowlaw mill pond by Mr. William Cowe on the 14th of May 1867, ${ }^{1}$ and one or two have been killed on the Leader, near Lauder. ${ }^{2}$ Dr. Stuart of Chirnside records that Mr. Millican, Foulden New Mains, saw a flock feeding in his mill pond there on the 16 th of July 1882 . Supposing them to be tame birds, he incautiously approached them, when they took wing and flew over in the direction of Blackburn. ${ }^{3}$ As this species is kept on a large pond at Gosford, in East-Lothian, with other water-fowl, and it rears its young there, it is probable that the examples seen in this county have come thence.

This bird is about forty-one inches in length, and may be known by its black head and neck, while a white patch extending from under the chin to behind the ears has given it the name of the Cravat Goose.

I Hist. Ber. Nat. Club, vol. vi. p. 435.

${ }^{2}$ Ibid. vol. vi. p. 18, and vol. viii. p. 147.

${ }^{3}$ Ibid. vol. x. p. 573.

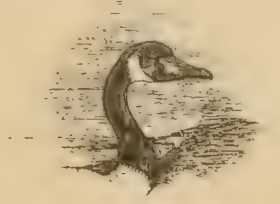




\title{
THE WHOOPER.
}

\author{
ELK, WHISTLING SWAN, WILD SWAN.
}

\section{Cygnus musicus.}

\section{The dála gman.}

\author{
'Truere sweet to mark the setting day \\ On Bourhope's lonely top decay; \\ Thence view the lake, ${ }^{1}$ with sullen roar, \\ Heave her broad billows to the shore: \\ And mark the Wild Swans mount the gale, \\ Spread wide through mist their snowy sail, \\ And ever stoop again, to lave \\ Their bosoms on the surginy wave.
}

SIR WALTER SCOTT, Marmion.

THe earliest record of an appearance of the Wild Swan in the county occurs in a diary kept by Captain Bell, of the Berwickshire Militia, who, about the begimning of this century, resided at Linthill, near Eyemouth. 'The entry in the diary is as follows:- "October 23rd, 1800.- Saw three Wild Swans-not flying high. Got in the last of my corn crop-oats - weather fine."

Writing in August 18:34, the Rev. J. S. Goldie, minister of Coldstream, says that Wild swans have been shot in that parish; ${ }^{2}$ and in January 1835 the Rev. John Turnbull, minister of Eyemonth, mentions that "a few months ago several Swans made their appearance in the bay of Eye-

2 Nero Statistical Accornt of Scotland, vol. ii. (Berwickshire), p. 206. 
mouth, one of which was shot." ${ }^{1}$ Mr. Hardy, Oldeambus, relates that about 1843 three were seen, one of which was captured at Heughhead, and another near Press. Mr. Wilson of Welnage has informed me that a specimen was killed on the Whitadder, near Cumledge, about thirty years ago. The late Mr. Wilson of Cumledge got the bird stuffed, and kept it for many years. During the very severe winter of 1879-80 several Wild Swans frequented the Tweed between Paxton and Berwick, some of which were obtained, one of them (a very large male) being in my collection. According to Mr. Millican, Foulden New Mains, four others visited his mill pond in winter a few years ago, and remained about six weeks. When disturbed, they rose, and after flying a mile or two round in a circle, returned to the pond. He saw them rise from the water one morning; and, after mounting high in the air by circling round and round, make straight off towards the sea at Lamberton, whence they did not return.

The Wild Swan does not breed in any part of Scotland, but visits this country on the autumn and spring migrations, its numbers depending upon the severity of the season. It frequents the sea-coast of Berwickshire, but is sometimes seen on the rivers and inland ponds of the county.

The whole length from the point of the bill to the end of the tail is five feet, and the weight about twenty-four pounds. The front of the bill is black, and the posterior part yellow.

The general colour of the young birds is greyish brown.

In the list of prices of game fixed by the Scottish Parliament in the reign of Queen Mary (1551), the Swan is entered at five shillings.

A curious old custom in connection with the Swan is

1 New Statistical Account of Scotland, vol. ii. (Berwickshire), p. 322.

VOL. II. 


\section{alluded to by Dumbar in his "Prayer that the King war John Thomsoun's Man ": ${ }^{1}$}

I wald gif all that ever I have

To that conditioun, sa God me saif,

That he had vowit to the Swan,"

Ane yeir to be Johne Thomsoun's man.

1 The phrase was proverbial for a person who was ruled by his wife.

2 " 'That ye had vowit to the Swan.' The stanza containing this line is quoted from the Mait. MS. by Mr. Tyrwhytt in his excellent Glossary to Chaucer, who there adduces a singular instance of this vow from Matthew of Westminster. When Edward I. was setting out on his last expedition to Scotland (1306), a festival was held at which 'allati sunt in pompatica gloria duo cygni, vel olores, ante regem, phalerati retibus aureis, vel fistulis deauratis, desiderabile spectaculum intuentibus. Quibus visis rex votum vovit Deo coli et eygnis se proficisci in Scotiam.' In the days of chivalry it was customary for the knights to make vows to God over a roasted Swan, Peacock, Heron, or other bird, and these vows were held to he inviolable. The bird was afterwards carried to the table."-Sibbald's Chron. of Scot. Poetry, vol. i. p. 323.

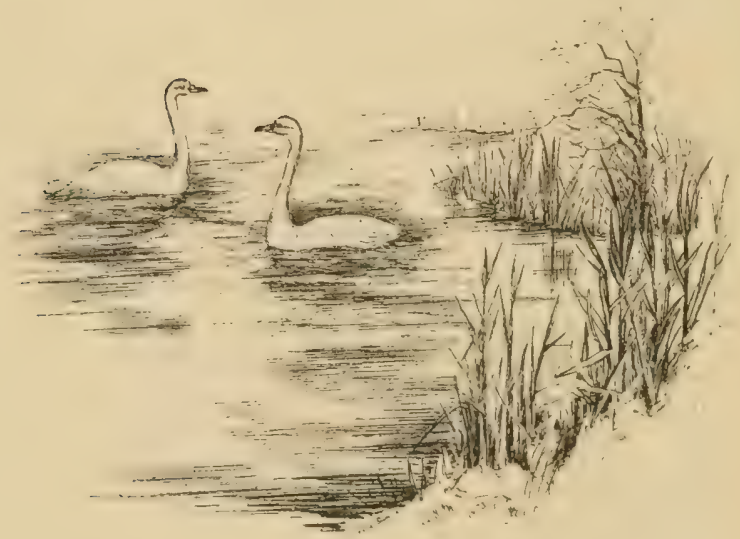




\section{BEWICK'S SWAN.}

\section{Cygnus Bewicki.}

\section{Tye Tấl swan.}

\section{Sum swallis swan, some swallis duik,} And I stand fastand in a nuik.

DUNBAR.

Bewick's Swan, which is about one-third smaller than the Whooper, and, like that bird, visits Scotland on migration, is occasionally seen off the coast of Berwickshire during the winter months. Mr. Hardy, Oldcambus, writing on the 12 th of November 1886 , mentions that a specimen of this Swan was brought to him from Redheugh on that day, and adds that it had been cast ashore, probably by the storm which took place on the 5th and 6th of the same month. ${ }^{1}$

The length of Bewick's Swan is about four feet, and the base of the beak is orange yellow. In young birds the plumage is greyish brown.

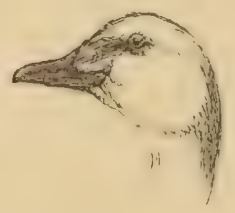




\title{
THE COMMON SHELD-DUCK.
}

\author{
SHIELDRAKE，SIELDRAKE，SKELGOOSE， SKEELING GOOSE, \\ BURROW-DUCK, ST. GEORGE'S DUCK, SLY GOOSE, STOCK- \\ ANNET, BARGANDER, BARDRAKE, BAY-DUCK.
}

\section{Tadorna cornuta.}

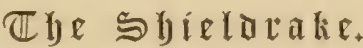

\begin{abstract}
The slecping Shell-Ducks at the sound arise, And utter loud their inharmonious cries; Fluttering, they move their weedy beds among, Or instant diving hide their plumeless young.
\end{abstract}

CRABBE.

THIs beautiful bird, which is a permanent resident in Scotland, is seldom seen in Berwickshire, as the coast is too precipitous for its habits. Small flocks, however, have been occasionally observed on the Tweed in the neighbourhood of Paxton during severe weather about the end of winter, when they were invariably very wild and shy.

Mr. Charles Watson, Duns, has informed me that a specimen of this bird was shot at Chirnside on the 27 th of April 1878; and Mr. Peter Cowe states that an example was killed on a pond at Lochton in 1884 .

The Shell-Duck nests in burrows on sandy links by the sea-shore, one of its breeding places being between Holy Island and Bamborough on the Northumberland coast. ${ }^{1}$

It may be easily distinguished by a broad band of rich chestnut which extends from the lower part of the white breast over the back at the base of the neck.

1 Birls of Northumberland and Durham, by J. Hancock, p. 150. 


\title{
THE MALLARD, ${ }^{1}$ OR WILD DUCK.
}

\author{
MIRE DUCK, MOSS DUCK, MUIR DUCK, GREY DUCK.
}

\author{
Anas boscas.
}

\section{Tye Tatilo gDuck.}

\begin{abstract}
High o'er the restless deep, above the reach
Of gunner's hope, vast flights of Wild Duck stretch

Far as the eye can glance on either side,

In a broad space and level line they glide,

All in the wedge-like figures from the North,

Day after day fight after fight go forth.
\end{abstract}

CRABBE.

Is former times the Wild Duck was much more plentiful in Berwickshire than it is at present, for agricultural drainage ${ }^{2}$ and improvements have removed nearly all the bogs and morasses which it loved to haunt, amongst which may be mentioned Billie Mire, where, until the early part of this century, it was seen in hundreds. As few people at the present day have any idea of the great alterations which have taken place over the surface of the county since the middle of last century, it is interesting to hear what Mr. John Wilson says of its state about that time: "As our grandfathers saw it," says that gentleman, "the whole country, with the most trifling exceptions, was unenclosed,

1 Both Mr. Howard Saunders, in vol. iv. of the revised and enlarged edition of Yarrell's British Birds, p. 358, and Mr. Seebohm, in his British Birds, vol. iii. p. 559, use Mallard as the English name of the Common Wild Duck. It is deriveu from the French word "Malart," which signifies the male of the Wild Duck.

2 Writing in 1842, under dates July 2nd aud 9th, Mr. Hardy says: "On a visit to west of Berwickshire and Lauderdale, the Wild Duck is becoming rarer and rarer on account of drainage." - MS. Notes. 
there was scarcely such a thing as a plantation of trees; there was no artificial drainage, and the hollow parts were full of bogs, marshes, and stagnant pools." 1 The late Dr. Henderson of Chirnside, an ardent lover of nature, ${ }^{2}$ lamenting the changes which were taking place in his day, remarks that " burnies, too, maun a' rin anither gate now frac what Nature intended; lochs, too, are a' drained, Wild Ducks hae nae well-ees now to waddle in; ane can hardly get a bit dub for a channel-stane rink." 3

Notwithstanding these changes, however, the Mallard is still seen, although in comparatively small numbers, in every district of the county, where it haunts the rivers, streams, lakes, and ponds, many frequenting certain favourite retreats, such as Duns Castle Lake, ${ }^{4}$ the Hirsel Lake, and the lochs of Legerwood and Bemersyde. It is also found on the sea-coast from autumn until spring, as many as two hundred having been observed by Mr. Hardy in a flock at Greenhaugh on the 16th of November 1875. He remarks that- " In the night-time they resorted to the inland ponds, burns, and marshes, but in the morning returned to the sea, on that part of the coast most beset with rocks and protected by high cliffs." 5

Although many Wild Ducks breed in the county, there can be little doubt that the numbers of our native birds

1 See Report on the Agriculture of Scolland, 1878, p. 23.

2 I love the uncultured spot where Nature revels free, Some place left sacred to the flower and bee.

Dr. Henderson, Scenes of Boyhood.

3 Popular Rhymes of Bemvickshire, p. 83.

4 This lake has been long known as a resort of wild-fowl. Writing in 1792, the Rev. Robert Bowmaker, minister of Duns, says : "On the north and west [of Duns Castle] are several hundred acres of thriving planting, much of it very old. In the bosom of this plantation is a fine basin of water called the Hen Pond ; it is above a mile in circumference, and in summer vast numbers of Wild Duck resort to it."-Old Statistical Account of Scotland, vol. iv. p. 384.

${ }^{5}$ Hist. Ber. Nat. Club, vol. vii. p. 486. 
are augmented in autumn by migratory flocks from regions

Where the Northern Ocean in vast whirls

Boils round the naked, melancholy isles

Of further Thule, 1

to which they return in spring.

During severe weather in winter, when our lakes and ponds are frozen, Wild Ducks betake themselves to the Whitadder, Blackadder, Eye, Dye, Eden, and other streams, which keep comparatively free from ice, and also to the seacoast. In ordinary weather at that season they are accustomed to rest on lakes, ponds, or the sea during the daytime; and at the twilight of the evening, which is known to the wild fowler as "flight-time," they fly off to the neighbouring marshes, small streams, and ditches to feed, returning in the early morning to their usual haunts for the day. In the evenings, towards the end of August and in September, great flocks often visit barley fields, where the corn is "laid," and devour large quantities of grain. ${ }^{2}$ The usual food of the Wild Duck consists of seeds of various kinds, aquatic plants, worms, slugs, and insects. An example killed near Gordon in the severe winter of 1878-79, besides the roots and leaves of aquatic plants and a large number of the shells of Pisidium pusillum, had a quantity of Sedum Acre in its stomach. ${ }^{3}$

The Mallard is an early breeder, and generally has eggs in April; the nest, which is composed of dry grass and lined with down, is usually placed on the ground by the side of a

\footnotetext{
1 Thomson, Autumn.

$2 \mathrm{Mr}$. Logan, late of Legerwood, informs me that they used to do considerable damage to his barley fields in the vicinity of the loch there, and that he has often shot numbers by waiting at the "darkening" near the "laid" spots. Mr. James Herriot says he has known large flocks visit the barley fields on Leetside Farm in the evenings, after the corn was cut. Mr. Black, Girrick, near Nenthorn, mentions that numbers frequent his barley fields and feed on the "laid" parts of the crops in the evenings just before harvest.
}

${ }^{3}$ Hist. Ber. Nat. Club, vol. viii. p. 537. 
pond, stream, or ditch, amongst rushes or other herbage, but it has been found in various abnormal situations, and even in a tree. One which I discovered by the side of the Whitadder on the 19 th of April 1873 was on such a steep bank that the young would have considerable difficulty in reaching the water in safety. The eggs, which vary in number from eight to thirteen, are of a dull greenish-grey colour.

The young are not able to fly for about two months after they are hatched, and when nearly fledged are called "flappers." Mr. Blackadder, Blanerne, has informed me that flapper shooting at Billie Mire was a favourite sport of the inhabitants of Chirnside long ago, who "used to go over with their guns to the Mire in bands about the month of August, when the young Ducks were nearly ready to fly, and bring back loads of them."

The following entries with reference to flapper shooting appear in a diary kept by Captain Bell, of the Berwickshire Militia, in 1812-14:-“1814, July 1?th.-Went to Blacksmill Burn and up above Dirrington Law for young Ducks. Got two young ones and two old ones. The young ones were rather small, few feathers being on the wing. July 17th - Went to Swinton Mill and tried for Wild Ducks. Got four very fine ones and a Water Hen. Saw three or four more."

At the end of the breeding season a great change takes place in the colour of the Drake; he then appears in a dress like that of the Duck, though a little darker, and the quills being cast simultaneously, he is rendered incapable of flight; but by the middle of October he has again acquired his full plumage.

Wild Duck shooting is most enjoyable, and a fine old Drake in full plumage, besides being a very satisfactory mark, forms a desirable addition to the contents of a game 
bag, and makes a very savoury dish for the table. The sport is frequently followed in the evening, when the Ducks fly in from the sea or from lakes to their feeding grounds, the sportsman concealing himself behind a hedge or tree in their usual line of flight, and lilling them on the wing as they fly overhead. I have found that one of the most successful ways of shooting Wild Ducks is to go to their feeding places-such as marshy grounds, the sides of small streams, ditches, and the like-very early in the morning ${ }^{1}$ before it is quite light, for they are then generally not so wary as usual, and allow the gunner to approach within range before they fly up. When severe frost occurs in winter, and snow covers the ground, Ducks are found on those parts of our rivers and small streams which keep free from ice, and if the fowler be provided with a suit of white linen to cover his clothes, and a white cap, they may be stalked with greater success than in ordinary shooting costume, for the white dress is not conspicuous when seen against a background of snow. I have frequently sat in the snow at dawn by the side of Langton Burn, near Wedderburn Castle, and shot Ducks as they came flying close past me, my white dress concealing me from their view. On the morning of the 9 th of January 1879 I killed eleven Mallards in this manner in half an hour, As daylight approaches, and the sun rises on such occasions,

What pen or pencil shall presume to draw

The glowing scene-the rosy hue that paints

The glistening snow, the fiery gleams that flash

From crystal icicles, the rocks which deck,

Or hoary willow roots, and with a flood

Of brightest splendour light the river up!

I Mr. John Black, Girrick, Nenthorn, informs me that Wild Ducks frequent the Eden (which forms the western boundary of his farm) in great numbers. The numerous bends in the course of the stream are very favourable for stalking the Ducks, and he has killed as many as eight in a morning by walking up the side of the river and shooting them as they rose from the water at the angles of the stream. He has killed seventy in a season. 
Now wand'ring by the river's winding side

Its mazy course we trace, explore each creek, Islet, or shelter'd cave, the Wild Fowl's haunts.

Rev. Joun Vincent, Fowling.

Several places in Berwickshire appear to have derived their names from the Wild Duck, amongst which may be mentioned Drakestruther, in Lauder parish; Drake Mire, a tract of marshy ground to the north of the Dog Bush Plantation, in Buncle parish; Wild Duck Ha', the old name of a place in Swinton parish, which, Mr. Hardy says, lay by the side of a moss near the Leet, where boys of a generation back used to gather Wild Ducks' eggs; and the Duck Ponds on the top of the moor at the highest point of the Black Hill above Dye Cottage, in Longformacus parish. ${ }^{1}$

A popular saying sometimes heard in the county is that "Ducks and Geese drown at the wing." 2

1 Colonel Brown of Longformacus gave me this information.

2 This has probably arisen from the fact that when a Duck or Goose is wounded in the wing while on the water, the feathers of the wounded wing get wet immediately, the bird having apparently lost the power of keeping them in such a position as to resist the action of the water.

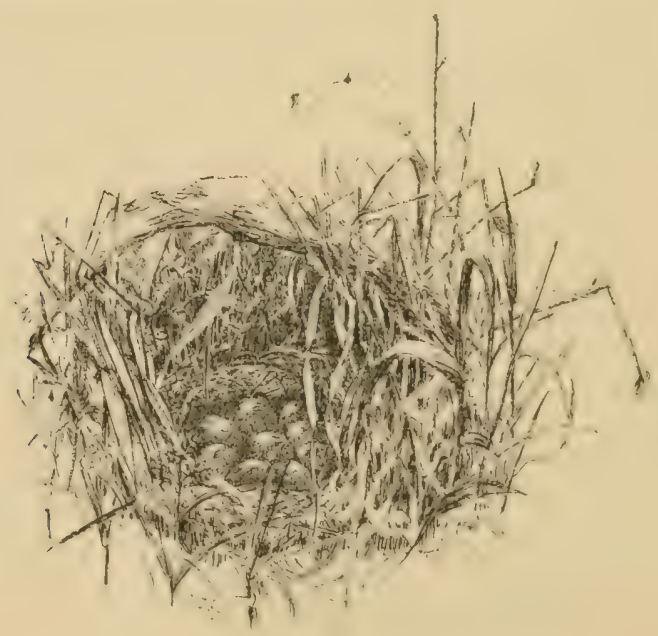




\section{THE SHOVELLER.}

SPOON-BILL DUCK, BROAD BILL, SHOVEL BILL, BLUE-IVINGED SHOVELLER.

Spatula clypeata.

The Schooler who so shakes the air with saily wings,

That even as he flies you still would think he sings.

Drayton, Polyolbion.

THE Shoveller, which is so called from the broad expansion of its bill towards the tip, has not yet been shown to be more than a rare winter visitor to Berwickshire.

Mr. Allan of Peelwalls has informed me that a specimen in his possession was killed on Billie Mains mill pond about thirty years ago, and a male and female are said to have been shot at Legerwood Loch in the winter of $1870 .^{1} \mathrm{Mr}$. Hardy records that on the 25 th of July $1872, \mathrm{Mr}$. Wilson, Coldingham, obtained an example from the mill pond at Fleurs near that village, ${ }^{2}$ and the Rev. William Stobbs mentions that a pair were got near Gordon Moss. ${ }^{3}$ On the 25 th of May 1886 Mr. James Aitchison, slater, Duns, showed me a male in fine plumage which had been obtained at the Hule Moss in the beginning of that month out of a flock of about twenty. Five Shovellers were observed on Duns Castle Lake on the 1st of December 1887 by Mr. William Smith, gamekeeper, who states that they are now seen there in small numbers nearly every winter.

${ }^{3}$ Ibid. vol. ix. p. 230. 
Although this beautiful Duck is generally only a winter visitor to Scotland, it has been found breeding in various Scottish counties, including East-Lothian, ${ }^{1}$ and also in Northumberland.

It is an excellent bird for the table. When it flies, the wings, which are moved rapidly, cause a peculiar sound, that may be heard at some distance.

1 Yarrell's British Birds, fourth edition, vol. iv. p. 376.

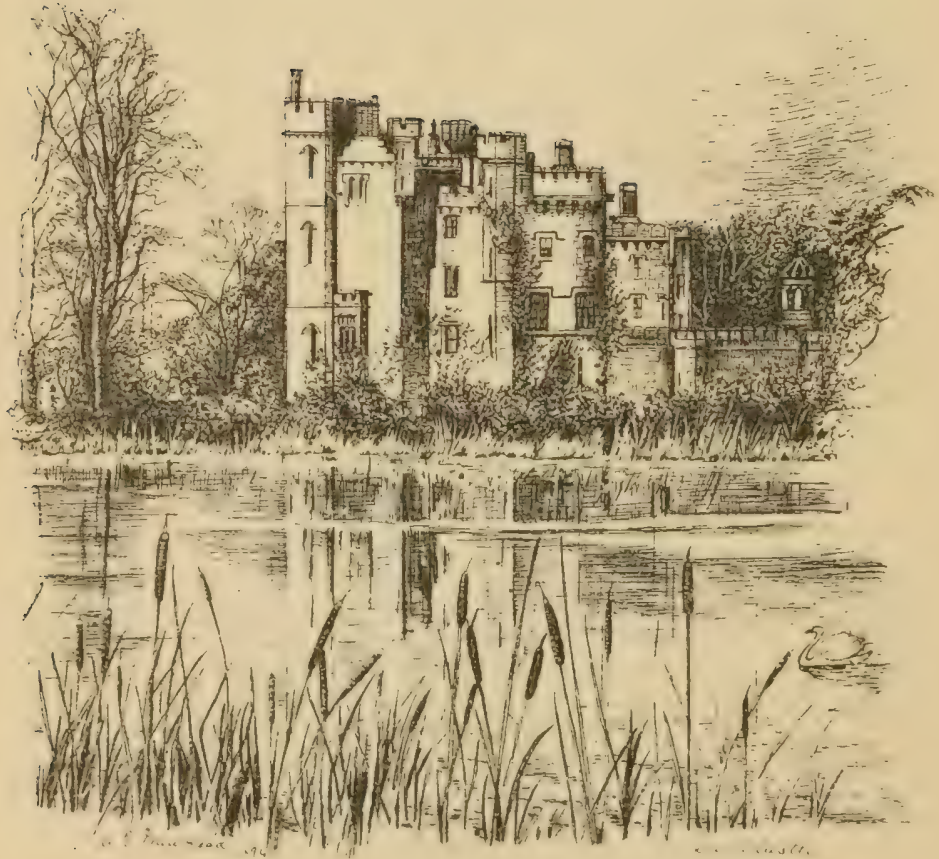




\section{THE PINTAIL DUCK.}

PINTAIL TEAL, WINTER DUCK, SEA PHEASANT, CRACKER, LADY-BIRD, HARLAN.

Dafila acuta.

A fight of forol

Scatter'd by winds and high tempestuous gusts.

Shakespeare, Titus Andronicus.

THIs elegant bird is occasionally seen as a winter visitor off the const of Berwickshire, but it seldom ventures into the interior of the county.

Mr. John Weddell, Long Birgham, informs me that a specimen was shot on the Tweed there a few years ago, and Mr. William Smith, gamekeeper, tells me that a Pintail Drake has been seen on the lake at Duns Castle during the winter months for some years past. He saw it there last on the 28th of November 1889 .

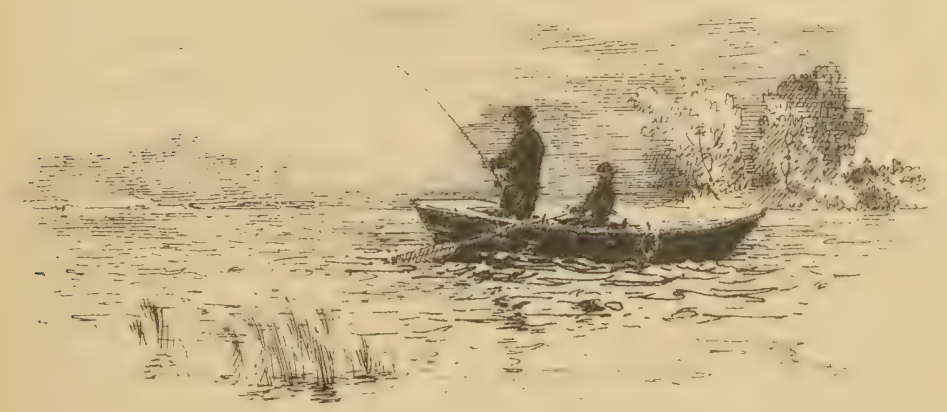




\section{THE TEA L.}

COMAON TEAL, GREEN-WINGED TEAL.

\section{Querquedula crecca.}

\section{Tael צ्dilk.}

\section{Mourn Sooty Coots and Speckled Teals: \\ $\mathrm{Ye}$ Fisher Herons watching eels: \\ Ye Duck and Drake wi" airy wheels \\ Circling the lake.}

BurNs, Elegy on Captain Matthezw Henderson.

THIs pretty little Duck is seen during the autumn, winter, and early spring months on most of the inland waters of the county, including streams and ponds. It is, generally speaking, a winter visitor, coming from the north in early autumn and returning there in spring, but a few remain in Berwickshire and breed during the summer in suitable spots, amongst which may be mentioned the bog on Greenlaw Common. It frequents the Langton Burn, in the neighbourhood of Wedderburn Castle in winter, while the pond at Wedderburn North Lodge was a favourite haunt before it was removed, as many as fifty having been occasionally seen there in a flock. Mr. Lockie says that it is found at Legerwood Loch and on the lake at Spottiswoode, and he mentions that it is common in the Earlston district, and breeds amongst reeds by the side of the Leader. Mr. Johnston, Fellcleuch, near Ellemford, informs me that it resorts to the Whitadder there. According to Mr. Edington, it occurs in Lumsden Moss, and Mr. Hardy says it visits Townhead Mill Pond. When shooting with Mr. Clapham, 
Broomhouse, on the 26th of November 1886, I saw several Teal rise from the Whitadder near Blanerne, and have sometimes observed them frequenting a small burn near Edrom Mains. This species is also occasionally noticed on the Tweed about Paxton and Milne Graden.

The Teal is the smallest of our Wild Ducks, and besides affording good sport with the gun, not being so wary as the Mallard, is excellent for the table. When rising from a stream it generally flies straight up into the air and requires quick shooting, as it is rapid on the wing.

In olden times it appears to have been a favourite quarry of the falconer, and we find it specially mentioned in an Act of the Scottish Parliament "against slaughter of Wild-fowles," 15 th November 1600 , James VI., 16, c. 23 - "Seing in tyme of peace in all tyme bygane, the saids pastymes of hunting and halking were the onely means and instruments to keepe the haill Leiges bodies fra not becomming altogether effeminat . . . they discharge any persons whatsomever, within this Realme in any wyse to sell or buy any fastan reid or fallowe Deare, Daes, Raes, Hares, Partridges, Moore-fowles, Black-cokes, Aith-hennes, Termigants, Wyld Dukes, Teilles, Atteilles, Goldings, Mortyms, Schidderems, Skaildraik, Herron, Butter, or any sik kynde of fowlles, commonly used to be chased with Halkes, under the paine of ane hundreth pounds, to be incurred alswell by the buyer as the seller."

The nest of the Teal is usually found amongst rushes or other herbage by the side of a loch or pond, or in a bog or marsh remote from cultivation, and is composed of dead grasses and other plants, with a lining of down and feathers. The eggs are of a greenish cream colour, and vary in number from eight to fifteen. The food consists of water plants, grasses, and insects. 


\section{THE GARGA NEY. \\ SUMMER TEAL, CRICKET TEAL, PIED WIGEON.}

\section{Querquedula circia.}

\section{Strange fowl light upon neighbouring ponds.}

Shakespeare, Cymbeline.

Tire Garganey, which is a little larger than the Teal and somewhat like it in appearance, has apparently been obtained only once in Berwickshire, a beautiful male having been shot by Mr. H. Hewat Craw on the mill pond at Foulden West Mains, on the 11th of March 1886. He has informed me that it was accompanied by another duck of the same kind, which may have been a female.

This species is a rare visitor to Scotland, but has occurred on migration in several counties. It winters in the south of Europe, and its breeding quarters extend as far north as Denmark, Sweden, and Russia.

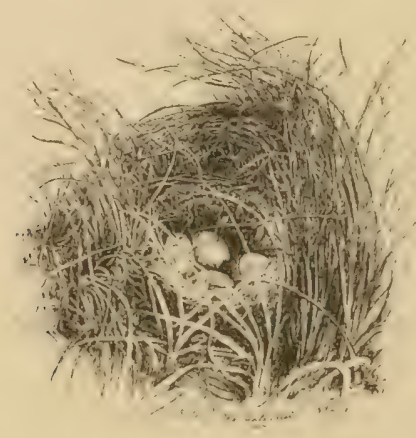




\title{
THE WIGEON.
}

\author{
WHEW DUCK, PANDLE WHEW, YELLOW POLL, WHISTLER, \\ WHIM, BALD PATE, HALF DUCK, SMEE DUCK.
}

\section{Mareca penelope.}

Who can recount what transmigrations there

Are annual made? What nations come and go?

And how the living clouds on clouds arise?

Infinite wings / till all the plume-dark air,

And rude resounding shore are one wild cry.

THOMSON, Autumn.

Thrs winter visitor is seen in flocks off the coast, and occasionally in small numbers on the ponds ${ }^{1}$ and rivers in the interior of the county. It generally arrives from the north in October and leaves in March or the beginning of April.

Mr. Kelly records that a flock frequented an old waterrun of the Leader, between New Mills ground and the haugh, from the beginning to the middle of October some years ago, and that the crop of one which was shot at Newbigging upper pond was full of the grass Poa annuc. ${ }^{2} \mathrm{He}$ also mentions that the bird generally associates in Lauderdale with Mallard and Teal, from which it can easily be distinguished when flushed by the whiteness of its under parts and its more rapid flight. ${ }^{3}$ The Rev. W. Stobbs of Gordon, in some notes on the birds of that district, alludes

1 Mr. William Smith, gamekeeper, Duns Castle, informs me that he observed fourteen Wigeon on the lake there on the 3rd of December 1889, and thirty-nine on the 11th of January 1890. He adds that considerable flocks frequent it in winter.

2 Hist. Ber. Nat. Club, vol. vii. p. 523. 3 Ibid, vol. viii, p. 147.

VOL. II. 
to a specimen which was killed in Gordon Bog. ${ }^{I}$ It has been occasionally observed on the Tweed at Paxton. Mr. Hardy relates that numbers have been obtained at the Cove Shore in winter. Small flocks of Wigeon sometimes visit the mill pond at Foulden New Mains, and Mr. Millican, the tenant of that farm, informed me on the 6 th of November 1886 that some time previous to that date he had killed six out of a flock one morning. It has been occasionally observed on the Eden near Nenthorn during hard weather by Mr. Black, Girrick. Great numbers of Wigeon were formerly taken in decoy ponds, as many as 44,677 having been caught at the decoy of Steeple, in Canney Marsh, Essex, between 1714 and 1726,2 and it affords more sport than any other duck to the wild-fowl shooter on the coast.

The food of this bird consists of grass, aquatic plants, and insects, and Mr. Waterton records that, unlike the Teal and Mallard, which obtain nearly the whole of their food during the night, it feeds in the day-time. It has a rapid flight and a whistling cry, and is a savoury dish for the table.

A few Wigeon nest in the shires of Ross, Sutherland, and Cromarty, and thence northwards. ${ }^{3}$

1 Hist. Ber. Nat. Club, vol. ix. p. 230.

2 Yarrell's British Birds, fourth edition, vol. iv. p. 39S.

3 Seebolım, British Birds, vol. iii. p. 539.

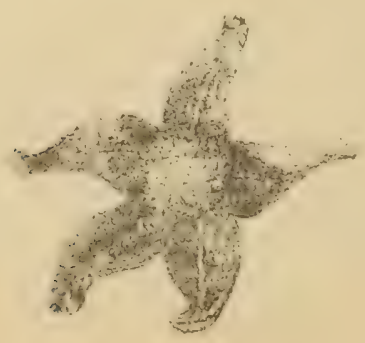




\title{
THE POCHARD.
}

\author{
DUN BIRD, DUNKER, POKER, RED-HEADED POKER, RED-EYED \\ POKER, GREAT-HEADED POKER.
}

\section{Fuligula ferina.}

How silly the Wild Duck and Wigeon appear, To be lured in decoy by the pranks of an ape! But crafty the Pochard, which cunningly dives, And beats under water a certain escape.

FOLKARD.

The Pochard is a winter visitor to the sea-coast and inland waters of Berwickshire from October until March or April, when it leaves for its breeding quarters. It is seen in considerable numbers off the shore, but only occasionally frequents the lakes, ponds, and rivers of the county, and then singly, or only in small flocks. The first notice of the Pochard in the History of the Bemichshire Naturalists' Club is in the presidential address of the Rev. Andrew Baird, minister of Cockburnspath, delivered at Duns on the 18th of September 1833, in which he states that at a meeting of the club held at Cockburnspath, on the 16th of April of that year, "Dr. Johnston mentioned that he had lately received from the Rev. Mr. Campbell a specimen of the Pochard Duck (Ancs ferinc, Linn.), shot near Coldingham Loch. $^{1}$

During severe winters the Poohard visits the Tweed and also the Whitadder, in the neighbourhood of Paxton. Several were killed on the former in the hard frost of 
1870-71, and I shot a beautiful male on the latter, near the Old Bound Road, in the end of December 1874. Mr. Kelly records that there are some specimens in local collections about Lauder which were procured in the vicinity of the Leader; ${ }^{1}$ and Mr. Hardy mentions one which was shot on the Whitadder, above Cockburn, in January $1877 .{ }^{2} \mathrm{Mr}$. Weddell, Long Birgham, writes to me that he has sometimes killed this duck on the Tweed in that neighbourhood; and Mr. H. H. Craw states that he has occasionally shot it on the mill pond at Foulden West Mains. The lake at Duns Castle, where wild-fowl of all kinds are carefully protected by the proprietor, W. J. Hay, Esq., is sometimes visited by the Pochard, a flock of seven having been observed there by the gamekeeper, Mr. William Smith, on the 27th of January 1887 , and from twenty to thirty on the 17 th of October of the same year.

Although the great majority of Pochards return to northern regions in spring, a few remain to breed in various parts of Britain, and Mr. Gray records that a nest has been found on the banks of a loch in Fifeshire. ${ }^{3}$

The subject of our notice is a wary bird, and when it enters the mouth of a decoy pipe with other wild-fowl it dives and escapes under water if any attempt be made to drive it further in along with them. For this reason it is taken on what is called a "flight pond," having nets at the sides so constructed that one of them can be raised by the fowler when the ducks are flushed, according to the direction in which they fly. A few of the leading Pochards are allowed to pass over the place where the net is concealed, and then it is suddenly raised up so as to intercept the great bulk of the flock, which strike against the net in their flight, and flutter down into a number of small pens con-

1 Hist. Ber. Nat. Club, vol. vii. p. 305.

2 Ibid. vol. viii. p. 196.

3 lbid. vol, ix. p. 366. 
structed at the bottom, out of which they cannot readily escape, several hundreds being sometimes taken at once in this manner. ${ }^{1}$

Pochards feed, when on fresh water, on aquatic plants, for which they dive, and they are then excellent for the table, being considered almost equal to the celebrated Canvas-back Duck of America. When at sea they subsist on molluses and other marine creatures, and are not then well flavoured.

The head and upper neck of the male Pochard are rich chestnut. In the female these parts are buffish brown.

1 See The Wild Fowler, by Folkard, second edition, 1864, pp. 82-94.

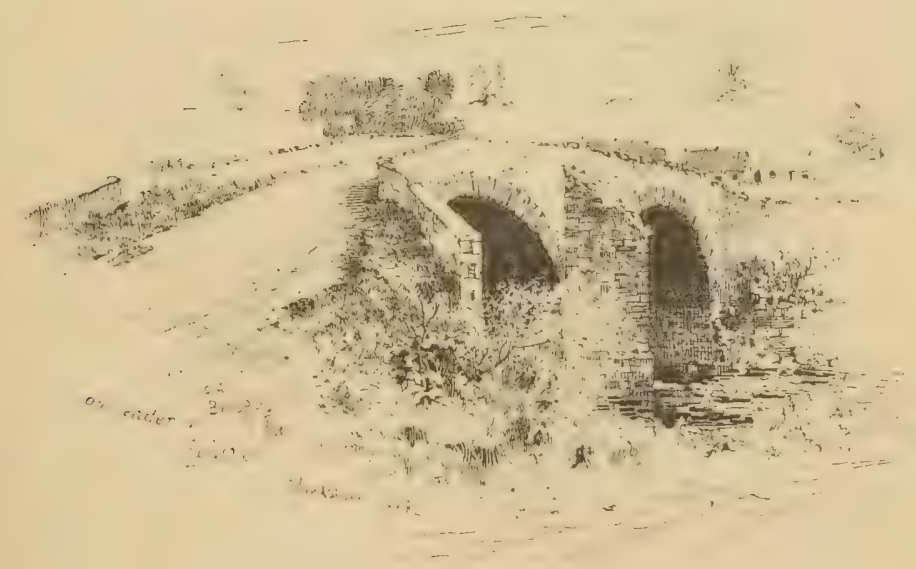




\section{THE TUFTED DUCK.}

BLACK DUCK, BLACK WIGEON, DOUCKER.

\section{Fuligula cristata.}

\section{.... the feather'd tribes in close array O'er the wide fields of ocean wing their way When from the rage of winter they repair To warmer suns and more indulgent air.}

PitT.

THIS duck is occasionally seen off the coast, and on some of the inland waters of the county, during autumn, winter, and spring. It has been observed on the Tweed at Paxton, a male in full plumage having been shot there during the snow-storm of 1870-71.

Mr. John Aitchison, plasterer, Duns, informs me that a male was killed at Marchmont in the autumn of $18 S 6$. Mr. William Smith, gamekeeper, Duns Castle, informs me that he saw two on the lake there on the 3rd of November 1857, and four on the 10th of Jaunary 1S90. Although the Tufted Duck is generally a winter visitor from northern regions and returns there in spring to breed, yet numbers remain and breed in various counties of England, including Northumberland. It has likewise been observed nesting in Perthshire, ${ }^{1}$ and at Tetholm Loch in Roxburghshire. ${ }^{2}$ It is a late breeder, incubation not taking place until May or the beginning of Jnne.

It is an expert diver, and feeds on various aquatic plants and insects, but is not considered a good bird for the table.

1 Yarrell's British Birds, fourth edition, vol. iv. p. 431.

2 Hist. Ber. Nat. Club, vol. viii. p. 521. 


\title{
THE SCAUP DUCK. ${ }^{1}$
}

\author{
WHITE-FACED DUCK, SPOON-BILL DUCK, MUSSEL DUCK, \\ BLACK-HEADED DIVER.
}

\section{Fuligula marila.}

\begin{abstract}
It was the dreariest depth of winter-tide, And on the ocean and its isles was felt The iron sway of the North. $Y e a$, even the forol, That through the polar summer months could see $A$ beauty in Spitsbergen's naked isles, Or on the drifting icebergs seek a home, Even they had fled, on southern wing, in search of less inclement shores.
\end{abstract}

DELTA, The Fowler.

The Scaup Duck is a winter visitor to the sea-coast, but is seldom seen on the inland waters of Berwichshire. When severe weather occurs, with snow and hard frost, it is occasionally seen on the Tweed near Paxton, where several were shot during the snow-storm of 1870-71, and again in December 1875.

It is an expert diver, and feeds principally on shell-fish and marine plants, and is not therefore a very palatable bird for the table.

The head, neck, and upper breast of the male are black, glossed with green, while the feathers round the base of the bill in the female are white.

1 So named from its feeding amongst broken mussel and oyster shells ; called in the north "Scaup."-Swainson, Provincial Names of British Birds, 1885, p. 159. 


\section{THE GOLDEN-EYE.}

GOLDEN - EYED GARROT, GOWDY DUCK, PIED WIGEON, WHITE-

SIDE, GREY - HEADED DUCK, RATTLE - WINGS, WHISTLER, DIVING DUCK, DIVER OR DOUCKER, MORILLON.

Fuligula clangula.

\section{The datígen, The Gea פ্dutk.}

\section{Clanging Golden-cye.}

Crabbe, Peter Grimes.

Althougin numbers of Golden-eyes frequent the coast of Berwickshire, and a few are found on the larger rivers and inland waters ${ }^{1}$ in the autumn, winter, and spring months, the adult male, in his beautiful black and white dress, is comparatively seldom noticed. ${ }^{2}$ During the continuance of very severe weather in winter he may be occasionally observed on the Tweed, where females and immature males are then frequently seen swimming about the pools and diving in the streams. ${ }^{3}$

The Golden-eye is sometimes noticed on the Whitadder as far up as Abbey St. Bathans. ${ }^{4}$ Mr. Kelly says that he has not noticed it on the Leader. ${ }^{5}$

$1 \mathrm{Mr}$. W. Smith, gamekeeper, informs me that this duck sometimes frequents the lake at Duns Castle in winter. He saw two there on the 8th of February 1890.

$2 \mathrm{Mr}$. Hardy, writing on the 25th of February 1879, says: "About forty-two Golden-eyes seen in Siccar Bay-only two males in full plumage."

${ }^{3} \mathrm{Mr}$. Cowe, Lochton, informed me on the 7th of August 1886 that an old male in full plumage was shot on the 'T'weed there in winter about 1872.

4 Mr. John Aitchison, plasterer, Duns, informs me that a female was shot at Ellemford on the 26th of November 1886.

${ }_{5}$ Hist. Ber. Nat. Club, vol. vii. p. 523. 
It arrives in the county from the north in autumn, and leaves in spring. It feeds on small fishes, shell-fish, and aquatic plants, which it obtains by diving, and is not an appetising dish for the table.

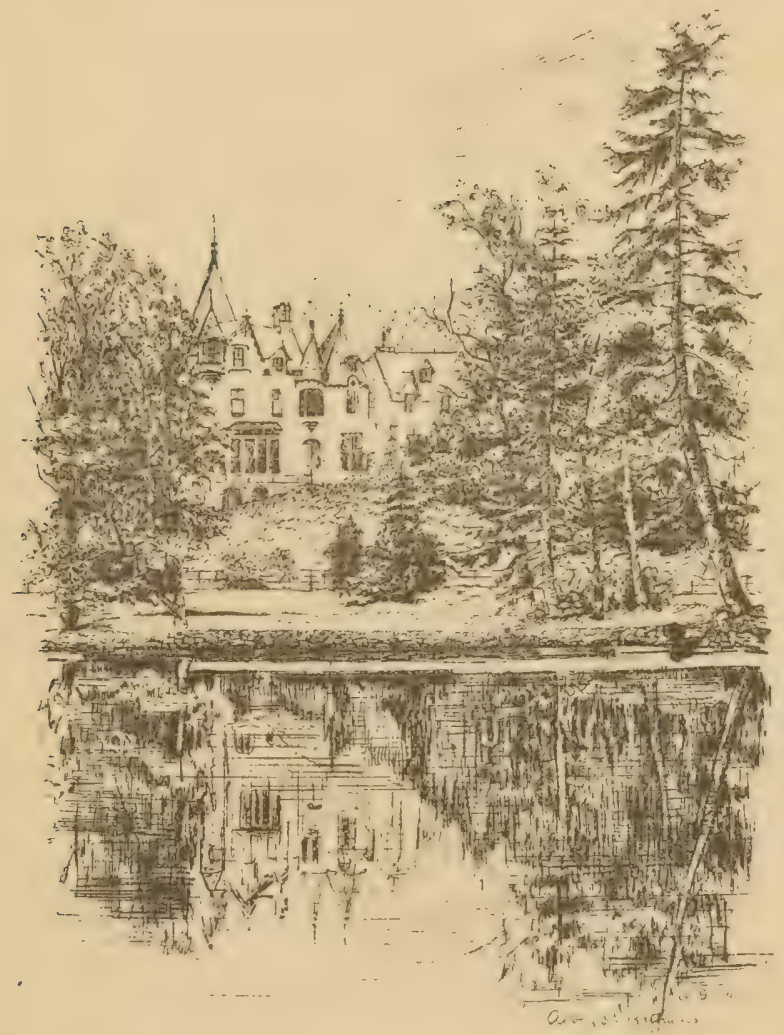




\section{THE LONG-TAILED DUCK.}

LONG-TAILED IARELD, NORTIERN HARELD, SHARP-TAILED DUCK, CALLOO, COAL-AND-CANDLE-LIGHT, COL-CANDLEWICK, COLDIE, MEALY-BIRD.

\section{Harelda glacialis.}

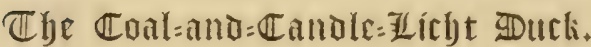

Fowls by winter forced forsake the floods, And wing their hasty fight to happier lands.

DRAYTON.

TuE Long-tailed Duck, which is an autumn and winter visitor, is seen in small Hocks off the coast of Berwickshire, and sometimes singly or in pairs on the inland waters of the county, including the T'weed and the lake at Duns Castle. Mr. Hardy records that two were killed in the Harbour Loch, Coldingham Shore, in January $1860 .^{1}$ I shot a female on the Tweed at Finchy, near Paxton, in the end of December 1874. Mr. W. Smith, gamekeeper, Duns Castle, informs me that he noticed a Long-tailed Duck on the lake there on the 13 th of January 1886.

Females and immature males are most frequently met with, the male in his beautiful adult plumage being comparatively seldom seen.

The food of this species consists chiefly of crustaceans, fish, and other marine creatures. Its flesh is coarse and unsavoury.

1 Uist. Ber. Nat. Club, vol, iv. p. 211. 


\title{
THE EIDER DUCK.
}

ST. CUTHBERT'S DUCK, ${ }^{1}$ DUNTER GOOSE, GREAT BLACK AND WHITE DUCK, DUSKY DUCK, CUD-DOO, CULVER DUCK.

\section{Somateria mollissima.}

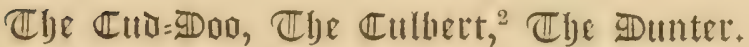

\author{
With instinctive love is drest \\ The Eider's downy cradle, where \\ The mother bird her glossy breast \\ Devotes; and with maternal care \\ And plumeless bosom stems the toiling seas \\ That foam round the tempestuous Orcades.
}

C. Sмiтн, Studies of the Sea.

DURING the autumm, winter, and spring months the Eider Duck frequents the coast of Berwickshire, usually in small numbers, though occasionally considerable flocks are observed. Mr. Hardy, Oldeambus, who, in his papers on the local migration of birds in the History of the Bervichstive Naturalists' Club, frequently notices the occurrence of this duck off the coast about Siccar Point from November to May, says: "They utter a noise like the cooing of a l'igeon, and the fishermen call them Cud-doos. They stay all the winter, but are seldom seen off here, and are said to breed in sone of the rocks near Fast Castle. In earlier times they also nestled in a rough part of the bank near the Cove Harbour." " Amongst many MS. notes on birds with which he

1 So called from its nesting on the Farne Islands, once the abode of St. Cuthbert.

2 This, says Mr. Hardy, is one of the coast names of the bird.

3 IIist. Ber. Nat. Club, vol, vii. p. 277. 
has very kindly favoured me, the same gentleman mentions under date of the 25th of April 1885: "A male Eider brought by one of the salmon fishermen. It was a very fine specimen, and had been caught in one of the salmon nets. It seized everything that approached its bill, and watched its opportunity readily to inflict a wicked bite. A nest with young was found last year by the salmonfishers on the west side of Fast Castle." On the 30th of June 1887, when passing "The Little Rooks," which are small rocky islets about half a mile to the west of Fast Castle, in a boat rowed by some of the salmon fishermen, they informed me that in the summer of 1885 several pairs of Eider Ducks nested in the vicinity, and that they had often tried to catch the ducklings, but without success. They said that they had observed a few birds of this species about that part of the coast in the first week of June 1887. A male was seen by me on the Tweed, near Paxton, in the end of December 1874, and Mr. W. Smith, gamekeeper, Duns Castle, informs me that he noticed two on the lake there on the 25th of January 1886. The Eider Duck breeds at the Farne Islands, and elsewhere on the coast of Northumberland. Its nest is generally composed of sea-weeds and dry grass, and as incubation proceeds it receives a lining of down plucked by the bird from her body. Seebohm says that "Eider-down is a highly prized article of commerce, and in some places, especially in Norway, Iceland, and Greenland, the birds are strictly protected for the profit they yield. By judicionsly removing the eggrs and down from the nests the birds are made to lay again, and furnish a fresh supply of the precious down. Each duck yields about four ounces of down, which, when cleaned, is worth about a sovereign a pound." ${ }^{1}$ It requires

1 History of British Birds, vol. iii. p. 620. 
about a pound and a half to make a coverlet. The eggs vary in number from five to eight, and are greyish green in colour. The bird generally begins to lay about the middle of May. Its food consists chiefly of crustaceans and shell-fish.

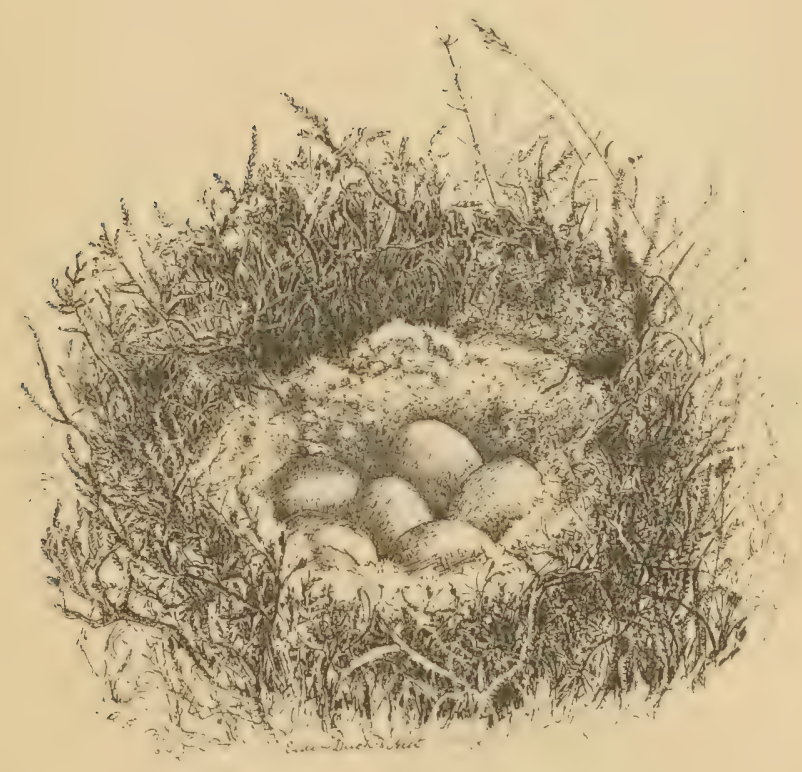




\section{THE COMMON SCOTER.}

BLACK SCOTER, BLACK DUCK, SURF DUCK.

\section{Edemia nigra.}

On dit d'un homme sur lequel on ne peut compter: "Il ressemble à une macreuse; il n'est ni chair ni poisson."

French Proverb.

TuE Common Scoter is a winter visitor, which is seen in flocks off the coast of the county, but seldom on the inland waters. I have noticed it several times on the Tweed, at Paxton, during winter. Two specimens were observed on the lake at Duns Castle, by the gamekeeper there, on the 11 th of March 1887 , and the same number on the 25 th of October following.

It feeds on shell-fish, which it obtains by diving, and its flesh has a strong fishy flavour; hence the French proverb quoted above. The plumage of the male is wholly black.

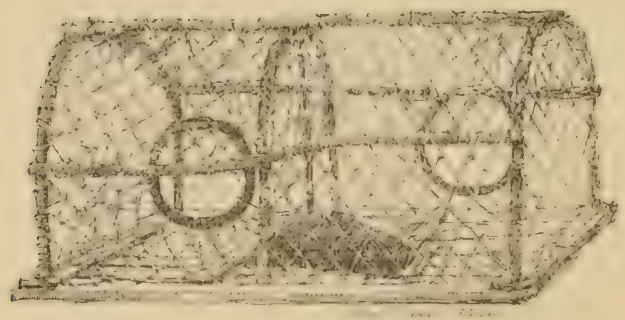




\title{
THE VELVET SCOTER.
}

\author{
WHITE-WINGED BLACK DUCK, GREAT BLACK DUCK, \\ DOUBLE SCOTER.
}

\section{Edemia fusca.}

\section{I gaze upon the stormy, troubled ocean, I hear her crested waves, Waking, as they roll with restless motion, The echoes of her caves.}

WALter Chisholm.

Tuis species, which can easily be distinguished from the Common Scoter, by its larger size and the white bar across its wing, is occasionally seen off the coast of Berwickshire in the autumn, winter, and spring months, but is rarely observed in the interior of the county. Mr. Peter Cowe, Lochton, has informed me that a specimen was shot on the sea near Dowlaw, in the parish of Coldingham, in 1860. A flock of ten Velvet Scoters was observed by the gamekeeper at Duns Castle, on the lake there, on the 7th of January 1886 ; and Mr. Hay of Duns kindly wrote to me on the 18th of April following that two were to be seen on the lake at the date of his letter.

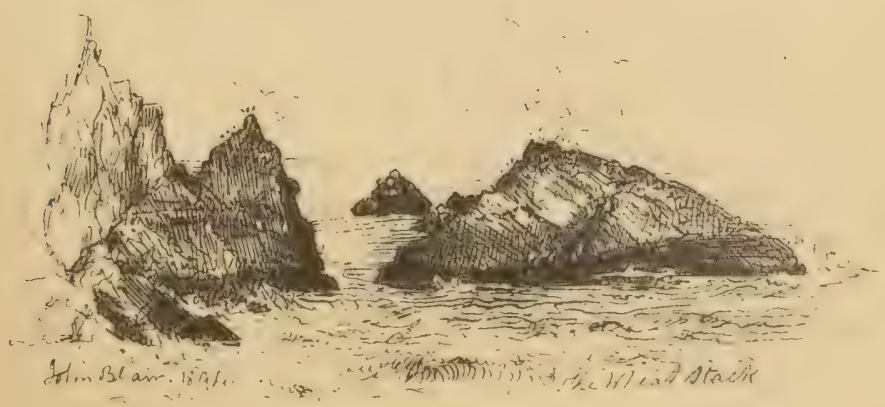




\section{THE GOOSANDER.}

SAW BILL, DUN DIVER, JACK LAW, GREATER GOOSANDER.

\section{Mergus merganser.}

The Gosander with them, my goodly fens do shew, His head as ebon black, the rest as white as snow.

DRAYTON.

ThE Goosander is a visitor from the north, which is frequently seen during the winter and early spring months on the inland waters of Berwickshire, including the Tweed, Whitadder, and Leader, ${ }^{1}$ when it is also observed on the seacoast of the county. The adult male in full plumage, with his shining green head and rich pinkish cream-coloured breast, is one of the most beautiful of our water-fowl, but he is of much less frequent occurrence than immature birds of the same sex and females in their dull coloured coats.

This species is very destructive to fish, which it catches readily with its serrated bill. Mr. Brotherston, bird-stuffer, Kelso, writing on the effects of the severe winter of 1878-79, says: "Goosanders have been numerous and fat. Nearly every one I have dissected has been gorged with trout and parr in various stages of digestion, and measuring from three up to nine and a half inches in length."

Although the Goosander generally departs towards the end of March for its breeding quarters in the north of

1 Mr. Kelly mentions St. Leonard's Cauld, on the Leader, as a well-known haunt of the Goosander.-Hist. Ber. Nat. Club, vol. vii. p. 305. 
Europe, a few remain and nest in some parts of the Highlands, including the counties of Perth, Ross, Sutherland, Inverness, and Argyle. It usually makes its nest in the hollow of a tree, or under some kind of shelter. It subsists almost entirely upon fish, and its flesh is unpalatable.

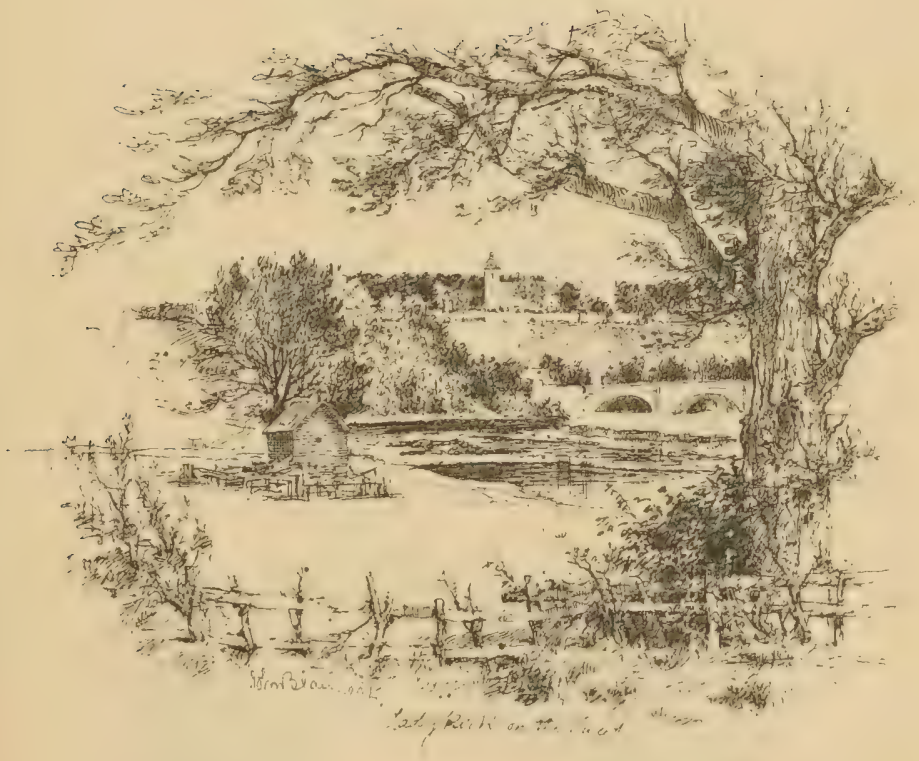

VOL. II, 


\section{THE SMEW.}

PIED SMEW, SMEE DUCK, WHITE NUN, WHITE-HEADED GOOSANDER, PIED DIVER, LOUGII DIVER,

VARE WIGEON.

\section{Mergus albellus.}

.... cautious water-fowl, from distant climes.

WORDSWORTH.

TuE Smew is a rare winter visitor to the coast of Berwickshire, and has been obtained only once in the interior of the county, a specimen in Kelso Museum having been killed at the Hirsel, near Coldstream. ${ }^{1}$ An adult male in full plumage was shot at Eyemouth a few years previous to 1880 , and is now in my possession, having been kindly presented to me by Mr. Evan Sanderson, Berwick-onTweed.

1 Mr. Hardy's MS. Notes.

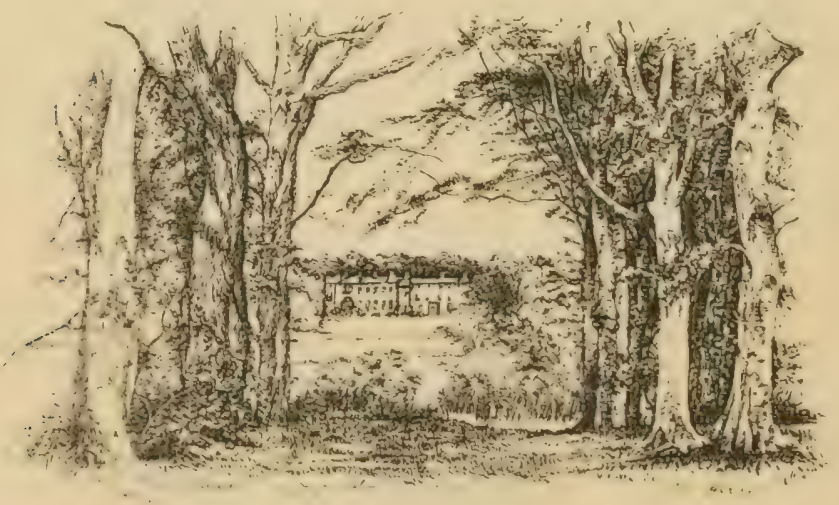




\title{
THE RING DOVE.
}

WOOD PIGEON, CUSHAT, QUEST.

Columba palumbus.

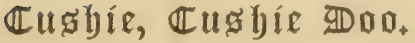

\author{
'Twas summertide, the Cushat sang \\ His am'rous roundelay, \\ $A n^{\prime}$ dews like cluster'd diamonds hung \\ On flow'r and leafy spray, \\ The coverlet of gloamin' grey \\ On everything was seen, \\ When lads and lasses took their way \\ To Polwart on the Green.
}

Song, Polwart on the Green.1

The Cuschetts on the branches green,

Full quietly they crowed:

ALEXANDER HUME.3

Trie soft cooing of the Cushat is one of the many delightful sounds which are heard in our woods and groves in the spring and early summer months, and it falls soothingly on the ear whilst we listen to the rich and varied strains of the Blackbird and the Thrush. There is something peculiarly pleasing in the low melancholy note, which is suggestive of peace and rest.

Nor is her changeless plaint

Unmusical, when with the general quire

Of woodland harmony it softly blends.

Gramame.

1 Written by John Grieve. See Scottish MFinstrel, vol. v. p. 4.

2 To coo like a dove.-Jamieson, Scot. Dict. "The kowsehot croultis and prykis on the ryse."-Gavin Douglas, 1513.

${ }^{3}$ Alexander Hume, parson of Logie, was the second son of Patrick, 5th Baron of Polwarth, the lineal ancestor of the family of Marchmont. His poems were printed in 1599. He is supposed to have been born about 1550.-Sibbald's Chron. Scot. Poetry, iii, p. 367. 
In the beautiful woods which adorn the banks of the Whitadder "the Ring Dove's deep melodious moan" can be heard to great perfection, and there, on a fine calm evening in early summer, it intermingles with the songs of many birds and the gentle murmur of the neighbouring stream.

Sa silent is the cessile air

That everie cry and call,

The hills and daills and forest fair,

Againe repeats them all.

Alexander Hume.

The Cushat, like the Starling, has greatly increased in numbers within the memory of many people in the county. ${ }^{1}$ This has probably been the result of various causes, amongst which may be suggested the widely extended cultivation of turnips and clover ${ }^{2}$ since the end of last century, which supply it with food in winter and spring when little else is available, the planting of numerous fir woods for ornament and shelter throughout the county during the same period, which form a safe retreat where it can build its nest and rear its young in security, and the destruction of all kinds of birds of prey by gamekeepers. ${ }^{3}$

Numerous flocks of migrating Cushats come to Berwick-

1 This had been observed by Mr. Hardy above forty years ago, for I find him writing under date the 12th of July 1844: "Wood Pigeons are greatly increased of late years on account of the number of young fir plantations which shelter them."-Mr. Hardy's MS. Notes.

2 Lord Kaimes, about the year 1746, had turnip fields dressed and cattle fed with the produce at Kaimes, which were the first turnips sown in the county for the express purpose of feeding cattle. Clover and the artificial grasses were also sown in abundance at Kaimes, and at sundry other places about the year 1750 . -General Vieio of the Agriculture of the County of Berwick, by Alexander Low and Arthur Bruce, 1794, p. 106.

3 Although there are comparatively few Hawks to be seen in the county now, I often notice spots by the sides of woods and strips of plantation in autumn where they have plncked Cushats. The partiality of Hawks for Pigeons as a quarry seems to have attracted the notice of Horace, for in Book I. Ode xxxvii., he says, "Accipiter velut molles columbas," 
shire in the autumn and early winter months ${ }^{1}$ from the northern parts of Europe, and finding food and shelter here, doubtless remain in some cases, and help to swell the ranks of our native birds. As an instance of this I may mention that, whilst many came to feed on the beech nuts in the woods at Paxton in October and November 1873, these, about the middle of the latter month, were augmented by vast numbers which passed up the valley of the Tweed from the direction of the sea at Berwick, arriving in the mornings and not being observed to return eastwards in the evenings. For about a fortnight during the same autumn hundreds continued to fly daily from the east over the Well Mire Wood, on the southern bank of the Whitadder, near the village of Paxton, and although many of them were shot, the reports of the guns did not seem to alter the line of flight taken by their successors. ${ }^{2}$ Mr. John Wilson, late of Edington Mains, has informed me that thousands used to visit that farm in autumn, and that fishermen about Coldingham have occasionally seen immense numbers passing over the sea towards the Berwickshire coast.

The Cushat is strong and rapid on the wing, and when on a long journey flies high in the air. If suddenly frightened when passing overhead it sometimes makes a peculiar whistling sound with its wings, and this appears to have the effect of communicating the alarm to any others which may be in the neighbourhood. During the

1 Between the 21st of October and the end of November 1884 there was an immense immigration of Cushats covering the East Coast between Berwick and Yarmouth. On the 29th of November 1885 a vast rush flying south-west in countless thousands was seen at the Isle of May. The noise they made was like a. railway train.-Reports on the MI igration of Birds, 1879-85.

2 Another great migration of Cushats was observed at Paxton in the autumn of 1887. On the 26th of November in that year Mr. Compton-Lundie of Spital and I shot fifty-seven Pigeons in the course of a few hours as they passed over our heads towards the west. We were concealed behind a screen of fir branches set up against the west wall of the Wester Park at Paxton House, and we placed the dead birds on the grass in front of our ambush to act as decoys. 
nesting season the gambols of the male as he rises and descends in his flight, or occasionally strikes the points of his wings together, is a pleasing sight, which is frequently witnessed on calm sunny evenings.

About 1859-60 this bird had increased to such an extent in the neighbouring county of East-Lothian ${ }^{1}$ that it had to be constantly herded off the ripening wheat and barley fields by men or boys with guns. I have seen great numbers rise off patches of "laid" wheat in the vicinity of Salton, where the "Big Wood" 2 harboured thousands in its dark and unfrequented recesses. When feeding on growing grain the Pigeons usually come in pairs or in small flocks, and alight, in the first place, on some neighbouring hedgerow tree-such as an ash, willow, or plane-whence, after resting for a short time, they fly down to join any others which may be engaged in feeding on the adjacent parts of the field where the wheat or barley has been laid flat on the ground by heavy rain. A favourite way of shooting them used to be by making a small hut of green boughs underneath a tree frequented by the birds, and waiting in it with the gun ready to bring down the

1 Mr. Archibald Hepburn, Whittingham Mains, East-Lothian, writing in 1847, draws attention to the fact that in the end of last century the Cushat was a comparatively rare bird in that county. He says: "I am acquainted with a man, now sixty-five years of age, whose bird-nesting days were spent in the woods near Gifford, and he states that Wood Pigeons were then so rare that the discovery of a nest was looked upon as a great feat."-Hist. Ber. Nat. Club, vol. ii. p. 273.

2 Sir Walter Scott mentions this wood in his description of the meeting of Lord Marmion and Sir David Lindesay of the Mount, Lord Lion King at Arms :-

\footnotetext{
The green sward way was smooth and good,

Through Humbie's and through Saltoun's wood;

A forest glade, which, varying still,

Here gave a view of dale and hill,

There narrower closed, till overhead

A vaulted screen the branches made.
}

It appears from the Accounts of the Lord High Treasurer of Scotland, 1473-98, that the "Big Wood" supplied timber to make gun carriages in the time of King James IV. of Scotland: "Item, that samyn day (xxij. February 1496), gevin to Johne Mawar, zongare, to pas to Borthuik and Saltoun to vesy tymmyre for gun paraling, . . . ix. $\tilde{\mathrm{s}}^{. "}$ 
Pigeons, which alighted anougst the branches overhead. It was advisable to allow the birds to settle for a short time before aim was taken, for they always looked well about them immediately after they perched, their sharp eyes quickly discovering any movement below, in which case they at once flew off in great alarm. They could also be shot on the wing as they approached or left the tree. I have sometimes killed twenty or thirty in the course of an hour or two in this manner; a quiet, sultry afternoon about the beginning of August being the most favourable time for success, as the Pigeons then came in extraordinary numbers to feed. They were obtained in the same manner in the spring months when they frequented the newly-sown fields to pick up the scattered grain, but as there were then no leaves on the trees or hedges to help to hide the shooter, his place of concealment had to be more closely constructed to screen his movements when taking aim. A few stuffed Cushats were used as decoys, and were placed on the "laid" wheat in the neighbourhood of the tree underneath which the shooter was hidden; or, in the case of newly-sown fields, within range of his retreat; and the birds which were killed were set on the ground near them, with their heads supported by small forked sticks, to make them look as if they were alive. These attracted Pigeons passing overhead so powerfully that it generally happened that they came down and alighted as soon as they saw them. I often observed that after settling beside the decoys, the risitors stood looking about them for a short time before commencing to feed; sometimes they walked up to the lures to make a closer inspection of them, and when this did not prove satisfactory they took alarm and flew away. On several occasions I have seen male Cushats attempting to pair with the stuffed decoys.

The destruction of crops by this voracious bird became 
so great in Haddingtonshire shortly after 1860 that, in 1862, the United East-Lothian Agricultural Society offered a premium of one penny for each Cushat's head produced to the collector appointed for the district in which the bird was killed. This scheme was so successful that between December 1862 and June 1870 the heads of 130,440 were presented for payment. ${ }^{1}$

An agricultural association was formed in the east of Berwickshire in 1875, and in January 1876 the members sent a memorial to the proprietors of land in the district to the effect that, considering the great damage done to the crops by the extraordinary and excessive numbers of Wood Pigeons in the county, they had resolved that means should be taken for their destruction, and for this purpose they invited the co-operation of the landowners. In 1877 the association offered a prize of $£ 5$ for the greatest number of Cushats killed, but there was no competition. In April 1878 the members decided to give a premium of one penny for each head, and one halfpenny for each egg produced to collectors appointed in various localities, with the result that during the year ending the 1st of April 1879, 2980 Wood Pigeons and 666 of their eggs were destroyed. Prizes for eggs were again offered by the association in 1885 , but there was no response. In some instances men devoted their whole time, during certain seasons of the year, to the shooting of Cushats, travelling about the county from place to place, and taking up their quarters wherever they could make the heaviest bags. They sold the I'igeons which they killed at from fourpence to sixpence each, and thus made a livelihood.

The Pistol I'lantation, on Blackadder Estate, which consists principally of lofty old Scotch and spruce fir-trees, is a favourite roosting place of this bird in the autumn months.

1 Information kindly supplied by the Secretary to the Society. 
Advantage is taken of this by sportsmen, who, in the evenings, stand with their guns under the trees in those parts of the wood which are most frequented by the Pigeons, and shoot them as they fly in to roost. A windy night is the most suitable for this kind of sport, when as many as seventy-two have been killed by one gun.

Besides consuming large quantities of ripening and newly-sown grain, such as wheat, barley, and oats, as well as beans, peas, and tares, ${ }^{1}$ the Cushats likewise do much injury to young Swedish turnips in early summer by feeding on the leaves; and they also eat the "shaws" 2 and roots of turnips in hard weather in winter. It is believed that they do not break open the roots, their bills not being strong enough to do so, but that they feed upon those which have been already broken by hares, or by Rooks, whose sharp beaks penetrate the tough skin of the turnip with ease. They also do great damage to young grass and clover fields. A singular instance of voracity in this respect is mentioned by Mr. Hardy, who records that Mr. Wood, Foulden Bastle, shot a Wood Pigeon on his farm on the 7th of February 1872, and found in its crop upwards of 4200 clover leaves; and that in the previous year he got 3800 leaves from one which he had killed. ${ }^{3}$ During long-continued snow-storms Cushats are often put to great straits for food, and are frequently driven to visit

\footnotetext{
1 Gray mentions, as an example of the extraordinary voracity of the Wood Pigeon, that Lord Haddington had forwarded to him the contents of the crops of four of these birds opened at different times. The first contained 144 field peas and 7 large beans; the second, 231 beech nuts; the third, 813 grains of barley; and the fourth, 874 grains of oats and 55 of barley. He likewise adds that a bird shot at Alyth, in Forfarshire, was found to have no less than 1020 grains of corn in its crop. - Birds of the West of Scotland, pp. 216, 217.

$2 \mathrm{Mr}$. Hardy, writing in 1860, says, under date January 27th: "The forester here (Penmanshiel), an Englishman, used to cook the turnip leaves found in Cushats' crops, and said they were tender and good to eat. This during snowstorms - snow a foot deep. Cushats very tame, going amongst turnips with raisedup backs and feathers dishevelled, picking out pieces of turnips." -MIS. Notes.

3 Hist. Ber. Nat. Club, vol. vi. p. 429.
} 
gardens, where they do great damage to cabbages, broccoli, Brussels sprouts, and the like. ${ }^{1}$

In May, when the tender foliage of the beech appears, the woods at Paxton were a few years ago annually visited by great numbers of Cushats, which fed on the newlydeveloped leaves of this ornamental tree, so that, in addition to the damage done by the Cushat to the crops of the farmer and the gardener, the forester has sometimes reason to complain of its misdeeds.

As a further instance of this it may be mentioned that at a meeting of the Berwickshire Naturalists' Club, held at Marchmont on the 27 th of August 1879, Mr. Loney called attention to the topmost shoots of many of the spruce and silver firs there which had been broken by the weight of I'igeons which had perehed upon them, and it was found that there were hundreds of trees in this condition. ${ }^{2}$

Although the Cushat, when its numbers hecome too great, is exceedingly destructive to the crops of the farmer, yet it does a certain amount of good by devouring the young leaves, seed pods, and seeds of several noxious weeds in the fields. Amongst these may be mentioned the wild mustard (Sinayis arvensis), the mother of wheat or speedwell (Veronica hedercfolia), the chickweed (Stellaria media), and Ccrastium viscosum. ${ }^{3}$

In antumn, after the corn is gathered into the stackyard, it assembles in great flocks, and feeds on the scattered grain left in the stubble fields. It is then very shy and wary.

1 Mr. Hardy, writing on the 27 th of January 1860 , mentions that Cushats have destroyed the broccoli in Dunglass garden.-MS. Notes. Dr. Stuart, Chirnside, in a paper on the effects of the winter of 1878-79, mentions, under date of the 16th of March 1879, that "Wood Pigeons came into the gardens in the middle of the village here, and, in front of the windows, ate the broccoli, Brussels sprouts, and other greens which they could get near."-Hist. Ber. Nat. Club, vol. ix. p. 134.

2 Ilist. Ber. Nat. Club, vol. ix. p. 48.

3 Mr. Hardy, writing under date of 26th July 1839, says: "I examined the crop of a young Cushat lying in Blackburnig Woorl, from which I had frightened a Hawk. It was crammed with the calices and capsules of Cerastium viscosum."MS. Noles. 
The Cushat begins to build in April, and continues to breed the whole season through until September, or even the berinning of October, August being a favourite month on account of the plentiful supply of food in the shape of ripening grain.

The well-known nest is constructed of small sticks and twigs, which are often so loosely put togrether that the eggs can be seen by a person looking up from below. In some instances, however, a new nest is constructed on the top of an old one, as in the illustration griven below. Although the bird usually nests in fir woods and plantations at a distance from the habitations of men, yet it often throws aside its natural timidity and selects a situation close to a dwelling-house. Several pairs used to breed in the trees around my house at Paxton every year, and were then so tame that they allower perple to approach within a few yards of the branch upon which they were perched before they took to flight. It is thought that their motive in selecting a site for their nests near dwelling-houses is to avoid the danger of being roblued loy Hooded Crows or Hawks. They likewise frequently rear their young in tall thorn herdges which surround corn-fields, a position in which I have often seen their nests in East-Lothian. The eggrs are two in number, and pure white. ${ }^{1}$

Any variation in the plumage of the Cushat is rare, but the occurrence of a white specimen at Lintlaw during the winter of 1874 is mentioned by $\mathrm{Mr}$. John Anderson, Preston, who also states that "there was another for two or three years among the woods on the Marygold Hills, where it was a very conspicuous object when sitting on the top of a lofty spruce fir; but, unfortunately, in the spring of 1869 it was shot by a crow-herd." 2 I have a pure white example in iny

1 Boys suck Cushats' eggs, which they think make them long-winded.

2 Hist. Ber. Nat. Club, vol, vii. p. 515. 
collection, which was killed near Kelso in March $1878,{ }^{1}$ and was kindly presented to me by Mr. W. C. Caverhill, Berwickon-Tweed. With regard to the local folk-lore of the Cushat, Mr. Hardy writes: "It is said that Cushie Doos once laid their eggs on the ground, and that cows destroyed the eggs. They afterwards had recourse to trees, and cry from their security, 'Rookety, coo, coo, ye'll no win at me noo." $\mathrm{He}$ likewise relates that it is said "there was once a man called Barney who went out to steal a cow, and the Cushie Doos saw him and called to him, 'Barney, take two, two.' For their knavery they have cried that ever since."

1 The young birds in their first plumage may easily be distinguished by their want of any white marks on the neck. The plumage of the Wood Pigeons which come on migration to the county from the north of Europe in the autumn and early winter months is in general darker and duller in hue than that of our home-bred birds.

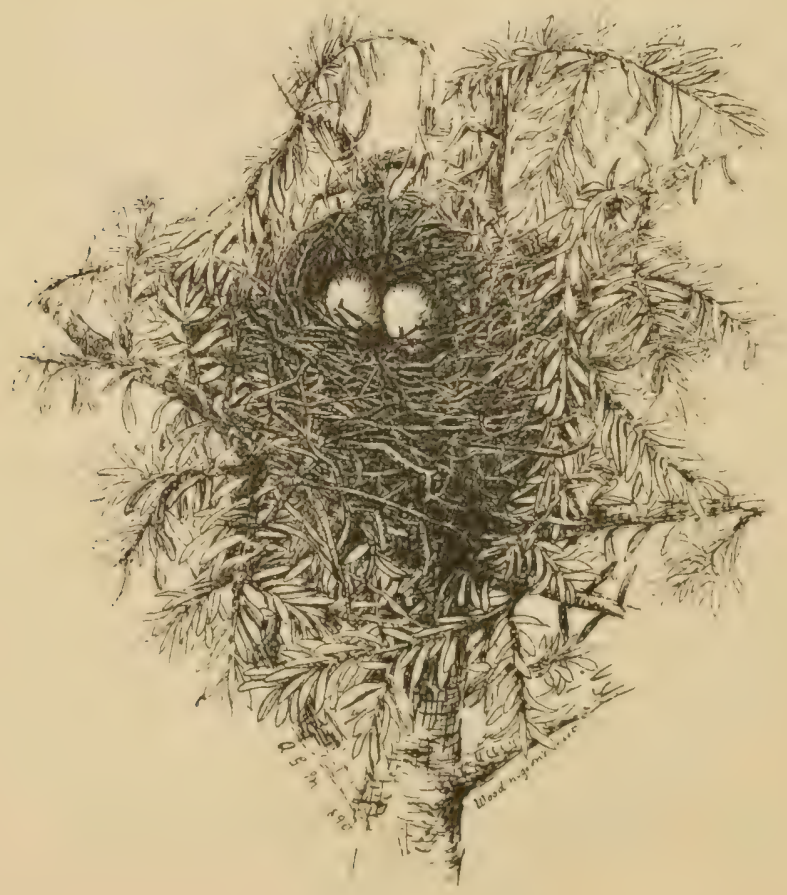




\title{
THE STOCK DOVE.
}

\author{
WOOD DOVE, BLUE-BACKED DOVE.
}

\section{Columba onas.}

The Stock Dove builds her nest

Where the wild flower odours float.

MACKAY, Angling.

Immediately to the west of Paxton House, which stands on elevated ground on the north bank of the Tweed, there is a deep, rocky, wooded dean, through which a small stream meanders; and there may be seen the remains of the "Old Heronry Wood," consisting of a few gigantic silver firs towering to a height of upwards of a hundred feet.

The opposing precipitous rocks almost meet at a narrow part of the defile, and, with the umbrageous trees above, form in summer a beautiful shady dell, whose sides are clothed with various kinds of ferns and wild flowers. At this season the little burn rippling over its stony bed is a favourite haunt of the Water Ouzel and the Grey Wagtail, whilst amongst the huge masses of fallen stone by its sides the Otter and the Fox find a secure retreat.

Here in the summer of 1877 the Stock Dove made its appearance. It was very shy, and rushed from its retreat with sounding wings in the greatest alarm whenever the place which it frequented was approached. The bird was again noticed in the spring and summer of the two following

${ }^{1}$ Here King Charles x. placed one of his outposts in May and June 1639, when he lay with an army of 16,000 men at the "Byrke Houses," a hamlet on the English side of the Tweed, opposite the village of Paxton, to overawe the Scottish Covenanters, who, under General Leslie, occupied the top of Duns Law. 
years flying out from the south side of the ravine, but the exact spot from which it came was not determined until the summer of 1879 , when it was seen to leave a rabbit hole, the mouth of which was almost entirely concealed by a large overhanging tuft of wood grass (Luzula sylvatica). On the burrow being examined a nest was found within a short distance of the mouth containing two white eggs, which were not disturbed. It has since nested there annually, as well as in the dean below the Avenue Bridge.

The late Mr. Robert Gray records that Mr. Charles Watson, solicitor, Duns, in a letter to him dated the 18 th of April 1878, stated that a few months before he was shown a specimen of this bird which was shot in the woods of Duns Castle, and that the gamekeeper there had informed him that Stock Doves had bred there for several years. ${ }^{1}$ Mr. Gray also mentions that a beautiful male of this species had been sent to him on the 12 th of March 1879 by Mr. Watson, which had been shot on the previous day in the same woods. ${ }^{2}$

Mr. George Bolam, writing in the History of the Berwickshire Naturalists' Chub regarding the Stock Dove, says: "I have to record what is, so far as I am aware, the first authenticated instance of the breeding of this bird in Scotland. On the 20th of April 1879, whilst walking on the steep banks on the north side of the Whitadder, a short way above Hutton Bridge, a Stock Dove flew out some little way below me, and on going down to the place I was agreeably surprised to find its nest, containing two eggs, a good deal incubated, placed a foot and a half down a rabbit hole. After watching the bird for some time, and satisfying myself that I had not mistaken the species, I removed the eggs, and they now form an interesting addition 
to my collection. On revisiting the place about six weeks later, namely, on the 3rd of June, in company with Mr. Muirhead of Paxton, we were not a little astonished to find that the nest contained two fine young ones almost fully feathered, and we again saw the old bird leave the hole." 1

Mr. Bolam states that, about the middle of April 1880, he discovered another nest with two eggs on the banks of the Whitadder, near Edrington, in a slight natural depression of the ground at the bottom of a whin bush, and sheltered by long grass, which, growing from both above and below, completely concealed it from view. ${ }^{2}$

Mr. Harvie-Brown mentions that in 1881 a bushy limetree in the grounds of Duns Castle, where the nest of this bird had been found, was pointed out to him by Mr. Wait, bird-stuffer, Duns. ${ }^{3}$

Dr. Stuart, Chirnside, has informed me that a Stock Dove had its nest in a rabbit hole in a terrace below Blackadder House in the spring of 1884 ; and Mr. John Thomson, Maxton, has written to me that "the bird is now (1886) pretty frequently met with at Mertoum, Dryburgh, Cowden Knowes, and Drygrange." Mr. Riobert Campbell-Renton, yr. of Mordington, told me on the 5th of May 1887 that a pair had their nest that year in a thick silver fir near the stables there, and that the bird was becoming so plentiful about Mordington that he had killed ten or twelve specimens while shooting Wood Pigeons during the previous winter. On the 12th of May 1887 I saw a Stock Dove fly from its nest at the Raven's Craig, near Fellcleugh, on the Whitadder, thus showing that it has extended its breeding grounds towards the Lammermuir Hills.

This bird does not appear to have been observed in Scotland before 1874 or 1875 , when it was seen in Perth- 
shire. $^{1}$ Since then it has been gradually spreading and increasing in various counties. In Berwickshire it seems to be partial to the banks of rivers and streams, where it breeds in rabbit holes or under overhanging bushes.

In its habits this species bears considerable resemblance to the Wood Pigeon, feeding on the stubble fields in the autumn and the newly-sown fields in spring, like that wellknown bird. It also eats the seeds of various weeds. ${ }^{2}$

The Stock Dove may be distinguished from the Cushat, even when on the wing, by its smaller size and the want of any white marks on the neck or wing coverts. It differs from the true Pock Dove in not having any white on the rump. Its note is not so sonorous or continuous as that of the Wood Pigeon. It nests in various situations, according to the locality, sometimes choosing a hollow tree, or the old nest of a Crow or Magpie, and frequently rabbit holes, or the ground under a whin or other thick bush. The eggs are two in number, and creamy white in colour.

It was formerly thought that the Stock Dove was the ancestor of our common dovecot Pigeon, and that it derived its name from this circumstance. It is now, however, believed that the Rock Dove is the progenitor of the domestic Pigeon, and that the Stock Dove got this name from building in the stocks of trees.

1 Proceedings of the Royal Physical Society, 1881-83, p. 251.

2 On the 14th of December 1887 as many as 1260 seeds of grub grass (Galium aparine) and two grains of barley were taken out of the crop of a specimen of this hird sent to me by Mr. Robert Camipbell-Renton, yr. of Mordington, which he hart shot there.

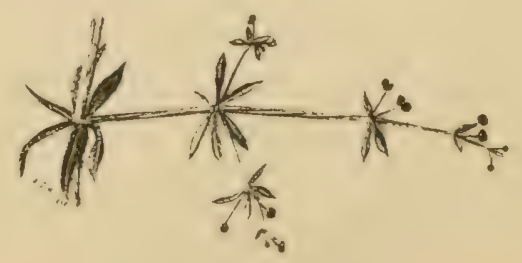




\section{THE ROCK DOVE.}

WILD PIGEON, ROCK PIGEON, WILD DOVE, DOO.

\section{Columba livia.}

\section{The פDoo.}

The Dow, with whistling wings sa blew, The winds can fast collect;

Her purpour pennes turnes merry hew, Agains the sunne direct.

Alexander Hume, Thanks for a Summer Day, I575-I590.

THIs interesting bird is found in considerable numbers in the caves which occur in several parts of the precipitous rocks on the sea-coast of the county, from Lamberton to Cockburnspath, and appears to be most abundant in the neighbourhood of St. Abb's Head. ${ }^{1}$

Proceeding along the sea-coast from Lamberton, and passing Burnmouth, we find in the neighbourhood of Fairneyside and Gunsgreen the "Dow Cave," so called on account of its having been long frequented by Pigeons Leaving Eyemouth and the little fishing village of Coldingham Shore behind, we next come to a cavern at Kirkheugh, ${ }^{2}$ where, as well as at the Caulderon or Piper's Cove, a short distance to the north, dwells a colony of Rock Doves. The Lighthouse is now reached, and we have before us the

1 There are some Pigeons of varions colours, such as sandy and white, which inhabit the caves frequented by the Rock Doves. The former are evidently either domestic Pigeons which have deserted their dovecot or have been bred from these. It may be conjectured that the majority of the blue Pigeous in the caverns are the descendants of the wild Rock Dove, which has inhabited the precipitons coast of Berwickshire from time immenorial.

2 So named from its proximity to the site of the ancient kirk of St. Abb's, of which very little now remains.

VOL. II. 
lofty and precipitous rocks of St. Abb's Head. "This magnificent promontory," says Dr. Johnston, "is a huge insulated mass of trap rocks, whose seaward sides form precipices of vast height, hollowed in many places with caverns, in which the wild Pigeons (Columba livia) build their nests and nurture their young in safety amid the spray of waves that never sleep in rest. In some parts the caverns penetrate far and end in darkness; in others they are pervious, and give a romantic passage by another opening equally superb." 1 A little distance to the west of the Lighthouse is the Cleaver Rock, immediately to the west of which another retreat occurs. Rounding the Head, and just before we reach Petticowick Harbour, we come to another great fissure inhabited by Pigeons, with Guillemots on the rocks above its entrance. Mr. Hardy writes to me that further along the coast towards the west there are several resorts of this bird about the Gull Rocks, in the neighbourhood of Fast Castle, and again at the Rammel Cove, which is nearly opposite Dowlaw Mill Pond. He adds that it likewise nests at Windylaw Cove, which is towards the Redheugh Shore, at Siccar, and in the cave mouth at Swallowcraig, and at Greenheugh, near Oldcambus. When the mouth of one of these deep and dark caverns, moist with the spray of the thundering surge, is entered by a boat, the Pigeons dash out in great alarm, bringing to our remembrance the following beautiful and descriptive lines in Dryden's translation of Virgil :-

As when a Dove her rocky hold forsakes,

Roused in a fright her sounding wings she shakes,

The cavern rings with clattering, out she flies,

And leaves her callow care and cleaves the skies;

At first she flutters, but at length she springs

To smoother flight, and shoots upon her wings.

\footnotetext{
I Address to the members of the Berwickshire Naturalists' Club by George Johnston, M.D. (read at its first anniversary meeting held at Coldstream on the 19th of September 1832).-Hist. Ber. Nat. Chib, vol. i. p. 5.
} 


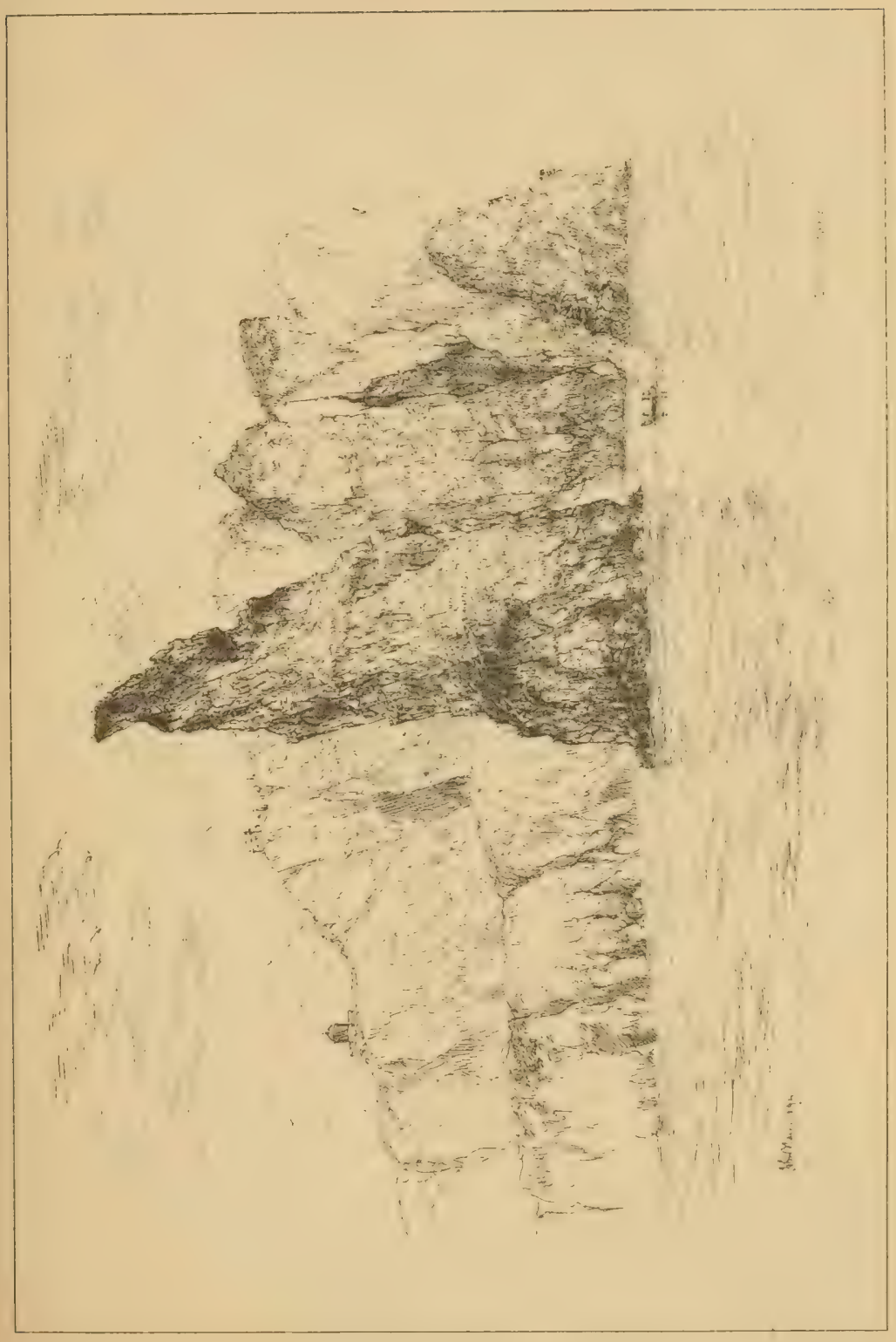



Sometimes sportsmen go round the coast in a boat to shoot the Pigeons as they fly out of the caves, frightening the birds off the rocky ledges inside by shouting, clapping the hands, or firing a shot at the entrance, ${ }^{1}$ whereupon they rush over the heads of the intruders, and are then very difficult to bring down. When thus disturbed they generally pass close round the face of the precipitous rocks and make for some other neighbouring retreat. Their flight is strong and very rapid. ${ }^{2}$

This species commences to breed early in spring, and continues to do so at intervals until autumn. It makes a slight nest on the rocky ledges of the caves, and lays two white eggss. It often assembles in large flocks, which may be seen feeding in the fields near the sea; and in snowy weather in winter it visits stackyards in the neighbourhood of the coast to pick up grain. In July it feeds on the lea fields in great numbers, and also on the ground from which hay has been cut. The food consists chiefly of grain and the seeds of various weeds.

There can be little doubt that this bird formed the principal stock from which the common Pigeon of our dovecots was originally derived, although the latter is modified in its habits and varies much in colour. Even yet the domestic bird sometimes reverts to the wild life of its original ancestors, and forsakes its home for a cavern on

1 When a gun is fired inside a Pigeon cave the reverberation is deafening.

2 Mr. Tegetmeier states that the average rate at which the fastest Homing Pigeons flew in eighteen races, which took place in 1883, and which extended to the aggregate distance of 3189 miles, was $17 \cdot 65$ yards per second, 1059 yards per minute, or about 36 miles an hour. The greatest speed attained was 27 yards per second, 1620 yards per minute, or about 55 miles an hour for four hours in succession.-See The Field of 22nd January 1887. Mr. Griffith found by experiments with the chronograph that the very best "Blue Rocks" supplied by Mr. Hammond of the Hurlingham Club flew through a forty-yard covered range at the average rate of 14.3 yards per second, 858 yards per minute, or about $29 \frac{1}{4}$ miles per hour. In the open they flew at the rate of $13 \cdot 15$ yards per second, 789 yards per minute or about 27 miles an hour,-See The Field of 19 th February 1887. 
the sea-coast, or a rocky hold on the banks of the Tweed or Whitadder.

The dovecot Pigeon has from early times been under the protection of the law, and for the purpose of encouraging its increase in Scotland we find James IV., in his sixth parliament (11th March 1503), enacting that " everilk Lord and Laird, make them to have Parkes with Deare, stankes, cunningares, dowcattes, orchardes, hedges, and plants, at the least, ane aicker of Woode." 1 In a confirmation by the same ling, given at Stirling the 20 th of July 1510 , of a husbandland in "Hirsell" to the Prioress of the Cistercian convent of Coldstream, "columbis" and "columbarijs" are mentioned, ${ }^{2}$ which shows that pigeon houses were then considered valuable adjuncts to landed property.

Thefts of "Dowes furth of Dowcates" were severely punished (James r., Parl. 2, c. 33 ; James III., Parl. 10, c. 60 ; James IV., Parl. 6 , c. 69 , \&c.) A breaker of "dowcats" by Scots law was fined $£ 10$ Scots for the first fault, and $£ 20$ for the sccond, and it bears that for the third and obduracy "he may be hanged to death." When children were the culprits, the fathers or masters were to pay $13 \mathrm{~s} .4 \mathrm{~d}$. for "ilk time of trespas," or "else sall deliver the said childe to the Judge, to be leisched, scourged, and dung for his fault." 3 It would seem that the enactment of James IV. with regard to the making of "dowcates" had been carried out too well, and that Pigeons became troublesome from their numbers in the reign of James VI., for he, "considering the great inconvenients sustained by the Leiges of this realm through the frequent building of dowcats

1 Laws and Acts of Parliament made by the Kings and Queen of Scotland. Collected by Sir Thomas Murray of Glendook, Bart., 1681.

${ }^{2}$ Chartulary of the Cistercian Abbey of Coldstream, by Rev. C. Rodgers, LL.D., p. 56 .

3 Regiam MFajestatem, edition 1609. The Forest Laves, fol. 139, b., chap. iii., Nos. 5 and 7.-Mr. Hardy's MS. Notes, 
by all manner of persons," passed an Act in 1617 to the effect that no person shall build a "doucate" unless he shall be possessed of lands yielding ten chalders of victual, lying around the said "doucate," or within two miles of it.

There is a farm near Fast Castle called Dowlaw, which has no doubt derived this name from the great number of Rock Doves frequenting the ground, the old spelling of the word in the Coldingham Session Records being Dovelaw.

Mr. Hardy informs me that a white Pigeon was supposed to be an emblem of innocence, ${ }^{1}$ and was sometimes sent up in the air at executions by friends of the culprit as a sign of guiltlessness. An example of this took place at the execution of Grace Griffins, who was hanged at Berwick on the 26 th of July 1823 for the murder of her husband, a white Pigeon being liberated above the crowd at the moment when the fatal bolt was withdrawn.

A popular saying sometimes heard in Berwickshire is that "a doo is the only bird without a ga,", 2 which peculiarity is thus referred to by the poet Oldham :-

As if thou hadst unlearned the power to hate, Or, like the Dove, were born without a gall.

A piece of Lauderdale folk-lore is that "Pigeons never breed when the pea blooms." Probably this may have had its foundation in the fact that they do not produce many young when their food is scarce, which is the case

1 He mentions as instances of this that when St. Quentin was decapitated during the persecution of Domitian against the Christians, "a white Dove escaping from his neck ascended to the heavens" (Proprium Sanctorum, f. cxxxvi., ap. Brev. Alerd. t. ii.); also that it is related that a certain damsel, severely distempered, having been carried to the shrine of St. Ebba, at Coldingham, recovered after beholding a white Dove on the altar as a vision (Proprium Sanctorum, f. Ixxxviii., ap. Brev. Alerd. t. ii.)-Mr. Hardy in letter dated the 15th of December 1886. For further instances see Folk-Lore of British Birds, p. 168.

2 "The gall-bladder is wanting in Pigeons, in which, as in many other respects they differ from the gallinaceous birds."-Macgillivray, History of British Birds, vol, i. p. 65. 
about the end of June when the pea blooms, for then there is little grain in the stackyards or in the fields.

In the neighbourhood of Paxton I have sometimes heard the country people describe a frosty morning in spring, when rime is seen lying thickly on the ground, by saying that "everything is as white as a doo this morning." In some districts it is a popular belief that the return of Pigeons to their dovecots later in the evening than usual is a prognostication of rain on the following day. ${ }^{1}$

Amongst some MS. Notes on Birds by the late Dr. Johnston of Berwick, kindly given to me by his daughter, Mrs. Barwell Carter, I find the following:- "A Pigeon or two is wont to stray occasionally from its dovecot and associate with the Rooks, and the boy who is sent to frighten away the latter from the newly-sown corn does his best to shoot the wanderer as a better prize and more worthy of his aim than the cawing crowd. Hence the saying common in the county when a young man has taken up with suspicious company, and is charged with an offence to which he pleads not guilty, 'An he hadna' taen up with the craws he wadna' been shot."

1 Information from Mr. John Thomson, Maxton, on the 3rd of May 1886.

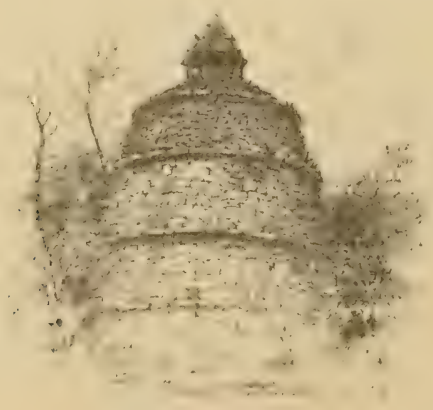




\section{THE TURTLE DOVE.}

\section{Turtur communis.}

The Turtour for hir maik,

Mair dule may nocht indure;

Nor I do for hir saik,

Evin hir quha hes in cure

My hairt, quhilk sal be sure.

DARNLEY'S Ballat, 15+2-1567.

The Turtle Dove is rarely seen in Berwickshire. It, however, sometimes occurs in the county in autumn, probably on migration southwards from Denmark or Scandinavia, which appenr to form its northern European breeding range.

An adult female, preserved in Berwick Museum, was shot near Edrington, on the Whitadder, on the 21st of October $1872,{ }^{1}$ and a young male was lilled not far from the same place on the 19 th of November $1874 .^{2}$ Another young male was obtained at Lamberton by Mr. James Mein on a very stormy day about the middle of September 1880 . It was apparently much fatigued, and could not fly well. ${ }^{3}$

This species is a summer visitor to England and Wales, where it generally arrives about the beginning of May, departing southwards again in September. It is common in the midland and southern counties, but becomes rare in the north.

I have seen numbers of Turtle Doves in the neighbourhood of Remorantin, Loir-et-Cher, France, where they fed in the rye-fields, and built their nests in the birch-trees which overhung the tributaries of the river Sauldre. Their flight was very rapid and tortuous. 
Seebohm says that the winter quarters of this species are absolutely unknown, but as it passes through Northern Africa, and has not been found in South Africa, they must be in some region in the centre of that continent. ${ }^{1}$

1 Seebohm, British Birds, vol. ii. p. 412.

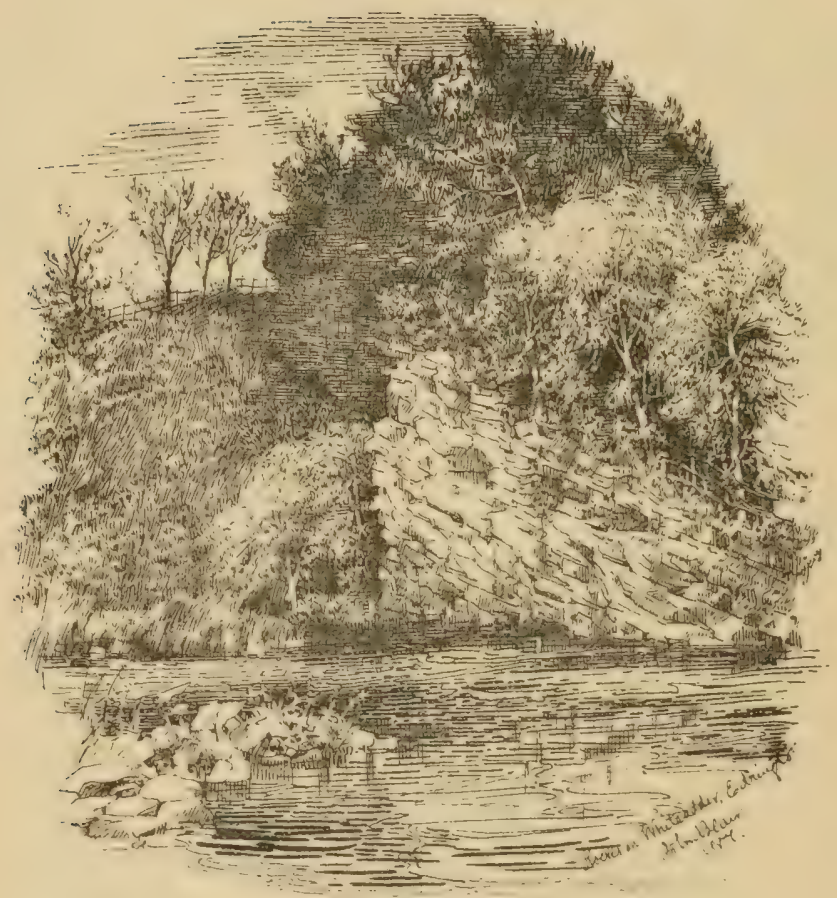




\section{THE PASSENGER PIGEON.}

\section{Ectopistes migratorius.}

Now down through dismal swamps pursue your way, Where pine and hemlocks thick obscure the day; Whose mingled tops an hundred feet in air, The clustering nests of swarming Pigeons bear.

Alexander Wilson.

According to Mr. Howard Saunders, in his continuation of Professor Newton's edition of Yarrell's British Bircts, ${ }^{1}$ there are only five undouloted instances of the occurrence of the Passenger Pigeon in the British Islands. Of these a specimen in the collection of the late Lord Haddington at Mellerstain, shot by himself in the immediate vicinity of that place, forms the fourth. Lord Binning, in communicating to Dr. Turubull a note of its occurrence at Mellerstain, adds: "The bird is, however, somewhat deprived of the interest which would otherwise attach to it, from the fact of a gentleman in Berwickshire having 'turned out' several Passenger Pigeons shortly before the Mellerstain specimen was shot. Presuming, however, that this was one of the birds 'turned out,' it is rather remarkable that, after their release, no other specimen was heard of as having been seen in our part of the country." 2 The date when the bird was shot is not given by Lord Bimning, but in some MS. notes, kindly supplied to me by Mr. Hardy for use in this work, I find that the latter, writing under date 1857 , says: "A Passenger Pigeon was killed at Mellerstain four years

1 Vol, iii, 1882-84, p. 28.

2 Turnbull's Birds of East-Lothian, 1867, p. 41. 
ago, and when opened by Mr. Heckford, ${ }^{1}$ who preserved it, the crop was full of beech nuts."

Audubon and Wilson, in their works on American Birds, give graphic accounts of the extraordinary migrations of the Passenger Pigeon, over which in boyhood I have often pored with delight.

Mr. Saunders says its food consists largely of the service berry (Amelanchicr alnifolia), acorns, and beech mast, and that as soon as the supply becomes exhausted, the immense flocks suddenly disappear, and do not return for a long period.

It may be distinguished from our other Pigeons by its long wedge-shaped tail.

1 Mr. G. S. Douglas of the Chronicle office, Kelso, writes to me under date 7th May 1887: "Mr. Heckford was a native of Blandford, Dorsetshire, and began life as a hairdresser. Mr. Douglas of Cavers was in that neighbourhood and took a fancy to Heckford, who was attending him (these were the days of perukes, \&c.) After twenty-three years' service at Cavers, Heckford came to Kelso in 1827, and settled there. When the museum was founded he was appointed conservator, and performed his duties gratuitously as well as efficiently. His knowledge of taxidermy and natural history generally had been gained at the University of Edinburgh, which he had the opportunity of attending when the Cavers family were resident in that city during winter. He died on the 28th of February 1877 , aged ninety years."

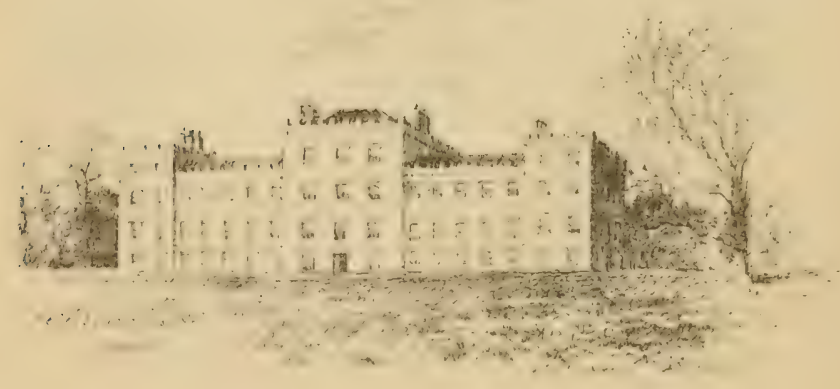




\title{
PALLAS'S SAND GROUSE.
}

\author{
THREE-TOED SAND GROUSE.
}

Syrrhaptes paradoxus.

The loveliest bird in Franguestan!

BYRON, The Giaour.

ON the morning of the 25th of May 1888 my friend Mr. William Evans telegraphed to me from Edinburgh that, as several pairs of Sand Grouse had been recently seen in the neighbourhood of Dunbar, the bird might be expected to make its appearance in Berwickshire. I mentioned this in Berwick Market to Mr. H. H. Craw, Foulden West Mains, on the afternoon of the same day, and asked him to be so good as to let me know if any specimens should be noticed in his neighbourhood. This he kindly undertook to do, and in the course of a few hours a messenger from him came to my house at Paxton with a cage containing a bird which had just been caught by a boy on his farm while engaged in rolling a field sown with barley. In the cage I found a beautiful live Sand Grouse in full plumage, and at once wrote to Mr. Craw suggesting that, to keep it alive, he should feed it on small seeds, and that he should present it to the Zoological Society of London. He accordingly forwarded the bird to Dr. Sclater, whose address I supplied, and I had the pleasure of seeing it in the gardens of the Society in a thriving condition in the month of December following. It was a female, and when captured by the boy was so exhausted that it could not fly. It was said to have been one of a flock of twelve which visited the farm on the day mentioned. 
The gamekeeper at Abbey St. Bathans informed me on the 17 th of June 1888 that, in the previous week, several Sand Grouse were shot on Fannanside, near Godscroft, by Mr. John Moffat, Bankend; and on the 1st of July following, Mr. Millican, Harelaw, near Chirnside, told me that two specimens had recently been got at Whitfield, near Ayton. On the 9 th of July 1888 the gamekeeper at Quixwood killed a fine male out of a flock of nine which were feeding in a field near the Retreat newly sown with rape and grass seeds. They were very wild, and rose at a distance of a hundred and fifty yards, but the bird which he secured remained sitting on the ground until he approached within thirty yards of it. ${ }^{1}$ In the same month a specimen was procured from a flock of ten or twelve at Raecleughhead by Mr. Charles Marshall, Duns.2 Flocks of Sand Grouse are said to have been seen also in the parishes of Hutton, ${ }^{3}$ Foulden, ${ }^{4}$ Chirnside, ${ }^{5}$ Coldingham, ${ }^{6}$ Longformacus, ${ }^{7}$ Cockburnspath, ${ }^{8}$ and Abbey St. Bathans ${ }^{9}$ in the months of June and July 1888.

This beautiful bird inhabits the sundy steppes of Asia in summer, from the eastern shore of the Caspian to Lake Baikal, migrating in winter to Mongolia and China. ${ }^{10}$ Its food in Scotland apparently consisted chiefly of the seeds of

1 Information from Mr. John Hogg of Quixwood, 19th July 1888.

2 Information from Mr. John Barrie, gamekeeper, Preston, 6th February 1892.

$34 \mathrm{Mr}$. Compton-Lundie of Spital observed a flock of twelve Sand Grouse passing over Spital House from south-cast to north-west, about ninety feet high in the air, on the morning of the 9th of June 1888. They uttered a cry like the words "turook, turook,"

5 Dr. Stuart, Chirnside.

${ }^{6}$ Mr. W. Evans, in Proceedings of the Royal Physical Society, vol, x. p. 109. Also Mr. Bertram, Heughheai, 28th July 1888.

7 Colonel Brown of Longformacus saw a flock on a grass park near Longformacus House on the 1st of June 1888. Information given to me by him on the 25th of July following.

8 J. Hardy, Hist. Ber. Nat. Club, vol. xii. p. 188.

9 J. Shiels, gamekeeper, Abbey St. Bathans, 13th July 1888.

10 Saunders, Manual of British Birds, 1889. 
various plants, such as spurrey (Spergulle arvensis), knotgrass (Arrhenatherum avenaceum), clover, chickweed (Stellaria media), dock (Rumex), and the like.

Its flight is rapid, and resembles that of the Golden Plover. Great numbers visited the British Islands in May 1863, when several flocks were observed in East-Lothian; but by the following winter and spring the bird had disappeared from England as well as from Scotland.

Little further was heard of the Sand Grouse in this country until May 1888, when it was again seen in nearly every part of the kingdom.

Professor Newton records that it bred on the Culbin Sands, Morayshire, in August 1889. ${ }^{1}$

An Act of Parliament was passed on the 24th of December $188 \mathrm{~S}$ for its protection from the 1st of February 1889 to the 1st of June 1892, with the view of the bird becoming acclimatised, but it has now (February 1892) quite disappeared from Great Britain.

1 Ibis sixth series, vol. ii. pp. 211-214.

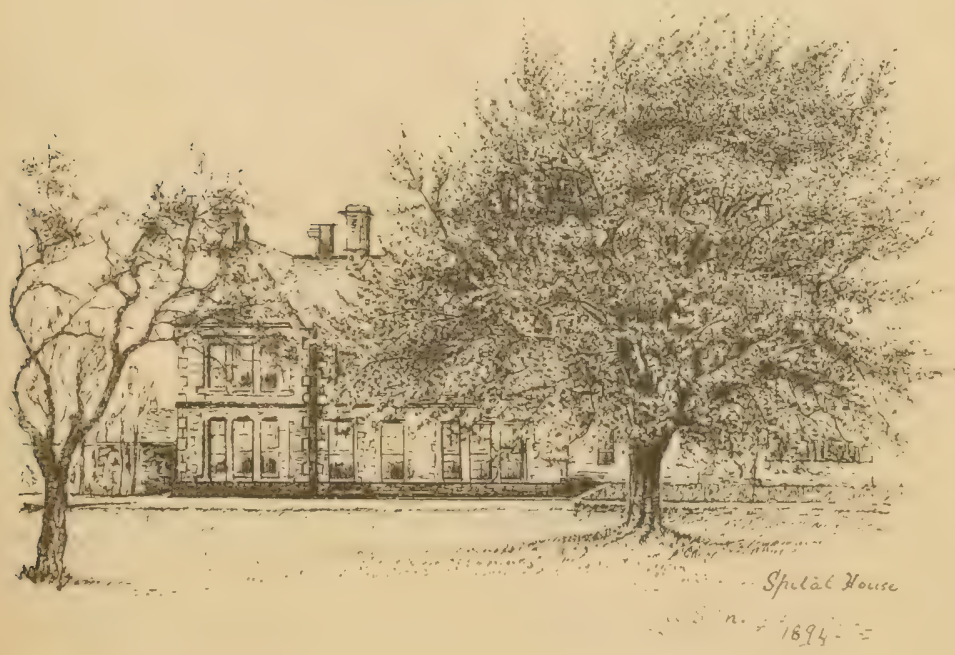




\title{
THE BLACK GROUSE.
}

\author{
BLACK-GAME, BLACK-COCK-THE MALE; \\ GREY HEN-THE FEMALE. \\ Tetrao tetrix.
}

\section{The 2Black: Cock, The Grep}

\begin{abstract}
The livelong day Lord Marmion rode:
The mountain path the Palmer show'd, By glen and streamlet winded still, Where stunted birches hid the rill. They might not choose the lowland road, For the Merse forayers were abroad, Who, fired with hate and thirst of prey, Had scarcely failed to bar their way. Oft on the trampling band, from crown Of some tall cliff, the deer looked down: On wing of jet, from his repose In the deep heath, the Black-Cock rose.
\end{abstract}

ScotT, Marmion.

Althougrn the great extension of cultivation during the last hundred years and the enclosing and draining of many parts of the moors and boggy grounds of the county have considerably reduced the area suitable for Black Grouse, yet it is probable that, in certain localities, they are more plentiful than they were in the beginning of the present century, when shootings were not preserved, and birds of prey were unmolested by gamekeepers. In support of this conjecture I may state that in some extracts from a diary which was kept by Captain Bell of the Berwickshire Militia, from 1802 to 1826 , kindly supplied to me by Mr. Hardy, I find that, between 1803 and 1814, he frequently shot over the moors at Kettleshiel, Bedshiel, Scarlaw, Longformacus, Monynut, Barnside, Godscroft, Quixwood, and Whit- 
chester, and although he often makes mention of seeing and killing a few "Moor-fowl," he does not allude to any Black Grouse being observed or shot. In the neighbourhood of Lauder this bird does not appear to have been known before the early part of the present century, for Mr. Scott, late gamekeeper of Thirlestane Castle, informs me that he was told by an old dyker named Chisholm that about the time mentioned it was first seen in that locality at a place called Langshaw, about six miles south of Lauder. A specimen was shot at Woodhead Hill on Lord Lauderdale's estate some time afterwards, and the man who killed it had not seen a bird of the kind before. It was forwarded to the Earl, who was staying in London at the time, and who sent word that it was a Black-Cock. Mr Kelly, in his Account of some of the Birds of Lauderdale, says: "Of the Berwickshire precincts of Lauderdale the Black-game does not appear to have been an acknowledged occupant till 1830." ${ }^{1}$ These statements would seem to suggest that it was by no means a plentiful bird in the county long ago. Unfortunately, very little is said about the game, or birds generally, by the writers of the reports on the various parishes in Berwickshire, which are given in the Old Statistical Account of Scotland (1795), and not much more information on these subjects is supplied in the Ncw Statistical Account (1835). This is to be regretted, for, if some notices of the wild animals and birds found in each parish had been given, they would now have been of great value for comparison with the fauna in the respective localities at the present time. One of the reporters in the Ncw Statistical Account, who alludes to the various kinds of game in his parish, is the Rev. George Fulton Knight, minister of Mordington, who, writing in February 1835 , states that the conımon varieties,

1 IIist. Ber. Nat. Club, vol. vii. p. 523. 
"as Hare, Partridge, Black-Cock, Dotterel, and Wood-Cock, are plentiful." The "Black-Cock" mentioned in Mr. Knight's list then frequented Lamberton MIoor, and continued to do so, as I have been informed by the proprietor of Mordington Estate, Major Campbell-Renton, for many years after the above date; they became extinct about 1870 , when a Grey Hen was shot near Mordington House. There were none seen for some years afterwards in the neighbourhood, until the winter of 1882, when a Black-Cock and three Grey Hens appeared; but since then they have regularly bred every year on the moor in small numbers. ${ }^{1}$

If a line be drawn on a map of Berwickshire from Coldingham Village to Earlston, it will divide the county into two halves of nearly equal size. The northern half is the district in which the Black Grouse is at present found in greater or less numbers, and includes the following parishes:-Abbey St. Bathans, Buncle, Channelkirk, Cockburnspath, Coldingham, Cranshaws, Duns, Earlston, Gordon, Greenlaw, ${ }^{2}$ Langton, Polwarth, Legerwood, Westruther, Lauder, and Longformacus. I have observed that this species is numerous in the neighbourhood of Cattleshiel and Bedshiel, as many as eleven brace having been killed at the latter place in a day's shooting in August about the year 1882 by the late Mr. Hume-Purves of Purves Hall.

The best bags of Black-game in the county are generally made on Spottiswoode Estate, concerning which the following notes have been kindly supplied to me by Mr. John Young, gamekeeper to Lady John Scott Spottiswoode

\footnotetext{
1 The gamekeeper at Mordington informed me on 9th December 1887 that there were then fifteen Black Grouse on Lamberton Moor.

$2 \mathrm{Mr}$. W. Smitl, hend gamekeeper, Hadlo House, Aberdeenshire, informed me on the 4th December 1891 that he once found as many as seven nests of this bird in a day while searching for Pheasants' eggs in Foulshotlaw Wood, Berwickshire, in the end of April 1878, the nests being placed amongst dead Scotch fir branches.
} 
of Spottiswoode, 1881, 17 brace; 1882, 34 $\frac{1}{2}$ brace; 1883 , $20 \frac{1}{2}$ brace; 1884, 32 brace; 1885, 38 brace; 1886,

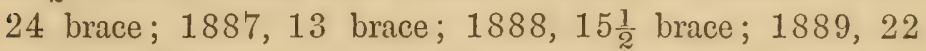
brace; $1890,6 \frac{1}{2}$ brace; $1891,25 \frac{1}{2}$ brace; or in all, $248 \frac{1}{2}$ brace in eleven seasons. The heaviest bag in one day was made on Flass Farm, on the 15th of September 1887, when 7 brace were killed. On the 16 th of October 1887,6 brace were got on Cattleshiel Farm.

The favourite haunts of this species are the lower slopes of the Lammermuirs, where fir plantations and thickets of birch, as well as stunted willow coverts, afford it shelter. In the early part of the shooting season the young birds are easily approached as they lie concealed in long heather, rushes, or ferns; but later, in autumn and winter, Black Grouse are very wild and wary, and will not allow the sportsman to come near them.

The principal food of this bird is heather; the seeds of rushes, and wild berries of various kinds are also eaten; while in autumn it visits the stubble fields on the skirts of the moors in search of barley and other grain. In winter it feeds upon the buds of the Scotch fir. ${ }^{1}$

It is polygamous, and in spring, during the time of the "lek," severe fights take place between the rival males. The nest is generally placed on the ground under a low bush or tuft of heather, and contains from six to ten eggs of a yellowish white, speckled with reddish brown.

Amongst the prices of the various kinds of game fixed by the Scottish Parliament in the reign of Queen Mary (1551), those of the Black-Cock and Grey Hen are stated to be "sex pennies" the "peece."

$1 \mathrm{Mr}$. Smith, head gamekeeper, Haddo House, Aberdeenshire, says he has seen numbers feeding on Scotch fir buds at Kyleshill, and Backlea Woods near Polwarth, Berwickshire. 


\title{
THE RED GROUSE.
}

\author{
MUIR-FOWL, MIOOR-FOWL, MOOR-COCK, MOOR-IIEN, GOR-COCK \\ RED GAME, RED PTARMIGAN.
}

Lagopus scoticus.

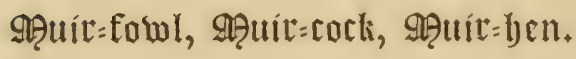

\author{
With earliest spring . . . . . \\ ..... the Gor-cock's call \\ Is heard from out the mist, high on the hill; \\ But not till when the tiny heather bud \\ Appears, are struck the spring-time leagues of love. \\ Remote from shepherd's hut, or trampled fold, \\ The new joined pair their lowly mansion pitch, \\ Perhaps beneath the juniper's rough shoots: \\ Or castled on some plat of tufted heath, \\ Surrounded by a narrow sable moat \\ Of swampy moss.
}

Grahame, Birds of Scotland.

Althougir the Red Grouse is indigenous to Berwickshire, the first notice of it which I can find with reference to this county is in Godscroft's MS. History of the Hornes of Wedderburn, written in 1611, where that author, writing of his brother, Sir George Home of Wedderburn, who was born about 1550 and died in 1616, says: "He was very handsome and well-proportioned, and of great strength and swift of foot. He was a keen hunter, and delighted in hawking. He was so much given to that sport that he built a hunting lodge, called Handaxe Wood, ${ }^{1}$ in the Lammermuir Hills, in which he often spent the night. He had Hawks called

I A locality in the neighbourhood of Byrecleugh. 
Merlins and Falcons, and afterwards another kind called Tercells, which he delighted in even in his old age. He caught both Partridges and Muir-foul." 1 Mr. CampbellSwinton of Kimmerghame mentions, in the Men of the Merse, ${ }^{2}$ that in a diary commenced by George Home of Kimmerghame in 1694, he finds the following entry referring to a day in June about the above date:- "To the setting at Kettleshiel, where the dog sett several times; but it was either an old fowl who rose before the net was ready, or young fowls that were scattered; so that there was none catched by the net but one old hen; but a hawk of Cavers took severals, and some were marked down where they sat and were taken." 3 These references show that upwards of two hundred years ago the pursuit of Muir-fowl was, as now, considered to be excellent sport, and was enjoyed by gentlemen in the county.

In the Old Statistical Account of Scotland, which was written in 1795, Muir-fowl are mentioned in two of the reports on the parishes in Berwickshire. Thus the reporter on Legerwood parish says: "The tracts covered with heath are frequented by Muir-fowl, and the cornfields are haunted by Partridges. During the long-continued and intense severity of the year 1794-95 many of these wild animals perished with cold and hunger, and many in the extreme weakness to which they were reduced became an easy prey to whatever chose to pursue them." 4 In the account of Abbey St. Bathans parish the writer says: "On the lands are plenty of Muir-fowl, Partridges, and Plover." 5

In the early years of the present century, before the days of game preservation, Grouse seem to have been

1 MS. History of the Homes of Wedderburn, 1611. 2 Page 60.

3 The probability is that Red Grouse are here referred to, although the "old hen " may refer to Black Grouse.

4 Old Statistical Account of Scotland, vol, xvi. p. 486. 5 Ibid. vol. xii. p. 66. 
very scarce on the Lammermuirs, for in a diary lept by Captain Bell of the Berwickshire Militia in 1812-14, I find the following entries:- "1812, Aug. 18th.-Went to the moors at Kettleshiel and Bedshiel from nine till after two o'clock. Saw only fourteen birds-did not get a shot. 1813, Aug. 12th.-From one to three o'clock tried the muirs of Scarlaw, and saw only a few birds, and they were very shy-got only one. Aug. 13th.-Tried the muirs at Longformacus-saw none; then Barnside, Godscroft, Monynut, Quickswood-saw very few, which were very shy. Got only one shot. 1814, Aug. ¿0th.-Tried the muirs of Kettleshiel and saw six birds, and did not get a shot. Sept. 10th.-Killed at Whitchester one muirfowl; a very long shot with No. 7."

In the Nerv Statistical Account (1835) only one writer mentions Red Grouse as inhabiting his parish in Berwickshire-the Rev. Andrew Baird, minister of the united parishes of Cockburnspath and Oldcambus, who says that "it is tolerably abundant;" but this must be due to omission. The following is a list of the various parishes in the county where this bird is now to be found:- Abbey St. Bathans, Channelkirk, Cockburnspath, Coldingham, Cranshaws, Duns, Earlston, Gordon, Greenlaw, Langton, Lauder, Legerwood, Longformacus, Mordington, Oldhamstocks, Polwarth, and Westruther. It is considered to be very plentiful in the neighbourhood of Byrecleugh, the Duke of Roxburghe's shooting lodge, in the parish of Longformacus, and at Carfrae, in the parish of Channellirk. As instances of the abundance of Grouse in these two localities, I may mention that Mr. James Smith, shepherd, Byrecleugh, told me in July 1886 that the Duke, about 1871, killed on the 13th of August, between nine A.M. and six P.Mr., 69 brace of Grouse to his own gun; and at a Gronse drive in 1885 his Grace shot 35 birds from one 


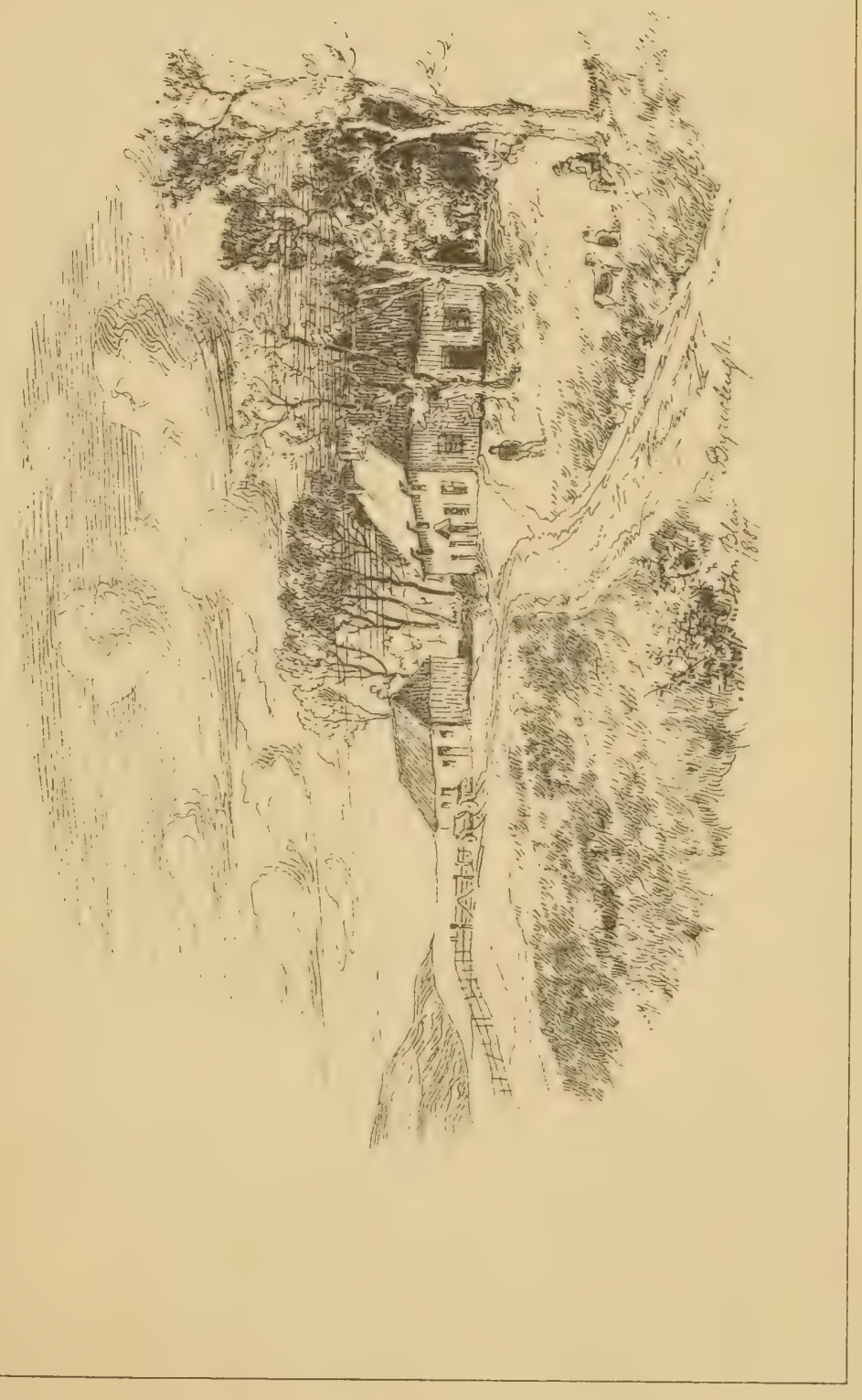



"box." 1 Sir George Houston-Boswall, Bart. of Blackadder, informed me, on the 6 th of September 1886, that when he was shooting with Lord Tweeddale near Carfrae Mill on the Lammermuirs on the 12th, 13th, and 14th of August in that year, the following bags of driven Grouse were got by a party of nine guns:-12th August, 161 brace; ${ }^{2} 13$ th August, 85 brace; 14th August, 122 brace; in all, 368 brace. The 85 brace were got between Lammerlaw and Carfrae Mill. Colonel Brown of Longformacus tells me that very large bags of Grouse were got during the shooting season of 1872 on the whole of the Lammermuirs, the greatest number being obtained on the Byrecleugh ground, where over 700 brace were shot in a fortnight by three guns.

On the 12 th of August 1882, Mr. George Turnbull of Abbey St. Bathans, Lord Low, and another gentleman, whilst shooting on Ellemford moors, bagged $27 \frac{1}{2}$ brace of Grouse; on the 12th of August 1889, 20 brace; and on the 12 th of August 1891, $20 \frac{1}{2}$ brace; all lilled over dogs. On the 25 th of November 1887, 21 brace were got there by Mr. George Turnbull, Mr. Hunter of Thurston, Mr. John Miller, Manderston, Mr. Brooks, Oxenden Tower, and Mr. George Muirhead, Paxton, the birds being driven over the guns. These moors have long been celebrated as a favourite resort of Grouse, and as early as 1639 we find David Hume in his Poemate Omnia ${ }^{3}$ thus referring to them:-

1 The following note appeared in the Bervickshire Nevs of the 13 th of September 1888:- "On the Byrecleugh moors a party consisting of the Duke of Roxburghe, the Marquis of Bowmont, Lord Kensington, and Lieutenaut-Colonel Brown of Longformacus, have bagged 450 brace of Grouse. Birds reported to be strong and plentiful."

2 Colonel Brown says this is the largest bag of Grouse ever killed on the Lammermuirs in one day, and, with the exception of 1872, the season of 1886 was the best for Grouse on these hills in his experience.

3 Davidis Humii, Wedderburnensis, Poemata Omnia, Parisiis, 1639. 
Collis erat modico tollens fastigio clivo Miscet ubi Albenti ${ }^{1}$ se Dius ${ }^{2}$ hospes aquie

Gleba uber : Cererisque coma formosus; et umbra Arborea : et Floræ numine amœnus ager.

Fons saliens sole a medio declivis ad ortum

Illimes leni murmure volvit aquas,

Hinc densæ circum salices, corylique, rubique Alitibus fidum perfugiumque feris.

Dives ager late ad dextram perdicibus illis, Quas humilis tenui nutrit Erica coma.

Hic me seu casu, seu jam tibi amica, Cupido, Clam tulit in casses flava Diana tuas

Incautum, dum sector; et in fruticeta paventes Specto agat ut pennâ præpete Nisus aves.

Elegia III.

A short distance to the north of Ellemford lies David Hume's patrimonial estate of Godscroft, ${ }^{3}$ in the parish of Abbey St. Bathans. Quixwood adjoins Godscroft, and here, on the 13th of August 1889, Mr. Hogg and party (five guns) got 28 brace, and two years later, on the 12 th, 26 brace. On Spottiswoode estate 23 brace were killed on Flass moor on the 14th of August 1886 (two guns); 24 brace on the 15th of August 1888 (two guns); and $25 \frac{1}{2}$ brace on Cattleshiel ground on the 12 th of August 1889 (two guns). The total bags of Grouse got on this

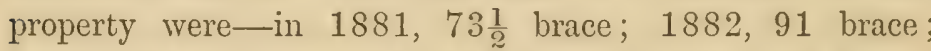
1883, 96 $\frac{1}{2}$ brace; $1884,64 \frac{1}{2}$ brace; 1885,124 brace;

1 Fluvius inter Lammyrios montes, vulgo Whytwater dictus.

2 Alius fluvius vulgo Daye dictus, in Albentum fluvium influens.

[Translation.]

There was a hill rising to a point with a moderate slope where the tributary, the Daye, mixes itself with the Whytwater-of fruitful soil-and beautiful with corn; and a leafy shade: and a field pleasant to the Goddess of Flowers. A fountain bubbling from the middle of the earth rolls its clear waters with gentle murmur, sloping towards the east.

Around this place are dense willows, hazel-trees, and brambles; and a safe refuge for wild birds : a field stretching towards the right rich in those partridges which the dwarfish heather nourishes in her tender hair. Here golden-haired Diana secretly drove me unawares, either by chance, or already friendly to thee, O Cupid, into thy nets: while I follow: and I see how the sparrow-hawk with swift wing drives the frightened birds into the thicket.

3 While shooting over the small moor belonging to this ancient property on the 12th of August 1878, I bagged $10 \frac{1}{3}$ brace of Grouse. 
1886, $162 \frac{1}{2}$ brace; 1887,30 brace (owing to disease); 1888, $159 \frac{1}{2}$ brace; 1889, 150 brace; 1890, 179 brace; 1891,178 brace; or in all, $1238 \frac{1}{2}$ brace in eleven years, no attempt having been made to secure large bags. ${ }^{1}$

Since 1838, when the Grouse disease first attracted attention, the Lammermuirs have been repeatedly visited by this scourge, the most destruction being caused by the epidemics of 1867 and 1872. In the winter of the latter year the birds were nearly exterminated by the disease, which commenced in December, althongh they were exceedingly plentiful during the previous autumn. It appeared again in the spring of 1887 at Byrecleugh and other localities, when many dead birds were found on the moors. Like the salmon disease, which for a number of years past has destroyed thousands of fish in the Tweed and other rivers, the Grouse disease has been studied by many naturalists, scientific men, and sportsmen, who do not seem, however, to have arrived at any definite conclusion as to its cause or cure.

The Red Grouse is an early breeder, making its nest with a little dry grass and a few feathers amongst the heather, and laying from eight to twelve eggs of a whitish ground colour closely blotched with dark brown and red. The hen alone attends to the hatching of the eggs, and
..... Sits, till, with redoubled joy,
Around her she beholds an active brood
Run to and fro, or through her covering wings
Their downy heads look out; and much she loves
To pluck the heather crops, not for herself,
But for their little bills.

Grahame, Birds of Scotland.

The chicks are generally seen running about the heather on the Lammermuirs for the first time in the season

1 Information kindly supplied by Mr. John Young, gamekeeper to Lady John Scott-Spottiswoode of Spottiswoode, 23rd December 1891. 
about the end of May or beginning of Junc. ${ }^{1}$ The "Kok, kok, kok" of the male when he is alarmed, and his morning cry, as well as the sudden spring of the covey from the heather, are familiar sounds and sights in the Lammermuirs which attract the attention of visitors from the Merse. Besides the young shoots of the heather ${ }^{2}$ and the leaves and fruit of various wild plants, such as crowberries (Empetrum nigrum), and blaeberries (Vaccinium myrtillus), the Red Grouse visits oatfields in the neighbourhood of the moors to feed on the stooks, and to search the stubble for fallen grain. When heavy snow lies on the hills it often descends in numbers to the lower ground for food and shelter. During severe weather in winter many frequent the grass parks at Longformacus. ${ }^{3}$ The plumage of this bird varies considerably, and an albino, or one variegated with white, is sometimes seen. A white Grouse was shot at Byrecleugh in 1885,4 and two were seen on Wedderlie Farm in $1887 .^{5}$

The indiscriminate burning of heather is so very injurious to Red Grouse that at various times Parliament has passed Acts on the subject.

So long ago as 1401 the Scottish Parliament ${ }^{\circ}$ made a statute " to be observed through the whole realm that there should be no muir-burning or burning of heath, except in

1 Mr. Hardy in his MS. Notes, under date 29th June 1844, says: "Moor-fowl led dog far away from her young by flying and alighting and fluttering, till, at a great distance,

\footnotetext{
O'er the rough moss, and o'er the trackless waste,

'The heath hen flutters, piots fraud! to lead

The hot-pursuing spaniel far astray."
}

THomson, Spring.

2 In the crop of a Grouse which was shot in a drive at Abbey St. Bathans on the 25 th of November 1887, I found no fewer than 6000 pieces of the top shoots of leather, which, when dried, weighed 318 grains, and filled three ordinary sherry glasses.

34 Information from Colonel Brown.

5 Information from Mr. Clay, Kerchesters.

"In the list of the prices of game fixed by the Scottish Parliament in the reign of Queen Mary (1551), "small mure fowle" stand at "four pennies." 
the month of March, and that a penalty of 40 shillings should be imposed upon any one who dared to contravene this regulation, which should be given to the lord of the land where the burning had place." 1 By the Act of George III., which is at present in force, every person who shall set fire to any heath, from the 11th of April to the 1st of November, shall forfeit $£ 2$ for the first offence, $£ 5$ for the second, and $£ 10$ for the third; or, in default of payment, six weeks', two months', or three months' imprisonment respectively. The annual burning of the heather on the Lammermuirs in spring is a sight which I remember seeing as a boy in East-Lothian, where the long straggling fires by night, and the clouds of smoke by day, ${ }^{2}$ reminded one of Leyden's graphic description:-

How grand the scene yon russet down displays,

While far the withering heaths with moor-burn blaze!

'The pillar'd smoke ascends with ashen gleam;

Aloft in air the arching flashes stream;

With rushing, crackling noise the flames aspire,

And roll one deluge of devouring fire;

The timid flocks shrink from the smoky heat,

Their pasture leave, and in confusion bleat,

With curious look the flaming billows scan,

As whirling gales the red combustion fan.

Mr. Hardy says: "It is a popular belief that when Moor-fowl call near houses in moorland places much rain may be expected, and that the cocks make an oft-repeated "Kick-dick, dick, dick," before rain." 3

1 Tytler's Scotland, vol. iii. p. 110.

2 In East-Lothian heather-burning was supposed to bring rain. According to Dr. Johnston of Berwick this belief was also prevalent in Berwickshire.Bot. East. Borders, p. 137.

3 MS. Notes.

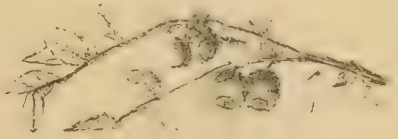




\title{
THE PHEASANT.
}

\author{
COMMON PHEASANT, RING-NECKED PHEASANT, BOHEMIAN \\ PHEASANT.
}

Phasianus colchicus.

\section{The 师aigan.}

\begin{abstract}
See from the brake the whirring Pheasant springs, And mounts exulting on triumphant wings, Short is his joy; he feels the fiery wound, Flutters in blood, and, panting, beats the ground.
\end{abstract}

POPE.

THE earliest record of the occurrence of the Pheasant in Great Britain is in a bill of fare drawn up by Harold in $1059 .^{1}$ It is first mentioned in Scottish Acts of Parliament in 1594, when it was "ordained, that quwhat-sumever person or persones, at onie time heirafter, sall happen to slay deir, harts, phesants, fouls, partricks, or uther wild-foull quwhat-sum-ever, ather with gun, croce-bow, hand-bow, dogges, halkes, or girnes, or be uther ingine quhat-sum-ever," in the King's "haill Wooddes, Forrests, Parkes, Hanynges," without His Majesty's special permission, "their haill guddes and gear sall be escheit and inbrocht to his Hienes use, and their persons punished at his Hienes will."

Although, from the above Act of Parliament, it would appear that this bird was to be found in Scotland in 1594, it does not seem to have been introduced into Berwick-

1 Yarrell's British Bircls, fourth edition, vol. iii. pp. 94, 95. 
shire for more than two hundred years afterwards; and there is apparently no record of its occurrence in the county previous to 1810 , in which year, according to an old game-book kept at the Hirsel, one Pheasant was killed there. The Hon. H. R. Scott, who has kindly furnished me with notes from the above game-book, adds that " in 1816 there is an entry by Lord Home that in shooting the covers on the Hirsel he saw only five or six Pheasants, where, the previous year, he had seen thirty brace." Writing in 1834, the Rev. George Cunningham, minister of Dunse parish, says: "Pheasants were introduced into the woods of Dunse Castle about twenty years ago, and abound there, and in the neighbouring plantations." Mr. Peter Scott, Lauder, whose father was for many years gamelieeper at Thirlestane Castle, has informed me that they were first turned out into the coverts there in the time of James, the Sth Earl of Lauderdale, who had taken into his employment a gamekeeper named Robert Fortune, from Salton Hall, or Whittingham, in East-Lothian. Fortune visited Whittingham, or Lochend, where he procured a supply of the eggs of this species, from which young birds were reared and set at liberty in the policy woods of Thirlestane Castle. Mr. Scott likewise told me that Pheasants were kept at Spottiswoode a year or two previous to their introduction to Lauderdale, but were confined in an enclosure. In 1821 they appear to have been still found in rather small numbers at the Hirsel, for in Captain Bell's diary I find an entry dated the 19th of October of that year: "Was at Hirsel shooting, and killed three Pheasants and three hares." 2 The Rev. George Knight, minister of Mordington parish, mentions in 1835 that

1 New Statistical Account of Scotland, vol. ii. (Berwickshire), p. 251.

2 Excerpt from diary kept by Captain Bell of the Berwickshire Militia, from 1802 to 1826 . 
"brown and silver Pheasants are occasionally found in the woods of Edrington." 1

Most of the landed proprietors in the county appear to have begun to preserve this beautiful game bird in their policy grounds and woods before the middle of the nineteenth century; and on properties where there is much cover shooting great numbers of Pheasants are now artificially reared every season, to form an addition to those which are hatched in the plantations and hedge-rows.

In former times when the birds were scarce, setters or spaniels were used to find them, but now they are generally driven out of the covers by men and boys, and forced to tly as high as possible over the sportsmen, who are conveniently placed to intercept them.

Some writers have decried Pheasant shooting as unmanly, owing to the alleged tameness of the birds; but in November and December, when they have become wild, and strong on the wing, great skill is required to bring them down as they pass like rockets high overhead in the air. $^{2}$ This they invariably do if the covers are properly driven, and the guns are posted at a suitable distance from the side of the wood out of which the birds suddenly spring and mount rapidly in the air to escape from the beaters.

The following records of some of the best bags of Pheasants got in various parts of Berwickshire have been kindly supplied to me by correspondents in the respective parishes mentioned; and I take this opportunity of thanking them for their notes, which will doubtless be of interest to sportsmen in the county, not only now, but in years to come.

\footnotetext{
1 New Statistical Account of Scotland, vol. ii. (Berwickshire), p. 340.

2 See sketch, "As high as ever you saw them," in Field and Covert Shooting. Badminton Library, second edition, 1887, p. 194.
} 


\begin{tabular}{|c|c|c|c|c|c|c|c|}
\hline Parish. & Estate. & Proprietor. & Cover. & Guns. & Date. & $\begin{array}{c}\text { Pheas- } \\
\text { ants } \\
\text { bagged. }\end{array}$ & Correspondent. \\
\hline Ayton. & $\begin{array}{l}\text { Ayton } \\
\text { Castle. }\end{array}$ & $\begin{array}{l}\text { Alex. Harold } \\
\text { Mitchell- } \\
\text { Innes, Esq. } \\
\text { of Ayton and } \\
\text { Whitehall. }\end{array}$ & $\begin{array}{l}\text { Ayton } \\
\text { Castle } \\
\text { Woods. } \\
\text { Whitfield } \\
\text { Woods. } \\
\text { Ayton } \\
\text { Castle } \\
\text { Woods. }\end{array}$ & \begin{tabular}{|l} 
Seven. \\
Regd. Pringle, \\
Esq. ; John \\
MIiller, Esq. ; \\
- Barclay, Esq. ; \\
R. Campbell- \\
Renton, Esq. ; \\
Major Brook; \\
G. IIuirhead, Esq.
\end{tabular} & $\begin{array}{c}1866 . \\
\text { Nov. } 22 . \\
1876 . \\
\text { Nov. } 18 . \\
1875 . \\
\text { Nov. 16. } \\
\\
\\
1858 . \\
\text { Nov. 13. }\end{array}$ & $\begin{array}{l}182 . \\
111 . \\
166 .\end{array}$ & $\begin{array}{l}\text { Mr. Hugh } \\
\text { Fraser, game. } \\
\text { keeper, Kelloe, } \\
\text { formerly head } \\
\text { gamekeeper to } \\
\text { the late Alex. } \\
\text { Mitchell-Innes, } \\
\text { Esq. of Ayton } \\
\text { and Whitehall. }\end{array}$ \\
\hline $\begin{array}{l}\text { Chirn- } \\
\text { side. }\end{array}$ & $\begin{array}{l}\text { White- } \\
\text { hall. }\end{array}$ & $\begin{array}{l}\text { Alex. Harold } \\
\text { Mitchell. } \\
\text { Innes, Esq. } \\
\text { of Ayton and } \\
\text { Whitehall. }\end{array}$ & $\begin{array}{l}\text { Harelaw, } \\
\text { West- } \\
\text { heads, } \\
\text { and } \\
\text { Pear- } \\
\text { bank. }\end{array}$ & $\begin{array}{l}\text { Hon. Edward Mar- } \\
\text { joribanks, M.P.; } \\
\text { Lord Curzon; } \\
\text { H. Gladstone, } \\
\text { Esq. ; Captain } \\
\text { Tippinge; } \\
\text { Guest, Esq. }\end{array}$ & $\begin{array}{c}1891 . \\
\text { Nov. } 6 .\end{array}$ & 91. & $\begin{array}{l}\text { Mrr. Thos. W. } \\
\text { Walker, gaine- } \\
\text { keeper to the } \\
\text { Hon. Edward } \\
\text { Mrarjoribanks, } \\
\text { MI.P., at } \\
\text { Edington Hill. }\end{array}$ \\
\hline $\begin{array}{l}\text { Cold- } \\
\text { stream. }\end{array}$ & $\begin{array}{l}\text { Milne } \\
\text { Graden. }\end{array}$ & $\begin{array}{l}\text { David Milne- } \\
\text { Home, Esq. } \\
\text { of Milne } \\
\text { Graden. }\end{array}$ & $\begin{array}{l}\text { Milne } \\
\text { Graden } \\
\text { Woods. }\end{array}$ & $\begin{array}{l}\text { Hon. Henry Scott; } \\
\text { Col. Milne-Home; } \\
\text { Captain Forbes, } \\
\text { R.N. ; Captain } \\
\text { Ramsay ; James } \\
\text { Hunter, Esq. ; } \\
\text { George Muirhead, } \\
\text { Esq. } \\
\text { Admiral Hotham; } \\
\text { Captain the Hon. } \\
\text { Henry Baillie- } \\
\text { Hamilton, R.N.; } \\
\text { Capt.Forbes, R.N.; } \\
\text { Jas. Hunter, Esq. } \\
\text { G. Muirhead, Esq. }\end{array}$ & $\begin{array}{l}1887 . \\
\text { Oct. } 6 . \\
\\
18 s s . \\
\text { Oct. } 10 .\end{array}$ & 65. & \\
\hline \multirow[t]{3}{*}{ Duns. } & $\begin{array}{l}\text { Manders- } \\
\text { ton. } \\
\text { Do. } \\
\text { Do. } \\
\text { Do. }\end{array}$ & $\begin{array}{l}\text { Sir James } \\
\text { Miller, Bart. } \\
\text { of Manders- } \\
\text { ton. } \\
\text { Do. } \\
\text { Do. } \\
\text { Do. }\end{array}$ & \begin{tabular}{|} 
Manders- \\
ton \\
Woods. \\
Do. \\
Do. \\
Do.
\end{tabular} & $\begin{array}{l}\text { Eight. } \\
\text { Eight. } \\
\text { Seven. } \\
\text { Eight. }\end{array}$ & $\begin{array}{c}1890 . \\
\text { Dec. } 3 . \\
\\
\text { Dec. } 4 . \\
1891 . \\
\text { Dec. } 8 . \\
\text { Dec. } 9 .\end{array}$ & $\begin{array}{l}103 . \\
233 . \\
122 . \\
329 .\end{array}$ & $\begin{array}{c}\text { Mr. Jas. Smith, } \\
\text { gamekeeper, } \\
\text { Mranderston. } \\
\text { Do. } \\
\text { Do. } \\
\text { Do. }\end{array}$ \\
\hline & $\begin{array}{l}\text { Duns } \\
\text { Castle. }\end{array}$ & $\begin{array}{l}\text { W. J. Hay, } \\
\text { Esq. }\end{array}$ & $\begin{array}{l}\text { Duns Law } \\
\text { and } \\
\text { Braid. } \\
\text { fern } \\
\text { Woods. }\end{array}$ & One, & $\begin{array}{c}\text { 1887. } \\
\text { Oct. 17. }\end{array}$ & 45. & $\begin{array}{l}\text { Mr. W. Smith, } \\
\text { gamekeeper, } \\
\text { Duns Castle. }\end{array}$ \\
\hline & $\begin{array}{l}\text { Wedder- } \\
\text { burn. }\end{array}$ & $\begin{array}{l}\text { Col. Mfilne- } \\
\text { Home. }\end{array}$ & $\begin{array}{l}\text { Policy } \\
\text { Woods. } \\
\text { Do. }\end{array}$ & $\begin{array}{l}\text { Six. } \\
\text { Five. } \\
\text { W. Compton. } \\
\text { Lundie, Esq. ; } \\
\text { S. Hull, Esq. ; } \\
\text { G. Muirhead, Esq. }\end{array}$ & $\begin{array}{c}1882 . \\
\text { Nov. 3. } \\
\text { Dec. } 7 . \\
\\
1887 . \\
\text { Nov. 3. }\end{array}$ & $\begin{array}{l}66 . \\
33 .\end{array}$ & $\begin{array}{l}\text { Mr. R. Bruce, } \\
\text { late game- } \\
\text { keeper to E. F. } \\
\text { Lautour, Esq. }\end{array}$ \\
\hline
\end{tabular}




\begin{tabular}{|c|c|c|c|c|c|c|c|}
\hline Parish. & Estate. & Proprietor. & Cover. & Guns. & Date. & $\begin{array}{c}\text { Pheas- } \\
\text { ants } \\
\text { bagged. }\end{array}$ & Correspondent. \\
\hline Earlston. & $\begin{array}{l}\text { Meller- } \\
\text { stain. }\end{array}$ & $\begin{array}{l}\text { Earl of } \\
\text { Haddington. }\end{array}$ & $\begin{array}{l}\text { Meller- } \\
\text { stain } \\
\text { Woods. }\end{array}$ & Four. & & 120. & $\begin{array}{l}\text { Mr. James } \\
\text { M'Pherson, } \\
\text { gamekeeper, } \\
\text { Mellerstain. }\end{array}$ \\
\hline Eccles. & Lees. & $\begin{array}{l}\text { G. F. Marjori- } \\
\text { banks, Esq. }\end{array}$ & $\begin{array}{c}\text { Ferneyrig } \\
\text { Covers. }\end{array}$ & Four. & $\begin{array}{c}1890 . \\
\text { Nov. } 21 .\end{array}$ & 101. & $\begin{array}{l}\text { Mr. G. Landels, } \\
\text { gamelkeeper, } \\
\text { Ferneyrig. }\end{array}$ \\
\hline \multirow[t]{2}{*}{ Edrom. } & $\begin{array}{l}\text { Broom. } \\
\text { house. }\end{array}$ & $\begin{array}{l}\text { Capt. Logan } \\
\text { Home of } \\
\text { Broom- } \\
\text { house. }\end{array}$ & $\begin{array}{l}\text { Broom- } \\
\text { house } \\
\text { Woods. } \\
\text { Do. }\end{array}$ & $\begin{array}{l}\text { E. Clapham, Esq.; } \\
\text { W. Compton- } \\
\text { Lundie, Esq.; } \\
\text { S. Hull, Esq. } \\
\text { G. Muirhead, Esq. } \\
\text { E. Clapham, Esq. ; } \\
\text { W. Stone, Esq. : } \\
\text { G. MIuirhead, Esq. }\end{array}$ & $\begin{array}{c}1887 . \\
\text { Nov. } 1 . \\
\\
1856 . \\
\text { Nov. } 26 .\end{array}$ & 75. & \\
\hline & $\begin{array}{l}\text { Nisbet. } \\
\text { Black. } \\
\text { adder. }\end{array}$ & $\begin{array}{l}\text { Lord Sinclair } \\
\text { of Herd- } \\
\text { manston. } \\
\\
\text { Sir George } \\
\text { Houston- } \\
\text { Boswall, } \\
\text { Bart. }\end{array}$ & $\begin{array}{l}\text { Nisbet } \\
\text { House } \\
\text { Covers. } \\
\\
\text { Black- } \\
\text { adder } \\
\text { Woods. }\end{array}$ & $\begin{array}{l}\text { Four. } \\
\text { Three. }\end{array}$ & $\begin{array}{c}1887 . \\
\text { Nov. } 5 . \\
1890 . \\
\text { Nov. 15. } \\
\\
\text { 1591. } \\
\text { Dec. - } \\
\text { (one } \\
\text { day's } \\
\text { shoot- } \\
\text { ing.) }\end{array}$ & $\begin{array}{l}33 . \\
14 . \\
210 .\end{array}$ & $\begin{array}{l}\text { Mr. John Nisbet, } \\
\text { gamekeeper to } \\
\text { the late Mrs. } \\
\text { Brown of } \\
\text { Longformacus, } \\
\text { at Nisbet } \\
\text { House. }\end{array}$ \\
\hline Fogo. & $\begin{array}{l}\text { Charter- } \\
\text { hall. }\end{array}$ & $\begin{array}{l}\text { Col. Trotter } \\
\text { of Charter- } \\
\text { hall. }\end{array}$ & $\begin{array}{c}\text { Fogo- } \\
\text { moor } \\
\text { Wood. } \\
\text { Big Wood. } \\
\text { Fogo- } \\
\text { moor. } \\
\text { Big Wood. } \\
\text { Do. } \\
\text { Fogo- } \\
\text { moor. } \\
\text { Big Wood. }\end{array}$ & $\begin{array}{l}\text { Five. } \\
\text { Five. } \\
\text { Five. } \\
\text { Four. } \\
\text { Four. } \\
\text { Four. } \\
\text { Four. }\end{array}$ & $\begin{array}{c}1889 . \\
\text { Nov. 16. } \\
\text { Nov. 23. } \\
1890 . \\
\text { Nov. 19. } \\
\text { Dec. 3. } \\
1891 . \\
\text { Jan. 3. } \\
\text { Dec. 1. } \\
\text { Dec. 9. }\end{array}$ & $\begin{array}{c}127 . \\
52 . \\
98 . \\
52 . \\
45 . \\
94 . \\
82 .\end{array}$ & $\begin{array}{l}\text { Mr. Wm. Thom- } \\
\text { son, game- } \\
\text { keeper, } \\
\text { Charterhall. }\end{array}$ \\
\hline \multirow[t]{2}{*}{ Hutton. } & Paxton. & $\begin{array}{l}\text { Col. Milne- } \\
\text { Homo of } \\
\text { Wedder- } \\
\text { burn, \&c. }\end{array}$ & $\begin{array}{l}\text { Paxton } \\
\text { Covers. }\end{array}$ & $\begin{array}{l}\text { R. Pringle, Esq. ; } \\
\text { George Turnbuli, } \\
\text { Esq. iW.Compton- } \\
\text { Lundie, Esq. } \\
\text { G. Muirhead, Esq.; } \\
\text { E. Clapham, Esq. } \\
\text { W. Compton. } \\
\text { Lundie, Esq. ; } \\
\text { Captain Godfrey ; } \\
\text { G. Muirhead, Esq. }\end{array}$ & $\begin{array}{l}1587 . \\
\text { Oct. } 24 . \\
\\
1857 . \\
\text { Nov. } 15 .\end{array}$ & 22. & - \\
\hline & Spital. & $\begin{array}{l}\text { W. Compton- } \\
\text { Lundie, Esq. } \\
\text { of Spital. }\end{array}$ & $\begin{array}{l}\text { Spital } \\
\text { Covers. }\end{array}$ & $\begin{array}{r}\text { Captain Richards; } \\
\text { G. Muirhead, Esq. } \\
\text { Captain Richards ; } \\
\text { G. Muirhead, Esq. }\end{array}$ & $\begin{array}{c}1881 . \\
\text { Nov. 23. } \\
1883 . \\
\text { Nov. } 11 .\end{array}$ & $\begin{array}{l}25 . \\
31 .\end{array}$ & \\
\hline
\end{tabular}


THE PHEASANT.

\begin{tabular}{|c|c|c|c|c|c|c|c|}
\hline Parish. & Estate. & Proprietor. & Cover. & Guns. & Date. & $\begin{array}{l}\text { Pheas. } \\
\text { ants } \\
\text { bagged. }\end{array}$ & Correspondent. \\
\hline Langton. & Langton. & $\begin{array}{l}\text { Hon. Robert } \\
\text { Baillie- } \\
\text { Hamilton } \\
\text { of Langton. }\end{array}$ & $\begin{array}{l}\text { Home } \\
\text { Covers. } \\
\text { Do. } \\
\\
\text { Do. } \\
\text { Do. } \\
\text { Do. } \\
\text { Do. } \\
\text { Do. }\end{array}$ & $\begin{array}{l}\text { Hon. Robt. Baillie- } \\
\text { Hamilton; Earl } \\
\text { of Haddinston; } \\
\text { Lord Binning; } \\
\text { Hon. and Rev. A. } \\
\text { Baillie-Hamilton; } \\
\text { Admiral Baillie; } \\
\text { Col. Milne-Home; } \\
\text { Capt. Hamilton; } \\
\text { E. F. Lautour, Esq. } \\
\text { Earlof Haddington; } \\
\text { Capt. Hamilton; } \\
\text { Hon. H. Scott; } \\
\text { Hon. G. Home; } \\
\text { Hon. and Rev, A. } \\
\text { Baillie-Hamilton; } \\
\text { - Hamilton, Esq. } \\
\quad \text { Six. } \\
\text { Five. } \\
\text { Seven. } \\
\text { Sir Geo. Houston. } \\
\text { Boswall, Bart. ; } \\
\text { Capt. Hamilton; } \\
\text { Captain Forbes, } \\
\text { R.N.; George } \\
\text { Dundas, Esq. } \\
\text { Earl of Hadding- } \\
\text { ton; Hon. and } \\
\text { Rev. A. Baillie- } \\
\text { Hamilton: } \\
\text { Sir R. B. Harvey; } \\
\text { Colonel Trotter; } \\
\text { - Trotter, Esq.; } \\
\text { Colonel Brown; } \\
\text { Sir Harry Vernon; } \\
\text { George Dundas, } \\
\text { Esq. } \\
\text { Same as on Dec. 2, } \\
\text { 1891, but Captain } \\
\text { Hunter instead of } \\
\text { Colonel Brown. }\end{array}$ & $\begin{array}{c}1883 . \\
\text { Dec. } 12 . \\
\\
\\
1884 . \\
\text { Dec. 10. } \\
\\
1885 . \\
\text { Dec. } 5 . \\
1886 . \\
\text { Dec. 15. } \\
1890 . \\
\text { Nov. } 15 . \\
\\
1891 . \\
\text { Jan. 28. } \\
\\
\text { Dec. 3. } \\
\\
\text { Dec. 2. } \\
\end{array}$ & $\begin{array}{l}100 . \\
114 . \\
131 . \\
131 .\end{array}$ & $\begin{array}{l}\text { Mr. Geo. Mercer, } \\
\text { gamekeeper, } \\
\text { Langton. }\end{array}$ \\
\hline $\begin{array}{l}\text { Mording- } \\
\text { ton. }\end{array}$ & $\begin{array}{l}\text { Mording- } \\
\text { ton. }\end{array}$ & $\begin{array}{l}\text { Major Charles } \\
\text { Fred. Camp- } \\
\text { bell-Renton } \\
\text { of Mording. } \\
\text { ton. } \\
\\
\\
\text { Robert C. } \\
\text { Campbell- } \\
\text { Renton, } \\
\text { Esq. of } \\
\text { Mordington. }\end{array}$ & $\begin{array}{l}\text { Mording- } \\
\text { ton } \\
\text { Covers. }\end{array}$ & $\begin{array}{c}\text { Seven. } \\
\text { Eight. } \\
\text { Six. } \\
\text { Six. } \\
\text { Seven. } \\
\text { Five. }\end{array}$ & $\begin{array}{c}1886 . \\
\text { Dec. } 31 . \\
\\
1887 . \\
\text { Nov. } 4 . \\
1888 . \\
\text { Nov. } 9 . \\
1889 . \\
\text { Nov. } 15 . \\
1890 . \\
\text { Nov. } 7 . \\
1891 . \\
\text { Nov. } 6 .\end{array}$ & $\begin{array}{c}100 . \\
126 . \\
98 . \\
115 . \\
105 . \\
202 .\end{array}$ & $\begin{array}{l}\text { Robert C. } \\
\text { Campbell. } \\
\text { Renton, Esq. } \\
\text { of Mordington. }\end{array}$ \\
\hline
\end{tabular}




\begin{tabular}{|c|c|c|c|c|c|c|c|}
\hline Parish. & Estate. & Proprietor. & Cover. & Guns. & Date. & $\begin{array}{l}\text { Pheas- } \\
\text { ants } \\
\text { bagged. }\end{array}$ & Correspondent. \\
\hline Polwarth. & $\begin{array}{l}\text { March. } \\
\text { mont. }\end{array}$ & $\begin{array}{l}\text { Sir Hugh } \\
\text { Hume-Camp- } \\
\text { bell, Bart. of } \\
\text { Marchmont. }\end{array}$ & $\begin{array}{l}\text { Fish Pond } \\
\text { Cover, } \\
\text { Saw Mill } \\
\text { Cover, } \\
\text { Willie } \\
\text { Close, } \\
\text { White } \\
\text { Gate } \\
\text { Railway } \\
\text { Banks. }\end{array}$ & $\begin{array}{l}\text { Sir Hugh Hume- } \\
\text { Campbell, Bart. ; } \\
\text { Sir George War- } \\
\text { render, Bart. of } \\
\text { Lochend ; Sir } \\
\text { George Houston- } \\
\text { Boswall, Bart. } \\
\text { of Blackadder: } \\
\text { Colonel Trotter } \\
\text { of Charterhall; } \\
\text { Charles Home } \\
\text { Purves, Esq. of } \\
\text { Purves Hall; } \\
\text { Hon, Robert } \\
\text { Baillie-Hamilton } \\
\text { of Langton; the } \\
\text { Earl of Home. }\end{array}$ & $\begin{array}{l}1883 . \\
\text { Nov. } \\
\text { (one } \\
\text { day's } \\
\text { shoot- } \\
\text { ing.) }\end{array}$ & $28 \pi$. & - \\
\hline $\begin{array}{l}\text { West- } \\
\text { ruther. }\end{array}$ & $\begin{array}{c}\text { Spottis- } \\
\text { woode. }\end{array}$ & $\begin{array}{l}\text { Lady John } \\
\text { Scott-Spot- } \\
\text { tiswoode of } \\
\text { Spottis- } \\
\text { woode. } \\
\end{array}$ & $\begin{array}{l}\text { Home } \\
\text { Covers. }\end{array}$ & $\begin{array}{l}\text { Two. } \\
\text { Two. } \\
\text { Two. } \\
\text { Three. }\end{array}$ & $\begin{array}{c}1885 . \\
\text { Jan. } 17 . \\
1887 . \\
\text { Dec. } 15 . \\
1885 . \\
\text { Dec. } 11 . \\
1889 . \\
\text { Dec. } 11 . \\
1891 . \\
\text { Jan. } 15 . \\
\\
\text { Year. } \\
1887 . \\
1888 . \\
1889 . \\
1890 . \\
1891 .\end{array}$ & $\begin{array}{c}40 . \\
43 . \\
53 . \\
75 . \\
65 . \\
\text { Total } \\
\text { bags. } \\
167 . \\
203 . \\
238 . \\
250 . \\
104 .\end{array}$ & $\begin{array}{l}\text { Mr. John Young, } \\
\text { gamekeeper at } \\
\text { Spottiswoode. }\end{array}$ \\
\hline
\end{tabular}

When fully on the wing the flight of this bird is very strong and rapid. ${ }^{1}$ As an instance of this, it may be mentioned that about fifteen years ago, during a cover shooting at Marchmont House, a Pheasant, which had sprung out of an adjoining plantation, dashed through a pane of the drawing-room window, and struck its head so severely against a large mirror which was hanging on the opposite wall that it cracked the centre of the thick plate glass of the mirror and fell dead on the floor. Several ladies

1 Mr. Griflith found by experiment that the average flight of three Pheasants in the open, the time being carefully taken by a stop-watch, was at the rate of 16! yards per second, 990 yards per minute, or $34 \frac{3}{4}$ miles per hour. See The Ficld of 19 th February 1887. 
were in the room at the time when this singular accident occurred. The reflection of the mirror had apparently deceived the bird and caused it to fly straight through the room.

There can be no doubt that Phasianus colchicus is the original stock of our common Pheasant, the so-called Bohemian being only a buff-coloured variety. The introduction of the Chinese species ( $P$. torquatus) to the coverts of this country has produced the beautiful ring-necked birds which we often see in our woods.

The Pheasant is fond of thick bushy under-cover, where brambles and long grass abound. It seldom strays very far from plantations, but in the morning and evening it may be seen feeding on the adjoining stubble fields, where it picks up fallen grain, insects, and worms. It eats large numbers of wire-worms. ${ }^{1}$ Acorns, beech-nuts, sloes, haws, and blackberries also form part of its food.

It makes its slight nest on the ground amongst the herbage of woods and plantations, or in the bottom of a thick hedge-row, or sometimes amongst growing corn. The eggs, which are olive-brown in colour, are usually laid in April or May, and vary from ten to fourteen, although a larger number has been found, when more than one hen has laid in the same nest.

Yarrell states that the well-known suppression of the scent of a sitting hen, so necessary for the safety of ground nesting species, is due to vicarious secretion-that is to say, the odoriferous particles which are usually exhaled from the skin are, during incubation, excreted from the intestinal canal. ${ }^{2}$

1 Yarrell mentions an instance of 1200 wire-worms being taken out of the crop of a single Pheasant.-British Birds, fourth edition, vol. iii. p. 99.

2 1bid. p. 98. 


\title{
THE COMMON PARTRIDGE.
}

\author{
THE GREY PARTRIDGE.
}

Perdix cinerea.

\section{The 翋aitrick.}

Stillness, heart soothing, reigns, Save, now and then, the Partridge's late call;

Featly athwart the ridge she muns, now seen, Now in the furrow hid; then, screaming, springs, Joined by her mate, and to the grass field fies: There, 'neath the blade, rudely she forms Her shallow nest.

Grahame, The Birds of Scotland.

Tre Partridge is plentiful in some of the lower parts of Berwickshire, but in other districts it is rather scarce, probably owing to the clayey nature of the soil or to the ground being too heavily wooded.

It appears to prefer well-cultivated, warm, and dry localities, where the fields are of moderate size and surrounded by thick hedge-rows, in the herbage at the bottom of which it can find a secure nesting place. In the higher districts of the county, however, and along the base of the Lammermuir Hills - in the vicinity of Abbey St. Bathans and Cockburn for instance-it is found in considerable numbers, though there it is generally much wilder than in the Merse, and takes longer flights in the shooting season; it is then occasionally a difficult matter to get a second time within range of the same covey, for the birds often fly a mile before they again alight.

Sornetimes it is found far from cultivated ground, and, as an example of this, Colonel Brown of Longformacus has informed me that for several years past a covey has been 
seen frequenting the bare moor about three miles above Byrecleugh.

Before fowling-pieces came into use Partridge hawking seems to have been a favourite amusement of some of the proprietors in the county; for we find Godscroft, in his MS. History of the Homes of Wedderburn, relating that his brother, Sir George Home of Wedderburn, who was born about 1550 and died in 1616, "had Hawks called Merlins and Falcons, and afterwards another kind called Tercells, which he delighted in, even in his old age. He caught both Partridges and Muir-fowl." 1

In later times nets with setters were used for taking Partridges, the dog lying down on pointing a covey and the net being then drawn over the birds by the men who carried it.

When milder Autumn Summer's heat succeeds, And in the new-shom field the Partridge feeds, Before his lord the ready spaniel bounds, Panting with hope, he tries the furrow'd grounds;

But when the tainted gales the game betray, Couch'd close he lies and meditates the prey. Secure they trust the unfaithful field beset, Till hovering o'er 'em sweeps the swelling net.

PoPE.

Shooting game while on the wing did not come into use until towards the middle of last century, after which period Partridges were killed with the gun over pointers and setters. This method was carried on so long as corn was cut with the sickle, and the stubble left rough enough to afford good cover for the birds, but with the advent of the reaping machine about 1860 and the consequent closely shaven stubble, the system of driving the birds into the cover of turnips and then walking them up in line, without the use of pointers or setters, began to be 1611.

1 MS. History of the Homes of Wedderburn, by David Home of Godscroft, 
practised. This plan is usually carried out in the following manner:-Early in the morning some men are sent to beat the stubbles and move the Partridges into the adjoining turnip fields, where, later in the day, the sportsmen, gamekeepers, and beaters form into a straight line and walk across the turnip drills, the birds being shot as they rise by the guns which have been placed along the line at equal distances apart. Retrievers only are used, and well-trained dogs are necessary, for without their aid many wounded birds are lost. "Driving" Partridges has of late years been practised in some parts of the county favourable for this system of shooting, which requires a large number of beaters and good management. The sportsmen stand behind a hedge or some other cover, and the beaters, walking in line through the turnip or other fields towards them, drive the birds over the guns, whilst assistants stationed in conspicuous positions with flags, which they wave when necessary, endeavour to prevent the birds from escaping at the flanks and to keep them flying in the required direction. This method has several advantages, as not only is great skill in shooting required to bring down the game, ${ }^{1}$ but a larger proportion of old birds is killed by this than by any other plan; for they are generally the first to fly over the guns, whereas by the other systems they often escape. ${ }^{2}$ Good sport can also be had by "driving" late in the season, when the birds will not generally allow the sportsmen to approach within range, but fly off as soon as the field in which they are resting or feeding is entered. The largest bags of Partridges ever made in Berwickshire have been got by this means on

$1 \mathrm{Mr}$. Griffiths, in his experiments with regard to the velocity of the flight of birds, found that in the open the Partridge flies at the rate of 14.6 yards per second, 876 yards per minute, or 29.8 miles per hour. - The Field of 19 th February 1887.

2 When there are too many old birds on the ground they drive off tho young, which are the most productive breeders. 
Lord Tweedmouth's property of Edington and Foulden West Mains, where the Hon. Edward Marjoribanks, M.P., with three friends, on the 21st of October 1891, bagged 130 brace, and on the following day, at Whiterig and Prendergnest, $113 \frac{1}{2}$ brace. Regarding the former wonderful bag, Mr. T. W. Walker, gamekeeper at Edington, writes to me: "The 260 Partridges which were killed at Edington on the 21st of October last, were got solely by 'driving,' and with only one set of beaters. We had a high cheek wind until lunch-time, which made it difficult to drive the birds up to the guns, as well as to bring them to the bag. Our total score of Partridges for the season (1891-92) is 1723."

I am indebted to the correspondents whose names are given below for the following records of some of the best bags of Partridges which have been got in their respective districts of late years.

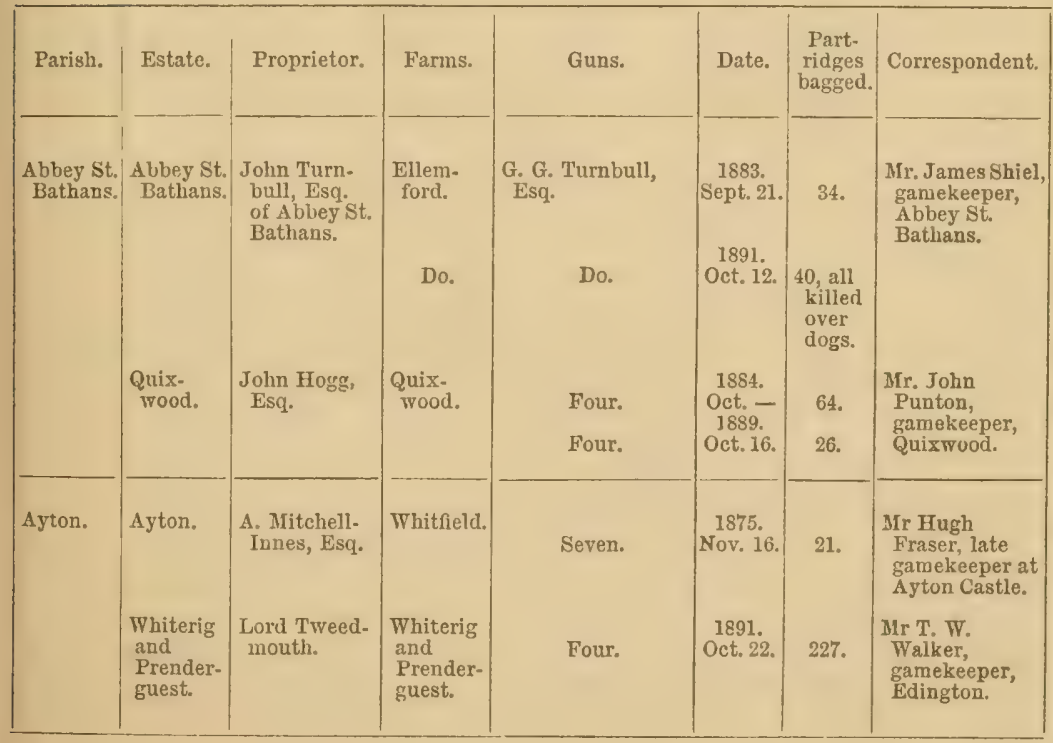




\begin{tabular}{|c|c|c|c|c|c|c|c|}
\hline Parish. & Estate. & Proprietor. & Famms. & Guns. & Date. & $\begin{array}{c}\text { Part- } \\
\text { ridges } \\
\text { bagged. }\end{array}$ & Correspondent. \\
\hline Buncle. & \begin{tabular}{|} 
Boukyl. \\
Do. \\
Billie.
\end{tabular} & $\begin{array}{c}\text { Earl of Home. } \\
\text { Do. } \\
\text { Col Milne- } \\
\text { Home of } \\
\text { Wedder- } \\
\text { burn, \&c. }\end{array}$ & $\begin{array}{l}\text { Ifarygold. } \\
\text { Preston. } \\
\text { Billie } \\
\text { Mains. }\end{array}$ & $\begin{array}{l}\text { Five. } \\
\text { Captain the Hon, } \\
\text { C. D. Home and } \\
\text { party. } \\
\text { Three. } \\
\text { Seven. }\end{array}$ & $\begin{array}{c}1854 . \\
\text { Nov. 3. } \\
\\
1887 . \\
\text { Sept. 9. } \\
1885 . \\
\text { Sept. 18. }\end{array}$ & $\begin{array}{l}102 . \\
101 . \\
111 .\end{array}$ & $\begin{array}{l}\text { MIr. John } \\
\text { Barrie, } \\
\text { gamekeeper, } \\
\text { Preston. } \\
\\
\text { Mr William } \\
\text { Preston, late } \\
\text { gaunekeeper at } \\
\text { Paxton. }\end{array}$ \\
\hline $\begin{array}{l}\text { Chimside } \\
\text { and } \\
\text { Foulden. }\end{array}$ & Edington. & $\begin{array}{l}\text { A.H.Mitchell. } \\
\text { Innes, Esq. } \\
\text { of } A \text { y ton and } \\
\text { Whitehall. }\end{array}$ & \begin{tabular}{|} 
Harelaw \\
and Old- \\
castles. \\
\\
Causeway- \\
bank, \\
Harelaw, \\
and Old- \\
castles. \\
Harelaw \\
and \\
Cause- \\
way- \\
bank. \\
Harelaw \\
and \\
Nether- \\
mains.
\end{tabular} & $\begin{array}{l}\text { Lord Wimborne; } \\
\text { Hon. E. Marjori. } \\
\text { banks, M.P.; } \\
\text { - Hope, Esq.; } \\
\text { - Whitbread, } \\
\text { Esq. } \\
\text { Duke of Rox. } \\
\text { burghe; Lord } \\
\text { Curzon; Hon. E. } \\
\text { Marjoribanks, } \\
\text { M.P.; M. Guest, } \\
\text { Esq.; H. Glad- } \\
\text { stone, Esq. ; } \\
\text { Captain Tippinge. } \\
\text { Lord Wimborne; } \\
\text { Hon. E. Marjori- } \\
\text { banks, M1.P.; } \\
\text { - Whitbread, } \\
\text { Esq.; - Hope, } \\
\text { Esq. } \\
\text { Do. }\end{array}$ & $\begin{array}{l}\text { Oct. } 20 . \\
\text { Oct. } 23 . \\
\\
1869 . \\
\text { Sept. } 23 . \\
\text { Sept. } 10 .\end{array}$ & $\begin{array}{l}144 . \\
142 .\end{array}$ & $\begin{array}{l}\text { MIr. Hugh } \\
\text { Fraser, late } \\
\text { gamekeeper at } \\
\text { Ayton Castle. }\end{array}$ \\
\hline $\begin{array}{l}\text { Cock. } \\
\text { burns- } \\
\text { path. }\end{array}$ & Dunglass. & $\begin{array}{l}\text { Sir Basil } \\
\text { Hall, Bart. }\end{array}$ & & Two. & $\begin{array}{l}\text { (One } \\
\text { day's } \\
\text { shoot- } \\
\text { ing.) }\end{array}$ & 26. & $\begin{array}{l}\text { Mr. John } \\
\text { Bolton, } \\
\text { gamekeeper, } \\
\text { Dunglass. }\end{array}$ \\
\hline
\end{tabular}




\begin{tabular}{|c|c|c|c|c|c|c|c|}
\hline Parish. & Estate. & Proprietor. & Farms. & Guns. & Date. & $\begin{array}{c}\text { Part- } \\
\text { ridges } \\
\text { bagged. }\end{array}$ & Correspondent. \\
\hline $\begin{array}{l}\text { Colding- } \\
\text { ham. }\end{array}$ & $\begin{array}{l}\text { Berry- } \\
\text { bank. } \\
\text { Billie. }\end{array}$ & $\begin{array}{l}\text { J. Mack, Esq. } \\
\text { of Berry- } \\
\text { bank. } \\
\text { Col. Milne- } \\
\text { Home of } \\
\text { Wedderburn. }\end{array}$ & $\begin{array}{l}\text { Berry- } \\
\text { bank, } \\
\text { 300acres. } \\
\text { Auchen- } \\
\text { crow } \\
\text { Mlains. } \\
\text { East } \\
\text { Reston. } \\
\text { Billie } \\
\text { Mains. } \\
\text { Reston- } \\
\text { hill. }\end{array}$ & $\begin{array}{l}\text { A. S. Logan, Esq. ; } \\
\text { J. Mack, Esq. } \\
\text { Col. Milne-Home } \\
\text { and party. } \\
\text { Do. } \\
\text { Do. } \\
\text { E. Clapham, Esq.; } \\
\text { Capt. S. Richards; } \\
\text { G. Muirhead, Esq. }\end{array}$ & $\begin{array}{c}1891 . \\
\text { Oct. 8. } \\
1887 . \\
\text { Sept. 12. } \\
\text { Sept. 15. } \\
\text { Sept. } 16 . \\
\\
1883 . \\
\text { Nov. } 7 .\end{array}$ & $\begin{array}{l}30 . \\
52 . \\
57 . \\
55 .\end{array}$ & J. Mack, Esq. \\
\hline Duns. & $\begin{array}{l}\begin{array}{l}\text { Duns } \\
\text { Castle. }\end{array} \\
\text { Mander- } \\
\text { ston. } \\
\text { Werder- } \\
\text { burn. }\end{array}$ & $\begin{array}{l}\text { W. J. Hay, } \\
\text { Esq. } \\
\text { Sir J. Miller, } \\
\text { Bart. } \\
\text { Col. Milne- } \\
\text { Home of } \\
\text { Wedderburn, }\end{array}$ & $\begin{array}{l}\text { Crum. } \\
\text { stane. } \\
\\
\\
\text { Weddler- } \\
\text { burn } \\
\text { Mains } \\
\text { and } \\
\text { Cairn- } \\
\text { hill. } \\
\text { Weclder- } \\
\text { burn } \\
\text { Mains, } \\
\text { \&c. } \\
\\
\text { Wedder- } \\
\text { burn } \\
\text { Mains } \\
\text { and. } \\
\text { Cairn- } \\
\text { hill. }\end{array}$ & $\begin{array}{l}\text { One. } \\
\text { Two. } \\
\text { E. F. Latour, Esq.; } \\
\text { Capt. Houstoun. } \\
\text { Boswall; Major } \\
\text { Latour; and } \\
\text { another. } \\
\qquad \\
\text { Five. } \\
\text { D. Brown, Esq., } \\
\text { and party. } \\
\text { A. T. Clay, Esq. ; } \\
\text { C. Vane-Tempest, } \\
\text { Esq. ; G. MIuir. } \\
\text { head, Esq. }\end{array}$ & $\begin{array}{l}1888 . \\
\text { Oct. } 7 . \\
1891 . \\
\text { Sept. } 17 . \\
\\
1890 . \\
\text { Sept. } 16 . \\
\\
\\
1887 . \\
\text { Sept. } 20 . \\
\\
1888 . \\
\text { Nov. } 19 .\end{array}$ & $\begin{array}{r}47 . \\
57 . \\
55 . \\
5 .\end{array}$ & $\begin{array}{l}\text { Mir. W. Smith, } \\
\text { gamekeeper, } \\
\text { Duns Castle. } \\
\text { Mr. J. Smith, } \\
\text { gamekeeper, } \\
\text { Manderston. } \\
\text { Mr. R. Bruce, } \\
\text { late game- } \\
\text { keeper to E, F. } \\
\text { Latnur, Esq., } \\
\text { at Wedderburn } \\
\text { Castle. } \\
\text { Mr. John } \\
\text { Nisbet, late } \\
\text { gamekeeper } \\
\text { to Mrs. Brown, } \\
\text { Nisbet House. }\end{array}$ \\
\hline Eariston. & $\begin{array}{l}\text { Meller- } \\
\text { stain. }\end{array}$ & $\begin{array}{l}\text { The Earl of } \\
\text { Haddington. }\end{array}$ & & One. & $\begin{array}{l}\text { One day } \\
\text { over } \\
\text { dogs. }\end{array}$ & 50. & $\begin{array}{l}\text { Mr. J. M'Pher- } \\
\text { son, game- } \\
\text { keeper, } \\
\text { Mellerstain. }\end{array}$ \\
\hline Eccles. & Lees. & $\begin{array}{l}\text { - Marjori- } \\
\text { banks, Lsq. } \\
\text { of Lees. }\end{array}$ & $\begin{array}{l}\text { West } \\
\text { Mains. }\end{array}$ & Three. & $\begin{array}{c}1891 . \\
\text { Nov. it. }\end{array}$ & 69. & $\begin{array}{l}\text { George Landles, } \\
\text { gamekeeper, } \\
\text { Ferneyrig. }\end{array}$ \\
\hline $\begin{array}{l}\text { Eccles } \\
\text { (and } \\
\text { Green. } \\
\text { law). }\end{array}$ & $\begin{array}{l}\text { March- } \\
\text { mont. }\end{array}$ & $\begin{array}{l}\text { Sir Hugh } \\
\text { Hume- } \\
\text { Campbell, } \\
\text { Bart. }\end{array}$ & $\begin{array}{l}\text { Eccles } \\
\text { Tofts. }\end{array}$ & Four. & $\begin{array}{l}\text { One day } \\
\text { in Oct. } \\
\text { about } \\
1882 .\end{array}$ & 168. & \\
\hline
\end{tabular}




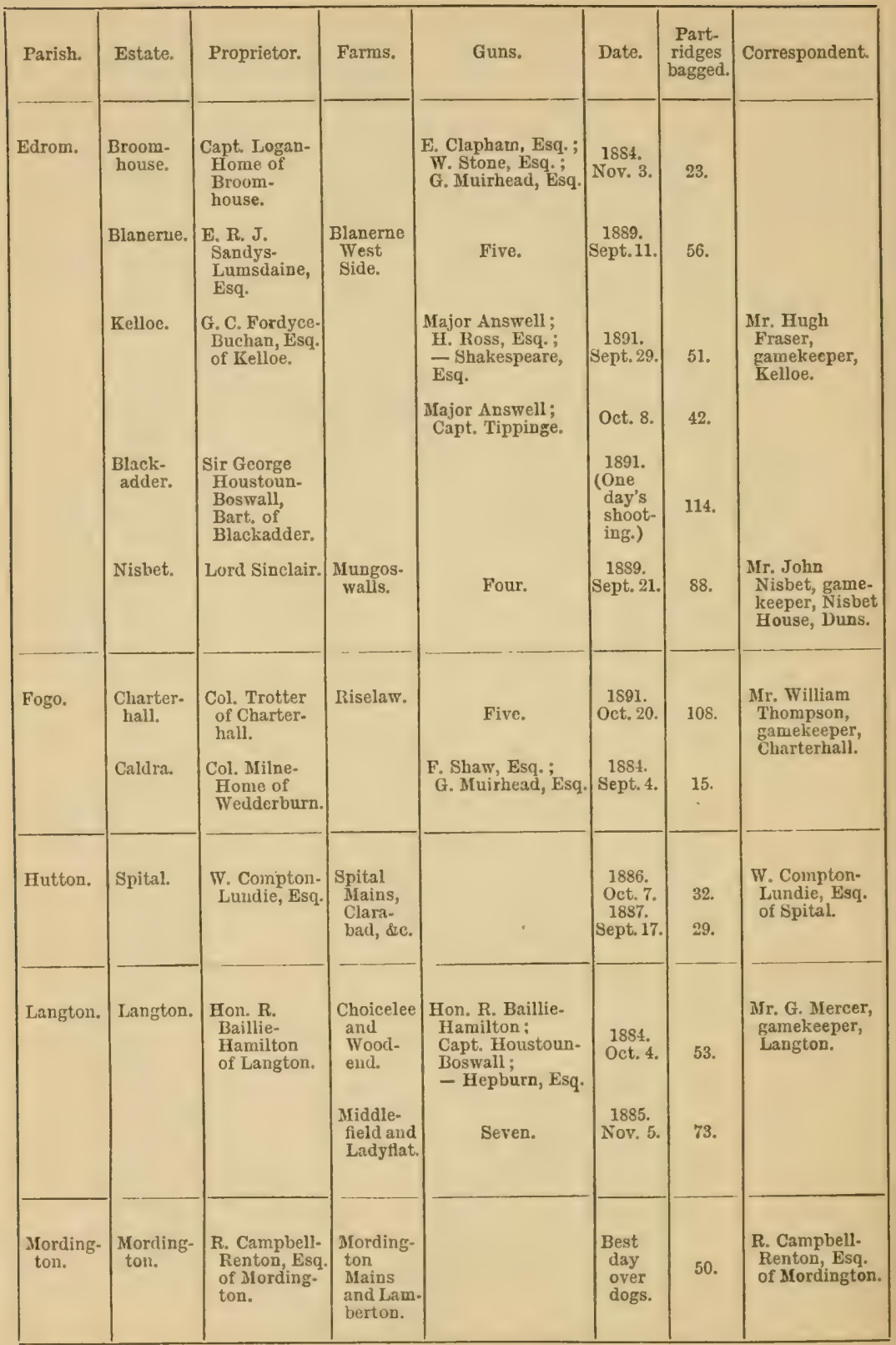




\begin{tabular}{|c|c|c|c|c|c|c|c|}
\hline Parish. & Estate. & Proprietor. & Farms. & Guns. & Date. & $\begin{array}{c}\text { Part- } \\
\text { ridges } \\
\text { bagged. }\end{array}$ & Correspondent. \\
\hline Swinton. & Swinton. & $\begin{array}{l}\text { Trustees of } \\
\text { Mrs. Swinton } \\
\text { of Swinton. }\end{array}$ & $\begin{array}{l}\text { Harcarse, } \\
\text { \&c. }\end{array}$ & $\begin{array}{l}\text { S. Hull, Esq.; } \\
\text { W. Compton- } \\
\text { Lundie, Esq. ; } \\
\text { G. Muirhead, Esq. }\end{array}$ & $\begin{array}{l}1887 . \\
\text { Sept.i3. }\end{array}$ & 33. & \\
\hline \multirow[t]{4}{*}{$\begin{array}{l}\text { West- } \\
\text { ruther. }\end{array}$} & \multirow[t]{4}{*}{$\begin{array}{c}\text { Spottis- } \\
\text { woode. }\end{array}$} & \multirow[t]{4}{*}{$\begin{array}{l}\text { Lady John } \\
\text { Scott-Spottis- } \\
\text { woode of } \\
\text { Spottis- } \\
\text { woode. }\end{array}$} & Flass. & Two. & $\begin{array}{l}1887 . \\
\text { Sept. } 15 .\end{array}$ & 33. & \multirow[t]{4}{*}{$\begin{array}{l}\text { Mr. John } \\
\text { Young, } \\
\text { gamekeeper, } \\
\text { Spottiswoode. }\end{array}$} \\
\hline & & & $\begin{array}{l}\text { Jordon- } \\
\text { law. }\end{array}$ & Two. & Oct. 12. & 40. & \\
\hline & & & $\begin{array}{l}\text { Thorng- } \\
\text { dykes. }\end{array}$ & One. & $\begin{array}{l}1888 . \\
\text { Oct. } 23 .\end{array}$ & 25. & \\
\hline & & & $\begin{array}{l}\text { Howlet's } \\
\text { Ha'. }\end{array}$ & One. & $\begin{array}{c}1889 . \\
\text { Nov. } 8 .\end{array}$ & 27. & \\
\hline
\end{tabular}

Some proprietors, in order to increase the stock of Partridges on their estates and improve the breed by the introduction of fresh blood, have purchased eggs from a distance and reared young birds from them. Neither this method, nor the turning down of old birds procured from other parts of the country, is, however, found to succeed so well as the simple plan of changing the eggs in the nests on a property every season, a few being taken from each nest discovered before incubation has begun, and replaced by those in the same state from another nest. It would appear that the birds in a brood pair with each other under ordinary circumstances, and the produce is then apt to be small in number and weak; but when the eggs are changed in the manner indicated fresh blood is introduced and the stock is consequently greatly strengthened and increased.

The Partridge sometimes suffers much in Berwickshire from the effects of heavy storms of rain and snow. The wet summer of 1877 destroyed great numbers all over 
the county, whole broods being found drowned in the hay-fields; ${ }^{1}$ and in the terrible winters of 1878-81 many perished of cold.

It pairs very early in the season, ${ }^{2}$ as mentioned by Grahame in the following beautiful lines:-
Bleak still, and winterly, o'er hill and dale, Is nature's aspect : yet some pleasing signs, Some heart-reviving preludes, faint and few, Of Spring's sweet season, meet the eye or ear. When calm the eve, I've heard the Partridge call, And seen the pairing couple as they tripped
Athwart the wreaths that in the furrows lurk.

The nest is generally placed amongst thick herbage at the bottom of a hedge, or in a hay or corn field, and often by the side of a road or footpath. It consists of a slight hollow scraped in the ground, with a little grass or a few dead leaves for lining, and in it, usually in May, are deposited from ten to fifteen eggs of a uniform olive-brown colour. Sometimes more than the number mentioned are found in the same nest, but it is thought that in this case they are the produce of more than one bird. Boys have always had the reputation of being very fond of searching for Partridges' nests. This is exemplified by the following anecdote, for which I am indebted to my friend Mr. Hardy. The Rev. Dr. Waugh of London, a native of Berwickshire, on coming down from the pulpit of a church in Duns where he had been preaching, was accosted by an old grey-headed man, who inquired regarding his welfare. "But, man," said the Doctor, "I dinna ken ye." "Do you no mind Tam

1 Mr. Hardy mentions that a well-grown brood of young Partridges with the old birds covering them were found all drowned in the summer of that year in a field near Oldcambus. - MIS. Notes.

2 The French have a proverb which says :-

Quand la Chandeleur est arrivéc

La Perdrix grise est mariée.

They apply the term "vin de couleur d'œil de perdrix" to a fine pale wine of full body. 
Houliston?" replied his grey-headed friend. "Aye, weel do I," added the Doctor. "Do you mind yon Sunday when we fand the Paitrick's nest and harried her?"

The young, which are hatched in twenty-one days, are attended to by both of the old birds, who show the greatest care for their safety, and often flutter away on being approached as if they could not fly, to draw the attention of the intruder from their offspring. The Partridge may be found on its feeding grounds in the morning and evening, but during the day it is generally concealed in cover of some kind, such as turnips, corn, or rough herbage.

Its food consists of insects and seeds of weeds of various kinds, as well as fallen grain which it picks up on the stubbles.

With regard to the means of distinguishing the sexes in this bird by the colours of the plumage, Mr. W. R. OgilvieGrant, of the British Museum, writes:-

"The only reliable characters by which a male Partridge may always be distinguished from a female, except when very young, are two.

"(1) In the male the sides of the neck are brownishgrey, or nearly pure slate colour, with fine wavy lines of black, and none of the feathers have pale buff stripes down the shaft.

"In the female these parts are olive-brown, and almost all the feathers have a pale buff stripe down the shaft, often somewhat dilated or club-shaped towards the extremity, finely margined with black.

"(2) In the male the ground colour of the terminal half of the lesser and median wing coverts is pale olivebrown, with a chestnut patch on one or both webs, and each feather has a narrow pale buff shaft-stripe, and narrow wavy transverse black lines.

"In the female the ground colour of these parts is 
mostly black, shading into buff towards the extremity; each feather has a fairly wide buff shaft-stripe, and is also transversely and somewhat irregularly barred with buff, narrowly edged with black.

"To put it more simply, for those who are not versed in the technical names given to the different parts of the plumage. Having looked at the sides of the neck, and seen whether they are grey or brown, with pale buff lines down the middle of each feather, turn the Partridge back uppermost and examine the smaller feathers which cover the upper parts of the wings. If they are sandy-brown, blotched with chestnut, and with small black lines across them, the bird is a cock; if they are mostly black, with conspicuous buff cross bars, the bird is a hen. The buff cross bars on the wing coverts are an unmistakable character, and quite sufficient to distinguish the hen at a glance. The Partridge assumes the adult plumage of these parts of the body at the first moult; and, consequently, the above differences are strongly marked before the commencement of the shooting season, except in late broods." 1

This species does not vary much in its plumage, but occasionally white, pied, and light-coloured birds are observed. Mr. Kelly mentions that several pure white broods frequented the farms of Boon and East Mains, near Lauder, for many years $;^{2}$ and Mr. Thomas W. Walker, gamekeeper at Edington, tells me that five very light or cream-coloured specimens were to be found on the farm of Whiterig, near Ayton, a few years ago, but have now disappeared. ${ }^{3}$ An example with the primary feathers of the wing nearly pure white was shot by Lord Binning at Mellerstain in October 1865 ; and another having a horse-shoe mark of the same

1 The Field of 21st November 1891, p. 795.

2 Hist. Ber, Nat. Club, vol. viii. p. 146.

3 Jetter dated 22nd February 1892. 
colour on its breast was killed by that nobleman in the following December.

The subject of our notice is held in high estimation as a dish for the table, as the following couplet testifies:-

If the Partridge had the Woodcock's thigh, It would be the best bird that ever did fly.

It appears to have been considered a great delicacy by the monks of old, for in The Freirs of Berwick we find from Freyr Robert's account of the interview between Dame Lauder and Freyr Johne, when the latter had "knolit at the yet," that

He thankit hir : and said, "My awin luif deir,

Thair is ane pair of bossis, gude and fyne,

Thay hald ane galloun-full of Gaskon wyne,

And als ane payr of pertrikis new slane;

And als ane creill full of breid of mane." 1

Mr. Hardy mentions "The Paitrick on the Pear Tree" as a rhyme which children in Berwickshire are sometimes heard repeating.

1 The Freirs of Bervick, a Tale, thought to have been written by Dunbar before 1539.-Sibbald, Chronicle of Scottish Poetry, vol, ii. p. $37 \%$.

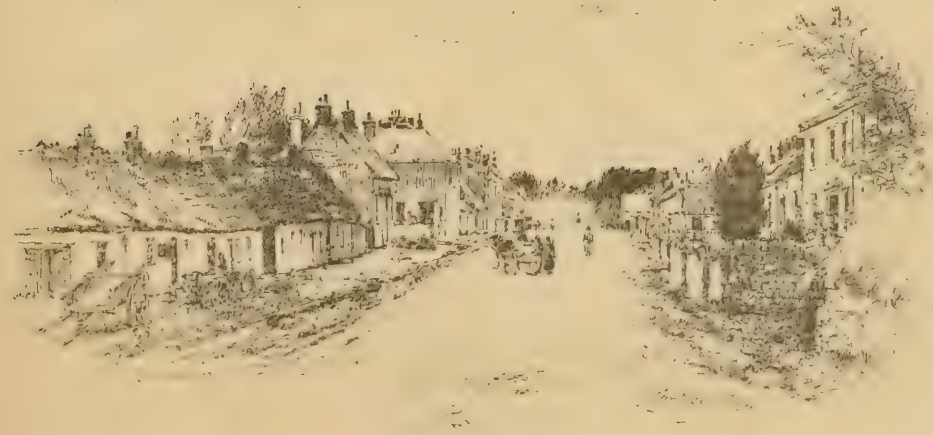




\title{
THE COMMON QUAIL.
}

\author{
THE QUAIL.
}

\section{Coturnix communis.}

The corn-land loving Quayle, the daintiest of our bits.

\section{DRAYTON.}

The Quail is an occasional summer visitor to the county, where it has been found in several localities.

Mr. Peter Cowe, Lochton, has informed me that a specimen was shot in a turnip field on the farm of Dowlaw, in the parish of Coldingham, about 1863; and two young birds were killed at Butterdean, in the parish of Oldhamstocks, in 1872. Mr. John Wilson mentions that it used to visit the farm of Edington Mains at wide intervals, though only once has he known it remain there throughout the year. ${ }^{1}$ Mr. Scott, gamekeeper, Thirlestane Castle, tells me that during the Partridge shooting season -about 1861-he shot two Quails in a stubble field on the farm of Bowerhouse, near Lauder, which he mistook for young Partridges when they first rose to the dog's point, and that they were very fat. ${ }^{2}$ Mr. Hardy records that in the second week of September 1874 an example was killed at Whitburn, in the parish of Cockburnspath, in the Lammermuirs, by one of the Dunglass gamekeepers. ${ }^{3}$ In November $1882 \mathrm{Mr}$. George Low mentioned to me that

1 Hist. Ber. Nat. Club, vol. vi. p. 400.

2 Yarrell says that the Hebrew name selav, in Arabic salwa, from a root signifying "to be fat," is very descriptive of the round, plump form and fat flesh of the Quail.-British Birds, fourth edition, vol, iii. p. 128.

3 Hist. Ber, Nat. Club, vol, vii. p. 515. 
his brother, the Hon. Lord Low of Laws, had shot a Quail at Godscroft, in the parish of Abbey St. Bathans, a few years previous to the above date. The gamekeeper at Mordington states that a specimen was seen amongst turnips in Jock's Park on Mordington Mains farm about 1874 ; and, according to Mr. George Duns, architect, Duns, two were got in the Damhead Field on Mungoswalls farm, in the vicinity of Nisbet House, in August 1885, another pair having been obtained in the same locality about eleven years before that date. Mr. James Purves, gamekeeper, Foulden, writes to me that he shot a Quail on St. John's farm, Foulden Estate, on the 12 th of October 1878 , and another in the Stackyard Field, Foulden Bastle, on the 30 th of September 1882. Two were bagged on Todhillrigg on the 15 th of October $1892 .{ }^{1}$

It may be mentioned that Mr. Hardy records the breeding of this bird on Springfield farm, in Oldhamstocks parish, East-Lothian, on the western borders of lierwickshire, ${ }^{2}$ and that $\mathrm{Mr}$. George Bolam states that on more than one occasion he has heard its call within "Berwick Bounds," in the fields adjoining the roads leading to Paxton and Chirnside, on the enstern borters of the county. He says: "Like the Corn Crake, Quails are most vociferous at sundown, and it is when the twilight has pretty far advanced on a fine summer evening, and when most other birds are silent, that their 'Plup,' 'plup' is most noticeable." He adds that the note, which is often repeated two or three times in succession, somewhat resembles one of the sounds made by a Turkey Hen. ${ }^{3}$

The Quail is fond of frequenting grass and corn fields, where, on summer evenings, the peculiar cry of the male may be heard as he "clamours for his rumning mate." 4

1 Information from James Hunter, Esq. of Antonshill.

2 Hist. Ber. Nat. Club, vol. vii. p. $515 . \quad{ }^{3}$ Ibid. vol. x. pp. 392, 393.

4 Thomson's Seasons-"Summer." 
It is sometimes seen by Partridge shooters in September, its flight being quick, and generally straight and low. While shooting at Rentonhall, near Haddington, in September 1869, I found a Quail amongst some standing barley; and $I$ have seen bevies in the rye fields near Orleans in France, where the cry of this bird is thought to resemble the words "paye tes dettes!" M. Rolland mentions that poachers in France employ an instrument made of the skin of a mole to imitate its cry. "On appelle courcaillet un instrument dont se servent les braconniers pour attirer les cailles. Il est formé d'une peau de taupe cousue comme une outre et à laquelle est adaptée une sorte de sifflet. Cette peau étant gonflée au moyen de la bouche, on imite parfaitement, par une pression particulière des doigts, le chant de la caille." 1

The food of the Quail consists of seeds of various kinds, including those of the chickweed, dock, and plantain, as well as grain; and it also eats many kinds of insects.

It generally makes its nest in a corn or grass field, scraping a slight hollow in the ground, and lining it with a little dry grass. The eggs, which are from seven to twelve in number, are yellowish-white, blotched with darkbrown.

It has long been esteemed an excellent bird for the table. Its price was fixed at "twa pennies" by the Scottish Parliament in 1551; and it is associated with "sum daintie fair" in the following advice by Macrell to the Madyn :-

Than tak to stanche your morning drouth,

Ane cup of mavesie for your mouth,

For sume cast sucker in at south,

Togidder with a toist :

1 Faune Populaire de la France, Eugène Rolland, tome ii., "Les Oiseaux Sauvages," p. 340 . 


\section{THE COMMON QUAIL.}

Thrie garden gowps tak of the air, And bid your page in haist prepair, For your disjone sum daintie fair,

And cair not for na coist.

Ane pair of plevaris pypping hait, Ane pertrick and ane quailyie get, Ane cup of sack, sweit and weill set, May for ane breckfast gaine.

ROBERT, LoRd SEMPLe, 1568.

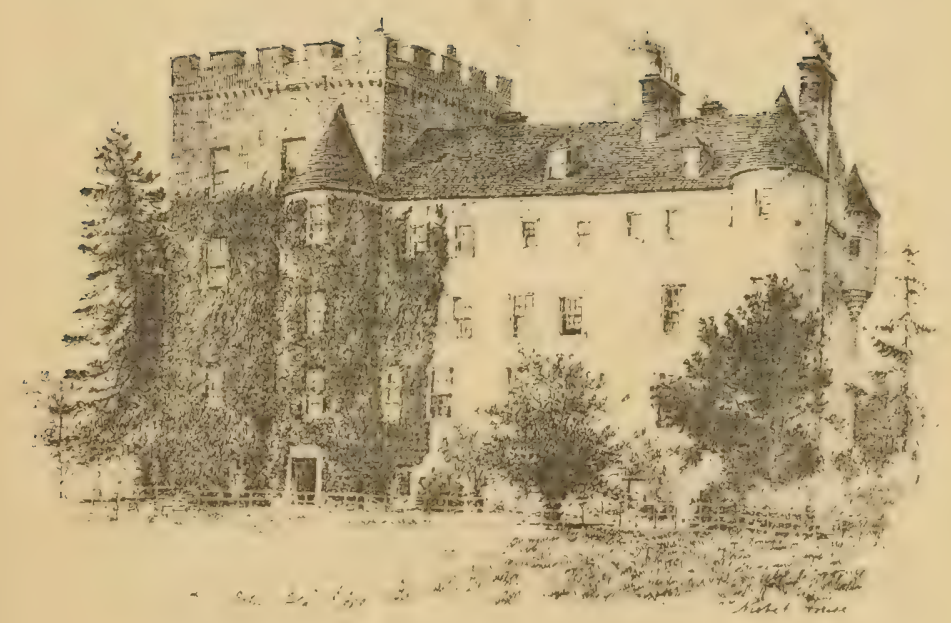

VOL. II. 


\title{
THE LANDRAIL.
}

CORN CRAKE, CORN CRAKER, LAND HEN, DAKER HEN.

Crex pratensis.

\section{The $\mathbb{C a r n} \mathbb{C r a k e}$.}

\author{
Poor bird, though harsh thy note, I love it well! \\ It tells of summer eves, mild and serene, \\ When through the grass, waist-deep, I wont to wade \\ In fruitless chace of thee; now here, now there, \\ Thy desultory call. Oft does thy call \\ The midnight silence break; oft, ere the dawn, \\ It wakes the slumbering Lark; he upward wings \\ His misty way, and, viewless, sings and soars.
}

GRAHAME, Birds of Scotland.

THE cry of the Corn Crake is generally heard in this county for the first time in the season from the beginning to the middle of May, when it arrives here from its southern winter quarters. The welcome note usually comes from some neighbouring grass field, but if the spring be late, as it was in 1887, and the grass and clover have not made sufficient growth to afford concealment, the bird hides amongst any rough herbage near its usual resorts, such as the long grass in young plantations and about boggy or waste places. As an instance of this, I may mention that on the afternoon of the 15 th of May 1887, while walking along the side of the Tweed near the boat-house at Paxton, I was agreeably surprised to hear the loud "Crek, crek" of a Corn Crake amongst some bushes in an adjoining strip of tall ash and elm 
trees, where it had taken shelter on its return from the south. Corn and hay fields are its favourite resorts, and its monotonous cry may be heard in the summer evenings and mornings, as well as during the day. It is very difficult to make out the exact spot where the bird is crying, the hopelessness of any endeavour to get a sight of it being thus quaintly alluded to by Montgomery :-

Go round the field, and round the field, and round,

You'll find my voice for ever changing ground;

And while your ear pursues my creaking cry,

You look as if you heard it with your eye.

I have, however, sometimes forced it to take wing by hunting it closely with a good terrier or spaniel;

and, when upraised,

With feet suspended, awkwardly she flies;

Her flight a ridge-breadth : suddenly she drops,

And, running, still cludes the following foot.

Grahame, Birds of Scotland.

Long ago the neighbourhood of Billy Mire, with its wide stretches of rushes and rough grassy meadows, would be a favourite resort of the Corn Crake; and we find Dr. Henderson thus alluding to the bird in that locality:-

On the Pyper knowes, ${ }^{1}$ where the lang broom grows,

I sat me down in the gloamin' dim;

While lay the white mist on the reedy Mire's breast,

And the Crake 'mang the corn sang his evening hymn.

Its food consists chiefly of worms, snails, and insects. It makes a slight nest on the ground amongst long grass or corn, and the eggs, which vary from seven to ten in number, are pale reddish-white spotted with ash-grey and reddish-brown. A curious circumstance connected with the finding of a Corn Crake's nest in 1808 by some men while cutting grass with the scythe on a little island

1 A round hill at the east end of Billie Mire, said to have been a favourite haunt of the fairies in bygone times. 
belonging to the Salmon Fishery of Low Bells, on the Tweed near Paxton, is related by Yarrell, who, quoting from Daniel's Rural Sports, says: "The men, while mowing, cut the head from a Corn Crake that was sitting upon eleven eggs; about twenty yards from this spot they had nearly destroyed a Partridge in a similar way, which was sitting upon eighteen eggs; but, observing her, the mowers took the eggs from the nest of the Corn Crake and put them into that of the Partridge. Two days after, she brought out the whole brood, which were seen running about the island. The Partridge catered for them all, and was observed to gather her numerous family under her wings without any distinction." 1

This species generally leaves us about the beginning of the harvest, a period of the year thus happily described by Dr. Henderson :-

The flowers now fade on hill and dale, And faintly bees are humming:

The corn is rustling in the gale, And harvest days are coming:

The harping Crake has left the land, The Swallow soon will follow, And many a merry harvest band Will meet in height and hollow.

It is, however, seen later in the season. An example was shot at Mellerstain on the 1 st of September $1880 ;{ }^{2}$ and Colonel Brown of Longformacus informs me that he got two specimens at Cranshaws on the Sth of October 1884. Mr. Hardy relates that in the middle of the winter of 1835 a Corn Crake was caught in Blackburn Rigg Peat Moss, the site of which is now occupied by the railway. He gives the following as a popular rhyme of Berwickshire, from which it would appear that this bird in former

1 Yarrell's British Birds, fourth edition, vol. iii. p. 141.

2 Hist. Ber. Nat. Chub, vol. ix. p. 399. 
times was believed to hide itself and sleep through the winter :-

The bat, the bee,

The butterflee,

The cuckoo and the swallow,

The kittiwake,

And the corn crake,

Sleep a' in a little hollie. ${ }^{1}$

It is highly esteemed as a dish for the table, and seems likewise to have had a reputation as a dainty in olden times, for we find Drayton in his Polyolbion alluding to it as-

The rayle, which seldom comes but upon rich men's spits.

It is referred to in the old Scottish poem entitled The Houlate, or the Danger of Pride, maid be Holland, 1453 :-

He gart the Emproure trow, and trewlye behald, That the Corncraik, the pundare at hand, Had poyndit all his pris hors in a poynd fald, Becaus thai eite of the corn in the kirkland.

1 Hist. Ber. Nat. Club, vol. i. p. 218.

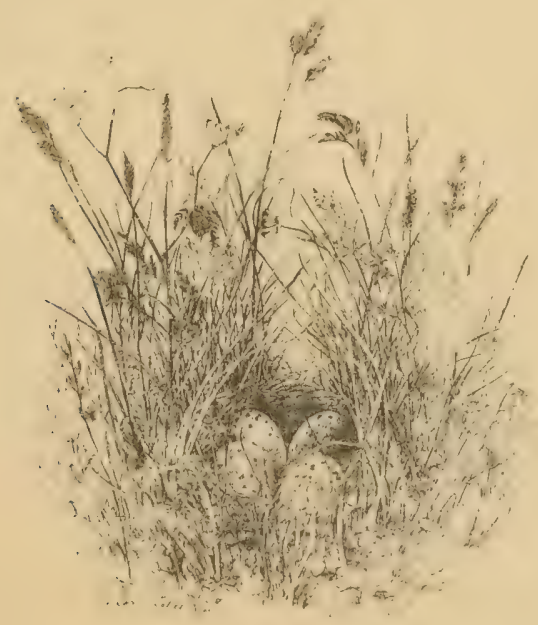




\title{
THE SPOTTED CRAKE.
}

\author{
SPOTTED RAIL, SPOTTED WATER RAIL, SPOTTED WATER HEN \\ SKILTY.
}

Porzana maruetta.

Where creeping waters ooze,

Where marshes stagnate, and where rivers wind.

THomson.

Tre Spotted Crake is very rarely seen in Berwickshire, there being only two instances on record of it having been found in the county. An adult female was shot at Greenknowe, near Gordon, by Mr. John Scott-Dudgeon, on the 18th of October $1873 ;^{1}$ and Mr. John Aitchison, Duns, has informed me that a specimen of this bird, now in his collection, was found dead near Duns Railway Station on the 18th of April 1887, having been killed by flying against the telegraph wires.

It is a summer visitor to this country, arriving in March and leaving towards the end of October, and is nowhere plentiful, but seems to be more frequently found in the fens and marshes of Norfolk than elsewhere. It frequents bogs, swamps, and the margins of rivers and lakes overgrown with rank herbage, where it breeds; and, as the nest has been found in the adjoining county of Northumberland, ${ }^{2}$ and as far north as Elgin, ${ }^{3}$ it is probable that it may yet be discovered in some of the few remaining

1 Hist. Ber. Nat. Club, vol. vii. p. 134.

2 Birds of Northumberland and Durham, by J. Hancock, p. 125.

3 Birds of the West of Scotland, by R. Gray, p. 333. 
bogs in Berwickshire, such as the Everett Moss at Legerwood, or Redpath Bog, near Cowdenknowes. Long ago, the great bog of Billie Mire, which extended for miles, and whose surface was covered with dense beds of reeds and rushes, would doubtless be a breeding place of the Spotted Rail.

The food of this bird consists of worms, slugs, and insects. Hewitson, quoting from Hancock, says that the nest, which is usually difficult to find, is placed in marshy ground in a thick bed of reeds, and is composed of the long ribbon-like grass of the reeds, lined with a finer soft grass. ${ }^{1}$ The eggs, from seven to ten in number, are reddishgrey, spotted with reddish-brown. This species is smaller than the Corn Crake, darker in colour, and spotted over with small white specks on the neck, back, and wings.

1 Hewitson, Eggs of British Birds, vol, ii. p. 376.

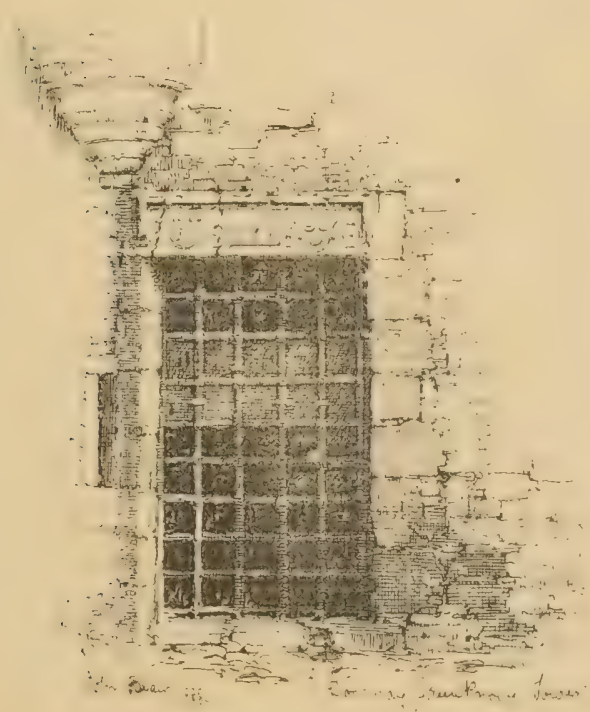




\section{THE WATER RAIL.}

BILCOCK, RUNNER, SKIT, SKIDDY-COCK.

\section{Rallus aquaticus.}

.... lead on, where through the reedy bank

The insinuating waters, filter'd, stray

In many a winding maze.

SOMERVILLE,

THIs bird is occasionally seen in Berwickshire during the autumn and winter months. It is, however, by no means plentiful, and as yet there is no record of its breeding in the county. Owing to its skulking habits, and the difficulty of finding the nest amongst the rank herbage of the marshes which the bird frequents, it may, however, nest unobserved in some of the few remaining bogs, such as Redpath Bog, in Earlston parish, or amongst some of the reedy pools and ditches between Greenlaw and Westruther. ${ }^{1}$

The Water Rail inhabits swamps and marshes, and the sides of streams, lakes, and pools, as well as ditches overgrown with reeds and other rank herbage, where it skulks, and from which it can scarcely be forced to take wing.

Mr. John Wilson, writing in 1872 , mentions that he had seen the Water Rail on Edington Mains Farm four or five times during a residence there of sixty years. ${ }^{2}$ A specimen is recorded by Mr. John Ferguson, Duns, as having been shot amongst the reeds at the side of Duns

1 Mr. Smith, late gamekeeper at Duns Castle, tells me that a pair of Water Rails frequented the lake there throughout the seasons of 1887, 1888, and 1889, and probably nested amougst the reeds.

2 Hist. Ber. Nat. Club, vol. vi. p. 400. 
Castle Lake in 1873; and he adds that the bird is seen every year about the pools and ditches of Dogden Moss. ${ }^{1}$ According to Mr. Cowe, Lochton, four examples were obtained on that farm in 1874. Mr. Kelly says that it is sometimes found at the side of the Leader, and that it frequents Legerwood Loch. ${ }^{2}$ Specimens were killed in some old clay pits near Harcarse, and at Kimmerghame, in the winter of 1878 , as recorded by Mr. Hardy. ${ }^{3}$ Dr. Stuart states that on the 5th of March 1879 a man brought to him a Water Rail which had been got at Billie Burn, in Chirnside parish; ${ }^{4}$ and Mr. John Aitchison, Duns, has informed me that about 1880 he sometimes found this bird in the ditches about Berrywell. Mr. Compton-Lundie of Spital shot a specimen in the bog near Spital House in October 1885, and another was caught in a ditch near the village of Whitsome in the first week of January 1886. It has been got several times during winter within the last fifteen years at Nabdean mill pond, in the parish of Hutton. Mr. Alexander Harold Mitchell-Innes of Ayton shot a specimen at the curling pond there on the 27 th of December 1887. When the Water Rail is forced to take wing it flies with its legs hanging down like the Corn Crake, and generally drops amongst the nearest herbage which will afford it sufficient concealment.

Yarrell says that during the nesting season the birds are very noisy, uttering a loud and somewhat explosive cry. The nest, which is well concealed, is made of sedge, and is placed amongst the thickest aquatic plants, or sometimes in willow beds. The eggs are of a creamy-white, with small specks or blotches of ash-grey and reddish-brown, and the usual number is seven.

1 Hist. Ber. Nat. Club, vol. vii. p. 121.

3 lbid. vol. viii. p. 532 .
2 Ibid. vol. vii. p. 305.

4 Ibid. vol. viii. p. 529. 


\title{
THE MOOR HEN.
}

WATER HEN, MARSH HEN, STANK HEN.

\section{Gallinula chloropus.}

\section{The oater ben.}

\author{
At distance from the water's edge, \\ On hanging sallow's farthest stretch, \\ The moorhen' gins her nest of sedge, \\ Safe from destroying schoolboy's reach.
}

ClaRe, March.

THIs well-known bird is plentiful all over the county wherever there are streams or pools, the lake at Duns Castle being one of its favourite resorts. Mill ponds and the parts of the Whitadder, Blackadder, Leader, and other streams, where the current moves slowly and where reeds, rushes, and other aquatic plants abound, are also much frequented by this species, and there it may often be seen swimming about on the surface of the water with a nodding motion of the head. Its usual haunts during the day are about the margins of pools, where it searches amongst the rank herbage for worms, insects, and water plants. When it is occupied in feeding at the cdge of a mill pond I have often been amused at the precipitate manner in which it retreats to the other side on being approached, fluttering over the surface of the pool with its legs hanging down, and splashing up the water in its line of flight. On reaching the opposite side, however, it seems to consider itself safe, for then it walks about in a leisurely manner, flicking up its tail and thus show- 
ing the white under coverts. In the morning and evening it often ventures out on the adjoining grass or meadow land to pick up worms and snails.

During the terrible severity of the winters of 1878-81, Water Hens suffered greatly; for all their usual resorts were frozen up, and in many cases the poor birds were reduced to such weakness for want of food that they allowed themselves to be caught by the hand in the snow. ${ }^{1}$

When severe frost occurs in winter and ponds are frozen over, this species frequents ruming streams, and also occasionally comes about places where poultry are fed, to pick up what it can get. In some parts of the county, such as about Oldcambus, it leaves the ponds in winter, and does not return to them until March, or the early part of April, to breed. ${ }^{2}$

The nest of the Water Hen is usually placed amongst herbage by the side of the water, or about the roots or low branches of overhanging alders and other bushes. I have, however, occasionally seen it placed on a branch at some height above the ground; also on the open shallow water of a pond, the foundation in this case being made with sticlis. ${ }^{3} \quad$ The nest is made of reeds, sedges, rushes, and other water plants, and the eggs-usually from five to ten in number-are of a cream-coloured white, spotted with reddish-brown.

1 On the 31st of December 1874 I found a Water Hen lying dead amongst the snow at Paxton, and several so weak that they allowed me to take them up in my hand. Writing on the 11th of February 1881, Dr. Stuart, Chirnside, says: "Coming home one day when at Broadhaugh I observed a Water Hen fly and alight on the top of a wall opposite the window of a cottage, where it allowed me to put my hands upon it."-Hist. Ber. Nat. Club, vol. ix. p. 390.

2 Mr. Hardy in his MS. Notes gives various dates between 24 th of February and 7 th of April, as the time when it returns to Oldcambus.

3 In the spring of 1886 a Water Hen built its nest in an open wooden spout used to Hood the curling pond at Paxton. 


\title{
THE COMMON COOT.
}

\author{
BALD COOT, CUTE, QUEET, BALD DUCK.
}

Fulica atra.

\section{The $2 \mathfrak{b e l l}=$ poot.}

The Coot dives merry on the lake.

SiR WALTER SCOTT.

Trie Coot is found in considerable numbers on Duns Castle Lake, Legerwood Loch, the Hirsel Lake, Coldingham Loch, and the lake at Spottiswoode. It also frequents pools and mosses about Greenlaw, and mill ponds in various districts, such as at Townhead farm in the parish of Cockburnspath, Dowlaw in the parish of Coldingham, Foulden West Mains, and Fairneyside near Burnmouth. Mr. Compton-Lundie of Spital has informed me that he has occasionally seen it at his boat pool on the Whitadder near Clarabad, in the parish of Hutton, and I have once or twice observed it at Nabdean mill pond in the same parish. Nowhere in the county can it be seen to greater advantage than on the lake at Duns Castle, which is a beautiful sheet of water sheltered on every side by rising ground and plantations, and having beds of bulrushes and other aquatic plants on its margin. These form favourite retreats and nesting places for the numerous water-fowl, including great numbers of Coots, which may be seen floating at ease on its surface, or diving in search of food. 
Mr. John Ferguson informs me that this bird remains at Duns Castle Lake throughout the winter, a part of the water being always kept free from ice for the benefit of the Swans and Geese, which are fed regularly in hard weather when the lake is frozen. He adds that in December 1886 and January 1887, when skating and curling were going on at the lake every day for several weeks in succession, the Coots were very tame, and that sometimes as many as fifty or sixty were seen feeding with the Swans at the edge of the ice. This bird leaves the smaller inland waters and betakes itself to the sea in the beginning of winter, returning again in March. ${ }^{1}$

The nest is large, and is strongly built of flags and other water plants, being often placed in a bed of reeds. The eggs, which are from seven to ten in number, are of a stone colour, spotted over with dark-brown.

The food of this bird consists of water insects, worms, and slugs, with portions of various aquatic plants.

In some parts of the country the Coot is used for the table. Yarrell, quoting from Colonel Hawker, says: "They are generally sold for eighteenpence a couple; previously to that they are what is called cleaned. The recipe for this is, after picking them, to take off all the black down by means of powdered resin and boiling water, and then to let them soak all night in cold spring water; by which they are made to look as white and as delicate as a chicken, and to eat tolerably well; but without this process, the skin in roasting produces a sort of oil with a fishy taste and smell, and if the skin be

$1 \mathrm{Mr}$. Hardy, writing under date the 7th of March 1860, notes that "Coots returned to Townhead farm mill pond, where they breed and erect a high and half-floating nest made of rushes and equisetum. In the autumn a shepherd encountered a Coot migrating by the wood border at North Cleugh to the Pease Burn. He caught her, and she bit him severely."--MS. Notes. 
taken off, the bird becomes dry and good for nothing. A Coot shot in the morning, just after roosting, is worth three killed in the day when full of grass, because it will then be whiter and milder in flavour." 1

1 Yarrell's British Birds, fourth edition, vol. iii. pp. 176, 177.

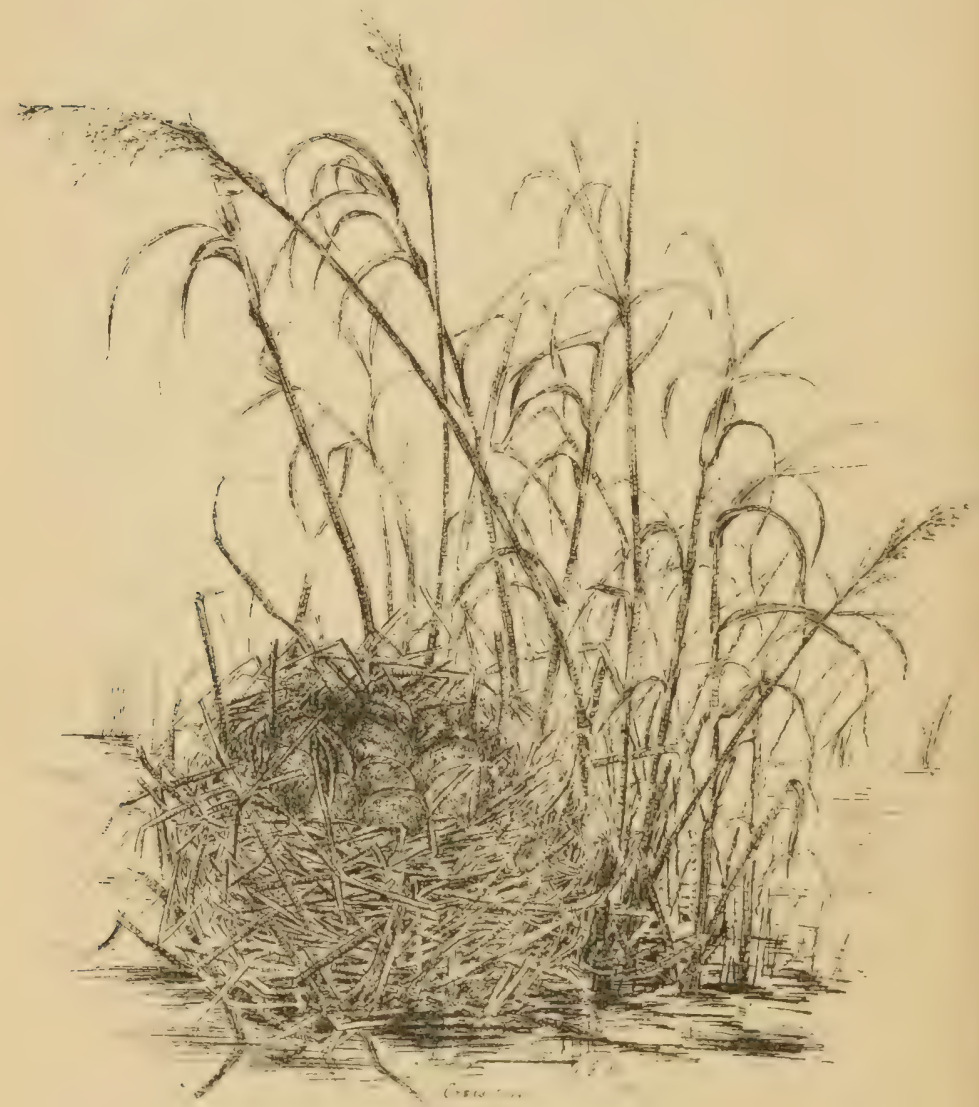




\title{
THE GREAT BUSTARD.
}

\author{
Otis tarda.
}

The big-boan'd Bustard then, whose body beares that size,

That he against the wind must runne, e'er he can rise.

DRAyton, Polyolbion.

Although there is no record of the Great Bustard having been found in Berwickshire since the early part of the sixteenth century, it may not be out of place to refer to it here, for the first British author who gave any account of the bird wrote of it in 1526 as then inhabiting the Merse. This was Hector Boece, who says: "Besides these, we have, moreover, another foule in Mers more strange and uncouth than all these aforementioned, called a Gustard, fully so great as a Swanne, but in colour of feathers and taste of flesh little differing from a Partriche; howbeit these byrdes are not verie common, nayther to be seen in all places; such also is their qualitie, that if they perceive their egges to have bene touched in theyr absence by man's hands (which lie commonly on the bare earth), they forsake those nestes and lay in other places." ${ }^{1}$ Mr. Hardy gives the following Latin version of the above from the original Scotorum Historic of Boece:- "Præter hæc aves in Merchia nascuntur Gustardes vernaculo sermone dictæ, colore plumæ ac carne perdicibus non dissimiles, sed quæ olores corporis mole exuperant. Rara est ea avis atque

1 The Description of Scotlande, in Hollinshed's Chronicles, first edition, vol, i. p. 10 (1577). 
humanum aspectum plurimum obhorrens; nuda humo ova ponit; quæ si ab homine contrectata, aut ejus anhelitu et afllatu vel leviter imbuta senserit (quod facile naturæ beneficio dignoscit) extemplo veluti inidonea ad pullos procreandos relinquens, alio ad ova parienda se confert."

Although it is probable that during the time of the Britons and Saxons Berwickshire was a well-wooded district, yet it appears that a few centuries later, in the reign of William the Lion, its woods, which formerly had been widely spread over the surface of the country, were confined to the sheltered valleys and ravines, ${ }^{1}$ the general face of the country being comparatively bare of trees. The wide plain which lies between the Tweed on the south and the Lammermuir Hills on the north, extending to upwards of one hundred thousand acres, ${ }^{2}$ and now known as the Merse, would then be a vast waste of heather mingled with pasture, and interspersed with impenetrable bogs and morasses, the haunt of the wolf ${ }^{3}$ and the wild boar, ${ }^{4}$ some traditions of which still linger in the county. Here and there on some precipice, or at the side of a marsh, but widely apart, would be seen the square fortlets of the landholders, surrounded by the rude villages which sprang up under their walls. Patches of the drier grounds only would be cultivated by the scanty inhabitants, whose cattle and sheep would browse in the vicinity of their dwellings. ${ }^{5}$ In this wild district the Great Bustard would roam along with the red

1 See Carr's History of Coldingham Priory, pp. 24, 25.

2 Ordnance Gazetteer of Scotland, by Francis Groome, 1885.

3 History of the Wolf in Scotland, by James Hardy, Hist. Ber. Nat. Club, vol. iv. p. 291.

4 See Old Statistical Account of Scotland, 1793, vol. vi. p. 322.

5 Mr. John Wilson, late of Edington Mains, in his report on The Farming in the East and North-Eastern Districts of Scotland, written in 1878, says at p. 23 : "As our grandfathers saw it, the whole country, with the most trifling exceptions, was uneuclosed ; there was scarcely such a thing as a plantation of trees; there was no artificial drainage, and what tillage existed was restricted to the naturally dry land; the hollow parts were full of bogs, marshes, and stagnant pools." 
deer ${ }^{1}$ and the roe, ${ }^{2}$ until they finally succumbed to the increase of population in the sixteenth or seventeenth centuries.

1 A farm near Lauder is called. Hartside, and two high hills in that locality are called respectively "North" and "South Hart Law." A ravine in the Lammermuirs, in the parish of Cranshaws, is known by the name of Hind's Cleugh.

2 There is a place called Raecleugh, in the parish of Westruther, and another in Langton parish which bears the name of Raecleugh Head.

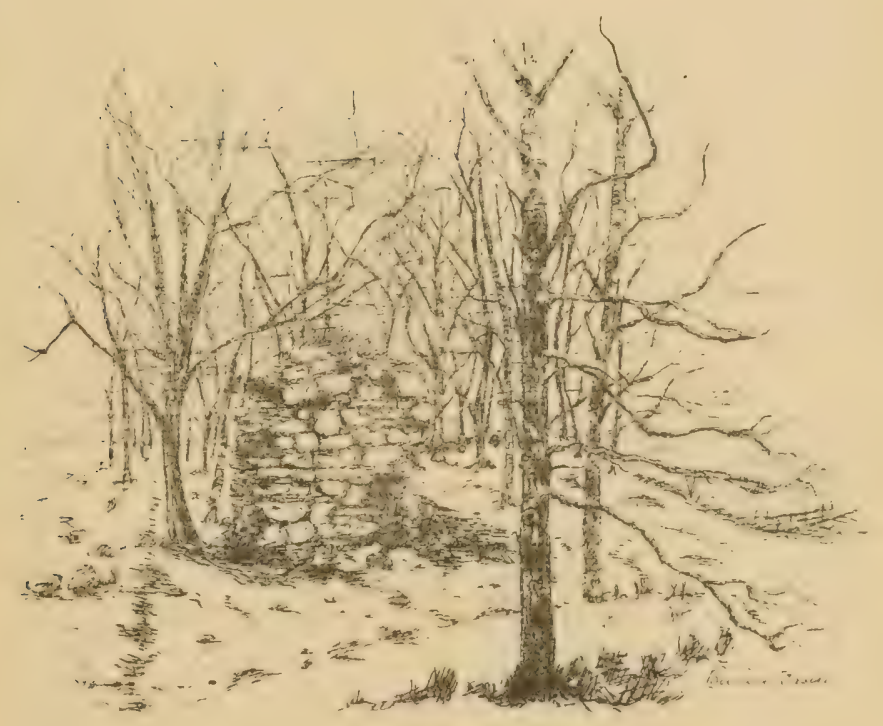

VOL. II. 


\title{
THE DOTTEREL。
}

\section{Charadrius morinellus.}

\author{
The Dotterell, which we thinke a very daintie dish, \\ Whose taking makes such sport, as man no more can wish; \\ For as you creepe, or cowre, or lye, or stoupe, or goe, \\ So marking you (with care) the apish bird doth doe, \\ And acting everything, doth never mark the net, \\ Till he be in the snare, which men for him have set.
}

Drayton, Polyolbion.

THE first notice of this interesting bird as occurring in Berwickshire is in Sibbald's Scotic Illustrata, published in 1684, where the author states that it often comes to the Merse: "Morinellus in Mercia frequens. In cibum expe-

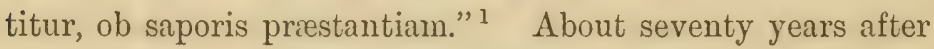
the publication of the above-mentioned work, Bishop Gibson, in his translation of Camden's Britannia, states, with reference to Berwickshire, that "about Bastenrig on the east hand, and the Moristons and Mellerstoun Downs to the west, they frequently take the Dotterel, a rare fowl, towards the latter end of April and beginning of May."2 Several notices of this bird as being found in the county occur in the Old Statistical Account of Scotland. The Rev. Abraham Ker, who, in 1793, wrote the report on the parish of Nenthorn, mentions that "Dotterels appear in a little flock on the muirs for a few weeks in June." 3 Mr. John Renton of Chesterbank, in his account of the parish of Coldingham in 1794, says: "There are only two kinds of birds of

1 Scotia Illustrata, sive Prodromus Historia Naturalis, auctore Roberto Sibbaldo, M.A., Eq. Aur., Edinburgh, 1684, fol., p. 19.

2 'Third edition, London, 1753, vol. ii. col. 1180.

3 The Statistical Account of Scotland, by Sir John Sinclair, Bart, vol, vi. p. 337. 
passage, the Wood-cock and the Dotterel, seen here; the first frequents the woods, and are few in numbers; the second appears in vast numbers on the heights." 1 The minister of the parish of Mordington, the Rev. George Drummond, writes in 1795: "In the higher grounds of this parish Dotterels are supposed to appear sooner than in any parts of the south of Scotland." ${ }^{2}$ The Reports on Berwickshire in the New Statistical Account of Scotland were written in 1834-35, and in them this species is mentioned as occurring in two parishes in the county, Cockburnspath ${ }^{3}$ and Mordington. ${ }^{4}$

The Dotterel is a bird of passage in Berwickshire, generally arriving from its southern winter quarters in Africa ${ }^{5}$ between the second week of April and the middle of May, and leaving the county for its northern haunts ${ }^{6}$ towards the end of the latter month, a few being known to nest in the Grampians and the English Lake District, while the principal breeding quarters are in the north of Europe. It has been occasionally observed in the county during the month of September on its return journey to the south.

In former times it visited in great numbers the highlying grounds in the parishes of Abbey St. Bathans, Ayton, Buncle, Cockburnspath, Coldingham, Cranshaws, Earlston, Eyemouth, Foulden, Greenlaw, Lauder, Legerwood, Longformacus, Mordington, Nenthorn, and Westruther. It has

1 The Statistical Account of Scotland, vol. xii. p. 57.

2 Ibid. vol. xv. p. 182.

3 The New Statistical Account of Scotland (Berwickshire), vol, ii. p. 300.

4 Ibid. p. 340.

5 Seebohm says it winters in Africa north of the Equator, and that Canon Tristram saw numerous flocks during winter in the hill country of Southern Palestine.-British Birds, vol, iii. pp. 30-32.

6 Seebohm states that its favourite breeding grounds in the British Islands are in the wildest parts of Scotland on the lonely Grampians in North Perthshire, and on the confines of Inverness-shire ; also that it has been found nesting in Ross-shire and the Orkneys.-British Birds, vol. iii. p. 30. 
of late years, however, been seen only on some of the heights in the parishes of Abbey St. Bathans, Cockburnspath, Coldingham, Cranshaws, Foulden, Greenlaw, Lauder, Longformacus, and Mordington, and that only in small numbers. It does not come to all of these localities every year, but appears at irregular intervals, sometimes a year or two elapsing between its visits. The high grounds in the neighbourhood of Redheugh in the parish of Cockburnspath, Dowlaw in the parish of Coldingham, and Lamberton in the parish of Mordington - all near the sea-are at present the usual resorts of the Dotterel in this county, and here it is generally seen in small flocks of from five to twelve birds. Its favourite haunts in these localities are old leas, newly broken up by the plough and sown with oats, where the numerous stones and turfy clods afford protection to the small beetles, grubs, and other insects upon which it feeds.

On its first arrival it is very tame and unsuspicious, and can easily be approached within gunshot, but after a flock has been fired at several times the birds become much wilder. From thirty to fifty years ago it was in great request by sportsmen in the county and visitors from a distance, not only on account of it being " a very dainty dish," 1 as old Drayton has it in his Polyolbion, but also because it came in at a time when game was out of season. Mr. Turnbull of Abbey St. Bathans informs me that he and Mr. Boyd of Cherry-

1 Folkard in his Wild Fowler says with regard to the Dotterel: "For centuries past it has been highly esteemed as one of the rarest delicacies of the table, consequently eagerly sought after by the fowler, and it appears by the Northumberland Household Book (temp. Hen. virr.) that whilst stints were purchased at twopence per dozen, Dotterels were bought at one penny each-a high price for so small a bird in those days." He thus describes the method of taking Dotterels by lamp or candle light on dark nights: "The fowler proceeds with a lanthorn to their most frequented haunts in the fens, when, by disturbing them, they run along the ground rather than attempt flying, and are thus easily taken with nets which are spread for them. They always run towards the light, so that the fowler fairly entices them to his net."-Second edition, 1864, pp. 307, 308. 
trees used to shoot numbers of Dotterels on Shannobank and Godscroft upwards of thirty years ago; and Mr. Joln Wilson, late of Edington Mains, tells me that a Mr. Anderson, who lived at Cockburn, obtained them on Blackerston and Quixwood about the same time. According to Mr. Bertram, Retreat, they were then frequently killed on Howpark by Mr. William Logan, Ayton; and Mr. John Blackadder, East Blanerne, states that about fifty years ago numbers were shot on the farms of Brockholes and Horsely by Mr. Joseph Hume, Retreat, and his friends. Mr. James Purves, gamekeeper at Foulden, says that about 1857 he sometimes bagged from ten to fifteen brace of Dotterels in a day on Lamberton farm towards the middle of May, when great flocks frequented the newly-sown fields on the sliirts of the moor near the Pit Houses. They allowed him at first to go quite near to them when they were sitting in a flock, but after they had been shot at several times they turned very wild and would not let him approach within range, and he had to stalk them from behind dykes and the like to get a successful shot at them. He sometimes got as many as thirty brace during their stay. He had heard an old dyker say that sixty or seventy years ago Dotterels used to visit the high-lying lands on Foulden Estate adjoining Lamberton Moor, and a man named Park, who lived in Horncliffe, was then employed to shoot them for the table of the proprietor, Mr. Wilkie of Foulden, to whom they were sometimes forwarded when he was living in London.

Mr. Hardy, Oldcambus, states that when this species is flying its wings look like those of the Plover, and when a flock rises the birds wheel round and round aloft in the clear air, and then give a dart, circle round, and alight in nearly the same place whence they rose.

In order to keep some record of the past and present haunts of the Dotterel in Berwickshire, the following notes 
regarding its resorts in the various parishes of the county have been collected by me, and I take this opportunity of tendering my thanks to the correspondents and others who have so kindly supplied me with the information which they contain. Much of it was obtained in the shape of answers to circulars containing queries about the bird, sent by me to upwards of three hundred farmers in every part of Berwickshire; while I am indebted to my friend $\mathrm{Mr}$. Hardy for a large proportion of the remainder.

\begin{tabular}{|c|c|c|}
\hline PARISH. & $\begin{array}{l}\text { Source of infor- } \\
\text { mation, and date } \\
\text { when obtained. }\end{array}$ & Notes. \\
\hline \multirow[t]{6}{*}{$\begin{array}{r}\text { Abbey St. } \\
\text { Bathans. }\end{array}$} & $\begin{array}{l}\text { Nr. George Cock- } \\
\text { burn, White- } \\
\text { burn, 4th Oct. } \\
1886 \text {. }\end{array}$ & $\begin{array}{l}\text { They come about the } 15 \text { th of May, and do } \\
\text { not stay later than the end of that month. } \\
\text { Not more than ten in a flock. }\end{array}$ \\
\hline & $\begin{array}{l}\text { John B. Boyd, } \\
\text { Esq. of Cherry- } \\
\text { trees, 11th Oct. } \\
\text { 1882. }\end{array}$ & $\begin{array}{l}\text { Used to shoot numbers at Abbey St. Bathans } \\
\text { about thirty years ago. }\end{array}$ \\
\hline & $\begin{array}{l}\text { James Hardy, } \\
\text { Esq., Oldcam- } \\
\text { bus, } 1856 .\end{array}$ & $\begin{array}{l}\text { 1856. - A late tenant of Shannobank said they } \\
\text { were formerly much more numerous about } \\
\text { the place than now. People used to come } \\
\text { from a distance to shoot them there. } \\
\text { They were very foolish. If you shot one } \\
\text { you might have the whole flock, as they } \\
\text { wheeled round and round and alighted } \\
\text { near where they lost their companion. }\end{array}$ \\
\hline & $\begin{array}{l}\text { J. Wilson, Esq. } \\
\text { of Welnage, } \\
\text { 4th May } 1886 .\end{array}$ & $\begin{array}{l}\text { A Mr. Anderson, who used to live at Cock- } \\
\text { burn, was in the habit of shooting them } \\
\text { either at Blackerston or Quixwood about } \\
\text { thirty years ago. }\end{array}$ \\
\hline & $\begin{array}{l}\text { John Turnbull, } \\
\text { Esq. of Abbey } \\
\text { St. Bathans, } \\
1886 \text {. }\end{array}$ & $\begin{array}{l}\text { Used to shoot them on Shannobank and } \\
\text { Godscroft many years ago. They were } \\
\text { not known to cross the Whitadder, but } \\
\text { kept always on the north side of that } \\
\text { stream. }\end{array}$ \\
\hline & $\begin{array}{l}\text { Mr. James Shiel, } \\
\text { gamekeeper at } \\
\text { Abbey St. } \\
\text { Bathans, 12th } \\
\text { Oct. } 1886 .\end{array}$ & $\begin{array}{l}\text { None come to Abbey St. Bathans estate } \\
\text { now. }\end{array}$ \\
\hline
\end{tabular}




\begin{tabular}{|c|c|c|}
\hline PARISH. & $\begin{array}{l}\text { Source of infor- } \\
\text { mation, and date } \\
\text { when obtained. }\end{array}$ & Notes. \\
\hline $\begin{array}{l}\text { Abbey St. } \\
\text { Bathans- } \\
\text { continued. }\end{array}$ & $\begin{array}{l}\text { John Blackadder, } \\
\text { Esq., East } \\
\text { Blanerne, 30th } \\
\text { Oct. } 1886 .\end{array}$ & $\begin{array}{l}\text { Very common at Quixwood about fifty } \\
\text { years ago. They were shot there by } \\
\text { Mr. Joseph Hume, Retreat, and his } \\
\text { friends. }\end{array}$ \\
\hline Ayton. & $\begin{array}{l}\text { Thomas Brodie, } \\
\text { Esq., Chester- } \\
\text { bank, 29th } \\
\text { Sept. } 1586 .\end{array}$ & $\begin{array}{l}\text { Dotterels used to come in large flocks to } \\
\text { Chesterbank farm about thirty-five years } \\
\text { ago. They appeared always at seed-time, } \\
\text { but did not remain long on the farm. }\end{array}$ \\
\hline \multirow[t]{2}{*}{ Buncle. } & $\begin{array}{l}\text { Charles Watson, } \\
\text { Esq., Duns, } \\
\text { 1s78. }\end{array}$ & $\begin{array}{l}\text { They were very common in the district } \\
\text { about Buncle Wood over twenty years } \\
\text { ago. I frequently got the wings for fly } \\
\text { dressing from the gamekeeper at Preston. } \\
\text { I believe they are now very rare, if not } \\
\text { extinct, in the above locality. }\end{array}$ \\
\hline & $\begin{array}{l}\text { W. Dunlop, Esq. } \\
\text { Mayfield, 12th } \\
\text { Oct. 1886. }\end{array}$ & $\begin{array}{l}\text { They do not visit this farm now. Small } \\
\text { flocks were seen from thirty to fifty years } \\
\text { ago. }\end{array}$ \\
\hline $\begin{array}{l}\text { Cock- } \\
\text { burns- } \\
\text { path. }\end{array}$ & $\begin{array}{l}\text { J. Hardy, Esq., } \\
\text { Oldcambus, } \\
1886 .\end{array}$ & $\begin{array}{l}\text { 1836, 7th MIay.-Dotterels seen at Penman- } \\
\text { shiel for first time this season.9 9th MIay.- } \\
\text { Dotterels peeping about Broad Bog new } \\
\text { ground on Penmanshiel Moor. 10th MIay. } \\
\text {-Dotterel shooter, who came from about } \\
\text { Lamberton, visited us. He had shot four, } \\
\text { and said they leave before Whitsunday. } \\
\text { 6th June. - I saw three Dotterels on our } \\
\text { lea. I have been told they have been } \\
\text { there since the 30th of May. A pair re- } \\
\text { mained long about Blackerston. } \\
\text { 1837, } 29 t h \text { April. - Flock of Dotterels near } \\
\text { Penmanshiel. Wheatear, said to be a } \\
\text { forerunner of this bird, appeared on the } \\
20 \text { th of April } 1837 . \\
1857 \text {, I6th Mlay.-Dotterels on the Black } \\
\text { Hill. Ist June. - Still here. A large por- } \\
\text { tion of the Black Hill which was in crop } \\
\text { after lea, where not drained and the soil } \\
\text { clayey, had the oats completely eaten up } \\
\text { by the grub of T'ipula oleracea, scarcely } \\
\text { any being left. Rooks were feeding on it } \\
\text { yesterday and turning up the clods, and } \\
\text { to-day I heard Dotterels on it. Long ago } \\
\text { the Dotterels used to haunt a portion of } \\
\text { this grub-frequented sod when in crop. } \\
\text { They were usually found first there by }\end{array}$ \\
\hline
\end{tabular}




\begin{tabular}{|c|c|c|}
\hline PARISH. & $\begin{array}{l}\text { Source of infor- } \\
\text { mation, and date } \\
\text { when obtained. }\end{array}$ & NOTES. \\
\hline $\begin{array}{l}\text { Cock- } \\
\text { burns- } \\
\text { path- } \\
\text { continued. }\end{array}$ & $\begin{array}{l}\text { J. Hardy, Esq., } \\
\text { Oldeambus, } \\
1856 .\end{array}$ & 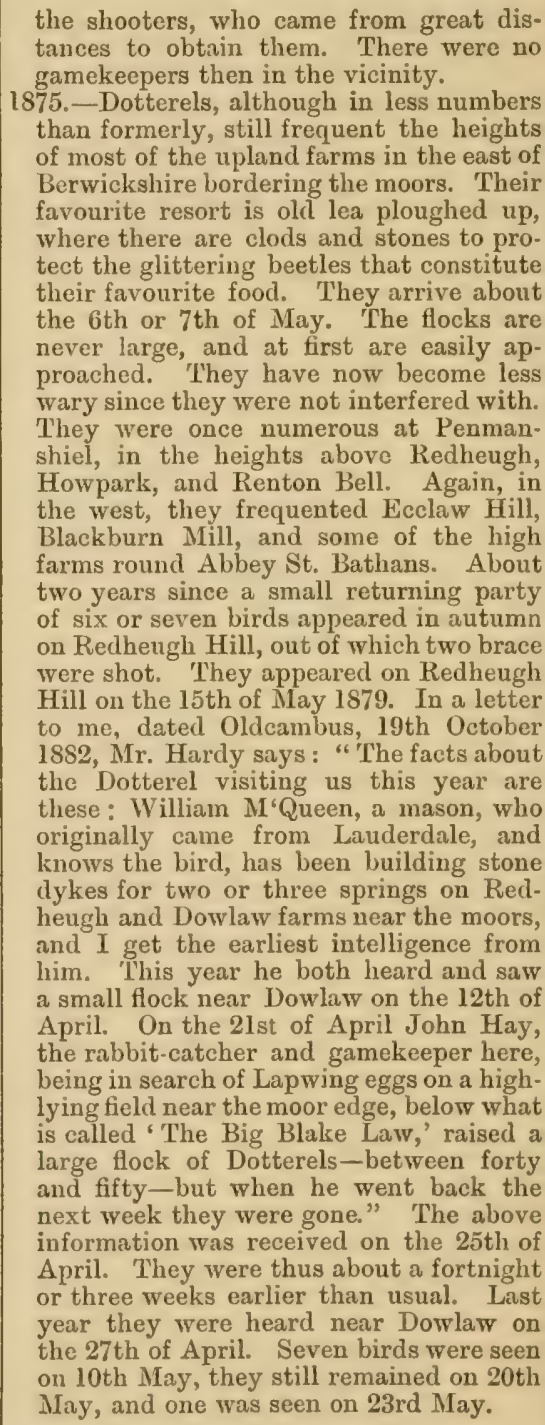 \\
\hline
\end{tabular}




\begin{tabular}{|c|c|c|}
\hline PARISH. & $\begin{array}{l}\text { Source of infor- } \\
\text { mation, and date } \\
\text { when obtained. }\end{array}$ & Notrs. \\
\hline \multirow[t]{4}{*}{$\begin{array}{l}\text { Cock- } \\
\text { burns- } \\
\text { path- } \\
\text { continued. }\end{array}$} & $\begin{array}{l}\text { J. Hardy, Esq. } \\
\text { Oldcambus, } \\
1886 .\end{array}$ & $\begin{array}{l}\text { 1876, 15th April.-For some years back } \\
\text { Dotterels came in the end of September } \\
\text { to high fields between Headchester and } \\
\text { Daurnae (otherwise Redheugh Hill). A } \\
\text { flock of seven noticed last year. } \\
\text { 1877, 15th DIay.-Heard about eight days } \\
\text { ago on heights above Redheugh. } \\
\text { 1879, 19th Mlay.-A flock is at present feed- } \\
\text { ing on the hill on Redheugh farm above } \\
\text { Post Road, not far from Headchesters. } \\
\text { They appeared there on the 15th inst. }\end{array}$ \\
\hline & $\begin{array}{l}\text { Mr. John Bolton, } \\
\text { gamekeeper, } \\
\text { Dunglass, in } \\
\text { letter dated } \\
\text { 3rd Dec. } 1884 .\end{array}$ & $\begin{array}{l}\text { The Dotterels generally come here about } \\
\text { the second week in May, but I have got } \\
\text { them in the first week. I have very } \\
\text { seldom got them on the moor, but always } \\
\text { in the fields adjoining the moor, either } \\
\text { in the old grass fields or on old grass } \\
\text { ploughed up and sown. They fly in } \\
\text { flocks, and have a peculiar sort of whistle. } \\
\text { Many a time I have heard them before I } \\
\text { saw them. They stay only a few days } \\
\text { here. I got several in September 1869, } \\
\text { which is the only time I have ever seen } \\
\text { them here in the autumn. }\end{array}$ \\
\hline & $\begin{array}{l}\text { Arthur Hardy, } \\
\text { Esq., Penman. } \\
\text { shiel, lst Dec. } \\
1886 .\end{array}$ & $\begin{array}{l}\text { They used to come about middle of April, } \\
\text { and remain about three weeks. Six to } \\
\text { ten in a flock. I have not seen any for } \\
\text { the last two seasons. }\end{array}$ \\
\hline & $\begin{array}{l}\text { Wm. Allan, Esq., } \\
\text { Bowshiel, Nov. } \\
1884 \text {. }\end{array}$ & $\begin{array}{l}\text { They used to frequent the farm of Bowshiel } \\
\text { about twenty years ago, and also visited } \\
\text { the farms of Blackburn, where Mr. David- } \\
\text { son killed numbers with his gun. } \\
\text { Edmonsdean was another resort. Mr. Hay } \\
\text { of Spott was in the habit of shooting } \\
\text { them seventy years ago. }\end{array}$ \\
\hline \multirow[t]{2}{*}{$\begin{array}{l}\text { Colding- } \\
\text { ham. }\end{array}$} & $\begin{array}{l}\text { Robert Cowe, } \\
\text { Esq., Old- } \\
\text { castles, July } \\
1855 .\end{array}$ & $\begin{array}{l}\text { About thirty-six years ago Dotterels in } \\
\text { flocks of fifteen or twenty came regularly } \\
\text { to Dowlaw farm in spring, and the Dun- } \\
\text { glass gamekeepers used to shoot them } \\
\text { there. }\end{array}$ \\
\hline & $\begin{array}{l}\text { James Hardy, } \\
\text { Esq., Oldcam- } \\
\text { bus, } 1886 .\end{array}$ & $\begin{array}{l}\text { 1840, lst May.-Was at Dowlaw Dean and } \\
\text { beard the Dotterel had come to some of } \\
\text { the places thereabouts. } \\
\text { 1860, 2lst and 24th May.-Dotterels at } \\
\text { Dowlaw. The Stirling Fauld, near the } \\
\text { Soldier's Dyke at Dowlaw, is a locality } \\
\text { which this bird frequents. }\end{array}$ \\
\hline
\end{tabular}




\begin{tabular}{|c|c|c|}
\hline PARISH. & $\begin{array}{l}\text { Source of infor- } \\
\text { mation, and date } \\
\text { when obtained. }\end{array}$ & Notes. \\
\hline \multirow[t]{3}{*}{$\begin{array}{l}\text { Colding- } \\
\text { ham-- } \\
\text { continued. }\end{array}$} & $\begin{array}{l}\text { James Hardy, } \\
\text { Esq., Oldcam- } \\
\text { bus, } 1886 .\end{array}$ & $\begin{array}{l}\text { 1881, 27th April.-Dotterel heard in higl } \\
\text { grounds at Dowlaw. 7th May. - Flock o } \\
\text { seven seen. 20th May. - Still remained. } \\
\text { 23rd May.-One seen. } \\
\text { 1882. - Mr. Weatherly of Park used to shoot } \\
\text { Dotterels at Howpark Hill. 12th April. } \\
\text { - William M'Queen saw and heard a } \\
\text { small flock on Dowlaw. } \\
\text { 1884, 23rd April.- William M'Queen saw } \\
\text { a pair at Dowlaw flying westward. } \\
\text { 18s6, 27th April. - William M'Queen saw } \\
\text { one Dotterel to-day on an oat field near } \\
\text { the Outer Moor at Dowlaw. }\end{array}$ \\
\hline & $\begin{array}{l}\text { James Bertram, } \\
\text { Esq., Retreat, } \\
\text { Sept. } 1883 .\end{array}$ & $\begin{array}{l}\text { Up to twenty - five or thirty years ago } \\
\text { Dotterels were seen in Hocks of from } \\
\text { fifteen to twenty on Howpark. }{ }^{1} \text { They } \\
\text { frequented the old grass land, and came } \\
\text { about the end of April. They left before } \\
\text { the term (26th May). Mr. W. Logan } \\
\text { shot them at Howpark sometimes. }\end{array}$ \\
\hline & $\begin{array}{l}\text { John Blackadder, } \\
\text { Esq., East } \\
\text { Blanerne, 30th } \\
\text { Sept, 1886. }\end{array}$ & $\begin{array}{l}\text { Very common every spring about fifty years } \\
\text { ago on Brockholes and Horseley farms. } \\
\text { Mr. Joseph Hume, Retreat, and his } \\
\text { friends sometimes shot them there. }\end{array}$ \\
\hline $\begin{array}{l}\text { Cran- } \\
\text { shaws. }\end{array}$ & $\begin{array}{l}\text { H. H. Craw, Esq., } \\
\text { Rawburn, 5th } \\
\text { Oct. 1886. }\end{array}$ & $\begin{array}{l}\text { The shepherds report that Dotterels are } \\
\text { seen in spring and autumn, but they are } \\
\text { not plentiful, about fifteen being in a } \\
\text { flock. }\end{array}$ \\
\hline Earlston. & $\begin{array}{l}\text { James Hardy, } \\
\text { Esq., Oldcam- } \\
\text { bus, } 1886 .\end{array}$ & $\begin{array}{l}\text { Mr. W. Brockie, in a notice of the rare } \\
\text { birds of Berwickshire and East-Lothian } \\
\text { in the "Border Treasury, pp. 587-58,, } \\
\text { says : "That curious bird, the Dotterel, } \\
\text { is a summer visitant. It may be seen in } \\
\text { flocks in the month of May for about a } \\
\text { fortnight in the upper parts of both } \\
\text { counties (East-Lothian and Berwick- } \\
\text { shire) on the skirts of the Lammermuir } \\
\text { Hills from Innerwick, Oldhamstocks, and } \\
\text { Abbey St. Bathans, to Earlston, Lauder, } \\
\text { Channelkirk, and Fala. It loves to settle } \\
\text { and feed on newly-ploughed moors. It } \\
\text { is easily shot, and is excellent eating." }\end{array}$ \\
\hline
\end{tabular}

1 On 11th October $1882 \mathrm{Mr}$. W. B. Boyd showed me at Faldonside a beautiful specimen of the male Dotterel in excellent preservation, which had been shot at Howpark by the late Nichol Milne, Esq. of Faldonside, on the 3rd of May 1831. 


\begin{tabular}{|c|c|c|}
\hline PARISH. & $\begin{array}{l}\text { Source of infor- } \\
\text { mation, and date } \\
\text { when obtained. }\end{array}$ & Notes. \\
\hline $\begin{array}{l}\text { Eye- } \\
\text { mouth. }\end{array}$ & $\begin{array}{l}\text { James Hardy, } \\
\text { Esq., Oldcam- } \\
\text { bus, } 1886 .\end{array}$ & $\begin{array}{l}\text { Captain Bell, of the Berwickshire Militia, } \\
\text { who lived at Linthill House, near Eye- } \\
\text { mouth, in the beginning of this century, } \\
\text { notes in his diary :- "1802, 8th May.- } \\
\text { Saw eight Dotterels this day on some } \\
\text { ploughed land at Linthill.". }\end{array}$ \\
\hline Foulden. & $\begin{array}{l}\text { H. H. Craw, Esq., } \\
\text { Foulden West } \\
\text { Mains, 5th Oct. } \\
1886 .\end{array}$ & $\begin{array}{l}\text { I have occasionally seen Dotterels on this } \\
\text { farm, but they are rarely observed, and } \\
\text { do not stay with us. }\end{array}$ \\
\hline \multirow[t]{2}{*}{$\begin{array}{l}\text { Green. } \\
\text { law. }\end{array}$} & $\begin{array}{l}\text { Mr. W. Smith, } \\
\text { gamekeeper, } \\
\text { Duns Castle, } \\
\text { Oct. } 1886 .\end{array}$ & $\begin{array}{l}\text { A few Dotterels are seen in spring on Bed- } \\
\text { shiel farm. }\end{array}$ \\
\hline & $\begin{array}{l}\text { Mr. Thos. Smith, } \\
\text { gamekeeper, } \\
\text { Marchmont, } \\
\text { 15th Oct. } 1886 .\end{array}$ & $\begin{array}{l}\text { A few are seen almost every spring on the } \\
\text { farms of Greenlaw Dean and Hally- } \\
\text { burton, from five to twelve birds being } \\
\text { in a flock. }\end{array}$ \\
\hline \multirow[t]{3}{*}{ Lauder. } & $\begin{array}{l}\text { James Hardy, } \\
\text { Esq., Oldcam- } \\
\text { bus, } 1886 .\end{array}$ & $\begin{array}{l}\text { 1842, 29th July. - Dotterels come to the } \\
\text { neighbourhood of Blythe Edge and the } \\
\text { moors on the Blythe and Boundreigh } \\
\text { waters every year about Whitsunday. } \\
\text { Information got from Lauderdale for- } \\
\text { ester. }\end{array}$ \\
\hline & $\begin{array}{l}\text { George M`Dougal, } \\
\text { Esq., Bly the, } \\
\text { 30th Oct. } 1886 .\end{array}$ & $\begin{array}{l}\text { The shepherds say they have seen them } \\
\text { in the spring, but not often. }\end{array}$ \\
\hline & $\begin{array}{l}\text { Robert S. Bruce, } \\
\text { Esq., Thirle- } \\
\text { stane, 12th } \\
\text { Oct. } 1886 .\end{array}$ & A few Dotterels sometimes seen. \\
\hline $\begin{array}{l}\text { Leger- } \\
\text { wood. }\end{array}$ & $\begin{array}{l}\text { Mr. John Jamie- } \\
\text { son, steward, } \\
\text { Rumbleton Law, } \\
\text { 9th Oct. } 1886 .\end{array}$ & $\begin{array}{l}\text { William Cairns, Gordon, says that Dotterels } \\
\text { used to come to Boon about twenty years } \\
\text { ago. }\end{array}$ \\
\hline $\begin{array}{l}\text { Longfor- } \\
\text { macus. }\end{array}$ & $\begin{array}{l}\text { Mr. Wm. Duns, } \\
\text { Duns, } 20 \text { th } \\
\text { May } 1886 .\end{array}$ & $\begin{array}{l}\text { Thomas Hill, gunsmith, Duns, used to } \\
\text { shoot Dotterels about Dronshiel and that } \\
\text { locality about the month of April fifty } \\
\text { years ago. They were plentiful in those }\end{array}$ \\
\hline
\end{tabular}




\begin{tabular}{|c|c|c|}
\hline PARISH. & $\begin{array}{l}\text { Source of infor- } \\
\text { mation, and date } \\
\text { when obtained. }\end{array}$ & Notes. \\
\hline $\begin{array}{l}\text { Longfor- } \\
\text { macus- } \\
\text { continued. }\end{array}$ & $\begin{array}{l}\text { Mr. Wm. Duns, } \\
\text { Duns, } 20 \text { th } \\
\text { May } 1886 . \\
\\
\\
\text { John Blackadder, } \\
\text { Esq., East } \\
\text { Blanerne, 30th } \\
\text { June 1886, } \\
\text { Mr. W. Smith, } \\
\text { gamekeeper, } \\
\text { Duns Castle, } \\
\text { 11th Oct. } 1886 .\end{array}$ & $\begin{array}{l}\text { days, and it was a regular practice every } \\
\text { year for some of the gunners about Duns } \\
\text { to go to shoot them, much the same as } \\
\text { people go to the "Crow shooting" at the } \\
\text { present time. } \\
\text { Very common at Blackerston about fifty } \\
\text { years ago. } \\
\text { A few Dotterels are seen on Kettleshiel in } \\
\text { spring. }\end{array}$ \\
\hline $\begin{array}{l}\text { Mording- } \\
\text { ton. }\end{array}$ & $\begin{array}{l}\text { Jas. Mein, Esq., } \\
\text { Lamberton, } \\
\text { 28th Oct. 18s6. } \\
\text { Mr. Jas. Purves, } \\
\text { gamekeeper, } \\
\text { Foulden, 11th } \\
\text { Oct. 1886. } \\
\text { Mr. Jas. Purves, } \\
\text { gamekeeper, } \\
\text { Mordington, } \\
11 \text { th Oct. 1886. }\end{array}$ & $\begin{array}{l}\text { The Dotterel is here nearly every spring. } \\
\text { Five were seen on the 18th of May 1881. } \\
\text { On the 26th of May } 1858 \text { ten brace of } \\
\text { Dotterels were shot at Mordington. } \\
\text { Dotterels visit the moor on Lamberton farm } \\
\text { in April and May. The largest number } \\
\text { which I have seen in a flock is seven. I } \\
\text { find by the Game Book that seven were } \\
\text { shot in a field on Lamberton, known by } \\
\text { the name of Heathery Howes, on the } 12 \text { th } \\
\text { of May } 1868 \text {; and again on the } 9 \text { th of } \\
\text { May } 1872 \text { seven were killed in the same } \\
\text { field. On the } 12 \text { th of April } 1884 \text { two } \\
\text { were obtained at Lamberton. }\end{array}$ \\
\hline & $\begin{array}{l}\text { Mr. John Nairn, } \\
\text { dyker, Mor- } \\
\text { dington, 7th } \\
\text { Aug. 1884. }\end{array}$ & $\begin{array}{l}\text { Saw Dotterels in the Camp Field on Lam- } \\
\text { berton farm in April last. They fre- } \\
\text { quented the rushy part of the field. }\end{array}$ \\
\hline $\begin{array}{l}\text { West- } \\
\text { ruther. }\end{array}$ & \begin{tabular}{|} 
Messrs Clark, \\
Kirklandhill, \\
East-Lothian, \\
20th Oct. 1884. \\
\\
Mr. John Young, \\
gamekeeper, \\
Spottiswoode, \\
11th Sept. 1886.
\end{tabular} & $\begin{array}{l}\text { Occasionally shot a dozen Dotterels in a } \\
\text { season on the farm of Harelaw, near } \\
\text { Westruther, about twenty-five years ago. } \\
\text { The Spottiswoode gamekceper used to } \\
\text { shoot them on the same farm. } \\
\text { No Dotterels visit any farm on the estate } \\
\text { of Spottiswoode now ; but I believe about } \\
\text { thirty years ago they were plentiful on } \\
\text { Westruther Mains farm, near Houndslow. }\end{array}$ \\
\hline
\end{tabular}




\title{
THE GOLDEN PLOVER.
}

\author{
YELLOW PLOVER, WHISTLING PLOVER, GREY PLOVER, ${ }^{1}$
}

Charadrius pluvialis.

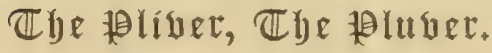

\author{
From the shore \\ The Plovers... scatter o'er the heath, \\ And sing their wild notes to the listening waste.
}

THOMSON, Spring.

Tife Golden Plover is plentiful on the Lammermuirs in spring, summer, and the early part of autumn, when its plaintive note gives an additional charm to the wild scenery of the hills.

In October and November great flocks ${ }^{2}$ may be seen associated with Peewits on the grass fields in certain parts of the Merse-the neighbourhood of Whitsomehill in the parish of Whitsome, and Whitelaw in the parish of Edrom, being two favourite localities. When the flocks take wing the Golden Plovers are generally mixed with their congeners for a short while, but they soon use their long, curved, sharp-pointed wings in rapid flight, and, separating from their slow companions, mount high in the air, where they wheel round, and round, occasionally uttering their well-known note, and again alight in the field from whence

1 The Golden Plover is sometimes called the Grey Plover, from its grey colour when at a distance. The true Grey Plover is Squatarola helvetica.

${ }_{2}^{2}$ It is probable that our native Golden Plovers receive additions to their numbers in autumn in the shape of immigrants from the north of Europe; for at that season great flocks are seen passing over Heligoland and the lighthouses on the coasts of this country. 
they arose. On the setting in of hard weather, this bird leaves the inland districts and frequents the neighbourhood of the sea-coast, where it generally remains more or less until spring, when it returns to the moors to breed, and may again be heard

Wild-whistling o'er the hill.

\section{BURNS.}

Its nest is generally placed in a slight hollow of the ground amongst heather, and is lined with a little dry grass. The eggs, which are three or four in number, are of a yellowishbrown colour, spotted and blotched with brownish-black. ${ }^{1}$

The food of this species, when inland, consists of worms, slugs, and insects; and on the sea-coast of small molluses of various kinds.

The Golden Plover has long been considered a great delicacy for the table, and we find in Dunbar's Dirige to the King bydand our lang in Stirling, that His Majesty is invited to return to Edinburgh-

To eat cran, pertrick, swan, and pliver,

And every fisch that swyms in river,

To drink with us the new fresch wyne

That grew upon the river Ryne,

Fresch fragrant Clarits out of France,

Of Angiers and of Orliance. ${ }^{2}$

The price of this bird was fixed by the Scottish Parliament in the reign of Queen Mary (1551) at "four pennies."

The word Plover is derived from the French Pluvier, ${ }^{3}$ a name which Rolland says this bird bears, because it arrives in flocks in the rainy season of the year. ${ }^{4}$ In some parts of Berwickshire its arrival in autumn is considered by

1 While walking over Harelaw Moor, near Westruther, on the 24th of April 1885, I found a nest of the Golden Plover with four eggs, which were neatly placed in it with their small ends together, thus enabling the bird to cover them conveniently.

2 Sibbald, Chron. Scot. Poet., vol. i. p. 237.

3 Latin pluvialis, rainy.

+ Faune Populaire de la France, tome ii., "Les Oiseaux Sauvages," p. 346. 
the country people to be the sign of approaching stormy weather. ${ }^{1}$

Its spring notes are said to be thought by the farm labourers in some parts of Scotland to resemble the words "pleugh weel, shave weel, harrow weel." 2

Plover's Cairn, which is situated about half a mile southwest of Twinlawford on the march between the parishes of Westruther and Lauder, and is 1230 feet above the level of the sea; and Plovering Haugh, in the parish of Lauder, have apparently got their names from this bird.

In summer the adult male and female have the throat, breast, and under parts of the body black. After the autumn moult the under parts are white, mottled with brown on the breast and flanks.

1 Note from Mr. Andrew Balsillie, Dykehead, 25th July 1887.

2 This is given (comme de M. Walter Gregor) by Rolland, and it is explained by him that "shave" means "sow"; but perhaps the word may be retained as it stands without being considered an unnecessary or superfluous advice.

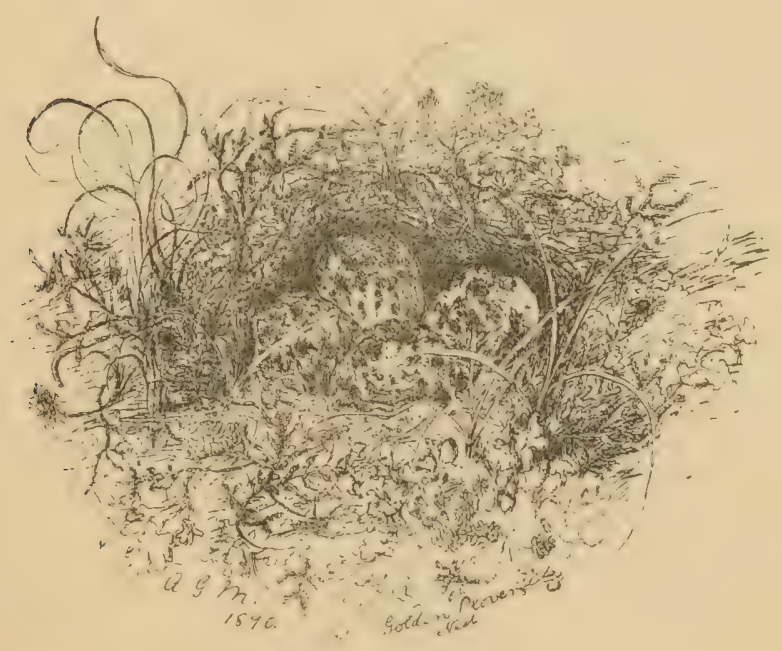




\section{THE RINGED PLOVER.}

RING DOTTEREL, SAND LARK, SANDY LAVEROCK, SANDY LOO, DULWILLY, STONEHATCH, STONE PLOVER.

\section{AEgialitis hiaticula.}

\section{..... the Plover fondly tries}

To lure the sportsman from her nest. And futtering on with anxious cries, Too plainly shows her tortured breast; Oh let him, conscious of her care, Pity her pains, and learn to spare.

SHENSTONE.

THE sea-coast of Berwickshire, which consists chiefly of precipitous rocks with very little sandy beach, is not suitable for the Ringed Plover, which, on that account, is but rarely seen. It is, however, occasionally observed at the sea-side, and also, though very seldom, along the banks of our rivers. Two specimens are recorded as having been observed on the Tweed near Coldstream by the President of the Berwickshire Naturalists' Club, when the Club met there on the 4 th of May $1842 ;{ }^{1}$ and a Ringed Plover is also mentioned as having been noticed on the Leader by Mr. Walter Simson, Lauder. ${ }^{2}$

This pretty bird is resident all the year in the neighbouring county of East-Lothian, where the sea beach is flat.

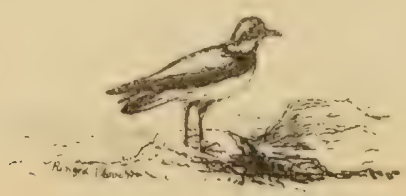




\title{
THE LAPW IN G.
}

PEWIT, PEESEWEEP, TUCHIT, GREEN PLOVER.

Vanellus vulgaris.

\section{The 想egetweep, ${ }^{1}$ The Teuchit. ${ }^{2}$}

\begin{abstract}
And here the lonely Lapwing whoops along,
That piercing shricks her still-repeated song,

Flaps her blue wing, displays her pointed crest, And, cowering, lures the peasant from her nest. But if where all her dappled treasure lies

He bend his steps, no more she round him fies;

Forlorn, despairing of a mother's skill,

Silent, and sad, she seeks the distant hill.
\end{abstract}

LEYDEN, Scenes of Infancy.

DURING the spring, summer, and autumm months the l'eeseweep is numerous all over the county; but on the approach of severe weather in winter it migrates southwards to milder

I So named from its well-known cry. Mr. Hardy likens the call of the Peeseweep to "Pear-weep," the $r$ being burred, more or less distinctly.

a Teuchit-the Lapwing, probably so named from its crest: French "toquet," the cap of a chill. It is termed "tuquheit" by Birrell in his "Passage of the Pilgrimer." Watson's Collection of Poems, part ii. p. 27.

The Tuquheit and the Sterling than

Togidder with the Pelican

Flew in ane randell richt:

The Piot and the Papingo

With Goldspink, I sa thame go,

Syne laich thay down did licht.

LEYDEN's Complaynt of Scotland.

The word "tuquheit" occurs in Holland's Houlat, written about 1445. The cry of the bird is said in the Complaynt of Scotland to be "theuis-nek:" "The teuchitis cryit theuis-nek, when the piettis clatterit."

Dr. Henderson of Chirnside gives in his MS. the following verse of an old song which relates to localities in the neighbourhood of Chirnside:-

$O$ meet me by the Tuchit yetts,

Or by the Kaeter Well,

And we will sit amang the gowans

Not bonnier than thysel.

VOL. II. 
localities, and does not usually return to the lower grounds of Berwickshire until about the end of February or beginning of March, when its well-known note, heard for the first time in the season, is always welcome. The bird generally reappears among the hill farms on the Lammermuirs abont the beginning of April; and if bad weather sets in at that season, old people call it a "Teuchit storm," on account of its occurring about the same time as the arrival of the Teuchit or Peeseweep. A similar term is said to be applied to a storm taking place about the period when the bird departs in autumn. ${ }^{2}$

In the nesting season it is seen scattered over the county in pairs. When the corn fields as well as the hedge-rows and woods are becoming green, and all nature is rejoicing at the approach of summer, the Peeseweep with its rounded wings, as it flies here and there over the land by the road-sides, now rising in the air and anon diving down almost to the ground, all the while uttering its peculiar cry, is a constant feature in the rural landscape, for at this delightful season

The Lapwing lilteth o'er the lee With nimble wing she sporteth.

Leader Haughs and Yarrow.

On the approach of autumn it assembles in great flocks and frequents the grass and turnip fields, where it may be seen resting, or running about in search of worms, snails, and insects, its beautiful crest and graceful attitude being all the while displayed to advantage. The birds at this season are often very restless, and keep flying in broad,

1 Mr. Hardy says in his MS. Notes: "April 1, 1858.-Wind north, frosty, ground covered with snow. Old people say it is a 'Teuchit storm.' This occurs usually in April, about the time when the Peeseweep makes its appearance amongst the hill farms."

2 Mr. Hardy's MIS. Notes. 
scattered bands from field to field, or, congregating in a rast flock, they mount high in the air, and after circling round and round with the Golden Plover,

Their front now deepening, now extending,

Their flank inclining, wheeling, bending,

Now drawing back, and now descending, 1

they by degrees alight at some favourite haunt in the neighbourhood.

The nest of the Peeseweep is often found in spring when the farming operations of that busy season are in progress, and is frequently destroyed by the harrow or the roller before it is observed. It is generally a shallow depression in the ground, lined with a little dry grass or other suitable material. On the Lammermuirs a very bare spot is sometimes selected. In describing a nest found at the side of Moss Maw, near Penmanshiel and Harelawside march, Mr. Hardy says: "Not a blade of grass or tussock of carices waved around the exposed habitation. The young ones, clothed only with down, 'paddy hair' as it is called, sat huddled together in pairs, one in each pair having its neck laid across that of the other. The parents screamed most piteously overhead as long as I was in search, making: their flight and loudest cry in the direction where the nest did not lie. As I drew near, the cries redoubled and became more earnest, and the flight of the old birds approached closer to the ground." Sometimes

Amid the marsh's rushy skirts, her nest

Is slightly strewn; four eggs, of olive hue,

Spotted with black, she broods upon:

.... She, if or dog,

Or man, intrude upon her bleak domain,

Skims, clamouring loud, close at their feet, with wing

Stooping, as if impeded by a wound.

Grahame, Birds of Scotland.

1 Sir Walter Scott, Marmion 
The eggs are highly esteemed as luxuries for the table, and Mr. Howard Saunders, in the fourth edition of Yarrell, says that the earliest "fetch such fancy prices as $15 \mathrm{~s}$. apiece, and a leading West End poulterer recently informed the editor that if he were assured of having the first ten eggs, he would not hesitate to give $£ 5$ for them. As the supply increases the value rapidly falls, until it reaches 4s. $6 \mathrm{~d}$. per dozen, which is the average London price in the season." 1

As the Peeseweep, when nesting, has a habit of flying and screaming round any intruder upon her domain, this, in Covenanting times, often led to the discovery of poor fugitive Presbyterians in the moors and mosses of the hills by the soldiers who were in search of them. On that account the bird acquired a bad name amongst the country people ${ }^{2}$ which is thus alluded to by Grahame in his Birds of Scotland:-

Ill-omened bird! oft in the times

When monarchs owned no sceptre but the sword,

Thou, hovering o'er the panting fugitive,

Through dreary moss and moor, hast screaming led

The keen pursuer's eye; oft hast thou hung,

Like a death flag, above the assembled throng,

Whose lips hymned praise.

Some remnant of this ill-feeling towards the bird seems still to linger in parts of the county, as may be gathered from the following account of the Peeseweep given by a shepherd at Godscroft to Mr. Hardy :- "When near their nests they jouk down and rin away the contrair way; they are very

1 Yarrell's British Birls, fourth edition, vol. iii. p. 284.

2 See Tales of a Grandfather, second series, p. 238. Tannahill says in his Soldier's Return-

The Peesweep's scraighin' owre the spunkie-cairn! My heart bodes ill.

The birl seems, however, to have borne a bad charncter long before Covenanting times, for Chaucer, in his Assembly of Foules (1561), calls it

The false Lapwing ful of trecherye. 
wily. They are nasty yelpin craturs and joost deave ye wi' their din. Ah! they're ill-set craturs. They frighten a' the sheep. They're as guid's a doug; whenever they see yin by itsel, they're on the tap on't. Whenever they see a hare they chase it through the middle o' the hirsel, and the sheep a' fear'd o' them, rin as 'twere frae a doug. I've seen me kill them when I fand them, although it was'na richt, ${ }^{1}$ joost for the noise they make. A craw daurna come near them. They play the hero wi't a'thegither, for they fa' on't and buffet it, and the craw has naething for't but joost to make off." Another herd, when alluding to localities frequented by this bird, said: "About Aikenga, Peeseweeps are scarce. Gowhscraft's King o' the Peeseweeps." It used to be considered a sign of bad weather in spring when the Peeseweep was observed flying about in flocks on the lower grounds, as may be seen from the following entries in Captain Bell's diary :-

"1813, April 4th.- Saw a flock of Green Plover near Eyemonth, and small birds sitting in trees at Linthill chirping in afternoon-a sign of bad weather. April 13th.Flock of Green Plover yesterday morning flying high about 10 A.M. - a sign of bad weather at this season, as they should be paired before this."

There are several popular rhymes and sayings in Berwickshire about the Peeseweep, of which Mr. Hardy has been good enough to furnish me with the following:-

Peeseweep! wallop away,

Cauld feet in a frosty day.

Another version is :-

Peeseweep ! wallop away,

Harries my nest in a rainy day.

1 Poor bird! where'er the roaming swain intrudes On thy bleak heaths and desert solitudes, He curses still thy scream, thy clamorous tongue, And crushes with his foot thy moulting young. 
The word "Peeseweep" is sometimes heard in the county as descriptive of a weak, poor-looking creature. For instance, a weak calf has been heard to be described as "just a thin speeder of a thing, just a hungry peeseweep of a cratur." The Peeseweep grass is Luzula campestris. ${ }^{1}$

1 Botany of the Eastern Borders, by Dr. Johnston, p. 200.

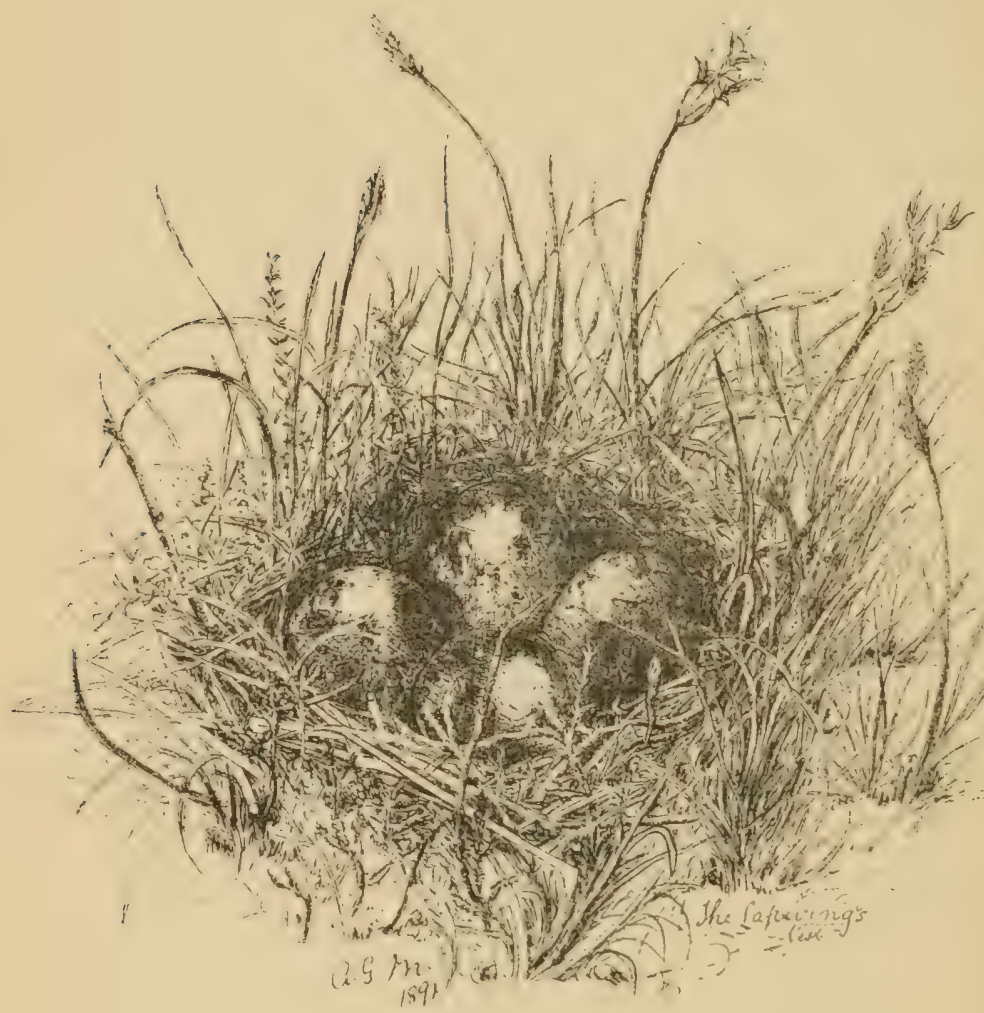




\section{THE OYSTER CATCHER.}

SEA PIE, SEA PIET, PIANET, MUSSEL PICKER.

\section{Homatopus ostralegus.}

\section{$\mathbb{C} \mathfrak{T} \mathfrak{e}$ 与ea}

The seamew, seapye, gull, and curlew, here doe keepe, As searching every shole and watching every deepe, To find the floating fry, with their sharpe piercing sight, Which suddenly they take by stouping from their height.

Drayton, Polyolbion.

TuE coast of Berwickshire is so precipitous that it is not suited to the habits of the Oyster Catcher, and on that account the bird is not much seen on the shores of the county. Mr. Hardy records that it is sometimes noticed in the neighbourhood of liedheugh and Siccar Point in spring and autumm. ${ }^{1}$ It is fond of frequenting sandy bays, with banks of shingle, where it feeds on molluses and marine insects. Mr. John Thomson has informed me that an Oyster Catcher was seen at Mertoun in December 1881. Sir William Jardine records that a specimen was lilled at Dryburgh.

${ }^{1}$ Hist. Ber. Nat. Club, vol. vii. p. 110 ; also vol. ix. p. 404.

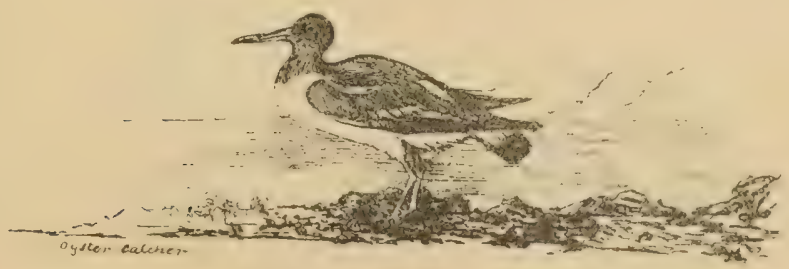




\title{
THE GREY PHALAROPE.
}

\author{
COOT-FOOT.
}

Phalaropus fulicarius.

Far away

To either hand, the broad, curved beach stretch'd on ;

And I could see the slow-paced waves advance,

One after one, and spread upon the sands,

Making a slender edge of pearly foam

Just as they broke.

Atherstone.

T'His pretty bird, which is a little larger than a common Sandpiper, is a very rare visitor to Berwickshire. The only recorded instance of its having been found in the county is that of a male which was shot at Girrick Pond, near Nenthorn Ilouse, on the 19th of November 1875. It was alone, and had frequented the pond for several days when it was killed. ${ }^{1}$

This species breeds in the circumpolar regions, and its reddish plumage in summer presents a striking contrast to its delicate grey colour in winter.

I Hist. Ber. Nat. Club, vol. vii. p. 502.

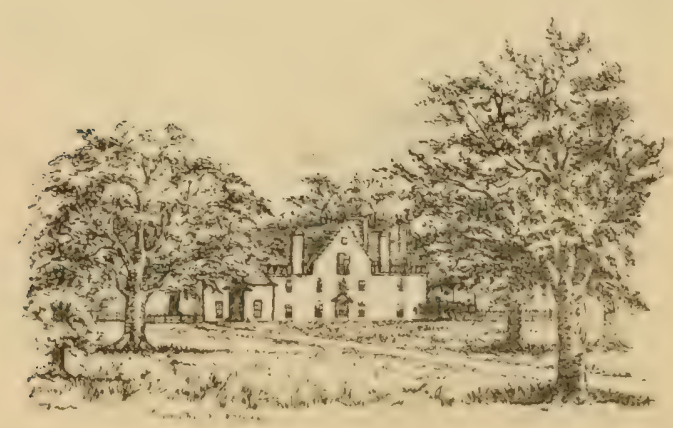




\title{
THE WOODCOCK.
}

\author{
Scolopax rusticula.
}

Oft at this season, near an oozy spring,

O'erhung by alder boughs, the Woodcock haunts;

(Sure harbinger, when thus so early come,

Of early winter tedious and severe) ;

There he imbibes his watery food; till, scared

By man and dog, upward, on pinion strong,

He springs, and o'er the summits of the grove,

Flies far, unless, flashing, the quick-aimed tube

Arrest his fight, and bring him lifeless down,

With his long bleeding bill sunk in the marsh.

Grahame, British Georgics-" November."

The Woodcock is found in small numbers in most of the woods and plantations of Berwickshire during the late autumn, winter, and early spring months, and in some instances a few have been known to remain in the county through the summer to breed, the nest and eggs having been found in one or two localities.

With the exception of those which stay to nest, the whole of the Woodcocks which are seen in our woods during the shooting season leave for their breeding quarters in the northern parts of Europe in March and April; while it has been observed that those which breed in the county disappear towards autumn, having probably migrated southwards. ${ }^{1}$ The autumnal flights of this species from the north generally arrive in Berwickshire about October and November. In some years the birds are much

1 Colonel Brown of Longformacus has informed me that the Woodcocks which stay during summer in the woods about the Watch Water leave early in autumn. He says that in the neighbourhood of Longformacus the autumnal flights appear earliest on Cranshaws Hill. 
more plentiful than in others, ${ }^{1}$ which may depend on the severity or otherwise of the weather in the north of Europe, and also on the influence of the prevailing winds during the period of migration. Mr. Selby of Twizell House, Northumberland, the well-known ornithologist, says, with regard to the migration of the Woodcock: "I have found that these birds always come over in the greatest bodies in hazy weather with little wind, and that blowing from the northeast." He adds that "the first flights, which seldom remain longer than for a few days and then pass southwards, consist chiefly of females; whilst, on the contrary, the subsequent and latest flights, which continue with us, are principally composed of males. ${ }^{2}$

Woodcocks generally make their first appearance in autumn in the neighbourhood of the sea-coast about Lamberton, ${ }^{3}$ Fast Castle, and Redheugh ${ }^{4}$ where they sometimes drop into hedges and turnip fields on their arrival, ${ }^{5}$ being exhausted by their long flight; but they soon spread inland and take up their quarters for the season in their usual liaunts. Some woods, amongst which may be mentioned the Grange Wood in the parish of Coldingham; Buncle Woods in the parish of Buncle; Edington Hill Wood ${ }^{6}$ in the

1 Dr. Johnston in his MIS. Notes mentions 1852 as a year when Woodcocks were unusually plentiful in Berwickshire. Yarrell also refers to great numbers being found that year in Norfolk.

2 Yarrell's British Birds, fourth edition, vol. iii. pp. 321, 322.

3 Woodcocks are often found in the early part of the season, poor, weak, and exhausted, probably from their long tlight across the German Ocean,-Old Statistical Account of Scotland, Mordington Parish, vol. xv. p. 182.

4 The first cold, misty east wind used to bring the Woodcocks to Redheugh, and amongst the turnips at Oldcambus East Mains. They were exhausted when they arrived. The gamekeeper usually finds them early on Dowlaw Braes.Mr. Hardy's MS. Notes.

5 They are sometimes found in very unusual places on their first arrival. Mr. Alexander Leitch, Fairneyside, near Ayton, has informed me that about eight o'clock on the morning of the 13th of November 1884 he found a Woortcock in a lambing shed at Fairneyside, and it escaped through a hole in the roof.

6 Dr. Stuart records that the gamekeeper at Edington Hill informed him on the 18th Jamuary 1856 that 18 ? couple of Woolcocks were killed in Edington Hill Woor during the season 1885-86. - Hist. Ber. Nat. Club, vol, xi. p. 241. 
parish of Chirnside; and the Moor Plantation near Whitchester in the parish of Longformacus, are favourite haunts of this bird, and in these it is usually found in greater numbers during the shooting season than elsewhere.

One or two Woodcocks may be generally found during the winter months in the woods about Paxton, where they appear to have certain favourite retreats. I have seen them oftenest in the Well Mire Wood, the Crow Dean Wood, and the Old Heronry Wood; but they also resort to the plantations on Nabdean Farm. During the severe snowstorm in the end of December 1874, Woodcocks in numbers frequented the woods at Paxton. They were generally found about the sides of the burns in the plantations, where the ground was comparatively free from frost, and where they searched under the fallen leaves and in the soft earth for worms and insect food. At the beginning of the severe weather the Cocks, on being flushed, flew off very rapidly, but after the storm had continued for a week or two they seemed to get weak and rise with reluctance from their haunts, flew slowly, and alighted at a short distance from the place where they rose. ${ }^{1}$ The burn which runs through the Well Mire Wood and falls into the Whitadder never freezes in the hardest frost; and as the ground along its course is soft, it is easily penetrated by the bill of the Woodcock, and is one of their favourite resorts when snow lies on the ground and the frost is severe. The Old Heromry Wood is a romantic and beautiful dean through which a small stream meanders before it joins the Tweed a short distance to the west of Paxton

1 On the 17th December 1884 my friend, the Rev. Thomas Marjoribanks of Prestonkirk, told me that during the severe frost of January 1881 Woodcocks were seen haunting all the small springs in the neighbourhood of East Linton, and the boys were throwing stones at them. When curling on the Tyne he noticed the birds continually flying over the rink on their way to and from the springs, and they were so weak in their flight that the curlers threw their brooms at them, and two were killed in this way. They flew just like bats. 
House. The banks on each side of the rivulet appear to have been originally planted with silver, scotch, and spruce firs, but of these only a few giants now remain, towering above their neighbours of a younger generation to the height of upwards of one hundred feet. When a storm of snow occurs with continued frost, the winter sun melts the icy covering on spots exposed to his rays along the sheltered southern slopes of the dean, and here the Woodcock may be occasionally found during the day, turning over the fallen leaves and dead herbage in search of food. In mild weather it sits concealed in the woods, and at night resorts to swampy places and marshes in the neighbourhood of its haunts to feed.

No bird is more highly prized by the sportsman than the Woodcock, not only on account of its variable flight, which tries his skill with the gun, but also from its wellknown reputation as a luxury for the table. The uncertainty when and where the bird will rise adds a further zest to the sport, as it is frequently flushed unexpectedly, and makes off amongst the trees with the speed of a Sparrow Hawk.

Right up he darts amongst the mingling boughs;

But bare of leaves they hide not from my view

His fated form, and ere he can attain

'I'h' attempted height, with rapid flight to cleave

The yielding air, arrested by the shot,

With shatter'd wing revers'd and plumage fair

Wide scatt'ring in the wind, headlong he falls.

VINCENT, Fowling.

When the covers in the neighbourhood of Legerwood and Chapel were young, excellent sport was sometimes got there with Cock, as many as twenty or thirty couple being occasionally killed in a day's shooting. ${ }^{1}$ In some years

$1 \mathrm{Mr}$. Patterson, Ancrum Woodhead, informed me on the 27th October 1887 that, about forty years before that time, he, in one day's shooting at the end of a 
heavy bags are made in the Dunglass Woods near Cockburnspath, 1864 being remarkable in this respect, when forty-seven couple were got during the season. Only fifteen couple were obtained there in 1891-92. ${ }^{1}$ On the 16 th of November 1875 seven couple were bagged in the Whitfield covers on Ayton Estate. ${ }^{2}$ Colonel Brown of Longformacus tells me that on the 8th of November 1876 eight couple were shot in Watch Cover. ${ }^{3}$ Seven couple were procured in the Harelaw Craigs Wood on Duns Castle Estate in a day's shooting in the winter of $1875 .{ }^{4}$ In the Spottiswoode home covers four couple were brought down on the 15 th of December $1887 ;^{5}$ and as many were got on the 21st of November 1890 in the Ferneyrig covers, in the parish of Eccles. ${ }^{6}$ Five Cock were shot in the covers at Paxton, in the parish of Hutton, on the 15 th of November 1887; and Mr. Macbraire of Broadmeadows has informed me that one day about 1864 he killed six at Tweedhill over a steady old pointer.

The Woodcock is an early breeder, generally making its nest, which consists of a slight hollow in the ground lined with dry grass and leaves, about the outskirts of the woods. The eggs, which are four in number, and are yellowish white, spotted with grey and reddish brown, are usually found in the month of April, but sometimes later. Writing under date the 31 st of May 1885, Mr. Hardy says: "A pair of Woodcock are breeding this year in the Oak Wood above Nesbit Haugh, near Penmanshiel

snow-storm, got to his own gun $21 \frac{1}{2}$ couple of Cock in the young plantations on Legerwood Farm, chiefly round the Legerwood and Whitslaid marches. He has known as many as 30 couple killed in a day on Chapel.

1 Mr. John Bolton, gamekeeper, Dunglass, Cockburnspath, 8th February 1892.

2 Mr. Hugh Fraser, late gamekeeper at Ayton Castle, December 1891.

3 Information from Colonel Brown on 10th March 1887.

$4 \mathrm{Mr}$. W. Smith, gamekeeper, Duns Castle.

5 Mr. J. Young, gamekeeper, Spottiswoode, 17th December 1891.

${ }^{6}$ Mr. George Landles, gamekeeper, Ferneyrig, 22nd December 1891. 
Tunnel. ${ }^{1} \quad$ They had four eggs, but one was broken by the discoverer of the nest. June 4th.-They have left their nest with an addled egg and some egg-shells in it, taking with them two hatched young," A paragraph in the Berwickshire News of the 21st of August 1884 states that "a few days ago a young Woodcock was found in Duns Castle Woods under circumstances which showed that it had been bred there. In the spring of 1886 a Woodcock's nest with four eggs was got in these plantations; and another containing the same number of eggs was discovered in the Peely Braes Wood, near Duns Castle, by Mr. William Smith, gamekeeper there, on the 3rd of April 1890 , who informed me that from the appearance of the eggrs at the time when they were found incubation had only recently begun, and that they were hatched in fifteen days.

It is now well known that in the evening the Woodcock carries its young between its legs and pressed against its breast with its bill, from the dry places in the woods where they are hatched, to soft swampy spots in the neighbourhood, where they can feed.

Externally the female cannot be distinguished from the male bird. The peculiar markings on the first quill feathers are not constant, and are thought to be indicative of age rather than of sex. $^{2}$

The average weight of a Woodcock is twelve ounces; young birds are much lighter, being seven or eight ounces. $^{3}$

A popular saying sometimes heard on the Borders is

1 Mr. Abraham Mack, Abbey St. Bathans, told me on the 5th of July 1886 that he found a Woodcock's nest near the side of Penmanshiel Wood in the summer of 1827. It had two eggs, and was on a dry knowe amongst some stumped heather near some birch bushes. He saw the old bird sitting on the nest several times.

2 See The Field, 9th January 1886.

${ }^{3}$ Ibid. 
that "one Swallow does not make a summer nor one Woodcock a winter." 1

In the reign of Queen Mary the Scottish Parliament fixed the price of the "woodde-cokke" at "four pennies." 2

1 Borderer's Table Book, vol. vii. p. 215.

2 Laws and Acts of Parliament made by King James $I$. and his Royal Successors, by Sir Thomas Murray of Glendook, Kt. and Bt., 1681.

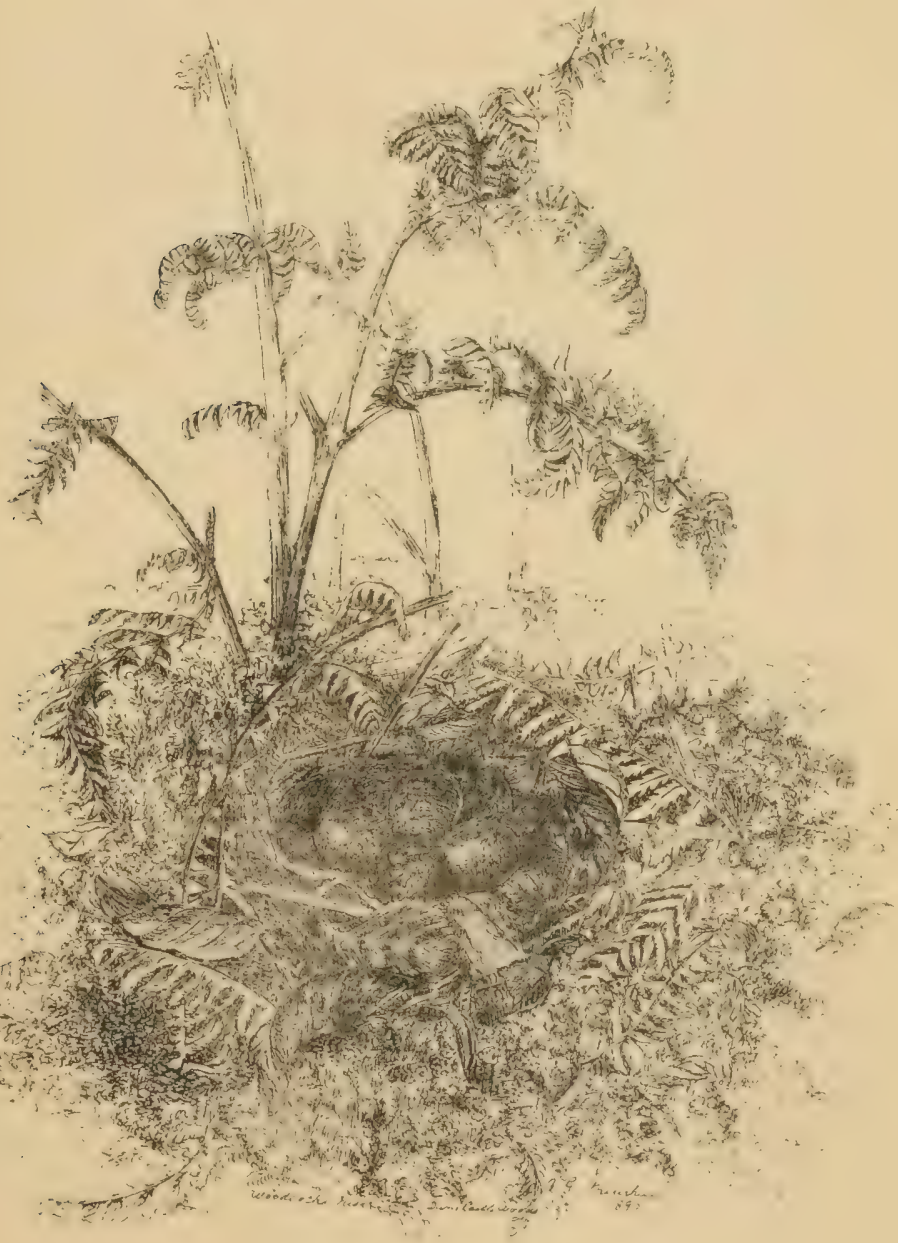




\section{THE GREAT SNIPE.}

DOUBLE SNIPE, SOLITARY SNIPE, WOODCOCK SNIPE.

\section{Gallinago major.}

And long-bill'd Snipe, that knows approaching rains.

WILSON, Loch Winnoch.

THis bird is rarely seen in Berwickshire. A specimen was shot by the Earl of Haddington in a dry grass park on the farm of Lightfield, near Mellerstain, in the autumn of $1865 ;^{1}$ and another was killed by Mr. Stow ComptonLundie in a field at Spital House, in the parish of Hutton, about the same time." Mr. Kelly records that an example was got by Mr. Scott, gamekeeper, Thirlestane Castle, in $1870 ;^{3}$ and $\mathrm{Mr}$. George Low told me in November 1882 that his brother, the Hon. Lord Low, saw a Creat inipe on Ellemford ground a few years previously.

It is known to be a visitor to the British Islands while on its way to its southern winter quarters, its arrival generally taking place between the middle, of August and the middle of October.

It may be distinguished from the Common Snipe by its greater size, and by the under parts being more profusely and closely barred. Seebohm says that the chief distinction lies in the tail; in the adult Great Snipe the terminal half of the four ontside tail feathers on each side is pure unspotted white, whilst in the Common snipe it is chestnut-buff, with a sub-terminal dark-brown bar.

1 Turnbull's Birds of East-Lothian, p. 43.

2 Information from W. Compton-Lundie, Esq. of Spital, 10th February 1886.

3 Hist. Ber. Nat. Club, vol. vii. p. 523. 


\title{
THE COMMON SNIPE.
}

MOOR OR MIRE SNIPE, HEATHER BLEATER, BLITER OR BLUTTER.

\section{Gallinago coelestis.}

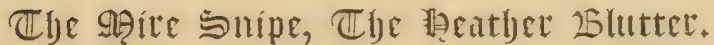

\author{
Amid these woodless wilds, a small round lake \\ I've sometimes marked, girt by a spungy sward \\ Of lively green, with here and there a flower \\ Of deep-tinged purple, firmly stalked, of form \\ Pyramidal - the shores bristling with reeds, \\ That midway over wade, and, as they bend, \\ Disclose the water lily dancing light \\ On waves soft-rippled by the July gale, \\ Hither the long and soft-billed Snipe resorts.
}

GRAHAME, Birds of Scotland.

In former times when reedy pools, bogs, and mires abounded all over the county, the Snipe would be much more plentiful than it is now; for agricultural improvements and drainage have left it very few swampy spots on which to rest the sole of its foot. It is, however, still found during the autumn in considerable numbers in suitable places, such as about Legerwood Loch, Lurgie Loch, ${ }^{1}$ and Redpath Bog, and on the wet moors and mosses of the hills ${ }^{2}$ - Harelaw Moor, in the parish of Westruther, having been a favourite

$1 \mathrm{Mr}$. Black, Girrick, says that this loch or bog, which is dry in summer, is much frequented by Snipe in autumn and winter, when he has seen as many as fifty or sixty upon it in a day. The site is covered with natural birch and rough hill grass.-Notes from Mr. Black, 12th January 1888.

2 Mr. Walter Elliot, Hollybush, informed me on the 16th of August 1887 that there is a bog on the march between Ellemford and Harehead Farms where Snipe are very plentiful in August and September. As many as fifty may be put up in walking over it.

VOL. II. 
resort until it was drained. Although a few Snipe breed in suitable localities throughout the county, yet it is probable that most of those which we see during the shooting season are visitors from the northern parts of Europe, which have joined our native birds; for this species is occasionally scen on migration at the lighthouses on the Fame Islands and Isle of May in autumu, and again in spring when it returns northwards. ${ }^{1}$

There is no better sport with the gun than Snipe shooting when the birds are fairly plentiful, but, unfortunately, this is seldom the case in Berwickshire. The "Scape, scape" of the game as it rises and makes rapidly off" with its zig-zag flight is always a pleasing sound in the sportsman's ear, and the first Snipe which falls to the gun in youth, like the first Woodcock, is long remembered. In the Grouse shooting season it is occasionally killed in small numbers in the Lammermuirs, and sometimes rises before Partridge shooters in damp turnip fields in the Merse. On these occasions the "pallat-pleasing snite," as old Drayton calls it in his Polyolbion, gives variety to the bag, and forms an agreeable addition to the table afterwards.

During severe frost and snow in winter the bird is very often pressed for food, and may be seen frequenting the sides of brooks, ditches, and open drains by road sides, or even close to houses and villages. It is then much tamer than usual, and does not fly far when disturbed. It is likewise found about the sea-side in autumn and winter. In March and April, according to the season, the Snipe begins to make a peculiar humming or bleating sound when on the wing. ${ }^{2}$ The bird soars high up in the air, and the humming

1 See Reports on the Migration of Birds, 1879-86.

2 Mr. Hardy in his MIS. Notes writes: "1840, March 16th.-Snipe bleating this morning at Penmanshiel. This is an early year. 1836, $A$ pril $19 t h_{\circ}$-Snipe piping to-day in the air. 1843, June 16th.-Dnipe bleating to-day." 
is heard when it is descending rapidly. ${ }^{1}$ There is considerable difference of opinion amongst ornithologists regarding the origin of the sound, but the greatest weight appears to be attached to the theory that the sound is caused by the vibration of the feathers of the wings during the descent of the bird. ${ }^{2}$ Mr. Hardy says that people in the Lammermuirs call the bird the "Mire Drum," on account of the peculiar noise which it makes in the air :-

Oh, how I love the moorland scene of spring Beneath the smile of morning's ruddy glow,

The whir of heath-cock and the curving wing Of snipe high booming o'er the marshy flow.

This species has often been found breeding in the neighbourhood of Penmanshiel. A nest discovered there by Mr. Hardy, in a bog, was made of withered sprits (Juncus articulatus) and a few grasses. It had four eggs, and their tips were placed inwards around the centre of the nest. ${ }^{3}$ It also rears its young occasionally amongst the herbage by the side of Dowlaw Mill Pond, and Colonel Brown has informed me that the nest is frequently found in the moors about Longformacus.

... here her house she forms,

Here warms her fourfold offspring into life.

Grahame, Birds of Scotland.

The eggs are yellowish or greenish white, spotted towards the larger end with several shades of brown.

- The food of the Snipe consists of worms and insects, which it procures by boring in moist or swampy ground with its long bill.

1 Mr. Hardy in his MS. Notes writes: "1863, April 16th.-Two days ago at Penmanshiel Moss, Snipe were circling round the moor, now rising aloft, then descending humming."

2 Yarrell's British Birds, fourth edition, vol, iii. pp. 344, 345.

3 The nest was found very late in the season, namely, on the 17th of July 1845. -Mr. Hardy's MS. Notes. 


\section{THE JACKSNIPE.}

JUDCOCK, JID.

\section{Gallinago gallinula.}

For I mine own gain'd knowledge should profane, If I would time expend with such a snipe, But for my sport.

Shakespeare, Othello, Act i. Sc. 3 .

Tre Jacksnipe is a much smaller bird than its common congener, ${ }^{1}$ and generally arrives in the county from its breeding grounds in the northern parts of Europe in small numbers towards the end of September or in October. It remains with us throughout the winter and early spring until March or the beginning of April, when it leaves for the arctic regions, where it spends the summer.

In its general habits the Jacksnipe resembles the Common Snipe, and is fond of frequenting marshy places where the herbage is rough. Here it sits closely concealed when not feeding, and is often difficult to put up, even with the assistance of a good dog. When it rises from the ground its flight is slow, zig-zag, and wavering, and on this account it is sometimes missed by the sportsman who thinks it is sure to fall to his gun. I have occasionally seen five or six shots fired at a specimen which, with short flights, kept moving from one part of the bog to another, and rising each time close to the shooter's feet. The Jacksnipe does not utter any cry when it is flushed, and although it is a

1 From its small size as contrasted with the Whole, or Common Snipe, it is called the Half Snipe in Norfolk. -Swainson's Folk-Lore of British Birds, p. 169. 
very small bird, it is considered a delicate morsel for the table; hence the old French quatrain :-

Le bécasseau ${ }^{1}$ est de fort bon manger,

Duquel la chair resueille l'appetet,

Il est oyseau passager et petit,

Et par son goust fait des vins bien juger.

During severe weather in winter, when its usual haunts are frozen and covered with snow, it may be seen frequenting the sides of open drains and ditches in search of its food, which consists of insects of various kinds.

There is no reliable record of this species having bred in the British Islands.

1 It is so called by the game-dealers in Paris.-E. Rolland, Faune Populaire de la France, tome ii. p. 358.

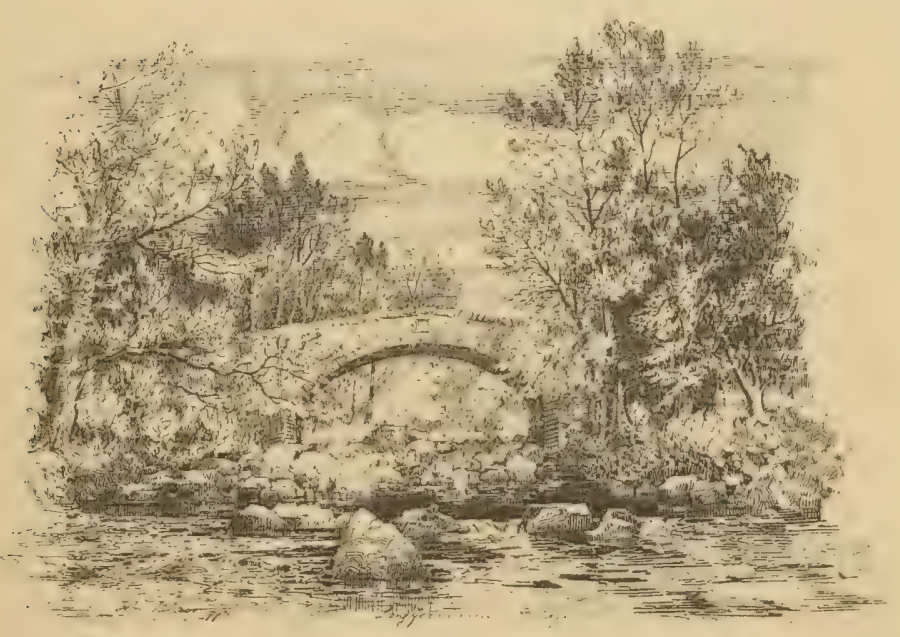




\title{
THE DUNLIN.
}

\author{
PURRE, STINT, SEA SNIPE, PLOVER'S PAGE, SEA LARK, \\ RED-BACKED SANDPIPER, OX BIRD, OX EYE.
}

\section{Tringa alpina.}

The puet, godwit, stint, the palate that allure, The miser and doe make a wastefule epicure.

DRAYTON.

TuE precipitous coasts of Berwickshire are not suitable for the Dunlin, which loves sandy flats projecting into the sea and the mud banks found at low water in the estuaries of rivers, where it feeds in great flocks during autumn and winter. Although most of the birds which compose these flocks migrate in spring to the north of Europe to breed, many betake themselves at that season to wild moorlands in various parts of Scotland, where they rear their young. After the nesting season is over, the birds which have bred in this country are joined at the sea-shore by great flocks which have returned from colder regions.

Although there is no record of the nest of the Dunlin having been found in Berwickshire, yet the presumption is that the bird has bred on the moors about Longformacus, for Colonel Brown has informed me that on the 16 th of July 1885 he shot a Dunlin on swampy, mossy ground, high up, near where the "Grey Mare" and the "Grey Mare's Foal" (two detached boulders) lie on the moor. The nest of this species is usually placed amongst short heather, or under a tuft of grass, and is sometimes difficult to find. The eggs, which are four in number, vary considerably in colour-from pale green to pale buff, spotted with two shades of reddish-brown. 


\section{THE PURPLE SANDPIPER.}

\section{Tringa striatu.}

\section{The Sandpipers,}

A tiny flock, innunnerable, as round

And round they flew, bezwailed their broken ranks.

DELTA, The Fowler.

THE Purple Sandpiper is occasionally seen during winter frequenting the low, tide-covered rocks on some parts of the coast of Berwickshire, including Greenheugh I'oint, near Oldeambus, where Mrr. Hardy says he has observed a small flock popping up and down close to the edge of the sea, like so many mice at play. At ebb-tide it searches amongst the sea-weed on the rocks for small marine creatures of various kinds, and when the tide is flowing in it seems to be fond of feeding close to the edge amid the splashing spray.

This species usually makes its appearance on the coast in October, and departs in May for its breeding grounds in the north of Europe.

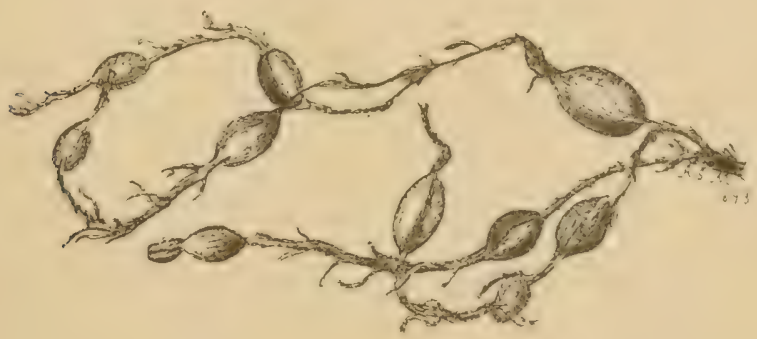




\section{THE R UFF.}

\section{Machetes pugnax.}

Of flesh of birds-roast, grilled, or fried;

Of hare or rabbit, woodcock, snipe:

Of partridge, pheasant, plover, wipe, 1

Of larks for breakfast, or for supper,

(On these I love to cram and stuff).

There's nothing nicer than a fattened ruff.

FOLKARD.

THIs interesting bird was formerly plentiful in the eastern counties of England, where it bred in great numbers, but, owing to drainage and other causes, it is now rarely seen there in the nesting season. It is, however, observed in small flocks on spring and autumn migration.

There are very few recorded instances of the occurrence of the Ruff in Berwickshire. Mr. Charles Watson, Duns, mentions that a female was shot near Burnmouth in October $1873,{ }^{2}$ and Dr. Stuart of Chirnside, writing on the 11th of September 1876, says: "Two rare birds made their appearance at Edington Mains Mill Pond the other day. Mr. Wilson's groom shot one, but the other escaped. Mr. Wilson sent the bird to Dr. Duns of the New College, Edinburgh, who made it out to be the Reeve, the female of the Ruff. I should also mention that the bird which escaped was a young bird, much lighter in the plumage than the one shot. The Reeve was observed to be feeding it with insects from the pond." ${ }^{3} \mathrm{Mr}$. Andrew Brotherston, bird-stuffer, Kelso, states that, on the 22 nd of September

1 The ancient name of the Lapwing.

2 Hist. Ber. Nat. Club, vol. vii. p. 127.

3 Ibid. vol. viii. p. 195. 
1881, he received two specimens in winter plumage from Lennel, near Coldstream. ${ }^{1}$ In these cases the birds appear to have been on autumn migration from their breeding grounds in the north of Europe to their winter quarters in the countries south of the Mediterranean.

Mr. Robert Gray remarks that the Ruff is found in small flocks on the shores of the Firth of Forth, ${ }^{2}$ and on the muddy parts of the estuary of the Tyne-chiefly in September-when its stay is short and its movements uncertain. $^{3}$

During the breeding season the males have a singular addition to their usual plumage in the shape of long feathers on the neck and sides of the head, which form a frill or ruff-hence the name of the bird-and at this time their plumage varies greatly in colour.

The Ruff is polygamous, and desperate fights occur in spring amongst the males. When so engaged they used to be caught with clap-nets in the fens in great numbers.

It has been held in high estimation for the table, and Folkard, writing in 1864, says: "At the present day the price paid for fattened ruff's is often as much as four guineas per dozen, almost as expensive as ortolans, and they are considered by some gastronomes as equally delicious. They are fattened for the table with bread and milk, hempseed, and sometimes boiled wheat, but if expedition is required sugar is added. This latter method of feeding makes them perfectly fat in a fortnight." 4

1 Hist. Ber. Nat. Club, vol. ix. p. 562.

2 Ibid. vol. vii. p. 465.

3 Ibid. vol, viii. p. 52.

4 H. C. Folkard, The Wild Fow 


\section{THE COMMON SANDPIPER.}

SANDY LAVEROCK, SAND LARK, WATER LAVEROCK, SAND SNIPE, SUMMER SNIPE, KILLIELEEPSIE, KITTIE-NEEDIE, WILLY-WICKET, WEET-WEET.

Totanus hypoleucus.

\section{The Sande 严a}

\section{Along the river's stony marge \\ The Sand-lark chants a joyous song.}

WORDSWORTH.

Aвоuт the end of April or beginning of May this pretty bird returns from its winter quarters in Africa to the sides of the Tweed, Whitadder, Blackadder, Leader, Eye, and other waters in the county, where it breeds in considerable numbers throughout the summer, departing southwards again in September.

Shortly after its arrival it may be seen in pairs haunting the gravelly edges of the streams, and flitting from stone to stone along their winding courses. The angler, as he wanders by the river side amongst the beautiful woods and wild flowers which border many of his favourite pools, loves to hear the joyous song of the Sandpiper, which, intermingled with the rippling sound of the water, falls pleasingly upon his ear. If his basket be well filled, contentment reigns in his breast as he rests upon some dry grassy turf for a few minutes whilst recalling to mind the delightful words of old Isaac:-

"I'll tell you, scholar, when I last sat on this primrose 
bank, and looked down those meadows, I thought of them, as Charles the Emperor did of the city of Florence, 'that they were too pleasant to be looked on, but only on holidays,' as I then sat on this very grass I turned my present thoughts into verse, 'twas a wish, which I'll repeat to you :-

$I$ in these flowery meads would be :

These crystal streams should solace me;

To whose harmonious bubbling noise

I with my angle would rejoice."

The "Sandy Laverock's" nest is looked upon by the boys of the county as "rare," being somewhat difficult to find. It is often placed amongst the herbage not far from the margin of the water, in a slight hollow scraped out by the bird and lined with a little dry grass. The egges, which are four in number, are reddish-white, spotted with brown.

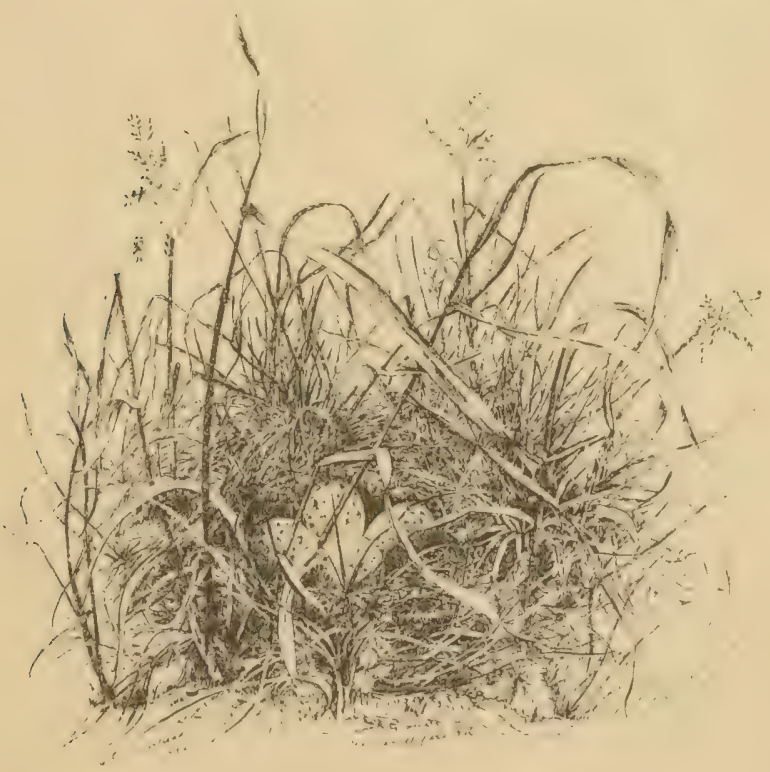




\title{
THE GREEN SANDPIPER.
}

\author{
Totanus ochropus. \\ .... birds of passage piping $u p$ and donn.
}

Tennyson.

ONE morning about the middle of September 1877 the gamekeeper at Paxton House, while walking with his gun in the Wester Grass Park, near my house, heard a shrill whistle over his head, and, looking up, saw two birds like Snipes flying rapidly towards the Tweed at a considerable height in the air. He fired at them, when one fell, which he brought to me, and I found it to be a beautiful specimen of the Green Sandpiper. Mr. Hardy records a male shot near Chirnside on the 1 st of May $1876 ;^{1}$ and, writing under date the 22 nd of August 1877, says: "After a continuation of wet weather several temporary pools were formed in the dean at Oldcambus, which were frequented by Wild Iucks; and the restless liedshanks, leaving the sea-side, circled round the margins. To one of the loneliest also a Green Sandpiper resorted for a few days. It appears to delight in quiet tarns and remote watercourses, where it can pick up worms undisturbed. This is the character of the situations in which hitherto I have surprised this occasional autumnal visitant." 2 It was observed at Oldcambus on the 17 th of July 1879.3 Mr. George Bolam, in a letter to me dated the 25 th of August 1884, writes: "It may interest you to know that yesterday Mr. Evan Sanderson

3 Ibid. vol. ix. p. 401. 
and I saw a Green Sandpiper on the Whitadder near Clarabad Mill." Mr. James Purves, gamekeeper at Mordington, has informed me that he has twice shot this species on that estate, the first instance being in a bog at the "Lang Belt" plantation, and the next in a ditch leading to Mordington Mains upper damhead. Mr. Andrew Brotherston, bird-stuffer, Kelso, mentioned to me on the 19 th of March 1885 that, about the middle of August 1884, three examples were shot on a pond on the march between the farms of Lochton, in the parish of Eccles and Harpertown. Mr. John Thomson, Maxton, tells me that a specimen was shot near Ninewells in the second week of January 1891.1

The Green Sandpiper is very erratic in its movements, and is a visitor to the British Islands on spring and autumn migration.

1 Letter lated the 29th of January 1891.

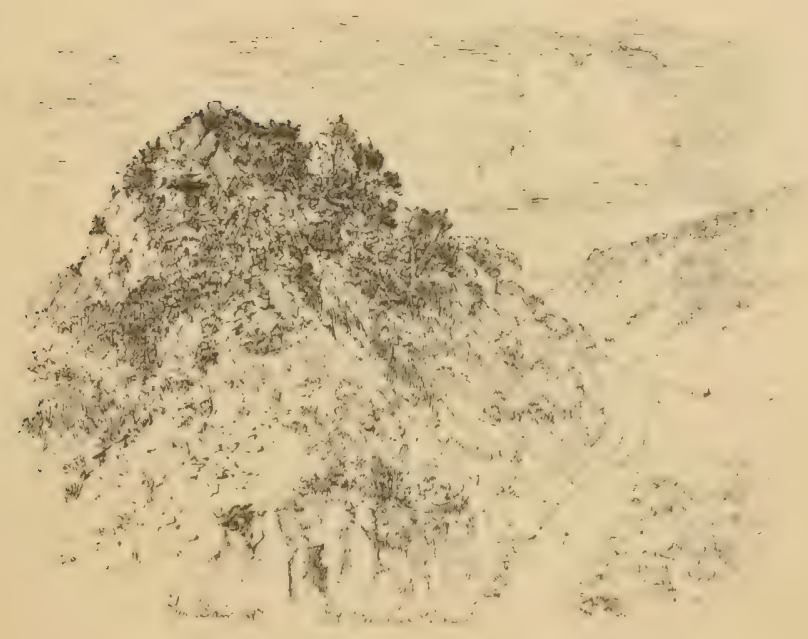




\section{THE COMMON REDSHANK.}

SEA SNIPE, POOL SNIPE, SAND COCK, RED-LEGGED SNIPE.

\section{Totanus calidris.}

\section{The $\mathfrak{e} \mathfrak{e}$ 乌nipe.}

The rede-schank cryit my fut, my fut. ${ }^{1}$

COMPLAYNT OF SCOTLAND.

THE Redshank is found during the autumn, winter, and spring months on some parts of the coast of Berwickshire, such as the neighbourhood of Oldcambus, where Mr. Hardy occasionally sees small flocks about Greenheugh and Siccar Point from about the beginning of July until the end of April.

Although the great majority of the Redshanks are migratory, and leave our shores in spring for their breeding grounds in the northern parts of Europe, returning again in autumn, yet many remain in Great Britain throughout the summer and rear their young in suitable localities. Mr. Gray says that a few pairs breed in the Lammermuirs. ${ }^{2}$ Mr. Tweedie, Swinton Public School, kindly sent to me a note on the 8th of April 1889, saying that a pair of Redshanks had again returned to a field of tussocky grass on the farm of Swinton Hill, lying immediately to the

1 Leyden, in his Glossary to The Complaynt of Scotland, makes out the "redeschank" to be the Fieldfare; but I cannot see how the Fieldfare can be the bird referred to, as its legs are dark-brown, and not red. The Redshank was known by the same name as at present several hundred years ago, at the time when the Complaynt was written (1513-42), and is frequently mentioned in the household books of the 5th Earl of Northumberland, circa 1512, and of the L'Estranges of Hunstanton circa 1527.

2 Hist. Ber. Nat. Club, vol, viii. p. 51. 
south of the village, where it was supposed they had bred in the previous year; and shortly afterwards he showed to my wife the nest containing four eggs, which she sketched on the spot.

The Redshank generally breeds in wild, marshy places, and the nest is but a slight depression in the ground, lined with a little dry grass. It lays four eggs, somewhat like those of the Lapwing in general appearance, though they have a lighter ground colour and redder spots. It is very noisy when the nest is approached. ${ }^{1}$ The food consists of worms and small aquatic creatures of various kinds.

A rock called "Redshank's Rock," on the coast, a little distance to the north of Coldinghan Shore village, has apparently derived its name from this bird.

1 On approacling its nesting ground in the field on Swinton Hill Farm I observed that the birds became very noisy, and flew rounch about me uttering loud calls. Occasionally they alighted on the top of the havthorn hedge and sat there for a short time.

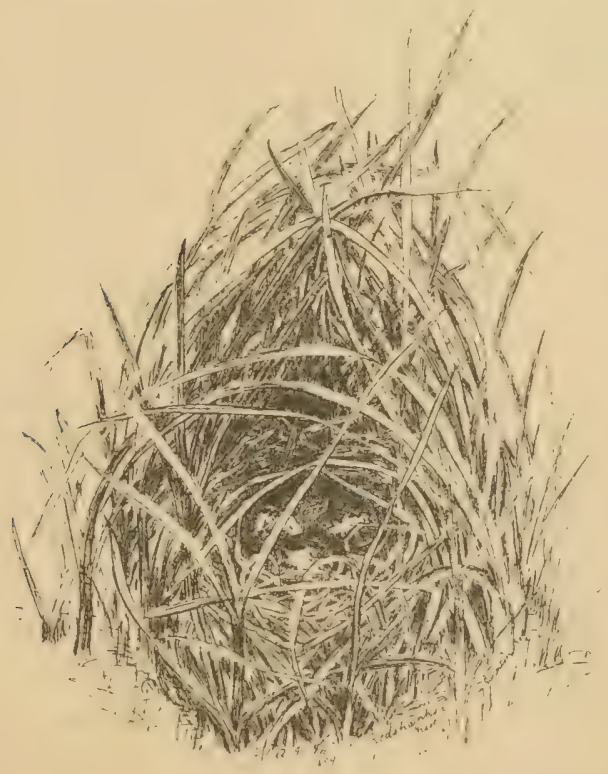




\title{
THE GREENSHANK.
}

\author{
GREEN-LEGGED HORSEMAN, GREATER PLOVER, \\ GREENSHANK SNIPE.
}

Totanus canescens.

The wandering flocks, expelled from northern shores, In varied forms pursue their trackless way, Courting the genial aspect of the south, Whilst iron winter holds his despot sway.

T. Hughes.

As there are no suitable haunts for the Greenshank on the coast of Berwickshire, such as mud-flats, slakes, or marshes, it is very seldom seen, only two instances of its occurrence in the county being recorded. In March 1871 a specimen was shot by Mr. James Trotter, gamekeeper, Paxton House, as it rose from a large ditch which runs through Paxton North Mains Farm and joins the Whitadder at Clairvale Wood. Mr. Andrew Brotherston, bird-stuffer, Kelso, informed me that a female of this species was killed at Lochton, in the parish of Eccles, in August 1884.

This bird is generally found on the coasts of the British Islands when it is passing to or from its principal breeding grounds in the northern parts of Europe, although a few nest in the north of Scotland. It is frequently seen on the shore about Holy Island from August to October, where it is shy and wary. It is larger than the Redshank, and its legs are olive-green. The food consists of worms, insects, crustaceans, and other small marine animals. It is an excellent bird for the table. 


\section{THE BLACK-TAILED GODWIT.}

\section{Limosa agocephala.}

The Godwits running by the water's edge.

JEAN INGELOW.

Like the Ruff, the Black-tailed Godwit was in former times plentiful in the fen districts of England, where it bred; but it is now known there only as a migrant in spring, while passing to its breeding grounds in the north of Europe, and in autumn on its return southwards. It is very rarely seen in Berwickshire, the only instance of its occurrence in the county known to me being that of a specimen which was shot at Dowlaw, near Fast Castle, by Mr. William Cowe about 1864, and which is preserved in the collection of Mr. Peter Cowe, Lochton. The Godwit was accounted a great dainty for the table, and birds fattened on bread and milk were, in the time of Pennant, sold for $5 \mathrm{~s}$. each. It is classed along with the Ortolan by Cowley in the following lines :-

Nor Ortolans, nor Godwits, nor the rest Of costly names that glorifie a feast.

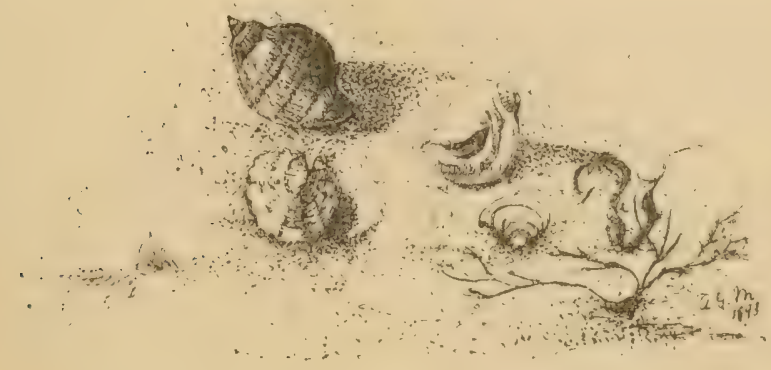

VOL. II. 


\section{THE COMMON CURLEW.}

WHAUP, WHAAP, STOCK WHAAP, WHITTERICK.

\section{Numenius arquata.}

\section{The aalyan.}

Wild as the scream of the Curlew, From crag to crag the signal flew.

Scotr, Lady of the Lake.

Ye Curlezes calling thro' a clud.

Burns, Elegy on Captain Matthew Henderson.

The Curlew is usually associated in our minds with the heaths and mosses of the Lammermuirs, ${ }^{1}$ where from spring to autumn it may be seen Hying in wide circles round the moors uttering its well-known call. Although the peculiar cry from which the bird derives its English name has an eerie and melancholy sound to some ears, yet to others it is very pleasing. ${ }^{2}$ The late Mr. Hewitson says: "I have never traversed the lone wild heath, deserted, except by the feathered race, and at a moment in which $I$ have felt the

1 It is plentiful on Coldingham Moor.-J. Bowhill, 1st April 1886. It abounds on the moors and mosses around Spottiswoode and in the Earlston district. It also frequents the east end of the moss at Legerwood Loch, and Corsbie Bog, near the Tower.-W. Lockie, 28th July 1886.

2 The Rev. John Sheppard, minister of the Parish of Nuirkirk, in Ayrshire, relates that: "A country gentleman from the West of Scotland, who lived in a parish very similar to Muirkirk, both in soil and climate, being occasionally in England for a few weeks, was one delightful summer evening asked out to hear the Nightingale, his friend informing him at the same time that this bird was a native of England, and never to be heard in his own country. After he had listened with attention for some time, upon being asked if he was not much delighted with the Nightingale, 'It's a' very gude,' he replied in the dialect of his own country, 'but I wadua' gie the wheeple of a Whaup for a' the Nightingales that ever sang." -Old Statistical Account of Scotland, vol. vii. p. 601. 
solitary dreariness of the scene, that the wild cry of the Curlew, so much in accordance with all around me, has not come like the voice of a companion to my ear, and produced a delightful feeling of gratitude to that Being who has thus adorned with life and beauty the most sterile and least interesting of His works; and I have thought how great would be the void in the creation were we deprived of this one branch of His glorious productions." 1

In the solitudes of the Lammermuirs the cries of the various birds which are found there-the oft-repeated "Peese-weep" of the Lapwing, the "Cok, cok, cok" of the Grouse, and the plaintive whistle of the Golden Plover -are drowned by the clamour of the Whaup when the wanderer intrudes upon its domain, reminding one of the lines of Leyden :-

How wild and harsh the moorland music floats,

When clamorous Curlew scream with long-drawn notes.

Mr. Hardy in his MS. Notes says: "At Penmanshiel Curlews call about six o'clock in the evening and carry on much later. Their first note is like "Powit, powit," quickly pronounced - usually twice. When sailing or rising up and down it is "Powit," slowly repeated, or the repetition of "Pǒoit-po-oit, po-oit."

In Berwickshire and in other counties of Scotland this bird is called the "Whaap." This seems to be an ancient name, for we find the Scottish Parliament in the time of Queen Mary (1551) enacting "that the wylde-meit and tame meit underwritten, be sald in all tymes cumming of the prices following:-the Quhaip, vl. d." Jamieson in his Scottish Dictionary gives "Quhaip, Quhaup, Whaap," as signifying a Curlew, and he also gives "Quhaip, Quhaup," as

${ }^{1}$ Eggs of British Birds, vol. ii. p. 322. 
the name of " a goblin or evil spirit, supposed to go under the eaves of houses after the fall of night, having a long beak resembling a pair of tongs, for the purpose of carrying off evil doers;" and he adds, "This goblin appears to have borrowed its name from the Curlew." The habit which this species has of flying about in the grey dark of evening, uttering its somewhat eerie cry, has doubtless associated the bird with goblins, witches, and the like. Sir Walter Scott in his Black Drvarf makes Hobbie Elliot say: "What needs I care for the Mucklestane-Moor ony mair than ye do yoursell, Earnscliff? To be sure, they say there's a sort of worricows and lang-nebbit things about the land, but what need I care for them?"

An amusing anecdote in connection with the Curlew is related by a gentleman in Berwickshire who had employed a village carpenter to fit up a glass case for a collection of stuffed birds in a room of his house. Going one morning to see how the work was proceeding, the carpenter, pointing to a number of birds which were standing on the floor at the opposite side of the room, said: "They're some fumnylooking birds owre there. Now what d'ye ca' that yin wi the lang neb?" "Oh," said the gentleman, "that is a Curlew." "Oh aye," remarked the carpenter, "I mind when I was at the schule learnin, "The Curlew tolls the knell of parting day.'" Dr. Henderson in his Popular Rhymes of Bervichshire ${ }^{1}$ says that the people on the Lammermuirs are called "Lammermoor Whaups," as distinguishing them from the inhabitants of the lower districts.

The Curlew is found on the shores of Berwickshire about Oldcambus during autumn, winter, and early spring. It generally leaves the coast about the middle of March for

1 Popular Rhymes of Bervickshire, p. 29. 
the Lammermuirs, where it breeds, and towards the end of July it begins to return to the sea-side. As numbers of this species are seen passing the lighthouses ${ }^{1}$ on the consts of England and Scotland during spring and autumm on migration, it is probable that our Berwickshire birds receive additions to their numbers from these in spring, and that some of those which are bred in this county leave us in autumn for more southern regions, their places being filled up by the autumn migrants from the Highlands of Scotland or more northern climes.

The nest of the Curlew commonly consists of a slight hollow amongst short grass, heather, or rushes, lined with some dry bents or other similar material. The eggs, which are large and pear-shaped, are three or four in number, olive green, blotched and spotted with olive brown, and are generally placed in the nest with their small ends together.

The food of this bird when on the moors in summer consists of worms and insects, ${ }^{2}$ while on the coast in winter it picks up sandworms and other small marine creatures.

On the ground the Curlew generally walks about in a stately manner, and as it is very wary and difficult to approach, I have seldom succeeded in stalking it. When in a flock the birds sometimes fly in the shape of an arrowhead, with a few of them straggling behind.

It is an excellent dish for the table when young and feeding on the moors. In the Eclogucs of Alexander Barclay, ${ }^{3}$ which were written a few years after the battle of Flodden, the poet, referring to the dainty meats at that date, says a shepherd at court must not think to get "swanne nor heron,

1 They frequently strike the lanterns of the lighthouses at night.

2 Mr. Hardy in his MS. Notes, dated the 9th of July 1842, says: "Lauderdale forester's opinion was that Whaups were no nice in their feeding, and eat snails and worms and they kind o' things."

${ }^{3}$ Sibbald's Chron. Scot. Poet., vol. ii. p. 426. 
curlew nor crane," and he again includes it in the following list of delicacies :

The crane, the fesaunt, the pecocke and curlewe, The partriche, plover, bittorn, and heronsewe, Seasoned so well in licour redolent, That the hall is full of pleasant smell and sent.

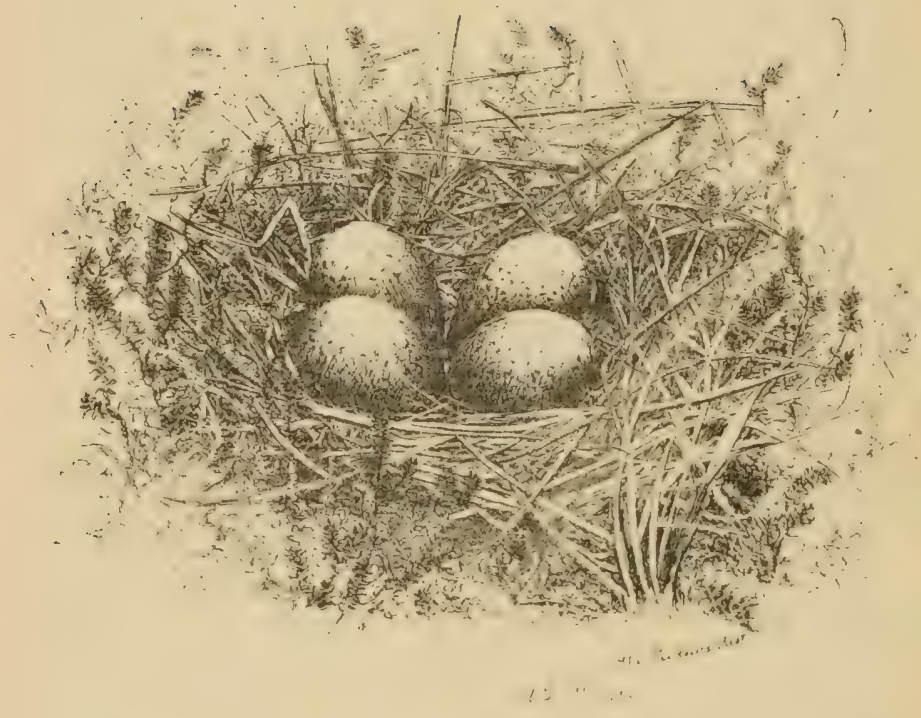




\section{THE WHIMBREL.}

LITTLE WHAUP, LITTLE CURLEW, TANG WHAUP, MAY FOWL, HALF CURLEW, CURLEW JACK.

\section{Numenius phoopus.}

A bird of passage! gone as soon as found.

POPE.

THIS bird is very rarely seen in Berwickshire, there being only one instance recorded of its occurrence in the county. This was in the neighbourhood of Lambden, in the parish of Greenlaw, a fine specimen of a male having been shot there in the beginning of September 1874. ${ }^{1}$

The Whimbrel much resembles the Curlew in its general appearance and habits, but it is considerably smaller in size, as its East-Lothian popular name of Little Whaup indicates.

Mr. Robert Gray says it is a well-known bird on the Dunbar coast in autumn when on migration southwards. ${ }^{2}$ Seebohm says that, so far as is known, the only breeding places of the Whimbrel in the British Islands are in the Orkneys and Shetlands and the north of Sutherlandshire. ${ }^{3}$

${ }^{3}$ Seebohm, British Birds, vol. ii. p. 100. 


\title{
THE BLACK TERN.
}

\author{
STERN, SCARE CROW, BLUE DARR, CAR SWALLOW, \\ CLOVER-FOOTED GULL.
}

\section{Hydrochelidon nigra.}

We hold our course o'er the deep, or the land,

$O^{\prime}$ er the swelling tide or weed-grown strand.

ElizA Cook, Song of the Seagulls.

THE only precise record of the occurrence of this bird in the county is by the late Dr. George Johnston, who, in his IIS. Notes, kindly placed at my disposal by his daughter Mrs. Barwell Carter of The Anchorage, Berwick-on-Tweed, states that a Black Tern was taken at Springhill, near Coldstream, on the 9 th of May 1851, the information regarding its capture having been communicated to him by Miss Anne Hunter.

This species formerly bred in great numbers in the eastern counties of England, but is now only a visitor to the British Islands on spring and autumn migrations. ${ }^{1}$

Mr. Robert Gray says that it is rare on the Dunbar coast, only one or two examples having been shot there. ${ }^{2}$

1 Yarrell's British Birds, vol. iii. p. 517.

2 Hist. Ber. Nat. Club, vol. viii. p. 55.

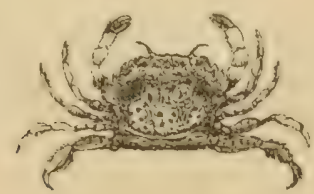




\title{
THE COMMON TERN.
}

PICTARNIE, TARNEY, TARRET, PICKET, SPURRE, SCRAYE, KIRMSU.

Sterna fluviatilis.

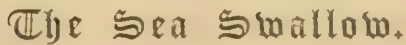

\begin{abstract}
We are safe and joyous when mad waves roll,
We sport o'er the whirlpool, the rock, and the shoal;

Away on the winds we plume our wings,

And soar the freest of all free things.
\end{abstract}

ElizA Cook, Song of the Seagulls.

The Common Tern, which is a summer visitor to the shores of Scotland, is occasionally seen on the Berwickshire coast from May to September, where it may be easily distinguished from the Gulls by its smaller size and forked tail.

I have sometimes observed it near St. Abb's Head, whither it probably came from the Farne Islands, where it breeds in considerable numbers. The food of this species consists chiefly of the fry of fishes, sand eels, and crustaceans.

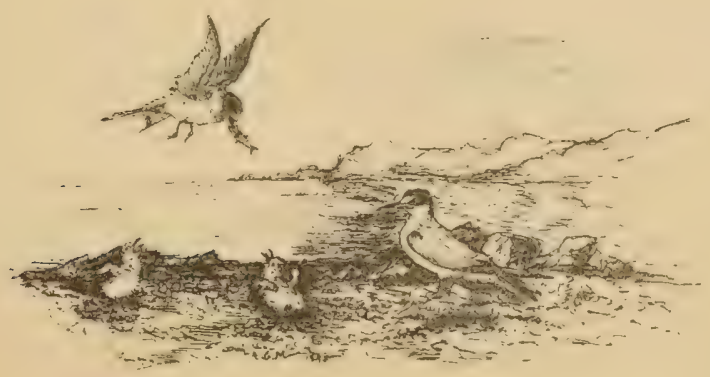




\title{
THE LITTLE GULL.
}

\author{
PIGMY GULL, LITTLE MEW.
}

\section{Larus minutus.}

Not down the breese more blithely flew, Skimming the wave, the light sea-merv.

SCOTT, Lord of the Isles.

THERE are only two instances on record of the occurrence of the Little Gull in Berwickshire, and both of these were at Coldingham Loch. Mr. Hardy, in some notes on this bird, which are given in the History of the Berwickshire Naturalists' $C l u b$, says: "Mr. Andrew Wilson writes to me that a specimen of this rare occasional winter visitant was procured at Coldingham during the stormy weather in the end of December 1869, and is now in his collection." 1 In the same publication Mr. Andrew Brotherston, bird-stuffer, Kelso, writes: "I saw an immature specimen of this beautiful little Gull on the 16th of August 1877 at Coldingham Loch. All the time I was at the loch-about an hour-it was flying gracefully about, busy catching insects, frequently lifting them from the surface of the water, and only occasionally alighting for a few seconds. In its manner of flight it resembled the Sea Swallow, especially at a distance; indeed, the first sight I got of it I thought it was one of those birds. But on a nearer approach - and it came very near, not being in the least shy or afraid-the square tail showed the difference at once. The Little Gull in the collec- 
tion of the late Mr. Wilson of Coldingham, and which was in similar plumage, was obtained at the same place." 1

This species is an irregular visitor to the shores of the British Islands on migration and in winter. In summer it feeds chiefly on insects, which it catches on the wing, and in winter it picks up small marine creatures of various kinds by the sea-shore.

Like our own well-known Black-headed Gull, the Little Gull nests in large colonies on lakes and marshes, its bestknown breeding quarters being near Lake Ladoga, in Russia.

1 Hist. Ber. Nat. Club., vol. viii. p. 522.

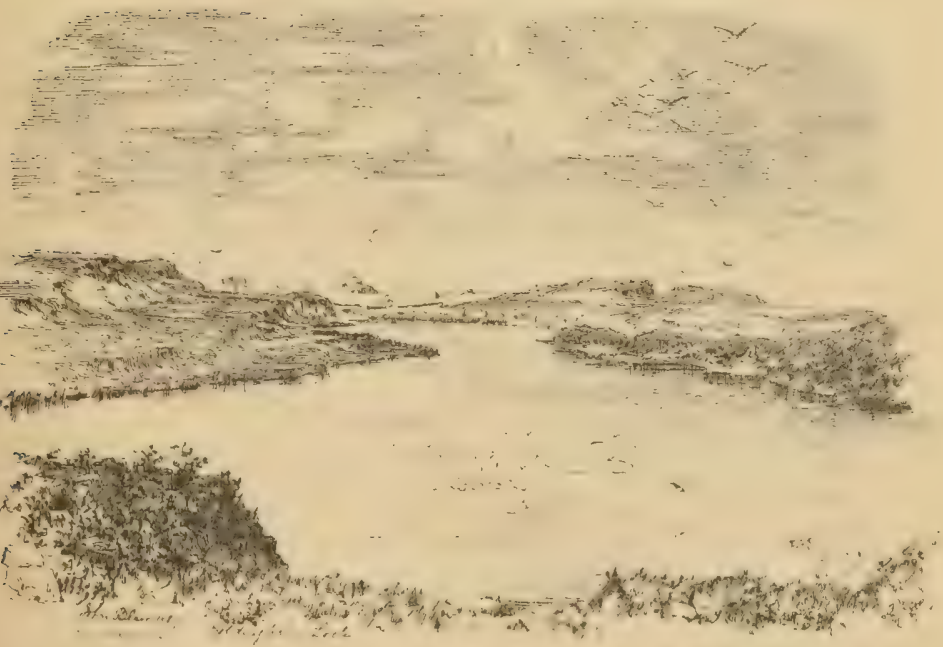




\title{
THE BLACK-HEADED GULL.
}

\author{
PICMAN, PICTAINIE, PICKMIRE, PEWIT GULI, LAUGHING GULL, \\ BLACK-CAP GULL, BLACK-CAP, HOODED MAW, RED- \\ LEGGED GULL, MURE-CROW, SEA-CROW.
}

Larus ridibundus.

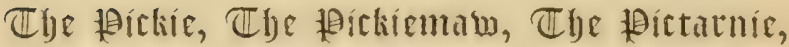 The 担eg:hírnet.}

Perfytelie thir Pikmawis, as for priowris, With thar party habitis, present tham thar.

HOLLAND's Houlat, circa $\mathbf{1 4 5 3}$.

"What do you sec extraordinary about that bird, Hector? It's but a scamaw." "It's a Pictarnie, Sir," said Edie.

Scotr, Antiquary.

Owing to the drainage of many of the pools and marshes which formerly abounded in Berwickshire, the breeding quarters of the Black-headed Gull in the county have been considerably reduced in numbers since the beginning of this century, but several nesting stations still remain. Of these the most important are the Everett Moss, in the parish of Legerwood, and Bemersyde Loch, in the parish of Merton. The Everett Moss, which is also known as the Pickie Moss, Dowie Den Moss Loch, or Legerwood Loch, is situated about a mile to the north of Legerwood, where, on looking eastwards from the rising ground near the road, it may be seen lying in a hollow in the foreground, with the top of old Corsbie Tower peering above the trees a mile further in the same direction, and Home Castle in the distance keeping watch over the Merse. The 
loch, which extends to about twelve acres, is surrounded by flat marshy ground on the north and west; whilst a fir wood of considerable size forms its southern boundary. In summer the surface is almost completely covered with sedges, rushes, and other aquatic plants, through which broad lines of open water appear winding about. Here the Black-headed Gull finds a congenial breeding place, and on approaching the loch during the nesting season it may be seen on the wing in immense numbers ${ }^{1}$ wheeling round and round in circles over the swamp, while little can be heard but its incessant cackling screams. The nests, which are placed amongst the rough herbage of the loch, are so numerous that it is said that upon one occasion as many as sixty dozen of eggs were taken in a night by people from the neighbouring farms, who sold them to the district carrier for $4 \mathrm{~d}$. per dozen. The eggs vary in number from two to three, and are greenish olive-brown, blotched with dark umber. The Gulls generally begin to return to the loch from the sea-side, ${ }^{2}$ where they have spent the autumn and winter months, about the end of February or begiming of March, and nesting operations commence in May. The young, which are distinguished by grey marks on their plumage, may be seen on the wing with their parents in July, and towards the end of that month, or in the beginning of August, the loch is deserted by the Gulls, which then leave their breeding quarters and frequent the sea-shore until the following spring. I have been favoured by Mr. John Thomson with the following account of Bemersyde Loch, which, as already mentioned, is another breeding station of the Black-headed Gull in

1 Mr. James Smail, referring to the Gulls at Legerwood Loch, says: "When startled from their nests they are so numerous that they rise on the wing like a white cloud."-Hist. Ber. Nat. Club, vol. viii. p. 105.

$2 \mathrm{Mr}$. Hardy says that about Oldeambus the Black-headed Gull leaves the coast in March and begins to return about the middle of July.-MS. Notes. 
Berwickshire:- "From time immemorial water-fowl have found a congenial haunt in Bemersyde Loch. In the summer time this stretch of swampy ground at the present day hardly merits the name of loch, for by drainage its dimensions have been gradually reduced until it has become a boggy hollow, the greater portion of which is covered by a luxuriant growth of sedges, reeds, rushes, and many other water-loving plants. The spaces of open water are very insignificant. In winter it attains greater proportions, and, rising to a considerable height, forms a pretty sheet of water. It lies in the northern portion of the parish of Mertoun and close to the Third, where, in former days, stood a peel tower in which members of the ancient family of Haig were wont to reside, Not far off were the towers of Brotherstone, Whitrig, and Sandyknowe, the last only remaining. The loch lies in a hollow where the properties of Mertoun and Bemersyde join, and on more than one occasion it had been the cause of strife and bitter feeling between the proprietors of the two estates until 1678 , when it was divided between Dryburgh and Bemersyde. This division continued for two hundred years, but in 1879 , by an amicable arrangement between Mr. Erskine and Colonel Haig, the latter purchased the half of the loch severed in 1678; thus the entire loch, as it now exists, belongs to Bemersyde. Judging from the conformation of the ground the loch must have been formerly of very considerable extent and depth. The first drainage operations were most probally carried out during the lifetime of Anthony Haig, the 18th laird of Bemersyde. Drainage has in more modem times greatly reduced its level and contracted its boundaries; still there are yet over fifty-five acres partially covered with water or liable to complete submersion. It is a favourite breeding haunt of the Black-headed Gull, and about fifteen hundred pairs 
annually resort thither to rear their young. They are seldom disturbed. Large numbers of Wild Ducks, Water Hens, Coots, Snipes, and Lapwings nest there; Herons are frequent visitors, and the Bittern is a tradition. In winter the loch is the haunt of immense flocks of wild-fowl, including the Wigeon, Teal, Wild Duck, Pochard, Golden-Eye, and Goosander; Wild Geese visit it, and Swans have been occasionally seen and oftener henrd. Whitrig Bog, on Lord Polwarth's estate, is close at hand, and with the exception of the Gulls it has always a share of the birds above noted."

During spring, when ploughing and sowing operations are in progress, the Black-headed (xull is frequently seen in the neighbourhood of its haunts, following the ploughmen in large flocks to pick up any grubs and worms which may be turned up.

An' whan the year smiles, an' Lav'rocks sing, My man Jock an' me shall be doin' o't ;

He'll thrash, an' I'll toil on the fields in the spring, An' turn up the soil at the plowin' o't.

An' whan the wee flow'rets begin then to blaw,

The Lav'rock, the Peasweep, an' skirling Pickmaw,

Shall hiss the bleak winter to Lapland awa,

Then we'll ply the blythe hours at the sawin' o't. ${ }^{1}$

In the summer months the Black-headed Gull is often seen frequenting the Tweed in small flocks, and it is also observed on the Leader. Mr. Hardy, in his interesting account of a meeting of the Berwickshire Naturalists' Club, which was held at Ednam on the 30 th of May 1883, says with reference to Birgham : "The celebrated historical haugh stretches away in a spacious open plain bounded and encircled by the broad Tweed, whose waters, flashing in the sunlight, are skimmed by the Black-headed Gulls, engaged in the pursuit of minnows or water insects, their lively forms finely relieved

1 Poems, chiefly in the Scottish Dialect, by Andrew Scott, Bowden, 1811. 
against the brightness." I It may also be observed haunting the streams immediately below Coldstream Bridge in search of prey, where its sprightly and graceful motions lend additional beauty and interest to the lovely scenery. Mr. Lockie remarks that it frequents the Leader about Earlston.

This species appears to be omnivorous, but its chief food consists of earthworms, grubs, wire-worms, insects, crustaceans, molluses, and small fish.

During the winter the head of this Gull is white, streaked with grey, and there is a patch of grey before the eye and behind the auricles. In March the head and upper part of the neck become dark-brown, making the bird look as if it had a black cap on its head; hence several of its local names. Both Yarrell and Seebohm state that the feathers of the head actually change colour in spring, and do not moult. Mr. Andrew Brotherston, bird-stuffer, Kelso, says : "That it is the result of moulting, in some cases at least, I am thoroughly satisfied. On the 15th of March 1876 I examined the head of an adult male, in which the change was nearly completed, only a few scattered white feathers were left, all of which were old and easily detached, so much so that, excepting a few at the base of the bill, they came off when I was skinning the bird. The black feathers, on the contrary, were all young, new, and in various stages of growth, some fully developed, others just appearing. I examined several examples of the same species in March 1877 , all of which showed unmistakable signs of moulting on the head, and also on the rest of the body, excepting the large feathers." 2

The late Dr. Colville Brown of Berwick writes on the 9th of April 1879: "For the last three years I have closely watched the change of colour in the Black-headed Gull, and I am now quite convinced this proceeds from moulting and

\footnotetext{
${ }_{1}^{1}$ Hist. Ber. Nat. Club, vol. x. p. $253 . \quad{ }^{2}$ Ibid. vol. viii. p. 187.
} 
not from the feathers altering in hue. This happens earlier or later, just as the spring is early or late. In 1877 I observed many Gulls with the brown tinge quite as distinct in the end of January as I did this year at the end of February, and precisely in the same way does the weather affect their departure from the sea-side to their inland haunts. In warm springs they go away early; in cold they remain three or four weeks later with us. Some individuals put on their dark head-dress earlier than others, and these are the first to take their departure. The moult itself begins on the occiput, and spreads over the top and sides of the head; and the slaty-black feathers behind the eye are also shed, and replaced by the sooty-black feathers common to the whole head." 1

Mr. Robert Gray mentions that an albino Black-headed Gull of pure spotless white was shot near Cockburnspath in 1874. ${ }^{2}$ Amongst former breeding quarters of the Blackheaded Gull in the county, which are now deserted, the following may be mentioned: Billie Mire, ${ }^{3}$ the "Hen Poo" 4

1 Hist. Ber. Nat Club, vol. viii. p. 531.

2 Ibid. vol. vii. p. 466.

$3 \mathrm{Mr}$. Alexander Nisbet, rabbit-catcher, Chirnside, informed me on the 22nd of May 1886 that he was born at Blanerne in 1819, and that Mr. John Allan, Billie Mains (father of Mr. John Allan of Peelwalls), had frequently told him that when he (Mr. John Allan, sen.) was a boy he used sometimes to wade into the water at Billie Mire for Picmaws' or Pickies' eggs. This would be about the beginning of this century.

4 Mr. William Duns, Duns, told me on the 20th of May 1886 that, down to about 1835, thousands of Pictarnies used to frequent the "Hen Poo" in the breeding season; and that about 1825, when St. Mary's Cottage at the north end of the lake was being built, the workmen engaged at the cottage used to place a long ladder between the edge of the water and the islands on which the Gulls had their nests for the purpose of procuring the eggs, which they ate. The islands were completely covered with the nests, and great baskets of eggs were collected and brought to Duns. Some years after this the late Mr. Hay caused fires to be kept burning on the islands during the nesting time of the Gulls, and this had the effect of completely driving the birds away. Mr. Hay did this because he disliked the great noise which they made by their screams when they were flying in clouds over the lake. It must have been subsequent to 1842 when the Gulls were banished, for I find Mr. Hardy in his MS. Notes writing in June of that year as follows: "At this period the Pickies or Pictarnies built in abundance on one island in the 'Hen Poo' at Duns Castle, and that the eggs were taken by using a boat to reach the island."

VOL. II. 
at Duns Castle; IJogden Moss, ${ }^{1}$ in the parish of Greenlaw; Corsbie $\mathrm{Bog},{ }^{2}$ on the borders of the parishes of Legerwood and Gordon; and Redpath Bog, in the parish of Earlston. ${ }^{3}$

There is a field on Shannobank Farm, near Abbey St. Bathans, called the "Gull Mire," and as it has the appearance of having been a swamp at one time, it was probably a breeding place of the Black-headed Gull formerly before it was drained.

1 On the 24th of April 1885 the farm steward at Harelaw, near Westruther, mentioned to me that before the Dogden Moss was drained great numbers of Black-headed Gulls used to breed there every year. He had seen them twenty years ago. This Moss is mentioned by the late Dr. Henderson in his Popular Rhymes of Berwickshire, p. 68 :-

\author{
Lift one, lift $a^{\prime}$, \\ Baith at back and fore wa'; \\ Up and away wi' Langton House, \\ And set it down in Dogden Moss.
}

2 "Corshie Moss was once the haunt of the Black-headed Gull, but has been deserted since it was drained."-Hist. Ber. Nat. Club, vol, ix. p. 236.

${ }^{3} \mathrm{Mr}$. Brownlie, Hangh Head, Earlston, wrote to me on 27th October 1887 : "An old man named Sandy Boyd, who lives at Redpath, says that when he was a boy the bog there used to be white with Pickiemaws. This would apply to fifty years ago."

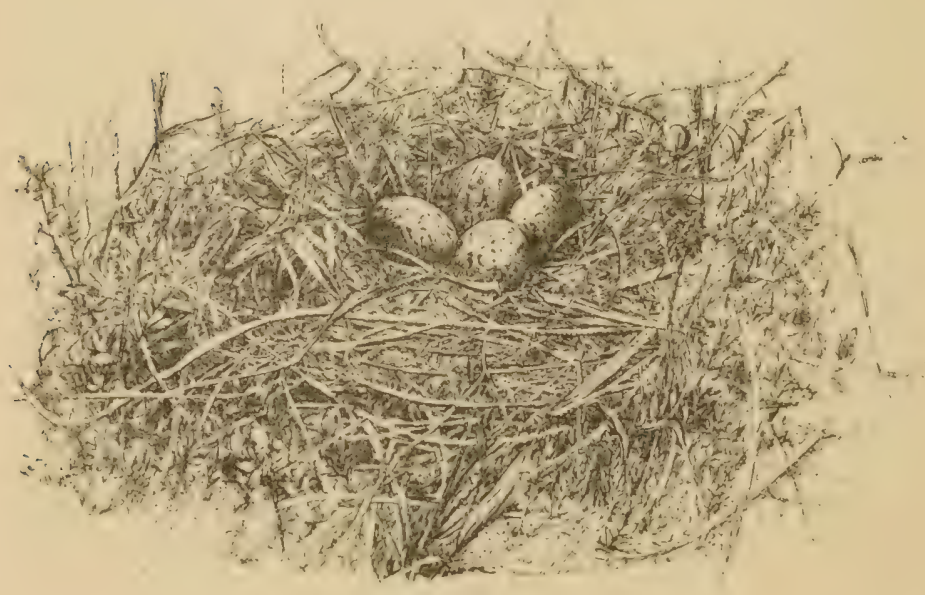




\section{THE COMMON GULL.}

SEA-MAW, MEW OR MALL, SEED BIRD, GREEN-BILLED GULL.

\section{Larus canus.}

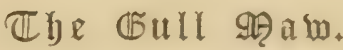

Moor, moor the barge, ye gallant crew! And, gentle ladye, deign to stay!

Rest thee in Castle Ravensheuch, Nor tempt the stormy firth to-day.

The blackening wave is edged with white:

To inch and rock the sea-mews fly;

The fishers have heard the Water-Sprite,

Whose screams forebode that wreck is nigh.

ScotT, Lay of the Last Minstrel.

DURING the autumn, winter, and spring months the Common Gull occasionally comes in flocks from the sea-coast to the interior of the county, where it frequents land which is being ploughed, and grass fields, feeding upon worms and grubs. Its sudden appearance inland in large flocks is, however, looked upon by the country people as a sure sign of an approaching storm of wind and rain, and this has given rise to the following rhyme which is sometimes repeated by children in Berwickshire, as well as other parts of Scotland :-

Sea Gull, Sea Gull, sit on the sand,

It's never good weather when you're on the land.

Dr. Henderson of Chirnside, in his Popular Rihymes of Berwicksture, mentions the following curious superstition: Maggie Shaw's Crockie is a broad, flat stone, abont a mile to the north of Eyemouth. This stone was placed over the 
remains of an old woman who hanged herself, and who, in the shape of a white Sea-Maw, is said to be frequently seen at night-sitting on the

\author{
"glitty stane, \\ Green wi' the dew o' the jaupin' main." \\ "Cold blows the stormy wind, \\ The waves are rushing loud; \\ The moon is in the wane- \\ No star looks through the cloud; \\ High on yon bare, cold rock, \\ Old Maggie sits alane; \\ Ilk night at twal o'clock, \\ She sits upon the stane."
}

The Common Gull does not breed upon any part of the Berwickshire coast at the present time.

The well-known ornithologist, P. J. Selby, mentions in a "Notice of the Birds observed in the neighbourhood of St. Abb's Head on 18th July 1832," which was read to the members of the Berwickshire Naturalists' Club on the 19th of September in the same year, that "this bold headland is also the great breeding station of Larus Camus, or the Common Sea-Maw; it affects the upper ledges and recesses of the precipices, and was observed in great numbers, but so shy as not to be approached within gunshot. The Larus rissa, or Kittiwake, is also numerous, but does not breed in company with the other, selecting in preference the small projecting angles, which barely admit of room for the reception of their eggs and young." " In a paper on "Observations on the Birds observed in the neighbourhood of Cockburnspath in April and those at St. Abb's Head in June 1833," read to the same Club on the 17th of July 1833, Selby again repeats the statement that the Common Gull then bred at St. Abb's Head, for he says: "This species [the Herring Crull-Larus argentatus] had not been observed during our 
excursion in July 1832, having taken its departure from those haunts previous to our visit, the Common Gull (Larus Canus), which breeds in great numbers on the rock to the south of the Head, being the only species then visible." 1

Mr. Archibald Hepburn, in his "Notes on some of the Mammalia and Birds found at St. Abb's Hend," writes: "On the 20th of June last [1851], accompanied by my friend, Mr. Robert H. Broughton, I hired a boat at Coldingham Shore to visit St. Abb's, for the purpose of procuring specimens of birds and making observations on their habits and distribution along the coast. No Common Gulls (Lavus Canus) breed about the Head, but there is a most extensive colony on the Ernesheugh, about two miles to the westward; their nests are placed on the grassy ledges; and although these birds abound on the eastern shores of East-Lothian and Berwickshire throughout the year, yet this is the only breeding place known to me in the sonth-east of Scotland." 2

Mr. Howard Saunders, in vol. iii. of the revisal of Yarrell's British Birds, 1882-84, pp. 613, 614, says with reference to the breeding of the Common Gull (Larus Canus) on the coasts of England: "During the summer the 'common' species are either the Herring Gull or the Kittiwake; and, without making any dogmatic assertions, the editor can safely say that during the past twenty years in which his attention has been given to the question, he has failed to obtain any proof whatever of the nesting of Larus Canus on any part of the English coast. Nor is the evidence satisfactory as to the asserted nesting of this species in the cliffs of St. Abb's Head, or, indeed, in any precipitous cliffs whatever, in the ordinary acceptation of the words. The Common Gull selects, as a rule, the comparatively low shores of small islands, either on the sea-coast or up the arms of the sea; and it is also partial to grassy islands in lochs; but although 
its nests may be found on broken ground, or even on small crags, yet flat surfaces are far more to its taste." $\mathrm{Mr}$ Seebohm, in his British Birds, vol. iii. p. 317, states that "the Common Gull (Larus canus) is intermediate in its habits between the inland and marine species; it breeds indifferently on an island off the coast or on the cliffs of the mainland, and is equally satisfied with an island on an inland lake, or the banks of a mountain tarn." The fact that the Common Gull (Larus canus) is not found breeding on any part of the Berwickshire coast at the present day does not prove that Mr. Selby and Mr. Hepburn-two wellknown and experienced ornithologists-were wrong in their statements as to its breeding about St. Abb's Head in 1832 and 1851, for, like the Kittiwake, which formerly nested there in large numbers, and is not now found breeding on any part of the lierwickshire coast, it may have deserted that locality ats a breeding station. Mr. Hepburn states distinctly that, when he visited St. Abb's Head on the 20 th of June 1851, there was "a most extensive colony of Larnes Canus on the Earusheugh, about two miles to the westward," and that "their nests are placed on the grassy ledges." 1

On the 27th of September 1887 I wrote to Mr. Hepburn on the subject, and on the 4th of October following he replied: "I beg to assure you that I adhere to the accuracy of the statements contained in the article on 'Some of the Mammalia and Birds found at St. Abb's Head,' Hist. Ber. Nat. Club, vol. iii. p. 75, and I may add that I always found Dr. Johnston a faithful and attentive editor of the papers submitted to the (Iub; also, that the Common Gull was a frequent visitor to my native fields in the interior of EastLothian; that the Herring Gull was common along the sea-shore, and several pairs bred on the Bass Rock, and I had in my early days three pets of this species."

${ }^{\prime H i s t . ~ B e r . ~ N a t . ~ C l u b, ~ v o l . ~ i i i . ~ p . ~} 75$. 


\title{
THE HERRING GULL.
}

GULL MAW, WILLIE GOW, CAT GULL, SILVERY GULL.

Larus argentatus.

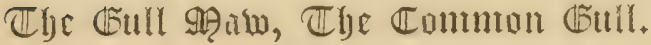

\author{
Bold-winged sea-bird! why so lonely straying \\ Far from thy rocky home, \\ Round which the wild sed-breczes still are playing \\ Above the ocean foam? \\ Say! dost thou hail from yonder cliffs so hoary- \\ From yon rude caverned halls, \\ Where strong Fast Castle, famed in olden story, \\ Still lifts its ruined walls?
}

Walter Chisholm. ${ }^{1}$

Tins Gull is more plentiful on the sea-coast of Berwickshire than any other kind, and is found there at all seasons of the year. It is, however, to be seen in the greatest numbers about St. Abb's Head, where its harsh, cacliling cries fill the air during the breeding season. ${ }^{2}$

Proceeding round the sea-coasi from Lamberton on the eastern boundary of the county to the Cove, towards Cockburnspath on the western limit, the first breeding station of the

$1 \mathrm{Mr}$. Walter Chisholm in his boyhood resided for some years at the upland farm of Dowlaw, near Fast Castle, and here, at the early age of twenty-one, he died on the 1st of Octoher 1877. His poems, edited by Mr. William Cairns, formerly of Oldcambus, are published by Mr. Thin, Edinburgh.

2 Mr. Archibald Hepburn, in his "Notes on Birds found at St. Abb's Head," IIist. Ber. Nat. Club, vol. iii. pp. 74, 75, says, with regard to the cries of the Herring Gull: "their loarse guttural cackle resembling Kaak-ka-kaak, varied only by a sharp loud scream like 'Pee-ul,' filled the air." Mr. Hardy, in his MIS. Notes, compares the cries of some Gulls of this kind, which he heard at Fast Castle on the 12 th of June 1877 , to those of a cat. 
Herring Gull which we reach is a high rock on the shore, about a mile north of Burnmouth village, called the "Gull Rock." Here a considerable number breed, and a few nests are found at Bleak Heugh, a rocky precipice about half a mile further north. There are no colonies of this Gull between Bleak Heugh and the Lighthouse on St. Abb's Head, but on the rocks below the Lighthouse there are a few scattered nests, and we next find it rearing its young on the Cleaver Rock. A short distance further west is Foul Carr, a great precipitous rock standing out in the sea near the part of the Head called the Rampart, and here we find the principal breeding quarters of the Herring Gull on the Berwickshire const. A fine view of the western slope of the top of this rock with its turfy ledges, where the gulls have their nests, and where they are seen sitting in numbers during the breeding season, may be had from the edge of the cliff immediately to the north-east of the ruins of St. Abb's Nunnery. From this point I have frequently watched them with a binocular as they sat on their nests or tended their young, and from it the vignette at the end of this article was taken on the 20 th of July 1887. About a hundred yards westwards the Little Channeler Rock juts out into the sea, and there another colony of this species is found breeding. Immediately to the north-west of the Little Channeler stands the lofty rocky island of Skelly, forming the most northern point of Berwickshire, with Flot Carr adjoining it. On the northern precipices of both of these rocks the Herring Gull nests. Passing the pretty little harbour of Petticowick and Broadhaven Bay we reach West in Thirle Bay, where on the grassy ledges of the Ravensheugh and Thrummie Carr a few more nests of this bird are observed. Further to the west on the rocks below the Uilystrand Brae and at Snuffiehole Stells more occur, also at Maw Carr. Before reaching the Brander Cliffs, where 
there are some more nests, we pass the Moor Baits ${ }^{1}$ and Dowlaw Burn Foot, where a few nests are seen on the rocks between the Standing Man and the Big Byrips. We now reach the ruins of Fast Castle, ${ }^{2}$ where on looking westward on a clear day the view is magnificent, embracing the Bass, North Berwick Law, and the adjoining coast of EastLothian. The situation of the castle is very lonely, and around its decaying walls the only sounds now to be heard are the constant beating of the waves on the rocky coast,

Mix'd with the seafowl's shrilly moans.

Sсотт.

Rounding the point at Fast Castle we see the lilack Mask Rock with a number of Herring Gulls' nests upon it, and still keeping westwards we pass Geddes' Haven and the Little Rooks, and then we reach the Gull Rock and Maw Craig, near the mouth of the Wolden Lee Burn, the most westerly breeding places of the Herring Gull on the Berwickshire coast. ${ }^{3}$ This point is about three-quarters of a mile to the west of Fast Castle.

The nest of the Herring Gull is formed of grass and moss, and the eggs, which are generally three in number, are light olive-brown or greenish, blotched and spotted with dark umber: Many years ago the eggrs of this and other Gulls

1 Mr. Robert Darrie, fisherman, Coldingham Shore, informed me, on the 29th of June 1887, that this was such a favourite spot for fishing for codlings that the following rhyme is sometimes heard amongst the fishermen:-

Come ye soou, or coine ye late, Ye'll a codlin get at Moor's Bait.

2 Here the Princess Margaret, daughter of Henry vII. of England, slept on the night of the 1st of August 1502, when on her way to Edinburgh from Lamberton Kirk, where she had been betrothed to James IV. of Scotland. About a hundred years later the gloomy fortress was the scene of dark plots in connection with the Gowrie Conspiracy, for here Logan of Restalrig resided. Fast Castle is the "Wolf's Crag" of The Bride of Lammermuir.

3 This Gull is, however, occasionally found breeding. further westwards. Mr. Hardy notes, under date 30th June 1886: "A Herring Gull's nest was found yesterday by Professor Lebour's pupils on rocks near Siccar-between it and Redheugh." 
were eagerly sought after by some of the fishermen on the Perwickshire coast, but now they do not appear to go often on egging expeditions. Mr. Hardy notes that about forty years ago "the fishers at Burnmouth went twice a week in 'Gull time' round the rocks which the Gulls frequent to get their eggs. They sometimes got as many as eighty or ninety in a morning, and found them quite as edible as hen eggs. About the above-mentioned time a very adventuresome boy named Kerr-son of William Kerr, fisherman, Burnmouth-was killed by falling from a steep yellowcoloured rock called Dunkirk, on Fairneyside Farm. He was hung round with eggs in handkerchiefs, and had a bonnetful also, when the portion of the rock he held by proved treacherous and down he fell on the black rocks below and was killed. The only expression his three companions heard was 'ae Johnnie.' Some time before this two boys were killed at St. Abb's Head by falling over the rocks when in search of Gulls' eggrs. The first notice which the mother of one of them got of the accident was from the children who had gone with him to the Head coming home crying."

The food of the Herring Gull consists of fish, crustaceans, star-fishes, and other marine creatures. ${ }^{1}$ It likewise feeds upon dead fish and other garbage cast ashore by the waves, and also eats eggs. Mr. Hardy has known it to feed upon the fragments of a bottle-nosed whale which had been carted to the fields at Oldcambus for manure; also under date 1st September 1868 , he writes: "At present when the sea is rough the Herring Gulls are sitting on the oat stubble, and sometimes I see them seated on the stooks. At Siccar

1 Mr. Robert Gray writes: "I have repentedly observed that on the Berwickshire coasts and elsewhere Herring Gulls, and especially young birds, feed to a great extent upon star-fishes. One of which I shot on the 11th of September vomited, when it fell, ten specimens of Asterias mubens, two of which measured nearly three inches across the rings."-Hist. Ber. N'at. Club, vol. vii. p. 466. 
Point, where they sit on the rocks, amongst their droppings are large quantities of oat husks, mixed here and there with mussels and limpets and shells of Purpura lapellus; they seem to feed much upon limpets, and hence frequent the rocks where these are found."

This Gull derives its common name from its habit of following shoals of herrings, whose presence off shore is indicated by its hovering over them in flocks, and every now and then dropping to the water and capturing a fish, reminding us of the following lines of Charlotte Smith :-

And hosts of sea-birds, clamouring loud, Scent with wild wing the welcome shoal, Swift o'er the animated current sweep, And bear their silver captives from the deep.

Captain Norman, R.N., of Cheviot House, Berwick-onTweed, has favoured me with the following interesting note: "While walking along the cliff edge between Burnmouth and Eyemouth on the 16th of August 1887 my attention was arrested by the large number of Gulls which were clustered at intervals along the const. I suspected that these birds marked the position of the fixed nets for salmon, and that they were waiting for the appearance of an inshore shoal of herring, which turned out to be the case. Taking my station, binocular in hand, above the site of one of the nets, I awaited the course of events. I had not long to wait, for in a few minutes the water seemed quite alive with silvery herrings, whose passage along shore had been interrupted by the curtain of the net, or that part of it with which the salmon first come into contact, and which turns their course. The Gulls became very much excited, and were soon in the midst of the shoal by hundreds."

In winter and spring this species is occasionally seen in the interior of the county, where it frequents the grass fields and ploughed land to search for worms and grubs. Its 
appearance in numbers in the inland parts is considered to be an indication of the approach of tempestuous weather, as mentioned by Grahame in his British Georgics:-

No sign of gathering storm, both wind and rain, Is surer than the sea-fowl's inland flight.

Sir David Lindsay, in his Complaynt of Scotland, also alludes to this Gull foretelling stormy weather, for he says: "The Swannis murnit because the gray goul mau pronosticat ane storme."

The Herring Gull is sometimes kept as a pet in gardens, and Mr. Hardy relates that "one which belonged to Mr. William Calder, Gunsgreen, used to go down to the water Eye to wash itself and then returned. A boy in Ayton kept one for a long time, and it used to fly daily to the Eye to wash itself, returning on buoyant wing to the heart of the village. Boys about Oldcambus sometimes catch Gulls by placing a worm on a fishing-hook with a long string attached to the hook."

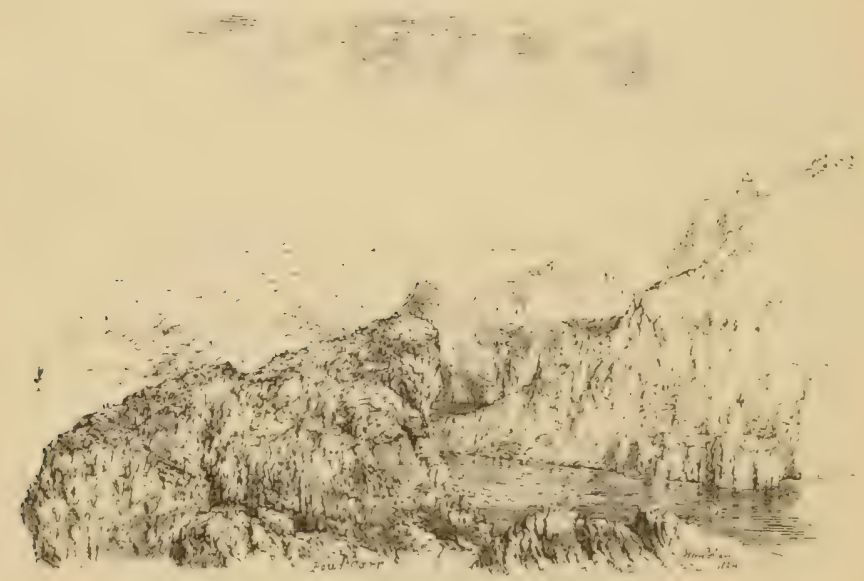




\title{
THE LESSER BLACK-BACKED GULL.
}

\author{
YELLOW-FOOTED GULL.
}

Larus fuscus.

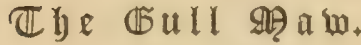

\begin{abstract}
As wave meets wave within some rocky bay, When varying currents hold their whiten'd way; When the shrill sea-mew with unwearied cries, Skimming the sea with restless pinion, fies; When deep ning clouds foretell the wintry gale, And the gaunt mariner clews up the sail.
\end{abstract}

SCAFE's King Coal's Levee, p. 35.

THIs species is seen in small numbers on the coast of Berwickshire at all seasons of the year, and a few pairs breed on the Cleaver liock, Foul Carr, and other precipices about St. Abb's Head in company with the Herring Gull. It occasionally visits the Tweed and the Whitadder ${ }^{1}$ in winter and spring. It feeds chietly upon small fishes and dead animals thrown on shore by the tide.

The nest is made of dry grass, and contains two or three eggs, which vary in colour from yellowish-grey to olivebrown, with spots of purplish-grey and dark-brown.

The feet of this Gull are yellow; hence the proverb: "As yellow as a gull's fit."

1 On the 4th of April 1887 I observed a pair of Lesser Black-backed Gulls sitting on the gravel at the junction of the Dye and the Whitadder.

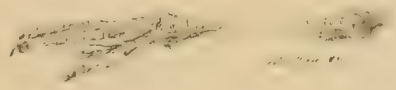




\title{
THE GREAT BLACK-BACKED GULL.
}

\author{
BLACK-BACK, CARRION GULL, GULL MAW.
}

\section{Larus marinus.}

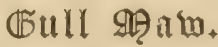

\section{The sea-birds shriek above the prey,} O'er which their hungry beaks delay.

BYRON.

Tuis large Gull is occasionally seen on the Berwickshire seaboard, chiefly in the neighbourhood of St. Abb's Head, but it is not found breeding on any part of the coast of the county at the present time. Mr. Archibald Hepburn, in his "Notes on some of the Birds found at St. Abb's Head in June 1851," says: "The boatman informed me that a single pair of the Great Black-backed Gull (Larus marinus) breeds annually on the Flood Carr, ${ }^{1}$ adjoining the Skelly liock. The Bass can likewise boast of one or two pairs of these noble birds." 2 About 1855 Mr. Wilson of Coldingham gave Mr. Hardy a list of birds which were then found at St. Abb's Head, and in it this species is mentioned as frequenting that locality, but seldom nesting there.

The large size, black back, and loud harsh cry of this Gull easily distinguish it from any of its congeners. Its flight is very powerful, and it seldom allows itself to be approached within gunshot, being very wary. It feeds on fish, carrion, and garbage thrown on shore by the tide; it is also very destructive to eggrs, and robs the nests of Guillemots and other birds. 
GAVIA.

\section{$\rightarrow$ \\ THE GLA UCOUS GULL。}

BURGOMASTER, GOLDEN MAW.

\section{Larus glaucus.}

Not swiftly-but as fly

The sec-gulls, with a steady, sober fight.

Byron, Don Juan.

During winter this large Gull is frequently seen on the coast of Berwiclishire, but generally in immature mottled plumage, in which stage, Mr. George Bolam remarks, that, even at a distance, it may be distinguished from the young of the Great Black-backed and other Gulls by its steady, soaring flight. ${ }^{1}$ A young bird was shot at Eyemouth on the 19th of December $1882 .{ }^{2}$

The Glaucous Gull breeds in the arctic regions, and is only a winter visitor to the British Islands. It is a greedy and voracious bird, and feeds largely upon carrion and garbage of all kinds. It frequently robs other Gulls of their prey.

\footnotetext{
${ }^{1}$ Hist. Ber. Nat. Club, vol. ix. p. 170.

2 Ioid. vol. x. p. 200.
}

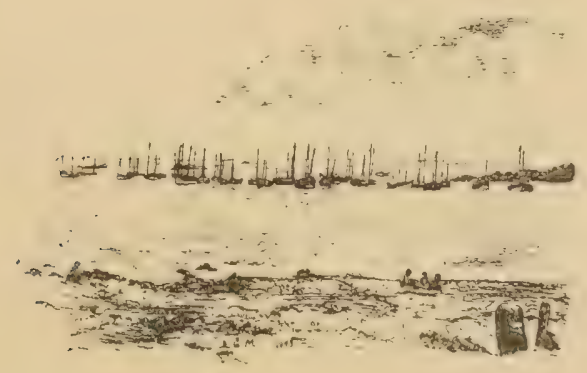




\title{
THE KITTIWAKE GULL.
}

BLACK-FOOTED KITTIWAKE, ANNET, TARROCK.

Rissa tridactyla.

\section{Tye 超aitiemake, Thye Tirrlie.}

\author{
Above, around, in cloudy circles wheel'd, \\ Or sailing level, on the polar gale \\ That cool with evening rose, a thousand wings, \\ The summer nations of these pregnant cliffs, \\ Play'd sportive round, and to the sun outspread \\ Their various plumage, or in wild notes hail'd \\ His parent-beam.
}

MALlet, Amyntor.

ThIs beautiful Gull formerly bred in great numbers on the high precipitous rocks at St. Abb's Head, but does not now nest on any part of the Berwickshire coast. Mr. John Renton of Chesterbank, who in 1794 wrote the report on the parish of Coldingham for the Old Statistical Account of Scotland, says, with regard to the sea-fowl which were then found in that parish: "There is also a prodigious number of sea-fowls known by the name of Scouts and Kittiwakes, with a mixture of Sea Gulls, that arrive in the spring yearly upon the high and inaccessible rocks on the south side of St. Abb's Head. They breed incredible numbers of young, and when the young are ripe, but before they can fly, the gentlemen in the neighbourhood find excellent sport by going out in boats and shooting great numbers of them; when they are killed or wounded they fall from the rocks into the sea, and the rowers haul them into their boats. Their eggs are pretty good, but their flesh is very bad, yet the poor people 
eat them. They leave the rocks about harvest, and none of them are ever seen here before the next spring. ${ }^{1}$ Selby, in his "Account of the Birds observed at St. Abb's Head on the 18 th of July 1832," which appears in the first volume of the History of the Berwickshire Naturalists' Club, remarks that: "The Larus rissa or Kittiwalie is also numerous, but does not breed in company with the other [Larus camus], selecting in preference the small projecting angles, which barely admit of room for the reception of their eggs and young. " The next notice of the Kittiwake on the Berwickshire coast is by Mr. Archibald Hepburn, who, in his "Notes on some of the Mammalia and Birds found at St. Abb's Head on the 20 th of June 1851," says: "Next to the foolish Guillemot, the Kittiwake (Larus tridactylus) is by far the most numerous bird about the Head. Unlike the other species of gull found here, they showed no preference for the tufts of grass growing on the precipices, but built their nests in crevices or ledges of rock, sometimes solitary or in small colonies, which again were occasionally distinct from, and at other times intermingled with, the nests of the Guillemot. This gull derives its name from its well-marked cry, 'Kitty-week,' sharp stress being laid upon the last syllable when the bird is angry or alarmed." ${ }^{3}$ Macgillivray, writing in 1852 , mentions St. Abb's Head as one of the principal breeding stations of the Kittiwake in Scotland. ${ }^{4}$ About 1855 or 1856 the late Mr. Andrew Wilson of Coldingham gave to Mr. Hardy, Oldcambus, a list of the birds which were then found breeding at St. Abb's Head, and in it this species is mentioned as nesting at Skelly, Foul Carr Rib, and the Rampart. About $1857 \mathrm{Mr}$. Hardy submitted the list to Mr. Francis Purves, who was well acquainted with the birds at

1 The Statistical Account of Scotland, by Sir John Sinclair, Bart., vol. xii. p. 57.

2 Hist. Ber. Nat. Club, vol. i. p. 19.

3 Ibid. vol, iii. p. 74.

4 History of British Birds, vol. v. p. 518.

VOL. II. 
St. Abb's Head, and in commenting upon it Mr. Purves noted that "the Kittiwake has deserted the Skelly and Foul Carr Cove or Rib, and now chiefly resorts to the Ramparts. This is since they were so much tormented by the large Newcastle steamboats calling in and firing at them. They are also fewer in number." Under date August 1857 , Mr. Hardy writes in his MS. Notcs: "Kittiwake dwindling away at St. Abb's Head; this is supposed to be on account of their being so much shot at by the London and Leith steamers." On the 11 th of August 1886, when I was on a visit to St. Abb's Head for the purpose of marking on the twenty-five inch Ordnance Survey Map of the coast the breeding stations of the various birds which are found there, Mr. Robert Thorburn, fisherman, Coldingham Shore, ${ }^{1}$ informed me that the Kittiwake reared its young numerously on the perpendicular precipices of the Cleaver Rock long ago, but that none had bred about St. Abb's Head for the last twenty years. It would thus appear that between 1857 and 1866 the Kittiwake gave up nesting there.

This species is now found in small numbers on the coast of Berwickshire during the winter and early spring months, ${ }^{2}$ and is occasionally seen on the Tweed, but it is not observed in the inland districts of the county frequenting the grass fields or ploughed land, like the Common and the Herring Gulls. Its great breeding stations in the vicinity are the Bass Rock and the Farne Islands, where it arrives in vast numbers in spring. After the nesting

1 Mr. Thorburn told me that he was seventy-seven years old, and had fished about the Coldingham coast all his life; also that he had accompanier the "Sappers and Miners," when they surveyed the coast at St. Abb's Head about 1857 , to tell them the names of the rocks. He appeared to be well acquainted with the breeding places of the birds about the Head.

2 Mr. Hardy notes under date 25th March 1874: "A number of Kittiwakes associated in a party with Common Gulls on the Pease Sands."-Hist. Ber. Nat. Club, vol, vii. p. 279. Also on 21st December 1874: "Kittiwake seen passing on the sea banks."-Ibid. vol, vii. p. 282. 
season most of the birds proceed southwards, only a few remaining to spend the winter, but it is supposed that the latter are supplemented by others migrating from the north.

The food of this Gull consists chiefly of small fishes and other soft marine animals.

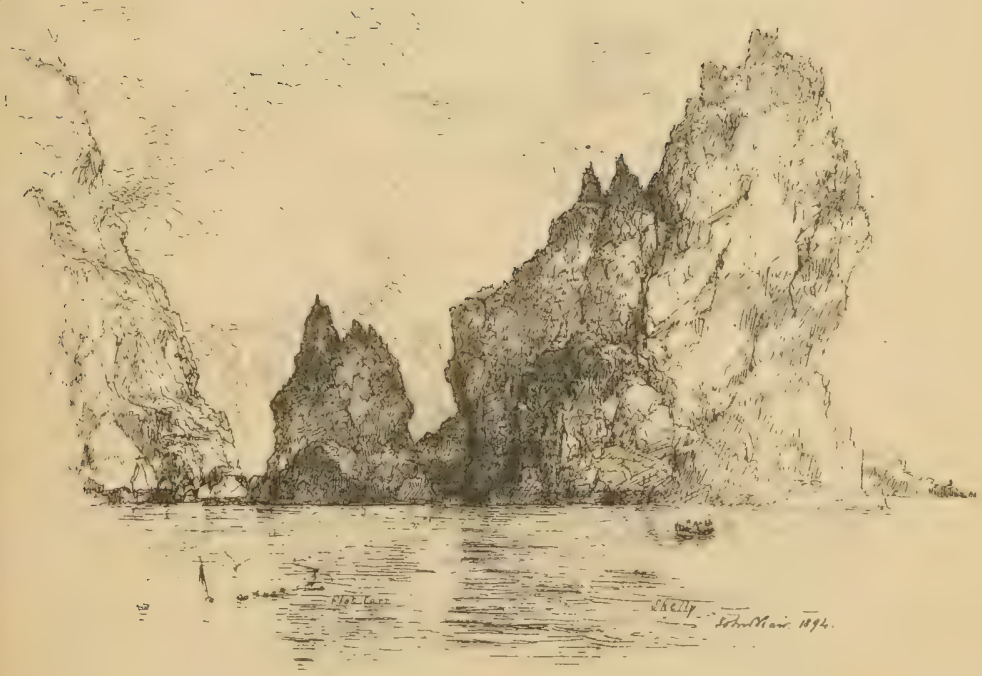




\title{
THE POMATORHINE SKUA.
}

\author{
Stercorarius pomatorhinus.
}

From the frowen north, where Winter's hand

With sway despotic and untam'd locks up

The shrinking world; o'er the wide ocean borne On vig' rous wing, pour forth the feather'd tribes Diverse and strange.

Rev. John VinCEnt, Fowling.

IN the autumn months this visitor from the arctic regions is occasionally seen on the coast of Berwickshire, where, in the middle of October 1879 , great numbers were observed, as well as on the shores of Northumberland, many of them being shot for preservation as specimens. The Pomatorhine Skua has a rapid flight, is bold and rapacious, and frequently robs Gulls of their prey. It breeds in the polar regions.

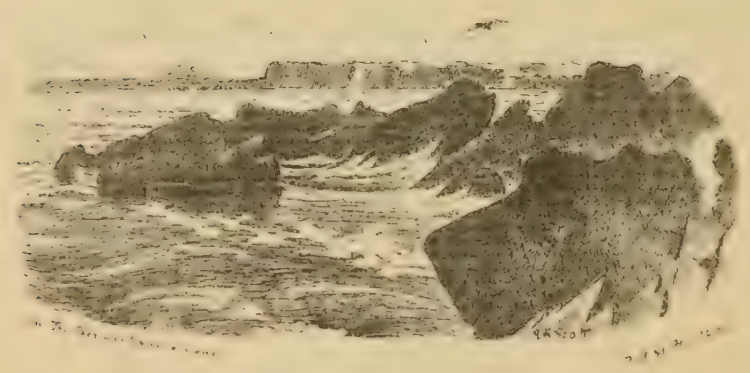




\section{THE ARCTIC, OR RICHARDSON'S SKUA.}

TEASER, SKAIT BIRD, DIRT BIRD, DIRTY ALLAN.

\section{Stercorarius crepidatus.}

\section{Ignorant elf, ape, owl yrregular,}

Skaldit skaitbird, and common skandelair;

Wansukkit funlin, that Nature made ane Yrle,

Baith John the Ross and thow sall squeil and skirle,

Gif eir I heir ocht of your making mair.

The Flyting of Dunbar and Kennedy, circa 508.

Tre Arctic, or Richardson's Skua is sometimes seen on the coasts of the county during the autumn and winter months, being a visitor from the north. A mature male was shot by Mr. Cotesworth on the farm of Whitefield, near Cowden Knowes, on the 12 th of November $1874,{ }^{1}$ this being the only instance of the bird having been found in any inland district of Berwickshire. This Skua occurred in unusual numbers from Coldingham to Cramond in the winter of 1874-75, ${ }^{2}$ when, as recorded by Mr. Hardy, a male and a female were shot at Coldingham Shore. ${ }^{3}$

Richardson's Skua may be distinguished from the Pomatorhine Skua by its smaller size, and narrow, pointed, central tail feathers. Like that bird, it has a powerful and rapid flight, resembling that of a Hawk, and is a great robber of Gulls and Terns, which it chases until they drop their prey. It likewise feeds upon the eggs and young of other birds, and garbage thrown up by the tide.

Its principal breeding quarters are in the arctic regions. 


\title{
THE LONG-TAILED, OR BUFFON'S SKUA.
}

\author{
Stercorarius parasiticus. \\ When the ocean rolls the proudest, \\ Through the foam the sea-bird glides.
}

ScotT.

DURing the storms of the autumn of 1879 great flocks of Skuas visited the coasts of England and Scotland, amongst which were considerable numbers of this species, an example being shot at Eyemouth in November of that year. It was a mature bird, and had the central feathers seven inches longer than the other plumage of the tail. ${ }^{1}$

The Long-tailed Skua resembles Richardson's Skua in its general habits, and may be distinguished from the latter by its smaller size and longer central tail feathers. It breeds in Lapland and other northern regions.

${ }^{1}$ Hist. Ber. Nat. Clutb, vol. ix. p. 169.

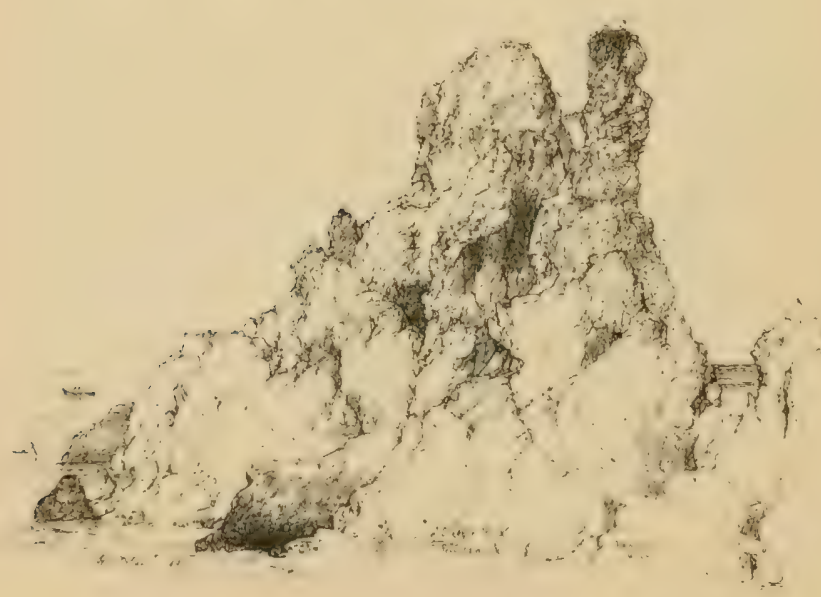




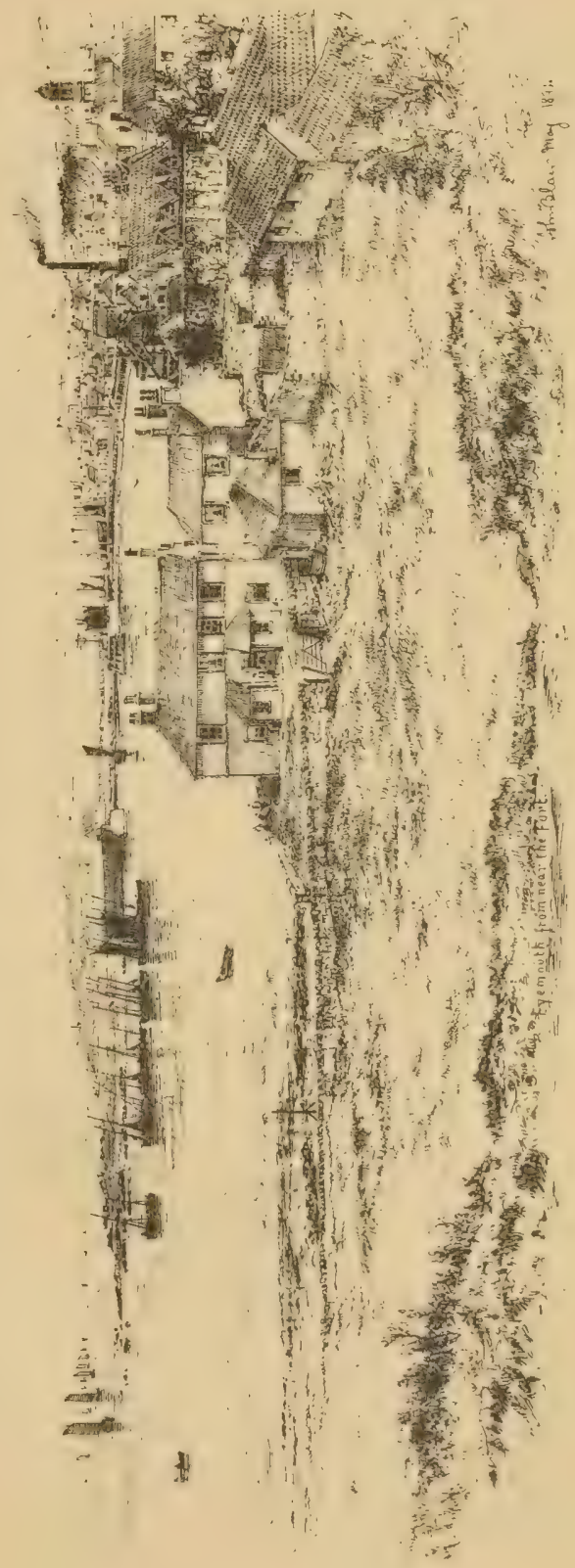





\title{
THE RAZOR-BILL.
}

COMMON AUK, MARROT, SCOUT, SEA CROW.

\author{
Alca torda.
}

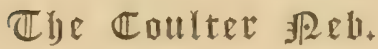

The billows burst, in ceaseless flow, Upon the precipice below.

The steepy rock, and frantic tide, Approach of human step denied.

SiR WALTER SCOTT.

SELrr, writing on the birds observed at St. Abb's Head on the 18th of July 1832, says: "Upon the ledges of the rocks the Guillemots (Uria truile) and Razor-bills (Alca. torda) were seen in great numbers, ranged in order, tier above tier, and looking at a distance like armies of pigmies; these upon the least alarm utter their peculiar curring lind of note, which, when mixed with the screams of the Sea Gull and Kittiwake, and heard from a distance, or softened by the murmurs of the waves, produces a wild though not disagreeable species of concert well according with the nature of the scenery which surrounds them." $1 \mathrm{Mr}$. Archibald Hepburn, in his "Account of the Birds found at St. Abb's Head on the 20th of June 1851," remarks that: "The Razor-bill (Alca torda) is pretty common, but not nearly so abundant as I had anticipated from the numbers found on the Bass; indeed, they did not appear to be so numerous as the Herring Gulls. They generally frequented 
loftier ledges than the Guillemot cared to occupy, and that in little parties, separately, or mixed with other species, and occasionally a solitary bird might be seen tenanting a snug cranny." 1 In a list of birds which frequent St. Abb's Head, given to Mr. Hardy in 1855 or 1856 by the late Andrew Wilson of Coldingham, it is stated that the "Coulter Neb" (Alca torda) then nested at the Rampart, Skelly, and Foul Carr Cove; and comments on this list in 1857 by the late Mr. Francis Purves show that it was then found on all parts of the Head.

From the above statement it would appear that the subject of our notice was formerly much more plentiful at St. Abb's Head than it is at the present time, when it is found breeding in small numbers only, along with colonies of Guillemots, on the ledges of the high precipitous rocks which run into the sea near the ruins of the ancient nunnery. When I visited this haunt in the end of Jume 1886, very few Razor-bills were to be seen, whilst the ledges were covered with hundreds of Guillemots. In size, colour, and habits, this species resembles these birds, and it returns to its nesting places in spring about the same time. Its single egg, which is usually deposited on the bare rock, is smaller and more oval than that of the Guillemot, and is white, blotched, and spotted with reddish-brown. During autumn and winter the Razor-bill is found off the coast of the county, where it feeds on small fishes and crustaceans. It swims with great ease, and is an expert diver.

Mr. Hardy, writing on the effects of the severe winter of $1878-79$, mentions that in February 1879 numbers of dead Razor-bills were found washed ashore near Oldcambus. ${ }^{2}$ 


\section{THE COMMON GUILLEMOT.}

FOOLISH GUILLEMOT, WILLOCK, MURRE, MARROT, SCOUT, SKIDDAW, SCUTTOCK, SEA HEN.

\section{Uria troile:}

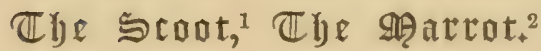

\section{The baron hath the landward park; the fisher hath the sea;}

$B$ ut the rocky haunts of the sea-fowl belong alone to me.

MARY HowItT, Song of the Sea-Fowler.

THE magnificent promontory of St. Abb's Head, where the dark sea-girt rocks tower to a vast height above the restless waves below, is the favourite haunt of the Common Guillemot in Berwickshire. Here it may be seen during the breeding season in closely-packed colonies on the rocky ledges of the gloomy precipices, which are. whitened by the mutings of countless generations of sea-fowl. When a boat approaches the bottom of the cliffs, and the birds are alarmed, vast numbers dash headlong from their eggs towards the sea, their harsh chattering screams, mingled with the clamorous cries of Gulls and other sea-fowl, reminding us of the following quaint description by old Dunbar:-

The air was dirkit with the fowlis

That come with yawmeris, and with yowlis,

With skryking, skryming, and with scowlis, To tak him in the tyde.

1 Scout's Croft, near Coldingham; Scout Cave, on the coast south from Eyemouth; and Scout Point, near Gunsgreen, have evidently derived their names from this bird.

2 So called by the Cove fishermen, -J. Hardy. 
Proceeding round the coast from Lamberton on the east to Cockburnspath on the west, the first colony of Guillemots which we reach is at Whiteheugh, immediately to the north of the village of Coldingham Shore. Here multitudes of birds are seen on the whitened leclges of the overhanging cliff, sitting erect in rows, and so closely wedged together that every available space seems to be occupied by them. As we draw near, their loud, hoarse, curring notes, which they appear to utter in concert from time to time, have a peculiar but not unpleasing effect upon the ear, and are in keeping with the wild nature of the surrounding scenery. When heard on a calm summer night, as the shades of darkness are berginning to creep over the rocky coast, the discordant screams of the innumerable sea-fowl, now swelling loudly along the face of the cliff and again dying away in the distance, produce a weird and fearful sound which clings to the memory, and reminds the listener of the stories of the gibbering holgoblins, witches, and warlocks of the past, who,

wi' monie an eldrich screech and hollow,

frightened the ancient inhabitants of the county.

On passing from the Whiteheugh towards St. Abb's Head a small breeding station of this species is seen on the cliff's immediately to the east of the Lighthouse, and after rounding the Head considerable colonies are found on the Cleaver Rock, Foul Carr, the precipices at the Ramparts, Skelly, and Flot Carr. There is also a nesting place on the face of the steep cliff which looks towards the west, between West Hurker and Petticowick Harbour. ${ }^{1}$ When we reach

1 James Melville in his Autobiography mentions the spring of delicious water which still exists at Petticowick. Describing his tlight in an open boat towards Berwick in June 1584, to escape from his persecutor Aman, he says: "It fell dead caln about the sun drawing laigh. Coming under the Craig, we rowed in within a pretty little howe betwixt the Main and the Head, where, easily going a-land, we refreshed us with cold water and wime, and, returning to our boat, sleeped the dead 


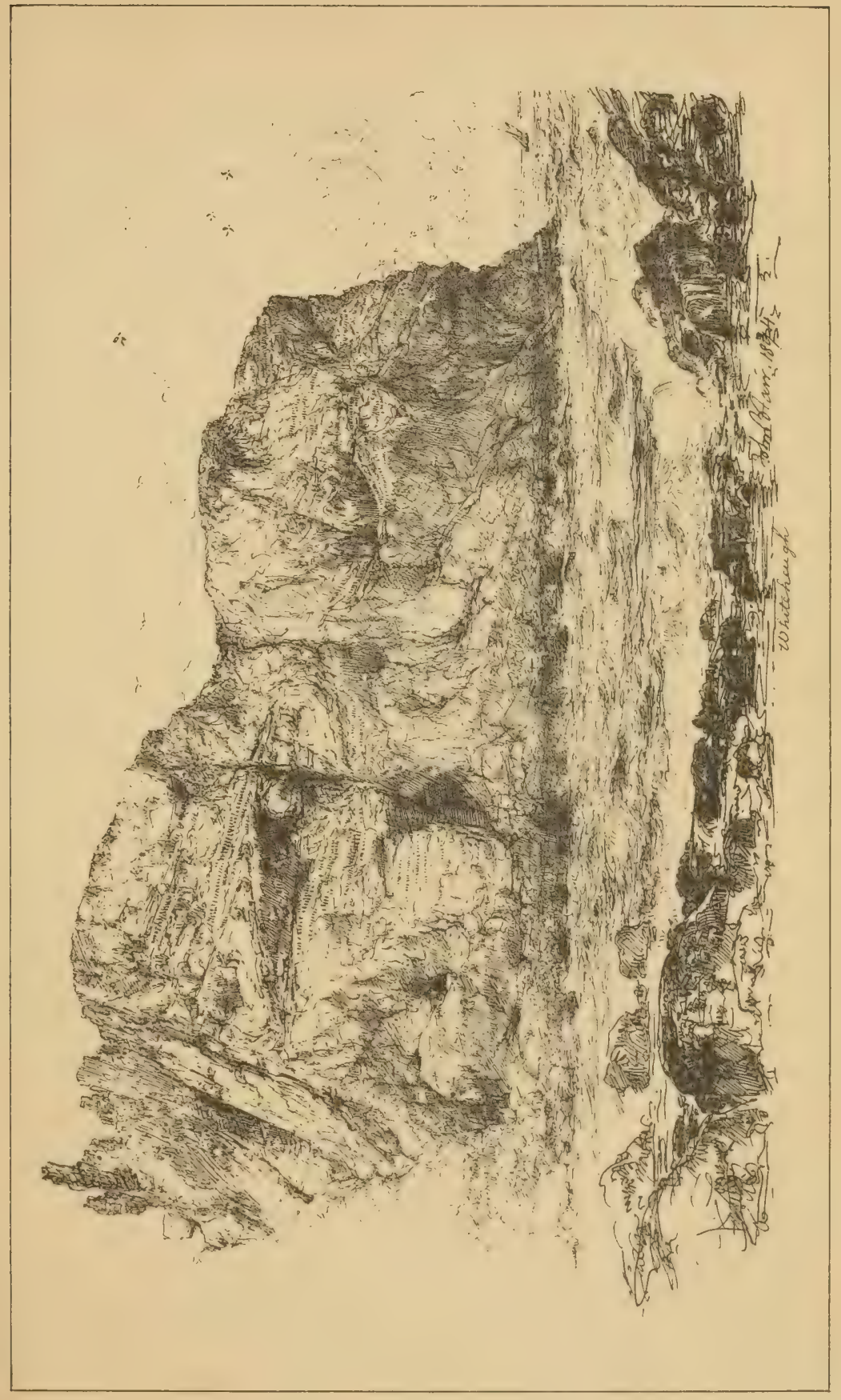



Broadhaven Bay a small colony is seen on the rocks there, and another at the Raven's Heugh ; further on at Thrummie Carr we find another occupying the most westerly breeding place of the Guillemot on the coast of Berwickshire.

Dr. Johnston of Berwick, in his address to the Berwickshire Naturalists' Club on its first anniversary meeting held at Coldstream, 19 th September 1832, referring to a visit of the Club to St. Abb's Head in July of that year, remarks that: "Many of the rocks are insulated, of a pyramidal form, and soar to a great height. The bases of most are solid, but in some pierced through and arched. They are covered with the dung of innumerable flocks of birds which resort here ammually to breed, and fill every little projection, every hole which will give them leave to rest. Multitudes were swimming about, others swarmed in the air and stunned us with the variety of their croaks and screams. Kittiwakes, Sea-mews, and Black-headed Gulls, Guillemots, Auks, and Corvorants are among the species which resort hither." 1

In his "Notes on some of the Birds found at St. Alb's Head on the 20th of June 1851," Mr. Archibald Hepburn states that: "The Guillemot (Uria troile) breeds in countless thousands; ledge above ledge was crowded with birds sitting on their solitary egg laid on the bare rock, and at the report of a gun the birds would waddle to the edge: springing downwards with outstretched legs to break their fall, they sped away on rapid pinion to the open sea. On approaching the base of one of the stupendous cliffs a large flock of these birds, which were reposing on a rocky shelf a foot or two above the water, dashed into the sea; some

of the night, but neederl nane to wake us, for soon be the daylight appeared there was sic a noise of fowls on the craig and about us, because of their young anes, that we were almost pressed to launch out."-Melville's Autobiography, pp. 169, 170.

1 Hist. Ber. Nat. Club, vol. i. pp. 5, 6. 
fluttered along the surface ere they acquired an impetus for flight; others swam about the boat in the most confiding manner, and delighted us all with their graceful movements." ${ }^{1}$ He likewise refers to the Guillemot as being more numerous than any other kind of bird at the Head, and the Kittiwake Gull standing next to it in numbers. ${ }^{2}$ An interesting paper on "St. Abb's Head and its Bird Life" was read to the Natural History Society of Glasgow by Mr. Harvie-Brown on the 26th of April 1881, who, in alluding to his own observations on the occasion of a visit to the Head on the 25 th of July 1880 , remarks that "The Guillemot must be much scarcer now than in Hepburn's time." 3

Judging from the above records, and from what I have noticed during the last few years when occasionally visiting St. Abb's Head in the breeding season, as well as from information obtained from old fishermen who have frequented the Head all their lives, it would appear that the Guillemot has greatly diminished in numbers within the last thirty or forty years. It is difficult to account for this decrease satisfactorily, but probably it may have proceeded from various causes, amongst which may be mentioned the vast quantities of Guillemots' eggs which were formerly taken by the fishermen, ${ }^{4}$ and also the marked increase of the Herring Gull, whose nest-robbing propensities are well known.

1 Hist. Ber. Nat. Club, vol, iii. p. 73.

2 Ibid. vol. iii. p. 74.

3 Proceedings of the Natural History Society of Glasgow, 26th April 1881.

$4 \mathrm{Mr}$. Robert Thorburn, fisherman, Coldingham Shore, who is seventy-eight years old, and has fished in the neighbourhoorl of St. Abb's Head all his life, told me on the 11th of August 1886, when he accompanied me to the Head, that, about forty years ago, he took as many as 180 Guillemots' eggs off Foul Carr in one day, and that he sold the eggs for 1d. each. The eggs of the Guillemots, which occupy the ledges of the precipitous cliffs at the Ramparts, appear to be taken at present by men or boys descending with ropes to the nests, for I have frequently observed strong wooden stakes firmly driven into the ground on the top of precipices to which ropes had evidently been hitched. Mr. Hardy's MLS. Notes bear that about 1837 Guillemots' eggs were sold at $4 d$. per dozen. 


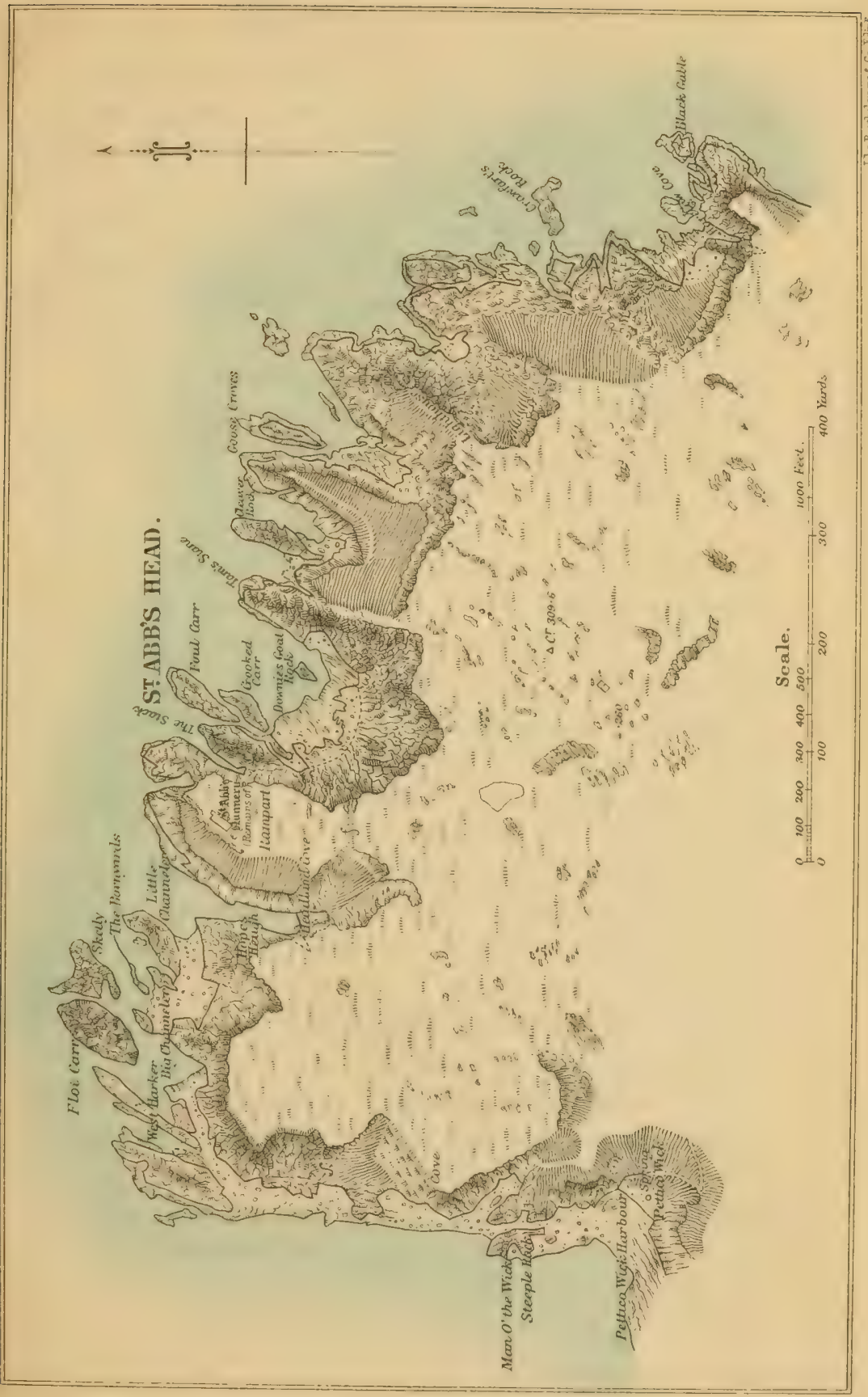



This species lays a single egg on the bare rock, and incubation lasts about a month; the eggs vary greatly in colour, scarcely two being exactly alike, but they are generally either bluish-green, blotched or streaked with dark reddish-brown or black, or white with similar markings. The eggs are very good for the table, and also are said to be used for clarifying wine, and for the preparation of patent leather. ${ }^{1}$

After the breeding season is over-about the beginning of August-the birds leave the clifis at St. Abb's Head with their young for the open sea, where they are seen dispersed during autumn and winter. They return to the rocks in March, and begin to lay in May.

The Guillemot flies with a rapid motion of the wings and at great speed, and, when it returus from the sea to the nesting ledges, curves upwards in its flight as it approaches the rock, and thus alights gently. Its flight is straight, and it is a very expert diver. Mr. Seebohm gives the following interesting account of its aquatic gambols in the salt-water tanks at the Brighton Aquarium: "Using their wings much after the manner that a fish does its fins, they progress through the water, darting hither and thither with great rapidity. In swimming the Guillemot uses its legs as a motor, but in diving the wings alone are used The whole body of the bird is covered with a mass of air-bubbles, and it leaves a train of these bubbles behind it, glistening like silver and pearls, which adds much to the beauty of the performance. Sometimes the descent of the bird is perpendicular, sometimes in an oblique direction, and its progress under the water is made apparently as easily as through the air; even more so, turning and gliding about with ever graceful movements, and sometimes hovering over a morsel

1 Yarrell's British Birds, fourth edition, vol. iv. p. 71. 
of food like a tern. The Guillemots at the Aquarium rarely stay under the surface more than half a minute, but in the open sea I have known them remain down for a much longer time." 1

The Ringed Guillemot which is found at St. Abb's Head is distinguished from the Common Guillemot by having a white ring round the eye. Formerly it was considered to be a distinct species, but ornithologists now look upon it as only a variety of the common bird.

1 History of British Birds, 1883-85, vol. iii. p. 392.

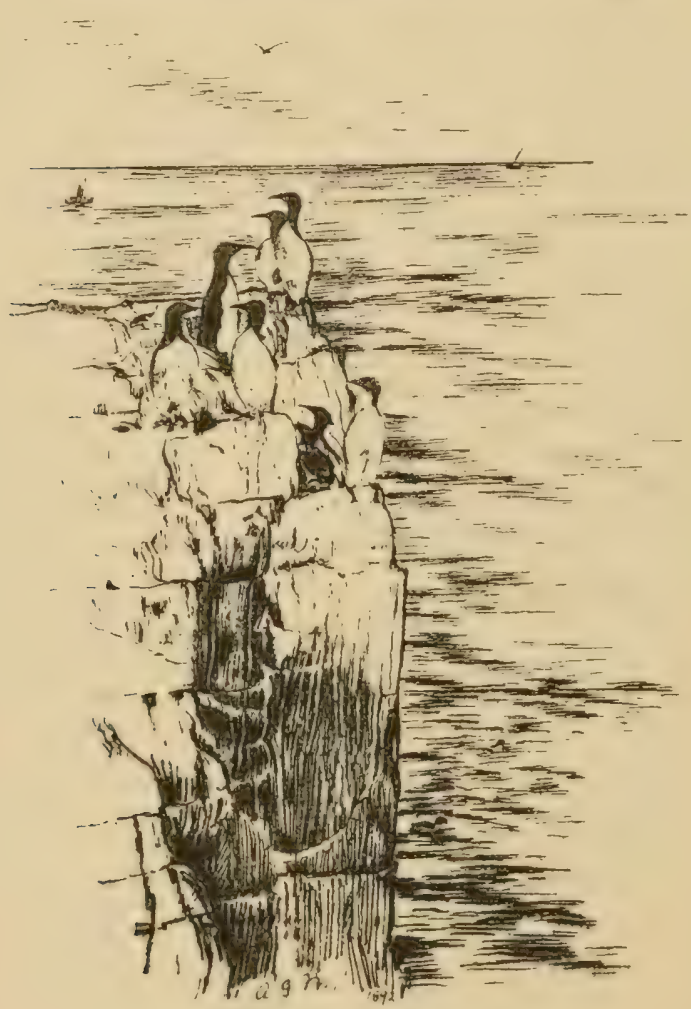




\title{
THE BLACK GUILLEMOT.
}

\author{
GREENIAND DOVE, DOVEKY, SEA TURTLE, LITTLE GUILLEMOT,
} SPOTTED GUILLEMOT, TYSTIE.

Uria grylle.

\section{The Turtle SDolie.}

\author{
I gaze upon the stormy, troubled ocean, \\ 1 hear her crested ruaves \\ Waking, as in they roll with reslless motion, \\ The echoes of her caves. \\ Like armed hosts, impatient for the battle, \\ They swell with deafening roar; \\ Then hurl their force, with thunder, crash and rattle, \\ Upon the sounding shore.
}

WALter Chisholm.

ON the 19th of June 1839 the Perwickshire Naturalists Club met at Coldingham under the presidency of the liev. Thomas Knight, Vicar of Ford, who, in his address to the members delivered at the anniversary meeting held at Milfield on the 18th of September of that year, records that there was exhibited at the Coldingham meeting above mentioned "a living specimen of the Uria grylle or Black Guillemot, which had been shot two days previously at St. Abb's Head." 1 Although this species is not now found breeding at St. Abb's Head, it appears from Mr. Hardy's MS. Notes that in 1857 two or three pairs frequented the rocky precipices there, and that it formerly nested at Tookey and Horsecastle Coves, which are situated to the south of the Head. He also mentions " that some time befure the above 
date a Mr. Pratt, son of a lawyer in Berwick, shot two 'Turtle Doves'1 at St. Abb's Head, and there have not been any seen there since."

The Black Guillemot is now seldom seen off the const of Berwickshire. Mr. Gray, writing in 1883, says: "A few pairs still linger in the vicinity of the Isle of May, in the Firth of Forth, where an occasional nest may yet be taken." 2 It is much smaller than the Common Guillemot, which it resembles in its habits, being about the size of a Puffin. In summer the plumage is wholly black, with the exception of a white patch on the wing, and in winter it is more or less mottled with white.

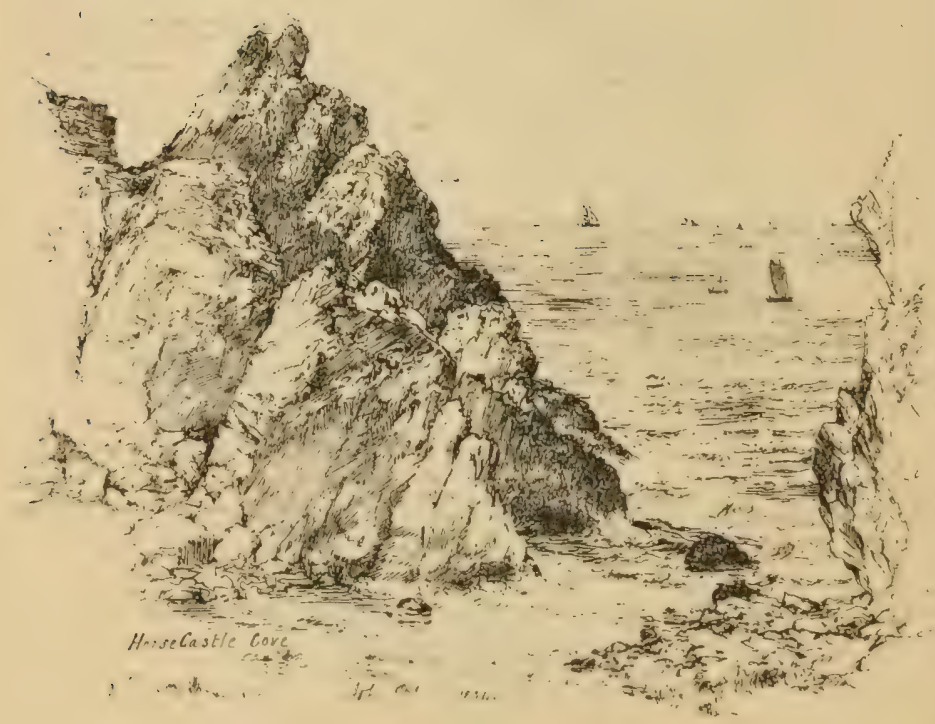




\title{
THE LITTLE AUK.
}

COMMON ROTCHE, LITTLE ROTCHE, LITTLE GUILLEMOT, SEA DOVE.

Mergulus alle.

\begin{abstract}
The time and sessoun bitter, cauld and pale
Thay schort dayis, that clerkis clepe Brumale:

Quhen brym blastis of the northyn art

Ouerquhelmyt had Neptunus in his cart,

And all to schaik the levis of the treis,

The rageand stormes ouerwelterand wally seis.

Ryveris ran rede on spate with wattir broun,

And burnis harlis all thare bankis doun.
\end{abstract}

Gawin Douglas, Description of Winter, ${ }_{5} 12$.

AFTER severe storms this winter visitor to our coasts is occasionally found far inland in a wasted condition, being driven there by the violence of the wind. Writing under date the 27 th of January 1860 , Mr. Hardy mentions in his MS. Notes that one of the Penmanshiel foresters had brought to him a Little Auk which he had found on the railway, wounded below the wing. Probably it had struck against a telegraph wire in its flight. Mr. Kelly relates that a specimen was caught at Harryburn House, near Lauder, which is about twenty-five miles from the sea; and Mr. Wood, lately farmer at Foulden Bastle, informs me that on the 29 th of December 1876 he shot a specimen of this bird which flew out of a plantation on Foulden Estate, near "The Camps," the weather having been very stormy for a week or two before that time. Mr. Hardy records that an

1 Hist. Ber. Nat. Club, vol, vii. p. 306.

VOL. 11 . 
example was caught near Duns in November $1875 ;^{1}$ and the gardener at Abbey St. Bathans lately showed me a specimen which he had picked up dead near the Saw-Mill there in winter, about 1881. This bird was more than usually numerous on the coast in the autumn and winter of $18780^{2}$

The Little Auk measures only about eight inches in length. It breeds within the Arctic Circle. ${ }^{3}$

1 Hist. Ber. Nat. Club, vol, vii, p. 517.

2 Ibid. vol. viii. p. 502.

3 It is stated in Turnbull's Birds of East-Lothian, p. 32, that the Little Auk breeds at St. Abb's Head, but this is a mistake.

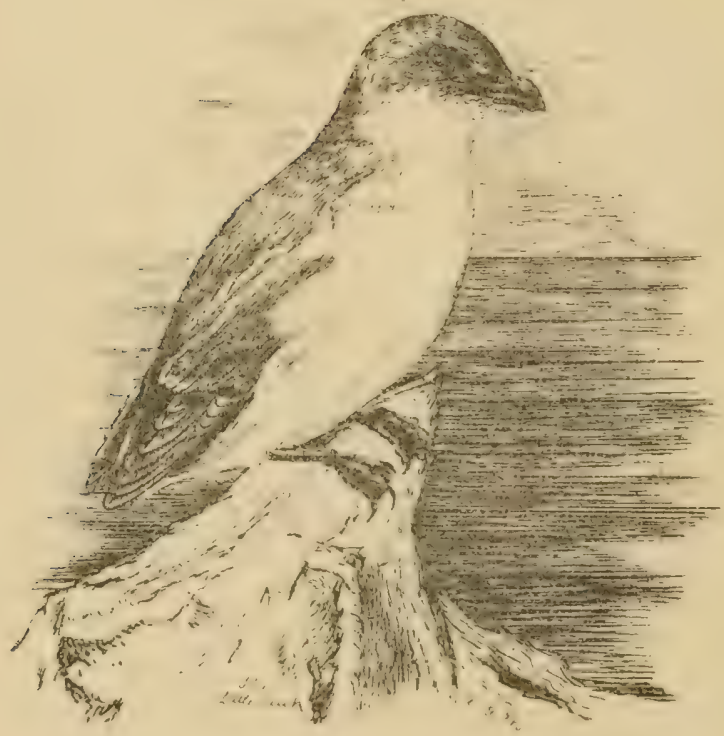




\section{THE PUFFIN.}

SEA PARROT, COULTER NEB, POPE, GULDER HEAD, TAMMY NORIE, ${ }^{1}$ MULLET, BOTTLE NOSE.

\section{Fratercula arctica.}

\section{Tye Tanmíe 海otie.}

Yonder peopled rocks,

To whose wild solitude, from worlds unknown, The birds of passage transmigrating come.

MALLET.

Mr. Robert Gray says that the Puffin is a migratory bird, and all those bred on the Bass disappear early in September, by which time, however, or very soon afterwards, they are replaced by other flocks from arctic waters. ${ }^{2}$

Although this species is found off the coast of Berwickshire at all seasons of the year, it does not appear to breed at St. Abb's Head now; but in former times a few pairs nested there. Mr. Selby, in his "Notice of Birds observed in the neighbourhood of St. Abb's Head on the 18th of July 1832," remarks that the Puffin " also finds appropriate holes wherein to deposit its eggs. It does not appear, however, to be very numerous, as only two or three individuals were

1 "Norweginn noere signifies puellus, homuncio - the boy, or mannikin."Jamieson, Scot. Dict. Chambers, in his Popular Rhymes of Scotland, says that the following couplet is repeated jocularly when a young man refuses to salute a rustic coquette:-

Tammie Norie o' the Bass

Canna kiss a young lass.

He adds that it is also customary to call a stupid-looking man a Tammie Norie.Popular Rhymes of Scotland, new edition, p. 190.

2 Hist. Ber. Nat. Chub, vol viii. p. 54. 
seen during the excursion." 1 Writing of a visit to St. Abb's Head on the 20th of June 1851, Mr. Archibald Hepburn says regarding this bird that "only about a dozen pairs annually build in crevices in the Foul Carr." " In 1855 and $1857 \mathrm{Mr}$. Hardy noted from local information that three or four pairs then nested at St. Abb's Head.

In an interesting paper on "St. Abb's Head and its Bird-Life," ${ }^{3}$ Mr. Harvie-Brown includes the Puffin in a list of species at the end of the paper, but he dnes not say that he saw it breeding when he visited that well-known haunt of sea-fowl on the 25 th of July 1880.

This bird flies very swiftly and is an expert diver, using its wings when under water in the same way as in the air. Its food consists of small fishes, molluses, and other marine animals.

1 Hist. Ber. Nat. Club, vol. i. p. 19.

2 Ibid. vol. iii. p. 74.

3 Read to the Natural History Society of Glasgow, 26th April 1881.

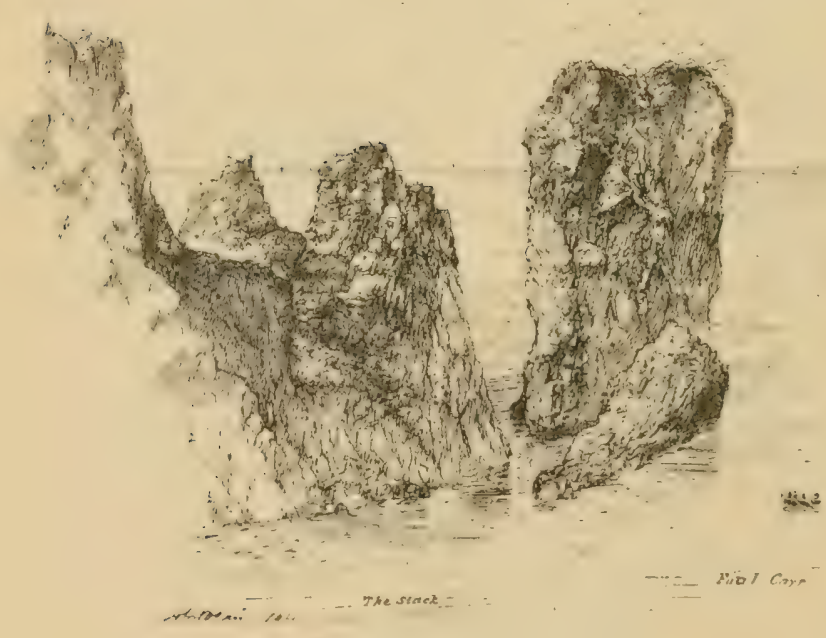




\section{THE GREAT NORTHERN DIVER.}

RING-NECKED LOON, GREATEST SPECKLED DIVER, IMMER OR EMBER GOOSE, GUNNER, NAAK, COBBLE, SEA HERDSMAN.

\section{Colymbus glacialis.}

The Divers were many, and various in hue;

Of the Northern, the Imber, Black-throated a few.

By tribes hyperborean their pelts often songht,

Into robes warm and flexile are frequently wrought.

JENNINGS.

Tile Great Northern Diver is an autumn and winter visitor to the coasts of Berwickshire, where it is occasionally seen, and where its weird and melancholy cry is sometimes heard amidst the booming of the waves when storms have lashed the sea into fury and the rocky shores are whitened with spray.

Mr. Hardy says that a specimen of this bird was found by the Cove fishermen in the nets on the $23 \mathrm{rd}$ of September' 1856 , and that it is considered rare on that part of the coast. ${ }^{1}$ He records that an immature bird was found dead on the shore near Oldeambus on the 1st of April 1875.2 Mr. William Patterson, late farmer at North Berwick Abbey, has informed me that his father, who was tenant at Edington Mill, on the Whitadder, about the beginning of this century, shot a Great Northern Diver on the mill cauld there when it was all frozen over except a small part in the centre. He had observed the bird frequently diving, and got his gun to try to shoot it, but it was not easy to get within gunshot, 
as the sides of the cauld were bare and afforded little or no concealment. He, however, waited until the bird dived, and then ran forward within range of the hole in the ice. When the Diver came up it had a large trout in its bill, and he shot it quite dead. A new difficulty then presented itself to him, namely, how he should get the bird which he had killed, for he was afraid to venture on the ice lest it should break, the water being very deep. His anxiety to secure the specimen was so great, however, that it overcame his fear, and he went cautiously towards the hole, trying the strength of the ice as he proceeded with the butt of his gun, and by this means he succeeded in securing the specimen. The Rev. Thomas S. Goldie, minister of Coldstream, writing in 1834 , records that "a gentleman some years ago succeeded in killing a Great Northern Diver" in that parish. ${ }^{1}$ In August 1884, Mrs. Greet of Birch Hill, Norham, kindly showed me a stuffed specimen of this bird which had been shot on the Tweed there in February 1865.

Its food consists of fish and crustaceans.

1 New Statistical Account of Scotland, vol. ii. (Berwickshire), p. 206.

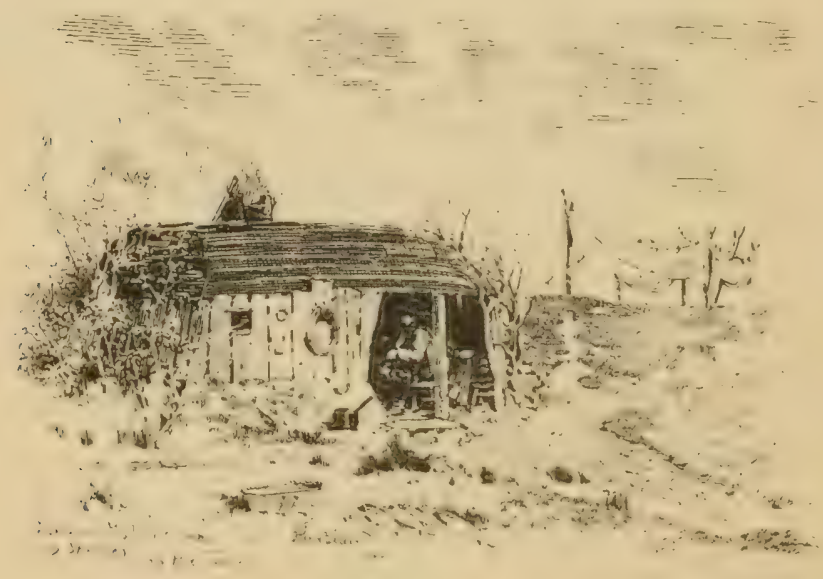




\title{
THE RED-THROATED DIVER.
}

\author{
RAIN GOOSE, SPECKLED DIVER, RED-THROATED LOON, \\ SPRAT LOON.
}

\section{Colymbus septentrionalis.}

\author{
They carol not, but wail from off the deep \\ In piteous accents of impatient grief, \\ And some, like spirits hardened by despair, \\ Joy in the savage tempest.
}

FABER, Sir Launcelot.

THE Red-throated Diver, which is seen off the coast of Berwickshire in the autumn, winter, and early spring months, is called the Rain Goose in the north of Scotland, where its wailing cry is thought to prognosticate wet and stormy weather, during which it is frequently heard. ${ }^{1} \quad$ It is sometimes found on the Tweed and the Whitadder. So long ago as 1793 we find the Rev. Thomas Mill, minister of Ladykirk, recording in the Old Statistical Account of Scotland that Speckled Divers sometimes resort to the Tweed in severe winters ${ }^{2}$ and $I$ have known two instances of its occurrence on that river near Paxton within the last seventeen years. Mr. William Patterson has informed me that he obtained for his collection a fine specimen of this bird killed on the Whitadder near Preston about thirty years ago. An example was caught near the village of Hutton in

1 "Rain Goose-the Red-throated Diver (Colymbus septentrionalis, Linn.), thus denominated because its crying is thought to prognosticate rain." Shet. Caith. -Jamieson, Scot. Dict. Folkard in his Wild Fowler says the cry sounds like "Kakeerah! kakeerah!"

2 old Statistical Account of Scotland, vol. viii. p. 74. 
November 1876. It was unable to fly, and had apparently been driven inland by the stormy weather.

The Red-throated Diver in breeding plumage has a patch of reddish chestnut on the throat, which disappears in winter. It feeds on fish, molluses, and crustaceans, and in diving uses its wings under the water in the same way as when flying. It breeds as far south as Jura, and in Iceland, and other northern parts of Europe.

Although the Black-throated Diver (Colymbus arcticus) has been procured at the mouth of the Tweed, ${ }^{1}$ I have no record of its occurrence in Berwickshire.

1 IIist. Ber. Nat. Club, vol. i. p. 255.

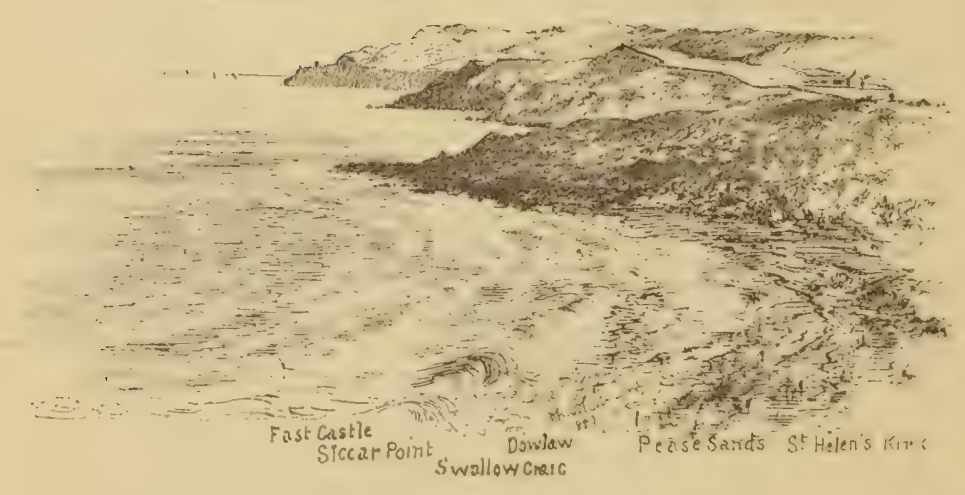




\section{THE GREAT CRESTED GREBE.}

CRESTED DOUKER, TIPPET OR SATIN GREBE, ${ }^{1}$ GAUNT, CAR GOOSE, GREATER LOON, GREY OR ASH-COLOURED LOON.

\section{Podiceps cristatus.}

Thou cream-faced Loon! Where got'st thou that goose look?

SHAKESPEARE, Macbeth, Act v. Sc. 3 .

DURING the autumn, winter, and spring months the Great Crested Grebe is occasionally found off the shores of the county in small numbers. Mr. Hardy mentions that of late years it has been noted as an annual winter visitor, and that it was very numerous in 1879 , when some were seen lingering on the coast as late as the 3rd of May. ${ }^{2} \mathrm{He}$ adds that in the spring of 1880 it was observed for the last time in the season on the $22 \mathrm{nd}$ of March, and reappeared on the 20th of December following. ${ }^{3}$ In 1881 it left the coast on the 29 th of April, and was not noticed in the autumn of that year; only two or three examples were seen in the spring of $1882 .{ }^{4}$ The smooth, silky breast of this Grebe is used for making ladies' muffs, and on this account the bird is frequently pursued by men with gums in a boat, when it dives with such rapidity that it can be shot only after a long chase.

\footnotetext{
1 "From the glossy, silky white skin of the breast being used by furriers for cape trimmings and tippets." -Swainson's Folk-Lore of British Birds, p. 215.

$2 \mathrm{Mr}$. G. Bolam records that he saw a specimen in 1881 as late as 30th May on the Tweed near Berwick Bridge.-Hist. Ber. Nat. Club, vol. x. p. 395.

${ }^{3}$ Hist. Ber. Nat. Club, vol. ix. p. 391.

Tbid. vol. ix. p. 552.
} 
Seebohm says that it has not hitherto been known to breed in Scotland, but that it nests in some parts of England and Ireland. ${ }^{1}$

It feeds generally on fish, frogs, and aquatic insects, and numbers of its feathers are usually found mixed with the food in its stomach on dissection.

1 Seebohm, British Birds, vol. iii. p. 455.

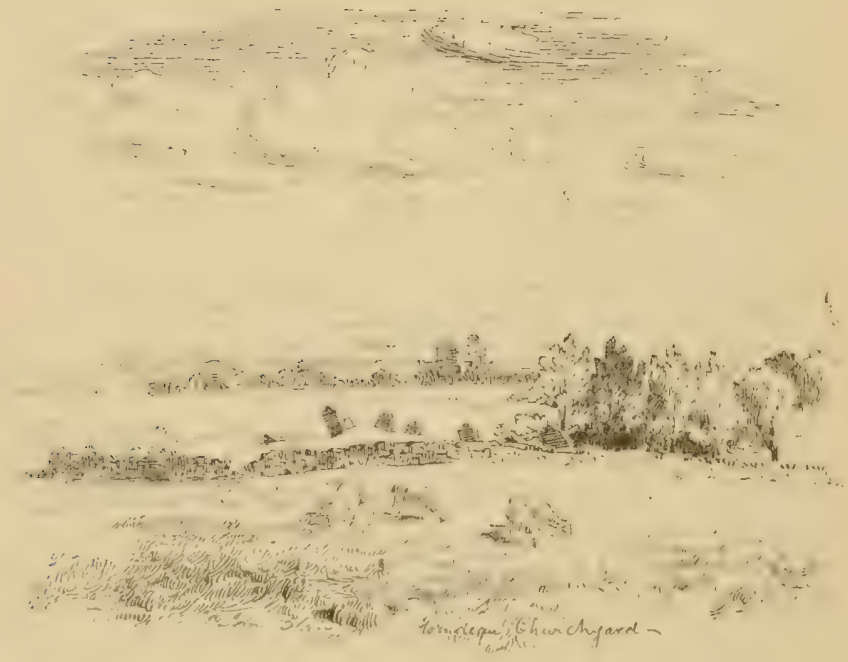




\title{
THE RED-NECKED GREBE.
}

\author{
GREY-CHEEKED GREBE.
}

Podiceps griseigena.

Now up, now downe againe, that hard it is to prove, Whether under water most it liveth, or above.

DRAYTON.

Trie Red-necked Grebe is sometimes seen on the coast of Berwickshire during the winter months, and occasionally in the inland parts of the county, generally in severe weather. Mr. Hardy mentions that a specimen which was shot at the Harbour Pier, Coldingham Shore, on the 10th of December, 1875 , in winter plumage, was added to Mr. Wilson's collection; ${ }^{1}$ and Mr. Gray records that a beautifully marked bird was killed at Coldingham on the 14 th of February $1879 .^{2}$ Mr. J. Logan Mack, Coveyheugh House, has informed me that Mr. Andrew Caverhill, Crichness, sent to him a Red-necked Grebe on the 2nd of February 1881, which was killed on the Lammermuirs during a snowstorm by a shepherd, who knocked it down with a stick. Mr. Compton-Lundie of Spital kindly presented to me a fine specimen of a male in immature plumage, which was shot on the Whitadder at Clarabad mill cauld on the 2nd of February 1888.

This species is considerably less than the Great Crested Grebe, while, like that bird, it dives with great facility. It feeds on fish and aquatic insects. 
Although the Sclavonian Grebe (Podiccps auritus) is doubtless a frequenter of our shores from autumn to spring I have no record of any example of this bird having been obtained in Berwickshire.

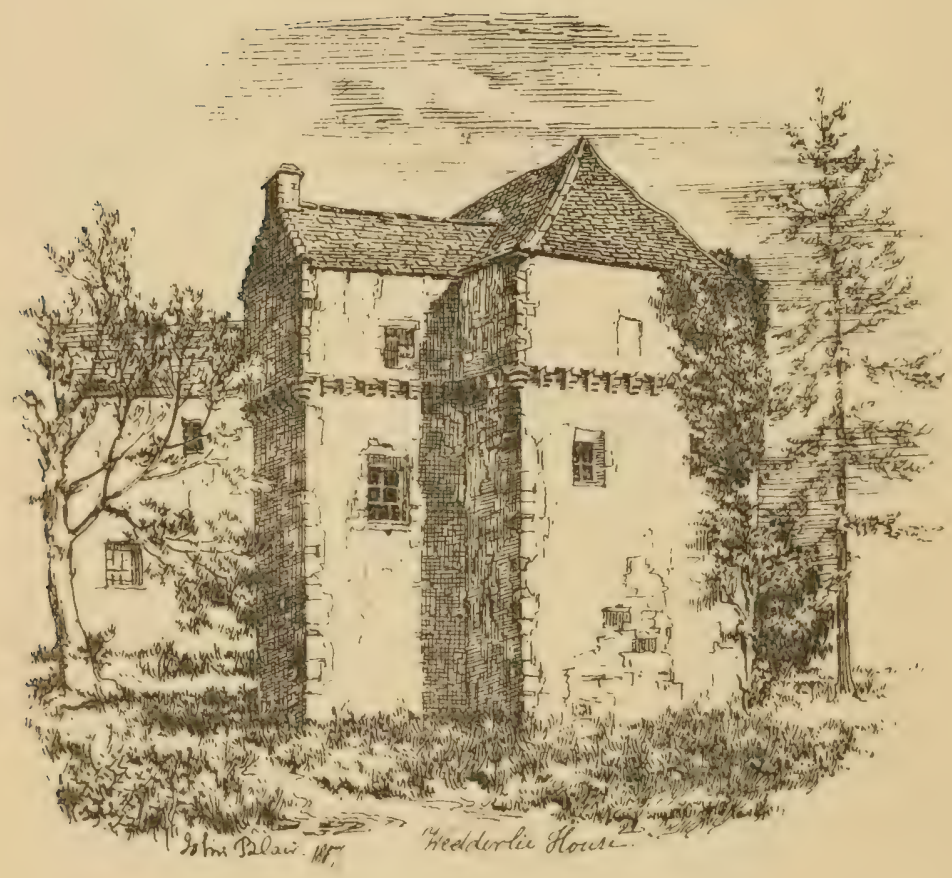




\section{THE EARED GREBE.}

THE BLACK-NECKED GREBE.

\section{Podiceps nigricollis.}

Birds, small and great, of endless shapes and colours, Here flew and percli'd, there swam and dived at pleasure; IVatchful and agile, uttering woices wild And harsh, yet in accordance with the waves Upon the beach.

MONTGOMERY.

Although this is the rarest of the five species of Grebes found in the British Islands, Mr. lobert Gray states that it seems to occur regularly every winter in suitable localities alongshore between Berwick-on-Tweed and Belhaven, ${ }^{1}$ which includes the whole of the Berwickshire coast. Mr. Andrew Brotherston, bird-stuffer, Kelso, informed me on the 1.9th of March 1885 that, some time previous to this date, a specimen was shot on Lithtillum Loch, which is situated on the march between the parishes of Coldstream and Eccles. This is the only instance with which I am acquainted of the bird having been got in the county, but an example killed on the Tweed near Berwick in March 1881 is in my collection. The Eared Grebe may be distinguished from the Sclavonian by the former having the bill slightly recurved, while in the latter it is straight. In its habits and food this bird resembles its congeners.

${ }^{1}$ Hist. Ber. Nat. Club, vol. vii. p. 465. 


\title{
THE LITTLE GREBE OR DABCHICK.
}

\author{
DIPPER, DIVER, DIEDAPPER, DIVEDAPPER, DOUCKER, LITTLE \\ DOUCKER, BOMETIE, MTHER O' THE MATKINS.
}

\section{Podiceps fluviatilis.}

\section{Thy IDipper. ${ }^{1}$}

Upon this promise did he raise his chin,

Like a dive-dapper peering through a wave,

Who, being look'd on, duccks as quickly in.

SHAKESPEARE, Venus and Adonis.

The Little Grebe is a permanent resident in the county, being found in spring, summer, and autumn on the lakes and ponds where it breeds; and in winter on rivers and along the sea-coast when its other haunts are covered with ice.

It is a very expert diver, ${ }^{2}$ and its habits are lively and engaging, especially during the nesting season, when the young may be seen floating about on the surface of the water, their parents coming up from beneath at short intervals to feed them. Mr. Hardy notes that it arrived at Townhead Poud, where it breeds, on the 8 th of April $1882,{ }^{3}$ and that it leaves that resort in the autumn. Mr. John Thomson wrote to me on the 3rd of May 1886 that it nests regularly at Mertoun, and at Hullidean Mill Pond,

\footnotetext{
$1 \mathrm{Mr}$. W. Lockie, Spottiswoode, gives this as the local name of the bird in that locality.

2 Mr. Black, farmer at Girrick, in the parish of Nenthorn, tells me that he has frequently shot at this Grebe on the Eden, but without success, as the bird always lived before the charge reached it.

$3 \mathrm{Mr}$. W. Evans, Edinburgh, has informed me that he saw the Little Grebe on Townhead Pond on the 22nd of April 1886.
} 
Bemersyde. Mr. W. Lockie says it is met with in considerable numbers on Legerwood Loch, and that in winter it frequents the bogs about Westruther and Spottiswoode. The Mill Pond at Foulden New Mains, according to Mr. Millican, is also a favourite resort. I have sometimes observed it on Nabdean Mill Pond, and on the Tweed at Paxton in the winter and early spring months. Mr. A. Kelly, Lauder, relates that "Mr. Scott shot a pair of Little Grebes in January 1875 in St. Leonard's Cauld. When he first came in sight of them they were standing on a broad hemming of ice enclosing the water, but this was only momentary, as both plunged into the water and reappeared in the same place, and this action was repeated over and over again. They were feeding, he thought, on the spawn of trout. ${ }^{1}$ He crept nearer them under cover of the branches to get within shot. Perceiving that they were watched, they instinctively kept in the water, only occasionally putting up their beaks for air in the current-the ice preventing them from getting under shelter of the willows and other strong herbage at the sides. Nany years before that date Mr. Simson, Lauder, obtained a specimen from the same place." 2 Mr. Kelly adds that this bird is very uncommon in his neighbourhood. The Rev. George Cook of Longtormacus has informed me that Mr. Smith of Whitchester shot two examples on the Dye in 1879. Dr. Stuart relates that a specimen was found dead at the side of the Whitadder, near Blanerne, after the ice broke up in December $1879 .^{3}$

I Mr. Brotherston, bird-stuffer, Kelso, writing on the effects of the severe winter of 1878-79, says that the Little Grebes were found to be in good condition, and that, in addition to the remains of aquatic insects and their larvæ, one had a quantity of salmon roe in its stomach.-Hist. Ber. Nat. Club, vol. viii. p. 538.

2 Mr. A. Kelly, "On some of the Birds of Lauderdale."-Hist. Ber, Nat. Club, vol. vii. pp. $305,306$.

3 Hist. Ber. Nat. Club, vol, ix, p. 407. 
The Little Grebe is seldom seen on the wing, and its awkward gait on land is thus alluded to by Pope:-

As when a dab-chick waddles through the copse On feet and wings, and flies, and wades, and hops.

The nest, which is rather large and flat, is composed of aquatic plants, and is generally placed amongst reeds, rushes, or other coarse herbage with little attempt at concealment; the eggs, which are from four to six in number, are white when first laid. They soon, however, become stained, and of a dirty yellow colour, for the bird generally covers the eggs with decaying water weeds on leaving the nest.

The food of this species, which it mostly obtains under the surface of the water, consists of small fishes and aquatic insects of various kinds. Quantities of feathers are frequently found in its stomach.

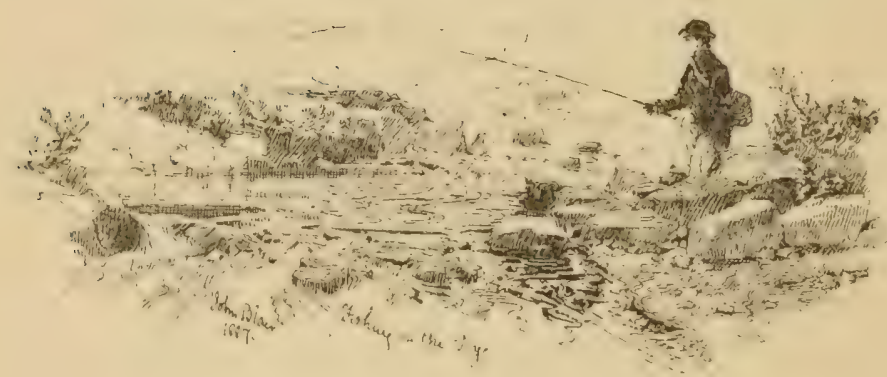




\title{
THE STORM PETREL.
}

MOTHER CATEY'S CHICKEN, STORMY PETREL, LITTLE PETREL, STORM FINCH, WITCH OR WATER WITCH, MITTY,

SPENEY, SEA SWALLOW.

Procellaria pelagica.

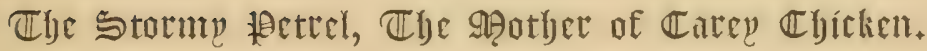

\author{
O'er the deep / o'er the decp! \\ Where the whale, and the shark, and the swordfish sleep! \\ Outflying the blast and the driving rain, \\ The Petrel 1 telleth her tale in vain! \\ For the mariner curseth the warning bird, \\ Who bringeth him news of the storm unheard.
}

B. CORNWALl.

The Rev. John Turnbull of Eyemouth mentions that in particular states of the weather this bird is seen at no great distance from the coast; ${ }^{2}$ and Mr. Hardy notes that it was seen at Coldingham Shore on the 7th of January 1861.

It is sometimes driven inland during very stormy weather, and as instances of this it may be mentioned that the occurrence of a specimen at Oxton, six miles north from Lauder, is recorded by Mr. Kelly, ${ }^{3}$ and another, which was got at Cranshaws, in the Lammermuirs, many years ago, was stuffed by Mr. W. Duns, Duns.

I The Petrel is so named from the French pétrel, a diminutive of Pétre, i.e., Peter; and the allusion is to the apostle walking on the Sea of Galilee. Whilst skimming along the waves its legs hang down, and the feet seem to touch the water, presenting the appearance of walking.-Swainson's Folk-Lore of British Birds, p. 211.

${ }^{2}$ New Statistical Acconnt of Scotland (Berwickshire), vol. ii. p. 322.

3 Hist. Ber. Nat. Club, vol, vii. p. 306.

VOL. II. 
Mr. Gray, writing of the effects of the storm of the 14th of October $1881,{ }^{1}$ on bird-life in the Firth of Forth, after alluding to the various sea-fowl which had been driven by the violence of the hurricane to take shelter near the coasts, says: "Simultaneously there appeared large numbers of Storm Petrels, many of which were blown some distance inland, where they were captured-records of the birds having been caught or otherwise dispersed having reached me from Dunbar and the Lammermuirs. The main body, however, remained in the Firth eight or ten days, during which time the birds frequented for the most part the lee side of Inchkeith, quite near to the anchored ships that had been forced there for shelter. A lesson, indeed, might have been derived from their presence by the captains of oceangoing steamers, several of whom, impatient of delay, had set sail-in some cases oftener than once-only, however, to return, partially disabled, to their former anchorage. The Petrel, actuated no doubt by an unerring instinct, wisely remained under shelter; and I would venture to say that in any future case, when these birds are seen under such circumstances, much expense might be saved by masters of windbound vessels if they quietly remained at their anchorage until the Petrels let them know when it was time to leave. I commend this observation to my friend Mr. Buchan, the excellent Secretary of the Scottish Meteorological Society, as

${ }^{x}$ During this terrible and disastrous storm, when the sea, lashed into unprecedented fury by the hurricane, overwhelmed upwards of one hundred and fifty fishermen, with their boats, from the villages on the sea-coast of Berwickshire, the Storm Petrel was seen at various places along the shore. Mr. Campbell-Noble of Coldingham has informed me that during the height of the tempest a boat, belong. ing to Alexander Wilson of Coldingham Shore, was driven with some others round by St. Abb's Head. When the boat was in momentary peril of being dashed to pieces on the rocks as it was rounding the most dangerous part of the Head, and the men were lying on the deck with their arms through the bulwarks, a "halflang" lad, named Thomas Wilson (John's Tam), stretching out his legs, touched one of the men, and said, "Geordie! yonder's a Stormy Petrel!" The man, apparently looking upon this remark as most untimely, was heard to reply, "Stormy Petrel! If I could get at ye, I would Stormy Petrel ye." 
a means of increasing the interest, if not the importance, of future weather forecasts." 1

The Storm Petrel is about the size of a Sparrow, and is one of the smallest web-footed birds. It breeds on various parts of the coasts of Great Britain and Ireland, and feeds on small fishes, crustaceans, and molluses.

1 Hist. Ber. Nat. Club, vol, x. pp. 85, 86.






\title{
MIGRATION OF BIRDS IN BERWICKSHIRE.
}

\author{
Birds, joyous birds of the wandering wing! \\ Whence is it ye come with the flowers of spring? \\ HEMANS. \\ . . . IVild birds that change \\ Their season in the night, and wail their way \\ From cloud to cloud.
}

Tennyson.

For many years past the Migration of Bircls has attructed the attention of ornithologists, and although much information has been collected regarding it since the days of Gilbert White, whose delightful work on the Natural History of Selborne is a perennial source of pleasure to all lovers of Nature, yet much has still to be obtained before the subject can be fully elucidated, and removed from the region of conjecture.

We find that with the approach of the cold weather in autumn certain species of birds, such as the Swallow, leave the county for southern climes, whilst somewhat later in the same season, others, like the Wild Goose, come here from northern regions and take up their abode with us for the winter. With the return of the genial weather in spring the former appear here again in their usual haunts, whilst the latter Hy away to the north to spend the summer in Lapland or Siberia. These are true migrants, as distingruished from birls of passage, such as the Dotterel, which only visits the county for a short time in spring on its way northwards to its nesting grounds, and again in autumm on its way southwards to its winter quarters. In addition to the true migrants and this bird of passage, we have partial migrants like the Thrush and the Redbreast, the majority of which pass southwards in winter and return 
in spring-a comparatively small number remaining with us during the winter months.

Speaking generally, scarcity of food and unsuitability of climate appear to be the chief causes of migration, and it is probable that they have been the origin of the habit, for birds have the means of moving rapidly across sea and land from one part of the surface of the earth where the conditions do not meet their requirements to another where they find what they want. Thus Siberia, which, during the short warm summer of that latitude, affords an ample supply of food and a suitable climate to the multitude of birds which migrate thither from their southern winter: quarters to breed, is deserted by them on the approach of winter, when the land becomes deeply corered with snow and all the rivers and lakes are ice-bound. With the advent of summer the snow and ice disappear and the birds return to find abundance of food and a congenial climate for the rearing of their young.

It is believed that in comparatively recent geological times Great Britain was connected by dry land with the continent of Europe, and that the birds on their passage across the North Sea still follow the old const lines of the connecting ground, although these have for ages been covered by the water. Geological changes usually take place very slowly, and it is probable that many thousands of years elapsed before the dry land which connected Britain with the continent of Europe finally disappeared under the surface of the sea. During the period when the land was slowly sinking it may be supposed that there would be long tracts of it stretching into the sea on both sides, with a series of islands between them, and that the migratory birds would naturally travel along the coast as far as they could and then fly from island to island until they reached the opposite side. When the islands finally disappeared 
under the waves, the birds would continue to take the same route as before, but would extend their flight from shore to shore. The Mediterranean Sea is also crossed by several stretches of submerged land which formerly connected Europe with Africa, and it is found that the principal routes taken at the present time by migratory birds when crossing that sea are over these stretches.

It is probable that, owing to the causes above mentioned, certain species of birds have migrated to a greater or lesser extent ever since they appeared in any considerable numbers on the surface of the earth, and that a hereditary tendency to migrate in autumn and spring has become a part of their nature, in the same way as a hereditary tendency to point game has become a part of the nature of a well-bred pointer, for a young dog of this kind which has never seen game will often point it on the first occasion on which the dog is taken into the field.

Birds while on migration fly very high in clear weather, when, doubtless, they can see a great extent of the surrounding country. That they are guided on their journey by experienced leaders who have migrated in previous years, and who thus know the landmarks to guide them on their way, is very probable. It is not likely that the young intuitively know the route to be taken on migration any more than a young untrained homing pigeon knows the direction in which to fly to reach its cote, when it is conveyed a long distance away from its native haunt. A homing pigeon is gradually trained to return from long distances by taking it away from its dovecot for short distances in the first place, and increasing these by degrees to enable it to become acquainted with the landmarks of the intervening comntry. Many homing pigeons are lost if they are flown during fogrgy weather, thus showing that they are gruided in their flight 
by looking on the earth beneath them. When birds on migration are overtaken by a very dark night or a fog they descend from their high line of flight towards the surface of the sea or land, and it is on these occasions that they are seen flying round about the lighthouses in a state of apparent bewilderment. On this account it has been thought that dark nights and hazy weather are favourable for migration, but there is nothing to support this view, except that on these occasions the birds are seen at the lighthouses on the coast. In clear weather they doubtless fly both during the day and night at such an immense height that they are not visible to the unaided eye. With the help of a telescope, however, they have been observed migrating at a height of about four miles above the surface of the earth and travelling at a rate of about forty miles an hour. At this speed and with a favourable wind they could cross the widest part of the North Sea in about eight or nine hours, and from the coast of Holland to England in about one-third of that time. Birds on migration seldom fly either directly against or with the wind, but generally within three or four points of it.

It is supposed that during hazy weather, with dark nights, when birds on migration fly low, they enter Berwickshire by two routes-one being across the Tweed from the adjoining county of Northumberland, where the sea-board is low, and the other from the neighbouring county of East Lothian, where the shore has little elevation. The sea-coast of Berwickshire is very lofty and precipitous, and on a dark night the high black cliffs probably appear like a barrier to the birds while they are approaching the land from the German Ocean and flying at no great height above the waves. They consequently continue their flight along the open sea towards the Firth of Forth, on reaching which numbers of them doubtless spread over the low grounds 
of East Lothian, whence a portion of them ultimately find their way to Berwickshire over the Lammermuirs, or along the land which skirts the sea in the neighbourhood of Cockburnspath.

It has been observed that while thousands of birds are seen on migration at the lighthouses on the Farne Islands and the Isle of May, where the adjoining coasts are low, very few, if any, have been noticed at the lighthouse on St. Abb's Head, where the coast is very high. In clear weather it is probable that the birds pass directly from above the German Ocean into the interior of Berwickshire, and there descend from their lofty flight. In apparent support of the above views with regard to the routes by which birds on migration enter the county, it may be mentioned that the recorded dates of the first arrivals in Berwickshire of some of the typical migrants as given in the following tables have been compared with the corresponding dates of their first appearances at the Farne Islands and the Isle of May, and it has been found that in some years the birds were observed in Berwickshire before they were noticed at either of these stations, while in other ycars they were seen at the Farne Islands or the Isle of May before they were noticed in this county.

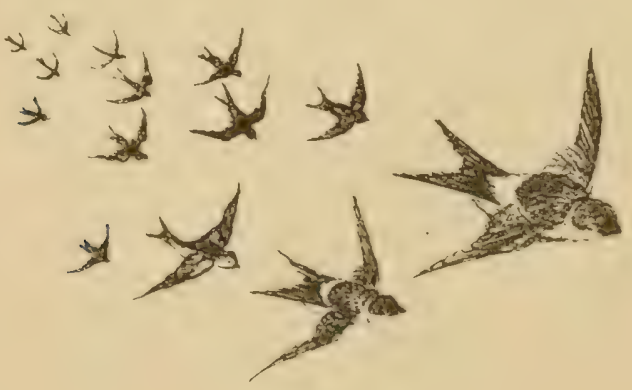


Table of Ornithological Orservations made in Berwickshire from 1799 until 1887, including the earliest, latest, and average dates of the arrival and departure of migratory birds. ${ }^{1}$

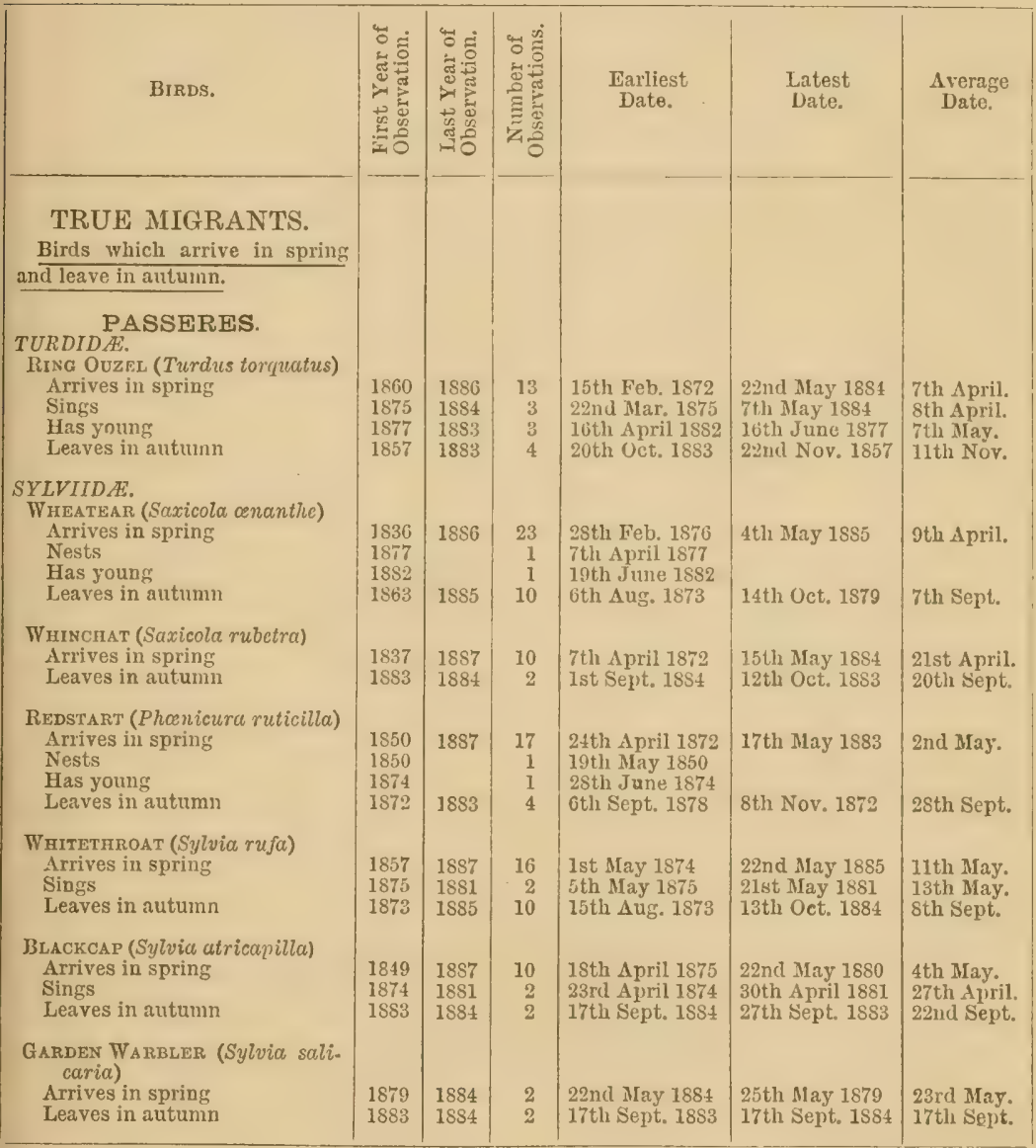

1 For voluminous notes of the arrival and departure of migratory birds in Berwickshire from 1799 until 1887, from which this Table and the Calendar which follows it have been chiefly prepared, I am indebted to the kindness of my friend Dr. James Hardy, of Oldcambus. I have also to thank my brother, Mr. Frank Muirhead, for the great assistance which he has given to me in the preparation of the Table and the Calendar. 


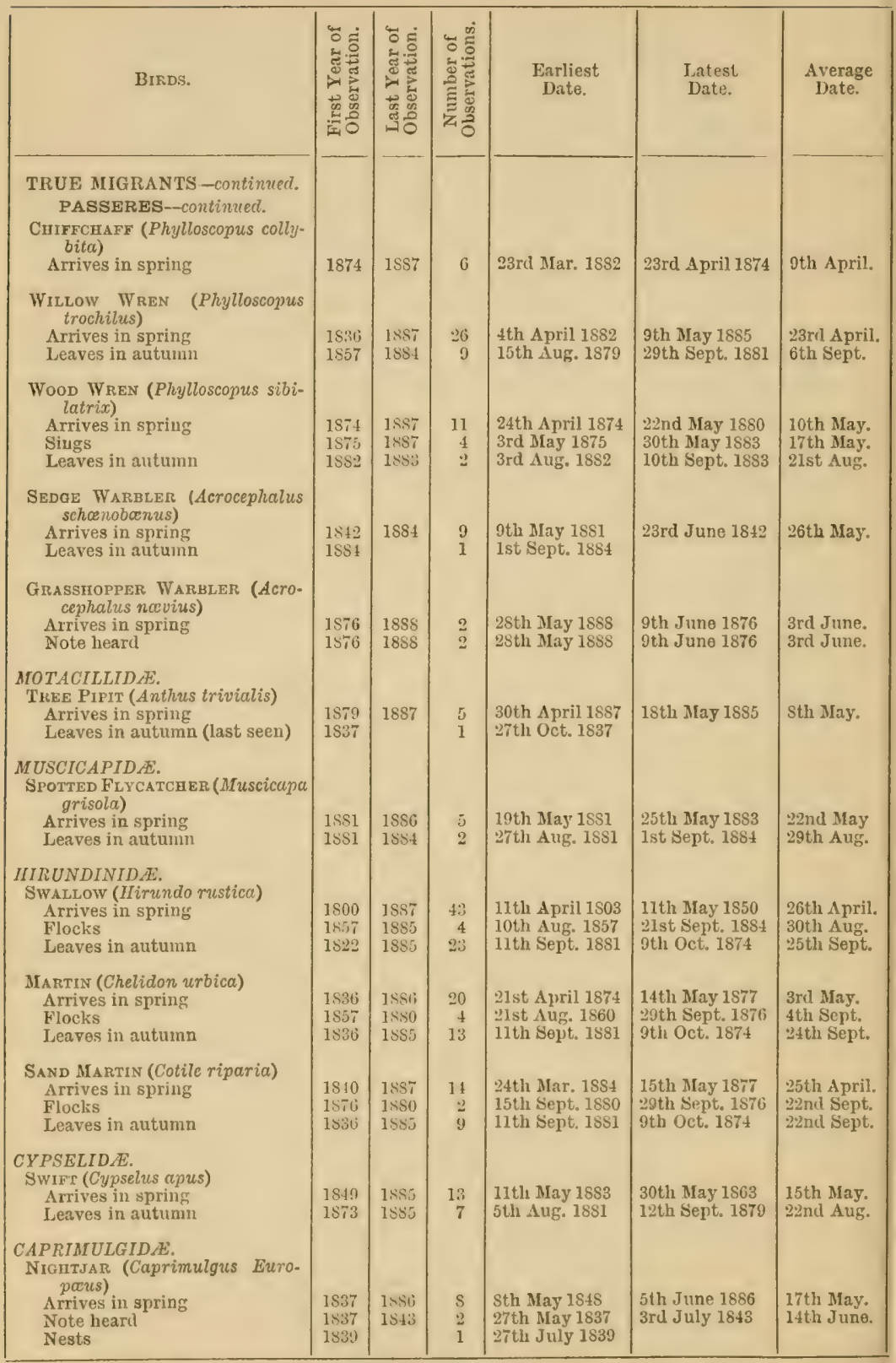




\begin{tabular}{|c|c|c|c|c|c|c|}
\hline Birds. & 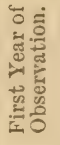 & 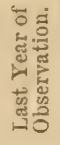 & 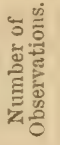 & $\begin{array}{l}\text { Earliest } \\
\text { Date. }\end{array}$ & $\begin{array}{l}\text { Latest } \\
\text { Date. }\end{array}$ & $\begin{array}{l}\text { Average } \\
\text { Date. }\end{array}$ \\
\hline \multicolumn{7}{|l|}{$\begin{array}{l}\text { TRUE MIGRANTS-continued. } \\
\text { PASSERES-continuel. } \\
\text { CUCULIDAE. } \\
\text { CUCKOO (Cuculus canorus) }\end{array}$} \\
\hline $\begin{array}{l}\text { Arrives in spring } \\
\text { Note last heard } \\
\text { Young in nest } \\
\text { Leaves in autumn }\end{array}$ & $\begin{array}{l}1821 \\
1837 \\
1842 \\
1881\end{array}$ & $\begin{array}{l}188 \pi \\
1881\end{array}$ & $\begin{array}{r}29 \\
6 \\
1 \\
1\end{array}$ & $\begin{array}{l}\text { 4th April 1833 } \\
\text { 18th June } 1837 \\
\text { 1st July } 1842 \\
\text { 25tl Aug. } 1881\end{array}$ & $\begin{array}{l}\text { 27th May } 1872 \\
\text { 1st July } 1838\end{array}$ & $\begin{array}{l}\text { 2nd May. } \\
\text { 23rd June. }\end{array}$ \\
\hline $\begin{array}{l}\text { FULICARIE. } \\
\text { RALLIDA: } \\
\text { LANDRAIL (Crex pratensis) }\end{array}$ & & & & & & \\
\hline $\begin{array}{l}\text { Arrives in spring } \\
\text { Leaves in autumn (last seen) }\end{array}$ & $\begin{array}{l}1800 \\
1581\end{array}$ & 1SS7 & $\begin{array}{r}12 \\
1\end{array}$ & $\begin{array}{l}\text { 1st May } 18 s 0 \\
22 \text { nd Sept. 18 } 1\end{array}$ & 20th May 1812 & 11th May. \\
\hline $\begin{array}{l}\text { LIMICOLAE. } \\
\text { SCOLOPACIDE. } \\
\text { CoMMON SANDPIPER (Totanus } \\
\text { hypoleucus) } \\
\text { Arrives in spring }\end{array}$ & $1 \mathrm{~s} 75$ & 1587 & 2 & 28th April 1887 & 29th April 1875 & \\
\hline $\begin{array}{l}\text { Birds which arrive in auturnn } \\
\text { and leave in spring. }\end{array}$ & & & & & & \\
\hline $\begin{array}{l}\text { PASSERES. } \\
\text { TURDIDAE. } \\
\text { REDWING (Turdus iliacus) }\end{array}$ & & & & & & \\
\hline $\begin{array}{l}\text { Arrives in autumn } \\
\text { Leaves in spring }\end{array}$ & $\begin{array}{l}1860 \\
1877\end{array}$ & $\begin{array}{l}1884 \\
1879\end{array}$ & $\begin{array}{l}5 \\
2\end{array}$ & $\begin{array}{l}\text { 27th Oct. } 1879 \\
\text { 6th April } 1877\end{array}$ & $\begin{array}{l}\text { 14th Dec. } 1878 \\
29 \text { th April } 1879\end{array}$ & $\begin{array}{l}\text { 16th Nov. } \\
17 \text { th April. }\end{array}$ \\
\hline Fietdfare (Turdus pilaris) & & & & & & \\
\hline $\begin{array}{l}\text { Arrives in autumn } \\
\text { Leaves in spring }\end{array}$ & $\begin{array}{l}1799 \\
1813\end{array}$ & $\begin{array}{l}1586 \\
1887\end{array}$ & $\begin{array}{l}22 \\
14\end{array}$ & $\begin{array}{l}\text { 12th Oct. } 1874 \\
6 \text { th Feb. } 1864\end{array}$ & $\begin{array}{l}\text { 19th Dec. 1S71 } \\
\text { 15th Mlay 1SS7 }\end{array}$ & $\begin{array}{l}\text { 7th Nov, } \\
7 \text { th April. }\end{array}$ \\
\hline $\begin{array}{l}\text { FRINGILLIDAE. } \\
\text { BRAMBLING (Fringilla montifrin- } \\
\text { gilla) }\end{array}$ & & & & & & \\
\hline Arrives & 1857 & $18 s 1$ & 3 & 23rll Dec. 1874 & 15th Jan. 1881 & 4th Jan. \\
\hline $\begin{array}{l}\text { EMBERIZID E, } \\
\text { SNow BuNTING (Plectrophanes } \\
\text { nivalis) }\end{array}$ & & & & & & \\
\hline $\begin{array}{l}\text { Arrives } \\
\text { Leaves }\end{array}$ & $\begin{array}{l}1 S 12 \\
1 S S 1\end{array}$ & $18 S 6$ & $\begin{array}{r}16 \\
1\end{array}$ & $\begin{array}{l}\text { 1st Oct. } 1851 \\
\text { 28th Mar. 18 } 81\end{array}$ & 20th Jan. 1884 & 9th Nov. \\
\hline $\begin{array}{l}\text { ANSERES. } \\
\text { ANATIDA. } \\
\text { BEAN GOOSE (Anser segetum) and } \\
\text { PINK-HooTED Goose (Anser } \\
\text { brachyrhynchus) }\end{array}$ & & & & & & \\
\hline $\begin{array}{l}\text { Arrive in autumn } \\
\text { Leave in spring }\end{array}$ & $\begin{array}{l}1 S 00 \\
1 S 01\end{array}$ & $\begin{array}{l}1886 \\
1886\end{array}$ & $\begin{array}{l}22 \\
23\end{array}$ & $\begin{array}{l}\text { 1st. Oct. } 1884 \\
\text { 9th Jan. } 1864\end{array}$ & $\begin{array}{l}\text { 15th Dec. } 1881 \\
\text { 1st May } 18 S 4\end{array}$ & $\begin{array}{l}\text { 26th Oct. } \\
23 \text { rd Mar. }\end{array}$ \\
\hline $\begin{array}{l}\text { BIRD OF PASSAGE. } \\
\text { LIMICOLZE. } \\
\text { CHARADRIIDE. } \\
\text { DOTTEREL (Charalrius morin. } \\
\text { ellus) in spring on passage } \\
\text { Arrives in }\end{array}$ & & & & & & \\
\hline $\begin{array}{l}\text { to the north } \\
\text { Leaves in spring for north } \\
\text { Seen in autumn on passage to }\end{array}$ & $\begin{array}{l}1836 \\
1836\end{array}$ & $\begin{array}{l}1886 \\
1883\end{array}$ & $\begin{array}{r}13 \\
6\end{array}$ & $\begin{array}{l}\text { 12th April } 1882 \\
\text { 25th April } 1882\end{array}$ & $\begin{array}{l}\text { 19th May Ist0 } \\
\text { 6th June } 1836\end{array}$ & $\begin{array}{l}\text { 3rd May. } \\
\text { 20th May. }\end{array}$ \\
\hline the south & 1837 & 1875 & 5 & 26th Sept. 1837 & 30th Sept. 1875 & 28th Sept. \\
\hline
\end{tabular}




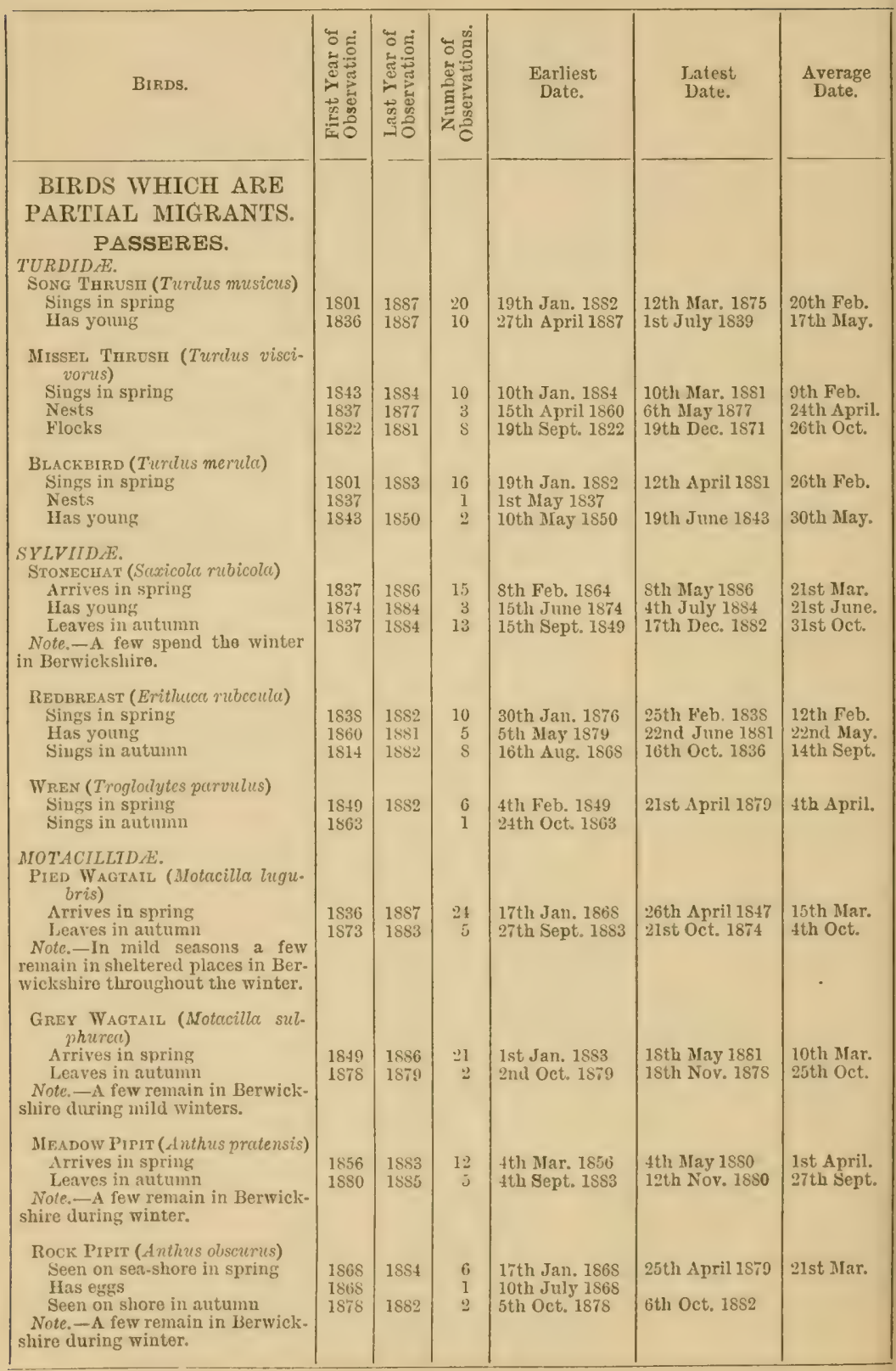




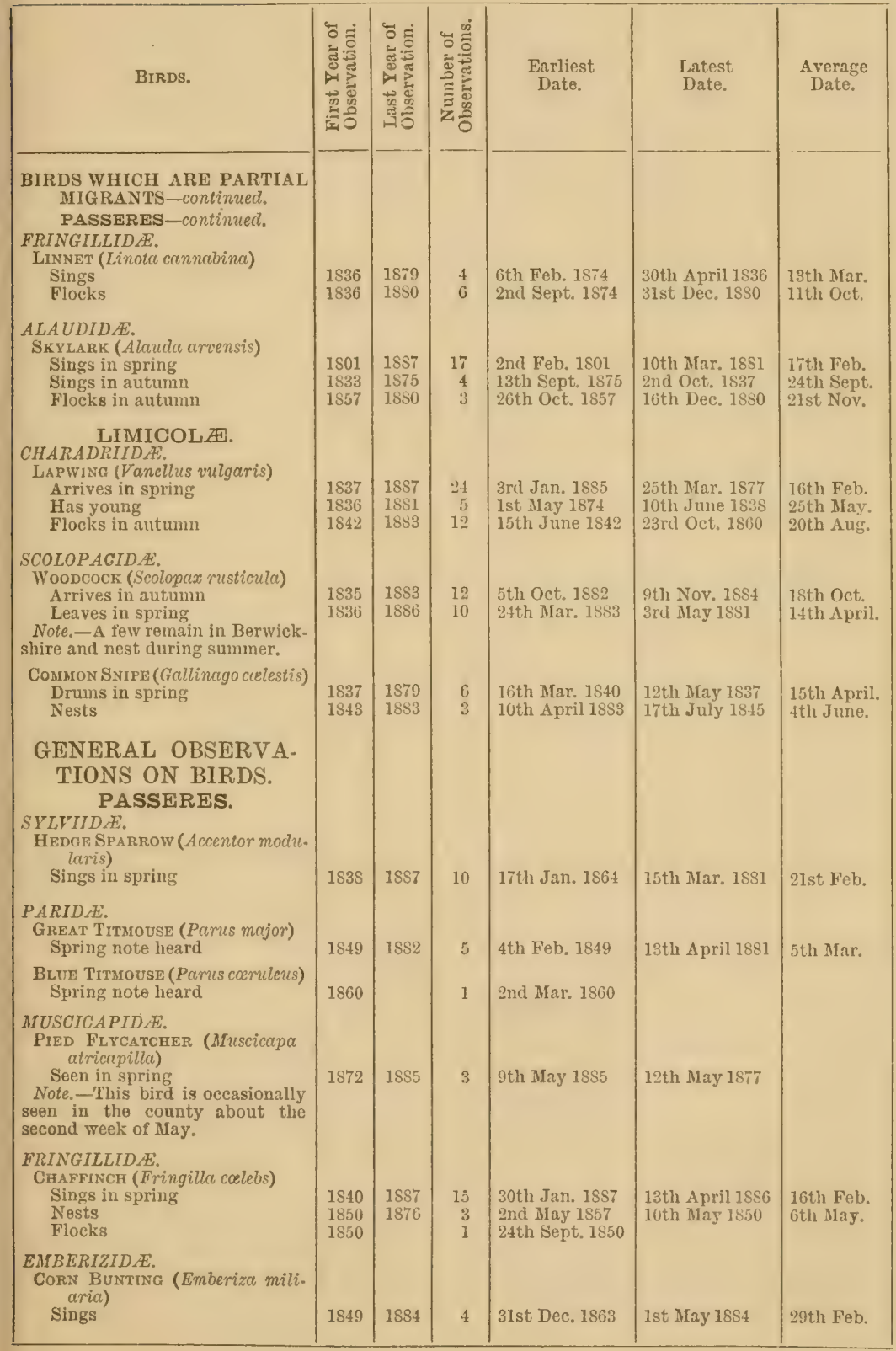




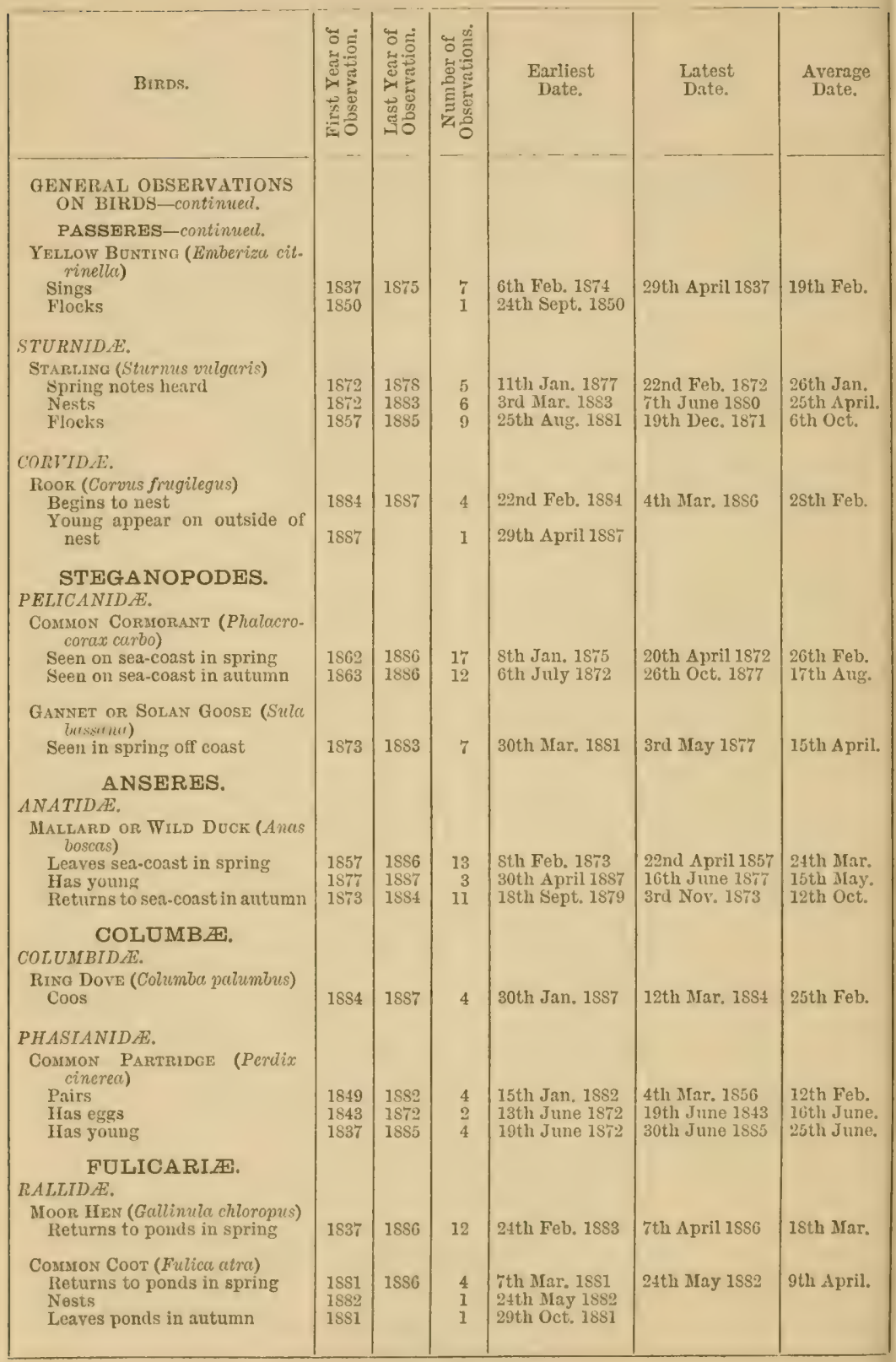




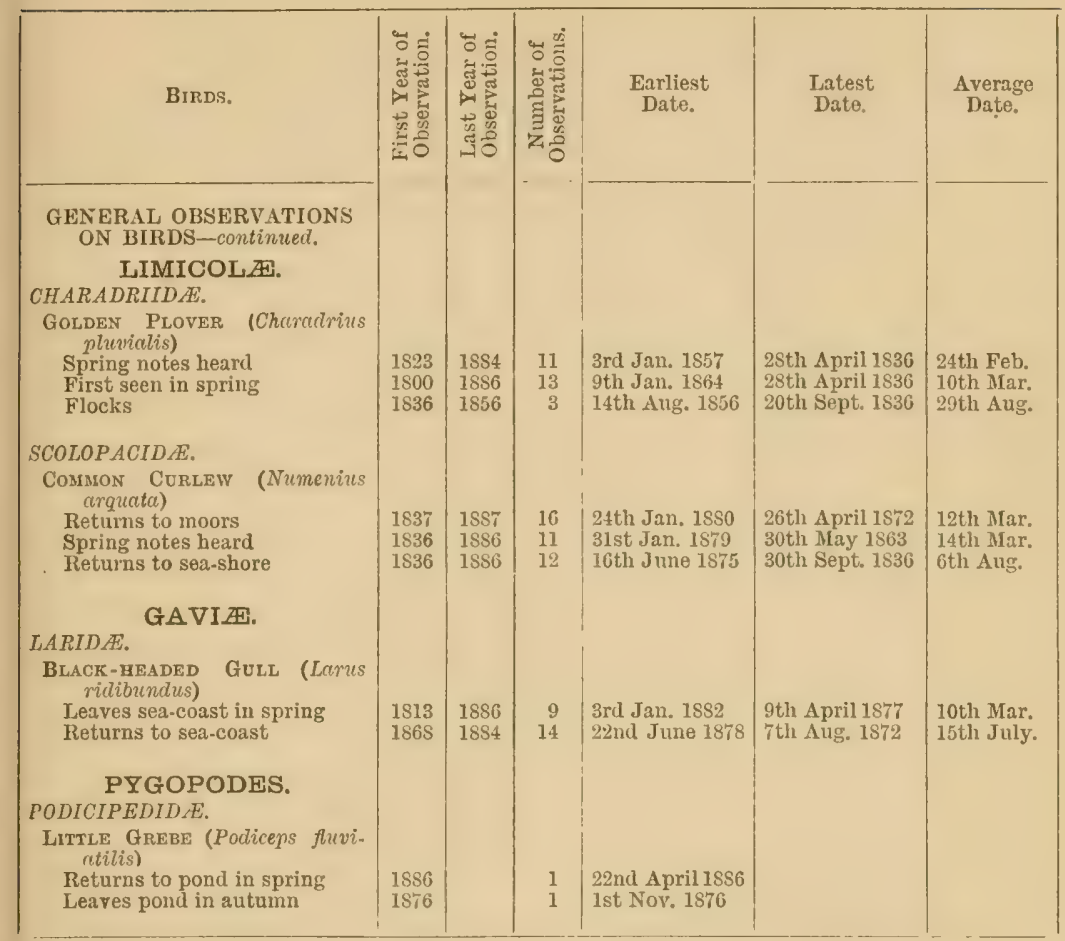

\section{CALENDAR OF MIGRATIONS \& OBSERVATIONS} OF BIRDS IN BEPWICKSHIRE.

\section{$1799-1887$.}

Jan. 1. GREY Wagtail (Motacilla sulphurea) seen 1883. (Earliest of twenty-one observations, 1849-86.)

3. Golden Plover (Charadrius pluvialis) spring notes heard 1857. (Earliest of eleven observations, 1823-84.)

BLACK-HEADED GOLL (Larus ridibundus) left coast 1882. (Earliest of nine observations, 1813-86.)

LAPWING (Vanellus vulgaris) seen inland 1885. (Earliest of twenty-four observations, 1837-87.)

4. Brambling (Fringilla montifringilla) arrives. (Average date of three observations, 1857-81.)

S. Common Cormorant (Phalacrocorax carbo) seen at coast 1875. (Earliest of seventeen observations, 1862-86.) 
Jan. 9. Golden Plover (Charadrius pluvialis) seen 1864. (Earliest of thirteen observations, 1800-86.)

WILD GEESE (Anser segetum and Anser brachyrhynchus) last seen 1864. (Earliest of twenty-three observations, 1801-86.)

Feb.

10. Missel Throsh (Turdus viscivorus) began to sing 1884. (Earliest of ten observations, 1843.84.)

11. Starling (Sturnus vulgaris) spring notes heard 1877. (Earliest of five observations, 1872-78.)

15. Partridge (Perdix cinerea) began to pair 1882. (Farliest of four observations, 1849-82.)

Brambling (Fringilla montifringilla) arrived 1881. (Latest of three observations, 1857-81.)

17. Hedge Sparrow (Accentor modularis) began to sing 1864. (Earliest of ten observations, 1838-87.)

Pied Wagtarl (Motacilla lugubris) appeared 1868. (Earliest of twenty-four observations, 1836-87.)

Rock Pipit (Anthus obseurus) seen on sea-shore 1868. (Earliest of six observations, 1868-84.)

19. Song Throsh (Turdus musicus) began to sing 1882. (Earliest of twenty observations, 1801-87.)

BLACKBIRD (T'urdus merula) commenced to whistle 1882. (Earliest of sixteen observations, 1801-\$3.)

20. Srow-Bunting (Plectrophanes nivalis) came 1854. (Latest of sixteen observations, 1812-86.)

24. CURLEW (Numenius arquata) returned to moors 1880. (Earliest of sixteen observations, 1837-87.)

26. Starling (Sturnus vulgaris) whistles. (Average date of five observations, 1872-78.)

30 Redbreast (Erithaca rubccula) singing 1876. (Earliest of ten observations, 1838-82.)

Chaffinch (Fringilla coelebs) in song 1887. (Earliest of fifteen observations, 1840-87.)

Ring Dove (Columba palumbus) cooing 1887. (Earliest of four observations, 1884-57.)

31. CuRLEW (Numenius arquata) first spring notes heard 1879. (Earliest of eleven observations, 1836-86.)

2. SixxLARK (Alaula arvensis) singing 1801. (Earliest of seventeen observations, 1801-87.)

4. WREN (Troglodytes parvulus) in song 1849. (Earliest of six observations, 1849-82.)

Great Trmouse (Parus major) spring notes heard 1849. (Earliest of five observations, 1849-82.)

6. YeLLow BunTiNG (Limberiza citrinella) singing 1S74. (Earliest of seven observations, 1837-75.)

LINNET (Linota cannabina) began to sing 1874. (Earliest of four observations, 1836-79.)

Fieldofare (T'urdus pilaris) left 1864. (Earliest of fourteen observations, 1813-87.)

S. Stonecinat (Saxicola rubicola) observed 1864. (Earliest of fifteen observations, 1837-86.) 
Fel. S. WILD DucK (Anas boscas) left sea 1873. (Earliest of thirteen observations, 1857-86.)

9. Misser Trrosh ('Turdus viscivorus) sings. (Average date of ten observations, 1843-84.)

Golden-Eye (Fuligula clangula) appears on coast. (Average date of six observations, 1879-86.)

12. RedBreast (Lrithaca rubecula) sings. (Average date of ten observations, 1838-82.)

Partridge (Perdix cinerea) pairs. (Average date of four observations, 1849-\$2.)

15. Ring Odzel (Turdus torquatus) seen 1872. (Earliest of thirteen observations, $1860 \cdot 86$.)

16. Ciraffinch (Fringilla colebs) sings. (Average date of fifteen observations, 1840-87.)

LAPwivg (Vanellus vulgaris) appears inland. (Average date of twenty-four observations, 1837-87.)

,. 17. SKYlaRK (Alauda arvensis) sings. (Average date of seventeen observations, 1801-87.)

,, 19. Yellow Bunting (Emberiza citrinella) sings. (Average date of seven observations, 1837-75.)

„20. Song Thrush ('Turdus musicus) sings. (Average date of twenty observations, 1801-S7.)

, 21. HEDGe Starrow (Accentor modularis) sings. (Average date of ten observations, 1838-87.)

„22. Starling (Sturnus vulgaris) first spring notes heard 1872. (Latest of five observations, 1572-78.)

Rook (Corvus frugilegus) began to nest 1884. (Earliest of four observations, 1884-87.)

, 24. Golden Plover (Charadrius pluvialis) calls. (Average date of eleven observations, 1823-84.)

Moor HEN (Gallinula chloropus) returned to ponds 1883. (Earliest of twelve observations, 1837-86.)

,25. REDBREAST (Erithaca rubecula) began to sing 1838. (Latest of ten observations, 1838-82.)

RING Dove (Columba palumbus) coos. (Average date of four observations, 1884-87.)

," 26. BlackBIRd (Trurdus merula) whistles. (Average date of sixteen observations, 1801-83.)

Common Cormorant (Phalacrocorax carbo) appears at sea-coast. (Average date of seventeen observations, 1862-86.)

,25. Wheatear (Saxicola cenanthe) arrived 1876. (Earliest of twenty-three observations, 1836-86.)

Corn Bunting (Emberiza miliaria) sings. (Average date of four observations, 1849-84.)

Rook (Corvus frugilegus) begins to nest. (Average date of four observations, 1884-87.)

Mar. 2. Blue Titmodse (Parus coeruleus) spring note heard 1860.

, 3. Starling (Sturnus vulgaris) nested 1883. (Earliest of six observations, 1872-83.)

VOL. II. 
Mar. 4. Meadow Pipit (Anthus pratensis) seen 1856. (Earliest of twelve observations, 1856-83.)

Partridae (Perdix cinerea) began to pair 1850. (Latest of four observations, 1849-82.)

Rook (Corvus frugilegus) began to nest 1886. (Latest of four observations, 1884-87.)

5. Great Titmoose (Parus major) calls. (Average date of five observations, 1849-82.)

7. Соот (Fulica atra) returned to ponds, 1881. (Earliest of four observations, 1881-86.)

10. Misser Throsir (Turclus viscivorus) began to sing 1S81. (Latest of ten observations, 1843-84.)

SKTLARI (Alauda arvensis) began to sing 1881. (Latest of seventeen observations, 1801-87.)

Grey Wagtail (Motacilla sulphurea) arrives at Oldcambus. (Average date of twenty-one observations, 1849-86.)

Golden Plover (Charadrius pluvialis) appears in neighbourhood of coast. (Average date of thirteen observations, 1800-86.)

BLACK-MEADED GULL (Larus ridibundus) leaves sea-coast. (Average date of nine observations, 1813-S6.)

12. Song Thrust (Turdus musicus) commenced to sing 1875. (Latest of twenty observations, 1801-87.)

Ring Dove (Columba palumbus) began to coo 1884. (Latest of four observations, 1884.87.)

CURLEw (Numenius arquata) returns to moors. (Average date of sixteen observations, 1837-87.)

13. LrNNEx (Linota cannabina) sings. (Average date of four observations, 1836-79.)

14. Corn Bunting (Emberiza miliaria) arrives at Oldcambus. (Average date of nine observations, 1856-84.)

CURLEw (Numenius arquata) calls. (Average date of eleven observations, 1836-86.)

15. Hedge Sparkow (Accentor modularis) began to sing 1881. (Latest of ten observations, 1838-S7.)

Pied Wagtail (Motacilla lugubris) appears. (Average date of twenty-four observations, 1836-87.)

16. SnIPE (Gallinago colestis) "drummed" 1840. (Earliest of six observations, 1837-79.)

15. Moor Hen (Gallinula chloropus) returns to ponds. (Average date of twelve observations, 1837-86.)

20. GoLden-Eye (Fuligula clangula) returned to sea-coast 1886. (Latest of six observations, 1879-86.)

21. Stonechat (Saxicola rubicola) appears in neighbourhood of coast. (Average date of fifteen observations, 1837-86.)

Rock Prit (Anthus obscurus) on sea-shore. (Average date of six observations, 1868-84.)

22. Ring Ovzel (Turdus torquatus) began to sing 1875. (Earliest of three observations, 1875-84.)

„ 23. ChiffirafF (Phylloscopus collybita) arrived 1882. (Earliest of six observations, 1874-87.) 
Mar. 23. Wild Geese (Anser segetum and Anser brachyrhynchus) leave. (Average date of twenty-three observations, 1801-86.)

24. Sand Martin (Cotile riparia) arrived 1884. (Earliest of fourteen observations, 1840-87.)

Woodcock (Scolopax rusticula) left 1883. (Earliest of ten observations, 1836-86.)

WILD Duck (Anas boscas) leaves sea-coast in spring. (Average date of thirteen observations, 1857-86.)

Apr. 1. MEadow PiPrt (Anthus pratensis) arrives. (Average date of twelve observations, 1856-83.)

4. WREN (Troglodytes parvulus) sings, (Average date of six observations, 1849-\$2.)

WiLlow Wren (Phylloscopus trochilus) arrived 1852. (Earliest of twenty-six observations, 1S36-87.)

Cuскоo (Cuculus canorus) arrived 1833. (Earliest of twentynine observations, 1821-87.)

6. REDwing (Turdus iliacus) left 1877. (Earliest of two observations, 1877 and 1879.)

7. FieldFare (Turdus pilaris) leaves. (Average date of fourteen observations, 1813-87.)

RiNG Ouzel (Turdus torquatus) arrives. (Average date of thirteen observations, 1860-86.)

Whinchat (Saxicola mbetra) came 1872. (Earliest of ten observations, 1837-87.)

Wheatear (Saxicola cenanthe) nested 1877.

Moor HeN (Gallinula chloropus) returned to ponds 1886. (Latest of twelve observations, 1837-86.)

S. Ring Odzer, (Turdus torquatus) sings. (Average date of three observations, 1875-84.)

9. WhEATEAR (Saxicola cenanthe) arrives. (Average date of twentythree observations, 1836-86.)

Chiffehaff (Phylloscopus collybita) comes. (Average date of six observations, 1874-87.)

Coot (Fulica atra) returns to ponds. (Average date of four observations, 1881-86.)

BLACK-HEADED GULL (Larus ridibundus) left coast 1877. (Latest of nine observations, 1813-S6.)

10. SNIPE (Gallinago coelestis) had eggs 1883. (Earliest of three observations, 1843-S3.)

11. Swallow (Hirundo rustica) arrived 1803. (Earliest of fortythree observations, 1800-87.)

Golden-Eye (Fuligula clangula) left coast 1881.

12. DOTTEREL (Charadrius morinellus) arrived 18S2. (Earliest of thirteen observations, 1836-86.) 
Apr. 12. Blackirid (Turdus merula) began to whistle 1SS1. (Latest of sixteen observations, 1801-83.)

Ring Dove (Columba palumbus) had eggs 1887.

,, 13. Chaffinch (Fringilla coelebs) commenced to sing 1886. (Latest of fifteen observations, 1840-87.)

Great Titmouse (Parus major) spring note heard for first time in season 1881. (Latest of five observations, 1849-82.)

,, 14. Wooncock (Scolopax rusticula) leaves. (Average date of ten observations, 1836-86.)

, 15. Missel Thrusir (Turdus viscivorus) nested 1860. (Earliest of three observations, 1837-77.)

SNIPE (Gallinago coelestis) "drums." (Average date of six observations, 1837-79.)

Solax Goose (Sula bassana) appears off coast. (Average date of seven observations, 1873-83.)

, 16. RiNG OUzeL (Turdus torquatus) had young 1882. (Earliest of three observations, 1877-83.)

, 17. Redwing (Turdus iliacus) leaves. (Average date of two observations, 1877 and 1879.)

,, 18. BLACKCAP (Sylvia atricapilla) arrived 1875. (Earliest of ten observations, 1849-87.)

Hooded Crow (Corvus cornix) left 1854.

Common Cormorant (Phalacrocorax carbo) seen on coast 1872. (Latest of seventeen observations in spring, 1862-86.)

,, 21. WREN (T'roglodytes parvulus) began to sing 1879. (Latest of six observations, 1849-82.)

Martin (Chelidon urbica) arrived 1874. (Earliest of twenty observations, 1836-86.)

22. Wrid Duck (Anas boscas) left sea-coast 1857. (Latest of thirteen observations, 1857-86.)

LitTLE GreBe (Podiceps fluviatilis) returned to ponds 1886.

23. BuACKCAP (Sylvia atricapilla) began to sing 1874. (Earliest of two observations, 1874 and 1881.)

Cimffreraff (Phylloscopus collybita) arrived 1874. (Latest of six observations, 1874-87.)

WILLOW WreN (Phylloscopus trochilus) arrives. (Average date of twenty-six observations, 1836-87.)

24. Missel Thrush (Turdus viscivorus) nests. (Average date of three observations, 1837-77.)

Wood Wren (Plylloscopus sibilatrix) returned 1874. (Earliest of eleven observations, 1874-87.)

REDSTART (Phœenicura ruticilla) arrived 1872. (Earliest of seventeen observations, 1850-87.)

25. Rock Pipit (Anthus obscurus) seen on sea-shore 1879. (Latest of six observations, 1868-84.)

Starlixa (Sturnus vulgaris) nests. (Average date of six observations, 1872-83.)

SAnd Martin (Cotile riparia) arrives. (Average date of fourteen observations, 1840-87.) 
Apr. 25. DotTerex (Charadrius morinellus) left 1882. (Earliest of six observations, 1836-83.)

" 26. Pied Wagtail (Motacilla lugubris) appeared 184\%. (Latest of twenty-four observations, 1836-87.)

Swallow (Hirundo rustica) arrives. (Average date of fortythree observations, 1800-87.)

Pheasant (Phasianus colchicus) had young 1887. (Earliest of six observations, 1839-87.)

Cunlew (Numenius arquata) returned to moors 1872. (Latest of sixteen observations, 1837-87.)

„27. Song Thrush (Turdus musicus) had young 1887. (Farliest of ten observations, 1836-87.)

28. Golden Plover (Charadrius pluvialis) first spring notes heard 1836. (Latest of eleven observations, 1823-84.)

Golden Plover (Charadrius pluvialis) seen for first time in spring 1836. (Latest of thirteen observations, 1800-86.)

Common Sandpiper (Totanus hypoleucus) arrived 1887.

29. Renwing (Turdus iliacus) left 1879. (Latest of two observations, 1877 and 1879.)

Yellow Bonting (Emberiza citrinella) in song 1837. (Latest of seven observations, 1837-75.)

Rook (Corvus frugilegus) young appeared outside of nest 1887.

30. BlackCap (Sylvia atricapilla) began to sing 1881. (Latest of two observations, 1874 and 1851.)

Tree PrPit (Anthus trivialis) arrived 1887. (Earliest of five observations, 1879-87.)

LINNET ( Linota cannabina) in song 1836. (Latest of four observations, 1836-79.)

WILD Duck (Anas boscas) had young 1887. (Earliest of three observations, 1877-87.)

May 1. BuAckbird (Turdus merula) nested 1837.

WhitethroAt (Sylvia rufa) arrived 1874. (Earliest of sixteen observations, 1857-87.)

CorN Bunting (Emberiza miliaria) singing 1884. (Latest of four observations, 1849-84.)

LAPwing (Vanellus vulgaris) had young 1874. (Earliest of five observations, 1836-81.)

Landealu (Crex pratensis) arrived 1880. (Earliest of twelve observations, 1800-87.)

WILD GEESE (Anser segetum and Anser brachyrhynchus) seen 1884. (Latest of twenty-two observations, 1800-86.)

2. Chaffinom (Fringilla colebs) nested 1857. (Earliest of three observations, 1850-76.)

REDSTART (Phonicura ruticilla) arrives. (Average date of seventeen observations, 1850-87.)

Cockoo (Cuculus canorus) arrives. (Average date of twentynine observations, 1821-87.)

3. Woov WreN (Phylloscopus sibilatrix) singing 1875. (Earliest of four observations, 1875-87.) 
May 3. Martin (Chelidon urbica) returns. (Average date of twenty observations, 1836-86.)

Woodcock (Scolopax rusticula) left 1881. (Latest of ten observations, 1836-86.)

SoLAN Goose (Sula bassana) seen off coast 1877. (Latest of seven observations, $1873 \cdot 83$.)

DotTEREL (Charadrius morinellus) arrives. (Average date of thirteen observations, 1836-86.)

4. Wheatear (Saxicola cenanthe) arrived 1885. (Latest of twentythree observations, 1S36-86.)

Blackcap (Sylvia atricapilla) comes. (Average date of ten observations, 1849-S7.)

MEADow PIPIT (Anthus pratensis) appeared 18s0. (Latest of twelve observations, 1856-83.)

5. REDBReAST (Ërithaca rubecula) had young 1879. (Earliest of five observations, 1860-81.)

Whitetiroat (Sylvia rufa) in song 1875. (Earliest of two observations, 1875 and 1881 .)

6. Misser Throsir (Turdus viscivomus) nested 1877. (Latest of three observations, 1837-77.)

Chaffincir (Fringilla coelebs) nests. (Average date of three observations, 1850-76.)

7. RING OdZEL (T'urdus torquatus) has young. (Average date of three observations, 1877-83.)

RING OUzeL (T'urdus torquatus) singing 1SS4. (Latest of three observations, 1875-84.)

S. Stonechat (Saxicola rubicola) appeared 1SS6. (Latest of fifteen observations, 1837-86.)

Tree Pipit (Anthus trivialis) returns. (Average date of five observations, 1879-87.)

NightJar (Caprimulgus europceus) arrived 1848. (Earliest of eight observations, 1837-86.)

9. Sedge Warbler (Acrocephalus schonobonus) came 1881. (Earliest of nine observations, 1842-84.)

WILlow WREN (Pliylloscopus trochilus) arrived 1885. (Latest of twenty-six observations of date of arrival, 1836-87.)

Pied Flycatcher (M I uscicapa atricapilla) seen 1855.

10. Chaffincir (Fringilla coelebs) nested 1850. (Latest of three observations, 1850-76.)

BLACkBIRD ('T'urdus merula) had young 1850. (Farliest of two observations, 1843 and 1850.)

WOOD WREN (Phylloscomus sibilatrix) arrives. (Average date of eleven observations, 1874-87.)

11. Wmitethront (Sylvia mufa) arrives. (Average date of sixteen observations, 1857-87.)

Swallow (Hirundo mistica) returned 1850. (Latest of fortythree observations, 1800-87.)

Swifr (Cypselus apus) arrived 1S83. (Earliest of thirteen observations, 1849-85.) 
May 11. Landrail (Crex pratensis) comes. (Average date of twelve observations, 1800-87.)

", 12. SNIPE (Gallinago coelestis) "drummed" 1837. (Latest of six observations, 1837-79.)

Pied Fliycatcher (Muscicapa atricapilla) seen 1877.

", 13. Whitethroat (Sylvia $r u f a$ ) is heard singing. (Average date of two observations, 1875 and 1881.)

, 14. MaRTin (Chelidon urbica) arrived 1877. (Latest of twenty observations, 1836-86.)

"15. FieldFARE (Turdus pilaris) left 1887. (Latest of fourteen observations, 1813-87.)

Winnchat (Saxicola rubetra) came 1884. (Latest of ten observations, 1837-87.)

Sand Martin (Cotile riparia) returned 1877. (Latest of fourteen observations, 1840-87.)

SwiFr (Cypselus apus) arrives. (Average date of thirteen observations, 1849-85.)

WiLd Duck (Anas boscas) has young. (Average date of three observations, 1877-87.)

17. Song Thrush (Turclus musicus) has young. (Average date of ten observations, 1836-87.)

REDSTART (Phonicura ruticilla) arrived 1883. (Latest of seventeen observations, 1850-87.)

NrghtJar (Caprimulgus europceus) comes. (Average date of eight observations, 1837-86.)

Wood Wren (Phylloscopus sibilatrix) sings. (Average date of four observations, 1875-87.)

", I8. Grey Wagtail (Motacilla sulphurea) appeared 18s1. (Latest of twenty-one observations, 1S49-86.)

Tree PIPIT (Anthus trivialis) arrived 1885. (Latest of five observations, 1879-87.)

19. Spotred Flycatcher (Mruscicapa grisola) came 1881. (Earliest of five observations, 1881-86.)

ReDStakt (Phonicura ruticilla) nested 1850.

DotTereu (Charadrius morinellus) arrived 1840. (Latest of thirteen observations, 1836-86.)

20. DotTERel (Charadrius morinellus) leaves. (Average date of six observations, 1836=83.)

21. IVhinchat (Saxicola mbetra) comes. (Average date of ten observations, 1837-87.)

Whitethroat (Sylvia mufa) singing 1881. ' (Latest of two observations, 1875 and 1881.)

22. REDBReast (Erithaca rubecula) has young. (Average date of five observations, 1860-1881.)

GARDEN WARBLer (Sylvia salicaria) arrived 1884. (Earliest of two observations, 1879-84.)

Spotted Flycatcher (Mrscicapa grisola) arrives. (Average date of five observations, 1881-86.)

RING Odzel (Turdus torquatus) came 1884. (Latest of thirteen observations, 1860-86.) 
May 22. BlackCaP (Sylvia atricapilla) arrived 1880. (Latest of ten observations, 1849-87.)

Whitethroat (Sylvia rufa) returned 1885. (Latest of sixteen observations, 1857-87.)

Woop Wren (Phylloscopus sibilatrix) arrived 1850. (Latest of eleven observations, 1874-87.)

June 4. SNIPE (Gallinago calestis) has eggs. (Average date of three observations, 1843-83.)

23. Garden WARbler (Sylvia salicaria) comes. (Average date of two observations, 1879-84.)

24. Соот (Fulica atra) returned to ponds 1882. (Latest of four observations, 1881-86.)

25. Spotted Flycatcher (Muscicapa grisola) arrived 1883. (Latest of five observations, 1881-86.)

LAPwing (Vanellus vulgaris) has young. (Average date of five observations, 1836-81.)

GARDEN WARBLer (Sylvia salicaria) arrived 1879. (Latest of two observations.)

26. Sedge Warbler (Acrocephalus schonobcmus) arrives. (Average date of nine observations, 1842-84.)

27. Cuckoo (Cuculus canorus) arrived 1872. (Latest of twenty-nine observations, 1821-87.)

NightJar (Caprimulgus europceus) heard 1837. (Earliest of two observations, 1837 and 1843.)

2S. Grasshopper WARBLER (Acrocephalus noviuls) heard 1888. (Earliest of two observations, 1876-88.)

29. LandraIL (Crex pratensis) arrived 1812. (Latest of twelve observations, 1500-87.)

30. Swift (Cypselus apus) arrived 1S63. (Latest of thirteen observations, 1849-85.)

CURLEw (Numenius arquata) spring note heard 1S63. (Latest of eleven observations, 1836-86.)

WOOD WREN (Phylloscopus sibilatrix) singing 1883. (Latest of four observations, 1875-87.)

5. NightJar (Caprimulgus europaus) arrived 18S6. (Latest of eight observations, 1837-86.)

6. Dotterel (Charadrius morinellus) left 1836. (Latest of six observations, 1836-83.)

7. Starling (Sturnus vulgaris) nested 1S80. (Latest of six observations, 1872-83.)

9. Grasshopper Warbler (Acrocephalus navius) heard 1876. (Latest of two observations, 1876-88.)

10. Lapwing (Vanellus vulgaris) had young 1838. (Latest of five observations, 1836-81.)

13. CorN Bunting (Emberizia miliaria) arrived at Oldcambus 1884. (Latest of nine observations, 1856-S4.)

Partridae (Perdix cinerea) had eggs 1872.

14. Nightjar (Caprimulgus europous) is heard. (Average date of two observations, 1837 and 1843.) 
June 14. Pheasant (Phasianus colchicus) has young. (Average date of six observations, 1839-87.)

15. Stonechat (Saxicola rubicola) had young 1874. (Earliest of three observations, 1874-84.)

LAPWING (Vanellus vulgaris) began to flock 1842. (Earliest of twelve observations, 1842-83.)

16. RING OvzeL (Turdus torquatus) had young 1877. (Latest of three observations, 1877-83.)

CURLEW (Numenius arquata) returned to shore 1875. (Earliest of twelve observations, 1836-86.)

WILd Drck (Anas boscas) had young 1877. (Latest of three observations, 1877-87.)

18. Cuckoo (Cuculus canorus) last heard 1837. (Earliest of six observations, 1837-81.)

19. BLACKBIRD (Turdus merula) had young 1843. (Latest of two observations, 1843 and 1850.)

WHEATEAR (Saxicola onanthe) had young 1882.

Partridge (Perdix cinerea) had young 1872. (Earliest of four observations, 1837-85.)

21. Stonechat (Saxicola rubicola) has young. (Average date of three observations, 1874-84.)

22. REDBREAST (Erithaca rubecula) had young 1881. (Latest of five observations, 1860-81.)

BLACK-HEADED GULI (Larus rilibundus) returned to coast 1878. (Earliest of fourteen observations, 1868-84.)

23. SEDGE WARBLer (Acrocephalus schoenobcenus) arrived 1842. (Latest of nine observations, 1842-84.)

Cuckoo (Cuculus canoms) last heard. (Average date of six observations, 1837-81.)

, 25. Partaidae (Perdix cinerece) has young. (Average date of four observations, 1837-85.)

25. Redstart (Phonicura micilla) had young 1874.

30. Partridge (Perdix cinerea) had young 1885. (Latest of four observations, 1837-85.)

July 1. Song Throsin ('Turdus musicus) had young 1839. (Latest of ten observations, 1836-87.)

Cuckoo (Cuculus canorus) last heard 1838. (Latest of six observations, 1837-81.)

3. NightJAR (Caprimulgus europeus) first heard 1843. (Latest of two observations, 1837 and 1843.)

4. Stonechat (Saxicola mubicola) had young 1884. (Latest of three observations, 1874-84.)

6. Common Cormorant (Phalacrocorax carbo) seen on sea-shore 1872. (Earliest of twelve observations, 1863-S6.)

10. Rock PIPIT (Anthus obscurus) had eggs 1868.

15. BLACK-HEADED Gull (Larus ridibundus) returns to sea-coast. (Average date of fourteen observations, 1868.84.)

Cuckoo (Cuculus canorus) young were seen flying 1842. 
July 17. Snipe (Gallinago coelestis) had eggs 1845. (Latest of three observations, 1843-83.)

, 19. Pheasant (Phasianus colchicus) had young 1877. (Latest of six observations, 1839-87.)

,27. NightJar (Caprimulgus europaus) nested 1839.

Aug. 3. Wood Wren (Phylloscopus sibilatrix) left 18S2. (Earliest of two observations, 1882 and 1883.)

" 5. Swift (Cypselus apus) left 1881. (Earliest of seven observations, 1873-85.)

," 6. WhEATEaR (Saxicola nnanthe) left 1873. (Earliest of ten observ. ations, 1863-85.)

CURLEW (Numenins arquata) returns to sea-shore. (Average date of twelve observations, 1836-S6.)

, 7. BLACK-HEADED GULL (Larus ridibundus) returned to coast 1872. (Latest of fourteen observations, 1865-84.)

„10. Swallow (Himundo mustica) flocked 1857. (Earliest of four observations, 1857-85.)

, 14. Golden Plover (Charadrius pluvialis) flocked on moors 1850. (Earliest of three observations, 1836-56.)

„15. Whitethroat (Sylvia mufa) left 1873. (Earliest of ten observations, 1873-85.)

WrLLow WREN (Phylloscopus trochilus) left 1879. (Earliest of nine observations, 1857-84.)

," 16. Redbreast (Erithaca mbecula) in song 1865. (Earliest of eight autumnal observations, 1814-82.)

„17. Common Cormorant (Phalacrocorax carbo) first seen on seacoast. (Average date of twelve observations, 1563-86.)

20. LAPwing (Vanellus vulgaris) flocks. (Average date of twelve observations, 1842-S3.)

21. Woov Wren (Phylloscopus sibilatrix) leaves. (Average date of two observations, 1882 and 1883.)

MARTiN (Chelidon urbica) flocked 1860. (Earliest of four observations, 1857-80.)

„22. Swift (Cypselus apus) leaves. (Average date of seven observations, 1873-85.)

,25. Starling (Sturmus vulgaris) flocked 1881. (Earliest of nine observations, 1857-\$5.)

Cuckoo (Cuculus canorus) left $18 s 1$.

„27. Spotted Flycatcier (Afuscicapa grisola) left $18 S 1$.

"29. Golden Plover (Charadrius pluvialis) flocks on moors. (Average date of three observations, 1836-56.)

, 30. Swallow (Hirundo rustica) flocks. (Average date of four observations, 1857-85.)

Sept. 1. Srotted Flycatcier (Afuscicapa grisola) left 1884.

IV minchat (Saxicola metra) left 1884.

Sedge Warbler (Acrocephalus schonobcenus) left 1884. 
Sept. 2. Linnet (Linota camnabina) flocked 1874. (Earliest of six observations, 1836-80.)

4. Meadow Pipic (Anthus pratensis) left 1883. (Earliest of five observations, 1880-85.)

MARTIN (Chelidon urbica) flocks. (Average date of four observations, 1857-80.)

6. Redstart (Phoenicura ruticilla) left 1878. (Earliest of four observations, 1872-83.)

Willow Wren (Phylloscopus trochilus) leaves. (Average date of nine observations, 1857-84.)

7. Wheatear (Saxicola ananthe) leaves. (Average date of ten observations, 1863-85.)

8. Whitrthroat (Sylvia rufa) leaves. (Average date of ten observations, 1873-85.)

10. WoOD Wren (Phylloscopus sibilatrix) left 1883. (Latest of two observations, 1882-83).

11. Swallow (Hirundo rustica) left 18s1. (Earliest of twentythree observations, 1822-85.)

Martin (Chelidon urlica) left 18S1. (Earliest of thirteen observations, 1836-85.)

Sand Martin (Cotile riparia) left 1881. (Earliest of nine observations, 1836-85.)

12. Swift (Cypselus apus) left 1879. (Latest of seven observations, 1873-85.)

13. SirYLARK (Alauda arvensis) singing 1875. (Earliest of four autumnal observations, 1833-75.)

14. Redbreast (Erithaca rubecula) sings. (Average date of eight observations, 1814-\$2.)

15. Sitonechat (Saxicola mbicola) left neighbourhood of sea-coast 1849. (Earliest of thirteen observations, 1837-84.)

Sand Martin (Cotile riparia) flocked 1880. (Earliest of two observations, 1876 and 1880.)

17. Blackcap (Sylvia atricapilla) left 1884. (Earliest of two observ. ations, 1883 and 1884.)

GARDEN WARbler (Sylvia salicaria) left 1883 and 1884.

18. WILd Drck (Anas boscas) returned to sea 1879. (Earliest of eleven observations, 1873-84.)

19. Missel Thrush (T'urdus viscivorus) flocked 1822. (Earliest of eight observations, 1822-81.)

20. Goldwe Plover (Charadrius pluvialis) flocked on moors 1836. (Latest of three observations, 1836-56.)

21. SWALlow (Hirundo rustica) flocked 1884. (Latest of four observations, 1857-85.)

22. Sand Martin (Cotile riparia) leaves. (Average date of nine observations, 1836-85.)

LANDRAIL (Crex pratensis) left 1881.

24. Skylakk (Alauda arvensis) sings. (Average date of four autumnal observations, 1833-75.) 
Sept. 24. Chaffinch (Fringilla colebs) flocked 1850.

Yellow-Bunting (Emberiza citrinella) in flocks 1850.

Martin (Chelidon urbica) leaves. (Average date of thirteen observations, 1836-85.)

25. Swallow (Hirundo rustica) leaves. (Average date of twentythree observations, 1822-85.)

26. DotTerel (Charadrius morinellus) seen 1837. (Earliest of tive autumnal observations, 1837-75.)

27. Buackcap (Sylvia atricapilla) left 1883.

Pied Wagtail (Motacilla lugubris) disappeared 1883. (Earliest of five observations, 1873-83.)

Mradow Pipit (Anthus pratensis) leaves neighbourhood of Oldcambus. (Average date of five observations, 1880-85.)

28. Redstart (Phoenicura ruticilla) leaves. (Average date of four observations, 1872-83.)

DotTEREL (Charadrius pluvialis) is seen on migration southwards. (Average date of five autumnal observations, 1837-75.)

29. WILlow WreN (Phylloscopus trochilus) left 1881. (Latest of nine observations, 1857-84.)

Martin (Chelidon urbica) flocked 1876. (Latest of four observ. ations, 1857-80.)

SAND MaRTrN (Cotile riparia) flocked 1876. (Latest of two observations, 1876 and 1880 .)

30. DotTEREL (Charadrius morinellus) seen on migration southwards 1875. (Latest of five autumnal observations, 1837-75.)

Corlew (Numenius arquata) returned to shore 1836. (Latest of twelve observations, 1836-86.)

Oct. 1. Snow-Bunting (Plectrophanes nivalis) arrived 1851. (Earliest of sixteen observations, 1812-86.)

WIr.D GeEse (Anser segetum and Anser brachyrhynchus) seen 1884. (Earliest of twenty-two observations, 1800-86.)

2. SкYLARK (Alauda arvensis) singing 1S37. (Latest of four autumnal observations, 1833-75.)

Grex WaGtatl (Motacilla sulphurea) left neighbourhood of Oldcambus 1879. (Earliest of two observations, 1878 and 1879.)

4. Pied Wagtail (Motacilla lugubris) disappears. (Average date of five observations, 1873-83.)

5. Rock Pipit (Anthus obscumus) seen on sea-shore 1878.

Woodcock (Scolopax rusticula) arrived 1882. (Earliest of twelve observations, 1835-83.)

6. Starling (Sturnus vulgaris) flocks. (Average date of nine observations, 1857-\$5.)

9. Swallow (Hirundo rustica) left 1874. (Latest of twenty-three observations, 1822-85.)

MARTIN (Chelidon urbica) left 1874. (Latest of thirteen observations, 1836-S5.)

Sand Martin (Cotile riparia) left 1874. (Latest of nine observations, 1836-85.) 
Oct. 11. Linnet (Linota cannabina) flocks. (Average date of six observations, 1836-80.)

12. Whinchat (Saxicola rubetra) left ISS3. (Latest of two observations, 1883 and 1884.)

WiLD Duck (Anas boscas) returns to sea. (Average date of eleven observations, 1873-84.)

Finldfare (T'urdus pilaris) arrived 1874. (Earliest of twenty. two observations, 1799-1886.)

13. Whitethroat (Sylvia $m u f a$ ) left 1SS4. (Latest of ten observations, 1873-85.)

14. Wheatear (Saxicola ananthe) left 1879. (Latest of ten observations, 1863-85.)

16. REDEREAST (Erithaca rubecula) singing 1836. (Latest of eight autumnal observations, 1814-82.)

18. Woodcock (Scolopax rusticula) arrives. (Average date of twelve observations, 1835-83.)

20. RING OdzeL (Thurdus torquatus) left 1SS3. (Earliest of four observations, $1857-83$.)

21. Pied WagtaIL (Motacilla lugubris) disappeared 1874. (Latest of five observations, 1873-83.)

23. LAPwING (Vanellus vulgaris) flocked 1860. (Latest of twelve observations, 1842-83.)

24. Wren (Troglodytes parvulus) singing 1863.

26. Missel Turosh (Turdus viscivorus) flocks. (Average date of eight observations, 1822-81.)

Sirylark (Alauda ariensis) flocked 1857. (Earliest of three observations, 1857-80.)

IVILd Geese (Anser segetum and Anser brachyrlynchucs) are first seen. (Average date of twenty-two autumnal observations, 1800-86.)

Common Cormorant (Phalacrocorax carbo) first seen on seacoast 1877. (Latest of twelve observations, 1863-86.)

27. REDIVING (Turdus iliacus) arrived 1879. (Earliest of five observations, 1860-84.)

Tree PiptT (Anthus trivialis) left 1837.

29. Coот (Fulica atra) left ponds 1881.

31. Sronechat (Saxicola rubicola) leaves neighbourhood of sea-coast. (Average date of thirteen observations, 1837-84.)

1. Little Grebe (Podiceps fluviatilis) left ponds 1876.

3. Wrud Duck (Anas boscas) returned to sea 1873. (Latest of eleven observations, 1873-84.)

7. Fieldfare (Thurdus pilaris) arrives. (Average date of twentytwo observations, 1799-1886.)

S. ReDSTART (Phonicura ruticilla) left 1872. (Latest of four observations, 1872-83.)

9. Svow Bunting (Plectrophanes nivalis) arrives. (Average date of sixteen observations, 1812-86.)

Woodcock (Scolopax rusticula) arrived 1884. (Latest of twelve observations, 1835-83.) 
Nov. 11. RiNG OdzeL (Turdus torquatus) leaves. (Average date of four observations, 1857-83.)

,, 12. MEAdow Pipit (Anthus pratensis) left 1880. (Latest of five observations, 1880-85.)

,, 16. ReDwing (Turdus iliacus) arrives. (Average date of five observations, 1860-84.)

, 18. Grey Wagtail (Motacilla sulphurea) disappeared 1S78. (Latest of two observations, 1878 and 1879.)

, 21. SKYLARK (Alauda arvensis) flocks. (Average date of three observations, 1857-80.)

, 22. Ring Ouzet (T'urdus torquatus) left 1857. (Latest of four observations, 1857-83.)

Dec. 14. REDwing (T'urdus iliacus) arrived 1878. (Latest of five observations, 1860-84.)

LiNNET ( Linota cannabina) left Oldcambus 1878.

, 15. Wild GEese. (Anser segetum and Anser brachyrhynchus) first seen 1881. (Latest of twenty-two observations, 1800-86.)

, 16. SkYiark (Alauda arrensis) flocked 1850. (Latest of three observations, 1857-80.)

, 17. Stonechat (Saxicola rubicola) disappeared ISS2. (Latest of thirteen observations, 1837-84.)

, 19. Misske Throsh (Turdus viscivorus) flocked 1871. (Latest of eight observations, 1822-81.)

Fieldarare (Turdus pilaris) arrived 1871. (Latest of twentytwo observations, 1799-1S86.)

StaRling (Stumus vulgaris) flocked 1871. (Latest of nine observations, 1857-85.)

,23. Brambling (Fringilla montifringilla) arrived 1874. (Earliest of three observations, 1857-81.)

,26. Corn Bunting (Emberiza miliaria) arrived at Oldcambus 1863. (Earliest of nine observations, 1856-\$4.)

,, 31. Corn Buntrna (Emberiza miliaria) singing 1863. (Earliest of four observations, 1849-84.)

LinNet ( Linota cannabina) flocked 1880. (Latest of six observations, 1836-80.)

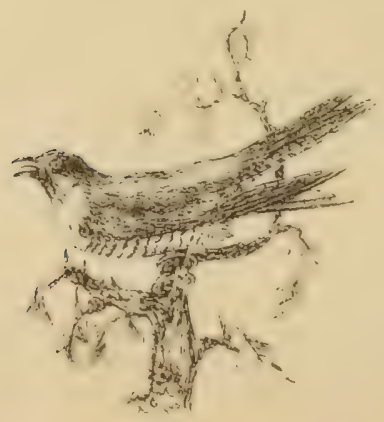


( 351$)$

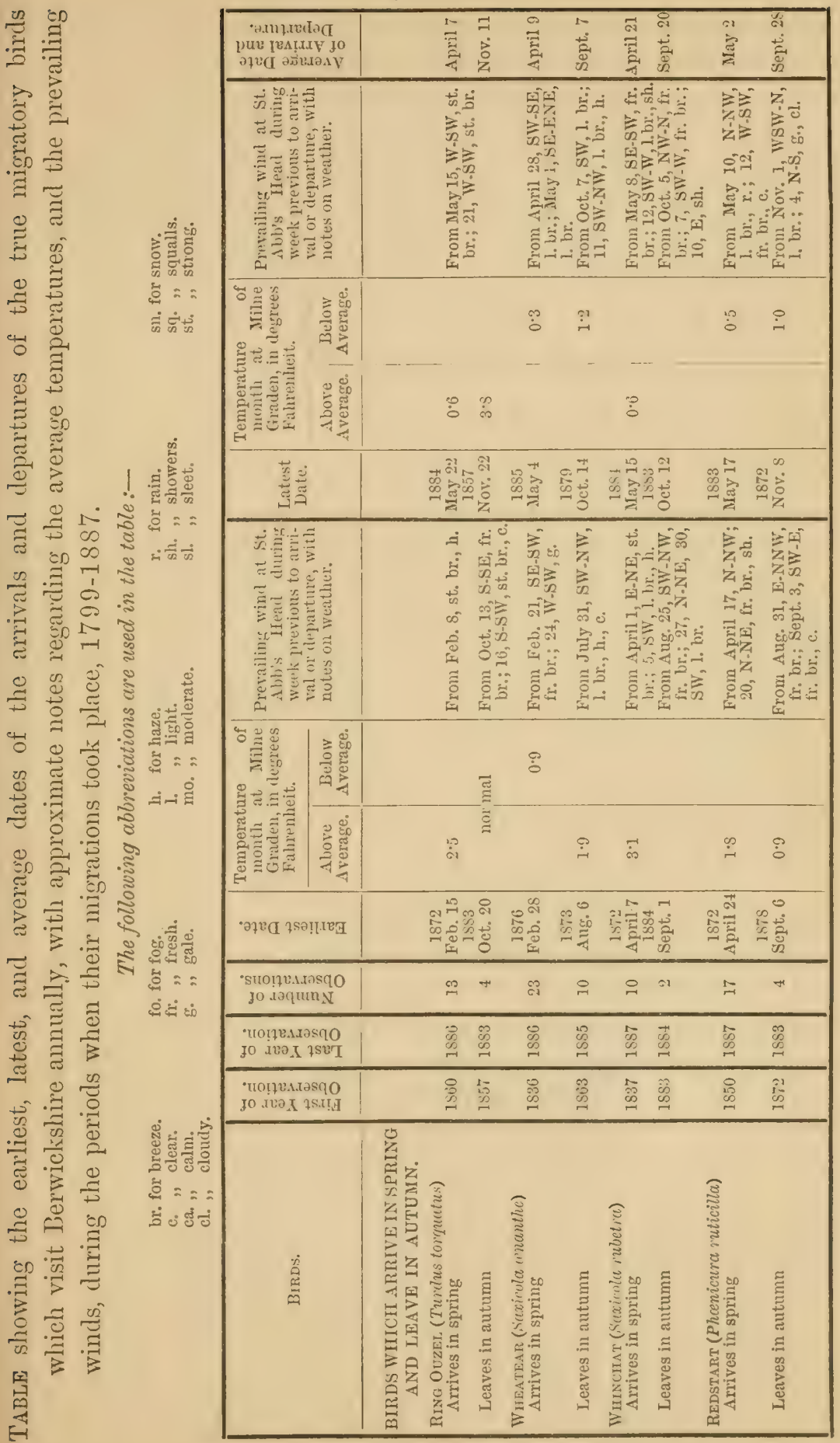


( 352 )

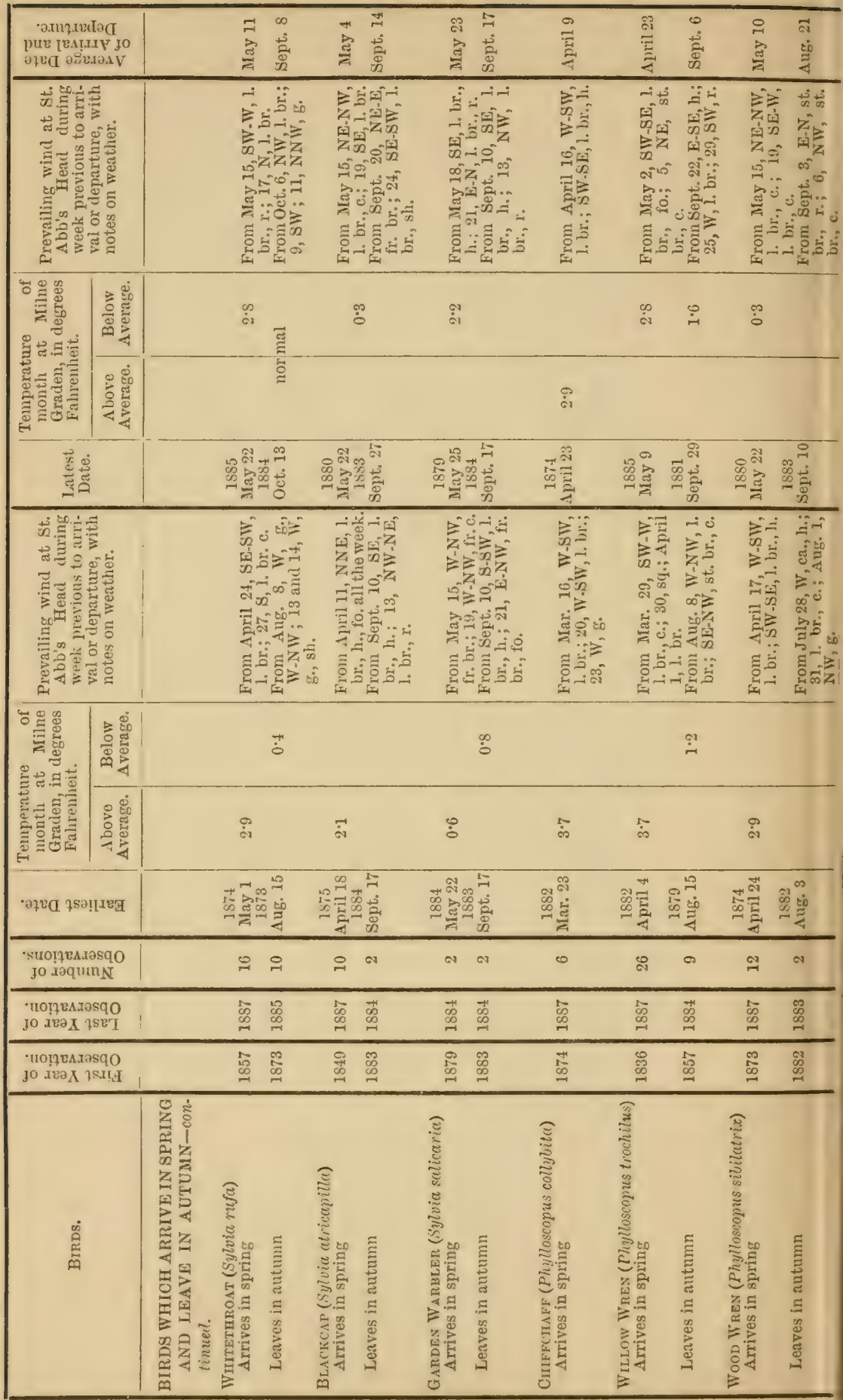


( 353 )

\begin{tabular}{|c|c|c|c|c|c|c|c|c|c|c|}
\hline 帘 & $\begin{array}{l}\infty \\
\Xi \\
\Xi\end{array}$ & $\begin{array}{l}\infty \\
\vec{E}\end{array}$ & 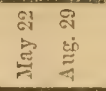 & 总 & 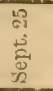 & 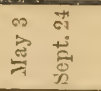 & 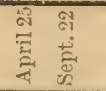 & 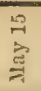 & 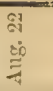 & 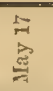 \\
\hline & 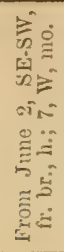 & 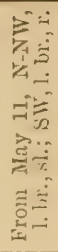 & 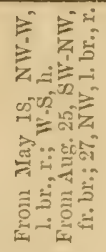 & & 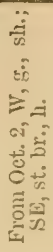 & 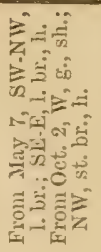 & 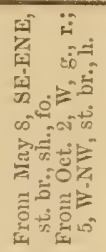 & & 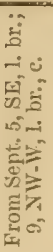 & 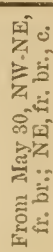 \\
\hline & & $\stackrel{r}{\therefore}$ & $\because$ & 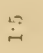 & & कs & $\stackrel{\infty}{\infty}$ & & $\stackrel{r}{-}$ & $\underset{\leftrightarrow}{0}$ \\
\hline
\end{tabular}

$\ddot{b} \ddot{0} \ddot{0}$

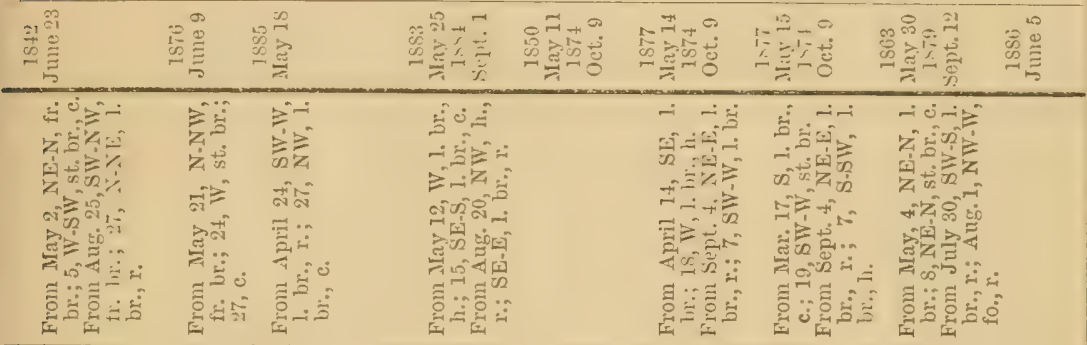

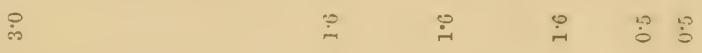

$\stackrel{i}{P} \stackrel{0}{\rightarrow} \quad \stackrel{5}{\rightarrow}$

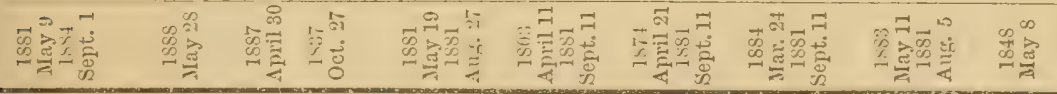

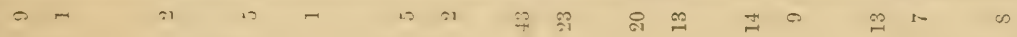

\begin{tabular}{|c|c|c|c|c|c|c|c|}
\hline 罳 & $\underline{\hat{\mathbf{x}}}$ & 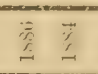 & 2 & $\frac{8}{3}$ & 公奠 & 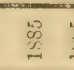 & 要 \\
\hline$\frac{21}{3}$ & 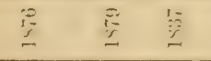 & 至至 & $\underline{\underline{1}}$ & 畄 & $\frac{9}{2}$ & 軎 & \\
\hline
\end{tabular}

\begin{tabular}{|c|c|c|c|c|c|c|c|c|c|c|c|c|}
\hline 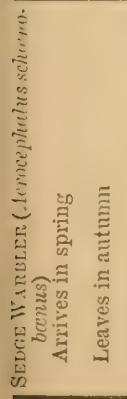 & 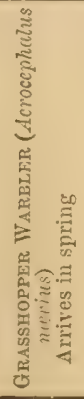 & 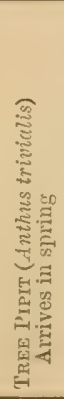 & 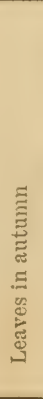 & 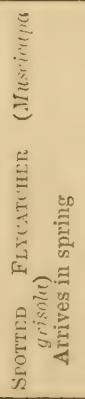 & 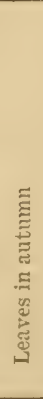 & 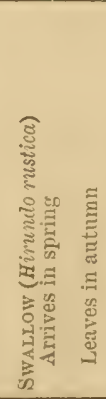 & 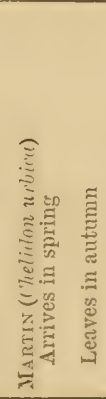 & 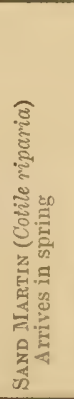 & 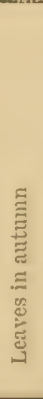 & 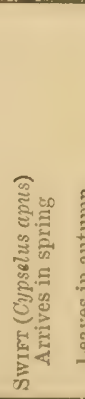 & 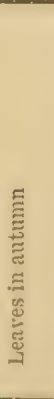 & 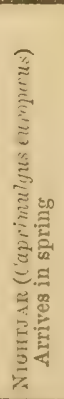 \\
\hline
\end{tabular}

TOL. II.

7. 
( 354 )

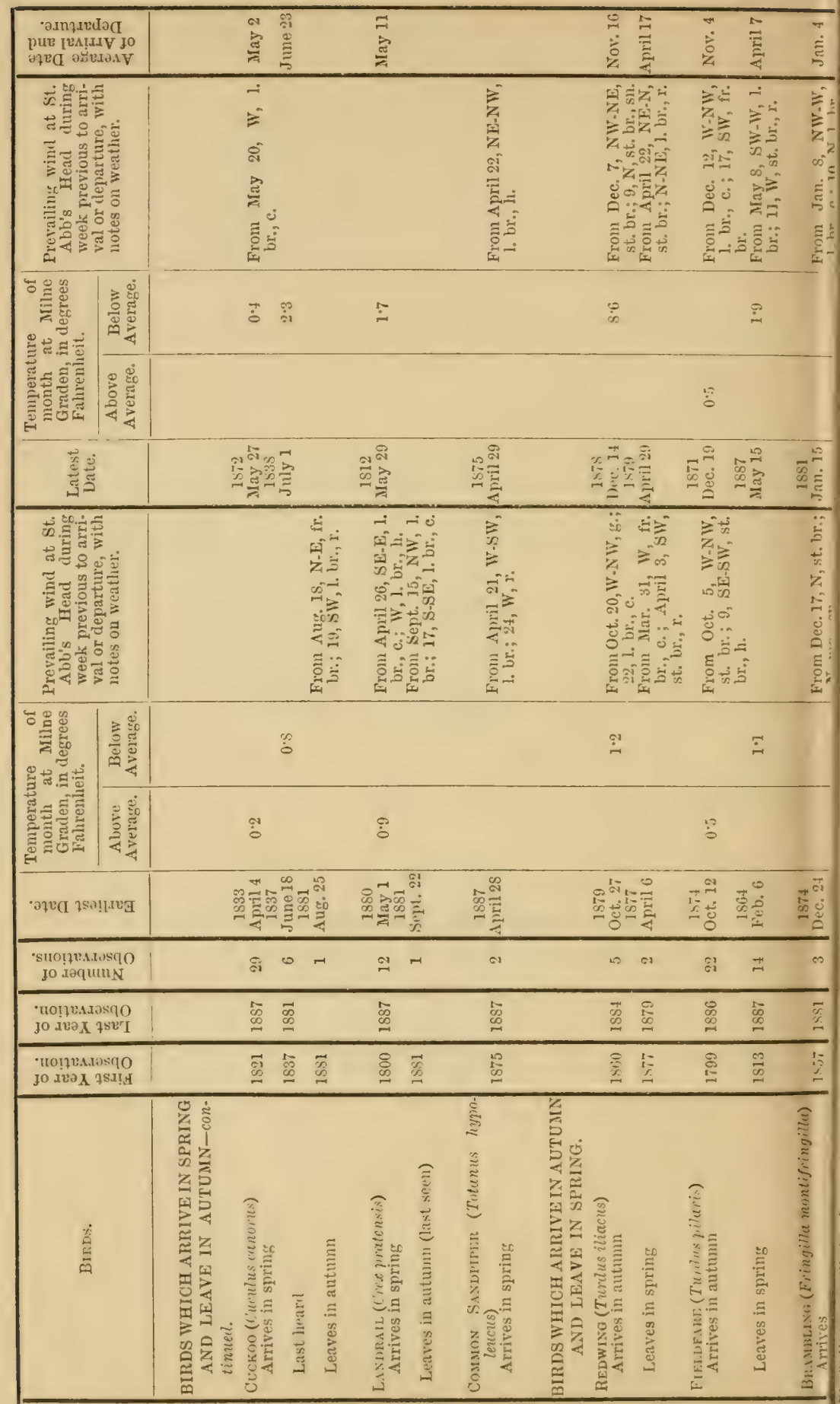


( 356 )

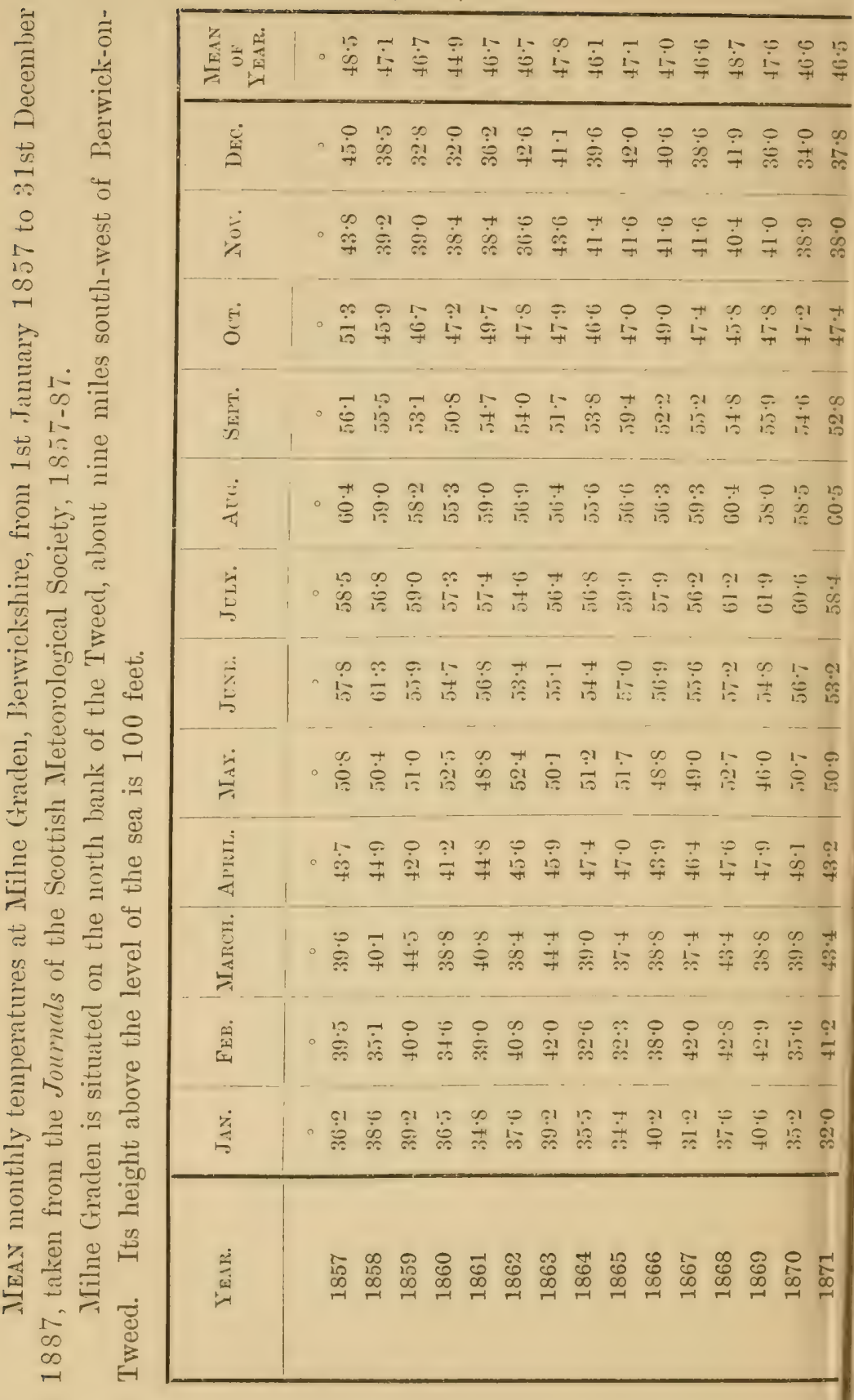




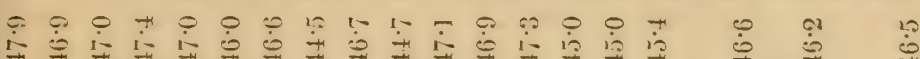

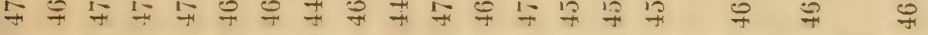

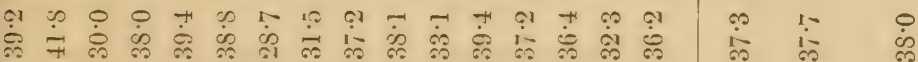

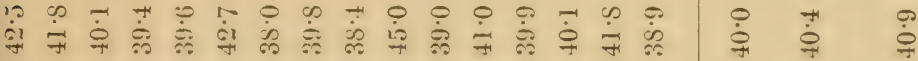

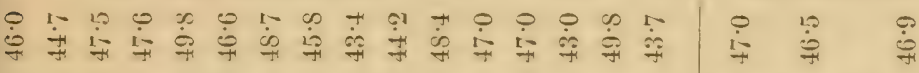

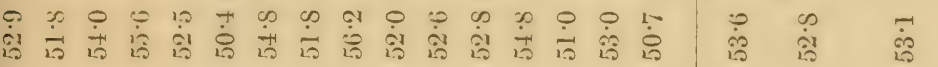

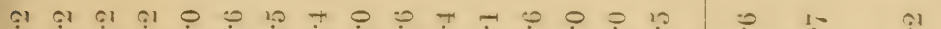

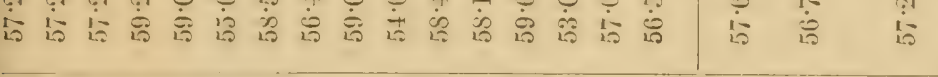

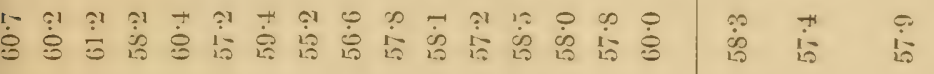

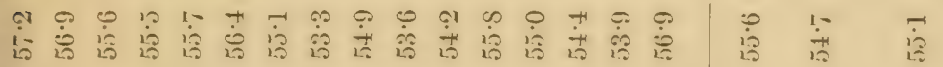

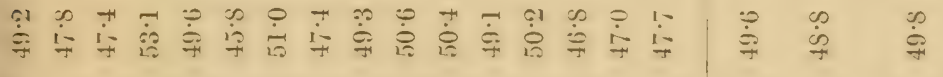

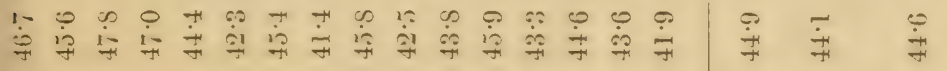

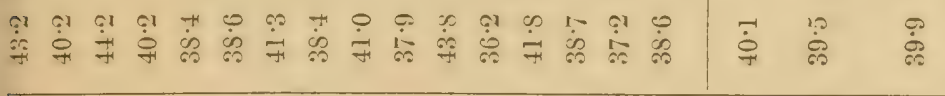

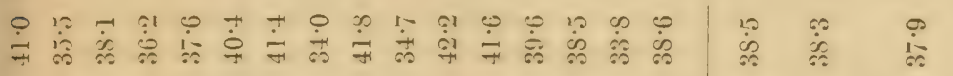

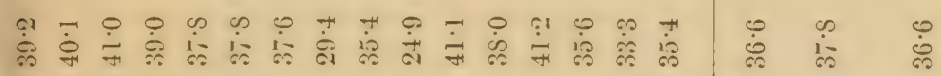
$\overbrace{2} \pi \sigma^{\circ}$

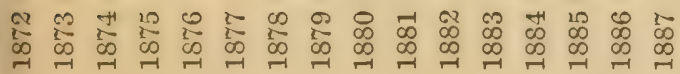

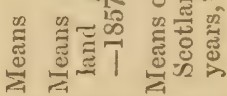




\title{
APPENDIX.
}

\section{THE HAWFINCH.}

\author{
GROSBEAK, CHERRY FINCII.
}

Coccothraustes vulgaris.

Miss Georina Milne-Home, Milne Graden, has kindly informed me that a female Hawfinch was caught in a fruit net in the garden at Ladykirk on the 2nd of September 1892. It was kept in a cage for a few days, when it was identified by Mr. John Irotherston, gardener at Milne Graden, who had frequently seen this species in the south of England.

The Hawfinch has seldom been observed in Scotland. Mr. Eagle Clarke, F.L.S., records in the Amals of Scottish Natural Histury, ${ }^{1}$ that on the Brd of August 1894 a specimen of this bird in immature plumage was captured in a net placed over a strawberry bed in the garden of Mr. Dundas of Arniston, Mid-Lothian.

1 The Annals of Scottish Natural History, 1894, pp. 195, 196.

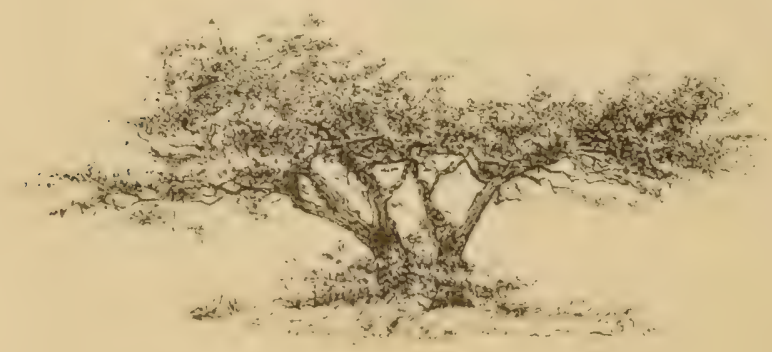




\section{THE GREAT SPOTTED WOODPECKER.}

PIED WOODPECKER, WITWALL, WOOD PIE, FRENCH PIE.

\section{Dendrocopus major.}

My friend Dr. Charles Stuart of Chirnside has been so good as to let me know that this species was found by Mrr. John Ferguson, Duns, nesting in a hole in an ash tree in the woods of Duns Castle, in the summer of $1894 .{ }^{1}$

Mr. William Smith, late gamekeeper at Duns Castle, has informed me that on the 12 th of July 1887 he shot a young Great spotted Woodpecker in Duns Castle woods, which, by its appearance, had only recently left the nest; and that a few days afterwards he noticed three others sitting on the top of a tall larch tree in the same plantations near St. Mary's Cottage.

1 Mr. William Evans, F.R.S.E., records that he found the Great Spotted Woodpecker rearing its young in the same tree in Duns Castle Woods on the 29th of Mlay 1895._L Anals of Sicottish Natural History, July 1895.

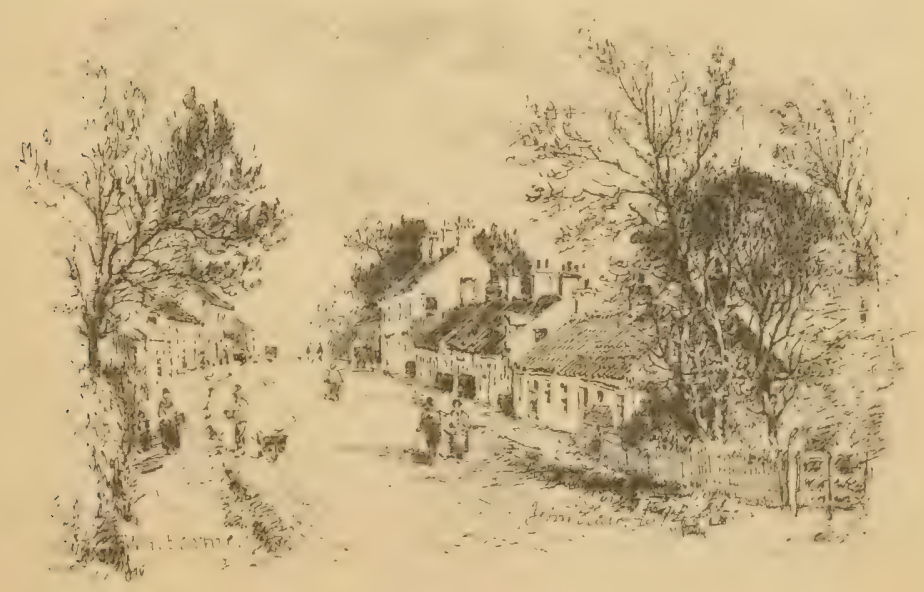




\section{I.-INDEX TO NAMES OF BIRDS IN VOL. II.}

\section{LA'TIN NAMES.}

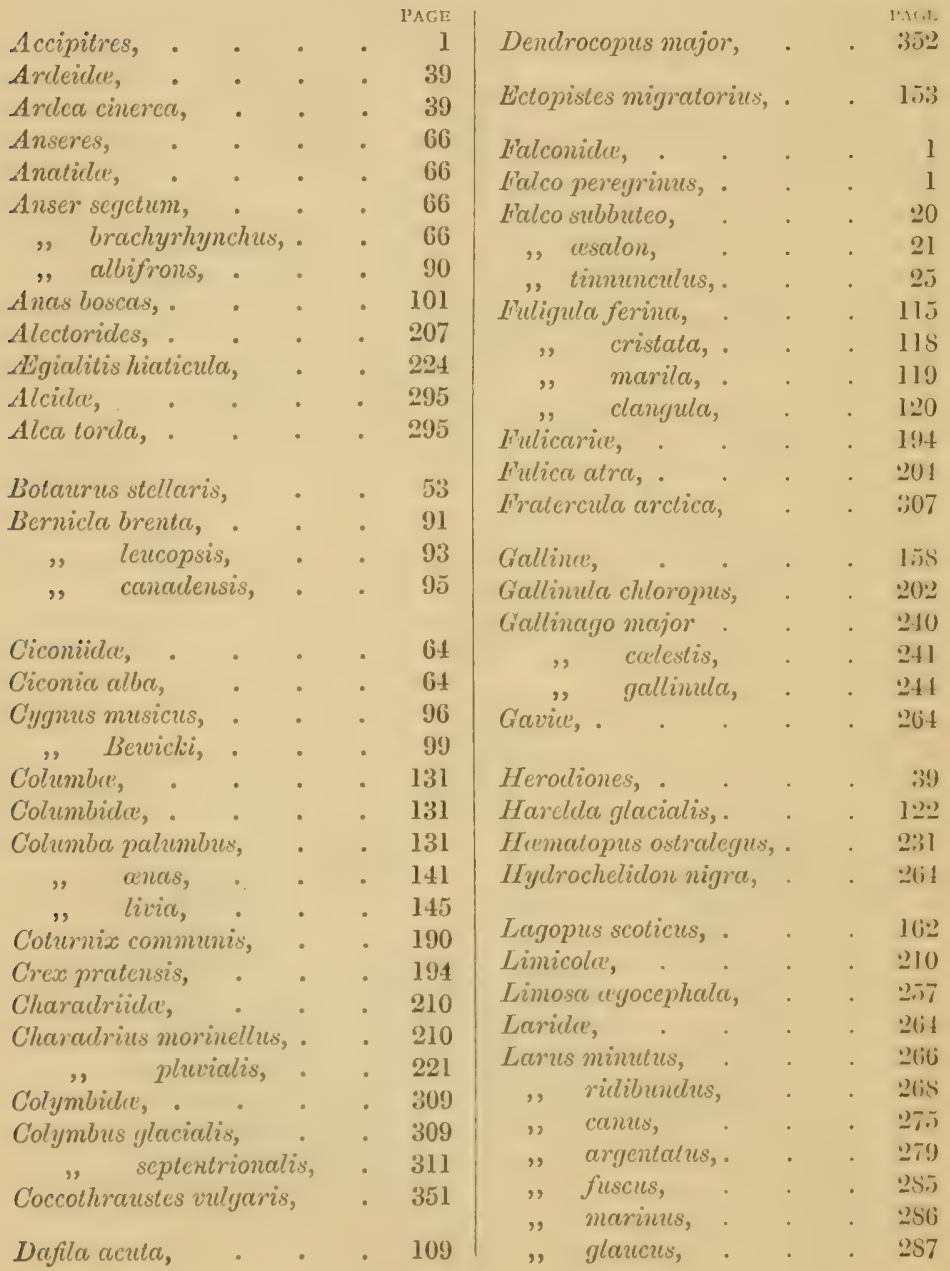




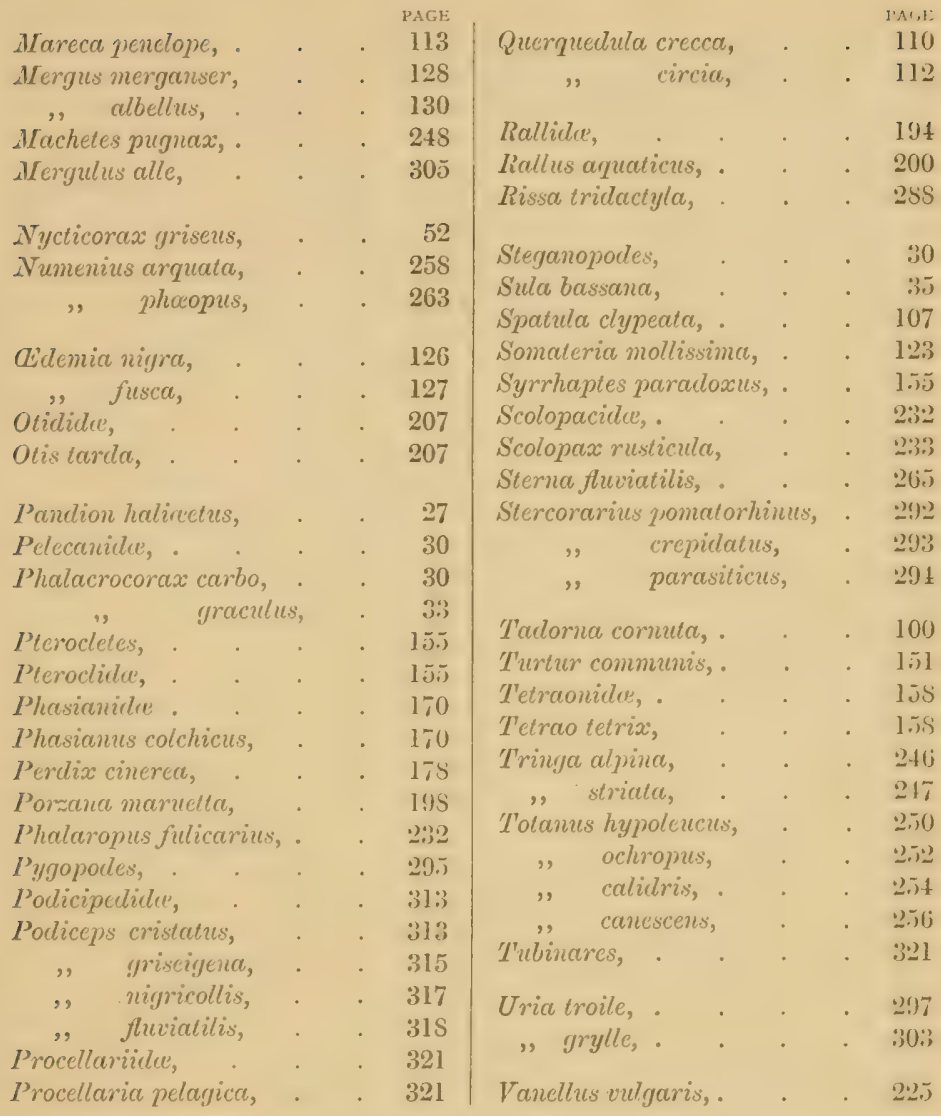

ENGLISH NAMES.

Arctic, or' Richardson's Skua, 293

Auk, Little,

Bittern, Common,

Bean Gioose, .

Brent Goose,

Bernacle Goose,

Bewick's Swan,

Black Grouse,

Bustard, Great, . . . 207

Black-tailed Godwit, . . 257

Black Tern, . . . 264

Black-headed Gull,
Black-backed Gull, Lesser,

28.) ," , , Great, . 2st

Buffon's Skua, . . . 294

Black Guillemot, . . . . : :0:3

Common Cormorant, . . 30)

Cormorant, Common, . . 30)

Green, . . $\quad 33$

Common Heron, . . . $\quad 39$

Bittern, . . . 5:3

Canada Goose, . . . 9.)

Common Sheld-Duck, . . 100

Scoter, . . 126 
Common Partridge, . . 17 " Quail,

Crake, Spotted,

Common Coot,

Coot, Common,

, Redshank,

Common Curlew, .

Curlew, Common,

Common Tern,

, Gull,

, Guillemot,

Crested Grebe, Great,

Duck, Wild,

" Pintail,

, Tufted,

"Scaup,

, Long-tailed,

", Eider,

Dove, Ring, .

,, Stock,

", Rock,

, Turtle,

Dotterel,

Dunlin,

Diver, Great Northern, , Red-throated,

Dabchick,

Eider Duck,

Eared Grobe,

Falcon, Peregrine,

Green Cormorant,

Gannet,

Goose, Solan,

$$
\begin{array}{ll}
, & \text { Beall, } \\
, & \text { Pink-footed, } \\
\text {, } & \text { White-fronted, } \\
, & \text { Brent, } \\
\text { " } & \text { Bernacle, . } \\
\text { " Canada, . }
\end{array}
$$

Garganey,

Golden-Eye,

Goosander,
I. AC:

190

195

204

204

$2: 31$

241

250

254

2.5

2.is

$2(i$.

275

297

313

101

109

118

119

122

$1 \div 3$

131

$1+1$

145

1.51

210

246

309

311

$31 \mathrm{~S}$

$1 \cdot 23$

$\$ 17$

1
Crotise, Pallas's Sand, o pacie

. 15j

"Black, . . . $15 \mathrm{~s}$

, Red, . . . 162

Great Bustard, . . . 207

Golken Plover, . . . 221

Grey Phalarope, . . . $\quad 2932$

Great Snipe, . . . 210

Green Sandpiper, . . . 252

Greenshank, . . . 256

Godwit, Black-tailed, . . 257

Gull, Little, . . . . 266

,, Black-headed, . . 265

"Common, . . . 275

"Herring, . . . 279

, Lesser Black-backed, . 255

, Great Black-backed, . 256

Great Black-backed Gull, . $\quad 2 S 6$

Glaucous Gull, . . . 287

Gull, Glaucous, . . . 2S7

, Kittiwake, . . 2ss

Guillemot, Common, . . $\quad 29$

," Black, . . 303

Great Northern Diver, . . 309

„Crested Grebe, . . 31:3

Grebe, Great Crested, . . : :31:3

, Red-necked, . . 315

, Eared, . . . 317

"Little, . . $31 \mathrm{~s}$

Great Spotted Woodpecker, 35:

Hobby, . . . . 20

Heron, Common, . . . $\quad 39$

, Night, . . . 52

Herring Gull, . . . 279

Hawfinch, . . . . 351

Jacksnipe, . . . . 244

Kestrel, . . . . 2.5

Kittiwake Gull, . . . $2 s s$

Long-tailed Duck, . . 122

Landrail, . . . . 194

Lapwing, . . . 225

Little Gull, . . . . 2lit

Lesser Black-backed Gull, . 285.5

Long-tailed Skua, _ . $\quad 29 ! 4$

Little Auk, . . . 305

"Grebe, . . . 31s 


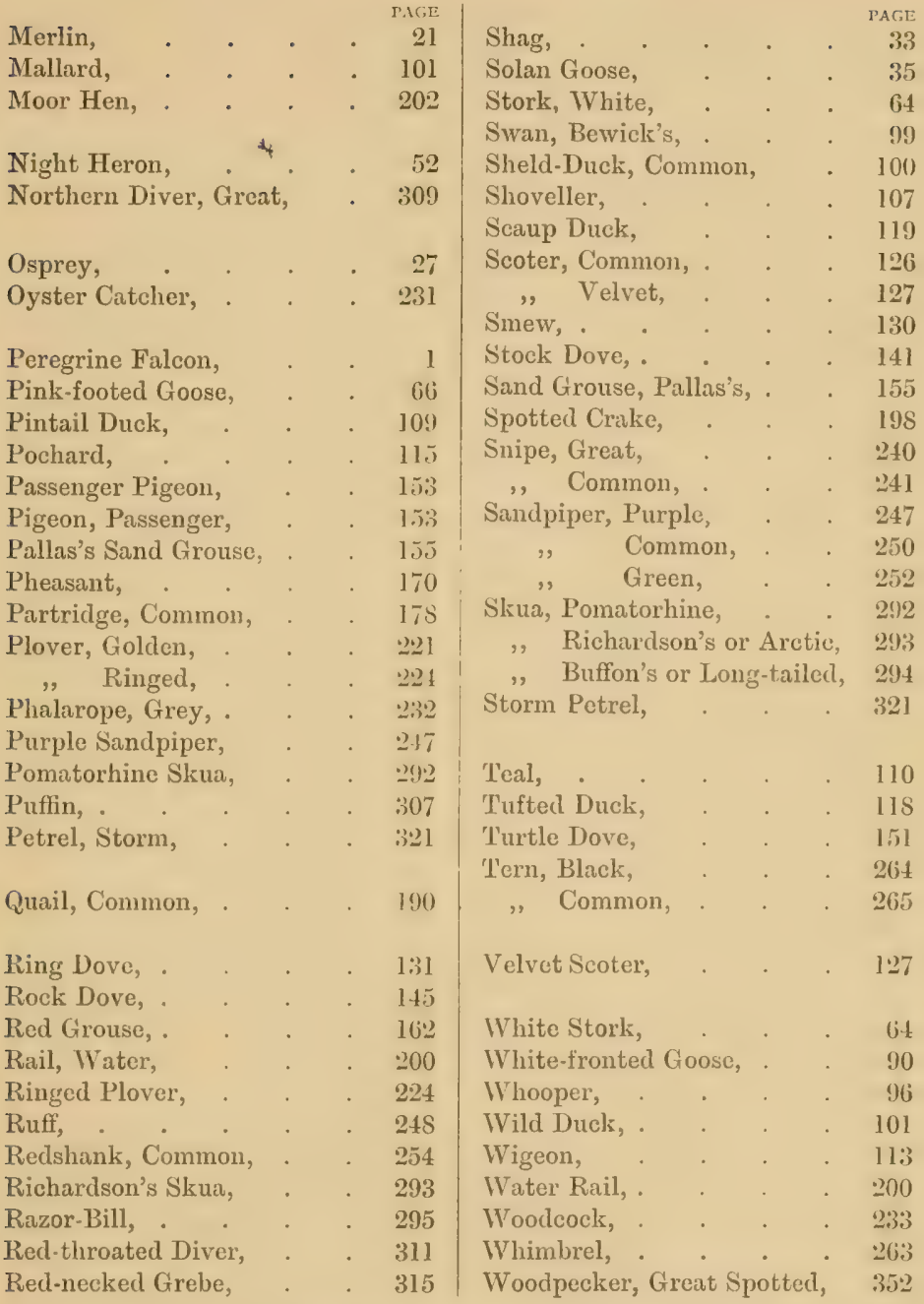

\section{BERWICKSHIRE NAMES.}

Blue Hawk, .

Black Cormorant, . . 30

Bull o' the Bog, . . . 53

Black-Cock, . . . 158

Bell-poot, . . . 204

Blutter, Heather, . . 241
Cormorant, Black, . . $\quad 80$

30

30

Coal-and-Candle-Licht Duck, 122

Cud-Doo, . . . . 1:23

Culbert, . . . 12:3 
Cushie, . . . . 131

Cushie Doo, . . . . 131

Corn Crake, . . . 194

Crake, Corn, . . . 194

Common Gull, . 279

Coulter Neb, . . . 295

Chicken, Mother of Carey, . 321

Drum, Mire, . . . 53

Duck, Wild, . . . 101

Duik, Tael, . . . . 110

Duck, Sea, - . . 120

, Coal-and-Candle-Licht, 122

Dunter, . . . . 123

Doo, Cushic, . . . 131

Doo, . . . . . 145

Dove, Turtle, . . . 303

Dipper, . . . . 318

Faisan, . . . 170

Goshawk, . . . . 1

Guise, Solan, . . . 35

Goose, Wild, . 66, 90, 91, 93

Grey Hen, . . . . 158

Gull Maw, - 275, 279, 285, 286

,, Common, . . . 279

Hawk, Blue, . . . 1

, Hunting, . . . 1

Hunting Hawk, . . . 1

Hawk, Keelie, . . . 25

Hurant, 。 . . 39

Huron, . . . . 39

Heronsheugh, . . $\quad 39$

Hen, Grey, . . . . 158

, Water, . . . 202

Heather Blutter, . . . 241

Keelie, . . . . 25

Keelie Hawk, . . . 25

Kaitiewake, . . . $2 S S$

Laverock, Sandy, . . 250

Mire Drum, . . . . 53

Muir-fowl, . . . 162

Muir-cock, . . . . 162

Muir-hen, . . . . 162
Mire Snipe, . . . 241

Maw, Gull, . 275, 279, 285, 286

Narrot, . . . 297

Mother of Carey Chicken, . 321

Neb, Conlter, . . . 295

Norie, 'Tammie, . • . 307

Paitrick, . . . . 17S

Pliver, . . . . . 221

Pluver, . . . . 221

Peeseweep, . . . . 225

Piet, Sea, . . . . 231

Pickie, . . . . 268

Pickiemaw, . . . . 268

Pictarnic, . . . 26S

Peg-birnet, . . . . 268

Petrel, Stormy, . . . 321

Stair Cormorant, . . $\quad 30$

Scart, . . . . . 30,33

Solan Guise, . . . . 35

Swan, Wild, $\quad . \quad . \quad .96,99$

Shieldrake, . . . $\quad 100$

Sea Duck, . . . . 120

Sea Piet, . . . . 231

Snipe, Mire, . . . 241

Sandy Laverock, . . . 250

Sea Snipe, . . . . 254

Snipe, Sea, . . . . 254

Sea Swallow, . . . 265

Swallow, Sea, . . . 265

Scoot, . . . . 297

Stormy Petrel, . . . 321

T'ael Duik, . . . . 110

Teuchit, . . . . 225

Tirrlie, . . . . 285

T'urtle Dove, . . . 303

Tammie Norie, . . . 307

Watch Cormorant, . . 30

Wild Goose, . 66, 90,91, 93

Wild Swan, . . . . 96, 99

Wild Duck, . . . 101

Wigeon, . . . . 120

Water Hen, . . . . 202

Whaap, . . . 258 


\section{II.-INDEX TO PROVERBS IN VOL. II.}

POPULAR RHYMES, SAYINGS, AND WEATHER LORE ABOUT BIRDS.

BFRNACLE Goose: belief in olden times about origin, 94 .

Common Bittere : "Boglo of Billie Myre," 53.

Common Cormorant : weather prognostic, 31.

Common Corlew : name associated with goblins, \&c., 260.

Common GuLL : weather prognostic, 275 ; rlyme, 275; superstition, 276.

Common Huron : saying of Archibald, seventl Earl of Angus, at Ancrum Moor, 40 ; weather prognostic, 42.

Common Pantridge: French proverb, 186 ; rhyme, 189.

GANnET: saying of salmon fishers, 36.

Golden Plover: weather prognostic, 222, 223.

Herring GulL: weather prognostic, $28 \pm$.
LANDIAIL : rhyme, 196.

LAPWING: weather lore, 226 : regarded as a bird of ill-omen, 228, 229 ; weather prognostic, 229 ; rhymes and sayings, 229.

LESSER BLACK-BACKED GULI: proverb, 285.

Maltain : saying, 106.

RED GRouse: weather prognostic, 169.

Red-Timoaten Divks: weather promostic, 311.

Rock Dove : superstition, 149 ; sayings, $149,150$.

Storm Petrel : origin of name, 321 ; weather prognostic, 322.

WILD Goose : arrival, sign of seasons, 67; belief amongst boys, 88 ; rhymes, 87,88 ; saying about geese, 106.

Whoophe : vows to the Swan, 97.

WOODCock : popular saying, 239.

Woon PIGEON : sayings, 140.

\section{III.-TOPOGRAPHICAL INDEX TO VOL. II.}

Abbey St. Bathans, Parish Wild Geese Report, 72 ; Golden-Eye on Whitadder, 120; Pallas's Sand Grouse, 156 ; Black Grouse, 160 ; Red Grouse, 164 ; bags got, 162 ; numbers in end of last century, 163 ; contents of crop, 165 ; Partridge shooting, 181; Common Quail, 191; Dotterel, high grounds visited by great numbers in former times, 211, 214; on heights in recent years, $212,214,216,218$; Black-headed Gull, 274; Little Auk found dead, 306. Abbey Farm, North Berwick, 64. Aikenga, Lapwing, 229.
Albentum fluvium, 166.

Alyth, Forfarshire, voracity of Wood Pigeon, 137.

Ancrum Hoor, Common Heron, 40. Ancrum Woollead, 236.

Angelrow, Wild Geese, 80.

Arniston, Hawfinch, 351.

Auchencrow Mains, 54 ; drainage of Billie Mire, 5S; Wild Geese, 76. Auchencrow, notes on Billie Mire by Mr. Thomas Hewit, 61.

Avenue Bridge at P'axton, 142.

Ayton, Hawks kept by Mr Belany, 3 ; Billie Mire, 54, 57; Parish Wild Geese Report, 72 ; Pallas's Sand Grouse got at IVhitfield, 
156; Water Rail, 201; high grounds visited by Dotterel in former times, 211 ; Woodcock in lambing shed, 234; tame Herring Gull, 284.

Ayton Castle, Osprey found, 2S; Pheasant shooting, 173; Partridge shooting, 182 .

Backlea Woods, Black Grouse, 161.

Bamborough, 100.

Bankend, 156.

Barmside, Wild Geese, 72 ; Black Grouse, 15S; Red Grouse shooting in 1813, 164 .

Bass, Gannet, 35, 36, 37 ; seen from Fast Castle, 281 ; Kittiwake Gull, 200 ; Razor-bill, 295 ; Puffin, 305.

Bastenvig, Dotterel, 210.

Bathgate Bog, James IV. hawking the Common Bittern, 62.

Bedshiel, Wild Geese, $\mathrm{SO}$; Black Grouse, 158, 160; Red Grouse shooting in 1812-14, 164.

Belhaven, 317.

Belidere, Common Heron, 45.

Bemersyde, 62 ; Little Grebe, 319.

Bemersycle Loch, a haunt of the Mallard, 102; a nesting station of Black-headed Gull, 268; Mr. John Thomson's account of loch, 269, $270,271$.

Berrington, rhyme about Wild G'eese, 87.

Berrybank, 54 ; Partridge shooting, 183.

Berrywell, Water Rail, 201.

Beruick, Grace Griffith's execution and White Pigeon, 149; popular saying regarding pigeons associating with Rooks, 150 ; Dr. Colville Brown's account of moulting of Black-headed Gull, 271.

Bervick Boundls, Common Quail, 191.

Bervick Brillge, 313.

Berwick-on-'T'weed, Falcons at Highland and Agricultural Society's Show in 1841, 3 ; IVild Swans, 97 ; Eared Grebe, 317.

Berwickshire, heather burning, 169 ; migration, 327, 328; Ornithological observations, 329.

Big Blake Law, Dotterel, 216.

Big Byrips, nest of Herriug Gull, 281.

Big Wood, Salton, Cushats, 134.

Billie, Partridge shooting, 182, 183.

Billie Burn, drainage of Billie Mire, 57, 59; Water Rail, 201.
Billie Castle, ruins of, 55 .

Billie Mains, 54, 55; Brent Goose shot, 91 ; Shoveller killed, 107 ; 273.

Billie Mill, 56.

Billie Mire, formerly a haunt of the Common Bittern, 53; meeting place of English and Scottish Commissioners, 54; Fosterland Burn, 55; Auchencrow Burn, 55 ; Billie Mire Burn, 55; Draeden Burn, 55 ; MS. notes on the plants formerly found here by the late Dr. Henderson, Chiruside, 57 ; birds, 5S; state in end of last century, 5S; plan in 1759,58 ; Mr. Joln Blackadder's notes about drainage of the Mire, 59; proposed caual between Duns and Eyemouth, 59 ; Mire bridge, 59 ; notes by Mr. William White, Lemnel Hill, 60; last Bittern shot, 60 ; bog oak and hazel nuts discovered, 60; old people in Chirnside having heard the Bull o' the Bog, 61 ; Tild Duck, $10 \mathrm{l}$; Flapper shooting, 104; Spotted Crake, 199; a breeding station of Black-headed Gull in former times, 273.

Billie Mire Burn, 55, 56.

Birch Hill, Norham, 310.

Birgham, Pochard on the Tweed, 116 ; Black-headed Gull, 271.

Blackadder, Kestrel, 26 ; Common Heron, 45; frequented by the Mallard, 103 ; Moor Hen, 202 ; Common Sanipiper, 250.

Blackadder Eistate, Pistol Plantation, favourite roosting place of Wool Pigeons, 136.

Blackadler House, Stock Dove's nest, 143 .

Blackbum, 54 ; "Mire Drum" shot, $60 ; 95$; Dotterel, 217.

Blackburn Mill, Dotterel, 216.

Blackburn Rigg Peat Moss, Landrail in winter, 196.

Blackcasile Rinys, Kestrel, 26.

Blackerston, Dotterel, 213, 214, 215, 220.

Black Hill, Dotterel, 215.

Black Hill, Longformacus, 106.

Black Mask Rock, near Fast Castle, nests of Herring Gull, 281.

Black's Iill Burn, shooting Wild Ducks in 1S12.14, 104 .

Blackpotts, Coldingham, White Stork, 64. 
Blakey, Peregrine Falcon's nest, 4, 5 ; Kestrel, 26.

Blanerne, Merlin, 21 ; Billic Mire, 58, 59 ; Teal on Whitadder, 111 ; Partridge shooting, 1S4; 273; Little Grebe found on Whitadder, 319.

Blaneme, Last, Wild Geese, 72.

Bleak Hengh, near Bummouth, 280.

Blue Braes, Peregrine Falcon's nest, $5,6$.

Blythe, IVild Geese, 82.

Blythe Eulge, Dotterel, 219.

Blythe Moor, Common Heron, 47.

Blythe Water, Dotterel, 219.

Boiling Park, Common Heron, 43.

Bonkyl, Partridge shooting, 182.

Bonkyl Lodge, 56.

Boon, Wild Geese, 82 ; White Par. tridge, 189 ; Dotterel, 219.

Borthuik, 134.

Boundreigh Water, Dotterel, 219.

Bowerhouse, Wild Geese, 73 ; Com. mon Quail, 190.

Bowshiel, Wild Geese shot, 71 ; Wild Geese, 74; Dotterel, 217.

Braid Boy, Penmanshiel, Wila Geese, 71 .

Brander Clifjis, nests of Herring Gulls, 280.

Brander Cove, Green Cormorant nesting, 33, 34 .

Brighton A quarium, Guillemot, 201.

Broall Bor, Dotterel, 215.

Broad Bor, Penmanshiel, Wild Geese, 67.

Broadhaugh, effects of severe weather on Moor Hen, 203.

Broadharen Bay, 2S0 ; small colony of Common Guillemots, 299.

Broadmeadows, Wild Geese, 80.

Broarlshawrig, Merlin mesting, 24.

Brokholes, Dotterel, $213,21 \mathrm{~S}$.

Broomhouse, Pheasant shooting, 174; Partridge shooting, 184.

Brotherstone 'Touer, 270.

Bruntaburn, Common Heron, 44.

Bruntiburn, Peregrine Falcon's nest, 6.

Buncle, 54.

Buncle Church, 56.

Buncle Parish, report on Wild Geese, 72 ; Mallard, 106 ; Black Grouse, 160 ; Dotterel in former times, 211, 215; Woodeock, 234.

Buncle Wood, Common Heron, 43, 56 ; a favourite haunt of IVoodcock, 234.

Burmonuth, Peregrine Falcon's nest,
2, 4; Osprey, 29; Rock Dove, 145; Coot, 204; female Ruff́ shot, 248; Herring Gull, 280 ; fishermen collecting eggs of Gulls for sale, 282; Captain Norman's account of Herring Gull feeding on shoal of herrings, 283.

Butterdean, Wild Geese, 8t; Common Quail, 190.

Byrecleugh, Merlin, 24; Common Heron, 47 ; bags of game got by the Duke of Roxburghe in $1880^{\circ}$ and $1872,164,165$; White Grouse shot, 168; Partridge, 179.

Byrke Houses, 141.

Byreloch Heugh, Green Cormorant, 33.

Caimeross, Wild Geese, 76.

Cairnsmill, IVild Geese, 77.

Caldra, Partridge shooting, 184.

Caldron Cov'e, Green Cormorant, 33.

Cammer Laws, IVild Geese, 85.

Cardross, falconry, King Robert the Bruce's Hawk-house, 13.

Carfrae Mill, large bags of Red Grouse got in 1886,165 .

Castleholes Heugh, Peregrine Falcon, 9.

Cattleshiel, Black Grouse, 160, 161 ; George Home of Kimmerghame hawking Grouse, 163; Rerl Girouse shooting, 166.

Caulcleron Coi'e, Rock Dove, 145.

Cansewaybank, 54, 56 ; plan of Billie Mire, 59, 60; bog oak and hazel nuts found in Billie Mire, 60.

Carers, 154.

Channelkirl;, Dotterel, 218.

Channelhirh Parish, report on Wild Geese, 73; 13lack Grouse, 160 ; Red Grouse, 164.

Chapel, Woodcock shooting, 236.

Chapel, near Duns, Gannet, 35.

Chapelhill, flock of Bermacle Geese, 93.

Charterhall, Pheasant shooting, 174 ; Partridge shooting, 184.

Chermitrees, 212.

Chesterbank, Dotterel, 210, 215; Mr. John Renton's account of the Sea-fowl at St. Abb's Head, 288.

Chiruside, 54; Dr. Henderson, 55 ; Billie Mire drainage, 59 ; Sheldduck shot, 100 ; Dr. Henderson's lamentations about change on the face of Nature, 102; Wood Piseons cating vecretables in gardens, 138 ; l'allas's Sand Grouse, 156 ; Com- 
mon Quail, 191 ; Lapwing, 225 ; 248; Green Sandpiper shot, 252 ; $273 ; 352$.

Chimside Mill, 57.

Chimside Parish, report on Wild Geese, 73 ; Pallas's Sand Grouse, 156: Viater Rail, 201 ; Woodcock, 235.

Choicelee, Wild Geese. 81.

Circle Plantation, Common Heron, 44.

Cleaver Rock, St. Abb's Heal, 146; nest of Herring Gull, 2S0 ; Lesser Black-backed Gull breeding, 285 ; nesting of Kittiwake Gull in former tinıes, 290 ; colonies of Com. inon Guillemots, 298.

Claimale Wood, Greenshank, 256.

Clarabad, Common Heron, 45; IVild Geese, 81 ; Coot, 204.

Clarabad Mill, Green Sandpiper seen, 253.

Claraboul Mill. Canld, Red-necked Grebe shot, 315.

Coal Point, Lamberton, Kestrel, 26.

Cocliburn, Pochard shot on Whit adder, 116; Partridge, 178; 213.

Cockburn Braes, Osprey, 28.

Cocliburn Law, popular rhyme about the weather, 87.

Coclibum Mill, Osprey, 273.

Cockburnspath, Peregrine Falcon, 2 ; flock of Bernacle Geese at Chapelhill, 93; 115; Albino Black-headed Gull shot, 273 ; migration, 328.

Cochburnspath Parish, Common Heron, 45; Common Bittern, 6l report on Wild G'eese, 73 ; l'allas's Sand Grouse, 156 ; Black Game, 160 ; Red Grouse in 1835, 164 ; Common Quail, 190; Dotterel, 210: Dotterel in former times, $21 \mathrm{I}$; Dotterel in recent years, 212.

Coclilaw, Ayton, Wild Geese, 72 .

Coldingham, Peregrine Falcon, entry of two aeries of Falcons in ancient rental, 1 ; falconry, 13 ; priory falconry, 13, 54; immigration of Ring Dove, 133; Rock Dove, 149 ; shrine of St. Ebba and White Pigcon, 149; 286 : Kittiwake Gull, 289 ; occurrence of Arctic or Richardson's Skua in unusual numbers, 293; Mr. Andrew Wilson's list of birds which frequent St. Abb's Hearl, 296, 297; Black Guillemot, 303 ; incident in great storm of 14 th October 1851, 322.
Coldingham Loch, Pochard shot, 115; Coot, 204; occurrence of Little Gull, 266.

Coldingham Moor, Curlew plentiful, 258.

Coldingham P'arish, report on Wild Geese, 75 ; Velvet Scoter, 127 ; Pallas's Sand Grouse, 156 ; Black Grouse, 160 ; Red Grouse, 164; Dotterel, 210 ; Dotterel in former times, 211; Dotterel in recent years, 212; Wooklcock, 234; Little Gull, 266, 267.

Coldingham Priory, FosterlandBurn, 55,$56 ; 208$.

Colclinghamshire, "Crachochtre,"56. Coldinghamshore, Peregrine Falcon, 2 ; Osprey, 29 ; Long-tailed Duck, 122; 145; Common Redshank, 255; visit of Mr. Archibald Hepburn in 1850,277 ; 281 ; 290; Aretic or Richarison's Skua shot, 293; Common Giuillemot, 29S ; notes about Guillemots' egres, 300 ; Red-necked Grebe shot, 315 ; Stom Petrel, 321, 322.

Coldlands, 55

Coldstream, Cistercian Abbey of, falconry, 15; Wild Swans shot, 96 ; 146 ; priory "columbis" and "columbarijs," 148; Ringed Plover, 224 ; 299 ; Great Northern Diver killed, 310.

Coldstream Bridge, Black-headed Gull haunting 'Tweed there, 272.

Coldstream Parish, Common Heron, 43 ; report on IVild Geese, 76; Black Tern, 264; Eared Grebe, 317.

Corlie's Heugh, Peregrine Falcon's nest, 6.

Corsbie, IVild Gicese, 82.

Corsbie Bor, a breeding quarter of the Black-headed (xinll in former times, 274.

Corsbie Tower, 268.

Cov'e Harbour, Eider Duck, 123.

Cove, near Cocliburnspath, 279; 297; Great Northern Diver foumd in nets, 309.

Cove Shore, IVigeon, 113.

Coreyheugh House, 315.

Cowdenknowes, 54: Stock Dove, 143; $199 ; 293$.

Craig 'T'aw, Common Cormorant, 31. Cramond, 293.

Cranshaws, WVild Geese, 77 : Landrail in Oetober, 196 ; 209 ; Storm Petrel got, 321. 
Cranshaws Hill, autumnal flights of Woodcock, 233.

Cranshaws Parish, report on Wild Greese, 77; Black Grouse, 160 ; Red Grouse 164; Dotterel in former times, 211 ; Dotterel in recent years, 212.

Cribbs, Wild Geese, 82.

Crichness, 315.

Crosslaw, Wild Geese, 76.

Crow Dean Wood, Paxton, Woodcock, 235.

Crumles Brillge, Common Heron, 44.

Cumledge, Common Bittern shot, 61 ; Wild Swan killed, 97.

Daurnae, 217.

Dawikkis, Common Heron, 40.

Daye, 166.

Dirringtons, Great and Little, popular rhymes about the weather, 87.

Dirrington Law, Wild Duck shooting, 104 .

Doldifill, Common Heron, 47 ; Bernacle Goose, 93.

Dogden Moss, 86 ; Water Rail, 201 ; a breeding station of the Black. headed Gull in former times, 274.

Dow Care, 145.

Dowlaw, P'eregrine Falcon's nest, 2 ; Merlin's nest, 24; Common Cormorant, 30 ; Canada Geese shot, 95; Velvet Scoter, 127 ; derivation of name, 149; Common Quail, 190; Coot, 204; a favourite haunt of Dotterel, 212, 216, 217, 218; Black-triled Godwit shot, 257; 279.

Doulaw Braes, arrival of Woodcock, 234.

Dowlaw Burn, Peregrine Falcon's nest, 5 .

Dowlaw Burn Foot, nests of Herring Gulls, 281.

Dowlaw Dean, 217.

Doulaw Mill Pond, 146 ; Common Snipe nesting, 243.

Draeden Burn, 55.

Draeden Field, Henghhead, Earl of IVemyss stalking Wild Geese, 69.

Drake Mire, derivation of name, 106.

Drakestruther, name derived from Wild Duck, 106.

Dronshiel, Dotterel, 219.

Dryburgh, Common Heron, 49; Stock Dove, 143; Oyster Catcher, 231.

Dryburgh Estate and Bemersyde Loch, 270.

VOL. II.
Drygrange, Stock Dove, 143.

Dunbar, falconry, 11, 12 ; Pallas's Sand Grouse seen, 155; Black Tern, 264.

Dunglass, Wood Pigeon destroying broccoli, 138; Partridge shooting, 183 ; Dotterel, 217.

Dunglass Dean, Common Heron, 45.

Dunglass IVoods, large bag of Woodcock, 237.

Dunkirk, 282.

Duns, Hobby, 20 ; 59 ; 219 ; 24S; 273 ; Little Auk caught, 306 ; $321 ; 352$.

Duns Castle, Common Heron, 47 ; Pintail Duck seen, 109; Stock Dove shot, 142; Stock Dove's nest, 143; Pheasant shooting, 173 ; Partridge shooting, 183; 219; 220; Black-headed Gull at Hen Poo in former times, 273.

Duns Castle Lake, a favourite retreat of Mallard, 102; Shovellers observed, 107; visited by Pochard, 116 ; Tufted Duck, 118; GoldenEye, 120; Long-tailed Duck, 122 ; Eider Duck, 124; Velvet Scoter seen, 127; Water Rail shot, 201; Moor Hen, 202; Coot, 204, 205.

Duns Castle Wroods, Common Heron, 43 ; young Woodcock found, 238; Woodeock's nest found, 238; Great Spotted Woodpecker, 352.

Durs Law, 141.

Duns Parish, report on Wild Geese, 78; Black Grouse, 160; Red Grouse, 164: introduction of Pheasant, 171.

Dun.s Railway Station, Spotted Crake found dead, 198.

Dye, Common Heron, 44, 45, 47 ; frequented by the Mallard, 103; Lesser Black-backed Gull, 2S5; Little Grebe shot, 319.

Dye Cottage, 106.

Dykegatehead, 223.

Earlston, Falconry, 11; Teal, 110 ; Black Grouse, 160 ; 200 ; Curlew on moors, 258.

Earlston Parish, Black Grouse, 160 ; Red Grouse, 164; Dotterel in former times, 211 ; Black-headed Gull, 27 .

Earl's Tower at Earlston, Falconry, 11.

East Blanerne, 56, 215, 218, 220.

East Linton, Woodcock in January 1S81, 235 . 
East Lothian, rhyme about Wild Geese, S7; Shoveller breeding, 108 ; increase of Cushats about 1859-60, 134; Wood Pigeon nesting in hawthorn hedges, 139; heather burning, 169; popular name of Whimbrel, 263 ; Common Gull on shore, 277; migration, 327, 328.

East Lothian Coast, 281.

Last ITains, Lauder, White Partriclge, 189.

Last Reston, 56.

Ecclaw, Wild Geese, 73.

Écclaw Hill, Dotterel, 216.

Eccles Parish, Common Heron, 43; report on IVild Geese, 77 ; IVoodcock shooting, 237 ; Green Sandpiper shot, 253; Greenshank, 256 ; Eared Grebe, 317.

Eden, Common Heron, 45; frequented by the Mallard, 103, 105 ; WVigeon near Nenthorn, 113.

Edington, Peregrine Falcon captured, 7 ; Partridge shooting, 181, 182 ; cream coloured Partridge, 189.

Edington Hill Woocl, a favourite haunt of Woodcock, 234; large bag of Woodcock, 234.

Erlinyton Mains, IVild Geese, 73; Common Quail, 190; occurrence of Water Rail, 199; Mr. John Wilson's account of country in former times, $208 ; 213$.

Edington Mains Mill Pond, Rufi shot, 248.

Edington 1Vill Cauld, Great Northern Diver shot, 309.

Edmondselean, Wild Geese, 73 ; Dotterel, 217.

Einam, 271.

Edrington, 'I'urtle Dove shot, 151; introduction of Pheasants, 172.

Eilrom Mains, 'I'eal frequenting burn, 111.

Eilrom Parish, Common Heron, 45 ; report on $\mathrm{Wild}$ Geese, 77 ; Golden Plover, 221.

Eillons, 88.

Elfole, 59.

Ellemforl, Common Heron, 44; IVild Geese, S3; Teal on Whitadder, 110 ; Golden-Eye, 120 ; bags of Red Grouse got, 162, 166 ; Great Snipe seen, 240; Common Snipe, 241.

English Lake District, nesting of Dotterel, 210.
Eimesheugh, Peregrine Falcon's eyrie, 2,5 ; colony of the Common Gull in $1850,277,278$.

Eskilale, Falconry, 11.

Everett Moss, 199; or Dowie Den Moss, Pichie Moss, or Legerwood Loch, a nesting place of Blackheaded Gull, 268, 269.

Eye, Osprey, 2S; Common Heron, 46 ; 54 ; 57 ; frequented by the Mallard, 103; Common Sandpiper, 250; tame Herring Gull, 284.

Eyemouth, 59; Wild Swans, 96 ; Smew shot, 130 ; 145; Lapwing, 229 ; 275 ; 2S3; young Glaucous Gull shot, 287; Long - tailed Buffon's Skua shot, 291; 297 ; Storm Petrel, 321.

Eyemouth Parish, Dotterel in foriner times, 211.

Fainlaw, 54, 55.

Fairneyside, Rock Dove, 145 ; Coot, 204 ; Woodcock in lambing shed, 234; Herring Gull, 282.

Faimieside, Peregrime Falcon's nest, 2.

Fala, Dotterel, 218.

Faldonside, 218.

Fallside, Wild Geese, 79.

Fangrist, Kestrel, 26.

Fannanside, Wild Geese killed, 71; Pallas's Sand Grouse shot, 156.

Farne Islanrls, Common Cormorant nesting, 30; Eider Duck, 123; Common Snipe seen on migration, 242; Common 'T'em breeding, 265; Kittiwake Gull, 290; migration, 328.

Fast Castle, Peregrime Filcon's eyrie, 1, 2, 3, 5, 8; Kestrel, 26; Green Cormorant, 33 ; Eider Duck breeding, 123 ; nest with young found, 124; Rock Dove's resorts, 146 ; Rock Dove, 146; Woodeock's arrival in autumn, 234; Blacktailed Godwit, $257 ; 279$; cry of Herring Gull, 279; Herring Gull, 281.

Fellcleugh, Common Heron, 44; Wild Geese, 83 ; Stock Dove, 143. Fenham Flats, immense flocks of Brent Geese, 91.

Fenham Slakes, IVild Geese, 70.

Fentonbarns, near Drem, shooting IVild Geese, 69.

Fierneycastle, 54, 55. 
Ferneyriy Covers, Woodeock shooting, 237.

Finchy, Long-tailed Duck on the Tweed, 122.

Firth of Forth, Common Cormorant, 30 ; Ruff, 249 ; Black Guillemot, 304 ; Storm Petrel, 322 ; migration, 327.

Flass, Black Grouse, 161.

Flass Moor, Red Grouse shooting, 166.

Fleurs, Shoveller obtained, 107.

Flodden, 261.

Flood or Flot Carr, St. Abb's Head, Great Black-backed Gull breeding in $1851,286$.

Flot Carr, St. Abb's Head, Herring Gulls' nests, 280 ; colonies of Common Guillemots, 298.

Fogo Parish, report on Wild Geese, 78.

Foyorig, Wild Geese, 78.

Ford, 303.

Forres, Falconry, 11.

Hosterland Burn, 54, 55.

Foulden, Common Quail, 191 ; Dotterel sent to London for Mr. Wilkie of Foulden, $213 ; 220$.

Foulden Bastle, voracity of Wood Pigeon, 137 ; Common Quail, 191 ; Little Auk shot, 305.

Foulden Estate, Little Auk, 305.

Foulden New Mains, Wild Geese, 79 ; flock of Canada Geese, 95 ; visit of Wild Swans, 97 ; Wigeon on Mill Pond, 113; Little Grebe, 319.

Foulden West Mains, Wild Geese, 79; Garganey shot, 112; Pochard shot on mill pond, 116; Pallas's Sand Grouse caught, 155 ; Partridge shooting, 181; Coot, 204; Dotterel, 219.

Foulden Parish, Common Heron, 44 ; report on W'ild Geese, 79 ; Pallas's Sand Grouse, 156; Dotterel in former times, 211 ; in recent years, 212.

Foul Carr, St. Abb's Head, principal breeding quarters of the Herring Gull, 2S0; Lesser Black-backed Gull breeding, 285; colony of Common Guillemots, 29s; taking of Guillemots' eggs, 300 ; Puffin nesting in 1851, 308.

Foul Carr Cove, Razor Bill nesting in 1855, 296.

Foul Carr Rib, nesting of Kittiwake Gull in former times, 289, 290.
Foulshotlaw Wood, Black Grouse, $16 \mathrm{I}$.

Gateside School, Common Heron, 44. Geddes' Haren, 281.

Gibbs' Cross, Wedderlie, IVild Geese, 70.

Girrick, Parish of Nenthom, Kestrel, 26; Mallard feeding on "laid" barley, 103; shooting Wild Duck on the Eden, 105; Wigeon, 114; Grey Phalarope, $232 ; 241$.

Glengelt, WVild Geese, 73.

Glen Urquhart, Inverness-stive, Merlin, 23.

Godscroft, Wild Geese, 72; Pallas's Sand Grouse, 156 ; Black Grouse, 158; Red Grouse shooting in 1813,164 ; bag of Red Grouse got in 1878, 166; Common Quail, 191 ; number of Dotterel shot, 213, 214.

Godseroft Woodheads, Wild Geese trapped, 71.

Gordon, Dotterel, 219.

Gordon Boy, Wigeon killed, 113.

Gordon Moss, Shovellers got, 107.

Gordon Parish, report on Wild Geese, 79; 13lack Grouse, 160 ; Red Grouse, 164; Black-headed Gull, 274.

Gosford, East Lothian, Canada Goose, 95.

Gowkseroft, Lapwing abundant, 229. Grampians, nesting of Dotterel, 210; Dotterel, 211.

Grange Wood, a favourite rest of Woodcock, 234.

Greenburn, 54.

Greenhauegh, Mallard, 102.

Greenhead, 54, 55.

Greenheugh, Rock Dove, 146.

Greenheugh, Oldcambus, Common Redshank in small tlocks, 254.

Greenheugh Point, near Oldcambus, purple Sandpiper occasionally seen, 247.

Greenknowe, Wild Geese, 77 ; Whitefronted Wild Goose shot, 88; Spotted Crake shot, 198.

Greenlaw, Merlin, 22; IVater Rail, 200 ; Coot, 204.

Greenlaw Dean, Wild Goose, S0 ; Dotterel, 219.

Greenlaw Moor, Kestrel, 26 ; Wild Geese at the Hule Moss, $80,86,87$.

Greenlaw Parish, report on IVild Geese, 80 ; Hule Moss, 86 ; Black Grouse, 160 ; Red Grouse, 164; 
Dotterel in former times, 211 ; Dotterel in recent years, 212 ; Whimbrel, 263; Black-headed Gull, 274.

Greenriggs, Wild Geese, 84.

Green Stane, Common Cormorant, 30.

Grey Mare, 246.

Grey Mare's lroal, 216.

Gull Rock, Peregrine Falcon's nest, 2.

Gull liock, Iiast Castle, Rock Dove, 146.

Gill Rock, near Burnmouth, 280.

Gull liock, near mouth of Wolden Lee $B u r n$, one of the most westerly breeding places of the Herring Gull on the Berwickshire coast, 281.

Gullane Sands, Wild Geese, 70.

Gunsyreen, "Dow Cave,"145 ; tame Herring Giull, 284; 297.

Hadulo IIouse, Aberleenshire, 160, 161.

IIallyburton, Wild Geese, 80 ; Dotterel, 219.

IIaltemsloup, nesting of Peregrine Fialcon, 2.

IIandaxe Wool, falconry, 18; hunt. ing lodge of Sir George Home of Wedderburn, 162.

Harbour Loch, Coldingham Shore, Long-tailed Duck, 122.

IIarcarse, Water Rail, 201.

Ifarlens, Wild Geese, 78.

Hareheal, Common Snipe, 241.

IIarelaw, Wild Geese, 85; 156 ; Dotterel, 220.

IIarelaw, Craig's Wool, Duns Castle Listate, Woodcock shooting, 237.

IIarelaw Coic, Green Cormorant, 33.

Harelaw, Westmither, 274.

Harelaw Moor, Golden Plover's nest, 222; Common Snipe, 241.

IIarelawside, Wild Geese killed, 71 ; Lapwing, 227.

IIarperton, 253.

Harryburn House, Lauler, Little Auk caught, 305.

Hartlaw, derivation of name, 209.

Hartside, Wild Geese, 73; derivation of name, $20 \mathrm{~s}$.

IIatchetnize, Wild Geese, 76.

Haugh Head, near Earlston, 274.

Hawh Kaim at Earlston, Falconry, 11.

Hawksheugh, sheep's fleece used to capture young Peregrine Falcons, 4.

Hawkshengh, near Burnmouth, derivation of name, 9 .

Ifawhsheugh, near Coclibmispath, derivation of name, 9 .

Hawlisheugh, near liast Castle, Peregrine Falcon's nest, 3,5 ; derivation of name, 9.

Hawhslaw, IVild Geese, 76.

Hawkislaw in Parish of Colilstream, derivation of name, 9.

Hawkslaw, formerly a part of II ally. down Listate, 9.

Healchester, appenrance of Dotterel in September, 217.

Helirides, 293.

Heligolanel, 221.

Hen Poo, Durs Castle, a breeding station of Black-hearled Gull in former times, 273.

IVeron Scaur on the Dye, 47.

Heron's Hole on the Dye, 47.

llemington, rhyme about IVild Geese, 87.

IIenyhhead, Earl of Wemyss stalking Wild Geese, 6S, 69; Mild Swan captured, 97.

J/expath, Wild Geese, 79.

IIind's Cleugh, derivation of name, 20 \%.

IIindsidehill, Wild Geese, 85.

Hirsel, Common Heron, 43 ; Night Heron shot by the Earl of Home, 52 ; Common Bittern shot, 61; Smew killed, 130; Pheasant shooting in 1810, 1816, and 1821, 171.

Hirsel Lake, a favourite haunt of the Mallard, 102.

Hirsel Loch, Coot, 204.

Holy Island, Brent Geese, 91 ; Sheld-Duck, 100; Greenshank frequently seen, 256.

Home, falconry, visit of King James IV., 14.

Home Castle, 268.

Horn Bum, 56; drainage of Billie Mire, 57.

Horncliffe, 213.

Horseccustle Cove, S't. Abb's IIeaul, 303.

Horseley, Dotterel, 213, 218.

Houndslow, Dotterel, 20.

Howparl, Dotterel, 213, 216, 218.

IIule Moss, in prarish of Greenlaw, Wild Geese, 67 ; 86 ; description of situation, 87; Shoveller shot, 107. 
Hullidean Mill Pond, Bemersyde, nesting of Little Grebe, 318.

IInmbie Wood, 134.

Hume Castle, visit of James IV. with falconers, 62.

Huntleyrood Moss, formerly a haunt of the "Bull o" the Bog," 61.

Hution, Red-throated Diver caught, 311.

Iutton Bridye, 142.

Hutton Hall, Peregrine Falcon, 5, 6.

Hutton Hall Mill, Peregrine Faleon's nest at Blue Braes, 5, 6.

Hutton Mains, Wild Geese, 81.

Hutton Parish, Common Heron, 45 ; report on Wild Geese, 80 ; Pallas's Sand Grouse, 156; Water Rail, 201 ; Coot, 204; Woodcock shooting, 237.

Huxton, in parish of Coldinuham, derivation of name, 9 .

Iceland, Red-throated Diver, 312.

Inncruicl; Dotterel, 218.

Isle of May, migration of Cushats, 133; Common Snipe seen on migration, 242 ; Black Guillemot, 304 ; migration, 328 .

Jura, Red-throated Diver, 312.

Kacter Well, 225.

Kaimes, turnips first sown in Berwickshire, 132.

Kelloe, Partridge shooting, 184.

Kelso, white WVod Pigeon, 140 ; $154 ; 248 ; 253 ; 256$; Mr. Andrew Brotherston's account of monlting of Black-headed Gull, 272; 317.

Kellleshiel, hawking at, 18; Black Grouse shooting, 1803-14, 158; Red Grousc shooting, 1812-14, 164: Dotterel, 220.

Kinlshielhaugh, Will Geese, 78.

Kimmeryhame, Hobby, 20; George Home of Kimmerghame hawking Grouse at Kettleshiel, 163; Water Rail, 201.

Kimmerghame E'state, White-fronted Wild Goose shot, 88.

Kimmeryhame Mains, Wild Geese, 78.

Kirkheugh, Rock Dove, 145.

Knebs Roclis, Common Bittern shot, 61.

Knock Hill, Merlin, 22.

Kyleshill, Black Grouse, 161.
Ladylirl;, Common Cormorant, 31 ; Hawfinch, 351.

Ladylirk: Lodye, 69.

Lalykirl: Parish, Wild Geese, 81.

Lake Ladoya, Russia, Little Gull's breeding quarters, 267.

Lambden, occurrence of Whimbrel, 263.

Lamberton, Wild Geese, 83, 97 ; Rock Dove, 145; Turtle Dove obtained, 151 ; a favourite haunt of Dotterel, 212 ; bag of Dotterel killed in 1857, 213; Dotterel shooter, 215; Dotterel, 220; Woodcock's arrival in autumn, $234 ; 279 ; 298$.

Lamberton Coal Point, Kestrel, 26. Lamberton Kirk, 281.

Lamberton Moor, "Cockit-Hat" plantation, occurrence of Merlin, 22 ; Merlin pursuing Snipe, 22; Black Grouse, 160.

Lammerlaw, large bags of Red Grouse got in 1888, 165.

Lammermior Whaaps, 259, 260.

Lammermuir Hills, Peregrine Falcon nesting in precipices, 5; Sir George Home's hunting lodge, Falconry, 18; Stock Dove, 143 ; Sir George Home of Wedderburn hawking Red Grouse in olden times, 162; Partridge, 178 ; Dotterel, 218; Common Red. shank nesting, 255; Curlew abundant from spring to autumn, 258.

Lammermuirs, Merlin, 21 ; popular rhyme about the weather, 87; Black Grouse, 161; Red Grouse scarce in 1812-14, 164 ; large bags of Red Grouse got in 1886 and 1872, 165; Grouse disease, 167; cries of Red Grouse, 168; heather burning, 169 ; Common Quail, 190; Golden Plover plentiful, 221 ; Lapwing, 226, 227 ; Curlew nesting, 261; Red-necked Grebe killed, 315 ; occurrence of Storm Petrel, 321, 322 ; migration, 328. Lammyrios montes, 166.

Lanele, Falconry, 15.

Lang Belt ylantation, Mortinglon, Green Sandpiper, 253.

Langshaw, Black Grouse, 159.

Lanystruther Boy, nest of Golden Plover, 222.

Lauyton, Pheasant shooting, 175 ; Partridge shooting, 185.

Langton Burn, Common Heron, 47 ; 
IVild Duck shooting, 105; Teal, 110.

Langton House, 274.

Langton Lees, Wild Geese, 81.

Lanyton Parish, report on IVild Geese, 81 ; Black Grouse, 160; Red Grouse, 164; 209.

Lapland, 294.

Lauder, Falconry, visit of King James IV., 14; Hobby, 20 ; visit of King James IV., Common Heron, 41; Lauder, Common Heron, 43; visit of James IV. with falconers, 62 ; Pochard in Leader, 116 ; Black Grouse, 159 : 223, 224; Little Auk caught, 305 ; Little Grebe, 319 ; 321.

Lauderdale, Merlin, 21; Wild Duck, 101 ; Wigeon, 113 ; folk. lore about Pigeons, 149; Black Grouse, 159; introduction of Pheasant, 171; 216; Dotterel, 219.

Lauder Parish, Peregrine Falcon's nest, 7 ; report on Wild Geese, S2 ; Mallard, 106 ; Black Grouse, 160 ; Red Grouse, 164; Dotterel in former times, 211; Dotterel in recent years, 212 .

Leader, Osprey, 28; Common Heron, 46 ; Canada Geese killed, 95; T'eal breeding near Lauder, 110 ; flock of Wigeon, 113 ; Pochard near Lauder, 116 ; Golden - Eye, 120; Goosander, 12S; Water Rail, 201; Moor Hen, 202; Ringed Plover, 224; Black-headed Gull, 271; Blackheaded Gull frequenting stream near Earlston, 272; Common Sandpiper, 250.

Leader Haughs, 226.

Lees, IVild Geese, 76; Pheasant shooting, 174; Partridge shooting, 184 .

Leet, Wild Ducks' eggs, 106.

Leetside, Wild Geese, 86; Mallard visiting barley fields, 103.

Legerwood, Wild Geese, 82; Mallard damaging barley fields, 103 ; Red Grouse in end of last century, 163; Woodcock shooting, 236, 237.

Legerwood Loch, a haunt of Mallard, 102 ; Shovellers shot, 107; Teal, 110; Water Rail, 201; Coot, 204; Common Snipe found in considerable numbers, 241 ; Little Grebe abumdant, 319.

Legenvood Parish, report on Wild
Geese, 82; Black Grouse, 160 ; Red Grouse, 164; Dotterel in former times, 211 ; Black-headed Gull, 268.

Leitholm, Peregrine Falcon killed, 7.

Lennel, Earl of Wemyss stalking Wild Geese, 69.

Lennel Hill Farm, Mr. William IVhite's notes on drainage of Billie Mire, 60.

Lennel, near Coldstream, occurrence of Ruff, 249.

Lightfield, near Mellerstain, Great Snipe shot, 240.

Lighthouse, St. Abb's Heal, 146; Herring Gull, 280; Common Guillemot, 298.

Linthill, Wild Swan, 96 ; sign of bad weather, 227 .

Linthill House, Dotterel, 219.

Lintlaw, 54, 55 ; Wild Geese, 73 ; occurrence of white Wood Pigeon, 139.

Lintlaw Burn, 55, 56.

Lithtillum or Ferneyrig Boy, Com. mon Bittern seen and heard, 62 .

Lithtillum Loch, Common Heron, 43 ; Eared Grebe shot, 317.

Little Billie, 55.

LittleChanneller Rock, St. Abb's Ilead, colony of the Herring Gull, 280.

Little Rooks, Eider Duck, 12t; 281.

Little Swinton, Wild Geese, 84.

Little Swinton Farm, Earl of Wenyss stalking Wild Geese, 69.

Lochend, Pheasant, 171.

Lochton, Wild Geese, 77 ; sheldDuck killed, 100; Water Rail, 201 ; Green Sandpiper shot, 253; Greenshank killed, 256, 257.

Long Birgham, Pintail Duck on the 'I'weed, 109.

Longcroft Water, nesting of Peregrine Falcon, 7.

Longformacus, Common Herou, 47 ; Wild Geese, 83; Black Grouse, 158; Red Grouse shooting, in 1813, 164; autumnal flights of Woodcock, 233; Woodcock shoot. ing, 237 ; Common Snipe nesting, 242; Dunlin shot in July, 246; 319.

Longformacus Ilouse, Pallas's Sand Grouse, 156.

Loniformacus Purish, Common Heron, 43 ; report on WVild Geese, S3; Duck ponds, 106; Mallard, 106; Pallas's Sand Grouse, 156; Black Grouse, 160 ; Red Grouse, 
164; Dotterel in former times, 211; Dotterel in recent years, 212; Woodcock, 235.

Low Bells, Landrail's nest, 196.

Lugyyy, Common Heron, 43.

Lumsden LIoss, 'T'eal, 110.

Lumsilen Rocks, Peregrine Falcon's nest, 5.

Luryie Loch, Common Snipe, 211.

Magdalen Fields, Falcons at Highland and Agricultural Society's Show in 1841, 3.

1Tayrie Shaw's Crockie, 275.

Wanclerston, Pheasant shooting, 173 ; Partridge shooting, 183.

Marchmont, Common Heron, 44, S6 ; Wild Geese shot at the Hule Moss, 87; Tufted Duck killed, 11S; 131 ; IVood Pigeon breaking topmost shoots of fir trees, 135 ; Pheasant shooting, 176; Partridge shooting, 184; 219.

March Wood, Common Heron, 44.

Marygold, 54; white Wood Pigeon, 139.

Marygold Burn, 56.

Maw Carr, nest of Herring Gull, 280.

Maw Craig, near mouth of Wolden Lee Bur, one of the most westerly breeding places of the Herring Gull on the Berwickshire coust, $2 S 1$.

Maxton, 253.

Mayfield, Merlin, 21; 5t; Wild Geese, 73 ; Dotterel, 215.

Meikle Law, Merlin, 24.

Mellerstain, last Common Bittern, 61 ; Passenger Pigeon shot, 153 ; Pheasant shooting, 174 ; Partridge shooting, 183 ; peculiarly marked Partridge, 189; late Landrail, 196.

Mellerstain Downs, Dotterel, 210.

Melrose, falconry, 11.

Werlin Grain, a raine near ITeikle Law, Merlin, 2 t.

Merse, falconry, visit of King James IV., 14; formerly covered with bogs and morass, Common Bittern, 62.

Mertoun, heronry, 48, 49 ; Stock Dove, 143 ; Oyster Catcher, 231 ; nesting of Little Grebe, 31S.

Mertoun House, Common Heron, $43,50,51$.

Mertoun Parish, Common Heron, 43 ; Black-headed Gull, 268.

Middlethircl, Wild Geese, 79.
Millfield, 303.

Milne Graden, Teal on the Tweed, 111 ; Pheasant shooting, 173 ; Meteorological Notes, 351-57; 358. Milne Graden West Mains, Wild Geese, 76.

Minchie Moss, Common Bittern, 61. Mont Albane, Wild Geese, 75.

Monynut, Black Grouse, 158; Red Grouse shooting in 1813, 164.

Moor Baits, nest of Herring Gull, 281.

Moor Plantation, Whitchester, a favourite resort of IVoodcock, 235.

Morctinglon, Stock Dove, 143; Black Grouse, 159, 160 ; Pheasant shooting, 175; Partridge shooting, 185 ; ten brace of Dotterel shot, 220 ; 253.

Mordington Mains, Wild Geese, 83 ; Common Quail, 191 ; Green Sandpiper observed, 253.

Mordington Parish, report on Wild Geese, 83; Red Grouse, 164; Dotterel, 210 ; Dotterel in former times, 211; Dotterel in recent years, 212 ; Woodcock, 234.

Moristons, Dotterel, 210.

Mos: 1 Iaw, Lapwing's nest, 227.

Mucklestane Moor, Hobbie Hilliot's "lang-nebbit things," 260.

Wuirkirl, Ayrshire, story about the "wheeple of a whaap," 258.

Murraylawiry, Merlin, 22.

Nabdean, Woodcock frequenting plantation, 235.

Nabdean Mill Pond, Water Rail, 201 ; Little Grebe, 319.

Nenthom, IVigeon on the Eden, 113 ; Dotterel, 210.

Venthorn Parish, Dotterel in former times, 211.

Nestrit House, Common Heron, 45.

Netherbyres Mill, Osprey, 28.

Newbinging, Laurler, Wigeon in pond, 113.

Verclyth, Peregrine Falcons got from Burnmoutl by Sir David Baird, Bart., 2; Falcons kept there, 19.

Neumills, Lauder, Wigeon on Leader, 113.

Ninevells, Green Sandpiper shot, 253.

Ninewells Old Bridge, Osprey, 27.

Nisbet, Pheasant shooting, 174; Partridge shooting, 184.

Nisbet House, Common Quail, 191.

North Berwick, Gannet, 37. 
North Bervick Law, 281.

North Cleugh, Coot, 205.

North Falaknowe, Wild Geese, 76.

Northumberland, Shoveller breeding, 108; Tufted Duck breeding, $11 \mathrm{~s}$; migration, 327.

Northumberland Coast, 100.

Oak Wood near Penmanstiel, Woodcock nesting, 237.

Old Bound lioad near Paxton, Pochard shot on WV hitadder, 116.

Olicambus, Peregrine Falcon, 2; Kestrel, 25 ; Common Heron, 46; Rock Dove, 146; effects of wet summer on Partridges, 186 ; Moor Hen, 203; 213; 218; Green Sandpiper frequenting Dean, 252; Common Redshank on coast, 254; Curlew on shore, 260 ; Blackheaded Gull leaving coast in spring, 269; 279; Herring Gull feeding on fragments of bottlenosed whale, 2S2; ways of catch. ing Gulls with hooks, 284; 289; Razor Bills washed ashore in severe winter of 1S78-79, 296; Great Northern I)iver found on shore, 309 ; ornithological observations, 329 .

Oldeambes and Cockburnspath Parish, Red Grouse in 1835, 164.

Oldecmbus Last ITains, arrival of Woodcock, 234.

old Camp at Milne Graden, Common Cornerake, 31.

Oldcastles, 54; Billie Mire, 60, 61.

Olel Craw Ha', Osprey, 28.

Olel Greenlaro, Wild Geese, So.

Oldhamstoclis, Dotterel, 218.

Oldhamstocks Parish (detached) report on Wild Geese, S4; Red Grouse, 164; Common Quail, 190 ; Common Quail nesting on Springficld Farm, liast Lothian, 191.

Old Heromy Wood, Paxton, Common Heron, 45; Stock Dove's nest, 141 ; Woodcock, 235.

Olister Dul, Common Heron, 43.

Orkney, Falconry, 13; Dotterel nesting, 211; Whimbrel, 263.

Orleans, France, Common Quail, 192.

Overhowlen, Wild Geese, 73.

Oxton, occurrence of Storm Petrel, 321.

Park, 218.

"Patie'sl'at," poolon the Whitadder, P'eregrine Falcon's nest, 5 .
Paxton, Crow Dean Wood, Merlin, 21 ; Finchy, Merlin, 21 ; Common Cormorant, 31 ; Common Heron, 35; Wild Swans on the Tweed,97; Sheldrake on the 'Tweed, 100 ; T'eal on the Tweed, 111 ; Wigeon on 'I'weed, 113; Pochardon'I'weed, 115 ; Tufted Duck on 'T'weed, 11s; Scaup Duck on Tweed, 119 ; Longtailed Duck on Tweed, 122 ; Wider Duck on 'Tweed, 124; Common Scoter on Tweed, 126 ; Ring Dove feeding on beechunts, 133 ; migration of Cushats, 133; Shooting Cushats in Wester Park, 133; Wood Pigeon feeding on young leaves of beech tree, 138; Pigeon nesting near house, 139 ; popular saying comparing frost-rime to White Pigeon, $150 ; 155$; Pheasant shooting, 174; Common Quail, 191; Landrail, 194; Moor Hen's nest in wooden spout, 203; fav. ourite retreats of Woodcock, 235 ; Woodcock shooting, 237; Redthroated Diver on Tweed, 311 : Little Grebe, 319.

Paxton House, Peregrine Falcon seen, 7; Stock Dove's nest, 141, 142, 143; Green Sandipiper shot, 252 ; Greenshank shot, 256.

Paxton North Mains, Greenshank shot, 256.

P'axton South Mains, Wild Geese, si.

P'ease Burn, Coot, 205.

P'ease Sands, Kittiwake Gull, 290.

Pech Stane, 55.

Peelivalls, 273.

Peely Braes Wood, Duns Castle, Woodcock's nest discovered, 238.

Penmanshiel, Kiestrel, 25; Wild Geese, 71 ; Wild Goose trapped, 71 ; Wild Geese, 74, 75; Wood Pigeon, 137; Dotterel, 215, 216; Golden Plover, 221; Lapwing, 227 ; Woodcock's nest, 23s; Common Snipe bleating, 242, 213; Curlew's ery, 259; Little Auk found, 305.

Perthshire, Tufted Duck feeding, 118.

Pctticowick Cove, Peregrine Falcon's eyrie, 2.

Petticowicli Harbour, 146; 280 ; Common Guillemot, 298.

Pickie Moss, Dowie Den Moss, Everett Aloss or Legericood Loch, 
nesting station of the Blackheaded Gull, 268.

Piper's Cove, Rock Dove, 145.

Piper's Knowe, 54.

Pistol Plantation, Common Heron, 43; Blackadder, a favourite roosting place of Wood Pigeons, 133.

Plover's Cairn, 223.

Plovering Haugh, 223.

Polearth, 131.

Polwarth Parish, Common Heron, 44; Black Grouse, 160; Red Grouse, 164.

Prenderguest, 56 ; Partridge shooting, 181, 182.

Press, Wild Swan captured, 97.

Preston, Wild Geese, 72 ; Dotterels' wing feathers used for fly dressing, 215.

Preston Cleugh, 56.

Prestonkirk, $93 ; 235$.

Printonian, Wild Geese, 77, 78.

Pyper Knou'es, Landrail, 195.

Quixwood, Peregrine Falcon trapped, 7 ; Merlin, 22; Wild Geese, 72; Pallas's Sand Grouse, 156; Black Gronse, 158; Red Grouse shoot. ing in 1813, 164; bags of Red Grouse got in 1889 and 1891, 166 ; Partridge shooting, 181; Dotterel, 213, 214, 215.

Raecleugh, derivation of name, 208.

l'aeclengh Farm, Peregrine Falcon's nest, 6.

Iiaecleugh Head, Pallas's Sand Grouse shot, 156 ; derivation of name, 208.

liammel Cove, Peregrine Falcon breeding, 2; Rock Dove's resorts, 146.

Rampart, St. Abb's Head, 280 ; nesting of Kittiwake Gull in former times, 289, 290 : Razor bill nesting in 1885, 296; colonies of Common Guillemots, 298 ; taking of Guillemot's eggs, 300 .

liaven's Craig, Fellclengh, Stock Dove's nest, 143.

liavensheugh, St. Abl's Heal, nest of Herring Gulls, 280 ; colony of Common Guillemots, 299.

liaven's Knowe, near 'l'ibbie Fouter's Glen, Kestrel, 26.

Rawburn, Wild Geese, 77 ; Dotterel, 218.

Redheugh, Peregrine Falcon, 2; Common Bittern, 61; Wild Geese,
74: Bewick's Swan cast ashore, 99 ; high grounds in neighbourhood a favourite haunt of Dotterel, 212; Dotterel in autumm, 216, 217; Oyster Catcher, 231; Woodcock's arrival in autumn, 234; arrival of Woodcock, 234; Herring Gull's nest, 281.

Redheugh Shore, 146.

Redpath Bog, 199, 200; Common Snipe, 241 ; a breeding station of the Black-headed Gull in former times, 274.

Redpath, near Earlston, 274.

Rerlshank's Rock, Coldingham Shore, 255.

Rentonbams, Wild Geese, 75.

Renton Bell, Dotterel, 216.

Renton Hall, Haddington, Common Quail, 192.

Restalrig, 281.

Retreat, Osprey, 28; Wild Gicese, 83; Pallas's Sand Grouse shot, 156 ; Dotterel, 213, 215, 218.

Romorantin, Loir-et-Cher, france, Turtle Doves plentiful, 151.

Ross-shire, Dotterel nesting, 211.

Rough Head, Common Heron, 45.

Roxburghshire, Tufted Duck breeding, 118 .

Rumbleton, Wild Geese, 79.

I'umbleton Law, Wild Geese, 79 ; 219.

Ryselav, Wild Geese, 78.

St. Abb's Head, Peregrine Falcon's eyrie, 1, 2, 3; Green Cormorant, 34; Rock Dove, 145, 146 ; Common T'ern, 265; Common Gull, $276,277,278$; Herring Gull in great numbers, 279 ; cry of Herring Gull, 279; boys killed while searching for Gulls' eggs, 282 ; Great Black-backed Gull occnsionally seen, 286; breeding of Kittiwake Gull in former times, 288, 289, 290 ; Razor Bills plentiful in 1832 and 1851, 295; Razor Bills now scarce, 296 ; a favourite haunt of the Common Guillemot, 297 ; notes on Guillemots by Mr. Archibald Hepburn in 1851, 299; Guillemots not so plentiful as formerly, 300 ; Guillemots leaving cliff after breeding season, 301 ; Ringed Guillemot, 302 ; Black Guillemot shot, 303, 304; Puffin, 307, 308 ; incident in connection with Storm Petrel in 
great storm of 14th October 1881 , 322 ; migration, 325, 351-355.

St. Abb's Nunnery, 280.

St Johu's Frarm, Foulden, Common Quail, 191.

St. Leonard's Cauld, on Leader, Goosander, 128; Little Grebe shot, 319 .

St. Mary's Cottaye, Duns, 273.

Salthench, Common Heron, 45.

Salton, Wild Geese, 87 ; Cushats on wheatfield, 134; "Big Wood," 134 ; Pheasant, 171.

Saltonn's Woal. Common Heron, 12.

Sandy Knowe 'T'ower, 270.

Sauldre liver, Loir-el-Cher, lrance, 'I'urtle Dove's nest, 151.

S'carlam, Black Grouse, 158; Red Grouse slooting in 1813, 164.

Searthenyh, Milne Graden, Common Cormorant, 31.

Seart liock, Common Cormorant, 30.

Scoul Cave, near Eyemouth, 297.

Scouts' Croft, near Coldiufham, 297.

Scouts' Point, near Gunsyreen, 297.

Shannolsank, IVild Geese, 72 ; number of Dotterel shot, 213, 214.

Shannohank Farm, ficle called the Gull IFire, a breeding station of Black- headed Gull in former times, 274.

Shetlanels, Whimbrel, 263.

Shillum Dikes, 55.

Siecar, 146; Herring Gull's nest, 281.

Siccar Bay, Golden-Eye, 120.

Siccar Point, Kestrel, 26 ; Common Cormorant, 30, 31 ; Heron's nest, 45 ; Oyster Catcher, 231 ; Herriner ('xull on rocks, 283 ; Common Redshank in small flocks, 254.

Simprim Mains, Earl of Wemyss stalking Wild Geese, 69; $\mathrm{Wild}$ Geese, $\$ \pm$

Sisterpath, Wild Geese, 78.

Skaithmir, IVild Geese, 76.

Skelly, Razol Bill nesting in 1855 , 296 ; colonies of Common Giville. mots, 298.

Skelly, St. Albl's Heal, Herring Gull's nest, 2280.

Slielly Rock, St. Abb's IIeacl, Great Black-backed Gull breeding in 1851, 286; mesting of Kittiwake Gull in former times, 259, 290.

Slifhouses, 54; source of Dracden Buxn, 55, 56.

Sinufiehole Stells, nests of Herring Gulls, 280.
Soldier's Dylie, Doutau, locility frequented by Dotterel, 217.

Spott, 217.

Spottisuoode, Hawking at, 19 ; Gannets, 35 ; Common Heron, 47 ; 'leal, 110; Black Grouse, 161; introduction of Pheasants, 171: Pheasant shooting, 176; Partridge slooting, 185; Coot, 204; 220; Woodcock shooting, 237 ; Curlew abundant, 258 ; Little Grebe, 319.

Sirottiswoode Estate, bags of Red Grouse got, $166^{\circ}$.

Spital, Pheasant shooting, 17t; Partridge shooting, $184 ; 315$.

Spital House, Pallas's Sand Grouse, 156 ; Water Rail, 201; Great Snipe shot, 240.

Spital Mains, IVild Geese, 81.

Syminghill, near Coldstream, Black 'Tern cilptured, 264.

Stanclimy Man or Sonter liock, Peregrine Falcon's eyrie, 4 ; nest of Herring Gulls, 281.

Stoneshiel, 54, 55.

Stirliuy Finulel, Doulaw, locality frequented by Dotterel, 217.

Summyside, 55, 60.

Sumvick, Wild Geese, 81.

Sutherlandshire, Whimbrel, 263.

Suallow Craig, Common Heron, 45; Rock Dove's cave, 146.

Swinton, Partrielge shooting, 185 ; Common Redshank, 255.

Suinton. Hill, WVild Geese, S4; Common Redsliank nesting, 25J.

Surinton Mill, Wild Duck shooting, 104.

Sucinton P'arish, report on Wild Geese, 8t; Mallard, 106.

T'antallon Castle, falconry, Mary of Lorraine and Carl of Angus, 11.

The Anchorage, Berwich-on-Trued, 264.

The Camm, near Foulden, 305.

The lstes, falconry, 13.

Thirlestane, Wild Geese, S2 ; Dotterel, 219.

Thirlestane Caste, Hobloy, 20; Common Heron, 43; Black Game, 159; introduction of Pheasints to coverts, 171 ; Common Quail, 190 ; Great Snipe got, 240.

Thirlestane Castle Saumill, Kestrel, 26.

Thrummie Carr, nest of Herring Gull, 280; the most westerly 
breeding station of Common Guillemot in Berwickshire, 299.

I'ookey Cove, St. A Ub's Head, Black Guillemot, 303.

I'ounhead, Cockburnspath, Coot, $204,205$.

I'ownhead Mill Pond, 'I'eal, 110.

'Tounhead Pond, near Cockburnspath, Little Grebe nesting, 318.

T'ueed, Osprey, 27 ; Common Cormorant, 31 ; Common Heron, 42, $45,48,49$; Wild Swans in severe winter of $1879-80,97$; SheldDuck near Paxton, 100; Pintail Duck shot, 109; Teal near Paxton, 111 ; Wigeon at Paxton, 113 ; Pochard at Paxton, 115 ; Pochard at Birgham, 116; 'Tufted Duck at Paxton, 118; Scaup Duck at Paxton, 119 ; Golden-Eye, 120 ; Golden-Eye at Lochton, 120; Long-tailed Duck, 122; Eider Duck seen at Paxton, 126; Gioos. ander, 128 ; Stock Dove's nest near Paxton, 141; Rock Dove, 148 ; Landrail, 194, 196 ; Ringed Plover, 224; Woodcock shooting, 237 ; Common Sandpiper, 250 ; Green Sandpiper, 252; lilack. headed Gull in small flocks, 271 ; Lesser Black-backed Giull, 285; Kittiwake Gull occasionally seen in spring, 290; Great Northern Diver shot, 310; Red-throated Diver sometimes seen on river, 311 ; Black-throated Diver, 312 ; Great Crested Grebe, 313 ; Lared Grebe, 317 ; Little Grebe at Paxton, 319.

I'uchit Yetts, 225.

T'uinlaw ford, 223.

I'winlaw Caims, 87.

I'wizell House, 234.

Tyme, Last Lothian, Common Sandpiper, 251.

Tyne Eistuary, Ruff, 249.

Uilystrand Brae, nests of Herring Gull, 280.

Warlautuanl; 54; source of Fosterland Burn, 55.

Watch Coier, Woodcock shooting, 237.

Watch Water, Woodcock, 233.

Waulkmill (C'umledge) Common Bittern, 61.

Wedderburn, falconry, 17, 18; Sir G'eorge Home's Hawks called Mer- lins, 22 ; Red Grouse hawling in olden time, 162 ; Pheasant shooting, 173; Sir Gieorge Home hawk. ing Partridges, 179; Partridge shooting, 183.

Wedderbum Castle, Common Heron, 47 ; Wild Duck shooting, 105; 'Teal, 110.

Wedderburn Worth Lodye, former haunt of T'eal, 110.

Wedderlie, late stay of Wild Geese, 71 ; Wild Geese, 85, 87.

Werlerlie Farm, White Grouse seen, 168.

Wellmire Wood, l'axlon, migration of Ring Dove, 133 ; Woodeock, 235.

Welnage, notes by Mr John Wilson on Billie Mire, $57 ; 60 ; 214$.

West Fïshwick, Wild Geese, 87.

West Hurler, Common Guillemot, 298.

West Mains Brae, Common Heron, 43.

West in 'Thirle Bay, nests of Herring Gull, 280.

Westruther, 200; Golden Plover, 222 , 223 ; 274 ; Little Grebe, 319. Westruther Mains, Wild Geese, S5; Dotterel, 220.

Westruther l'arish, Common Heron, 44 ; report on Wild Geese, 85 ; Black Grouse, 160; 209; Dotterel in former times, 211, 220; Common Snipe, 241.

Whitadder, Peregrine Falcon's nest in former times, 5, 6 ; Kestrel, 26 ; Usprey, 27, 28; Common Heron, $45 ; 54,56,57$; Wild Swan killed, 97 ; frequented by the Mallard, 103 ; Wild Uuck's nest, 104 ; 'Tcal near Ellemford, 110; Teal near Blanerne, 111; Pochard shot near Old Bound Road, 116; Pochard killed above Cockburn, 116; Golden-Eye at Abbey St. Bathans, 120 ; Goosander, 128; Ring Dove, 132, 133 ; near Hutton Bridge, Stock Dove's nest, 142 ; Stock Dove's nest near Edrington, 143 ; Stock Dove's nest near Fellcleuglı, 143 ; Kock Dove, 148; 'Lurtle Dove shot near Edriugton, 151 ; Moor Hen, 202 ; Coot, 20t; Dotterel, 214; 235; Common Sandpiper', 250 ; Green Sandpiper seen, 253; Greensliank, 256; Lesser Blackbacked Gull, 285; Great Northern Diver at Edrington Mill Cauld, 
309; Red-throated Diver sometimes found on river, 31]; Redthroated Diver killednear Preston, 311 ; Red-necked Grebe shot at Clarabad Mill Cauld, 315 ; Little Grebe found at Blaneme, 319.

Whithurn, Common Quail, 190.

Whitchester, Black Game, 159; Red Grouse shooting in 1814,164 ; Little Grebe shot on Dye, 319.

Whiteburn, Wild Geese, 72; Dotterel, 214.

Whitefieldnear Cowdenknowes, Arctic or Richardson's Skua shot, 293.

Whitehall, 59 ; Pheasant shooting, 173 ; Partridge shooting, 182.

Whitheugh, Peregrine Falcon's eyrie in $1857,2$.

Whiteheugh, near Coldingham Shore, colony of Common Guillemots, 298.

Whitelaw, a favourite haunt of Golden Plover, 221.

Whiteviy, Partridge shooting, 181, 182.

Whitesomehill, Wild Geese, S6.

Whitfield near Ayton, 156; Woodcock shooting, 237.

Whitrif Boy, Mr. Joln 'Thomson's account of Wildfowl found there, 271.

Whitrig Tower, 270.

Whitslaid, Woodcock shooting, 237.

Whitsomehill, a favourite haunt of

Golden Plover, 221.

Whitsomelav, Wild Geese, S6.

Whitsome Parish, Common Heron, 43 ; report on Wild Geese, 86 ; Golden Plover, 221.

Whitsome Village, Water Rail, 201.

Whittingham, Pheasant, 171.

Whytwater, 166.

Wild Duck $H \alpha^{\prime}$, derivation of name, 106.

Winden Caim, Golden Plover's nest, 222.

Windylaw Core, Rock Dove's nest, 146.

Winfield, Wild Geese, S6.

Wolf's Cray, 281.

Woodend, Wild Geese, 81.

Woodhead Hill, Lauder, Black Grouse first seen, 159.

Yarrow, 226.

Yetholm Loch, Tufted Duck breeding, 115 .

\section{IV.-MIGRATION ANI) OBSERVATION INDEX TO VOL. I. AND VOL. II.}

Auk, Little (Mergulus alle), ii. 305.

Bean Goose (Anser segetum). S'sec Goose, Bean.

Blackcap (Sylvia atricapilla), i. 60, 61 ; i. $329,340,341,342,344$, $3 \pm 7,348,352$.

Blackbird (T'urlus merula), i. 27, 30 ; ii. $332,336,337,340,341$, $342,344,345$.

Brambling (Fringilla montifinuille), i. 166,167 ; ii. $3: 31,3335,336,350$, 3.54.

Bullfinch (Pyrrhula europea), i. 170.

Bunting, Corn (Emberia miliaria), i. 181 ; ii. $333,337,338,341,344$, 350.

Bunting, Reed(Emberiza schaniclus), i. 187 .
Bunting, Snow (Plectrophanes nivalis), i. 189,190 ; ii. 331,336 , $339,348,349,355$.

Bunting, Yellow (Emberiza citrinclla), i. 183 ; ii. $334,336,337$, $341,3 \pm 7$.

Buzzard (Buteo vulgaris), i. 302.

Buzzard, Rough-legged (Buteo layopus), i. 305.

Chaftinch (Fringilla colebs), i. 163, 164 ; ii. $333,336,337,340,3 \pm 1$, $342,347$.

Chiffchaff (Plyylloscopus collybita), i. 69,70 ; ii. $330,338,339,340$, 352.

Coot, Common (Filica atra), ii. 334, 33S, 339, 344, 349.

Cormorant, Common (Phalacrocorax 
carbo), ii. $334,335,337,340,345$, 346,349 .

Crake, Spotted (Porzana maruetta), ii. 198.

Crow, Carrion (Corvus corone), i. $210,211$.

Crow, Hooded (Corvus comix), i. 214 ; ii. 340.

Cuckoo (Cuculus canorus), i. 274 ; ii. $331,339,342,344,345,346,354$.

Curlew, Common (Numenins arryata), ii. 260, 261, 335, 336, $33 \mathrm{~S}, 341,344,345,346,348$.

Diver, Great Northern (Colymbus ylacialis), ii. 309.

Diver, Red-throated (Colymbus septentrionalis), ii. 311.

Dotterel (Charadrins morinellus), ii. $210-220,324,331,339,341$, $342,343,344,348,355$.

Dove, Ring (Columba palumbus), ii. $132,133,334,336,337,338$, 340.

Dove, Turtle ('Turtur communis), ii. 151.

Duck, Long-tailed (Harelda glacialis), ii. 122.

Duck, Pintail (Dufila acuta), ii. 109.

Duck, Tufted (Fuligula cristata), ii. 118 .

Duck, Scaup (Fuligula mavila), ii. 119.

Duck, Wild (Anas boscas). Sec Mallard.

Dunlin ('Tringa alpina), ii. 246.

Fieldfare (T'urdus pilaris), i. 18 ; ii. $331,336,339,343,349,350,354$.

Flycatcher, Pied (Muscicana alricapilla), i. 133; ii. 333, 342, 343.

Flycatcher, Spotted (Muscicapa (frisola), i. 131 ; ii. $330,343,344$, 346,353 .

Gamnet or Solan Goose (Sula bassana), ii. $35,36,334,339,340$, 342.

Garganey (Querquedula circia), ii. 112.

Godwit, Black-tailed (Limosa arjocephala), ii. 257.

Golden-Eye (Fuligula clangula), ii. $120,337,338,339$.

Goosander (Mergus merganser"), ii. 128.

Goose, Bean (Anser segetum) and Goose, Pink-footed (Anser brachy- rhynchus), ii. 66-89, 321, 331, $336,338,341,348,349,350,355$.

Goose, Bernacle (Bemicla leucopsis), ii. 93.

Goose, Brent (Bernicla brenta), ii. 91.

Goose, Solan (Sula bassana). See Gannet.

Goose, White-fronted (Anser albifroms), ii. 90.

Grebe, Eared (Pocliceps nigricollis), ii. 317.

Grebe, Great Crested (Podiceps cristatus), ii. 313.

Grebe, Little (Policep)s furiatilis), ii. $335,340,349$.

Grebe, Red-necked (P'odicep)s griseigena), ii. 315.

Greenfinch (Coccothranstes chloris), i. 154 .

Greenshank ('T'otanus canescens), ii. 256.

Gull, Black-headed (Larus ridibundus), ii. 335, 338, 339, 345.

Gull, Glaucous (Larus glaucus), ii. 287.

Gull, Little (Lamus minuuss), ii. 267.

Hen, Moor (Gallimula chloropus), ii. $334,337,338,339$.

Hobby (Falco subbuteo), ii. 20.

Jacksnipe (Gallinargo gallinula), ii. 244.

Kestrel (Falco tinnunculus), ii. 25.

Landrail, (Crex pratensis), ii. 194, $196,331,341,343,344,347,354$.

Lapwing (Vanellus vulgaris), ii. 225, $226,333,335,337,339,311,344$, $345,346,349$.

Linnet (Linota cannabina), i. 170 ; ii. $333,336,338,341,346,349$, 350 .

Mallard or Wild Duck (Anas boscas), ii. $334,336,339,340,341,343$, $345,347,349$.

Martin (Chelidon urbica), i. 141, 143 ; ii. $330,340,342,343,346$, $347,348,353$.

Martin, Sand (Cotile riparia), j. 144, 145 ; ii. $330,339,340,343,347$, $348,353$.

Nightjar (Caprimulyus europons), i. 258 ; ii. $330,342,343,344,345$, 346,353 . 
Osprey (Pandion haliaetus), ii. 27.

Ouzel, Ring ('Turdus torquatus), i. 32,34 ; ii. $329,337,335,339,340$, $342,344,345,349,350,351$.

Owl, Long-eared (Asio otus), i. 257.

Owl, Short-eared (Asiouccipitrinus), i. 289.

Partridge, Common (Perdix cinerea), ii. 334, 336, 337, 338, $344,345$.

Pheasant (Phasianus colchicus), ii. $341,344,345$.

Pink-footed Goose (Anser brachyrhynchuss). See Goose, Bean.

Pipit, Meadow (Anthus mratensis), i. 114,115 ; ii. $332,337,339,342$, $347,34 \mathrm{~S}, 350$.

Pipit, Rock (Anthus obscurus), i. 118 ; ii. $332,336,338,340,345$, 348.

Pipit, Tree (Anthus trivialis), i. 116 ; ii. $330,341,342,343,349,353$.

Plover, Golden (Charadrius plurialis), ii. $221,335,336,337,338$, $3 \pm 1,346,347$.

Pochard (Fuligula ferina), ii. 115, 116.

Puffin (Fratercula arctica), ii. 307.

Quail, Common (Cotumix communis), ii. 190.

Rail, Water (Rallus aquaticus), ii. 200.

Redbreast (Erithaca rubecula), i. 50, 51 ; ii. $324,332,336,337,342$, $343,345,346,347,349$.

Redpoll, Lesser (Linota rufescens), i. 172 .

Redshank, Common (T'otanus calidris), ii. 254 .

Redstart (Phoenicure ruticilla), i. 47 ; ii. $329,340,341,343,345$, $347,348,349,351$.

Redwing (Turdus iliacus), i. 14, 15 ; ii. $331,339,340,341,349,350,354$.

Rook (Corvus frugilegus), ii. 334, $337,338,341$.

Ruff (Wachetes pugnax), ii. 24S.

Sandpiper, Common ('Totanats hypolencus), ii. $250,331,341,354$.

Sandpiper, Green (T'otamus ochro. pus), ii. 252, 253.

Sandpiper, Purple (Tringa striata), ii. 247.

Scoter, Common (Edemia nigra), ii. 126
Scoter, Velvet (Eilemia fusca), ii 127.

Shoveller (Spatule clypeata), ii. 107.

Siskin (Carduelis spinus), i. 152.

Skua, Arctic, or Richardson's (Stercorarius ciepidatus), ii. 293.

Skua, Long-tailed, or Buffon's (Stercorarius parasiticus), ii. 294.

Skua, Pomatorhine (Stercorarius pomatorhinus), ii. 292.

Skylark (Alauda arvensis), i. 25l, 252 ; ii. $333,336,337,338,347$, $345,349,350$.

Snipe, Common (Gallinago crelestis), ii. $242,333,338,339,340,343$, 344,345 .

Snipe, Great (Gallinago major), ii. 240.

Smew (1Kergus albellus), ii. 130.

Sparrow, Hedge (Accentor modularis), ii. 333, 336, 337, 338.

Sparrow, House ( Passer clomesticus), i. 158,159 .

Sparrow, Tree (Passer montanus), i. 160 .

Starling (Sturmus vulgaris), i. 194, 195 ; ii. $334,336,337,340,344$, $346,348,350$.

Stonechat (Saxicola rubicola), i. 44, 45 ; ii. $332,336,338,342,344$, $345,347,349,350$.

Swallow (Hirundo rustica), i. 135, 136,138 ; ii. $324,330,339,341$, $343,346,347,348,353$.

Swan, Bewick's (Cygnus Bevicki), ii. 99.

Swift (Cypselus apus), i. 256; ii. $330,343,344,346,347,353$.

Teal (Querquedula crecca), ii. 110.

T'ern, Common (Sterna Auriatilis), ii. 265.

Thrush, Missel (T'urdus viscivorus), i. $9,10,11,12$; ii. $332,336,337$, $338,340,342,347,349,350$.

Thrush, Song (Trurdus musicus), i. $3,4,5$; ii. $324,332,336,337,338$, $341,343,345$.

Titmouse, Blue (Parus caruleus), i. 95 ; ii. $333,337$.

Titmouse, Cole (Parus ater), i. 93.

'Titmouse, Great (Pames major), i. 91 ; ii. $333,336,338,340$.

Titmouse, Long-tailed (Acredula caudat $a)$, i. $\$ 9$.

Wagtail, Grey (Motacilla sulphurea), i. 111,112 ; ii. $332,335,338,343$, $34 \mathrm{~S}, 350$. 
Wagtail, Pied (Motacilla lugubris), i. 108,109 ; ii. $332,336,338,341$, 348,349 .

Warbler, Garden (Sylvia salicaria), i. 63,64 ; ii. 329,343 , $344,347,352$.

WVarbler, Grasshopper (Acrocephalue nuevines), i. 79 ; ii. 330 , $344,353$.

Warbler, Sedge (A crocephalus schonobcenus), i. 75 ; ii. $330,342,344$, $345,346,353$.

Wheatear (Swxicola (manthe), i. 36, 37 ; ii. $329,337,339,342,345$, $346,347,349,351$.

Whimbrel (Numenius phoopus), ii. 263.

Whinchat (Suxirola rubetra), i. 41,42 ; ii. $329,339,343,346$, 349, 351 .

Whitethroat (Sylvia rufo), i. 57,
$5 \mathrm{~S}$; ii. $329,341,342,343,344$, $346,347,349,352$.

Whooper (Cygnus mussicus), ii. 96, 97. Wigeon (Mareca penelope), ii. 113.

Wild Goose. See Goose, Bean, and Pink-footed.

Woodeock (Scolopax rusticula), ii. $233,234,333,339,340,342,348$, 349.

Woodpecker, Great Spotted (Dendrocopus major), i. 263.

Wren (Troglodytes parvulus), i. 102; ii. $332,336,339,340,349$.

Wren, Golden - crested (Rergulus cristatus), i. 65, 66.

IVren, Willow (Phylloscop)es trocthilus), i. 71,72 ; ii. $330,339,340$, $3 \pm 2,316,347,348,352$.

IVren, Wrood (Phyllosrop) sibila. trix), i. 73,74 ; ii. $330,340,342$, $343,344,346,347,352$.

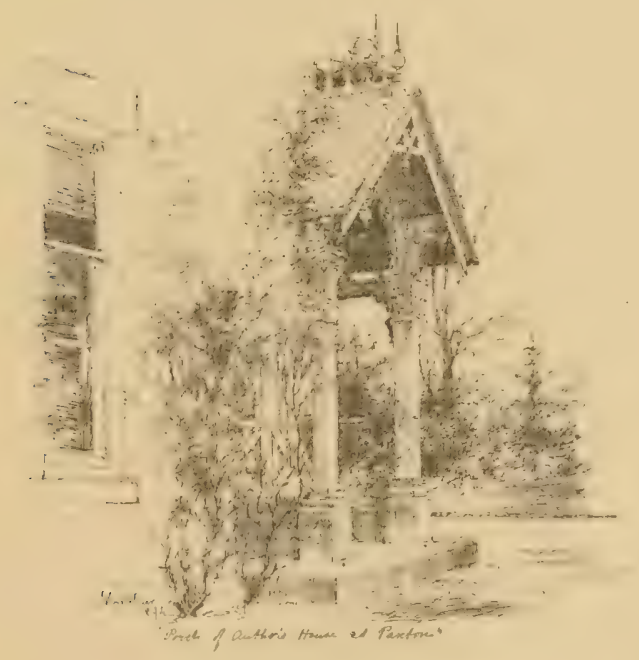




\section{V.-INDEX TO NAMES OF BIRDS IN VOL. I. AND VOL. II.}

\section{LATIN NAMES.}

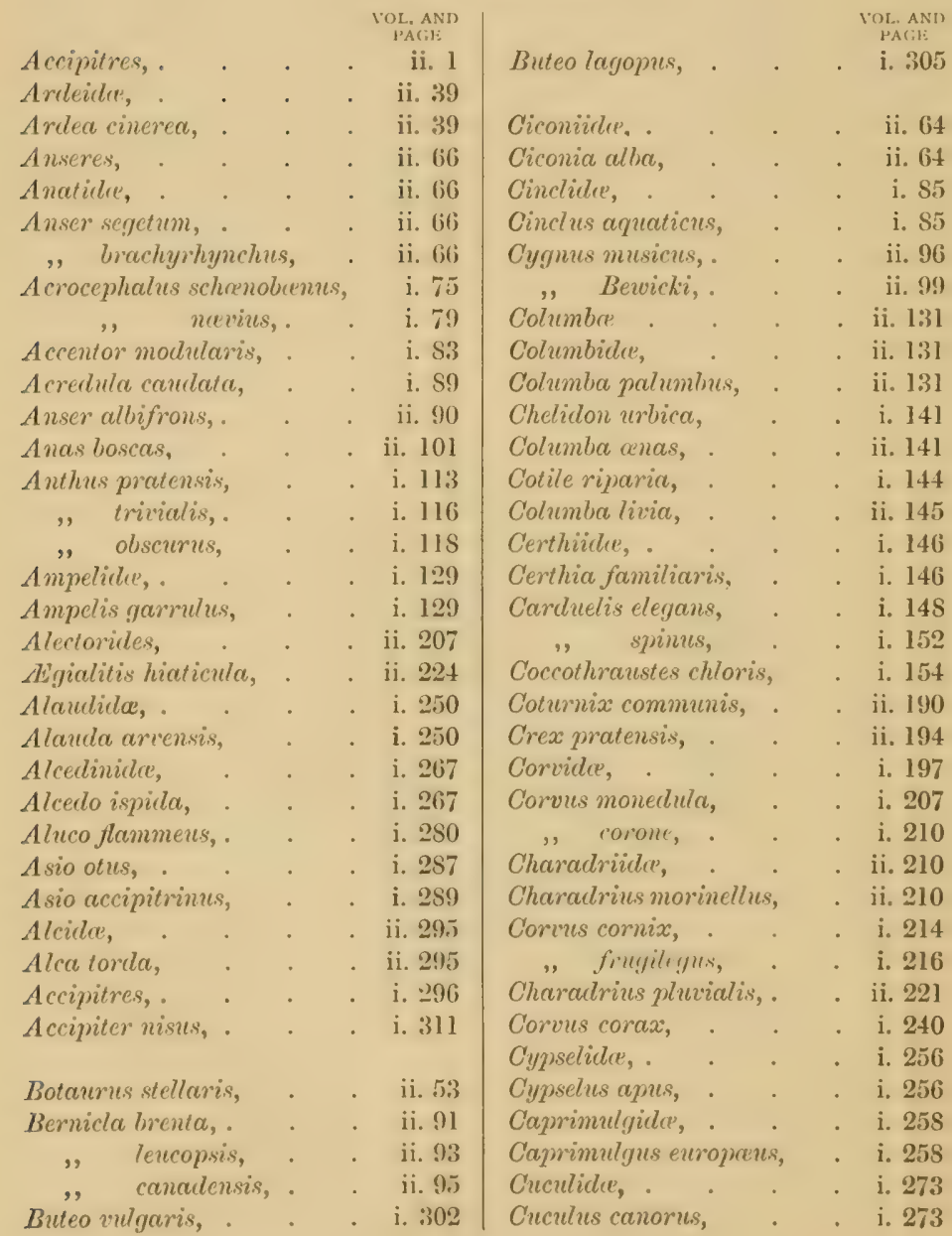




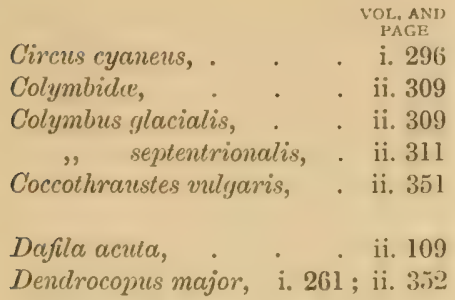

Erithaca rubecula,

Letopistes miyratorius,

ii. 153

Eimberizidce,

Emberiza miliaria, ", citrinella, ,. schoniclus,

Falconidce, .

Falco peregrinus,

,, subbuteo,

, resalon,

". timmunculues,

Fuligula ferina, .

", cristata,

". marila,

" clangula,

Fringillida,

Fringilla coelebs, .

, montifringilla,

Fulicarice, .

Fulica atra,

Falconida, .

Fratercula arctica,

i. 150

i. 180

i. 183

i. 156

ii. 1

ii. 1

ii. 20

ii. 21

ii. 25

ii. 11.5

ii. $11 \mathrm{~s}$

ii. 119

ii. 120

i. $14 \mathrm{~S}$

i. 162

i. 166

ii. 194

ii. 204

i. 296

ii. 307

Gallince,

Garrulus glandularins,

ii. $1.5 \mathrm{~s}$

Gallinula chloropus, .

Gallinago major,

i. 200

ii. 202

ii. 240

ii. 241

ii. 244

Gavice, gallinula, .

Herodiones,

ii. 264

Harelda glacialis,

ii. 39

Hirundinidee,

ii. 122

i. 135

Hirundo rustica,

i. 135

Homatopus ostralegus,

ii. 231

Hydrochelidon nigra, .

ii. 264

Haliaetus allicilla

i. 307
Iynx torquilla, .

VOL. AND

PAGE

i. 265

Laniidee, . . . . i. 123

Lanius excubitor, . . i. 123

, collurio,. . . i. 127

Layopus scoticus, . . ii. 162

Linofa cannabina, . . . i. 168

, rufescens, . . i. 172

, flavirostris, . . i. 174

Loxia curvirostra, . . i. 179

Limicole, . . . ii. 210

Limosa wgocephala, . . ii. 257

Lavidle, . . . . ii. 264

Larus minutus, . . . . ii. 266

, ridlibundus, . . ii. 268

" cantes, . . ii. 275

"argentatus, . . ii. 279

,, fuscus, . . . . ii. 285

" marinus, . . . ii. 286

"ylaucus, . . . ii. 287

Notacillida, . . . i. 108

Motacilla lugubris, . . i. 108

"sulphurea,. . i. 111

Mareca penelope, . . ii. 113

Meryus meryanser, . . ii. 128

ii. 130

i. 131

i. 131

i. 133

ii. 248

Mergulus alle, . . . ii. 305

Nycticorax grisens, . . ii. 53

Numenius arquata, . . ii. 258

ii. 263

Oriolida, . . . i. 120

Oriolus galbula, . . . i. 120

Edemia nigra, . . . ii. 126

"fusca, . . . ii. 127

Otididce, . . . . ii. 207

Otis tarda, . . . . ii. 207

Passeres, . . . i. 1

Pandion halicretus, . . ii. 27

Pelecanida, . . . ii. 30

Phalacrocorax carlo, . . ii. 30

" graculus, . ii. 33

VoL, II. 


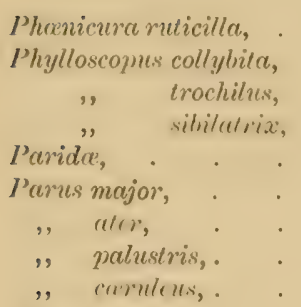

Querquedula crecca, ,, circia,

Regulus cristatus,

\section{Rallidee,}

Rallus aquaticus, liissa tridactyla,

Steganopodes,

Sula bassana,

Sylviida,

Stexicola enanthe, ", melvetra,

Saxicola mebicola, Sylvia mefa,

\begin{tabular}{|c|} 
VI. ANI \\
PAGI \\
i. 47 \\
i. 68 \\
i. 71 \\
i. 73 \\
i. 89 \\
i. 91 \\
i. 93 \\
i. 9.7 \\
i. 97
\end{tabular}

\section{ii. 155}

ii. 15.5

i. 156

i. 160

ii. 170

ii. 170

i. 176

i. 178

ii. 178

i. 189

i. 197

ii. $19 \mathrm{~s}$

i. $20^{\circ} 2$

ii. 232

i. 261

ii. 29.5

ii. $31: 3$

ii, $31: 3$

ii. 315

ii. 317

ii. 315

ii. 321 ii. 321

ii. 110 ii. 112

i. (j.) ii. 194

ii. 200 ii. 285

ii. 30

ii. 3.5

i. 36

i. 36

i. 41

i. 44

i. 57
S'yleva atricapilla, , salicaria, Sillirler,

Sitta cresia,

Spatula clypeata,

Somateria mollissima,

Syrrhaptes paraloxus,

Sturnidu, .

Sturnus vulyaris,

Shrolopuceriler,

Scolopax misticula,

Stema fluciatilis,

Striges,

Strigidle,

Strix aluco,

Stercorarius pomatorhinus, .

$$
\begin{aligned}
& \text { crepidatus, } \\
& \text {, parasiticus, }
\end{aligned}
$$

T'urdida',

T'urdus musicus, . ", riscierus, " iliuerus,

, pilaris,

,, rerins.,

,, merila,

, torquatus,

I'adorna cornuta,

Troylodytider,

I'roglodyles parvulus,

Turtur communis,

T'etraonida,

T'etrao tetrix,

Tringa alpina, " striata, .

T'otanus hypoleucus,

", ochropus,

, calidris,

, canescens,

Trubinares, .

Upupida, .

Umupa epops

Uria troile, " srylle,

Vanellus vulgaris, i. 271
i. 271
ii. 297
ii. 303

i. 271
i. 271
ii. 297
ii. 303

i. 271
i. 271
ii. 297
ii. 303

i. 271
i. 271
ii. 297
ii. 203

1.ni.1.

i. 60

i. $(33$

i. 100

i. 100

ii. 107

ii. 123

ii. 155

i. 192

i. 192

ii. 2.2

i. ....

i. 280

i. 280

i. 292

ii. 292

ii. $29: 3$

ii. 2914

i. 1

i. $s$

i. 14

i. 15

i. 22

i. 25

i. 32

ii. 100

i. 102

i. 102

ii. 151

ii. 158

ii. 1.58

ii. 246

ii. 247

ii. 2.50

ii. 2.52

ii. 2.54

ii. 2.56

ii. 321

ii. 225 


\section{ENGLISH NAMES.}

Arctic or Richardson's Skua, ii. 29?

Auk, Little,

ii. 305

Blackbird, .

i. 25

Bittern, Common,

Blackcap, .

Bean Groose,

Brent Goose,

Bernacle Goose,

Blue Titmouse, .

Bewick's Swan, .

Black Grouse,

Brambling,

Bullfinch, .

Bunting, Com,

"Yellow,
$" \quad$ Reed,
"Snow,

Bustard, Great, .

Black-tailed Godwit,

Black Tern,

Black-headed Gull,

Barn Owl,

Black-backed Giull, Lesser, , ", Great,

Buffon's Skua,

ii. 5.3

i. 6 (5)

ii. 6 (j)

ii. 9]

ii. 93

i. 97

1i. $4 ! 9$

ii. 155

i. 16,5

i. 176

i. 109

i. $1 \times \%$

i. $\ln 6$

i. 185

(i. 207

ii. $2 \%$

ii. 26,4

1.. 20 is

i. $2-1)$

(i. $2-5$

ii. $2-6$;

Buzzard,

i. 2.14

i. $: 302$

Black Guillemot,

ii. : :r):;

Buzzard, Rough-letgrged,

i. $.50 \%$

," Honey,

i. :3:5

Common C'ormorant,

ii. : 30

Cormorant, Common, Green,

Common Heron, Bittern,

Chiffchaff, .

i. : 30

ii. $: 3$

ii. :39

ii. .i:

i. (i)

i. 9:3

Cole Titmouse, .

Canada Goose,

ii. 9.5

Common Sheld-Duck,

ii. 100 „, Sooter,

ii. 12 ;

Creeper, Tree,

i. $14 \%$

i. $16 ; 2$

ii. $17 \mathrm{x}$

i. 17 !

Common Partridge, .

Crossbill,

i. 100
Common Quail, .

Chough,

Crake, Spotted,

Common Coot,

Coot, Common, .

Carrion Crow,

Crow, Carrion, .

"Hooded, .

Catcher, Oyster,

Common Snipe, .

$\begin{array}{ll}" & \text { Sandpiper, } \\ " & \text { Redshank, } \\ \text { " } & \text { Curlew, }\end{array}$

Curlew, Common,

Common 'Tern, .

Cuckoo,

Common Gull,

Common Guillemot, .

Crested Grebe, Great,

Dipper,

Duck, Wild,

, Pintail,

," 'Tufted,

"Scaup,

, Longr-tailed,

," Eider,

Dove, Ring,

, Stock,

,, Rock,

,, Turtle,

Dotterel,

Dunlin,

Diver, Great Northern, ", Red-throated,

Dabchick, .

Eider Duck,

Eagle, Sea,

Eared Grebe,

ot.. Anit

ii.

i. 15

ii. $19=$

ii. 201

ii. 204

i. 210

i. 210

i. 214

ii. 291

i. 211

ii. $2 \%$

i. 2.5

ii. 25

4. 2.5

it. 26,5

i. $27: 3$

ii. 2 i.j

ii. 295

ii. :31:3

i. 5

ii. 101

ii. 196

ii. $11 \mathrm{~s}$

ii. 119

ii. 122

ii. 1:2:;

ii. 131

ii. 141

ii. 145

ii. 1.51

ii. 210

ii. $24 ;$

ii. :\%?

(3. 311

ii. 31 ,

Falcon, Peregrine, . . A. I

Fieldfare, . i. Is

Flycatcher, Spotted, . . i. 1.31 i. $1: \% ;$

ii. $12: 2$

i. $: 35,7$

is. :317

$$
\text { , Pied, }
$$




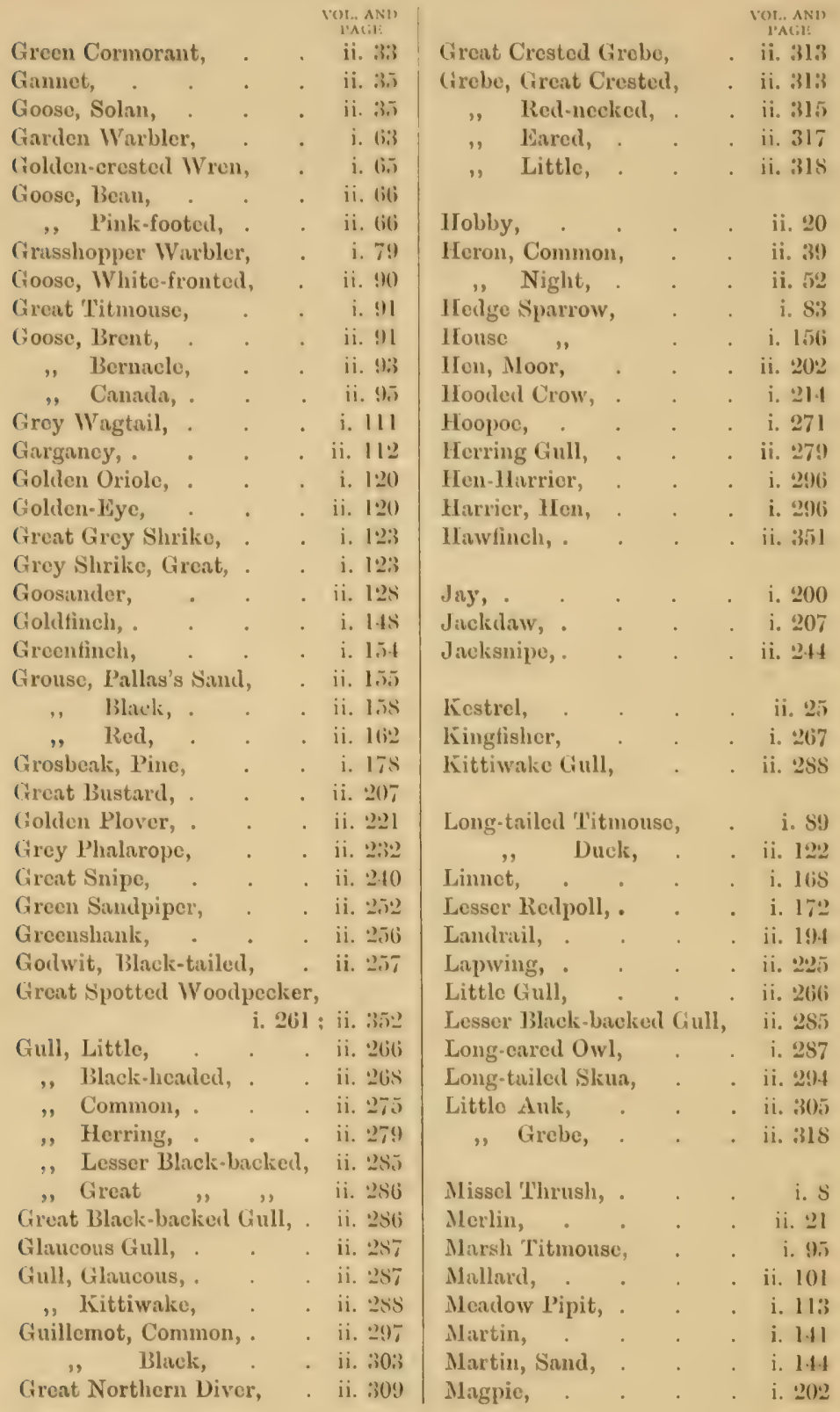




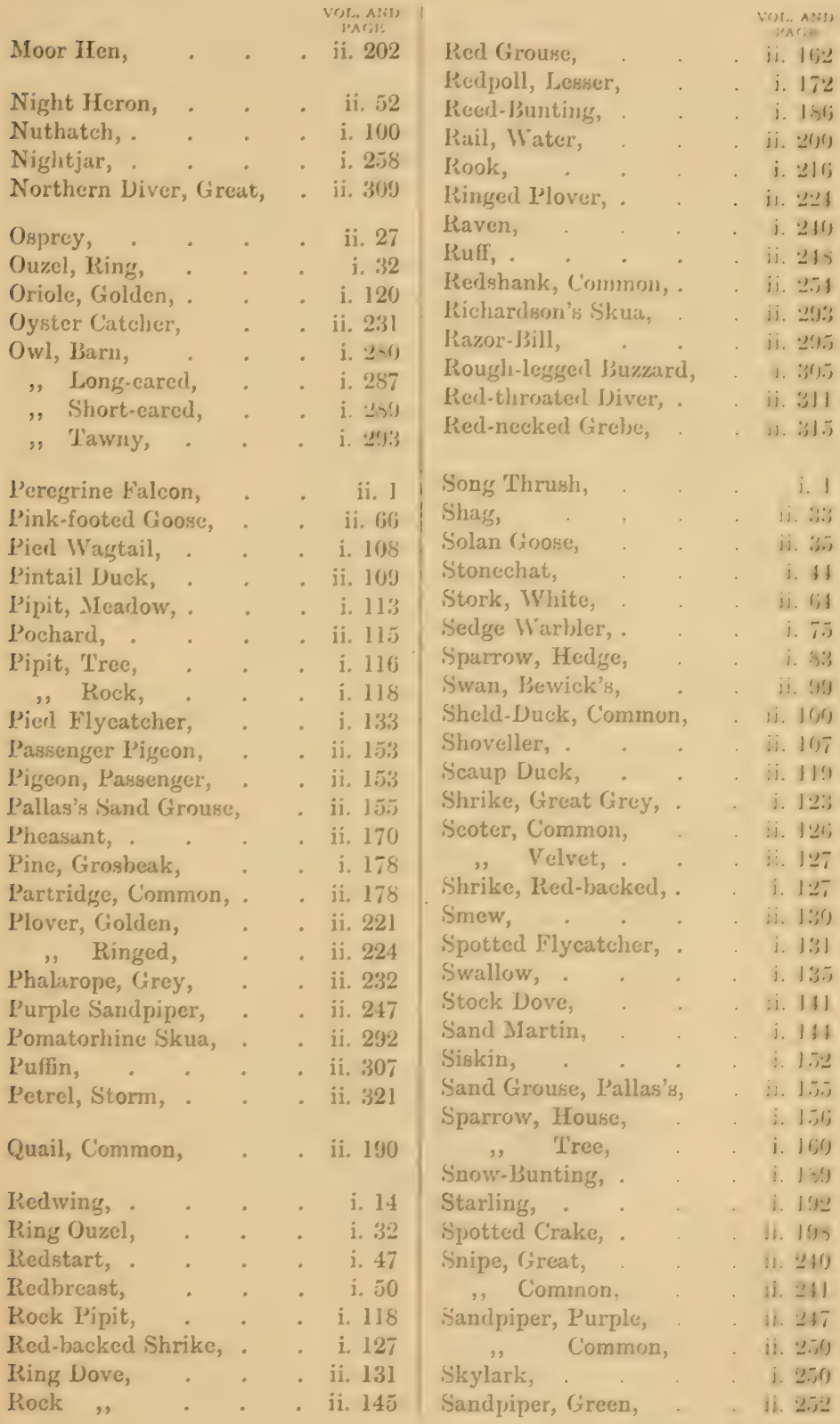




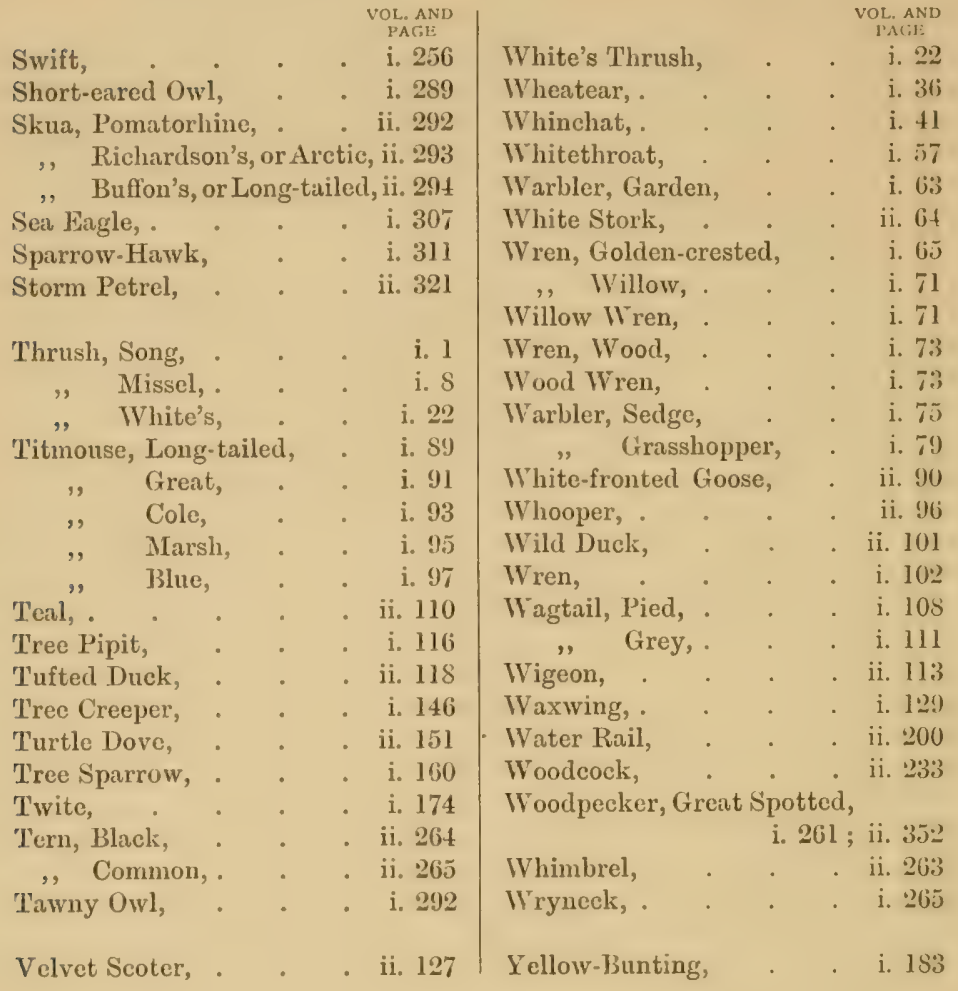






\section{BOOKS}

ON

\section{SPORT' \& NATURAL HISTORY}

PUBLISHED BY

\section{DAVID DOUGLAS}



One Volume, Royal 8vo. 50s. net.

WITH 40 FULL-PAGE ILLUSTRATIONS OF SCENERY AND ANIMAL LIFE, DRAWN BY

SIR GEORGE REID, P.R.S.A., AND J. WYCLIFFE TAYLOR, AND WNGLAVED BY AMAND DURAND.

\title{
NATURAL IIISTORY \& SPORT
}

\section{IN MORAY}

\author{
By CHARLES ST. JOHN
}

AUTHOR OF "WILD SPORTS IN THE MIGHLANTS"

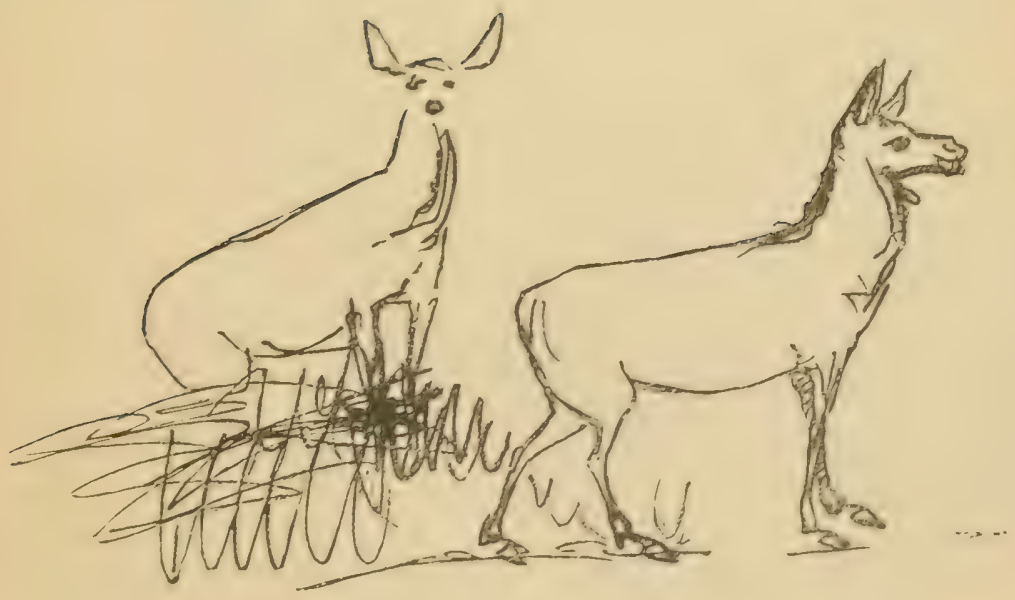

EDINBURGH: DAVID DOUGLAS 
One Volume, Small 4to. 24 s.

Also a Cheaper Edition, with Lithographic Illustrations,

Demy 8vo. $12 s$.

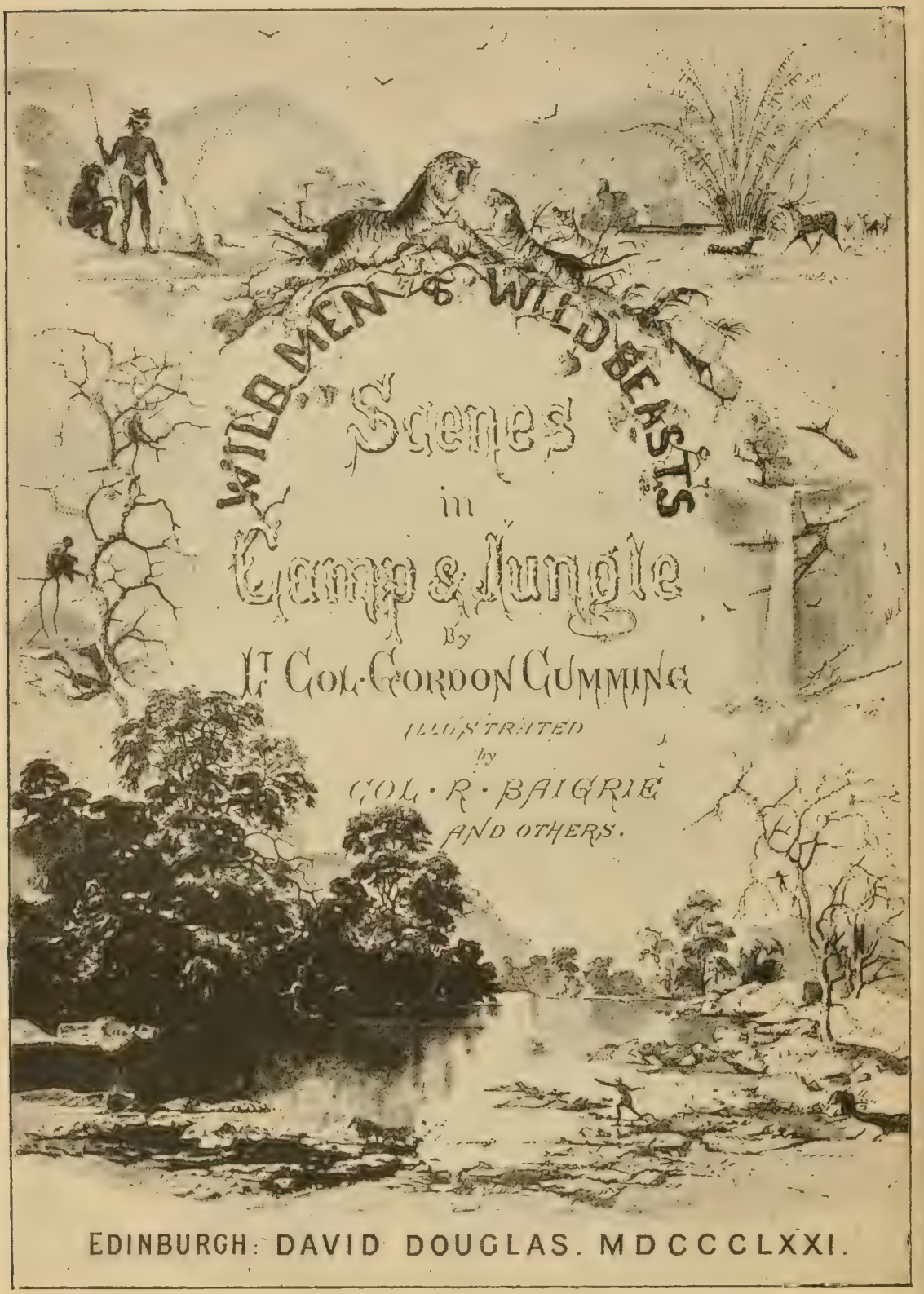


One Volume: New and Pevised Edition, with Illustrations from Nature by various Artists. Royal 8ro. 31s.6d.

\section{WILD SPORTS IN THE SOUTH}

OR

\section{THE CAMP-FIRES}

OF THE

\section{EVERGLADES}

By CHARLES E. WHITEHEAD

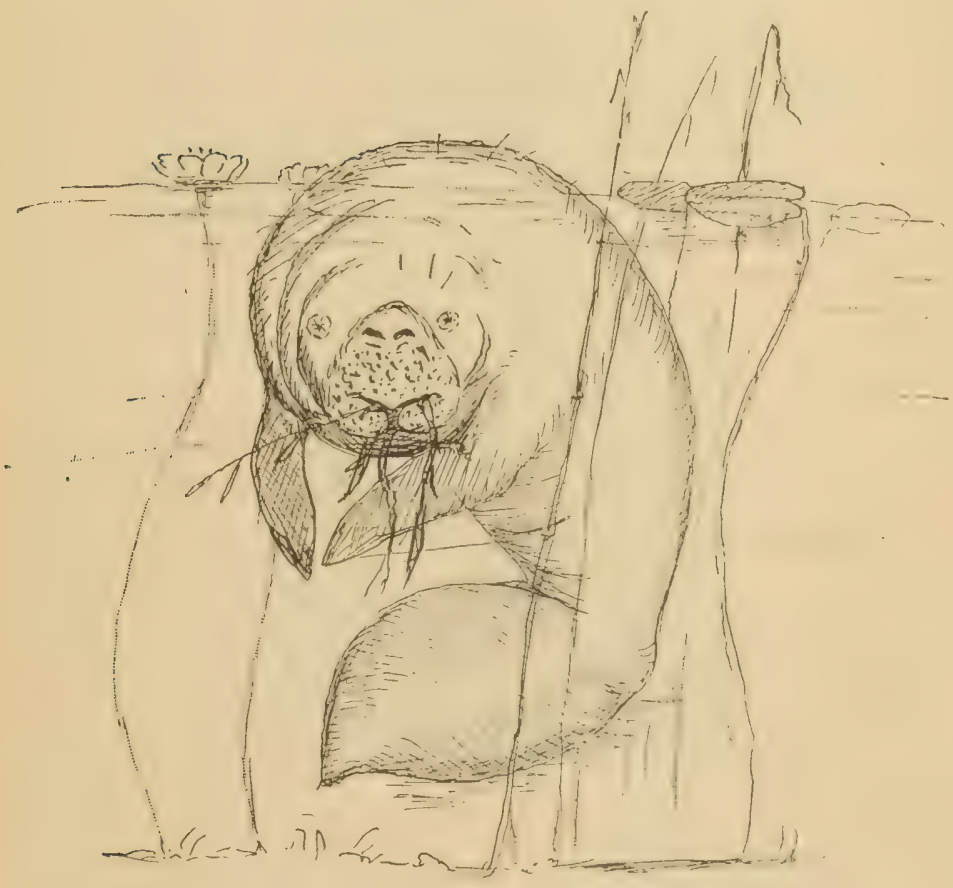

EDINBURGH : DAVID DOUGLAS 
Two Volumes, Crown 8vo, Illustrated. 21 s.

\title{
A TOUR IN
}

\section{SUTHERLA N DSHIRE}

WITI EXTRACTS FROM THE FIELD BOOKS OF A SPORTSMAN AND NATURALIS'T

BY CHARLES ST. JOHN

AUTHOR OF "NATURAL HISTORY AND SPORT IN MORAY"

\author{
SECOND EDITION
}

WITH AN APPENDIX ON THE FAUNA OF SUTHERLAND

Br J. A. Harvie-Brown ANd T. E. Buckley

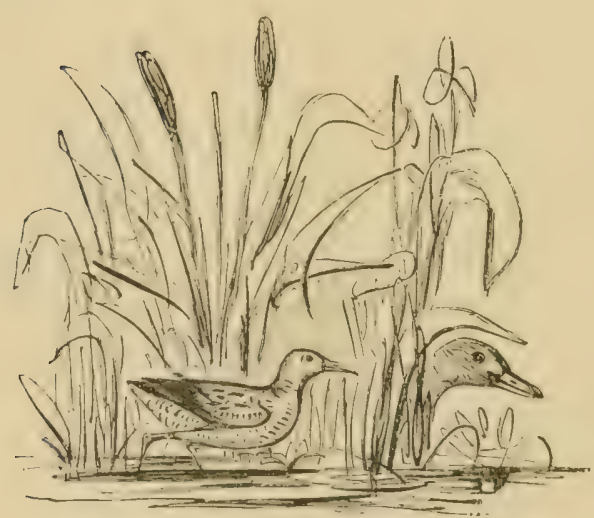

EDINBURGH : DAVID DOUGLAS 1884 
One Volume, Demy Sro, with Maps and Mllustrations. $12 s$.

\title{
NOTES AND SKETCHES
}

FROM THE

\section{WILD COAS'TS OF NIPON}

\author{
WITH CHAPTERS ON CRUISING AFTER PIRATES
}

IN CHINESE WATERS

By CAPTAIN H. C. ST. JOHN, R.N.

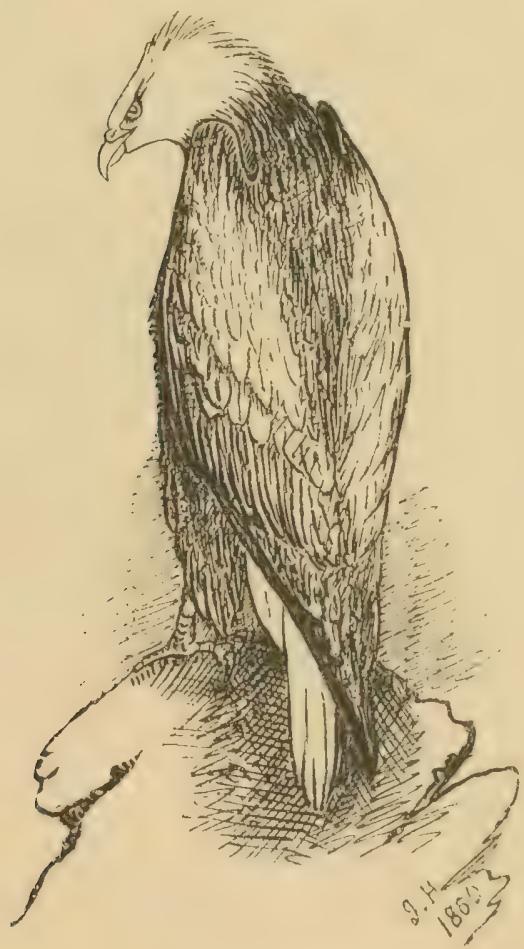

EDINBURGH： DAVID DOUGLAS 
One Volume, Demy Svo. $18 s$.

\section{SASKATCHEWAN}

AND

\section{THE ROCKY MOUNTAINS}

A DIARY AND NARRATIVE OF TRAVEL, SPORT, AND ADVRNTURE DURING

A JOURNEY THROUGH THE HUDSON DAY COMPANY'S TERRITORIES

By THE EARL OF SOUTIIESK, K.T.

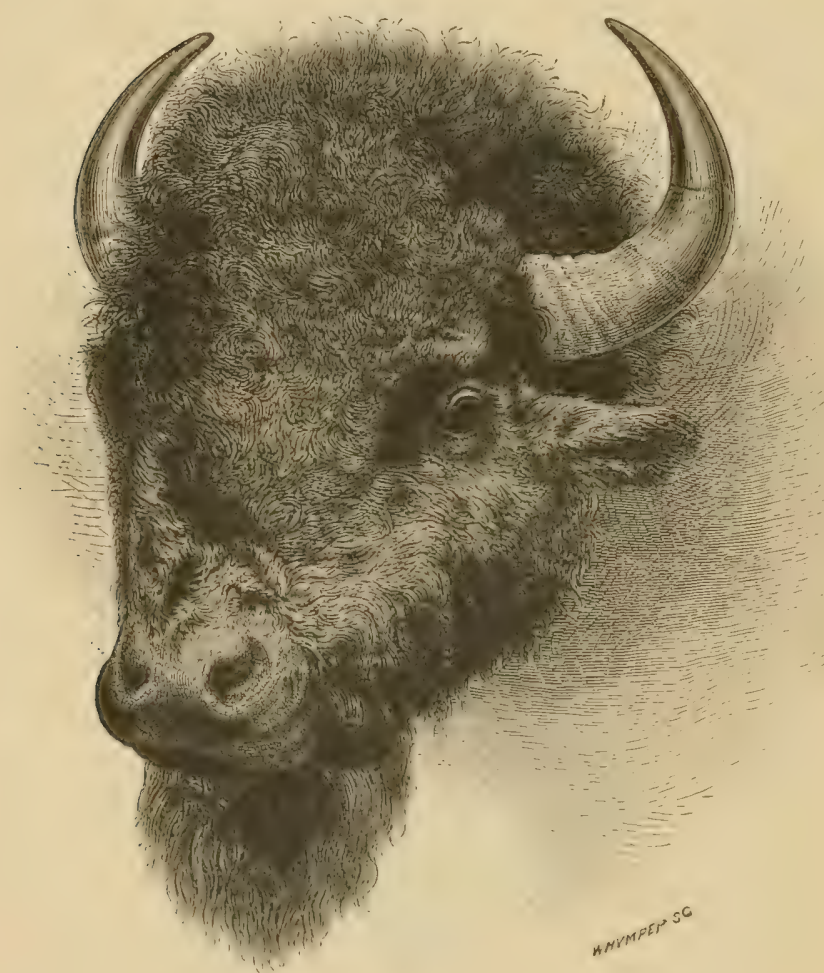

WITI MAP'S AND ILLUSTRATIONS

EDINBURGH：DAVID DOUGLAS 
One Volume, Demy 8vo, with Etchings and Map. $8 s .6 d$.

\section{THE}

\section{CAPERCAILLIE IN SCOTLAND}

WITH SOME ACCOUNT OF TIIE EXTENSION OF ITS RANGE SINCE ITS RESTORATION AT TAYMOUTII IN 1837 AND $183 S$

By J. A. HARVIE-BROW N, F.Z.S. MEMBER OF THE BRITISI ORNITHOLOGISTS' UNION, ETC.

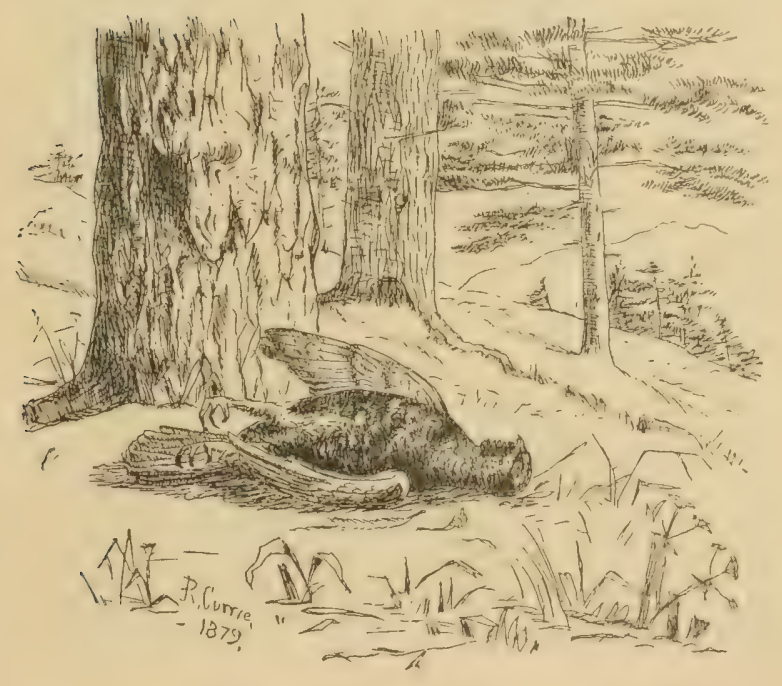

EDINBURGH: DAVID DOUGLAS. MDCCCLXXIX A 2 
One Volume, Demy Svo, 21s. Fifth Edition, Reuritten and Enlarged. Illustrated by 60 Moment Photographs.

\section{Modern Horsemanship}

An Original Method of Teaching the Art BY MEANS OF

Pictures from the Life

BY EDWARD L. ANDERSON

EDINBURGH : DAVID DOUGLAS MDCCCXCV 
One Volume. New and Revised Edition. Demy 8vo. 15 s.

\section{THE ART OF GOLF}

By SIR WALTER G. SIMPSON, BART.

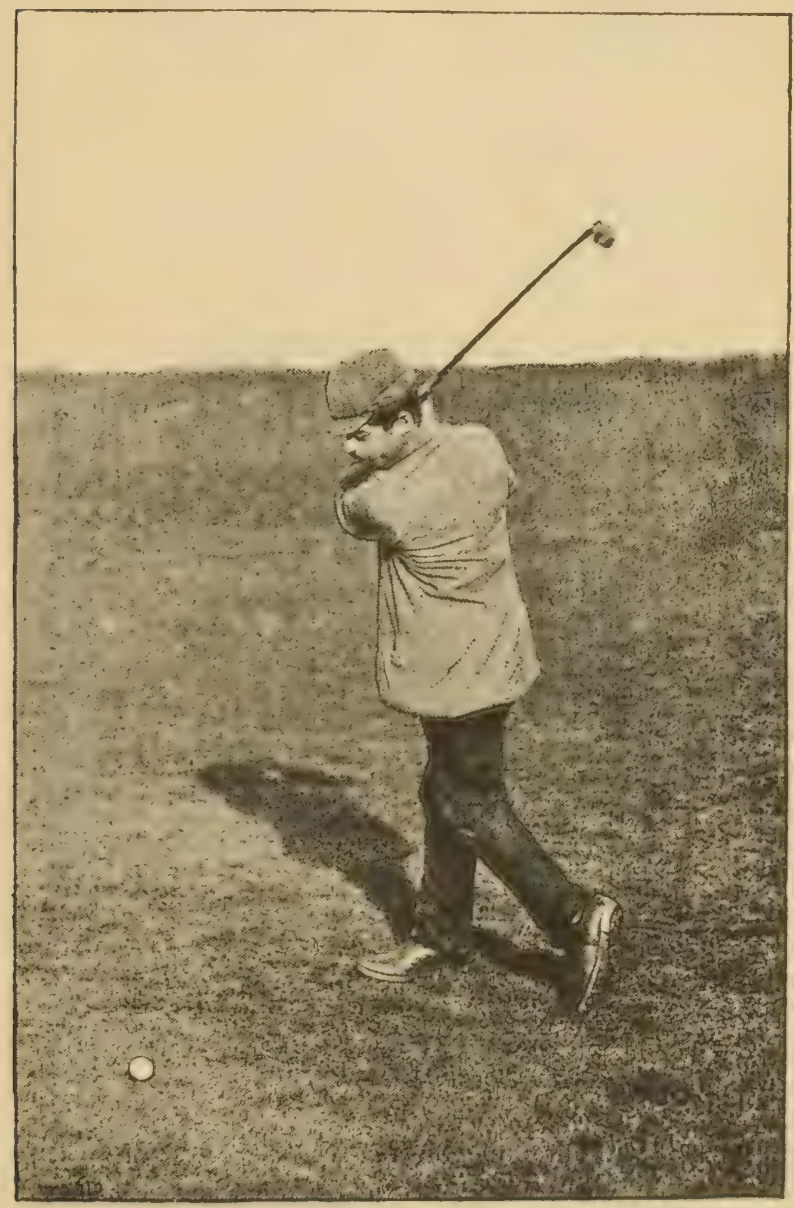

IVith 20 Illustrations from Instantaneous Photographs of Professional Players, chiefly by A. F. Macfie, E'sq. 
One Volume, Royal 8vo. 31s. 6d. net.

\title{
A HISTORY OF CURLING
}

\author{
SCOTLAND'S AIN GAME
}

AND OF FIFTY YEARS OF

THE ROYAL CALEDONIAN CURLING CLUB

By JOHN KERR, M.A.

MINISTER OF THE PARISH OF DIRLETON

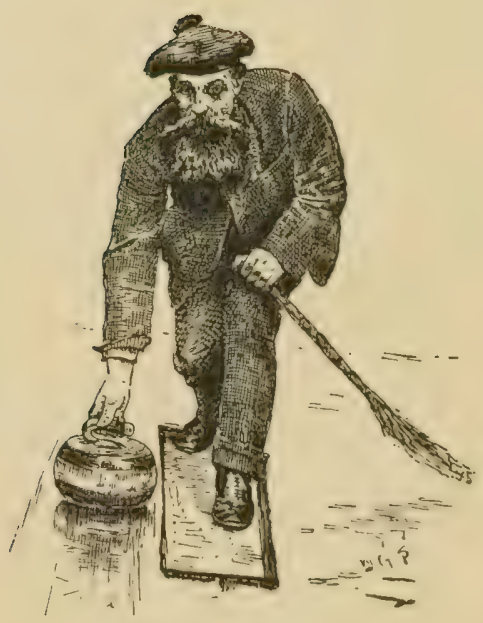

With 15 full-puge Plates from Original Slietches by Sir IV. Fette's Dougles, P.Ii.S.A., Sir George Licit, P.R.S.A., John Smart, R.S.A., I. Alexander, R.S.A., and others; and over one humdred illustrations in the text (Also in Demy Sro, without the Photograrure Plates, 10s. 6d.)

EDINBURGH: DAVID DOUGLAS 
Vol. I., Demy 8vo, Price 15s. net.

Profusely Illustrated with Etchings and Lithographs.

Vol. II., completing the work, in the Press.

\section{THE}

\section{BIRDS OF BERWICKSHIRE}

WITH REMARKS ON THEIR LOCAL DISTRIBUTION MIGRATION, AND HABITS, AND ALSO ON THE FOLK-LORE, PROVERBS, POPULAR RHYMES AND SAYINGS CONNECTED WITH THEM

BY

\section{GEORGE MUIRHEAD, F.R.S.E., F.Z.S.}

MEMBER OF THE BRITISH ORNITHOLOGISTS' UNION, MEMBER OF TIE BERWICKSHRE NATURALISTS' CLUB, ETC.

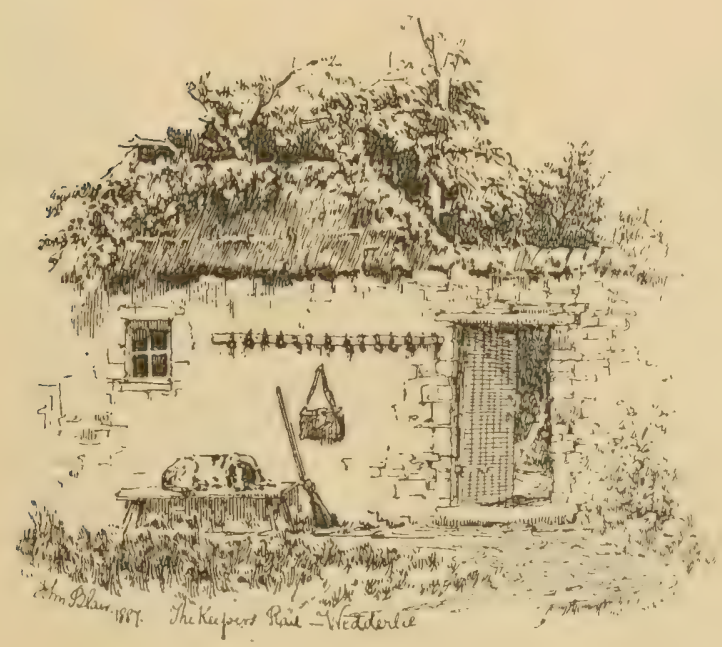

EDINBURGH: DAVID DOUGLAS 
THE VERTEBRATE FAUNA OF SCOTLAND. First Volume, out of print. In One Volume, Small 4to, with Map and Mllustrations by Messis. J. G. Millais, T. G. Keulemans, Samuel Read, and others.

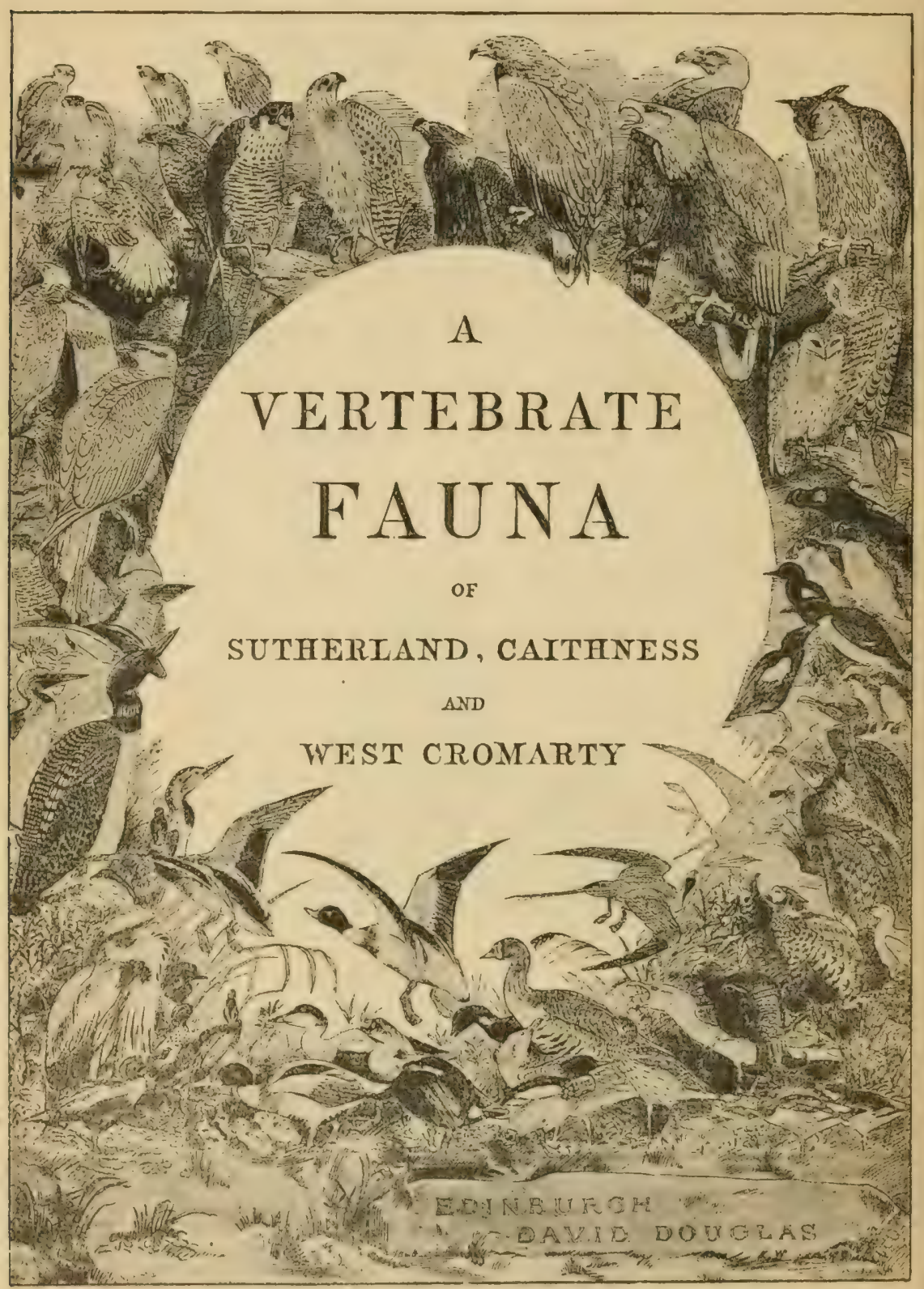


SeCond Volume, out of print.

In One Volume, S'mull 4to, with MIops, cond Illusticted by Etchings, Cuts,

Lithographs and Photogravure plates.

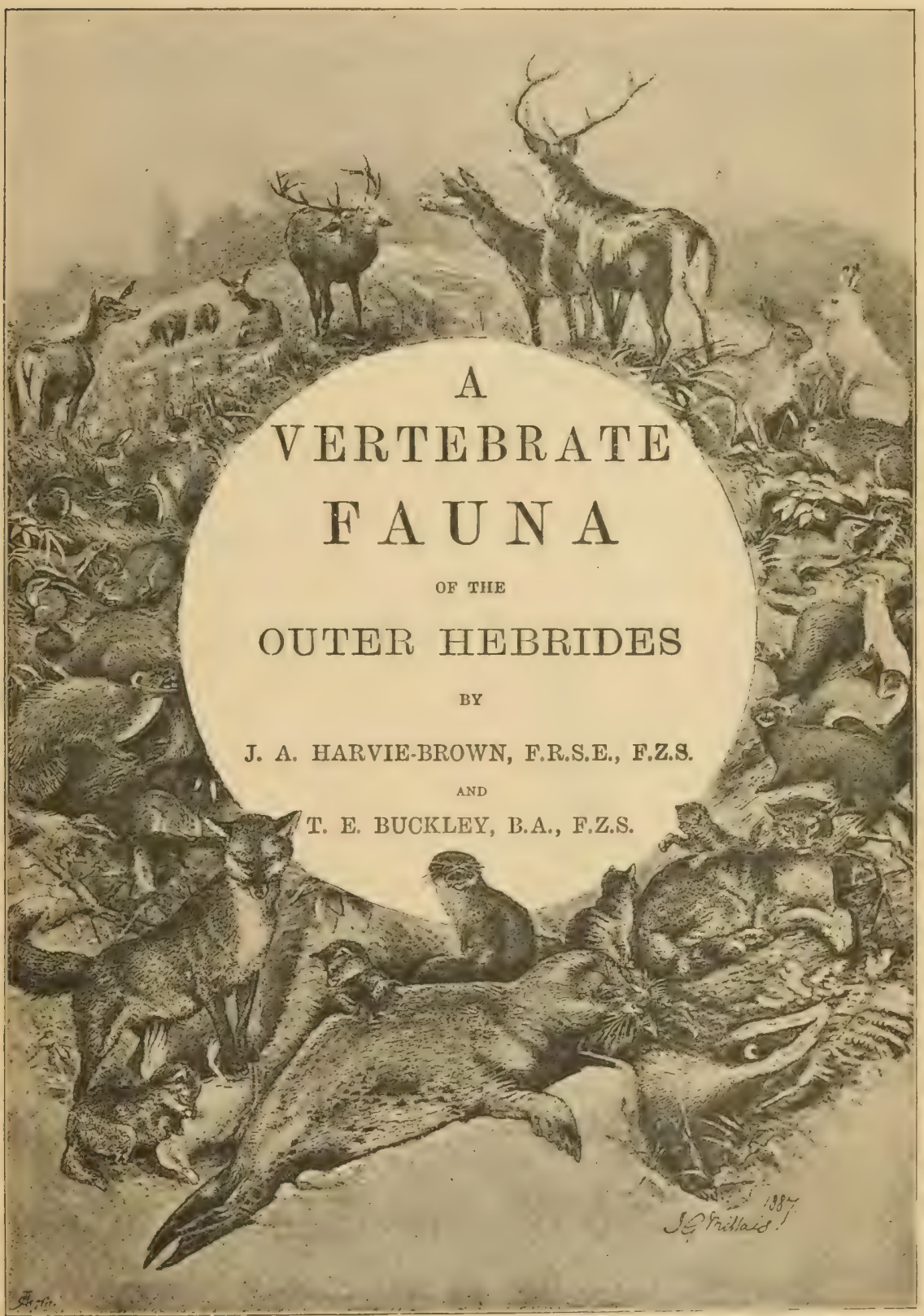


THIRD VoLUMe.

In One Volume, Small 4to, with Illustrations from the Author's Sketch Book. 21s. net.
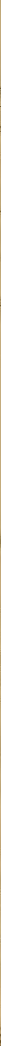

H. D. GDI I AM
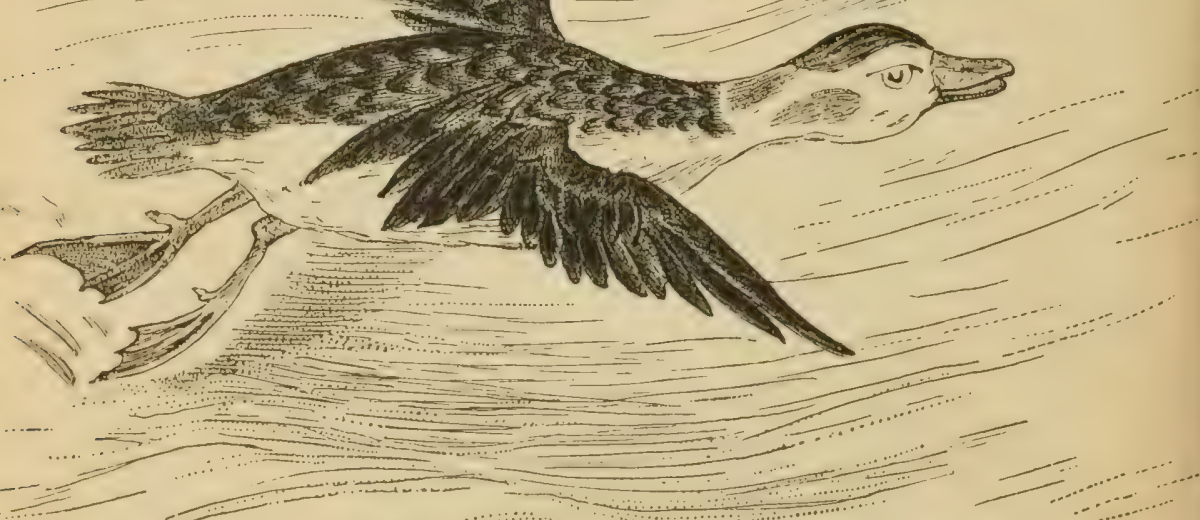

EDINBURGH: DAVID DOUGLAS: MDCCCXC. 
Fourth Volume.

In One Volume. Small 4to. Illustrated with Photogranare Plotes from Drancings lyy

J. G. Mrilluis, us well as fiom Photographls tuken specially for the leceli. I'rice 30s.

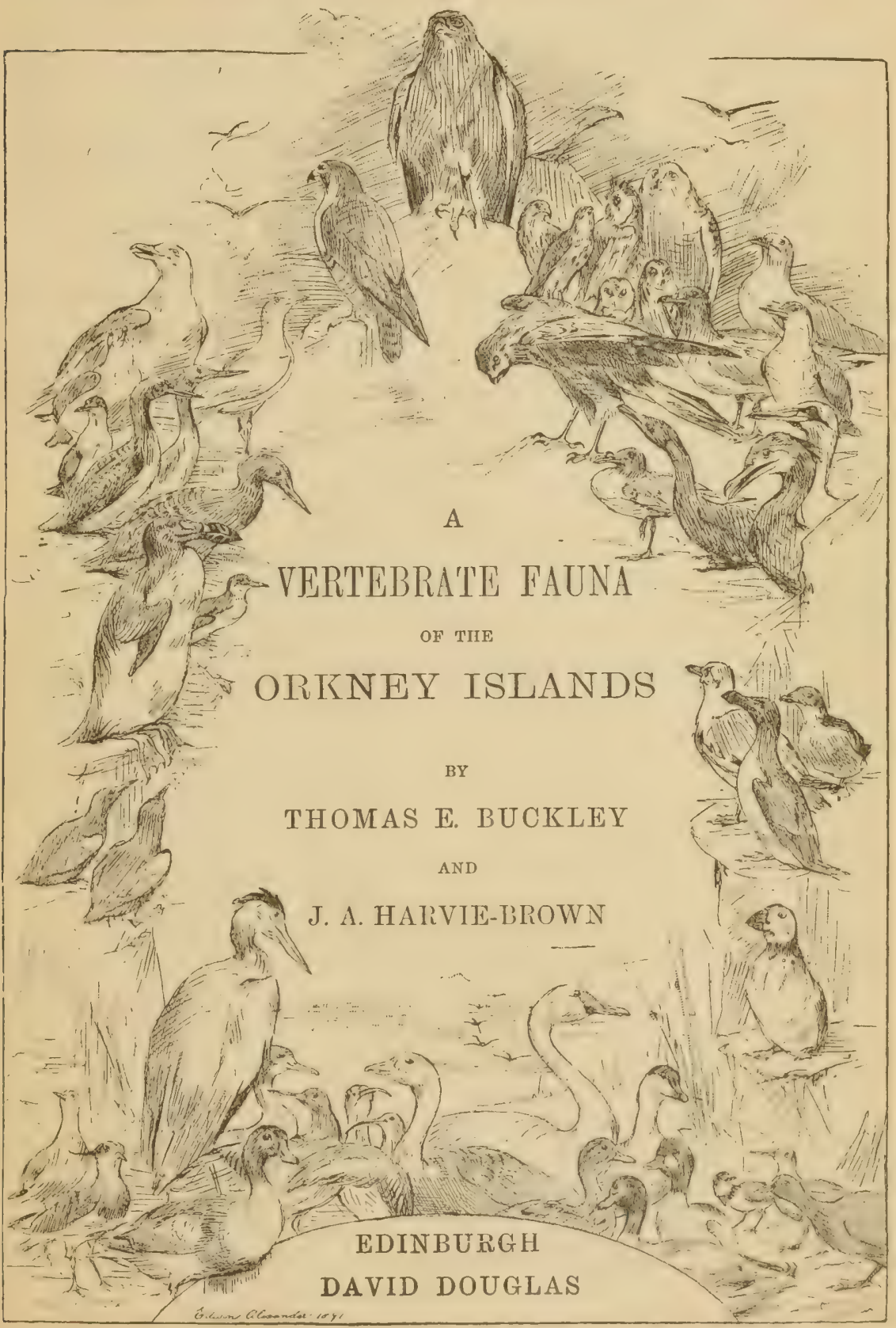


Fifth Volume.

In One Volume, Small 4to, with Maps and Plutes. Price 30 s.

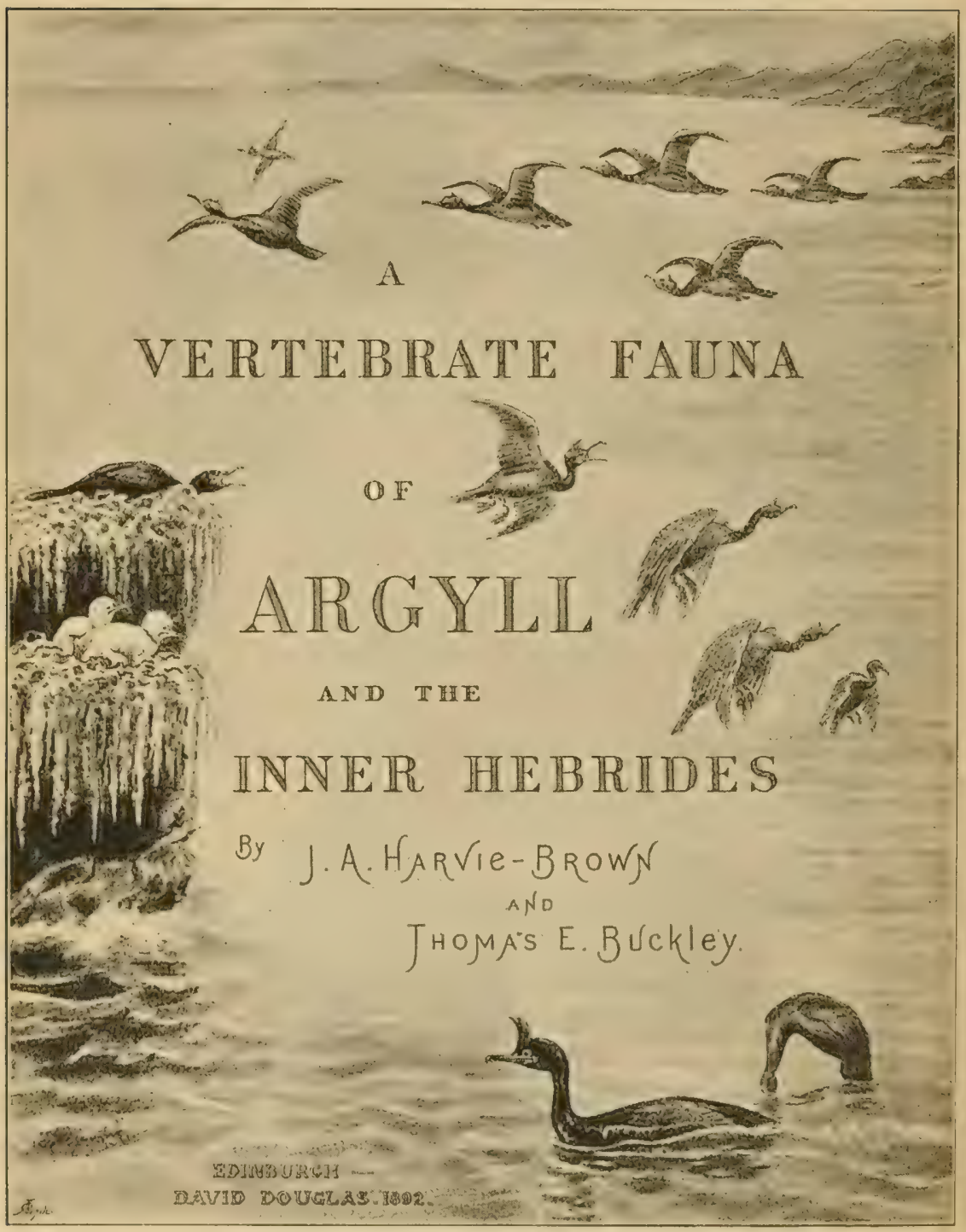

EDINBURGH : DAVID DOUGLAS 
Sixth and Seventh Volumes.

In the Press, in two Volumes, Small 4to. Priee to Subscribers, 42s. net.

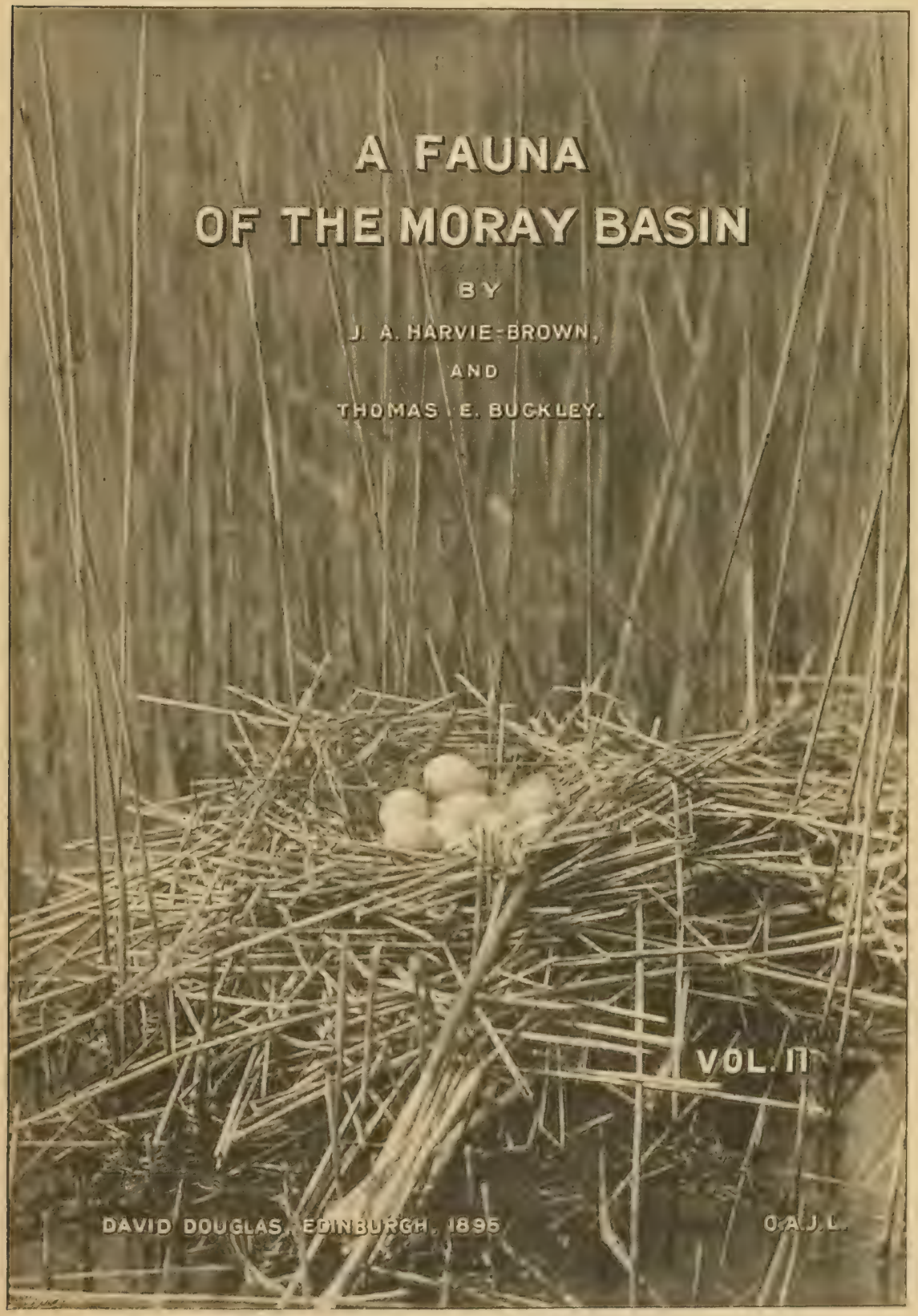

EDINBURGH : DAVID DOUGLAS 
One Vol., Royal 8vo. 30s.

\section{H E L I G O L A N D}

AS AN

\section{ORNITHOLOGICAL OBSERVATORY}

THE RESUL'T OF FIFTY YEARS' EXPEPIENCE

BY

\section{H EINRICH G Ä T K E}

CORRLSPONDING MEMEER OF THE ZOOLOGICAL SOCHETY OF IONDON, HUXORARY MFMBER OF THE BRITISII ORNITHOLOGISTS' UNION, AND OF THE AMERICAN ORNITHOLOHISTS' UNION, HONGRARY TFMBER OF THE NORFOLK AND KORWICI NATURALISTS' SOCIETY, OF THE ORNITHOLOGISTS' UNION OF YIENNA, AND TIE HUNGARIAN ORNITHOLOGICAI. CENTRALE, AND MEMEER OF THE PERMANENT ORNITHOLOGICAI, COMMITTEF

TRANSLATED BY

RUDOLPH ROSENSTOCK, M.A. OXON.

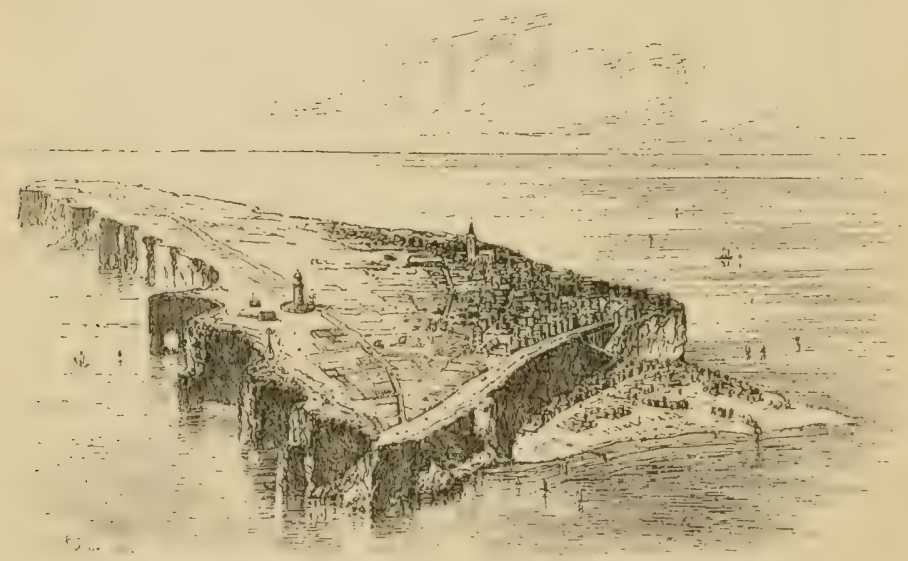

Rot if das Sand, Grŭn if die Sane',

यहeif if der Sand, das find Die Farben son Spetgotand. 
In One Volume, Demy 8vo, with Illustrations. Price 30 s.

\section{A VERTEBRATE \\ FAUNA OF LAKELAND}

INCLUDING CUMBERLAND AND WESTMORELAND WITH LANCASHIRE NORTH OF THE SANDS

BY THE

REV. H. A. MACPHERSON, M.A.

MEMBER OF THE BRITISH ORNITHOLOGISTS' LNION, PRESIDENT OF THE CATLISLE SCIENTIFIC SOCIETX, 2OOLOGICAL KECORDEIL OF THE CEMBEILAND AND WESTMORELAND ASSOCIATION, ETC. ETC, AUTHOR OF

"AN INTRODECTION TO THE STUDY OF HRITISI HIRU,, "THE VISITATION OF PALLAS'S SAND GROESE TO SCOTLAND,' ETC.

WITII AN INTRODUCTORY CHAPTER ON THE TOPOGRAPHY OF' 'THE DIST'RIC'T'

By R. S. FERGUSON, F.S.A.

CHANCEllor OF CARLISLE, ALTHOR OF 'A HISTORY OF CCMBERLAND, ETC. ETC.

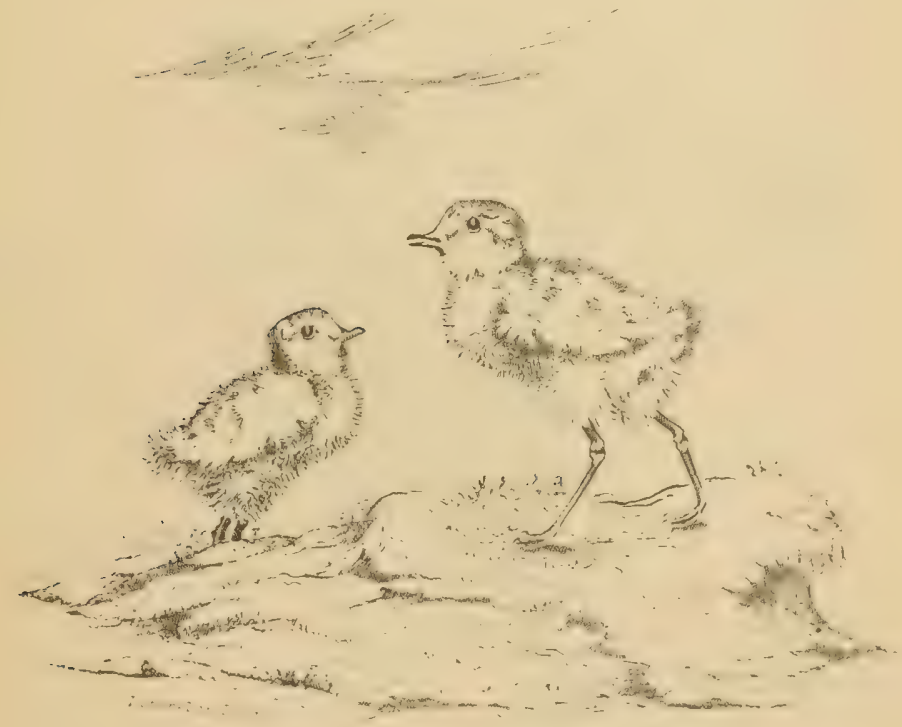

EDINBURGH : DAVID DOUGLAS 
One Volume, Royal Svo, with cighteen full-page Plates and eight Vignettes. Price 30 s.

\section{THE \\ SCOTTISH DEERHOUND \\ WITH NOTES}

ON ITS ORIGIN AND CHARACTELISTICS

BY

E. WESTON BELL, F.Z.S., F.S.A. (Sсот.)

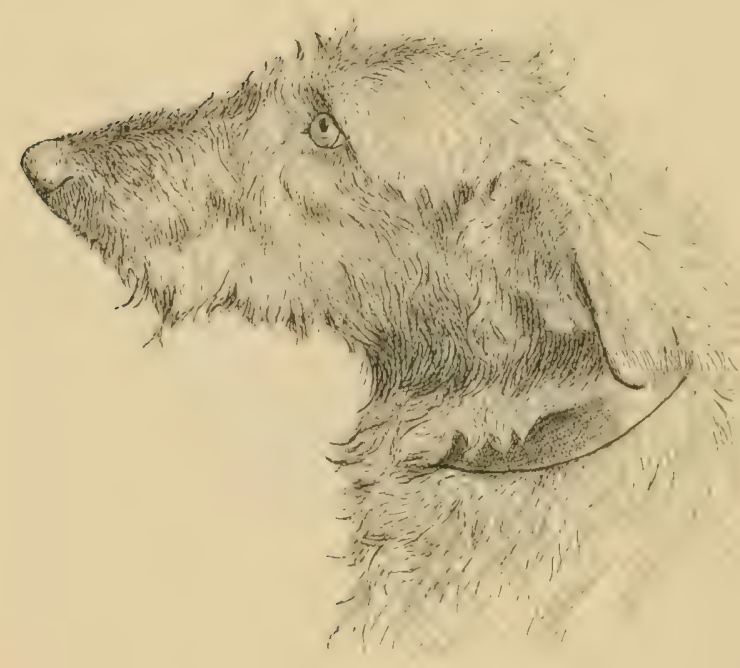

EDINBURGH : DAVID DOUGLAS 1892 


\title{
THE ANNALS OF SCOTTISII NATURAL HISTORY
}

\author{
A Quarterly Magazine
}

WITH WHICH IS INCORPORATED "THE SCOTTISH NATURALIST."

Edited by J. A. Harvie-Brown, F.R.S.E., F.Z.S.

James W. H. Trail. M.A., M.D., F.L.S., and Whliam Eagie Clarke, F.L.S.

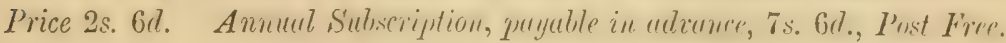

\section{A TREATISE ON ANGLING.

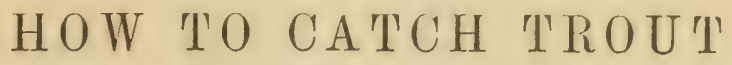 \\ By THREE ANGLERS. \\ Illustrated. Price 1s., by Post 1s. 2d.}

The aim of this book is to give within the smallest space possible such practical information and advice as will enable the beginner without further insiruction to attain moderate proficiency in the use of every legitimate lure.

"A delightful little book, and one of great value to anglers."-Scotsman.

"The advice given... is always sound."-Field.

"As perfect a compendium of the subject as can be compressed within eighty-three pages of casily read matter." - Scotch Waters.

"A well written and thoroughly practical little work."-Land and Water.

"The most practical and instructive work of its kind in the literature of angling."-Dundee Advertiser.

ALEX. PORTER.

\section{THE GAMEKEEPER'S MANUAL}

BEING AN EPITOME OF THE GAME LAWS OF ENGLAND AND SCOTLAND, AND OF THE GUN LICENCES AND WILD BIRDS ACTS

For the USE of Gamekeepers and others interested

in the Preservation of Game.

Jiy Alexander PORTER, Ghef Constable, of lioxburghshiz.

Second Edition. Crown 8vo, Price 3s., Post free.

" $\Lambda$ concise and valuable epitome to the Game Laws, specially addressed to those who are engaged in protecting game."-Scotsman.

"Quite a store-house of useful information. . . Although not pretending to be a 'law book," this work will certainly serve the purpose of one; no subject being omitted that comes within the province of the game laws."-Glasgow Herald.

\section{COLONEL CAMPBELL. \\ MY INDIAN JOURNAL}

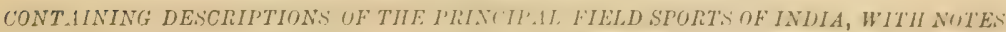

ON THE NATURAL HISTORY AND HABITS OF THE WILD ANIMALS OF THE COUNTRY.

By Colonel WALTER CAMPBELL, Altior of "The Old Forest lianger.

Small Demy 8vo, with Drawings on Stone by Wolf. Price 16.

\section{MISS WARRENDER.}

\section{WALKS NEAR EDINBURGH}

\section{BY MARGARET WARRENDER.}

With Illustrations by the Author. Foolscap Sio. Second ellition. 3s. 6d.

"Every page bears narks of first-hand knowledge,"-A thenam . 
In One Volume, Demy 8vo. Eighth Edition. Price I5s.

\title{
VETERINARY MEDICINES
}

THEIR ACTIONS AND USES

\author{
BY \\ FIN LA Y D U N \\ FORMERLY LECTURER ON MATERIA MEDICA AND DIETETICS AT THL EDINBUAGII \\ VETELINARY CULLEGE, AND EXAMINER IN CILEISTRY IN THE ROYAL \\ COLLEGE OE VETERINARY SURGEUNS
}

"All the latest information on the subject las been incorporated in the Volume, which is certainly an enduring montment to the indefatigable industry and eneyclopedic attainments of its rifted and lighly respected author."-North British Agriculturist.

"The book is sure to maintain and enhance further its already high reputation."-Glasyow Ilerald.

"Remains a standard text-book of its subject."-Scotsman.

Now Ready, in One Volume, Demy Svo. Price 5s., post free.

\section{IN ACCIDENT AND DISEASE}

NOTES AND SKETCHES

By J. ROALFE COX, F.R.C.V.S.

"Th aid the veterinary student and horse amateur in clistinguishing between diflerent maladies and mishaps, Mr. Cox, an able veterinary surgeon of long experience, has published, in which verhal deseription is made altogether subordinate to the artistic clelincation of twenty-eight cases of particular diseases and accidents frequently met with. The ligures, if somewhat rumglily, are yet strikingly portrayed, and in addition to being fairly well drawn, convey at a glance a capital series of object lessons in clinical veterinary medicine and surgery which camnot fail to be instructive to those for whom they were produced." - Lancet.

In One Volume, Demy Svo. Price gs.

\section{TIIE PROTECTION (OF IVOOI)LANDS}

\author{
AU'HORISED TRANSLATION FRONI THE \\ GERHAN
}

I3Y

J OH N NISBE'T, D. CEc.

OF THE INDIAN FOLEST SERYICE, AUTHOT OF "BRITISH FOREST TREES, AN1) THEIR SYLVICULTURAL CHARACTERISTICS AND TRFATMENT"

Thus work, a translation of the fourth edition of Kauschinger-First's Iruldschutz, is intended to supply a want eoncerning which frequent expression was given in the evidence laid before the Select Parliamentary Committee on Forestry in 18s6-87.

Whilst making no pretence of treating any branch of the subject exhaustively, the various portions are dealt with in a strictly scientifie manner, though at the same time tersely, ancl from it thoroughly practical standpoint.

As there is no special work on Sylvicultural Entomology in English, the chapter on noxious Forest Insects has been somewhat implified, and it is hoped that, witl, the aid of the coloured plates at the end of the book, the identilication of the chief insect enemies of our woodlanis will be easily eflected by students of Forestry and practical Sylviculturists.

EDINBURGH : DAVID DOUGLAS, 10 CASTLE STREET 


$$
\text { . }
$$ 
